\title{
IntechOpen
}

\section{Energy Efficiency and Sustainable Lighting a Bet for the Future}

Edited by Manuel Jesús Hermoso-Orzáez and Alfonso Gago-Calderón 



\section{Energy Efficiency and Sustainable Lighting - a Bet for the Future}

Edited by Manuel Jesús Hermoso-Orzáez

and Alfonso Gago-Calderón 

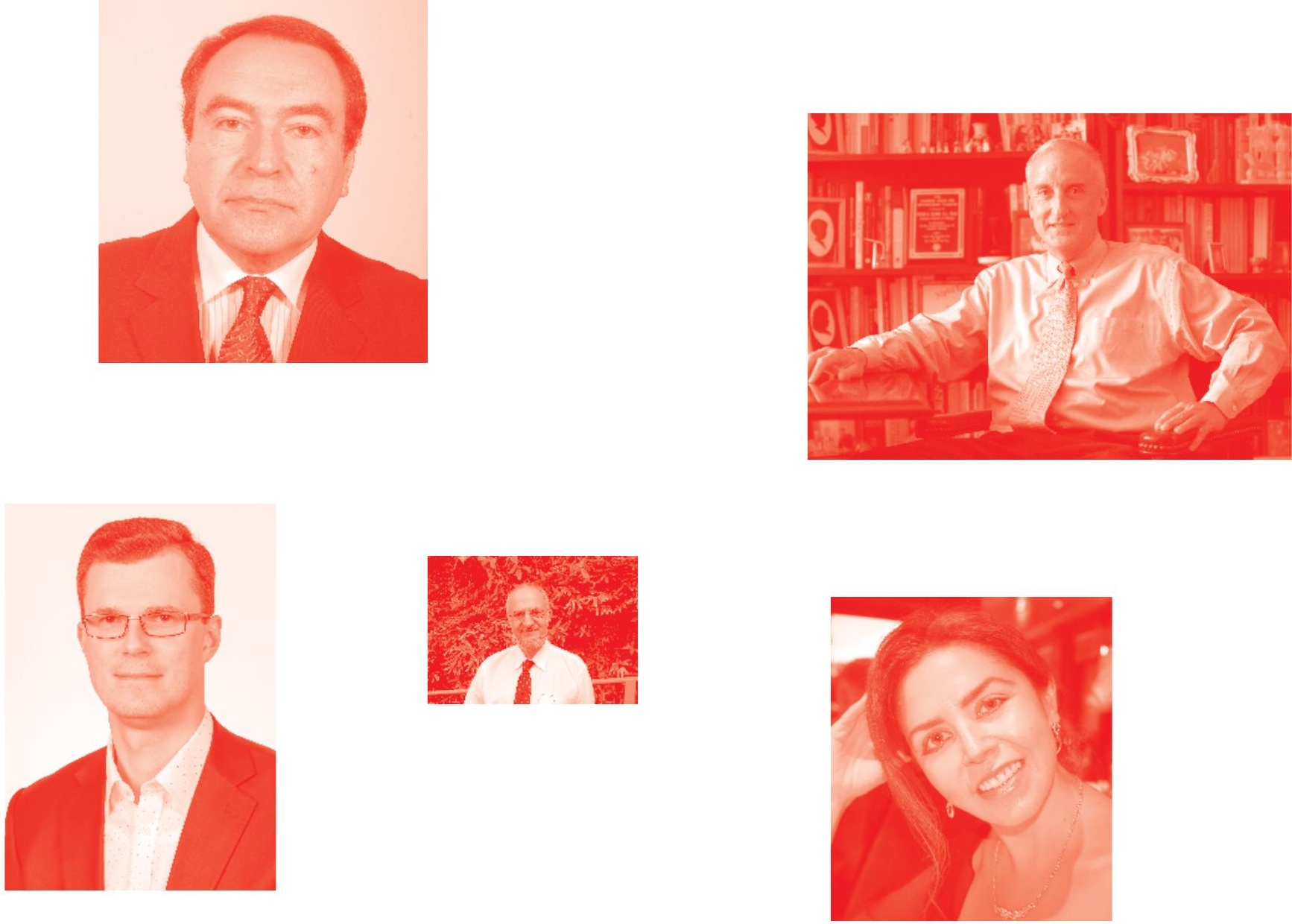

Supporting open minds since 2005
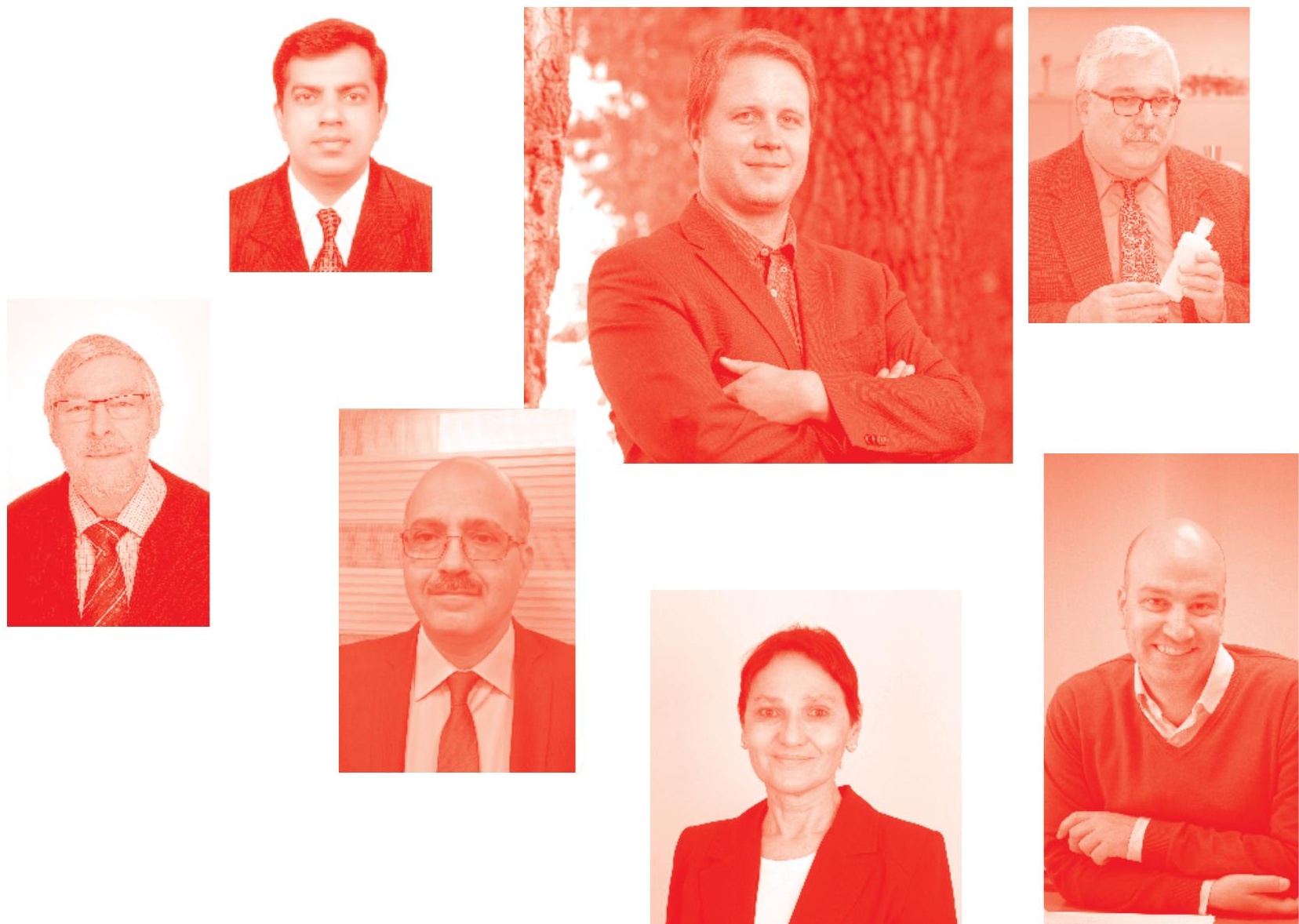
Energy Efficiency and Sustainable Lighting - a Bet for the Future

http : //dx . doi.org/10.5772/intechopen. 85907

Edited by Manuel Jesús Hermoso-Orzáez and Alfonso Gago-Calderón

\section{Contributors}

Rowan Machaka, Mohammad Omar, Ahmad Mayyas, Mudrite Daugaviete, Baiba Bambe, Dagnija Lazdina, Andis Lazdins, Roman Sikora, Przemysław Markiewicz, Blas Ogayar, Eduardo Ruiz Vela, Andres López, Manuel J. Hermoso-Orzáez, Manuel Jesús Hervas-Pulido, Alfonso Gago-Calderón, Olfa Bel Hadj Brahim Kechiche, Marwa Hamza, Habib Sammouda, Abubakar Danlami, Rabiul Islam, Nassim Iqteit, Khalid 0. Moh. Yahya, Nancy Varela, Daniel Espinoza Diaz, José Zamora Salido, Juan Cantizani Oliva, Eduardo Ruíz Vela, Md. Kamrul Alam Khan

$\odot$ The Editor(s) and the Author(s) 2020

The rights of the editor(s) and the author(s) have been asserted in accordance with the Copyright, Designs and Patents Act 1988. All rights to the book as a whole are reserved by INTECHOPEN LIMITED. The book as a whole (compilation) cannot be reproduced, distributed or used for commercial or non-commercial purposes without INTECHOPEN LIMITED's written permission. Enquiries concerning the use of the book should be directed to INTECHOPEN LIMITED rights and permissions department (permissions@intechopen.com).

Violations are liable to prosecution under the governing Copyright Law .

\section{(c)) BY-NC}

Individual chapters of this publication are distributed under the terms of the Creative Commons Attribution - NonCommercial 4.0 International which permits use, distribution and reproduction of the individual chapters for non-commercial purposes, provided the original author(s) and source publication are appropriately acknowledged. More details and guidelines concerning content reuse and adaptation can be found at http : //www . intechopen . com/copyright-policy . html .

\section{Notice}

Statements and opinions expressed in the chapters are these of the individual contributors and not necessarily those of the editors or publisher. No responsibility is accepted for the accuracy of information contained in the published chapters. The publisher assumes no responsibility for any damage or injury to persons or property arising out of the use of any materials, instructions, methods or ideas contained in the book.

First published in London, United Kingdom, 2020 by IntechOpen

IntechOpen is the global imprint of INTECHOPEN LIMITED, registered in England and Wales, registration number: 11086078 , 7th floor, 10 Lower Thames Street, London,

EC3R 6AF, United Kingdom

Printed in Croatia

British Library Cataloguing-in-Publication Data

A catalogue record for this book is available from the British Library

Additional hard and PDF copies can be obtained from orders@intechopen.com

Energy Efficiency and Sustainable Lighting - a Bet for the Future

Edited by Manuel Jesús Hermoso-Orzáez and Alfonso Gago-Calderón

p. $\mathrm{cm}$.

Print ISBN 978-1-78985-959-1

Online ISBN 978-1-78985-960-7

eBook (PDF) ISBN 978-1-83880-186-1

An electronic version of this book is freely available, thanks to the support of libraries working with Knowledge Unlatched. KU is a collaborative initiative designed to make high quality books Open Access for the public good. More information about the initiative and links to the Open Access version can be found at www. knowledgeunlatched. org 


\section{We are IntechOpen, \\ the world's leading publisher of Open Access books}

Built by scientists, for scientists

\section{$4,700+$}

Open access books available

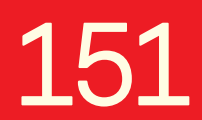

Countries delivered to

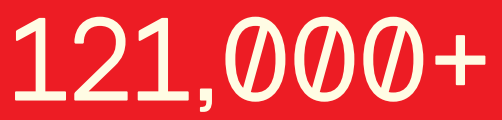

International authors and editors

Our authors are among the

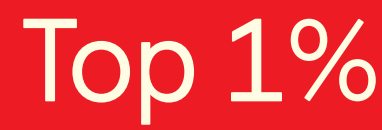

most cited scientists

Contributors from top 500 universities
40010

Downloads

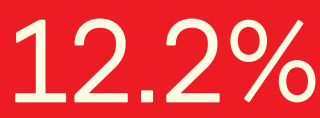

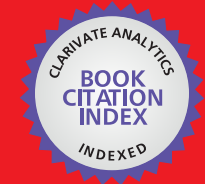

WEB OF SCIENCE ${ }^{\text {MM }}$

Selection of our books indexed in the Book Citation Index in Web of Science ${ }^{\mathrm{TM}}$ Core Collection (BKCI)

Interested in publishing with us?

Contact book.department@intechopen.com

Numbers displayed above are based on latest data collected.

For more information visit www.intechopen.com

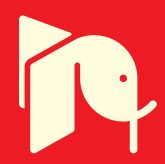





\section{Meet the editors}

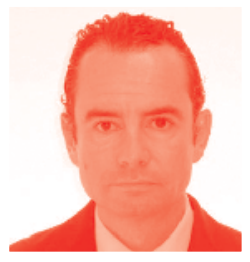

Hermoso-Orzáez Manuel Jesus, $\mathrm{PhD}$, has been a full-time assistant professor doctor at the University of Jaén since February 2009. He developed his professional activity in the world of engineering and projects with experience of more than 20 years in public administration (municipal public lighting technician) and in the private sector. He has significant experience as a researcher with more than 20 of 30 articles published JCR-Scopus and Web of Science, 10 of them very relevant in high-impact journals Q1-Q2. His presence at international congresses has resulted in very diverse oral communications, writings, posters, and conferences. He also participates as a Publons journal reviewer and is a member of several scientific committees. His outstanding research field includes public lighting, applied energy efficiency, LED lighting, project management and management, alternative energies, energy sustainability, gasification, hydrogen, building information modeling (construction information modeling), economic and financial analysis, and industrial maintenance and storage.

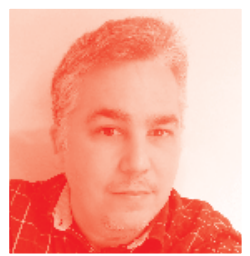

Alfonso Gago Calderón received his MS (best overall academic achievement) and PhD degrees in Industrial Engineering in 2002 and 2010, respectively, and his MS degree in Audiovisual Systems in 2010, all from the Universidad de Málaga (UMA), Spain. From 2003 to 2016, he was the director of the R\&D department of the electronic development company SOLITEC and Associate Professor of the Manufacturing Engineering Department at UMA. Currently, he is Assistant Professor of the Department of Graphics, Design and Projects at the same university. He holds seven patents and a large number of papers in indexed journals and communications in scientific conferences. His current research interests are LED lighting, LED displays, renewable energies, energy efficiency, and light electric vehicles. 



\section{Contents}

Preface

Section 1

Introduction to Sustainability

Chapter 1

The Improved Model of the Method, Rights, and Resources (MRR) for the Evaluation of the EIA System: Revising the Sustainability Indicators

by Rowan Kushinga Machaka

Chapter 2

Eco-Material Selection for Lightweight Vehicle Design

by Ahmad T. Mayyas and Mohammed Omar

Chapter 3

Plantation Forests: A Guarantee of Sustainable Management of Abandoned and Marginal Farmlands

by Mudrite Daugaviete, Dagnija Lazdina, Baiba Bambe,

Andis Lazdins, Kristaps Makovskis and Uldis Daugavietis

Section 2

Sustainable Lighting at Home

Chapter 4

Explorative Analysis of Household Energy Consumption in Bauchi

State, Nigeria

by Abubakar Hamid Danlami and Rabi'ul Islam

Chapter 5

Roof Lighting with Recycled Plastic Bottles

by Nancy Varela Terreros and Daniel Espinoza Díaz

Chapter 6

Dimensioning of an Autonomous Photovoltaic Installation: Case

Study in Msaken, Sousse (Tunisia)

by Olfa Bel Hadj Brahim Kechiche, Marwa Hamza

and Habib Sammouda 
Energy Efficiency and Sustainability in Outdoor Lighting - A Bet for the Future by Kamrul Alam Khan, Salman Rahman Rasel, S.M. Zian Reza and Farhana Yesmin

\section{Section 3}

Energy Efficiency and Sustainability in Outdoor Lighting

Chapter 8

Analysis of Outdoor Lighting Control Systems Applied to the New Smart City Models by Eduardo Ruiz Vela, Blas Ogáyar Fernandez, Andrés López Valdivia and Hermoso-Orzáez Manuel Jesús

Chapter 9

Improvement the Efficiency of Distribution Network Using

an Efficient Lighting System of Streets

by Nassim Iqteit and Khalid Yahya

Chapter 10

Energy Efficiency of the Road Lighting: The Impact of Active

Power Losses on Energy Performance Indicators and

Electricity Costs

by Roman Sikora and Przemystaw Markiewicz

Chapter 11

The Thermal Dissipation of LED Outdoor Lighting Luminaires:

Comparative Analysis for a Real Case of Study

by Hermoso-Orzáez Manuel Jesús, Hervás-Pulido Manuel Jesús,

Unión-Sánchez Juan de Dios, Ogáyar-Fernández Blas

and Gago-Calderon Alfonso

Chapter 12

Control Systems and Ornamental Lighting. A Case study:

Illumination of the Facade of Santiago Hospital in Úbeda (Jaén)

by Juan Cantizani Oliva, Eduardo Ruiz Vela and José Zamora Salido 


\section{Preface}

Energy efficiency, applied to the sustainable management of natural resources in our cities and towns, is a concern that transcends purely economic aspects and the same time is a social demand. The recent climate summit held in Madrid (December 2019) marked as strategic goals for the future the making of our cities and homes increasingly energy efficient and environmentally sustainable. The sustainable management of forest resources in rural areas, sustainable crops, production of sustainable energy of a renewable nature at local and domestic levels, and the use of sustainable energies are strategic objectives that are framed within the new ecoefficient strategies oriented towards the circular economy of cities, towns, and homes.

In this book we try to provide innovative solutions for sustainable energy production at a domestic or local level, by looking at the energy efficiency applied to sustainable lighting. We also analyze the new concept of the "smart city" as a future option for sustainable energy management of the towns and cities of the immediate future. This work deals with very innovative aspects associated with production, management, energy production systems, and efficient lighting. On the one hand, we describe innovative autonomous sustainable lighting systems with luminescence techniques applied in rural or remote areas away from the energy production centers as an alternative for self-consumption. On the other hand, we study the techniques of remote management and control of sustainable savings, perfectly applicable in large urban centers. Also, we present some problems that have been detected in the application of new technological forms of lighting, as well as case studies of the practical application of sustainable lighting.

The innovative nature of the topics presented in this book attempt to give a globalized version of the new systems and innovative ideas that are currently being applied in different parts of the planet. These are sustainable solutions designed to impact the problems of energy efficiency and sustainable lighting and are a clear sustainable commitment to our cities and homes.

We want to thank the editorial staff at IntechOpen for the opportunity to value the experiences and work carried out by different researchers and scientists who have presented their work within this exciting project. The excellent contributions collected in this book will surely serve to disseminate among scientists and researchers their innovative experiences in the field of energy efficiency and sustainable lighting.

Manuel Jesús Hermoso-Orzáez

University of Jaén, Spain

Alfonso Gago-Calderón University of Málaga, Spain 

Section 1

\section{Introduction to Sustainability}





\title{
The Improved Model of the Method, Rights, and Resources (MRR) for the Evaluation of the EIA System: Revising the Sustainability Indicators
}

\author{
Rowan Kushinga Machaka
}

\begin{abstract}
Measuring effectiveness of environmental impact assessment systems is central to the implementation of environmental impact assessment, considering the debate about relevance and usefulness of environmental impact assessment systems. Many models for evaluating environmental impact assessment system's effectiveness have been developed. Difficulties in quantifying environmental impacts have restricted the effectiveness mostly to procedural effectiveness evaluation, though substantive effectiveness evaluation is better. The method, rights, and resources (MRR) model was initially developed to harness the indicatorbased evaluation theory into the evaluation of environmental impact assessment system's effectiveness. This chapter reviews the method, rights, and resources model and proffers some improvement. The method, rights, and resources model evaluates environmental impact assessment systems using indicators of compliance, participation, and capacity. The indicators incorporate both procedural and substantive approaches; hence, it attempts to present a more indicative measure of environmental impact assessment system's effectiveness. The guiding idea in this chapter is that monitoring and evaluating environmental impact assessment systems should be embedded in the environmental impact assessment system itself as opposed to being concepts that are externally and subsequently applied on existing environmental impact assessment systems.
\end{abstract}

Keywords: environmental impact assessment, procedural and substantive effectiveness, indicator-based evaluation, compliance, participation and capacity

\section{Introduction}

The concept of environmental impact assessment (EIA) was developed in the USA in 1960. From there, the concept quickly spread across the world. European countries adopted EIA very early after that. Most developing countries adopted EIA after 1992. For example, although no African country had mandatory EIA procedures prior to 1992, over 40\% had established EIA systems by 1997 [1]. After 1992, EIA was rapidly adopted as a national decision-making 
tool by many countries. This rapid adoption is in most countries was undoubtedly influenced by the Rio Summit.

The Rio Declaration on Environment and Development and the Local Agenda 21 placed EIA firmly as an important concept in environmental management processes.

The EIA system's primary role is to incorporate environmental issues into decision-making to ensure that new developments include steps to protect the environment and social well-being. EIA is therefore a series of steps that enable environmentally responsible decisions to be made. A logical question that follows is whether EIA systems actually contribute to environmental protection and, if so, how effectively.

Although the finer details of how EIA is implemented vary from country to country, the basic idea is the same. In this chapter, it is assumed that the reader has reasonable knowledge about the EIA process; therefore, only a brief description is given. It starts with a detailed knowledge of the proposed project. This detailed knowledge informs the possible impacts that may arise from the implementation of the project.

Studies are done to determine the environmental baseline on which possible environmental impacts of the proposed project may be benchmarked. The baseline also enables experts to understand details about the potential impacts such as magnitude, type, severity, and so on. The next step is to plan for ways of reducing any negative environmental impacts that would have been identified and analyzed while enhancing any positive impacts, if any. An environmental management plan is put together and married to project implementation. One of the important steps of EIA is the consultation of affected and interested parties (stakeholder consultation) to gain and incorporate their views.

The effectiveness of the EIA process is a growing subject of scholarly research $[2,3]$. Governments and private companies commit many resources to implement the EIA process. The major question that remains partly unanswered is whether EIA is achieving environmental protection as expected. From this question arises another question which is the focus of this chapter. How can the effectiveness of an EIA system be measured?

The MRR model is one such a means introduced to evaluate EIA system effectiveness [4]. The purpose of this chapter is to introduce an updated method, rights, and resources (MRR) model for evaluating EIA system effectiveness [4], an alternative conceptual and practical model based on the evaluation theory. The next section describes the research method of this chapter followed by presenting different approaches to evaluating EIA system effectiveness and then discussing the challenges associated with evaluating EIA system effectiveness. After that the theoretical framework of the MRR model is presented followed by the MRR model and its application and finally the conclusion and recommendations.

\section{Research methodology}

This chapter sets out to review and improve the MRR model for EIA system evaluation. To do so, the literature review of the current EIA evaluation models was conducted together with the UN conventions on which the MRR model is based. After adding more theoretical context, the description of the MRR model was reviewed to add rigor and flow diagrams.

Further improvement was made by discussing the pros and cons of the MRR model using a SWOT analysis. Further recommendations toward the application of the MRR model were added. 


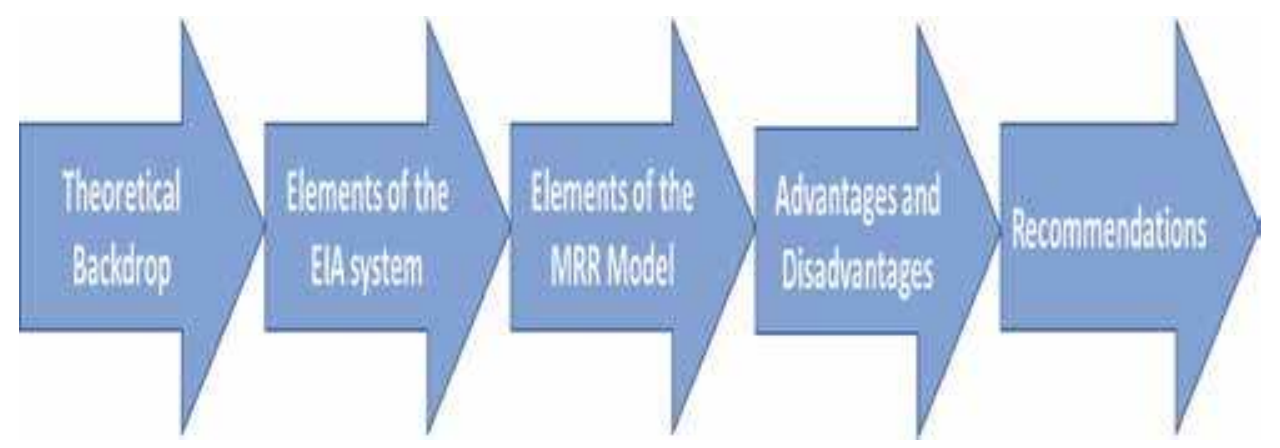

\section{EIA system evaluation approaches}

Firstly, it is important to set apart EIA review models whose primary purpose is to assess the compliance and content of EIA reports/statements. Examples of these are the Lee and Colley review package [5], the European Commission Guidelines on EIS Review, the Oxford-Brookes University EIS review package, and the Guide to Technical Analysis of Environmental Impact Studies.

This chapter is concerned about evaluating the effectiveness of the entire EIA system. Effectiveness of EIA systems has been researched since EIA systems were introduced. EIA effectiveness evaluation approaches were originally divided into two categories, vis-à-vis the procedural and the substantive effectiveness [6].

Adherence to the stipulated method of conducting EIA is the focus of procedural effectiveness. For example, in procedural effectiveness, the focus is on whether EIA studies were conducted thoroughly, whether the public had adequate opportunity to air their views, and whether the views were taken into consideration. Hence procedural effectiveness emphasizes on assessing how well information was gathered and used for decision-making and much less on whether tangible environmental stewardship itself was actually achieved. The actual environmental protection objectives are assumed to be achieved once a certain method is followed in conducting EIA studies and making decisions about it.

A typical procedural effectiveness viewpoint is the "democratization of governmental decision-making processes" as suggested by Macintosh [7]. In this case, simply ensuring that affected stakeholders have contributed to the decision-making process would be considered an achievement of its objectives.

Procedural EIA system evaluation is the easiest to perform since the focus is on whether specific procedural steps have been complied with. There are many procedural EIA evaluation models that have been developed. Two examples are given below.

The first one is the systemic and foundation measures model which was developed by Ahmad and Wood [8]. Features of EIA (system) "that are designed to deliver quality assurance in both practice and the administration are called systemic measures" [9]. Foundation measures are those "actions undertaken to improve the effectiveness of the EIA system and ensure successful application of the systemic measures" [9].

The other model is the EIA evaluation criteria developed by Wood which consists of 18 questions grouped into 3 categories, namely, institutional aspects of the EIA system, EIA process, and other requirements of the EIA system [10]. The EIA evaluation criteria have been widely used $[11,12]$.

There are a number of other criteria that have been developed and applied such as the 21 criteria [13], 5 criteria [14], 62 criteria [15], and 80 criteria [16]. All these are primarily procedural effectiveness models (Table 1 ). 


\begin{tabular}{|c|c|c|}
\hline Approach/model & $\begin{array}{l}\text { Effectiveness } \\
\text { evaluation }\end{array}$ & Focus \\
\hline $\begin{array}{l}\text { - Lee and Colley review package } \\
\text { European Commission Guidelines on EIS } \\
\text { Review } \\
\text { - Oxford-Brookes University EIS review pack- } \\
\text { age and the Guide to Technical Analysis of } \\
\text { Environmental Impact Studies }\end{array}$ & Procedural & Quality of EIA reports \\
\hline - Systemic and foundation measures model & Procedural & $\begin{array}{l}\text { Presence of the basic conditions } \\
\text { and requirements for EIA system } \\
\text { implementation }\end{array}$ \\
\hline $\begin{array}{l}\text { - } \\
\text { - } 5 \text { criteria evaluation criteria (18 questions) } \\
\text { - } 21 \text { criteria } \\
\text { - } 62 \text { criteria } \\
\text { - } 80 \text { criteria }\end{array}$ & Procedural & $\begin{array}{l}\text { Diverse including EIA report quality, } \\
\text { conditions, and requirements for } \\
\text { EIA system implementation } \\
\text { Historical view of EIA system }\end{array}$ \\
\hline $\begin{array}{l}\text { - Cost-effective analysis (CEA) } \\
\text { - Cost-benefit analysis (CBA) }\end{array}$ & Transactive & $\begin{array}{l}\text { More empirical measure of the } \\
\text { effectiveness of EIA systems }\end{array}$ \\
\hline
\end{tabular}

Table 1.

List of approaches to EIA system effectiveness evaluation.

Substantive effectiveness focuses on whether EIA systems are actually achieving the tangible outcomes, the ultimate tangible outcome being the protection of the environment and improving social well-being. Without achieving the actual protection of the environment, the EIA process is not adequately effective. Therefore, understanding if EIA systems protect the environment is very important.

For that reason, substantive effectiveness of EIA systems is a better measure of EIA system effectiveness than procedural effectiveness because it addresses the actual environmental protection outcomes of the EIA system. To give an example, we can ask the question: "Has the implementation of the EIA system actually resulted in less pollution, less land degradation, or enhancement of the natural and social environment?"

To answer this question requires the use of some metrics which quantify impacts such as pollution, land degradation, and enhancement of the natural and social environment. Only with quantitative information is it possible to objectively measure impact attributable to EIA systems and, as a result, to assert that substantive effectiveness is present. Quantitative metrics go as far as assigning monetary value to environmental goods, services, and impact, to measure whether the society has actually benefitted from implementing EIA systems.

However, there are challenges with quantitatively measuring environmental and social impacts and even more challenges with monetizing the same. For example, since any country has implemented its EIA system, how much flora and fauna has been saved, and how much is better off because of it?

At a project level, it may be possible to quantify some of the impacts more objectively. For example, a single project can make a case that the level of pollution in an adjacent river has not increased, measured in terms of concentration of pollutants and compared to the baseline before the project started. However, to cascade this measurement to the EIA system level and involving all possible impacts cannot be easily demonstrated.

Therefore, substantive models of EIA system evaluation are much more challenging for two reasons. Firstly, methods of measuring environmental goods and 
services in order to measure environmental damage avoided through the EIA system are contestable. Secondly, even if there was such a widely accepted method, the attribution gap could be impossible to objectively account for.

Besides the procedural and substantive models postulated by Cashmore, two more models of EIA effectiveness have been added vis-a-vis the transactive and the normative $[15,17]$.

Transactive EIA effectiveness is one which focuses on relating the cost of carrying out the EIA process to the relative outcomes/benefits of doing so. Hence transactive EIA effectiveness places emphasis on efficiency of resource use. As noted by Veronez and Montaño [18], not much attention has been paid to transactive EIA effectiveness. However, in this chapter cost-effectiveness analysis and cost-benefit analysis are identified as possible tools to use for transactive EIA effectiveness.

CEA can be used to compare two alternative courses of action based on the ration of the cost of the course of action to an indicator of the outcomes. The outcomes are not quantified, but a suitable indicator can be used to quantify the outcomes. Although the author could not locate examples where CEA has been applied in EIA effectiveness, it is conceivable how application can be done. For example, the cost of operating the entire EIA system can be compared to its outcomes such as the number of EIA studies conducted, reviewed, and licensed. Similarly, the efficiency of monitoring EIA implementation in the post-certification stage can also be evaluated.

CBA [19] is similar to CEA except that in CBA, the outcomes are expressed in monetary value. For example, the efficiency of the extra costs incurred by businesses as a result of implementing the environmental management plan can be evaluated against the zero option or other options.

It is important to note that the use of CBA in EIA is common but at the EIA study level in the pre-certification phase of EIA [20]. How to use CBA for EIA system effectiveness evaluation is not clear yet and still needs to be developed.

The last and fourth approach to EIA effectiveness (after procedural, substantive, and transactive) also postulated by Loomis and Dziedzic [17] and Veronez and Montaño [18] is the normative approach. In normative effectiveness, the focus is on the broader impacts of EIA on "sustainable development and participatory process" involved. Normative EIA effectiveness takes into account EIA best practices for continuous improvement.

As noted by Veronez and Montaño [18], there is a conceptual basis for bringing together the different EIA effectiveness models into an integrative EIA effectiveness model. The method, rights, and resources model, as described in this chapter, is one such attempt to produce a more integrative model of evaluating EIA effectiveness.

\section{Challenges to EIA effectiveness models}

This section discusses the challenges that affect evaluation or measurement of EIA effectiveness.

\subsection{Effectiveness of EIA: an afterthought}

The first is that, by design, at both policy and project levels, EIA systems lack inherent evaluation mechanisms. Concerns by US citizens over environmental degradation triggered the birth of EIA. As a result, emphasis has always been placed on the processes which support popular participation and decisionmaking in the pre-certification phase but less in the post-certification phase. Another characteristic of its political origins is that the EIA steps did not include 
a clear path to evaluate its success. The need to evaluate the effectiveness of EIA systems was almost an afterthought.

Therefore, EIA systems usually do not have built-in evaluation mechanisms comparable to inherent evaluation mechanisms of policies planned through the logical framework analysis. Indicators of progress to outputs, outcomes, and impact are used in LFA planning approaches to inculcate evaluation before policy implementation even starts.

\subsection{Quantifying impact}

As discussed before, the second challenge is about quantifying environmental impact. For EIA to be considered effective, the question of how much of the environment and social well-being an EIA system saves in pertinent quantification of environmental damage and social well-being levels is necessary to ensure objective answers to this question. Empirical baseline using environmental and social well-being indicators enables future measurement of chance. For example, before a mine is set up, ground water quality can be measured as a baseline. Future periodic measurements will then be measured against the baseline to determine if negative or positive impact has been made.

However, other stakeholders may emphasize on monetary value of the impacts so that they can offset against the cost of implementing the EIA. Unfortunately, there are many models of putting a monetary value to the environment, but they all suffer from the challenge of what is the real value of nature. Hence, this challenge will continue to exist.

\subsection{Attribution gap}

Attribution gap is another challenge. In all policy interventions such as EIA, the impact of policy is often subject to other policies or forces such that the resultant change, whether negative or positive, cannot be attributed to one intervention. Hence the attribution gap requires accounting for unplanned forces of change and unplanned change itself. Such other forces may include environmental awareness campaigns affecting the attitude of citizens toward environmental issues in general and other policies such as local environmental action plans and waste management plans.

\section{Theoretical framework of the MRR model}

The theoretical framework for the method, rights, and resources model is derived from the outcomes of the Rio Summit of 1992. This may be unusual that a theoretical framework is derived from policy documents, but as will be demonstrated, that makes EIA effectiveness evaluation very practical and relevant.

The MRR model starts by recognizing that the EIA system is enshrined in the outcomes of the Rio Summit and national policy and legal documents. Therefore, the MRR attempts to identify what these documents intended to be the elements of the EIA system and draw from them. Method, rights, and resources are the three elements of the MRR model for EIA system effectiveness evaluation.

In the Rio Declaration on Environment and Development [21], the world governments agreed on 27 principles to guide the world toward sustainable development. Principle 17 states that: 


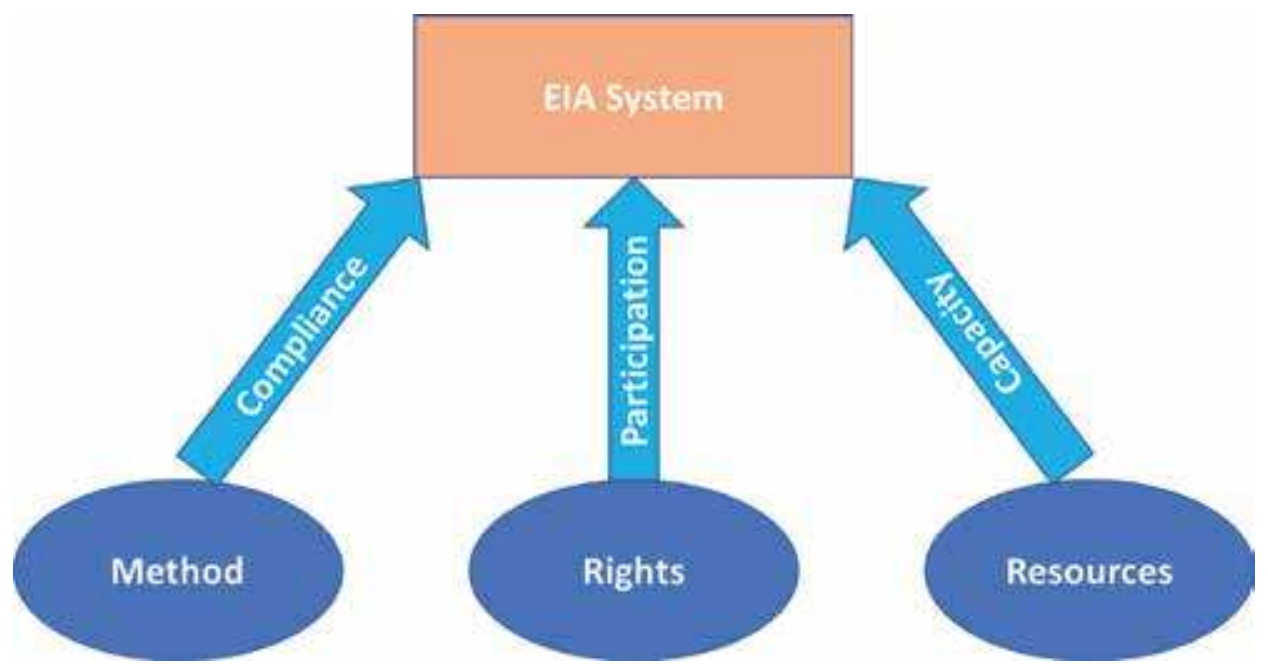

Figure 1.

$M R R$ model's theoretical framework.

"Environmental impact assessment, as a national instrument, shall be undertaken for proposed activities that are likely to have a significant adverse impact on the environment and are subject to a decision of a competent national authority."

Principle 15 advanced the precautionary principle stating that:

"In order to protect the environment, the precautionary model shall be widely applied by States according to their capabilities. Where there are threats of serious or irreversible damage, lack of full scientific certainty shall not be used as a reason for postponing cost-effective measures to prevent environmental degradation."

After placing EIA as a tool for environmental decision-making, the necessary elements for implementing sustainable development initiatives were also identified.

Section 8.3 (d) of the LA 21 stipulates the need for procedures:

"To establish domestically determined procedures to integrate environment and development issues in decision-making."

Section 22 of the LA 21 [22] states the right of affected people to participation in decision-making:

"One of the fundamental prerequisites for the achievement of sustainable development is broad public participation in decision-making. ... the need of individuals, groups and organizations to participate in environmental impact assessment procedures and to know about and participate in decisions, particularly those which potentially affect the communities in which they live and work."

Principle 10 of the Rio Declaration on environment and development also promulgates that "environmental issues are best handled with the participation of all concerned citizens ..." and promotes "access to information" and "the opportunity to participate in decision-making processes."

We can therefore say, by design, compliance (with the method/procedure) is identified as a requirement for implementing EIA systems. The other element is participation (stakeholder's rights), and the third one is capacity (or resources). It is proposed that EIA systems can be used to evaluate based on these three to gauge whether intended objectives are being achieved. Based on this discussion, we have the three elements as method (M), rights (R), and resources (R), respectively (Figure 1).

The figure above shows a schematic representation of the theoretical framework of the MRR model. 


\section{The updated MRR model}

This chapter proposes the method, rights, and resources model, which is more flexible and all-encompassing while involving less of subjective assessment of the researcher. This model proposes that the entire EIA system of any country can be broken down into three elements, namely, method, rights, and resources. From this point of view, the MRR model is an integrative model, seeking to bring together procedural, substantive, transactive, and normative issues into EIA effectiveness evaluation.

By nature, evaluation is a process of collecting and analyzing information, with the aim of measuring the difference between the situation and a set standard. Since information collection is involved, decisions must be made about what information to collect and how to analyze it.

In MRR model, the set standard against which effectiveness can be evaluated is derived from the founding principles of the EIA origins as discussed below. On the other hand, what information to collect is guided by indicators specifically chosen for EIA systems.

\subsection{Method}

Method has to do with the procedures or process putting the EIA system into practice. The procedures or process ensures that stakeholder views and environmental issues are taken account of in decision-making. This is the pre-certification phase. Procedures or process also ensures mitigation/enhancement measures stipulated for a project are implemented (post-certification phase). The pre-certification phase is often laid out in the form of step-by-step guidelines (the EIA process). Splitting the EIA process into two (pre- and post-certifications phases) makes it easier to understand.

The main focus of the pre-certification phase is to produce an EIA report which a regulatory authority will use to decide whether a project should be allowed to be implemented or not. The report is produced through a scientific study of environmental and social issues relating to a specific project.

The pre-certification phase process can have the following general steps: screening to eliminate activities which do not need detailed studies followed by scoping the extent of the EIA study, collecting baseline information, stakeholder participation platforms, impact identification analysis, impact analysis (e.g., magnitude, severity, etc.), formulating mitigation/enhancement measures, and formulating the environmental management plan (EMP) and impact monitoring plan (IMP).

The role of the post-certification phase is the implementation of the EMP and IMP within the project activities. Often, reports about the progress of implementation of the EMP and IMP are required to be submitted to the regulatory authority on a regular basis. In this way, the method becomes a reasonable proxy for substantive effectiveness as companies report the achievement of environmental and social protection at that level.

Given the importance of the process in determining the information available to regulatory authorities for decision-making, compliance with the process is a necessity. In fact, the degree of compliance with the process is a measure of the effectiveness of EIA systems including the extent of integration of environmental issues into both decision-making and, if granted permission, the implementation of projects.

An important point to note here is that measurement of environmental and social impacts can be embedded in the method in the post-certification phase, 
The Improved Model of the Method, Rights, and Resources (MRR) for the Evaluation of the EIA... DOI: http://dx.doi.org/10.5772/intechopen.88747

hence giving the opportunity to measure substantive effectiveness, first at project level and by extension at a higher EIA system level. For example, periodic reporting of the success and failure in the implementation of the environmental and impact monitoring plan provides information about the post-certification phase, indicating potential substantive effectiveness of the EIA system.

\subsection{Rights}

Citizens who are affected by economic and social development have the right to have a say in such activities. The EIA system provides a platform for affected citizens to contribute their views to EIA decision-making. It is therefore essential to measure the effective participation of all stakeholders as this demonstrates the effectiveness of an EIA system. To effectively contribute their views, adequate information and an opportunity to contribute both need to be provided.

Some stakeholders participate because of their mandates as organizations. For example, a tourism project that has potential impacts on the river system may require input from the ministry responsible for water even though the ministry responsible for the environment may be responsible for facilitating the EIA system. Environmental associations may also have a say on the mandate given to them by their membership. Hence a wide array of stakeholders may participate in an EIA process where their interests may be at stake.

The participation of all stakeholders can also be measured both in the precertification and post-certification phases. In the pre-certification phase, participation is about stakeholders having their views included in decision-making before a project can be implemented. In the post-certification phase, participation is about stakeholders being heard about the environmental and social impacts of the project. Hence a strong post-certification participation is a proxy measure for substantive effectiveness.

\subsection{Resources}

Policy implementation requires resources. In fulfilling their roles, the capacity of the EIA system as well as that of the individual stakeholders is dependent on the resources they have. This includes financial, human, institutional, legal, and material resources for the EIA system to function. The LA21 constantly emphasizes on the need for "means of implementation" which imply capacity required to implement the dictates of the declaration.

Just as discussed for the method and rights above, resources can also be measured in both pre- and post-certification phases. Similarly, the post-certification measure of the resource capability of each stakeholder is a proxy measure of the substantive effectiveness of the EIA.

Therefore, the MRR model is about measuring the level of compliance (with the method), participation (upholding stakeholder rights), and capacity (in the form of each stakeholder's resources) in the two phases of the EIA system which, together, give the measure of the effectiveness of the EIA system.

\section{Application of the MRR model}

In this section, the summarized overview of the MRR model is presented. Development of indicators of effectiveness of the EIA system at all levels is the 
basis for applying the MRR model. Indicators can be developed based on the three elements presented before, i.e., compliance, participation, and capacity.

Further to that, the indicators must clearly measure the pre- and the post-certification phases separately. The importance of this is that by design, the post-certification phase indicators must be proxies for the actual protection and enhancement of the natural and social environment.

The set of indicators suggested below are categorized according to the three pillars of the EIA system, namely, compliance, participation, and capacity. The author cannot formulate an exhaustive list of indicators. In addition, indicators can be formulated at different levels depending on the focus of the evaluation (e.g., national level or sector level). Similarly, indicators can be developed for each phase of the EIA process, i.e., pre- and post-certification phases.

The indicators individually or collectively measure the effectiveness of the EIA system. The rational further emphasizes that if compliance, participation, and capacity are effective, the objectives of the EIA system are being achieved. The objectives may be procedural, substantive, transactive, or normative.

Next, the application of the model indicates the sources of data from where data can be collected to inform the analysis of each indicator. Data can be characterized in several ways including whether it pertains to the pre- or post-certification phase of the EIA system, whether it is secondary, primary, qualitative, quantitative, and so on. The last part of the application suggests methods of data analysis suitable to answer the question about whether a particular indicator is being achieved or not. Emphasis is placed on quantitative analysis.

It is important to note that these indicators are derived from an EIA system with detailed EIA process guidelines. The EIA process guidelines provide the standard against which some of the indicators can be evaluated as shown in the following tables (Tables 2-4).

\subsection{Compliance indicators}

Below are listed some suggested compliance indicators:

\begin{tabular}{ll}
\hline Data source & Indicator explanation \\
\hline $\begin{array}{l}\text { Sample of approved EIA } \\
\text { report (enumeration) }\end{array}$ & $\begin{array}{l}\text { Average \% of steps of the EIA process guideline that are complied with by } \\
\text { the EIA studies }\end{array}$ \\
\hline $\begin{array}{l}\text { Questionnaire survey of EIA } \\
\text { practitioners }\end{array}$ & $\begin{array}{l}\text { Level of compliance in general } \\
\text { Level of compliance of the pre-certification stage in general } \\
\text { Level of compliance of the post-certification stage in general }\end{array}$ \\
& $\begin{array}{l}\text { Length of EIA process, from referral/prospectus/scoping to certification } \\
\text { Length of approval/review process } \\
\text { Integration of the approved environmental management plan and the } \\
\text { project's/business's environmental management system (if any) }\end{array}$ \\
& $\begin{array}{l}\% \text { of EMP monitoring reports submitted to responsible authority compared } \\
\text { to overall number of approved projects } \\
\% \text { projects stalled before certification } \\
\text { Report of the responsible } \\
\text { authority }\end{array}$ \\
& $\begin{array}{l}\text { Length of } \text { projects approved within prescribed timeframe } \\
\text { Length of approval/review process }\end{array}$ \\
\hline
\end{tabular}

Table 2.

Compliance indicators. 
The Improved Model of the Method, Rights, and Resources (MRR) for the Evaluation of the EIA... DOI: http://dx.doi.org/10.5772/intechopen.88747

\subsection{Participation indicators}

Below are some suggested participation indicators:

\begin{tabular}{|c|c|}
\hline Data source & Indicator explanation \\
\hline $\begin{array}{l}\text { Sample of approved EIA reports } \\
\text { (enumeration) }\end{array}$ & $\begin{array}{l}\text { Number of stakeholders consulted during the EIA study process } \\
\text { Stakeholders' recommendations that are integrated into the EIA report } \\
\text { for decision-making } \\
\text { Consultation methods used during EIA studies } \\
\text { Availability of information/feedback to stakeholders before } \\
\text { certification }\end{array}$ \\
\hline Report of the responsible authority & $\begin{array}{l}\text { Involvement of other government departments in the EIA review stage } \\
\text { (collaboration) } \\
\text { Involvement of other government departments in impact monitoring } \\
\text { (collaboration) } \\
\text { Availability of legal complaint systems }\end{array}$ \\
\hline $\begin{array}{l}\text { Questionnaire survey of EIA } \\
\text { practitioners }\end{array}$ & $\begin{array}{l}\text { Involvement of other government departments in the EIA review stage } \\
\text { (collaboration) } \\
\text { Involvement of other government departments in impact monitoring } \\
\text { (collaboration) } \\
\text { Availability of information/feedback before certification } \\
\text { Availability of information/feedback after certification }\end{array}$ \\
\hline EMP monitoring reports & Availability of information/feedback after certification \\
\hline
\end{tabular}

Table 3.

Participation indicators.

\subsection{Capacity indicators}

Below are some suggested capacity indicators:

\begin{tabular}{ll}
\hline Data source & Indicator explanation \\
\hline Report of the responsible authority & Capacity to monitor EMP implementation \\
& Capacity to enforce EIA conditions \\
& Capacity to review EIA reports \\
& Stakeholder capacity to contribute to EIA process \\
& Capacity to measure the environmental baseline \\
& Capacity to identify and analyze impacts \\
& Availability of baseline information \\
Availability of competent experts & Capacity to meet EIA study costs \\
Capacity to meet EMP implementation costs \\
Capacity to monitor impacts \\
practitioners & Capacity to monitor EMP implementation \\
& Capacity to enforce EIA conditions \\
Capacity to model impacts \\
Capacity to review EIA reports \\
Stakeholder capacity to contribute to EIA process \\
Capacity to measure the environmental baseline \\
Capacity to identify and analyze impacts \\
Availability of baseline information \\
Availability of competent experts \\
Capacity to meet EIA study costs \\
Capacity to meet EMP implementation costs \\
Capacity to monitor impacts \\
Capacity to produce EIA reports \\
\hline
\end{tabular}




\begin{tabular}{ll}
\hline Data source & Indicator explanation \\
\hline Sample of EIA reports & Capacity to model impacts \\
Capacity to review EIA reports \\
Stakeholder capacity to contribute to EIA process \\
Capacity to measure the environmental baseline \\
Capacity to identify and analyze impacts \\
Availability of baseline information \\
Availability of competent experts \\
Capacity to meet EIA study costs \\
Capacity to produce EIA reports \\
\hline EMP monitoring reports & Capacity to monitor EMP implementation \\
Capacity to enforce EIA conditions \\
Capacity to measure the environmental baseline \\
Capacity to identify and analyze impacts \\
Availability of baseline information \\
Availability of competent experts \\
Capacity to meet EMP implementation costs \\
Capacity to monitor impacts \\
\hline
\end{tabular}

Table 4.

Capacity indicators.

\subsection{Data sources and collection methods}

Data collection follows the scientific research method conventions. There are both primary and secondary sources of data from which to choose from for each indicator. Some of the indicators allow the collection of both secondary and primary data, but some may not. From the tables above, it can be observed that most of the data comes from the EIA reports and questionnaire survey of all stakeholders.

\subsubsection{Secondary data sources}

Secondary data sources for analyzing the indicators are documents found within the stakeholders such as the government offices, regulatory authorities, proponents, consultants, and any other institution. Reports from the regulatory authority, the EIA reports reviewed by the regulatory authority, and the EMP monitoring reports are the main sources of secondary data. If the regulatory authority produces an annual report, relevant data such as the total annual number of EIA reports approved and rejected can be found. This data is relevant for evaluating the effectiveness of the EIA systems overseen by the regulatory authority.

Data collection from regulatory authority documents is by reviewing and capturing both qualitative and quantitative data.

EIA reports, environmental audit reports, impact monitoring reports, environmental management systems, prospectuses, referrals, project proposals, terms of references, environmental certificates (and conditions), and environmental management plan reviews are other important sources of secondary data. These secondary data sources are mostly found within the regulatory authority but can also be obtained from the proponents implementing approved EIA plans.

From the EIA reports, data can be collected by reading and enumerating. For example, EIA reports do show how much of the EIA guidelines are complied with during their compilation. Hence the number of the steps of the EIA process that each EIA report complies with can be counted or enumerated. Similarly, one can calculate the number of the different types of consultation methods used which indicates how well the stakeholders participated in the EIA process. 
The Improved Model of the Method, Rights, and Resources (MRR) for the Evaluation of the EIA... DOI: http://dx.doi.org/10.5772/intechopen.88747

\subsubsection{Primary data sources}

Stakeholders' experiences are the main source of primary data. The main stakeholders of the EIA system include the government officials, proponents of projects that have undergone the EIA process, consultants who undertake the EIA studies, the public that is affected by the projects undergoing EIA study, and the regulatory authority responsible for deciding on the EIA acceptance.

Any suitable primary data collection method can be used. Questionnaire instruments can be designed to collect data on most if not all the indicators. Interviews, if necessary, can be used to provide in-depth information to explain the results of quantitative analysis.

From the questionnaires, data can be collected to measure any of the indicators that show compliance, participation, and capacity. Questionnaires can be used to capture stakeholder experiences about the achievement of the procedural, substantive, transactive, and normative objectives of the EIA system. Questionnaires collect information that fills in the gaps in secondary data from the regulatory authority and proponents.

\subsection{Data analysis}

The MRR model places emphasis on quantitative analysis of data since the primary focus of EIA effectiveness evaluation is to benchmark the achieved versus

\begin{tabular}{|c|c|}
\hline Statistical analyses & Example \\
\hline $\begin{array}{l}\text { - Test of association between observed compliance and } \\
\text { expected compliance }\end{array}$ & $\begin{array}{l}\text { For example, if desired compliance is set at say } 70 \% \\
\text { percent, a test of association can determine whether } \\
\text { the compliance level is significantly below, above, or } \\
\text { equal to } 70 \%\end{array}$ \\
\hline $\begin{array}{l}\text { Calculate means of compliance, participation, or } \\
\text { capacity for each project type, and compare means } \\
\text { between the project types } \\
\text { Do the same for economic sectors, consultants, } \\
\text { project size, year, location, or any other categoriza- } \\
\text { tion of projects }\end{array}$ & $\begin{array}{l}\text { For example, projects in the mining sector can be } \\
\text { compared to projects in the tourism sector in terms } \\
\text { of compliance or participation or capacity indicators }\end{array}$ \\
\hline $\begin{array}{l}\text { Calculate compliance, participation, or capacity } \\
\text { for the pre-certification and the post-certification } \\
\text { phases, and compare the two phases }\end{array}$ & $\begin{array}{l}\text { For example, the pre-certification phase can be } \\
\text { compared to the post-certification phase in terms of } \\
\text { compliance or participation or capacity indicators }\end{array}$ \\
\hline $\begin{array}{l}\text { Set an expected benchmark of compliance, } \\
\text { participation, or capacity, and compare with the } \\
\text { observed/actual compliance, participation, or } \\
\text { compliance }\end{array}$ & $\begin{array}{l}\text { For example, if desired capacity is set at say } 70 \% \\
\text { percent, a test of association can determine whether } \\
\text { the capacity level is significantly below, above, or } \\
\text { equal to } 70 \%\end{array}$ \\
\hline $\begin{array}{l}\text { - Collate all compliance indicators into one overall } \\
\text { compliance indicator, and compare against a set } \\
\text { benchmark. Do the same for participation and } \\
\text { capacity }\end{array}$ & $\begin{array}{l}\text { For example, from the questionnaire data, calculate } \\
\text { the mean compliance, and perform a test of } \\
\text { association to determine if the mean compliance } \\
\text { level is equal or less than a set benchmark such as } \\
70 \%\end{array}$ \\
\hline $\begin{array}{l}\text { - Calculate and graph the trends (trend analysis) in } \\
\text { overall compliance and participation of capacity over } \\
\text { several years }\end{array}$ & $\begin{array}{l}\text { For example, grouping all EIA reports into the } \\
\text { corresponding years of compilation, calculate the } \\
\text { compliance indicators for each year, and observe if } \\
\text { compliance has been increasing or decreasing }\end{array}$ \\
\hline
\end{tabular}

- Rank stakeholders by participation levels

Table 5 .

Suggested data analysis techniques. 


\begin{tabular}{ll}
\hline Advantages & Weaknesses \\
\hline Simplicity & Costly extensive data collection \\
\hline Holistic & Unavailability of information \\
\hline Improved objectivity & \\
\hline Flexible analysis approach & \\
\hline Triangulation & \\
\hline
\end{tabular}

Table 6.

Advantages and weaknesses.

the planned. Below are some suggested statistical tests which can be used to analyze the quantitative data that arise from enumeration and scoring of EIA reports and regulatory authority reports as well as questionnaire data (Tables 5 and 6).

\section{Advantages and weakness}

\subsection{Advantages and weaknesses}

\subsubsection{Advantages}

This section will outline the advantages of the MRR model. Firstly, the MRR model has the advantage of simplicity. Being based on the simple pillars of the implementation of any policy intervention (compliance, participation, and capacity), the MRR model is very easy to conceptualize. Further, the MRR model uses the evaluation theory, a commonly accepted and widely used approach in policy interventions and development planning.

Secondly, the MRR model provides a framework to encompass all issues related to the implementation of an EIA system. Any conceivable EIA issues including effectiveness, efficiency, relevance, and sustainability of the EIA system can be brought down to indicators within the three elements, i.e., compliance, participation, and capacity (or method, rights, and resources).

Thirdly, the MRR model is a possible reduction to the subjectivity that sometimes underlies the evaluation of effectiveness using other models. The MRR model ensures that the EIA system is evaluated according to its fundamental principles more than subjective concepts of researchers. For example, the idea of systemic and foundation issues [9] discussed before is very dependent on the authors' conceptualization of issues. However, compliance, participation, and capacity are more objectively defined.

In addition, the MRR model emphasizes on quantitative data obtained as objective data collection process using standardized data collection tools.

In the MRR model, analysis can be adapted to suit the availability of data. The indicators can also be crafted to suit the expected scope of EIA system evaluation.

Multiple sources of data used toward a single indicator are a means of triangulating data collection. This allows a more robust analysis process and a richer and more representative analysis outcome.

Lastly, the MRR model can be easily adapted to compare EIA systems from different geographical locations and jurisdictions. The MRR model is particularly suitable for use by regulatory authorities who have easy access to all the data required for a rigorous evaluation of the EIA system. 
The Improved Model of the Method, Rights, and Resources (MRR) for the Evaluation of the EIA... DOI: http://dx.doi.org/10.5772/intechopen.88747

It is suggested that further fine-tuning of the MRR model can enable a more objective and in-depth inter-country comparison of the performance of EIA systems.

\subsubsection{Weaknesses}

There are also challenges with the MRR model. The main challenge is that although quantitative methods can be used with the MRR model, the model still falls short of completely addressing the inherent challenge of quantifying environmental impact. Secondly, applying the model can be very costly depending on other factors. Thirdly, application will vary considerably depending on how the respective country's EIA system is set up. The MRR model will apply best where the EIA system is elaborate including specific guidelines, monitoring, and report systems from which data can be made available. Where no such elaborate EIA system guidelines exist, applying the MRR model is likely to be more challenging. However, the MRR model can be narrowed down to suit the situation.

Lastly, data collection proposed in the MRR model is extensive. It may not always be easy to obtain all the data. The availability of data also depends on having a welldeveloped system of recording and EIA reports and other sources of secondary data. Without a significant pool of practitioners effectively involved in the EIA system, it is not possible to obtain adequate information through the questionnaire surveys.

\section{Conclusion and recommendations}

This chapter introduced the MRR model for EIA system effectiveness evaluation. The chapter shows that the MRR model can address, albeit partially, some of the objectivity and comparability issues of EIA system evaluation. The MRR model does not intend to be a magic bullet to solve all the inherent challenges of quantifying environmental impact. It only suggests presumably a better approach to evaluating the effectiveness of EIA systems based on the evaluation theory and indicator formulation.

The intention of the chapter was not to give a step-by-step guide but the basic thinking behind the MRR model [4], hence opening it up to trial by other evaluators of EIA systems.

\section{Author details}

Rowan Kushinga Machaka

Christ University, Bangalore, India

*Address all correspondence to: kushinga.machaka@res.christuniversity.in

IntechOpen

(C) 2020 The Author(s). Licensee IntechOpen. Distributed under the terms of the Creative Commons Attribution - NonCommercial 4.0 License (https://creativecommons.org/ licenses/by-nc/4.0/), which permits use, distribution and reproduction for non-commercial purposes, provided the original is properly cited. (cc) BY-NC 


\section{References}

[1] Mulders R. "The state of EIA in the developing countries”. Post-Doctoral Course in Environmental Management [EPCEM]. University of Amsterdam. 1997

[2] Pope J, Bond A, Morrison-saunders A, Retief F. Advancing the theory and practice of impact assessment: Setting the research agenda. Environmental Impact Assessment Review. 2013;41:1-9. DOI: 10.1016/j.eiar.2013.01.008

[3] Morrison-Saunders A, Bond A, Pope J, Retief F. Demonstrating the benefits of impact assessment for proponents. Impact Assessment and Project Appraisal. 2015;33(2):108-115. DOI: $10.1080 / 14615517.2014 .981049$

[4] Machaka RK. The method, rights and resources model for evaluation of the effectiveness of environmental impact assessment systems. African Evaluation Journal. 2017;5(2):a200. DOI: 10.4102/ aej.v5i2.200

[5] Lee N, Colley R, Bonde J, Simpson J. Reviewing the quality of environmental statements and environmental appraisals. Occasional Paper number 55. Manchester: Department of Planning and Landscape. University of Manchester. 1999

[6] Cashmore M, Gwilliam R, Morgan R, Cobb D, Bond A. Effectiveness of EIAThe interminable issue of effectiveness: Impact assessment theory. Impact Assessment and Project Appraisal. 2004;22(4):295-310

[7] Macintosh A. The Australian Government's environmental impact assessment (EIA) regime: using surveys to identify proponent views on costeffectiveness. Impact Assessment and Project Appraisal. 2010;28:175-188. DOI: 10.3152/146155110X12772982841168

[8] Ahmad B, Wood C. A comparative evaluation of the EIA systems in Egypt,
Turkey and Tunisia. Environmental Impact Assessment Review. 2002;22(3):213-234

[9] El-sayed EA. Evaluation of the environmental impact assessment system in Egypt. Impact Assessment and Project Appraisal. 2009;27:193-203. DOI: $10.3152 / 146155109 X 465959$

[10] Wood C. Environmental impact assessment in developing countries. International Development Planning Review. 2003;25(3):301-321

[11] Ruffeis D, Loiskandl W. Evaluation of the environmental policy and impact assessment process in Ethiopia. Environmental Protection. 2010;28:2940. DOI: $10.3152 / 146155110 X 488844$

[12] Zeremariam TK, Quinn N. An evaluation of environmental impact assessment in Eritrea. Impact Assessment and Project Appraisal. 2007;25(1):53-63. DOI: 10.3152/146155107X190604

[13] Hollick M. Environmental impact assessment-an international evaluation. Environmental Management. 1986;10:157-178

[14] Hirji R, Ortolano L. EIA effectiveness and mechanisms of control-Case studies of water resources development in Kenya. International Journal of Water Resources Development. 1991;7:154-167

[15] Leu W-S, Williams WP, Bark AW. Development of an environmental impact assessment model and its application: Taiwan case study. Environmental Impact Assessment Review. 1996;16:18

[16] Sadler B. International Study of the effectiveness of environmental assessment: Environmental assessment in a changing world: evaluating practice 
The Improved Model of the Method, Rights, and Resources (MRR) for the Evaluation of the EIA... DOI: http://dx.doi.org/10.5772/intechopen.88747

to improve performance. Canadian

Environmental Assessment Agency and International Association for Impact Assessment. 1996

[17] Loomis JJ, Dziedzic M. Evaluating EIA systems' effectiveness: A state of the art. Environmental Impact Assessment Review. 2018;68:29-37

[18] Veronez F. A., and Montaño M. EIA Effectiveness: conceptual basis for an integrative approach. IAIA15 Conference Proceedings: Impact Assessment in the Digital Era, (April). 2015. 6. doi:10.13140/RG.2.1.4698.0965

[19] Laslett R. The assumptions of cost-benefit analysis. In: Willis KG, Corkindale JT, editors. Environmental Valuation: New Perspectives. Wallingford, U.K.: CAB International; 1995

[20] Caldwell LK. Implementing policy through procedure: Impact assessment and the National Environmental Policy Act. In: Porter AL, Fittipaldi JJ, editors. Environmental Methods Review: Retooling Impact Assessment for the New Century. AEPI and IAIA. Fargo, North Dakota, USA: The Press Club; March 1998

[21] United Nations (UN). The Rio Declaration on Environment and Development. New York: United Nations; 1992a

[22] United Nations (UN). The Local Agenda 21. New York: United Nations; 1992b 



\title{
Eco-Material Selection for Lightweight Vehicle Design
}

\author{
Ahmad T. Mayyas and Mohammed Omar
}

\begin{abstract}
In order for automakers to meet the new stringent environmental policies and to improve fuel efficiency of their vehicles, they started to change the design of their vehicles to be better aerodynamically, to downside their vehicle sizes, thus they can reduce the engine size as well, and to increase the level of the electrification (partial or full electrification) of their fleet vehicles. Lightweight design is another widely used strategy to improve fuel economy of automobiles. Potential lightweight material needs to be cost effective, has the ability to reduce the weight of the vehicle and can meet the functionality requirements. Thus, we need a systematic material selection process that takes into consideration all design aspects such as cost, performance, and environmental impacts. Eco-material selection provides a systematic method for material selection and takes into account material's mechanical properties, cost, and ability to reduce environmental impacts over product's lifetime. This chapter summarizes methods of eco-material selections for automotive structural panels in the body-in-white. A set of numerical and qualitative metrics for eco-material selection will be developed and discussed in this chapter. These metrics cover products' environmental impact, functionality, manufacturability, economic, and societal and safety factors.
\end{abstract}

Keywords: automotive, body-in-white, eco-material selection, lightweight design, sustainability

\section{Introduction}

Automakers today work on three major areas to improve the fuel economy of their fleet vehicles. Lightweight design, electrification and advanced powertrain technologies have been widely investigated and adapted by many OEMs (original equipment manufacturers) as the key solutions to improve fuel economy, thus reduce GHG emissions over the vehicle's lifespan. One of the early solutions to improve fuel economy of the vehicles was to reduce their weights and to improve their aerodynamic performance by changing the outer shape of the vehicle. Lightweight design emerged as a strategic solution to reduce the dependency on foreign energy sources after the Arab oil embargo in 1973. Early lightweight vehicle design aimed to reduce vehicle weight by substituting some of the heavy cast iron and steel parts used in vehicles with lighter materials like magnesium and aluminum.

Recently advanced high strength steel (AHSS thereafter) and reinforced plastic 
composite materials emerged as new lightweight materials with a wider acceptance than other expensive materials due to the decreasing trends in their production costs and the new innovations in the manufacturing processes that allow for mass production of these materials. Other lightweight design approaches also include redesigning of the vehicle and downsizing. Some automakers redesigned their cars to reduce aerodynamic resistance and improve fuel economy. In the downsizing approach, the car dimensions and engine size are reduced to save the mass of the vehicle, which require small engines that utilize less amount of fuel per driven mile. One of the key issues encounter lightweight materials is the high cost of these materials compared with the cost of conventional steel used in vehicles, the cost associated with manufacturing these lighter vehicles is nontrivial and could reach \$3-22 per kilogram of total weight saved for parts made from aluminum and magnesium and between $\$ 11$ and $\$ 33$ for parts made from carbon fiber reinforced plastic, CFRP [1-3]. Cost is not the only challenge that is still facing the lightweight materials such as magnesium and CFRP, and to a lesser extent aluminum, these materials also known of being energy-intensive materials especially in material extraction and manufacturing phases [4-5]. Many researchers focus on the vehicle use phase and under emphasize energy and GHG (greenhouse gas) emissions in the materials extraction and manufacturing of the vehicles which could potentially result in a biased judgment towards favoring these lightweight materials over steel or high strength steel.

If we look at the trend of passenger car weights in the last four decades, we can see that the average passenger vehicle weights declined from about $4035 \mathrm{lb}$ $(\sim 1830 \mathrm{~kg})$ in 1975 to $<3200 \mathrm{lb}(\sim 1460 \mathrm{~kg})$ in 1982 . Over the same time period, according to the U.S. Environmental Protection Agency numbers, the amount of plastics used in a typical US passenger vehicle increased from about $4.6 \%$ in 1980 to about $10-12 \%$ today [6]. However, the customer demand shifted their preference in the last few years to the larger and heavier vehicles such as sport utility vehicles (SUVs) and pickup trucks because of their heavy-duty functions. As a result, the average vehicle weight has increased again until it reached about $4150 \mathrm{lb}$ $(\sim 1890 \mathrm{~kg})$ in 2009 [6]. The average weight for new vehicles produced in 2016 was $1830 \mathrm{~kg}$ (4035 pounds) as a result of the added weights of electronics and new subsystems in the car. The average new 2016 car weight fell by 23 pounds from 2015 value, and the weight of an average new truck fell by 24 pounds from previous year value (Figure 1). However, the new trends in vehicle light-weighting aims at enhancing the vehicle fuel efficiency as well as improving its driving performance while lowering its emissions [6-7]. Many experimental studies found that a $10 \%$ reduction in vehicle weight translates into a 5-7\% improvement in the vehicle's fuel economy in terms of miles per gallon MPG or kWh per mile [7-9].

Electrification of vehicle drivetrain was proven to be an economic and environmental-friendly solution to overcome the problem of the tailpipe emissions in the congested cities. However, many studies have raised questions on the economics of electric vehicles vs. conventional gasoline powered vehicles and the total environmental impacts when the vehicle uses electricity from power generation plants that uses coal or heavy oil [4]. Electric vehicles that are charged from power grids that associated with larger footprints of the generated electricity ( $\mathrm{kg} \mathrm{CO}_{2-\mathrm{eq}} /$ $\mathrm{kWh}$ ), might not be competitive from the environmental standpoint, thus giving more advantages to the economic petroleum-operated vehicles that have advanced powertrains and higher MPG (miles per gallon).

In this chapter, we will introduce and discuss a systematic eco-material selection method that can be used in the early design phases to screen materials and then 


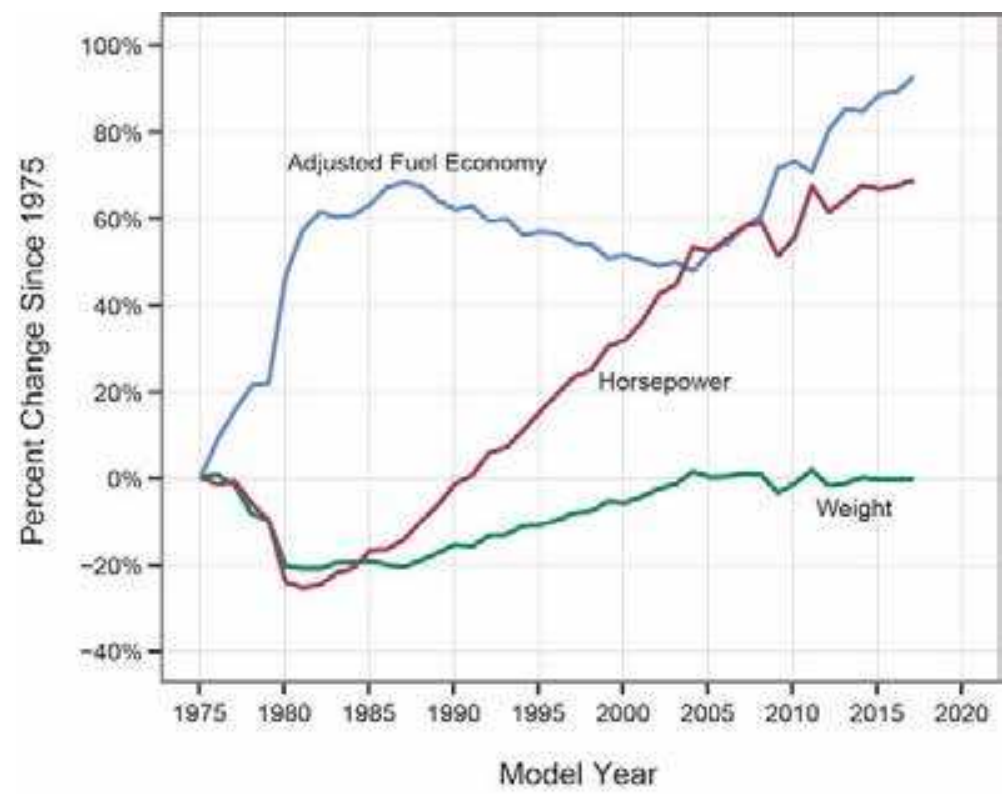

Figure 1.

Change in adjusted fuel economy, weight, and horsepower for model years 1975-2017 (1975 values are: fuel economy 13.5 miles per gallon; horsepower $138 \mathrm{hp}$; and fuel weight $1830 \mathrm{~kg}$ ) (image source: Ref. [6]).

select the most suitable candidates that can replace conventional steels in the passenger cars using functionality and mass of the parts as the key requirements in the design, and then expand the selection to include other environmental and economic aspects in the design problem. By following this proposed procedure in the design process, design team could save time and efforts in selecting lightweight materials and make sure they consider all sustainability factors in their part design and selected materials.

\section{Eco-material selection methods}

Sustainability is a multidisciplinary approach that encompasses the design for the environment factors (e.g., energy, greenhouse gas (GHG) emissions, and endof-life, recycling and circular economy analysis), safety and societal factors, and economic factors. Safety and societal factors in the sustainability model focus on safety, health, and wellness of the product from premanufacturing all the way until the retired products being disposed or recycled at their end-of-life stage. Economic factors are costs incurred in the materials and part production and any cost incurred or saved at the end-of-life phase. Automakers use several sustainability models to select materials for auto-bodies. While some of these models focus on the environmental aspects of the material selection process in the early design stages, other models are based on a single portion of the product's life cycle (e.g., energy use or the recyclability of the materials). Some of the popular material selections methods include qualitative and quantitative methods. Artificial intelligence and multicriteria decision-making methods have also recently emerged as new tools to facilitate the material selection process of the complex design problems where multiobjectives and many constraints can be added simultaneously in one step instead of 
the tedious, time consuming classical screening and selection process. Below is a brief description of these material selection methods:

1. Qualitative methods: qualitative material selection methods have been used as guidelines for eco-material selection (e.g., "choose abundant, non-toxic material if possible," "select cheap lightweight material," etc.). Analysis of material performance requirements is another qualitative method that relies on screening materials based on certain mechanical, environmental, or economic requirements. Performance evaluation can also be expanded to select material based on their manufacturability or their performance in the field [10]. So, the beauty of the qualitative methods comes from their versatility in classifying materials based on their relative performance or functionality, but they cannot be used as the basis in the larger eco-informed decision-making processes when multi-objectives are considered simultaneously or when conflicting goals start to emerge in the design problem.

2. Quantitative methods: quantitative approaches are used to rank different materials using specific metrics that derived from numerical material selection process that uses material selection indices as the basis for material screening and selection. The framework of this quantitative material selection process was established by professor Ashby and his colleagues from University of Cambridge, UK. Single environmental indicator or eco-indicator was proposed by Wegst and Ashby [11] to assess materials from the environmental perspective. Ashby [12] extended this single eco-indicator and added energy content indicator to the material selection process. Coulter et al. [13] and, Ermolaeva et al. [14] proposed adding the environmental cost as another measure to assess the relative performance of the candidate materials and how they can do the specified functions at the lowest cost possible.

Another quantitative method using material selection indices was proposed by Kampe [15]. In this study Kampe developed an energy-based material selection model in which a specific material could be used as a part of the overall decision-making process. Kampe used an expanded version of the Ashby's material selection method to assess materials from the lifetime environmental load perspective. Kampe provided and an example of energy-based material selection of auto body beams, which its main design function is to support a uniformly-distributed load, $W$, along its length without experiencing overload failure. The derived material selection index for this beam can be expressed as $\frac{\frac{2}{3}}{\rho}$. $\frac{\sigma_{f}}{\rho}$. Then Kampe introduced another selection factor to the problem, total energy expenditure, $\boldsymbol{Q}$ to assess materials using a combination of several functionality and mechanical parameters. Kampe extended the classical Ashby's material selection methods by multiplying the derived mass by the energy content per unit mass, $\boldsymbol{q}$. By doing so, Kampe was able to derive a material selection index for a strong beam with low embodied energy which can be expressed as $\frac{\sigma_{f}^{\frac{2}{3}}}{\rho \cdot q}$. This method could help designers in dealing with multiple design requirements using a quantitative material selection ranking process based on the material selection index.

3. Decision-making (DM) and artificial intelligence (AI) methods: multicriteria decision-making methods (e.g., an analytical hierarchy process, quality function deployment, or material selection numerical ranking methods) have 
been used extensively in recent years to facilitate material selection process by including multiple goals and multiple constraints in the design problem (see, for example, [16-18]). On the other hand, AI methods such as neural networks, fuzzy logic, genetic algorithms, and digital logic also emerged as new methods to facilitate the material selection processes especially when exploring large material datasets [19-22]. Both DM and AI methods provide versatile material selection methods that takes into consideration multiple objective functions with multiple constrains and provide designers with and expanded search domain that can include hundreds or thousands of candidate materials.

Besides the abovementioned DM methods, researchers have also used other effective DM methods such as TOPSIS, VIKOR, and ELECTRE. The technique for order preference by similarity to an ideal solution (TOPSIS) method is based on the logic that the chosen alternative should have the shortest distance from the ideal solution and the longest distance from the negative-ideal solution [23]. Vise Kriterijumska Optimizacija Kompromisno Resenje (VIKOR) is very similar to TOPSIS in the logic sequence but differs in the normalization process. VIKOR uses a linear normalization where the normalized values do not depend on the evaluation unit of the criterion, whereas TOPSIS uses vector normalization where the normalized value can change for different evaluation units of a particular criterion [23-24]. The second key difference is the aggregation function in each method, VIKOR uses a function that factors in only the distance from the ideal value and TOPSIS uses the ideal and anti-ideal values [23-24]. While authors of these studies discussed the beauty and limitations of these methods, they concluded their discussion by emphasizing that there is no technique that can be considered the most powerful for any given selection process, rather they presented versatile methods that can simplify the calculations and produce a more reliable result when studying a multiobjectives problem. As a matter of fact, it was reported in many articles that several $\mathrm{AI}$ and DM methods could produce different outcomes in ranking a set of alternative materials/decisions, which is partially due to the bias arises when making assumptions or assigning relative scores for certain material selection criteria; thus caution should be practiced when adopting any of these AI or DM methods.

\section{Sustainability model for auto-bodies}

Sustainability is a holistic approach that takes into consideration all environmental, economic and societal factors of the product. It also covers all lifespan phases from cradle to the grave. In the last few decades, many new terms and buzzwords start to emerge referring to new aspects in the environmental research. However, some of these new aspects are not more than an expansion of the sustainability framework to give more emphasis to the economic and societal related factors. Now, if we want to summarize these research areas, we can definitely place sustainability in the upper level of the hierarchy as shown in Figure 2. In the second level we can place economic, environmental and societal aspects of the product. We can also group other research aspects under each of these major sustainability fields, for example, design for environment which goes under environmental pillar of the sustainability also covers other research subareas such as life cycle assessment, design for recycling and dematerialization. Industrial ecology is part of the environmental aspects of the product, which in turn contains models that cover material flow through industry (MFI) and industrial energy (IE) analysis. Economic factors include analysis of the total cost of ownership which covers all cost incurred in the 


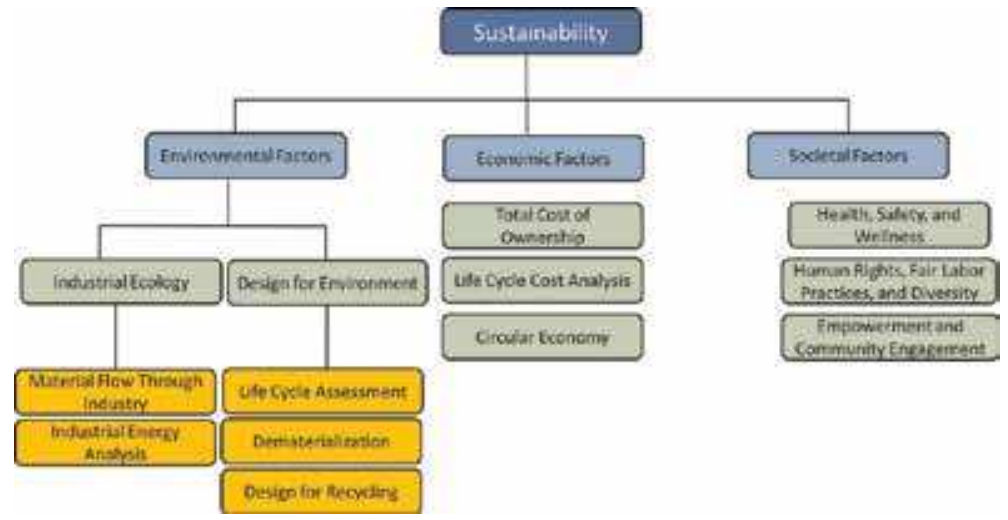

Figure 2.

Sustainability model and its branches.

product starting from material extraction and production, through operation and maintenance and ending with the recycling/reuse/landfilling of the end-of-life product. Life cycle cost analysis is in essence very similar to the total cost of ownership model and attempts to cover all cost associated with the product manufacturing and use. Circular economy is a new term that has gained a wider acceptance in the last few years because it overlaps economic and environmental aspects of the product use and recycling. The idea is to conserve resources by converting all end-of-life products into materials that can be used to make new products.

Eco-materials selection as another branch of the general sustainability model, is considered a multi-criteria decision-making process that starts by collecting and analyzing design requirements and design goals. Then the design engineers establish well-defined and accepted limits for each design requirement and try to classify materials based on their abilities to meet design requirements and perform the function the part is designed for. While finding a unique material that satisfies all design needs is generally difficult, the design team usually tries to compromise between economic, environmental, and societal factors and find a suboptimal set of candidate materials that can fulfil most of the design requirements.

Eco-material selection for auto-bodies is a typical material selection process that usually associated with conflicting objectives on hand, so tradeoffs between these objectives represent, in most cases, the only possible solution designers can use in their design process. For example, lightweight materials such as aluminum and magnesium are known for their ability to reduce energy and emissions in the use phase, but they are expensive and require much energy in the mining and refining processes. Plastic-based composites (CFRP, GFRP) look very appealing when it comes to the density and mass savings, but their manufacturability and cost represent two key challenges that limit their use in the vehicles. These are just two simple example of conflicting objectives the design team usually encounters in the design and material selection phase while they try to narrow down the selection to choose the most practical alternatives.

In this section, we propose a sustainability model for selecting eco-materials for auto bodies that covers most of the environmental, economic, societal, and technical factors in the design process. This sustainability model (Table 1) takes many attributes simultaneously and narrow down the selection process to a small group of materials that can meet as many sustainability factors as possible. While this interim model is developed to cover almost all sustainability factors, it can be modified 


\begin{tabular}{llll}
\hline Environmental & Economic & Societal and safety & $\begin{array}{l}\text { Technical/ } \\
\text { manufacturability }\end{array}$ \\
\hline Resource depletion & Materials cost & Crashworthiness (safety) & Formability \\
\hline Water pollution & Manufacturing cost & $\begin{array}{l}\text { Noise, vibration and } \\
\text { harshness }\end{array}$ & Jointability \\
\hline Energy consumptions & $\begin{array}{l}\text { Operation and } \\
\text { maintenance cost }\end{array}$ & $\begin{array}{l}\text { Health and wellness } \\
\text { (externalities) }\end{array}$ & Paintability \\
\hline $\begin{array}{l}\text { Greenhouse gas } \\
\text { emissions }\end{array}$ & End-of-life credit/cost & & Durability \\
\hline $\begin{array}{l}\text { Particulate matter } \\
\text { pollutants }\end{array}$ & & & \\
\hline $\begin{array}{l}\text { Toxic materials } \\
\text { End-of-life and } \\
\text { recyclability }\end{array}$ & & & \\
\hline
\end{tabular}

Table 1.

Sustainability model for eco-material selection for auto bodies.

when needed to include other factors not discussed here. The model focuses on selecting materials that minimize vehicle weight, but it also ensures any material selection conforms to the sustainability holistic approach.

The material selection process should adhere to the sustainability requirements shown above for the selected materials to be considered sustainable. The importance of these factors in the model can be described as follows:

Resource depletion: represents the scarcity of certain materials and how much we consume annually in vehicle production and in the other end uses.

Water pollution: environmental impacts and contaminations into water during material extraction and manufacturing. Chemical or foreign substance that contaminate water could be detrimental to human, plant, or animal health.

Life cycle assessment (LCA): the LCA provides a comprehensive framework to assess materials or products from material extraction all the way to the end-of-life where products can be recycled, reused or landfilled depending on the economic value of the materials/products and environmental regulations in the country where the products end up. Use phase is the most demanding energy and most contributing phase for GHG emission in the typical LCA for vehicles. Besides the traditional LCA that focuses on emission analysis, new sub-topics have been introduced recently to emphasize certain aspects of the life cycle impacts. Examples of these LCA sub-topic include LCEA (life cycle energy analysis), LCIA (life cycle impact analysis to quantify environmental and health impacts), LCC (life cycle cost analysis to assess the ownership cost of the vehicle).

End-of-life and recyclability: retired or end-of-life vehicles can be recycled, reused, or disposed in the landfill. Sending end-of-life vehicles to the landfill means that we are going to lose invaluable resource for recycled materials and will also result in environmental issues such as contaminations of surface and ground water and the loss of the usable land. Recyclability has several metrics (e.g., recycle fraction $(\psi)$; cost of recycling, energy consumption in relative to the energy consumed in producing virgin materials, etc.).

Economic impact factors: Total cost of ownership method represents a comprehensive costing model that takes into consideration material and manufacturing costs, operation and maintenance cost, and end-of-life cost. It also accounts for emissions costs and monetized externalities (health impacts and premature deaths). 
Societal factors: two metrics are used to quantify societal factors. First, safety is an indirect measure for material properties (i.e., toughness and yield strength). Second, "health and wellness" is another indirect measure that is governed by:

- Greenhouse gas emissions, particulate matters, and other effluents to the environment, and their expected adverse effects (e.g., acid rain, global warming potential, and ozone depletion).

- Noise-vibration-harshness performance (which is controlled by dynamic stiffness of the BIW structure and damping capacity of joints and material).

Technical factors: this is an extra pillar added to auto-bodies sustainability model to account for technical requirements to manufacture autobodies using certain hard to manufacture materials, or materials that need special manufacturing routes beyond what is available in the auto assembly plants. Four sub-categories can be considered under technical factors: formability (metals vs. plastic composites), joinability (i.e., weldability and ability to join two different materials using common joining process: riveting, bolting, and brazing), and paintability (the level of difficulty for painting multi-material bodies, or bodies made from plastic composites).

Durability (technical): This parameter can be classified under either environmental or technical factors. Nonetheless, durability in the sustainability model overlaps all economic, environmental, and societal factors, thus enhancing the versatility and effectiveness of the sustainability model.

\subsection{Material selection indices and eco-material selection process}

In the product development process several design iterations are investigated by engineers to decide on which material to use and the required manufacturing routes to make the final product. In this chapter, we discuss eco-material selection process for the primary panels in the body-in-white (BIW). BIW includes several hundred parts but contains a few major structural panels that constitute more than $80-90 \%$ of the BIW weight $[17,25]$. These major panels are shown in Figure 3, and their key design requirements are summarized in Table 2.

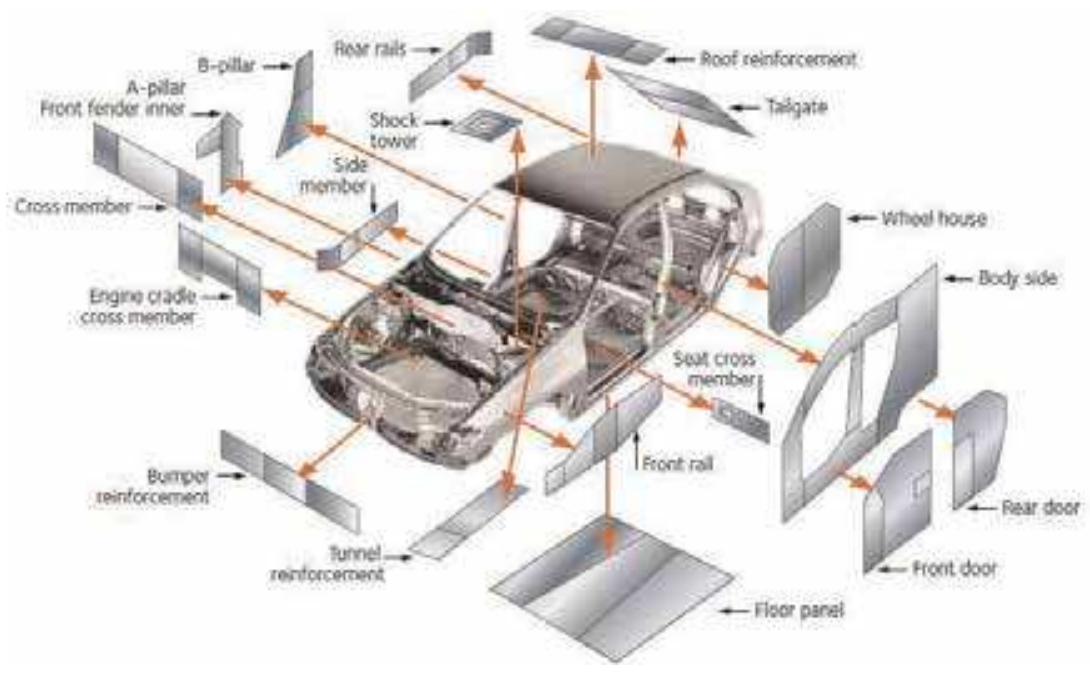

Figure 3.

Body-in-white with closures (courtesy: Ref. [26]). 


\begin{tabular}{|c|c|c|}
\hline No. & Panel name & Main design functions \\
\hline 1 & Roof & Dent resistance, $\mathrm{NVH}^{\dagger}$, durability \\
\hline 2 & Roof reinforcement & Bending stiffness, $\mathrm{NVH}$, ease of manufacturing \\
\hline 3 & Hood (inner) & Bending stiffness, $\mathrm{NVH}$, ease of manufacturing \\
\hline 4 & Hood (outer) & Dent resistance, $\mathrm{NVH}$ \\
\hline 5 & Trunk (inner) & Bending stiffness, NVH, ease of manufacturing \\
\hline 6 & Trunk (outer) & Dent resistance, $\mathrm{NVH}$ \\
\hline 7 & Trunk pan & Strength, NVH, durability \\
\hline 8 & Tunnel reinforcement & Strength, NVH, durability \\
\hline 9 & Engine cradle & Crashworthiness, temperature performance, $\mathrm{NVH}$, durability \\
\hline 10 & Shock towers & Bending stiffness, NVH, durability \\
\hline 11 & Splash/fire wall & Temperature performance, NVH, durability \\
\hline 12 & Quarter panel & Dent resistance, $\mathrm{NVH}$ \\
\hline 13 & Front fender & Dent resistance, $\mathrm{NVH}$ \\
\hline 14 & Door (inner) & Bending stiffness, $\mathrm{NVH}$, ease of manufacturing \\
\hline 15 & Door (outer) & Dent resistance, $\mathrm{NVH}$ \\
\hline 16 & Side members & Bending stiffness, NVH, durability \\
\hline 17 & Wheel house & Bending stiffness, NVH, durability \\
\hline 18 & A, B pillars & Bending stiffness, $\mathrm{NVH}$, ease of manufacturing, durability \\
\hline 19 & Floor pan & Strength, NVH, durability \\
\hline 20 & Bumper & Crashworthiness, NVH, durability \\
\hline
\end{tabular}

Table 2.

BIW major panels and their main design functions [7, 25].

In the proposed material selection strategy, the objective function for each panel is used to rank the candidate materials based on its closeness to the best candidate, which is calculated numerically using a set of derived material selection indices (discussed in the next section). In most cases, the design objective can be expressed in terms of either maximizing or minimizing a mathematical problem. According to Ashby [12], materials selection indices and material selection charts are powerful tools that can be used to map all engineering materials in one chart and then isolate a subset of materials that meets most of the design objectives. The design problem is usually developed with more than one objective function, which requires plotting design requirements on the selection charts and/or using several sequential charts to screen these materials. In some cases, material selection charts can be designed to handle two or more selection indices in one plot to emphasize the tradeoffs between these objectives. The following sections give some examples of the eco-material selection process for several BIW panels.

\subsection{Material selection for bending resistance, lightweight panel}

In this section, we will discuss the method of deriving a simple material selection index using Ashby method. For a flat panel subject to a bending force that has a length $L$, width $w$, and wall thickness $t$, subjected to a bending force $F$ (Figure 4). 


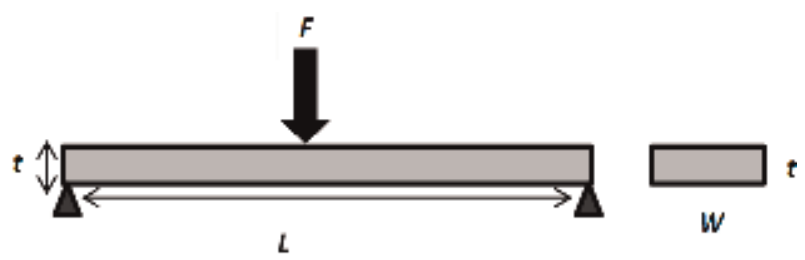

Figure 4.

Simply supported solid rectangular panel under bending force that is designed to withstand certain load without failures.

This panel must not fail under pure bending load, with the objective of minimizing the mass of the panel $(m)$. That is the bending stress on the panel should not exceed its yield stress:

$$
\begin{gathered}
\sigma_{y}>\frac{M \cdot t / 2}{I}=\frac{3 F \cdot L}{w \cdot t^{2}} \\
I=\frac{w \cdot t^{3}}{12}
\end{gathered}
$$

where $m=$ mass, $w=$ width, $L=$ length, $\rho=$ density, $t=$ thickness, $I=$ second moment of area, $\sigma_{y}=$ yield strength.

In this example, assuming that we have an autobody panel with fixed length and width due to the limitations in the space design, while thickness can be varied to meet the design requirements.

Rearranging Eq. (1), will give us the following equation as a function of the panel thickness:

$$
t=\left(\frac{3 F \cdot L}{w \cdot \sigma_{y}}\right)^{1 / 2}
$$

Substituting this in the mass equation $m=$ A.L. $\rho=w . t . L . \rho$, will give us the following:

$$
m=(3 F \cdot w)^{1 / 2}(L)^{\frac{3}{2}}\left(\frac{\rho}{\sigma_{y}^{1 / 2}}\right)=K \cdot\left(\frac{\rho}{\sigma_{y}^{1 / 2}}\right)
$$

where $K=(3 F \cdot w)^{1 / 2}(L)^{\frac{3}{2}}$ is constant. As mentioned above, the panel thickness can be varied for the lightweight design. Under this assumption, the mass substitution rate defined in terms of the ratio of the material density and yield strength and can be expressed mathematically as:

$$
\frac{m_{L W M}}{m_{r e f}}=\frac{\rho_{L W M}}{\sqrt{\sigma_{y, L W M}}} \frac{\sqrt{\sigma_{y, r e f}}}{\rho_{r e f}}
$$

Where subscript LWM: refers to the lightweight material under consideration, and subscript ref refers to the reference material. Note that alternative assumptions regarding how the cross-sectional dimensions are allowed to vary will produce different results for the substitution rate. Using Eq. (5) and the material yield strength will give us the mass substitution rates for this unit cell in relative to any other material used as a reference. For illustration purposes, Dual Phase 280/600 (yield strength $280 \mathrm{MPa}$, ultimate tensile strength $600 \mathrm{MPa}$ ), was selected as the 


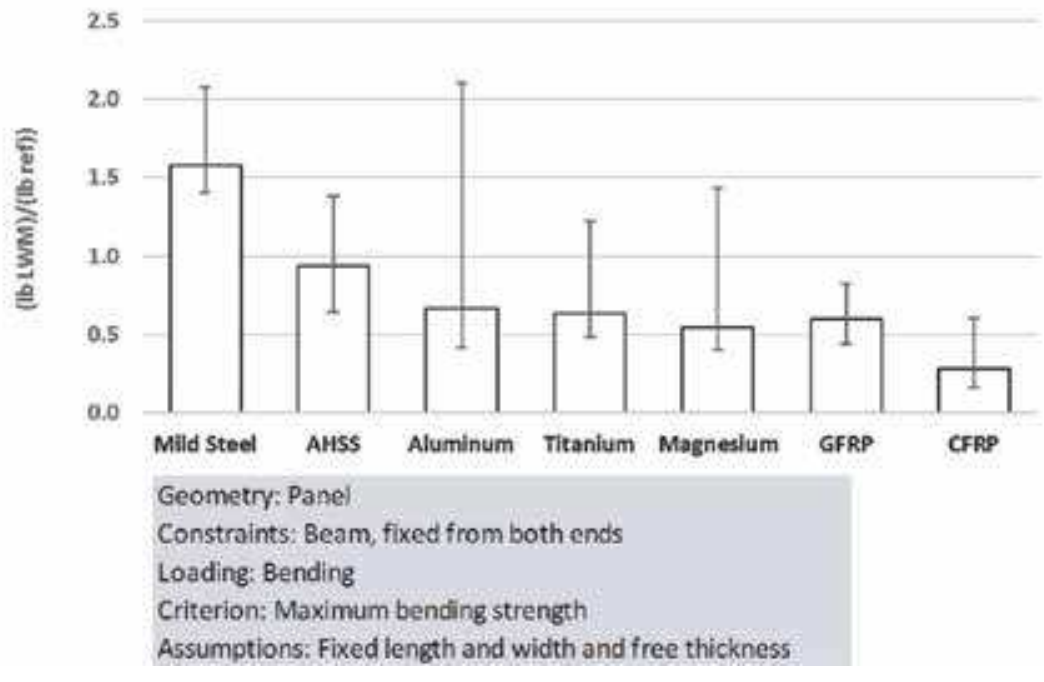

Figure 5.

Average, minimum, and maximum mass substitution rates relative to dual phase $280 / 600$ steel (reference material) (error bar represents min and max).

reference in this example. Figure 5 provides a comparison of the average, minimum, and maximum substitution rates within each material class. Error bars represent minimum and maximum within each material class.

\subsection{Material selection for stiff, lightweight panel}

This example discusses the method for driving a material index for a flat panel, subject to a compressive load. The performance design criterion is maximum stiffness. Figure 6 shows a schematic of this panel with length $L$, width $w$, and wall thickness $t$, subjected to a compressive force $F$.

This panel must not exceed certain stiffness, with the objective of minimizing the mass of the panel:

$$
S=\frac{C \cdot E . I}{L^{3}}
$$

where $I=\frac{w \cdot t^{3}}{12}$

where $m=$ mass, $w=$ width, $L=$ length, $\rho=$ density, $t=$ thickness, $I=$ second moment of area, $E$ = Young's modulus of elasticity.

Length and width are assumed to be fixed due to the limitations in the space design, while thickness is assumed to be free. Rearranging equation 6 , will give us the following:

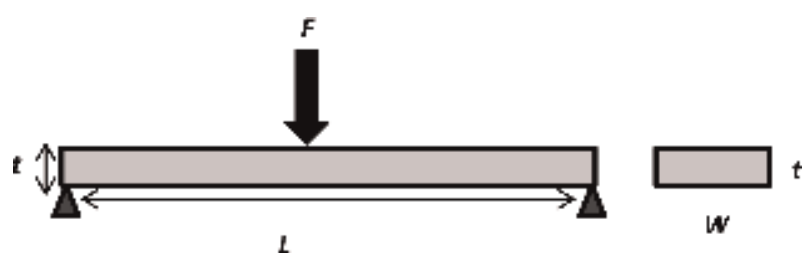

Figure 6.

Simply supported solid rectangular panel under bending force that is designed not to exceed certain deflection. 


$$
t=\left(\frac{12 S . L}{C . E . w}\right)^{1 / 3}
$$

Substituting this in the mass equation $(m=A . L . \rho=w . t . L . \rho)$, will give us the following:

$$
m=\left(\frac{12 S \cdot w^{2}}{C}\right)^{1 / 3} L^{2}\left(\frac{\rho}{E^{1 / 3}}\right)
$$

The component thickness can be varied for the lightweight design. In order to uniquely determine the substitution rate in terms of material properties, an assumption of fixed length and width are adopted and only the panel thickness is allowed to vary. Under this assumption, the mass substitution rate defined in terms of the ratio of the material density and yield strength:

$$
\frac{m_{L W M}}{m_{r e f}}=\frac{\rho_{L W M}}{\sqrt[3]{E_{L W M}}} \cdot \frac{\sqrt[3]{E_{r e f}}}{\rho_{r e f}}
$$

Where subscript LWM: refers to the lightweight material under consideration, and subscript ref refers to the reference material. Note that alternative assumptions regarding how the cross-sectional dimensions are allowed to vary will produce different results for the substitution rate. Using Eq. (9) and the material properties, the mass substitution rates for this panel can be determined for each of the material specifications relative to any other specification used as the reference. Again, we used dual phase 280/600 steel as the reference material for illustration purposes. Figure 7 shows a comparison of the average, minimum, and maximum substitution rates within each material class. Error bars represent minimum and maximum within each material class.

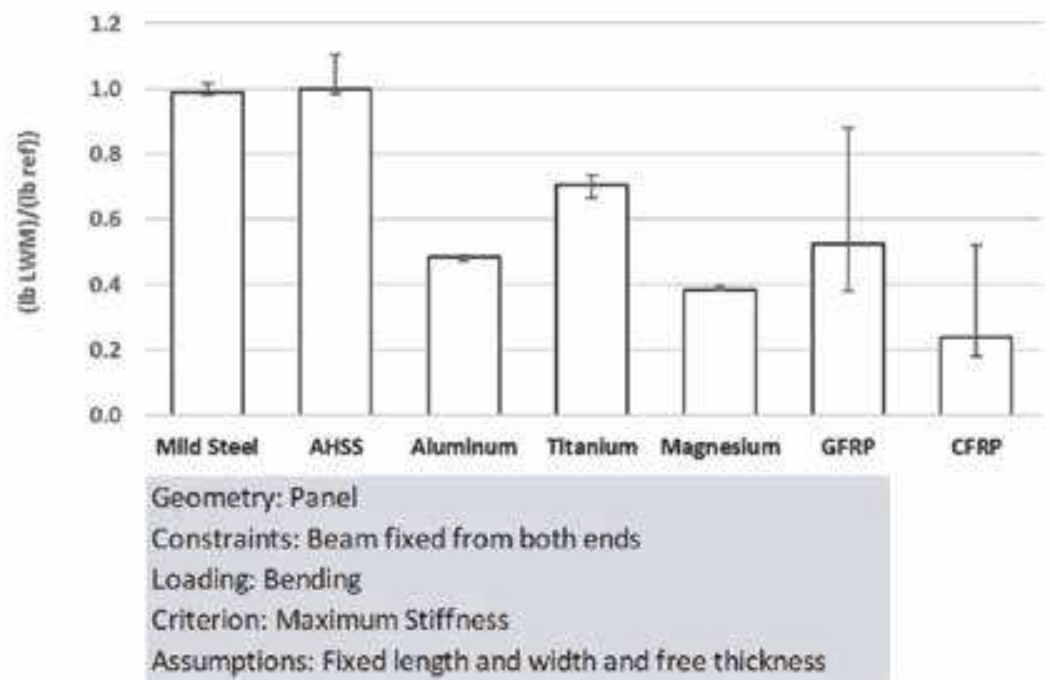

Figure 7.

Average, minimum, and maximum mass substitution rates relative to dual phase $280 / 600$ steel (reference material) (error bar represents min and max). 


\subsection{Eco-material selection for auto-bodies}

In this section, we will discuss an example for deriving a material selection index for a stiff, recyclable, and lightweight panel under bending load. Now let us formulate the design problem using a similar procedure. In this example we have:

Fixed variables: panel, width $w$ and length $L$ are specified.

Objectives: minimize mass, $m$; and maximize recycle fraction $\psi$.

Objective function of this problem in this case is a type of the mixed mix-min function, "minimize mass, $m$ and maximize recycle fraction, $\psi(0 \leq \psi \leq 100 \%)$." Now, if we set the objective functions as a minimization problem only, then:

$$
m \cdot\left(\frac{1}{\psi}\right)=(A L)(\rho) \cdot\left(\frac{1}{\psi}\right)=(w t L)(\rho) \cdot\left(\frac{1}{\psi}\right)
$$

Constraints: stiffness of the panel, $S$ :

$$
\begin{gathered}
S=\frac{F}{\delta} \Rightarrow S=\frac{C E I}{L^{3}} \\
I=\frac{w t^{3}}{12}
\end{gathered}
$$

where $m=$ mass, $w=$ width, $L=$ length, $\rho=$ density, $t=$ thickness, $S=$ stiffness, $I=$ second moment of area, $E=$ Young's modulus.

Variables: material choice, panel thickness " $t$ " or combination of both.

Hence, if we eliminate $t$ and re-arrange the equation, we will get:

$$
\frac{m}{\psi}=\left(\frac{12 S w^{2}}{C}\right)^{1 / 3} L^{2}\left(\frac{\rho}{\psi \cdot E^{1 / 3}}\right)
$$

To maximize this equation, one should choose materials with largest:

$$
M=\frac{\Psi E^{1 / 3}}{\rho}
$$

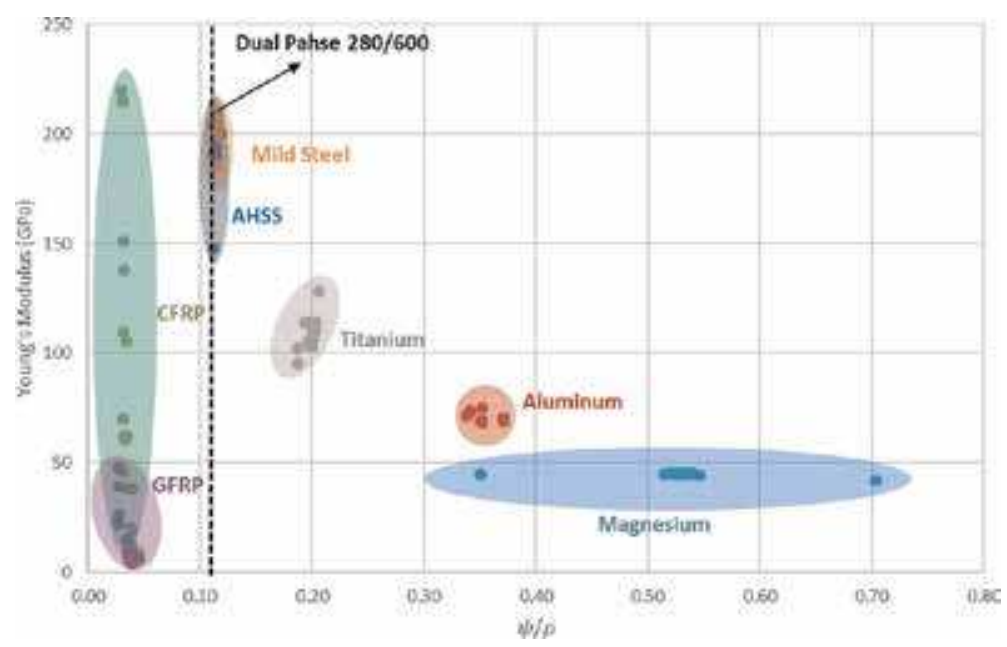

Figure 8.

Materials for stiff, lightweight-recyclable panels (e.g., A-, B-, and C-pillars, inner door and inner hood panels). 
So for material 2 to replace material 1, the following equation should be valid:

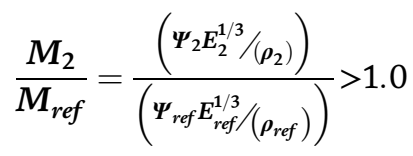

Material selection chart for a stiff, lightweight, and recyclable panel is shown in Figure 8. The dashed line in this chart separates materials with a $\psi / \rho$ value $>0.1128$. These candidate materials such as titanium alloys, aluminum alloys, magnesium alloys, and some types of mild steel and AHSS are considered suitable to replace dual phase 280/600 steel in lightweight stiffness panels. While CFRP and GFRP represent very good candidate materials from the lightweight perspective, their low recyclability could limit their use when recycling is considered in the design requirements.

\subsection{Example of material selection for recyclable hood (inner panel)}

In this section, we will discuss a numerical example for eco-material selection for lightweight hood (inner panel) (Figure 9). The main design function for this panel is to withstand certain bending load without failure, so the derived material selection is $M=\frac{E^{1 / 3}}{\rho}$. However, for ecomaterial selection that combines part's functionality and recyclability, the selection index for light stiff panel becomes $M=\frac{\psi \cdot E^{1 / 3}}{\rho}$. The mass of inner panel in the hood is around $4.35 \mathrm{~kg}$ and has an average thickness of $0.65 \mathrm{~mm}$. We assumed that reference hood panel is made from dual phase steel (DP steel) with an average yield strength (YS) of $280 \mathrm{MPa}$ and an average ultimate tensile strength (UTS) of $600 \mathrm{MPa}$. Figure 8 shows the required thickness based on the functionality of the hood (inner panel) made out of DP steel as a reference material and the corresponding thickness of same panel/part made out from other materials. We also calculated the new thickness for panel made from lightweight materials using functionality and recyclability of the materials (shaded bars).

From functionality perspective (i.e., stiffness), magnesium and aluminum alloys can offer more than 50\% in weight savings and some types of GFRPs and CFRPs can save on average 51 and $71 \%$, respectively (Figure 10). Titanium provides modest weight savings with an average weight reduction of $29 \%$ in relative to the dual

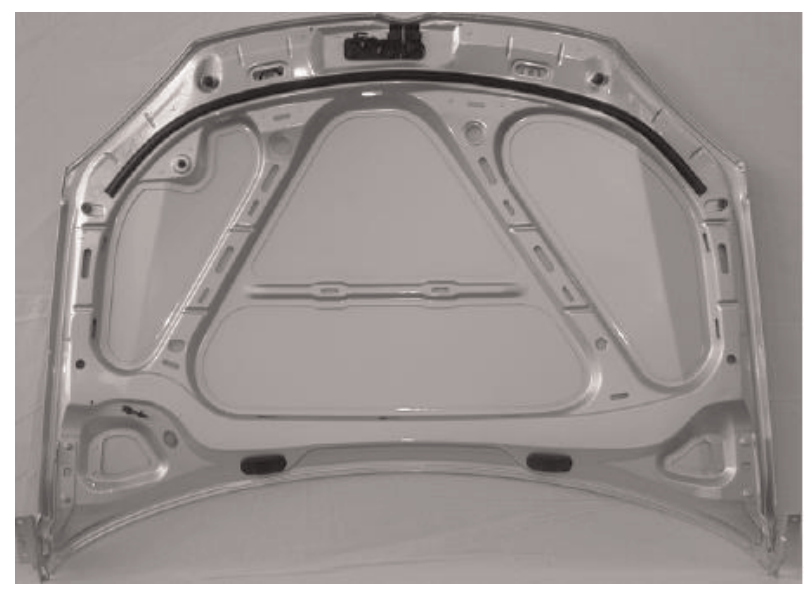

Figure 9.

Hood inner panel (source of picture: Ref. [27]). 


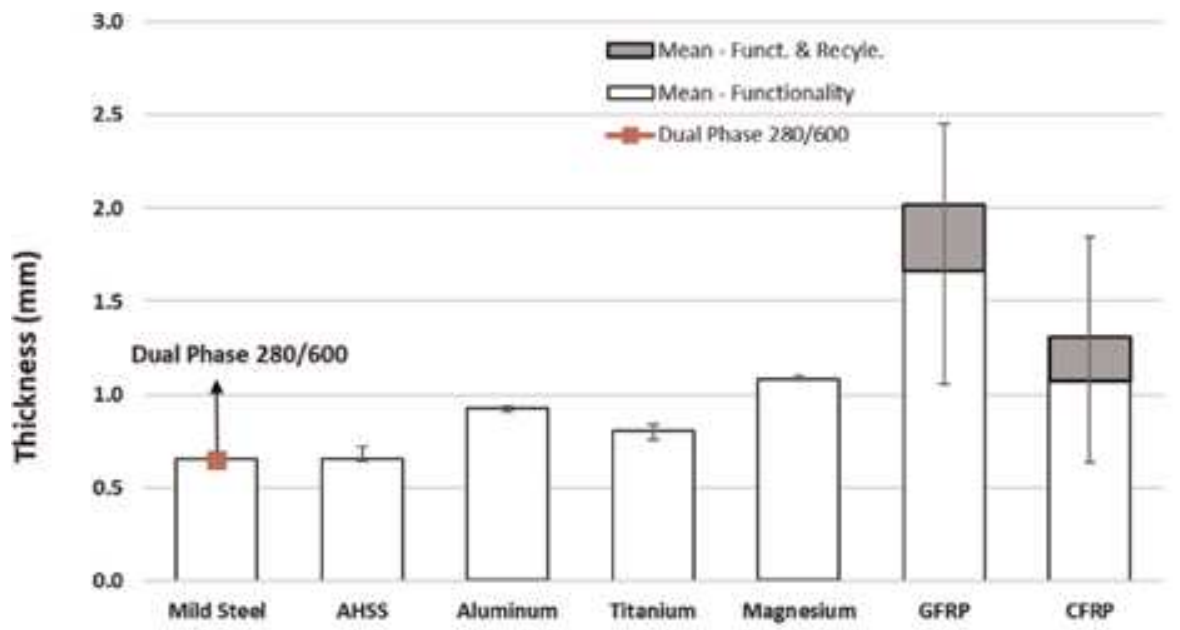

(a)

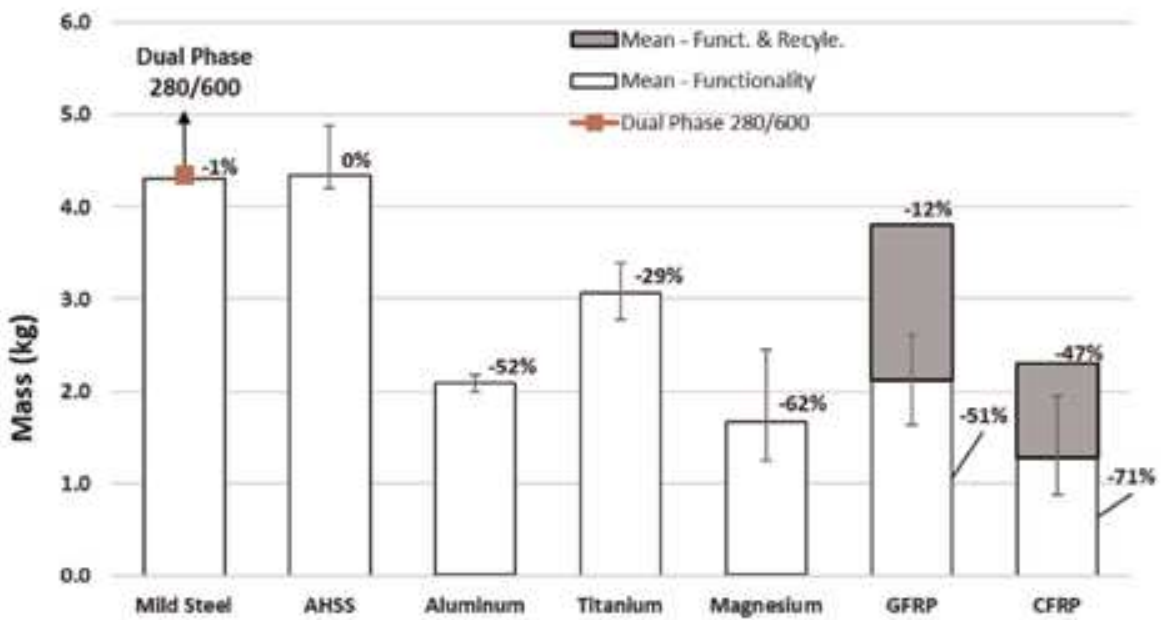

(b)

Figure 10.

New inner hood panel thickness (a), and mass (b) using eco-material selection index for recyclable stiff panel in relative to the panel made from dual phase 280/600 steel. Note 1: shaded bars represent the difference in thickness and mass if the materials are selected based on their stiffness and recyclability. Note 2: percentages represent calculated mass saving in relative to a hood (inner panel) made from dual phase $280 / 600$.

phase steel. Since our derived material selection indices go beyond classical functionality selection and consider sustainability factors, then we may need to consider recyclability when we select candidate materials to replace dual phase in the hood inner panel. Now, if we look back at the thickness and mass saving charts in Figure 10, we can see slight changes (in the range of 0-2\%) in the values for steels, AHSS, aluminum, magnesium and titanium which have recycle fraction that exceed 90\% in most case. CFRP and GFRP are known for their poor recyclability at the end of the life, so we assumed that recycle fraction is $50 \%$ for these composite materials. Upon incorporating these recycle fractions in the thickness and mass calculations, we found that these materials start to look less appealing from the "functionality and recyclability" perspective. That is, their low recyclability divert the selection 
toward more recyclable materials that have the ability to reduce the panel weight and have good recyclability at the same time.

If we want to rank those materials that can meet functionality and recyclability requirements, then we can consider other factors such as cost or manufacturability and add them to the design problem as new constrains. By doing so, we expect aluminum to have better advantage in terms of manufacturability and cost if compared with magnesium and titanium alloys.

\section{Qualitative material selection}

As mentioned previously in Section 2, that some sustainability factors are qualitative in nature and can be used in their natural units or can be quantified using certain transformation methods. For example, corrosion resistance of material is a qualitative parameter and materials can be classified as having high, medium, or low corrosion resistance. Similarly, wear resistance can be also expressed qualitatively. An example of these simple scaling systems is shown in Figure 11a which can be used to rank materials based on their yield strength and resistance to saltwater (as a result of the salt used to melt the snow on the roads). This chart has five scales along x-axis: very poor, poor, average, good, and very good, and yield strength along the $y$-axis. This type of qualitative charts can help guide design engineers in selecting loadbearing, corrosion resistance materials. A good example of such application is floorpan and some other parts in the chassis. Alternatively, engineers can plot two durability characteristics in a single chart to learn more about relative performance of the candidate material or group of materials (Figure 11b). Material selection chart shown in Figure 11b can be used to assess relative performance for materials that in contact with the hot parts in the engine and can be affected from saltwater. Examples of such panels include firewall or floorplan parts that are in contact with the exhaust pipes and subject to contact to the saltwater from the roads.

On the other hand, the absence of a well-established scientific method to quantify some of the societal factors (i.e., safety and health and wellness) and technical factors (formability, weldability/joinability and ability to be paint) also shows the need for design team to have those qualitative charts that help them understand the relative performance of these materials in the material screening during the early design phases.

There are some sustainability factors that can be expressed in a mixed quantitative/qualitative way depending on the function of the part and the material properties. For example, safety can be expressed in many ways such as the resistance of the part to permanent deformation (yield strength) or based on the assessed crashworthiness of the whole vehicle. While yield strength is an intrinsic material property, it seems that crashworthiness is a mixed design function that factors material properties (yield strength, toughness, etc.) and the part design parameters (e.g., shape and geometry of the part). The complexity of the sustainability factors in this case does not mean we cannot derive a sustainability material selection index to facilitate material selection in the early design stages, rather it should simplify the ecomaterial selection process. In this study, we define safety from a material selection perspective as the material property that plays a key role in determining crashworthiness if a vehicle is involved in any accident including minor crashes. By doing so, safety is assumed to have strong relationship with yield strength and the material toughness. Similarly, health and wellness can be defined as the material characteristics that interfere with human health and quality of the air. A simple function of health and wellness should include the amount of emissions released to the 


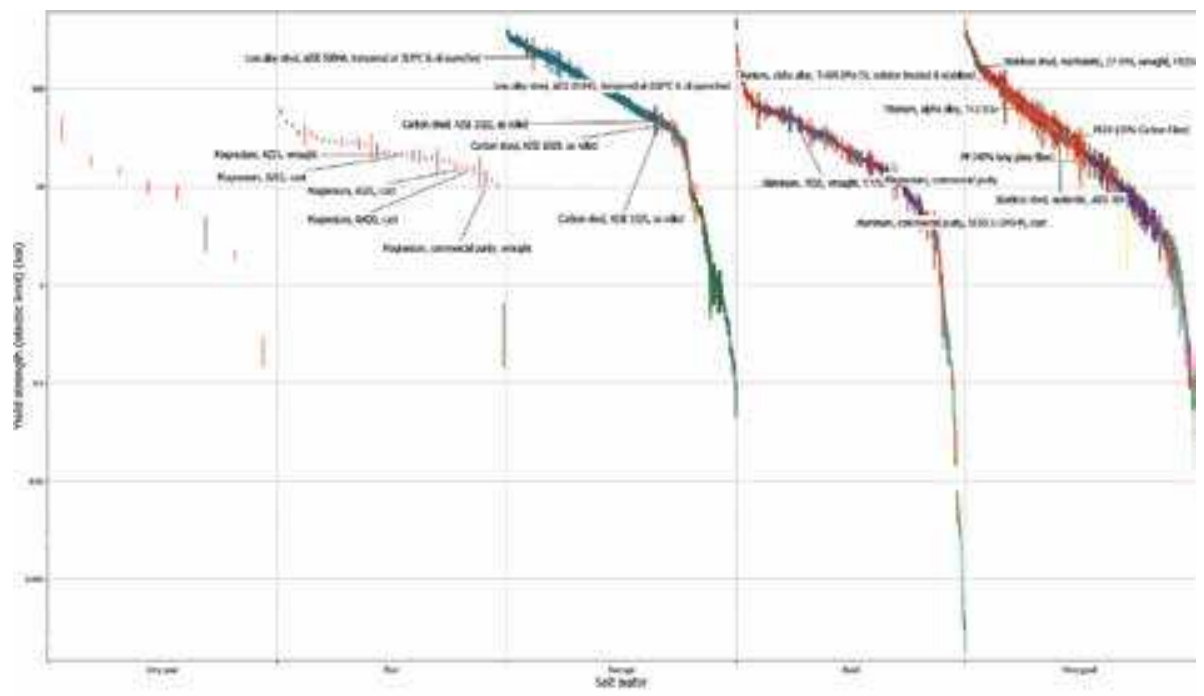

(a)

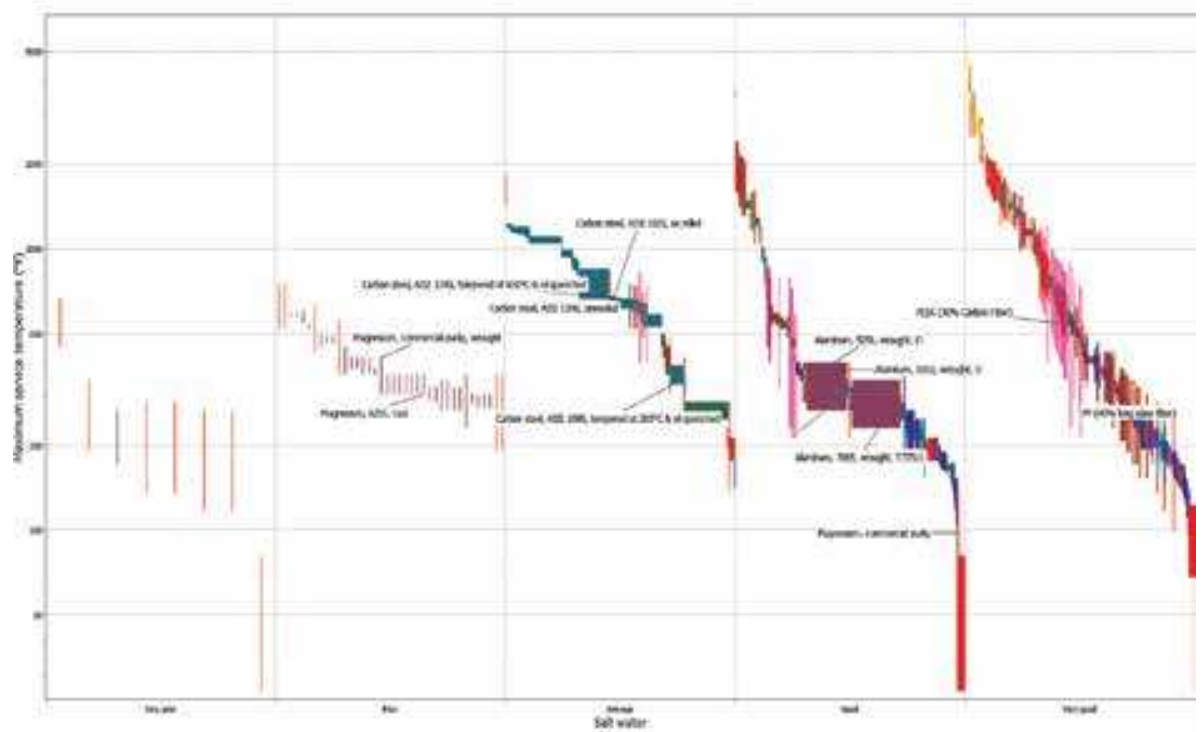

(b)

Figure 11.

Example of scaling method for (a) corrosion resistance (in saltwater) for stiff materials, and $(b)$ material selection chart with combined durability selection criteria for corrosion resistance and maximum service temperature.

environment from cradle to grave (i.e., in all mining and manufacturing processes involved in production and use of the vehicle, and ultimately the recycling or landfilling of the retired parts made from these materials). Thermal performance here represents a qualitative metric that measures relative performance of certain materials in a high temperature environment, especially those parts near or in contact with the engine block where temperatures could easily reach $100^{\circ} \mathrm{C}$ or more [28]. While classical sustainability models have three pillars to cover environmental, economic and social factors, we still believe that a good sustainability model for auto-bodies should also take into consideration extra technical factors (i.e., forming, welding and joining, and painting) which describe the manufacturability 


\begin{tabular}{|c|c|c|c|c|c|c|c|c|}
\hline \multirow[b]{2}{*}{ Material } & \multicolumn{3}{|l|}{ Durability } & \multicolumn{2}{|l|}{ Societal } & \multicolumn{3}{|c|}{ Technical } \\
\hline & Corrosion resistance & Thermal performance & Wear resistance & Health and wellness $\left(\mathrm{NVH}^{\mathfrak{S}}\right)$ & Crash-worthiness $^{\mathscr{I S}}$ & Forming & Joining & Painting \\
\hline Dual phase steel 280/600 & Avg. & VG & VG & Avg. & G & G & VG & VG \\
\hline Mild Steel & Avg. & VG & VG & Avg. & G & G & VG & VG \\
\hline AHSS & Avg. & VG & VG & Avg. & VG & Avg. & G & VG \\
\hline Aluminum alloys & G & VG & Avg. & VG & $\mathrm{P}$ & G & Avg. & VG \\
\hline Magnesium alloys & $\mathrm{P}$ & VG & Avg. & VG & $\mathrm{P}$ & Avg. & Avg. & G \\
\hline Titanium alloys & VG & VG & Avg. & Avg. & VG & Avg. & Avg. & G \\
\hline CFRP & VG & Avg. & G & $\mathrm{P}$ & VG & VG & G & VG \\
\hline GFRP & VG & Avg. & VG & $\mathrm{P}$ & $\mathrm{P}$ & VG & G & VG \\
\hline $\begin{array}{l}\text { V: very poor }(V P), \text { poor }(P), \\
V H \text { is function of vehicle stif } \\
\text { rashworthiness is function of }\end{array}$ & $\begin{array}{l}\text { verage (Avg.), good }(G), \\
\text { less and material dampin } \\
\text { yield strength and toughn }\end{array}$ & $\begin{array}{l}\text { and very good (VG). Sourc } \\
\text { properties. } \\
\text { ss the material. }\end{array}$ & of data: $[25,29-3$ & & & & & \\
\hline
\end{tabular}

Table 3.

Scales for some qualitative material selection criteria for several material classes used in making autobodies [17, 25$]$. 
of different materials considered in the complex eco-material selection problems. Unfortunately, these technical factors have neither well-established material selection indices nor any material selection charts that designers can use for screening and sorting purposes. For these reasons, we propose using a scale that has five classes (very poor, poor, average, good, and very good) to evaluate the relative performance of candidate materials from the manufacturability perspective. The ratings provided in Table 3 were collected from different sources (e.g., [29-30]) and should be used with caution and only provide guidelines to assist engineer in the material selection process.

\section{Impact of light-weighting on the life cycle assessment of the vehicle}

In this section we will study the impact of using lightweight materials on the greenhouse gas GHG emissions over the vehicle's lifetime. Table 4 summarizes key lightweight design parameters including curb weight and percentage weight reduction assuming a steel-intensive body design as the base case in this analysis. We can say that most lightweight materials including aluminum alloys, magnesium alloys and carbon fiber reinforced plastics are associated with higher values of GHG emission in the material extraction and refining. Manufacturing phase accounts for about $2-4 \%$ of the total LCA emissions, so it has low impact on the overall LCA. End-of-life credits indicate that recyclable materials are more favored from LCA perspective because they can save energy upon recycling when the vehicle is retired. Use-phase is the most contributing source of GHG emissions in the vehicle's

\begin{tabular}{|c|c|c|c|c|c|}
\hline \multirow{3}{*}{$\begin{array}{l}\text { Powertrain } \\
\text { Car type (base) } \\
\text { Material }\end{array}$} & \multicolumn{5}{|c|}{ Internal combustion engine } \\
\hline & \multicolumn{5}{|c|}{ Mid-size car } \\
\hline & Conv. steel & Adv. steel & Al & $\mathrm{Mg}$ & CFRP \\
\hline Potential weight saving $(\%)^{1}$ & 0 & $19 \%$ & $30 \%$ & $37 \%$ & $37 \%$ \\
\hline Estimated curb wt. (lb) ${ }^{2}$ & 3370 & 2729 & 2359 & 2123 & 2123 \\
\hline Estimated Curb wt. (kg) & 1528 & 1238 & 1070 & 1024 & 1024 \\
\hline$\$ /$ kg saved in vehicle weight ${ }^{3}$ & $\$-$ & $+\$ 0.50$ & $+\$ 5.00$ & $+\$ 6.50$ & $+\$ 10.00$ \\
\hline Fuel Economy (MPG) ${ }^{4}$ & 34.40 & 39.68 & 43.54 & 46.42 & 46.42 \\
\hline \multicolumn{6}{|c|}{ GHG Emissions (metric tons of $\left.\mathrm{CO}_{2-\mathrm{eq}}\right)^{5}$} \\
\hline Pre-manufacturing & 4.29 & 4.29 & 5.51 & 13.13 & 13.13 \\
\hline Manufacturing & 1.74 & 1.74 & 1.70 & 1.81 & 1.81 \\
\hline Use & 69.77 & 60.49 & 55.12 & 51.70 & 51.70 \\
\hline End-of-life ${ }^{6}$ & -1.18 & -1.18 & -3.33 & -10.00 & 0 \\
\hline Total LCA GHG (metric tons) & 74.62 & 65.34 & 59 & 56.64 & 66.64 \\
\hline Percent Reduction & 0 & $-12 \%$ & $-21 \%$ & $-24 \%$ & $-11 \%$ \\
\hline \multicolumn{6}{|c|}{$\begin{array}{l}{ }_{1}^{1} \text { From Ref. [1]. } \\
{ }^{2} \text { Assuming a steel-intensive vehicle as the base case. } \\
3 \text { Estimates based on values from }[1,5,8] . \\
{ }^{4} \text { Using values from U.S. EPA (Ref. [6]) and adjusted for lightweight designs assuming } 6 \% \text { improvement in vehicle's } \\
\text { fuel economy (mile/gallon) for } 10 \% \text { reduction in the vehicle weight [7-9]. } \\
{ }^{5} \text { Based on values from several sources, see, for example, [1-5, 8-9, 17]. } \\
{ }^{6} \text { Assuming } 90 \% \text { recycle fraction for steels, } 95 \% \text { for aluminum and magnesium and } 0 \% \text { for CFRP. }\end{array}$} \\
\hline
\end{tabular}

Table 4.

Impacts of lightweight materials on the GHG emissions from the vehicle's life cycle. 
lifespan. The good news is that the higher emissions of the lightweight materials in the pre-manufacturing and manufacturing phases will be compensated for in the use phase. As we can see in Table 4, magnesium and aluminum perform better than plastic composites from the LCA perspective. When it comes to the cost, advanced high strength steels are more favored. Unfortunately, CFRP tends to be less favored from both cost and ease of manufacturing perspectives, thus should be considered with those facts in mind in the design process.

\title{
6. Conclusions
}

Many solutions have been adopted in the recent decades to reduce the environmental burdens associated with the production and use of passenger vehicles. Downsizing, design modifications, electrification and lightweight design are among the most common methods used by automakers. Recently, eco-material selection was emerged as a supporting methodology for lightweight design. Eco-material selection process represents a versatile material selection process that combines two or more of the design parameters in the problem formulation, and thus provides a better way of dealing with multi-criteria material selection problems. Other material selection methods may focus on environmental impacts associated with the production, the use phase, or the end-of-life phase. Historically, less emphasis has been given to economic or societal parameters in the discussion of lightweight materials and more emphasis was given to the environmental impacts. To get a balanced approach for eco-material selection, we proposed a holistic design for sustainability (DFS) model for material selection for the major structural panels in the auto-body. This holistic model covers all environmental, economic, safety and societal factors alongside with the technical challenges in manufacturing of the lightweight materials. Unfortunately, the integration of all sustainability aspects in the design process tends to complicate material selection process and requires proper knowledge of relative importance of the design functions and material selection criteria. Design for sustainability model with the aid of the materials selection indices and material charts offer good tools that can help designers screen and rank materials using their relative performance in the early conceptual design stage.

\section{Author details}

\author{
Ahmad T. Mayyas and Mohammed Omar* \\ Department of Industrial and Systems Engineering, Khalifa University of Science \\ and Technology, Abu Dhabi, United Arab Emirates \\ *Address all correspondence to: mohammed.omar@ku.ac.ae
}

\section{IntechOpen}

(C) 2020 The Author(s). Licensee IntechOpen. Distributed under the terms of the Creative Commons Attribution - NonCommercial 4.0 License (https://creativecommons.org/ licenses/by-nc/4.0/), which permits use, distribution and reproduction for non-commercial purposes, provided the original is properly cited. (cc) BY-NC 


\section{References}

[1] Goguen S, Schutte C, Joost W. Lightweight Materials. Available from: https://www.energy.gov/sites/prod/file s/2015/06/f24/lm999_joost_2015_o.pdf

[2] Cheah LW. The trade-off between automobile acceleration performance, weight, and fuel consumption. SAE International Journal of Fuels and Lubricants. 2009;1:771-777

[3] Fuchs E, Field F, Roth R, Kirchain R. Strategic materials selection in the automobile body: Economic opportunities for polymer composite design. Composites Science and Technology. 2008;68:1989-2002

[4] Mayyas A, Omar M, Hayajneh M, Mayyas AR. Vehicle's lightweight design vs. electrification from life cycle assessment perspective. Journal of Cleaner Production. 2017;167:687-701

[5] Das S. The life-cycle impacts of aluminum body-in-white automotive material. Journal of the Minerals, Metals and Materials Society. 2000;52:41-44

[6] EPA Environmental Protection Agency. Fuel Economy Website. 2018b. Available from: https://www.epa.gov/f uel-economy-trends/highlights-co2-a nd-fuel-economy-trends. [Accessed: 25 March 2019]

[7] Mayyas AT, Qattawi A, Mayyas A, Omar M. Life cycle assessment-based selection for a sustainable lightweight body-in-white design. Energy. 2012;39: 412-425

[8] Brooker AD, Ward J, Wang L. Lightweighting impacts on fuel economy, cost, and component losses. NREL/CP-5400-57607. 2013. SAE International 2013-01-0381

[9] Cheah LW. Cars on a diet: The material and energy impacts of passenger vehicle weight reduction in the U.S. [thesis]. Massachusetts:

Institute of Technology; 2010

[10] Farag MM. Quantitative methods of materials selection. In: Kutz M, editor. Handbook of Materials Selection. New York: John Wiley \& Sons, Inc.; 2002

[11] Wegst GK, Ashby MF. The development and use of a methodology for the environmentally-conscious selection of materials. In: Proceedings of the Third World Conference on Integrated Design and Process Technology (IDPT); 5; 1998. pp. 88-93

[12] Ashby M. Materials and the Environment. 1st ed. Oxford, UK: Butterworth-Heinemann; 2009

[13] Coulter S, Bras B, Winslow G, Yester S. Designing for material separation: Lessons from automotive recycling. In: Proceedings of the 1996 ASME Design Engineering Technical Conferences and Computers in Engineering Conference; 18-22 August 1996; Irvine, California

[14] Ermolaeva NS, Castro MBG, Kandachar PV. Materials selection for an automotive structure by integrating structural optimization with environmental impact assessment. Materials \& Design. 2004;25:689-698

[15] Kampe SL. Incorporating green engineering in materials selection and design. In: Proceedings of the 2001 Green Engineering Conference; Sustainable and EnvironmentallyConscious Engineering, Virginia Tech's College of Engineering and the U.S. Environmental Protection Agency; Roanoke, VA; 2001

[16] Mayyas AM, Omar M, Hayajneh M. Using quality function deployment and analytical hierarchy process for material selection of body-in-white. Materials \& Design. 2011;32:2771-2782 
[17] Mayyas AT, Omar M, Hayajneh MT. Eco-material selection for auto bodies. In: Martínez L, Kharissova O, Kharisov B, editors. Handbook of Ecomaterials. Cham.: Springer; 2017

[18] Rao V. A decision-making methodology for material selection using an improved compromise ranking method. Materials and Design. 2008;29: 1949-1954

[19] Zhou CC, Yin GF, Hu XB. Multiobjective optimization of material selection for sustainable products: Artificial neural networks and genetic algorithm approach. Materials and Design. 2009;30:1209-1215

[20] Cicek K, Celik M. Multiple attribute decision-making solution to material selection problem based on modified fuzzy axiomatic design-model selection interface algorithm. Materials and Design. 2010;31:2129-2133

[21] Dehghan-Manshadi B, Abedian MH, Mahmudi R. A novel method for 400 materials selection in mechanical design: Combination of non-linear normalization and a 401 modified digital logic method. Materials and Design. 2007;28:8-15

[22] Sharif-Ullah AM, Harib KH. An intelligent method for selecting optimal materials and its application. Advanced Engineering Informatics. 2008;22: 473-483

[23] Brifcani N, Day R, Walker D, Hughes S, Ball K, Price D. A review of cutting-edge techniques for material selection. In: 2nd International Conference on Advanced Composite Materials and Technologies for Aerospace Applications; Wrexham, UK; 11-13 June 2012

[24] Opricovic S, Tzeng G. Compromise solution by MCDM methods: A comparative analysis of VIKOR and TOPSIS. European Journal of Operational Research. 2002;156:445-455
[25] Mayyas A, Omar M, Hayajneh M. Eco-material selection for auto bodies. In: Njuguna J, editor. Lightweight Composite Structures in Transport. Sawston, Cambridge, UK: Woodhead Publishing; 2016

[26] ArcelorMittal Tailored Blanks [Internet]. Available from: http://www. arcelormittal.com

[27] Hamacher M, Wohlecker R, Ickert L. Simulation of a vehicle hood in aluminum and steel. In: 2008 Abaqus Users' Conference; Newport, Rhode Island, USA; 19-22 May

[28] Hamzehei M, Rashidi M. Determination of piston and cylinder head temperature distribution in a 4-cylinder gasoline engine at actual process. In: Proceedings of the 4th WSEAS Int. Conf. on Heat Transfer, Thermal Engineering and Environment; 21-23 August 2006; Elounda, Greece; pp. $153-158$

[29] Cambridge Engineering Selector software (CES 2008). Cambridge, UK: Granta Design; Available from: https:// grantadesign.com/industry/products/ ces-selector/selection-tools/

[30] Davies G. Materials for Automobile Bodies. 1st ed. Oxford, UK:

Butterworth-Heinemann; 2004 


\title{
Plantation Forests: A Guarantee of Sustainable Management of Abandoned and Marginal Farmlands
}

\author{
Mudrite Daugaviete, Dagnija Lazdina, Baiba Bambe, \\ Andis Lazdins, Kristaps Makovskis and Uldis Daugavietis
}

\begin{abstract}
The chapter summarises the research data on cultivating forest crops in abandoned and marginal farmlands (AL). The course of growth and productivity of different tree species in the local climatic conditions is clarified in a variety of agricultural soils. The research results show the most appropriate tree species for short-rotation or special end-use monoculture or mixed plantations, using Scots pine (Pinus sylvestris L.), Norway spruce (Picea abies (L.) Karst.), silver birch (Betula pendula Roth.), pedunculate oak (Quercus robur L.), grey alder (Alnus incana (L.) Moench), alder (Alnus glutinosa (L.) Gaertn.), wild cherry (Cerasus avium (L.) Moench syn. Prunus avium), aspen (Populus tremula L.), hybrid aspen (Populus tremula $x$ tremuloides), and small-leaved lime (Tilia cordata Mill.). At the same time, research results show sustainability of management of plantation forests-positive impact on soil agrochemical properties, proportionate changes on above-ground vegetation, and improvement of economic benefits of farmlands.
\end{abstract}

Keywords: plantation forest, abandoned, marginal farmlands, forest tree species, soil agrochemical properties, above-ground vegetation, productivity, yield, biomass

\section{Introduction}

The issue of rational and sustainable management of land has been the focus of the countries of the world for several centuries, but the term sustainable was coined in the 1990s of the twentieth century. The term implies that the issue must be addressed as a set of issues:

- Quality of the surrounding environment.

- Economic sustainability.

- Social viability [1-19]. 
Meanwhile, the quality of the surrounding environment is characterised by the quality of soil, water, and air that forms the basis for ecosystems and sustainability [1-19].

Scientists and practitioners have unanimously recognised that, as the population of the planet increases, the demand for wood, wood biomass, and their products is increasing, and therefore the importance of plantation farms in the meeting of these needs is considerable [1-19]. Large-scale afforestation projects are developed in many countries of the world to resolve the economic problems of the national economy starting from the 1960s of the previous century in European countries: Germany, France, the UK, Denmark, Poland, Ireland, Spain, Italy, Portugal, Greece, Sweden, Norway, Finland, etc. [19].

Currently, large afforestation projects are being implemented in the USA, Canada, countries of South America, African countries, China, Indonesia, New Zealand, Japan, and countries of Southern Asia [19]. Woody plants were already planted as one of the main sources of human existence (food, timber, medicinal plants, etc.), thousands of years ago [15]. One of the first woody plants that was planted in large areas for food purposes was the olive tree (Olea europaea). Initially, the plantations occupied large areas in Romania, Greece, and China. About a thousand years ago, the selection of the best specimens of various tree species was commenced, and plantations for obtaining high-quality timber and other products were developed. From 1500 onwards, the selection and propagation of the best specimens of eucalyptus, pine, and other woody plant species were performed in Western Europe with the purpose of obtaining high-quality plantations. Furthermore, woody plants were used for landscaping purposes, the creation of parks, etc. The development of teak, balsa, eucalyptus, various species of pine, and other plantations has been practised in the Southern Hemisphere-Africa, Asia, South America, Australia, etc., since 1950. Meanwhile, in Europe, extensive afforestation of unused agricultural land commenced in the 1960s-in Europe: Sweden, Finland, Denmark, Germany, etc.; in North America: the USA and Canada; and in South America: Brazil, Chile, etc.

The plantations are subdivided into industrial and protective plantations, plantations of various technical crops, plantations for the improvement of low-yielding agricultural lands, short-rotation technical biomass production plantations, and other plantations. The scope of development of these types of plantations is growing worldwide [2].

In the boreal and semi-boreal forest zone, as well as in the countries of the northern part of Europe-Norway, Finland, Sweden, the Baltic states-the main coniferous tree species planted in the forest plantations are those of the pine (Pinaceae) family, pines (Pinus spp.: Pinus sylvestris, Pinus murrayana, Pinus contorta a.o.), spruce (Picea spp.: Picea abies, Picea sitchensis a.o.), and larches (Larix spp.: Larix decidua, Larix sibirica, Larix $x$ eurolepis a.o.); as the main deciduous tree species we can mention birch family (Betulaceae) species: birches (Betula pendula, B. pubescens), alders (Alnus glutinosa, Alnus incana a.o.), hybrid aspens and poplars (Populus tremula $x$ P. tremuloides, Populus $x$ canadensis a.o.), and osier varieties (Salix spp.) a.o. [1, 5, 7-12, 14, 18, 20-23]. Scientists conclude that when selecting areas for plantation establishment, not only the choices of the location, soil type, hydrological regime, and microclimate must be taken into consideration, but also, depending on those characteristics, the plantation establishment technology, one or several tree species, management regime, and potential future products must be determined. Depending on the type of plantation, short rotation for obtaining biomass and roundwood plantations for obtaining pulpwood, and veneer log and sawlog productions, appropriate tree species must be selected and density established (500-5000 trees/ha or 10,000-25,000; species of ligneous plants-Salix 
species, willow species, viburnums, and elders [1, 7-12, 14, 18, 20-34]). Experience with afforestation demonstrates that throughout the Nordic region of the EU, there has been an increased emphasis on the use of native species-Scots pine, Norway spruce, and silver birch [1, 2, 5, 8, 10, 11, 17, 27, 30, 31]. The scientists and practitioners came to the conclusion-in Northern Europe, silver birch and Norway spruce are commercially the most important tree species for plantation forestry $[2,11,14,20-34]$.

Energy wood plantations intended for the production of wood biomass, which are also serving as reducers of large amounts of atmospheric carbon dioxide $\left(\mathrm{CO}_{2}\right)$ and reduce the salinity of soils by enabling the use of sewage water sludge for the increase in wood biomass, have been becoming increasingly important over recent decades $[2,35,36]$.

Today, more than 287 million hectares worldwide are occupied by plantation forests, which ensure $1 / 3$ of forest industry production, which mainly produces timber for the needs of construction and the paper industry $[2,6]$. According to the data of the FAO, the areas of plantation forests have increased by about 5 million hectares per year [19]. The management of plantation forests contributes to the conservation of natural forests, where the harvesting of timber has significantly decreased taking into account the productivity of plantation forests, $[2,5,14,16]$. According to the data of the FAO, timber produced by plantation-type stands ensures approximately $15 \%$ of the worldwide demand for timber [19].

The first record of the establishment of forests in low-fertility agricultural land in the territory of Latvia dates back to the nineteenth century, but the extensive afforestation of low-value and unused agricultural land started in the 1920-1930s of the twentieth century, i.e. after the declaration of the independence of Latvia [37]. To promote the economic growth of the country, particular attention was paid to the development of forestry as a very important sector of the economy, especially to the increase in forest areas $[38,39]$. However, experts of forestry admitted that significant mistakes were made while planting trees in agricultural fields, primarily soil types that were inappropriate for tree species were selected $[38,39]$. First of all, it refers to pine, which was extensively planted in any type of soil. Examples include plantations of pine in former agricultural lands of middle regions of Latvia, resulting in the loss of $39 \%$ of the plantations by the late nineteenth century, meanwhile during the 1910-1920s of the twentieth century, approximately $80 \%$ of pine plantations in former agricultural lands were lost [38].

The second tree species that was most commonly used in the afforestation of agricultural land was oak, as well as, slightly later, Norway spruce. Both common oak and red oak (Quercus rubra) were used. Extensive plantations of oak were developed in the entire territory of Latvia. Some of these plantations have survived to date, and now they have reached the age of 90-110 and more years.

The main measures for the increase of forest areas in Latvia from the eighteenth century to the first half of the twentieth century were as follows:

- Reinforcement and afforestation of dunes.

- Afforestation of low-value agricultural soils, mainly with common pine, lessNorway spruce (Picea abies). The most commonly used deciduous tree was oak (Quercus robur). Later on, the planting or preservation of naturally afforested areas with the stands of deciduous species-birch (Betula pendula) and common ash (Fraxinus excelsior) —was permitted.

- Development of plant nurseries for the growing of plantlets. 
- Improvement of planting methods [38, 39]. One of the recommended methods was sowing of tree seeds together with cereal crops or in beds, by sowing $40 \mathrm{~kg}$ of seeds per 1 ha, and then rolling the field, because the cereal crop protects the young birch trees from excessive sunlight [43]; the other method involved the use of turf plantlets-young forest trees that were removed with a ball of soil $[39,43]$; cylindrical shovels were used for this method. Usually, 3-4-year-old forest plantlets or plants were chosen [43].

If in 1923 the forest area of Latvia amounted to 1472 thousand ha (forest covered area-22.8\%), then already in 2018, the area of forests increased to 3383 thousand ha (forest covered area-52\%) (Figure 1) [1, 40-42].

In Latvia the issue about rational land utilisation once again became topical in the mid-1990s of the twentieth century when, following the agrarian reform, 36.6\% of agricultural lands (AL) and $42 \%$ of forest land ended up in the possession of private owners ${ }^{1}$. From 2000 to 2017, the area of AL afforested with improved planting material already constituted 61,693 ha, including 18,018 ha of plantation forests (29.4\% of afforested areas), of which 18,000 ha have been reported as plantations (Figure 2) [41]. During the same period, 233,000 ha of uncultivated agricultural land have been naturally afforested [42].

In the time period from 1993 to 2013, the ratio of tree species in naturally afforested areas and plantation-type cultivated stands reached 233,000 ha, of which birch was registered in 91,000 ha, white alder 47,000 ha, pine forest 25,000 ha, aspen 14,000 ha, spruce 13,000 ha, black alder 11,000 ha, and other species (oak, ash, walnut, elk, maple, linden, grasshoppers, willow) 32,000 ha

(Figure 3) [25, 42].

In Latvia, substantial research about the growth and management of Scots pine, Norway spruce, silver birch, aspen, hybrid aspen, ash, and European larch stands in AL was performed by forest scientists after the Second World War [43-45]. In the 1960s the growth of silver birch plantations on former AL shows that the plantations in these areas reach the site index of I-Ia and that in the 1950s their standing volume was up to $439 \mathrm{~m}^{3} \mathrm{ha}^{-1}$ [44]. Extensive research on Scots pine and Norway spruce growth on former AL between the 1950s and 1970s of the twentieth century has been performed by Latvian scientists [43-45]. Plantations on former AL

\section{Forest area, thous. ha}

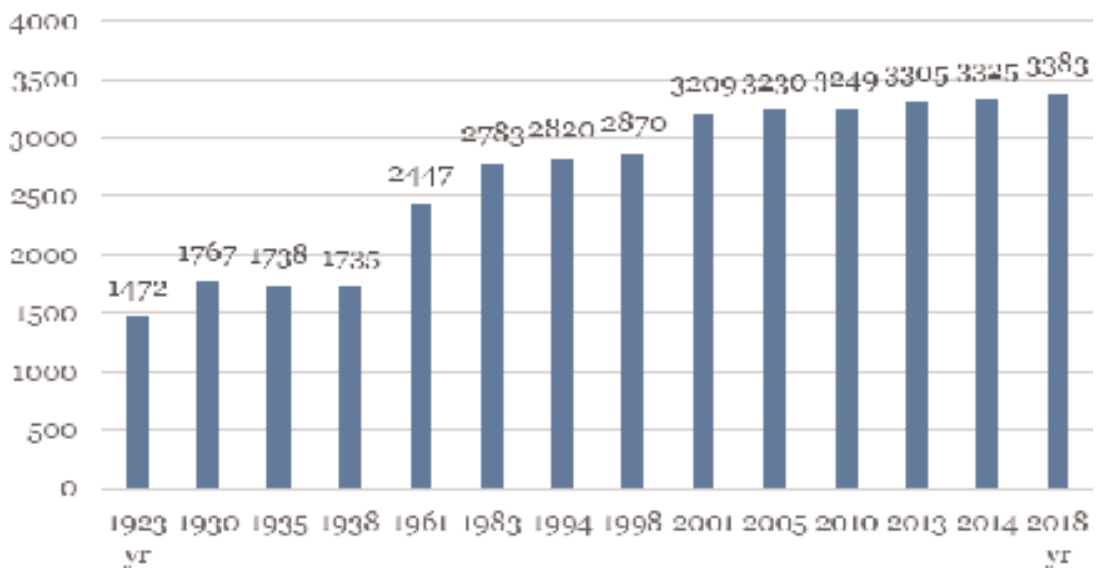

Figure 1.

Forest area dynamics in Latvia 1923-2018 (thousand ha) [1, 40, 41]. 
Plantation Forests: A Guarantee of Sustainable Management of Abandoned and Marginal... DOI: $h$ ttp://dx.doi.org/10.5772/intechopen.88373

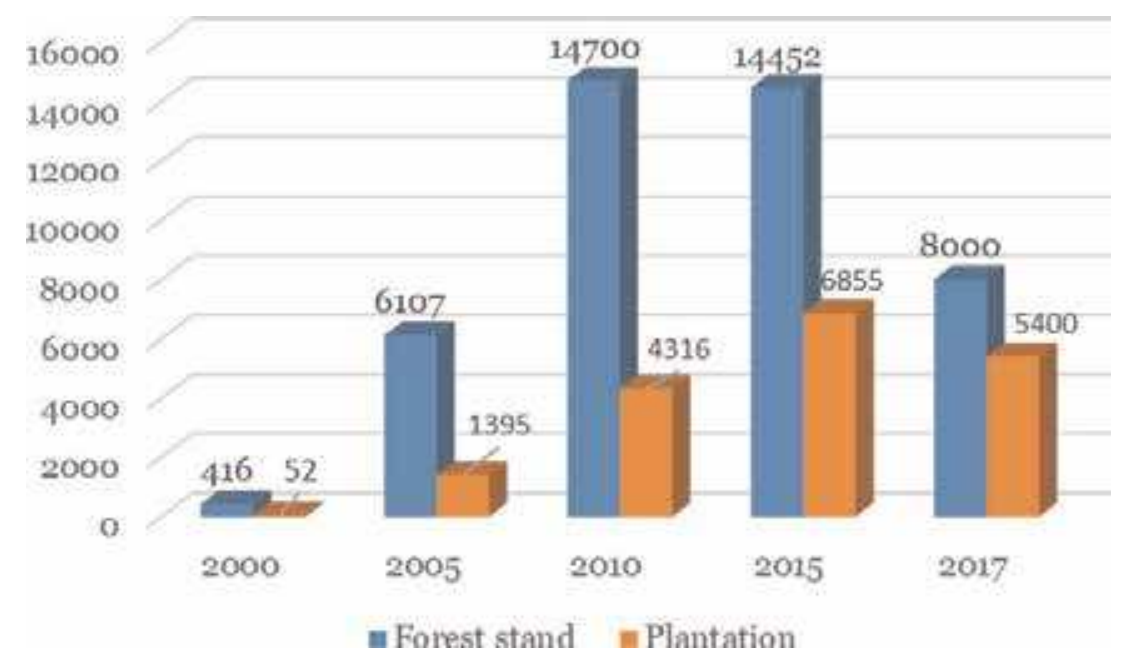

Figure 2.

Afforested abandoned farmland in Latvia during the period 2000-2017 (ha).

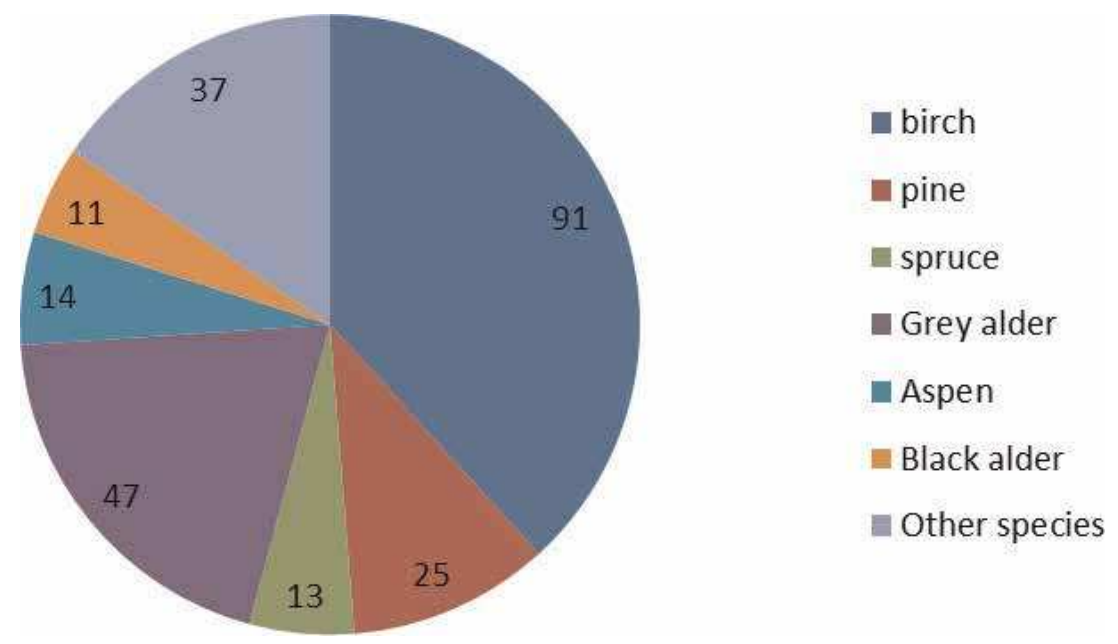

Figure 3.

Area on a per-species basis for natural and planted tree stands in abandoned farmlands, 1993-2013 (thous. Ha) $[25,41]$.

show a high site index class: Norway spruce plantations Ia-Ic and Scots pine plantations-Ia site index. Since 1995 research has been carried out on the growth of plantation forests on former $\mathrm{AL}$, assessing the growth of various tree species and stem quality in current and former year plantations [1, 21, 27, 28, 31, 33]. It has been concluded in this research that in age class I (0-20 years) stands on former AL show higher growth indices (mean height, mean diameter, volume current annual increment), but in the following age classes, the growth evens out. The research continues, as the processes in the environment and the plantation establishment technologies have changed significantly.

In the last decade in Latvia, due to both climatic changes and rational land management guidelines, scientists are carrying out in-depth research about the development and productivity of plantations and plantation forests on afforested $\mathrm{AL}$, improvement of the volume and quality of the grown planting material, as well as the assessment of these stands. The introduction of regulations on "long term plantings" that allow for the possibility of establishing tree plantations on AL, the 
maximum growth period of which is up to 15 years, without transforming the land into forest land also increase interest of fast growing tree cultivation [1]. Statistics show that research on the cultivation of different tree species in plantation-type stands is required, since only $29 \%$ of plantation-type stands have been reported.

The aim of the research is (1) to explain the growth and productivity of plantation-type stands of the most widespread tree species-Scots pine, Norway spruce, silver birch, alder, grey alder, aspen, hybrid aspen, small-leaved lime, pedunculate oak, and wild cherry-in various AL soils, (2) changes in soil agrochemical properties, and (3) changes in above-ground vegetation and (4) assess the economic effectiveness of these plantations.

\section{Material and methods}

The research material has been gathered at 21 established experimental plantations and 150 sample plots in plantations of AL on different soil types: typical sodcalcareous soil (TSC), sod-podzolic gley soil (SPG), gleyic sod-calcareous soil (GSC), sod-podzolic soil (SP), typical podzol (TP), alluvial sod-gley soil (ASG), leached sod-calcareous soil (LSC), base unsaturated brown soil (BUB), strongly altered by cultivation soil (CAS), and humi-podzolic gleyic spoil (HPG) (Table 1; Figure 4).

Pure or mixed species plantations of different stocking density were established using the following tree species: Scots pine (Pinus sylvestris L.), Norway spruce (Picea abies L. Karst.), silver birch (Betula pendula Roth.), alder (Alnus glutinosa L. Gaertn.), grey alder (Alnus incana L. Moench.), pedunculate oak (Quercus robur L.), small-leaved lime (Tilia cordata L.) and European syn. Sweet cherry (Cerasus avium (L.) Moench syn. Prunus avium L.), aspen (Populus tremula L.), and hybrid aspen (Populus tremula $x$ tremuloides Michx.) (Table 1).

In each plantation four circular sample plots $\left(500 \mathrm{~m}^{2}, \mathrm{R}=12.62 \mathrm{~m}\right)$ were set up, choosing their location randomly. The following actions were performed on each sample plot:

- Measuring the DBH of all trees (accuracy $0.1 \mathrm{~cm}$ ) and determining the Kraft class.

- Measuring tree height with Vertex III for 15 trees (5 trees in each diameter class: small, average, and large), (accuracy $0.2 \mathrm{~cm}$ ).

- Determining the number of decaying and dead trees.

- Extracting core samples at chest height from 15 trees to determine the exact tree age and annual ring width; core samples were analysed with WinDendro 2007 software.

In each plantation, tree growth and productivity monitoring has been conducted, determining the following parameters: tree height $(\mathrm{H}), \mathrm{m}$; tree diameter at breast height (D), cm. Measurements repeated every 1-5 years. The first 5 years after the establishment of plantation measurements are repeated each year. The total monitoring period was 15 years. In each sample plot, the standing volume has been calculated [46] and the volume of mean tree, standing volume current annual increment, biomass of each tree component (stem, branches, leaves), and freshly cut biomass were calculated per unit area. 
Plantation Forests: A Guarantee of Sustainable Management of Abandoned and Marginal... DOI: $h$ ttp://dx.doi.org/10.5772/intechopen.88373

\begin{tabular}{|c|c|c|c|c|c|}
\hline $\begin{array}{l}\text { No. } \\
\text { of } \\
\text { trial }\end{array}$ & $\begin{array}{l}\text { Site location: } \\
\text { municipality/ } \\
\text { parish }\end{array}$ & $\begin{array}{c}\text { Site } \\
\text { location }\end{array}$ & $\begin{array}{l}\text { Soil } \\
\text { type }\end{array}$ & $\begin{array}{l}\text { Year of } \\
\text { establishment/ } \\
\text { thinning }\end{array}$ & Tree species, kind of plantation \\
\hline 1 & $\begin{array}{l}\text { Priekule/ } \\
\text { Ozolbunci (Priek/ } \\
\text { Ozolb) }\end{array}$ & $\begin{array}{l}56^{\circ} 23^{\prime} 29^{\prime \prime} \\
21^{\circ} 40^{\prime} 35^{\prime \prime}\end{array}$ & TSC & 1997/- & $\begin{array}{l}\text { Pedunculate oak: } 1100-10,000 \text { trees } \\
\qquad \text { ha }^{-1} \\
\text { Wild cherry: } 2000 \text { tree ha }^{-1}\end{array}$ \\
\hline 2 & $\begin{array}{l}\text { Grobina/ } \\
\text { Berzpurvi (Grob/ } \\
\text { Berz) }\end{array}$ & $\begin{array}{l}56^{\circ} 30^{\prime} 43^{\prime \prime} \\
21^{\circ} 07^{\prime} 11^{\prime \prime}\end{array}$ & $\mathrm{TP}$ & $1997 /-$ & $\begin{array}{l}\text { Silver birch, Scots pine, Norway } \\
\text { spruce: } 3300 \text { trees } \text { ha }^{-1}\end{array}$ \\
\hline 3 & $\begin{array}{l}\text { Kuldiga/Rumnieki } \\
\text { (Kuld/Rumn) }\end{array}$ & $\begin{array}{l}57^{\circ} 03^{\prime} 03^{\prime \prime} \\
21^{\circ} 46^{\prime} 05^{\prime \prime}\end{array}$ & SP & $1997 /-$ & $\begin{array}{l}\text { Silver birch, different spacing: } \\
\quad 1100-10,000 \text { trees } \mathrm{ha}^{-1} \\
\text { Pedunculate oak: } 1,600 \text { trees ha } \\
\text { European cherry: } 3300 \text { trees } \mathrm{ha}^{-1}\end{array}$ \\
\hline 4 & $\begin{array}{l}\text { Kandava/Aizlolas } \\
\text { (Kand/Aizl) }\end{array}$ & $\begin{array}{l}57^{\circ} 55^{\prime} 11^{\prime \prime} \\
22^{\circ} 42^{\prime} 30^{\prime \prime}\end{array}$ & GSC & $1997 /-$ & $\begin{array}{l}\text { Scots pine, Norway spruce, Silver } \\
\text { birch: } 3300 \text { tree ha } \\
\text { Pedunculate oak: } 1100 \text { trees ha }^{-1}\end{array}$ \\
\hline 5 & $\begin{array}{l}\text { Dobele/Mezansi } \\
\quad(\text { Dob/Mez })\end{array}$ & $\begin{array}{l}56^{\circ} 15.465^{\prime} \\
25^{\circ} 25.470^{\prime}\end{array}$ & SP & $1997 /-$ & $\begin{array}{l}\text { Norway spruce, Silver birch, Alder: } \\
3300 \text { trees ha }^{-1}\end{array}$ \\
\hline 6 & $\begin{array}{l}\text { Iecava/Skujenieki } \\
\quad(\text { Iec/Skuj })\end{array}$ & $\begin{array}{l}56^{\circ} 32.605^{\prime} \\
24^{\circ} 19.414^{\prime}\end{array}$ & ASG & $1997 /-$ & $\begin{array}{l}\text { Monoculture: Scots pine, Norway } \\
\text { spruce, Silver birch-3300 trees } \\
\text { ha }^{-1}\end{array}$ \\
\hline 7 & $\begin{array}{l}\text { Viesīte/Palsani } \\
\text { (Vies/Pals) }\end{array}$ & $\begin{array}{l}56^{\circ} 15^{\prime} 28^{\prime \prime} \\
25^{\circ} 25^{\prime} 23^{\prime \prime}\end{array}$ & BUB & $\begin{array}{l}\text { 1997/thinning of } \\
\text { birch plantation at } \\
\text { the age of } 15 \text { years }\end{array}$ & $\begin{array}{l}\text { Monoculture: Silver birch, Norway } \\
\text { Spruce-3300 trees ha } \\
\text { Pedunculate oak: } 2000 \text { trees ha }^{-1}\end{array}$ \\
\hline 8 & $\begin{array}{l}\text { Amata/Laubites } \\
\text { (Amat/Laub) }\end{array}$ & $\begin{array}{l}57^{\circ} 00^{\prime} 15^{\prime \prime} \\
25^{\circ} 12^{\prime} 16^{\prime \prime}\end{array}$ & $\mathrm{TP}$ & $1997 /-$ & $\begin{array}{l}\text { Monoculture: Norway spruce, Silver } \\
\text { birch-3300 trees ha }\end{array}$ \\
\hline 9 & $\begin{array}{l}\text { Koceni/Zarini } \\
\quad(\text { Koc/Zar })\end{array}$ & $\begin{array}{l}57^{\circ} 39^{\prime} 17^{\prime \prime} \\
25^{\circ} 03^{\prime} 22^{\prime \prime}\end{array}$ & LSC & $1997 /-$ & $\begin{array}{l}\text { Monoculture: Silver birch, Alder } \\
\qquad-3300 \text { trees ha }^{-1}\end{array}$ \\
\hline 10 & $\begin{array}{l}\text { Madona/Birzes } \\
(\text { Mad/Birz })\end{array}$ & $\begin{array}{l}56^{\circ} 54^{\prime} 55^{\prime \prime} \\
25^{\circ} 57^{\prime} 16^{\prime \prime}\end{array}$ & SPG & $\begin{array}{l}1997 / \text { thinning of } \\
\text { pine plantation at } \\
\text { the age of } 9 \text { years }\end{array}$ & $\begin{array}{c}\text { Silver birch, different spacing } \\
\text {-1100-10,000 trees ha }{ }^{-1} \\
\text { Monoculture: Scots pine, Norway } \\
\text { spruce-3300 trees } \mathrm{ha}^{-1}\end{array}$ \\
\hline 11 & $\begin{array}{l}\text { Gulbene/Sopuli } \\
\text { (Gulb/Sop) }\end{array}$ & $\begin{array}{l}57^{\circ} 09^{\prime} 25^{\prime \prime} \\
26^{\circ} 58^{\prime} 33^{\prime \prime}\end{array}$ & ASG & $1997 /-$ & $\begin{array}{l}\text { Pedunculate oak: different spacing } \\
\quad-1100-10,000 \text { trees ha } \\
\text { Monoculture: Silver birch, Aspen } \\
\quad-3300 \text { trees ha }^{-1}\end{array}$ \\
\hline 12 & $\begin{array}{l}\text { Rezekne/Bitites } \\
\quad(\text { Rez/Bit) }\end{array}$ & $\begin{array}{l}56^{\circ} 14.768^{\prime} \\
27^{\circ} 17.277^{\prime}\end{array}$ & SPG & 1997/- & $\begin{array}{l}\text { Silver birch, different spacing } \\
\text {-1100-10,000 trees ha }{ }^{-1} \\
\text { Monoculture: Scots pine, Norway } \\
\text { spruce-3300 trees ha }{ }^{-1}\end{array}$ \\
\hline 13 & $\begin{array}{l}\text { Iecava/Gaili } \\
\text { (Iedc/Gail) }\end{array}$ & $\begin{array}{c}56^{\circ} 34.192^{\prime} \\
24^{\circ} \\
08.863^{\prime}\end{array}$ & CAS & $\begin{array}{l}\text { 1994-1995/ } \\
\text { thinning of spruce } \\
\text { plantation at the } \\
\text { age of } 14 \text { years }\end{array}$ & $\begin{array}{l}\text { Different spacing, Norway spruce } \\
\quad-2000-3300 \text { trees ha } \\
\text { Silver birch-2000 trees ha } \mathrm{ha}^{-1} \\
\text { Pedunculate oak-1600 trees ha } \mathrm{ha}^{-1}\end{array}$ \\
\hline 14 & $\begin{array}{l}\text { Ozolnieki/Medni } \\
\text { (Ozol/Med) }\end{array}$ & $\begin{array}{l}56^{\circ} 36.005^{\prime} \\
24^{\circ} 04.212^{\prime}\end{array}$ & SPG & 1993-1995/- & $\begin{array}{l}\text { Silver birch, different spacing: } \\
\text { 1600-3300 trees ha }{ }^{-1} \\
\text { Monoculture: Scots pine, Norway } \\
\text { spruce-2000-4000 trees } \mathrm{ha}^{-1}\end{array}$ \\
\hline 15 & $\begin{array}{l}\text { Kandava/Viesturi } \\
\text { (Kand/Viest) }\end{array}$ & $\begin{array}{l}57^{\circ} 03^{\prime} 11^{\prime \prime} \\
22^{\circ} 44^{\prime} 21^{\prime \prime}\end{array}$ & SPG & $2000 /-$ & $\begin{array}{l}\text { Scots pine, Norway spruce, Silver } \\
\text { birch-2000 trees ha }{ }^{-1}\end{array}$ \\
\hline 16 & $\begin{array}{l}\text { Talsi/Zeltini } \\
\text { (Kand/Zelt) }\end{array}$ & $\begin{array}{l}57^{\circ} 08^{\prime} 50^{\prime \prime} \\
22^{\circ} 54^{\prime} 31^{\prime \prime}\end{array}$ & SPG & $2003 /-$ & Wild cherry-1000 trees ha ${ }^{-1}$ \\
\hline 17 & $\begin{array}{l}\text { Kuldiga/Berzi } \\
\text { (Kuld/Berz) }\end{array}$ & $\begin{array}{c}56^{\circ} \\
59^{\prime} 49.474^{\prime \prime}\end{array}$ & SP & $1997 /-$ & $\begin{array}{l}\text { Wild cherry-10,000 trees ha } \\
2000 \text { trees }^{-1} \\
\text { ha }\end{array}$ \\
\hline
\end{tabular}




\begin{tabular}{|c|c|c|c|c|c|}
\hline $\begin{array}{l}\text { No. } \\
\text { of } \\
\text { trial }\end{array}$ & $\begin{array}{l}\text { Site location: } \\
\text { municipality/ } \\
\text { parish }\end{array}$ & $\begin{array}{c}\text { Site } \\
\text { location }\end{array}$ & $\begin{array}{l}\text { Soil } \\
\text { type }\end{array}$ & $\begin{array}{l}\text { Year of } \\
\text { establishment/ } \\
\text { thinning }\end{array}$ & Tree species, kind of plantation \\
\hline & & $\begin{array}{c}21^{\circ} \\
41^{\prime} 13.965^{\prime \prime}\end{array}$ & & & \\
\hline 18 & $\begin{array}{l}\text { Krustpils/Paki } \\
\text { (Krust/Pak) }\end{array}$ & $\begin{array}{l}56^{\circ} 35^{\prime} 12^{\prime \prime} \\
26^{\circ} 10^{\prime} 04^{\prime \prime}\end{array}$ & SPG & 1993-1997/- & $\begin{array}{c}\text { Monoculture: Norway spruce Silver } \\
\text { birch-2000 trees ha }{ }^{-1}, \text { Small- } \\
\text { leaved lime-1100 trees ha }{ }^{-1}\end{array}$ \\
\hline 19 & $\begin{array}{l}\text { Bauska/Ziedini } \\
\text { (Bausk/Zied) }\end{array}$ & $\begin{array}{l}56^{\circ} 23^{\prime} 01^{\prime \prime} \\
24^{\circ} 10^{\prime} 48^{\prime \prime}\end{array}$ & SP & 2009/- & $\begin{array}{l}\text { Wild cherry, clone 'Trust', Denmark } \\
\qquad-1100 \text { trees ha }{ }^{-1}\end{array}$ \\
\hline 20 & $\begin{array}{l}\text { Malpils/ } \\
\text { Dizavotini (Malp/ } \\
\text { Diz) }\end{array}$ & $\begin{array}{l}57^{\circ} 01.998 \\
24^{\circ} 54.538\end{array}$ & SP & 1995/- & $\begin{array}{l}\text { Monoculture: Silver birch-2000 } \\
\text { trees ha }{ }^{-1}\end{array}$ \\
\hline 21 & $\begin{array}{l}\text { Dobele/Ezernieki } \\
\text { (Dob/Ezer) }\end{array}$ & $\begin{array}{c}57^{\circ} \\
35^{\prime} 34.85^{\prime \prime} \\
23^{\circ} 15^{\prime} \\
21.27^{\prime \prime}\end{array}$ & GSC & 2011/- & $\begin{array}{c}\text { Monoculture: } \\
\text { Wild cherry, Sweden clone-2000 } \\
\text { trees ha }{ }^{-1}\end{array}$ \\
\hline
\end{tabular}

Scots pine (Pinus sylvestris L.), Norway spruce (Picea abies (L.) Karst.), European larch (Larix decidua Mill.), silver birch (Betula pendula Roth.), aspen (Populus tremula L.), alder (Alnus glutinosa L.), grey alder (Alnus incana (L.) Moench), pedunculate oak (Quercus robur L.), small-leaved lime (Tilia cordata L.), wild cherry (Cerasus avium Moench (L.) syn., Prunus avium L.).

TSC_typical sod-calcareous soil, GSC_for gleyic sod-calcareous soil, BUB_base unsaturated brown soil, SP_sodpodzolic soil, TP—typical podzol, SPG—sod-podzolic gley soil, HPG—humi-podzolic gleyic soil, ASG—alluvial sodgley soil, and CAS-strongly altered by cultivation soil.

Table 1.

Characteristics of experimental plots.

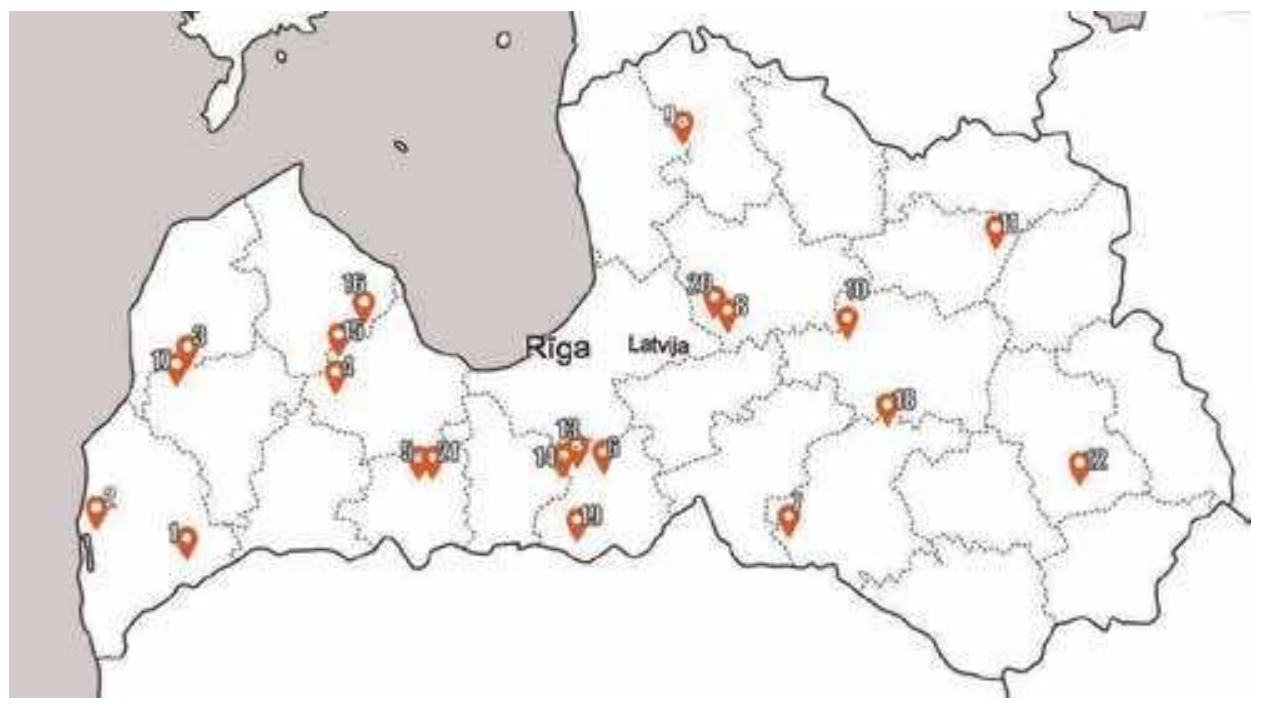

Figure 4.

Locations of experimental plantations.

Individual tree stem volume has been calculated with the formula [46]:

$$
v=\psi L^{\alpha} D^{\beta \lg L+\varphi}
$$


where $\mathrm{v}$ is stem volume with bark, $\mathrm{m}^{3}$; $\mathrm{L}$ is stem length, $\mathrm{m}$; $\mathrm{D}$ is stem breast height diameter with bark, $\mathrm{cm}$; and $\psi, \alpha$, and $\beta$ are coefficients dependent on tree species [46].

Using the sample tree data, the stand volume current annual increment has been calculated with the formula [46]:

$$
Z_{M}=k G\left[\frac{2 Z_{D}\left(H-2 Z_{H}+4\right)}{10 D+Z_{D}}+Z_{H}\right]
$$

where $\mathrm{ZM}$ is the current actual stand volume increment, $\mathrm{m}^{3} \mathrm{ha}^{-1} ; \mathrm{H}$ is the average stand height, $\mathrm{m}$; $\mathrm{G}$ is the stand basal area, $\mathrm{m}^{2} \mathrm{ha}^{-1} ; \mathrm{k}$ is the empirical ratio; $\mathrm{D}$ is the mean breast height diameter of the stand, $\mathrm{cm}$; $\mathrm{ZD}$ is the current increment of $\mathrm{D}$ of the stand, $\mathrm{mm}$; and $\mathrm{ZH}$ is current increment of the stand height, $\mathrm{m}$.

To determine the volume of the above-ground biomass produced by various tree species, three sample trees were cut down in each plantation at the root collar-one Kraft class I and two Kraft class II. After felling the tree height has been measured using a tape measure (with precision to $1 \mathrm{~cm}$ ), and the stem is pruned and cut into metre-long sections. The sample tree weight is determined on site by weighing separately: stem wood, dry branches, and live branches.

Wood samples of each tree were collected for drying in the laboratory-dry branch, three live branches (from different sections of the crown), and three discs (from various sections of the stem).

According to the latest data of the prices of pulpwood (EUR per $\mathrm{m}^{3}$ ) and wood waste (EUR/loose $\mathrm{m}^{3}$ ), the gross income of a 15-year-old Scots pine, Norway spruce, and silver birch plantations is calculated.

Soil properties in the sample plots were examined every 3-5 years taking soil samples at the specified locations. The samples were taken in the active tree root zone at a depth of $0-40 \mathrm{~cm}(0-10,10-20,20-30,30-40 \mathrm{~cm})$ in five replications in each sample plot with one averaged sample made for each soil horizon. In this study, variations in the soil humus content and acidity in the active root zone of trees $(0-40 \mathrm{~cm})$ were analysed before planting, and analyses were repeated at specified intervals till the age of 15 years. Soil analyses were performed in the laboratory of the Latvian Environment, Geology and Meteorology Centre following international standards (organic substance content in dry matter, LVS EN 13039:2003; pH (KCl), LVS ISO 10390:2002) [47].

On the afforested sites, vegetation was inventoried before forest establishment and then after each 3 years in order to study the changes in ground-cover vegetation of the agricultural ecosystems (meadow, fallow land) gradually turning into forest. During the first inventory, a total of 10 sample plots $(1 \times 1 \mathrm{~m}$ each $)$ were described throughout the whole territory of plantation. In the inventories carried out after each 3 years, three $1 \times 1 \mathrm{~m}$ sample plots were established in each tree plantation, and the total number of survey plots is 219. A full list of flora species was compiled for each site, including the species found next to the survey plot. Vegetation data was stored using TURBOVEG software $[1,48]$. The projective cover of each plant species in the tree, shrub, and herbaceous and bryophyte layer was assessed as a percentage of the respective species, using the Braun-Blanquet method [49]. The mean indicator values were calculated for each plot from all present vascular plant species, from which an indicator value was calculated according to Ellenberg et al. [50].

Data validation and mathematical calculations were performed with Microsoft Excel 2016. Summary statistics for D, H, and basal area were calculated using SPSS software [51]. The formulas of (1) and (2) were used to calculate the stem volume 
for different tree species [46]. One-way analysis of variance (ANOVA) and a t-test were used in the statistical analysis $(\mathrm{p}<0.05)$. The mean values in the tables are presented together with the standard deviation $( \pm \mathrm{SD})$.

\section{Changes in agrochemical properties of soil}

Changing the type of land use causes changes in the ecosystem, as a result of the changes in biotic factors (the impact of microorganisms on other organisms of the biological community), as well as changes in abiotic factors (temperature, light, humidity, soil, acidity of the soil, amount of salts, amount of minerals, etc.).

As we know, the most important parameters of growth conditions are determined by the interaction of several factors-physical, chemical, and biological soil properties-as well as climate, which ensure soil fertility. The analysis of Holubik et al. reviewing 43 afforestation studies found the key factors to be (in the order of importance) (i) previous land use, (ii) climate, and (iii) the type of forest [52]. The research indicates that basic properties of the soil are comparatively stable; they have developed over a long period of soil formation processes under the influence of climate, terrain, geological substratum, flora, and fauna and are characterised by their granulometric composition, ion exchange capacity, depth of geological substratum, and drainage. Human economic activity has a minor effect on this or no effect at all $[53,54]$. However, a series of soil characteristics exist that can change significantly over a short period of time: content of soil organic matter, soil structure, bulk density, water infiltration capacity, reaction, plant nutrient resources, etc. Changes in these characteristics are mainly determined by human economic activity: type of land use, soil tillage technology, and cultivated crops or trees. According to the assessment of scientists, organic matter in soil is one of the main indicators of soil quality and productivity [53-59]. The accumulation of organic carbon in the soil occurs in forest and grassland ecosystems. European forests

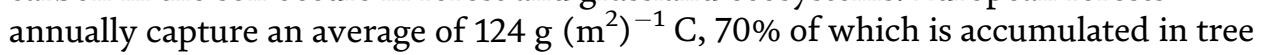
biomass of trees and $30 \%$ in the topsoil and soil. Furthermore, the biomass of the forest ecosystem accumulates more carbon than crops grown on agricultural land, thus reducing the concentration of carbon dioxide in the atmosphere and improving the global environment.

Studies conducted by the Latvian State Forest Research Institute (LSFRI) Silava indicate that the concentration of nutrients in soil, as well as physical properties of soil, have great importance in ensuring the optimum growth of new stands of different tree species in mineral soils of former agricultural lands [1]. The research of the researchers of Latvia University of Life Sciences and Technologies A. Kārkliņš and I. Lipenite also bears evidence that after afforestation of former agricultural lands, the physical and chemical properties of the soil have changed: the bulk density of topsoil has decreased, and its total porosity and relative water retention potential has increased $[54,55]$. Trials suggest that it is advisable to choose naturally dry mineral soils or soils with a controlled moisture regime to create productive plantations.

According to the studies of LSFRI Silava, aeration, temperature, and humidity regime deteriorate significantly in compacted soils $[56,57]$. The scientists have concluded that the optimal soil density for the development of trees, especially at an

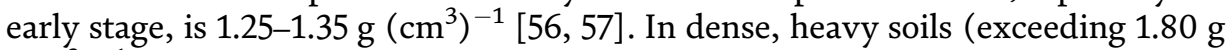
$\left(\mathrm{cm}^{3}\right)^{-1}$ ), the introduction and development of any tree species are difficult without additional soil tillage (continuous ploughing, deep digging, soil structure improvement, etc.). However, as the trees grow, the ability of their roots to penetrate into the denser layers of bedrock increases, and, already at the age of a 
maturing stand (at the age of around 30-40 years), productive plantations can be grown in heavy clay soils $[56,57]$. An important parameter for ensuring the successful growth of trees is soil $\mathrm{pH}$, which does not always conform to the optimum. Scientists have found that mildly acidic soils ( $\mathrm{pH}$ 5.5-6.5) are the most suitable for normal tree development, except for pines growing on acidic soils ( $\mathrm{pH} 4.5-5)$, but tree species like sweet cherry, oak, ash, etc. are the most productive growers in neutral and even alkaline soils ( $\mathrm{pH} 6.5-7.5$ and above) [56-60]. An important condition to ensure optimal tree growth is the selection of a suitable site with appropriate hydrological conditions for planting to ensure that the groundwater table in spring and autumn does not rise above the average depth of $30 \mathrm{~cm}$ from the ground surface $[61,62]$. Coniferous, as well as many deciduous, species, such as silver birch, oak, and sweet cherry can tolerate flooding of active roots for a period that is no longer than 5 days; after this period, growth disorders may develop. In contrast, tree species like black alder and downy birch are more suitable for wet areas and can withstand 7-9 days of root flooding, even though the largest growth in these species is registered in medium wet loam and sandy loam soils [61, 62].

The optimal soil temperature, which regulates the processes of uptake of available minerals by the plants, as well as the activity of microorganisms, and fluctuates at an average of $15-20^{\circ} \mathrm{C}$ in our climatic conditions, ensuring the optimum mode of woody plant nutrition provided that the amount of soil moisture is sufficient, is also important for successful tree growth [63]. Soil temperature is largely determined by the mass of herbaceous vegetation: soil temperature in dense and thick grass will be $3-5^{\circ} \mathrm{C}$ lower than in an open area [63]. Therefore, soil preparation and further plantation care are required to ensure the introduction of trees and faster initial growth. Agrochemical soil properties are equally important prerequisites for the successful cultivation of trees: content of organic substance, amount of minerals (phosphorus, potassium, nitrogen, calcium), and trace elements (magnesium, manganese, boron, iron, copper, sulphur, zinc, etc.) in the soil water solution. Since the leaves of deciduous trees are decomposed quickly, the stands of these trees are predominantly characterised by accumulative processes of soil formation: the buildup of humus results in a content of organic matter in the upper horizons of soil that exceeds $10 \%$, and the amount of potassium and calcium is sufficient, while a deficiency of nitrogen and phosphorus may occur, especially in heavy clay soils, as well as alkaline soils $[1,60,64,65]$. As scientists report, afforestation of agricultural land leads to considerable changes in processes that occur in the soil, including the circulation of plant nutrients: depending on the species of trees cultivated, biomass that is accumulated in the soil differs in terms of quantity and chemical composition. The rate of soil mineralisation, which is affected by the $\mathrm{C}$ and $\mathrm{N}$ ratio, as well as the presence of lignin and other secondary carbon compounds, determines the circulation and supply of nitrogen and other plant nutrients in the soil [56-60, 64, 65]. According to the studies of Sanborn[62], soil acidity $\mathrm{pH}$ and total N, available to plants $\mathrm{P}, \mathrm{Ca}, \mathrm{Mg}$ and $\mathrm{K}$, have considerably increased 23 years after the afforestation of agricultural land, where mixed stand of paper birch (Betula papyrifera Marsh.) and Rocky Mountain lodgepole pine (Pinus contorta var. latifolia Dougl. ex Loud.) were developed, while the C: $\mathrm{N}$ ratio has decreased, as it is in forest soils [65]. The trials on changes in soil properties after the afforestation of agricultural lands conducted in Latvia have indicated that the physical and agrochemical properties of soil have changed-the bulk density of topsoil has decreased, and its total porosity and relative water retention potential have increased [55-59]. After 15 years of accumulation of the humus in the soil horizon caused by afforestation, the acidification of soil and an increase in the content of organic matter have occurred in comparison with arable soil, while the proportion of total nitrogen in organic matter has decreased, and the amount of phosphorus and potassium in the soil under the 
pine stands that is available to plants has been higher than in the nearby nonafforested agricultural land [55-59].

To explain the changes in the agrochemical properties of soil under the influence of afforestation, the monitoring of soil agrochemical properties was performed in different soil types of the afforested areas: TSC, GSC, SPG, CAS, SP, TP, ASG, LSC, and BUB. Soil agrochemical properties (N, P, K changes) were evaluated prior to the establishment of tree plantations and then in year 4 and year 15 after the establishment of plantations [1]. In all objects, the plantations were set up in uncultivated agricultural land-fallow land that has not been cultivated for 1-3 years, with the dominant species being creeping thistle and couch grass.

Variation in the proportion of soil organic matter and acidity in the active root zone at a depth from 0 to $40 \mathrm{~cm}$ over a period of 15 years since the establishment of the plantation forest on the respective site were chosen as the indicators to evaluate the impact of afforestation on soil agrochemical properties. The amount of soil humus has changed on sites with a high volume of above-ground vegetation biomass, both trees and ground-cover vegetation (trial plots 1-12, 14, and 16). No significant changes in soil humus content are recorded for sites with a relatively small volume of above-ground biomass (trial plots 3, 10, 11, 12, and 16) (Table 2).

Similar results are also quoted by researchers of other countries [52, 64, 65]. As concluded in a number of studies, forest floor humus on the soil surface is completely new [65].

The field data show that 15 years after the establishment of plantation forest on farmlands, the soil tends to become more acidic. On sites, where trees were planted on arable land right after harvesting the previous crops, the soil acidity in most cases was close to neutral (trial plots $2,4,6,10,16$ ) and in the 15 years had reduced by 1.15 units on the $\mathrm{pH}$ scale on average (Table 2 ).

Investigations show that 15 years after afforestation, the content of organic matter in active root layer $(0-40 \mathrm{~cm})$ increases by $22.5 \%$ average in all experimental trials (Table 2, Figure 5).

\begin{tabular}{|c|c|c|c|c|c|}
\hline \multirow[t]{2}{*}{ No. of trial } & \multirow{2}{*}{$\begin{array}{c}\text { Soil } \\
\text { type } \\
{[52]}\end{array}$} & \multicolumn{2}{|c|}{ Humus content, \% } & \multicolumn{2}{|c|}{$\mathrm{PH}_{\mathrm{KCl}}$} \\
\hline & & $\begin{array}{c}\text { Before } \\
\text { establishment }\end{array}$ & $\begin{array}{c}\text { After } 15 \text { years of } \\
\text { establishment }\end{array}$ & $\begin{array}{c}\text { Before } \\
\text { establishment }\end{array}$ & $\begin{array}{c}\text { After } 15 \text { years of } \\
\text { establishment }\end{array}$ \\
\hline 1 Priek/Ozolb & $\mathrm{TSP}$ & 1.4 & 4.56 & 5.92 & 5.19 \\
\hline 2 Grob/Berz & $\mathrm{TP}$ & 2.42 & 3.82 & 6.52 & 6.48 \\
\hline 3 Kuld/Rumn & SPG & 3.06 & 2.68 & 6.17 & 5.41 \\
\hline $4 \mathrm{Kand} / \mathrm{Aizl}$ & GSC & 2.13 & 4.01 & 6.60 & 5.75 \\
\hline $5 \mathrm{Dob} / \mathrm{Mez}$ & SP & 2.62 & 3.54 & 5.27 & 5.70 \\
\hline $6 \mathrm{Iec} / \mathrm{Skuj}$ & ASG & 2.19 & 2.53 & 6.7 & 5.20 \\
\hline 7 Vies/Pals & BUB & 3.22 & 3.45 & 5.15 & 4.26 \\
\hline $9 \mathrm{Koc} / \mathrm{Zar}$ & LSC & 3.86 & 3.95 & 5.45 & 5.30 \\
\hline $10 \mathrm{Mad} / \mathrm{Birz}$ & SPG & 3.24 & 2.40 & 7.02 & 5.61 \\
\hline 11 Gulb/Sop & ASG & 2.95 & 3.07 & 6.00 & 5.72 \\
\hline 12 Rez/Bit & SPG & 3.05 & 2.46 & 6.3 & 4.21 \\
\hline $14 \mathrm{Ozoln} / \mathrm{Med}$ & SPG & 2.71 & 3.78 & 5.55 & 5.08 \\
\hline 16 Tals/Zelt & SPG & 3.86 & 3.2 & 6.9 & 5.70 \\
\hline
\end{tabular}

Table 2.

Changes in soil chemical properties in the active root layer $(0-40 \mathrm{~cm})$ in the 15-year plantations. 
Plantation Forests: A Guarantee of Sustainable Management of Abandoned and Marginal... DOI: http://dx.doi.org/10.5772/intechopen.88373

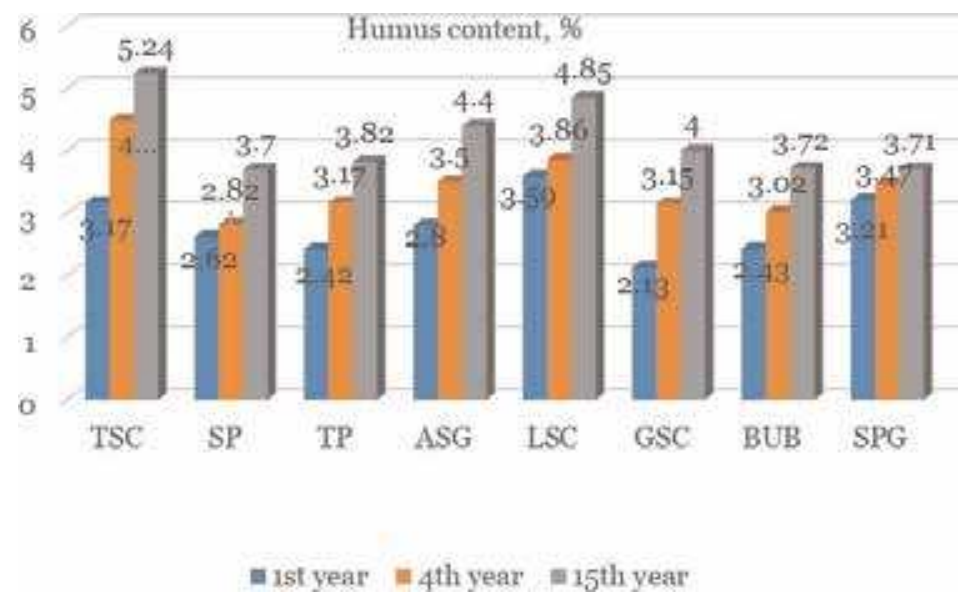

Figure 5.

Dynamic changes in humus content after afforestation in different soil types: Average indicator for all tree species (\%).

\section{Changes in above-ground vegetation}

In all afforested objects, 247 species of vascular plants, 32 species of moss, and 1 species of lichens were listed during the latest inventories. The following trends of changes in ground cover have been observed: the occurrence of grassland and fallow land grass species has decreased, while at some sites, the introduction of up to 20 new ground-cover species has been observed. In fertile soils, meadow species have been replaced by eurybiont nitrophytes Anthriscus sylvestris, Artemisia vulgaris, and Urtica dioica. However, grassland specific grasses have still been present at almost all research sites: Agrostis gigantea, A. tenuis, Deschampsia cespitosa, Festuca rubra, and Phleum pratense, as well as other meadow and set-aside fallow land plants: Campanula patula, Galium album, Leucanthemum vulgare, and Taraxacum officinale. Mosses have disappeared-species colonising bare soils Barbula unguiculata, Pleuridium subulatum, and Pohlia wahlenbergii. The flora of mosses is still most widely represented by species that are common in forests, as well as grasslands, Sciuro-hypnum curtum, Plagiomnium affine, and $P$. undulatum, but the cover of mosses under the thick layer of herbaceous plants is usually negligible. Introduction of typical boreal coniferous forest cover species Pleurozium schreberi and Hylocomium splendens occurs faster at the objects where dry and low-fertility fallow lands have been afforested, while dwarf shrubs Vaccinium myrtillus and $V$. vitis-idaea that are typical for coniferous forests have not been detected at any object to date.

Herbaceous vegetation has changed as a result of afforestation at all objects: the replacement of original ground cover of grassland and fallow land species with forest-specific plants has begun. Most species belong to native flora; however, certain garden escaping plants and adventive species have been registered: Lupinus polyphyllus, Oxalis stricta, Sambucus racemosa, Solidago canadensis, Symphytum asperum, and Heracleum sosnowskyi. Among the aforementioned species, only Lupinus polyphyllus plays a significant role in the phytocoenosis of some objects. Some indicator species of natural grasslands can still be found: Agrimonia eupatoria, Linum catharticum, Pimpinella saxifraga, Polygala vulgaris, and Primula veris. Rare and protected species are represented by individual orchid specimensDactylorhiza sp. and Platanthera sp. $[1,17,66]$. 


\section{Growth and development of Scots pine (Pinus sylvestris L.) plantations in agricultural land}

By assessing the growth of Scots pine plantations in four different soil types (TP, SPG, GSC, ASG), we conclude that the growth of pine in farmlands differs from that in forestlands. So, the diameter of the mean tree of 15 -year plantation pine is comparable to that of 25-28-year forest pine of site index I, with the mean height corresponding to that of 16-18-year forest pine of site index I (Table 3) [67].

The stock volume of well-growing plantation pine may by the age of 15 be as high as $80-155 \mathrm{~m}^{3} \mathrm{ha}^{-1}$ and by 22 years reach even $243 \mathrm{~m}^{3} \mathrm{ha}^{-1}$. Pine plantations produce the highest stock volume in podzol, cultivated, and soddy-podzolic soils, where the stock volume for $15-16$-year pine is $112-155 \mathrm{~m} 3 \mathrm{ha}^{-1}$, with the current volume growth of 5-8 $\mathrm{m} 3 \mathrm{ha}^{-1}$ per year (Table 3 ).

When evaluating the growth of above-ground biomass of plantation pines by analysing sample trees, the biomass weight for a single tree is found to be on average $136.6-190.15 \mathrm{~kg}$ (100\%), of which stem biomass is $69.8-148.5 \mathrm{~kg}$ (51.1$78.1 \%$ ) and crown biomass (branchwood and foliage) $66.8-41.7 \mathrm{~kg}$ (48.9-21.9\%). To gain an appreciable stock volume of plantation pine already by the age of 40 , purposeful and properly timed tending, including the pruning of future crop trees, should be started no later than at the age of 14-15 (Table 4).

It is to be noted that in fertile agricultural soils (cultivated, alluvial, calcareous), the plantation pines develop twin stems and thick branches that adversely affect the potential height and diameter growth and, consequently, the mean stem volume, quality, and the stock volume anticipated. When tending pine in similar growing conditions, the emphasis should be on removing all low-quality stems or using the plantation for short-rotation (15-20 years) cultivation of pinewood biomass.

To get high-quality sawlogs from pine plantations, branches of the lowest whorl should be pruned no later than at the age of 5-7 years, followed by removing in each ensuing year the branches of the next whorl. After the first pruning, the length of the remaining crown should be $2 / 3$ of the tree height, reducing in each subsequent pruning the crown length to $1 / 2$ of the stem height, so that by the age over 30 years the crown length should be $1 / 3$ of the tree height.

\begin{tabular}{lccccc}
\hline Experimental trial & 2Grob/Berz & 4Kand/Aizl & 14Ozol/Med & 6Iec/Skuj & 12Rez/Bit \\
\hline Soil type & TP & GSC & SPG & ASG & SPG \\
\hline Density stems ha ${ }^{-1}$ & 3774 & 2651 & 2925 & 1853 & 1510 \\
\hline $\mathrm{D}, \mathrm{cm}$ & $11.6 \pm 2.78$ & $13.9 \pm 2.6$ & $12.9 \pm 2.6$ & $12.7 \pm 2.2$ & $10.3 \pm 2.88$ \\
\hline $\mathrm{H}, \mathrm{m}$ & $7.7 \pm 0.60$ & $7.3 \pm 0.74$ & $7.4 \pm 0.95$ & $7.7 \pm 0.43$ & $8.2 \pm 0.90$ \\
\hline Volume of mean tree, $\mathrm{m}^{3}$ & 0.04 & 0.03 & 0.04 & 0.06 & 0.06 \\
\hline $\begin{array}{l}\text { Volume, } \mathrm{m}^{3} \text { ha }^{-1} \\
\begin{array}{l}\text { Average volume } \\
\text { increment } \mathrm{m}^{3} \text { ha }\end{array} \\
\text { year }\end{array}$ & 152 & 79 & 117 & 111 & 91 \\
\hline $\begin{array}{l}\text { Significant difference at } \\
p<0.05\end{array}$ & $\begin{array}{l}\text { Except 6 } \\
(\mathrm{p}>0.05)\end{array}$ & Between all & Between all & $\begin{array}{l}\text { Except 14 } \\
(\mathrm{p}>0.05)\end{array}$ & $\begin{array}{l}\text { Except 14 } \\
(\mathrm{p}>0.05)\end{array}$ \\
\hline
\end{tabular}

Table 3.

Stand data of scots pine plantations on different soils (age 15 years). 
Plantation Forests: A Guarantee of Sustainable Management of Abandoned and Marginal... DOI: http://dx.doi.org/10.5772/intechopen.88373

\begin{tabular}{lccc}
\hline Trials & $\begin{array}{c}\text { Total biomass, freshly cut, } \\
\text { kg/abs. Dry, kg/\% }\end{array}$ & $\begin{array}{c}\text { Stem mass freshly cut, } \\
\text { kg/abs. Dry, kg/\% }\end{array}$ & $\begin{array}{c}\text { Branch mass, freshly cut, } \\
\text { kg/abs. Dry kg/\% }\end{array}$ \\
\hline 2Grob/Berz & $174.42 / 106.05 / 100$ & $143.14 / 87.03 / 82.1$ & $31.28 / 19.02 / 17.9$ \\
\hline 14Ozol/Med & $210.52 / 128 / 100$ & $170.1 / 103.42 / 80.8$ & $40.42 / 24.57 / 19.2$ \\
\hline 6lec/Skuj & $185.52 / 112.80 / 100$ & $132.12 / 80.32 / 71.2$ & $53.4 / 32.47 / 28.8$ \\
\hline Average & & & \\
\hline Freshly cut, kg & $190.15 \pm 15.1$ & $148.45 \pm 15.95$ & $41.7 \pm 9.1$ \\
\hline Abs. dry, kg & 115.61 & 90.26 & 25.35 \\
\hline$\%$ & 100 & 78 & 22 \\
\hline
\end{tabular}

Table 4 .

The average indices of sample tree above-ground biomass (freshly cut/abs. Dry/\%) 15-year-old pine plantations.

In highly productive pine plantations, the protection of trees against the damage of artiodactyls is a must. For this purpose we may use repellents and stem protection tubes or fence the site in.

\section{Growth and development of Norway spruce plantations on agricultural land}

The assessment of the growth of spruce plantations on AL had been performed on nine sites, and their growth and cumulative productivity has been researched in plantations on AL in naturally dry mineral soils (SP, BUB, CAS, ASG, and PGx)

(Table 5).

Investigations show that Norway spruce may be successfully cultivated in open farmland areas. Its rooting and growth in intensively managed (additional fertilisation and soil liming in case of need) and duly tended sites should be evaluated as good and excellent. However, spruce as a shade-tolerant species adapts itself much slower to the growing conditions of open farmlands. As it follows from the field data, the growth in height of spruce in the first 5-6 years after planting is stunted (on average $0.10-0.15$ m.year ${ }^{-1}$ ), and only in optimum growing conditions it reaches the height of DBH $(1.3 \mathrm{~m})$ by the said age (Table 5).

The data acquired in experiments show that by carrying out timely agrotechnical tending in sod-podzolic agricultural lands, the (exp. trials 5, 8, 10,12) Norway spruce mean height at the age of 15 years had reached $8.3 \mathrm{~m}$, which corresponds to the Norway spruce dominant height of site index I $(\mathrm{H}=12 \mathrm{~m})$ in forest stands [67], whereas the Norway spruce mean height in soils' CAS (13Iec/Iec2) and in plantations at the age of 15 years, where additional fertilisation has been performed (8Amat/Zaube), reaches $\mathrm{H}=9.5-10.5 \mathrm{~m}$, corresponding to the 18-year-old site index I spruce dominant height in forest stands, in forest soils [67].

In AL of soil types CAS, ASG, and SPG without fertilisation, the tree mean diameter at breast height in 15-year-old plantations shows a greater difference: $8.3-12.6 \mathrm{~cm}$, tree height $\mathrm{H}=7.1-8.9 \mathrm{~m}$, and standing volume $68-142 \mathrm{~m}^{3} \mathrm{ha}^{-1}$. The current standing volume increment in these trials constitutes $6.57-15.76 \mathrm{~m}^{3} \mathrm{ha}^{-1}$ per year (Table 6).

When determining the Norway spruce plantation above-ground biomass volume, it was found that in a 15-year-old plantation, the above-ground biomass of mean tree constitutes $143 \mathrm{~kg}(100 \%)$ on average, including stem biomass $66 \mathrm{~kg}$ (46\%) and crown biomass (branches plus needles) $77 \mathrm{~kg}$ (54\%), which in turn splits 


\begin{tabular}{|c|c|c|c|c|c|c|c|c|c|}
\hline Experimental trial & 5Dob/Mez & 6Iec/Skuj & 7Vies/Pals & $\begin{array}{l}\text { 8Amat/ } \\
\text { Laub }\end{array}$ & 10Mad/Birz & 12Rēz/Bit & $\begin{array}{c}\text { 13Iec/Gaili } 3300 \\
\text { trees ha }^{-1}\end{array}$ & $\begin{array}{c}13 \mathrm{Iec} / \mathrm{Gaili} \\
2500 \text { trees ha }^{-1}\end{array}$ & $\begin{array}{l}14 \text { Ozol/ } \\
\text { Med }\end{array}$ \\
\hline Soil type & SP & ASG & BUB & TP & SPG & SPG & CAS & CAS & SPG \\
\hline Density, stems ha ${ }^{-1}$ & 2840 & 2660 & 3128 & 1400 & 3100 & 2957 & 2230 & 2165 & 2640 \\
\hline $\mathrm{H}, \mathrm{m}$ & $7.7 \pm 1.91$ & $7.7 \pm 0.71$ & $6.7 \pm 0.86$ & $10.5 \pm 0.91$ & $7.8 \pm 0.69$ & $7.4 \pm 1.92$ & $8.9 \pm 1.90$ & $9.5 \pm 1.12$ & $7.1 \pm 1.01$ \\
\hline Volume of mean tree, $\mathrm{dm}^{3}$ & 0.0318 & 0.0534 & 0.0205 & 0.0669 & 0.0389 & 0.0304 & 0.0396 & 0.0491 & 0.0258 \\
\hline $\begin{array}{l}\text { Significant difference at } \\
p>0.05\end{array}$ & $\begin{array}{l}\text { Except } 7 \text { Vies/Pals } \\
\text { 10Mad/Birz }\end{array}$ & $\begin{array}{c}\text { Except } \\
\text { 7Vies/Pals }\end{array}$ & $\begin{array}{l}\text { Except 5Dob/Mez } 10 \\
\text { Mad/Birz }\end{array}$ & $\begin{array}{l}\text { Between } \\
\text { all }\end{array}$ & $\begin{array}{l}\text { Except 5Dob/Mez } \\
\text { 7Vies/Pals }\end{array}$ & $\begin{array}{c}\text { Except } \\
\text { 7Vies/Pals }\end{array}$ & Except 6lec/Skuj & $\begin{array}{l}\text { Except 6Vies/ } \\
\text { Skuj }\end{array}$ & $\begin{array}{l}\text { Between } \\
\quad \text { all }\end{array}$ \\
\hline
\end{tabular}

Table 5 .

Growth and productivity of Norway spruce plantations on agricultural lands. 
Plantation Forests: A Guarantee of Sustainable Management of Abandoned and Marginal... DOI: http://dx.doi.org/10.5772/intechopen.88373

\begin{tabular}{|c|c|c|c|c|c|}
\hline \multirow[t]{3}{*}{ Trial } & \multirow{3}{*}{$\begin{array}{c}\text { Total biomass, } \\
\text { kg/\% }\end{array}$} & \multirow{3}{*}{$\begin{array}{c}\text { Stem biomass, } \\
\mathrm{kg} / \%\end{array}$} & \multicolumn{3}{|c|}{ Tree crown biomass } \\
\hline & & & \multirow[t]{2}{*}{ Live branches, kg/\% } & \multicolumn{2}{|r|}{ Incl., needles } \\
\hline & & & & kg & $\%$ of stem biomass \\
\hline 13Iec/Gail & $177 / 100$ & $85 / 49$ & $91 / 51$ & 44 & 25 \\
\hline 6Iec/Skuj & $143 / 100$ & $66 / 46$ & $77 / 54$ & 38 & 27 \\
\hline 10Mad/Birz & $153 / 100$ & $66 / 43$ & $86 / 56$ & 46 & 30 \\
\hline 7Vies/Pals & $122 / 100$ & $50 / 41$ & $72 / 59$ & 35 & 28 \\
\hline 5Dob/Mez & $134 / 100$ & $61 / 45$ & $73 / 55$ & 37 & 27 \\
\hline 14Ozol/Med & $129 / 100$ & $66 / 51$ & $62 / 48$ & 29 & 22 \\
\hline Average & $143 /$ & $66 /$ & $77 /$ & 38 & 27 \\
\hline freshly cut, kg & $66 /$ & $30 /$ & $35 /$ & 19 & \\
\hline $\begin{array}{l}\text { /abs. Dry, kg } \\
\%\end{array}$ & 100 & 46 & 54 & & \\
\hline
\end{tabular}

Table 6.

The average indices of sample tree above-ground biomass (freshly cut/abs. Dry) in 15-year-old Norway spruce plantations.

into branch biomass $32 \mathrm{~kg}$ (41\%) and needle biomass $45 \mathrm{~kg}$ (59\%) (Table 6). The profitability of plantation cultivation of spruce may be raised by delivering foliage biomass to the manufacturers of medicinal preparations and food additives.

\section{Growth and development of silver birch plantations on agricultural land}

The research on the growth of silver birch and productivity on former AL, in naturally dry mineral soils, it is suggested that overall, compared to conifers, the growth of silver birch in these plantations is more dynamic [1, 17, 27, 28, 31, 33].

The greatest silver birch height is recorded exactly in plantations in fertile agricultural soils-in soil CAS in the trial 13Iec/Gail and in SPG soil in the trial $14 \mathrm{Ozol} / \mathrm{Med}$; the mentioned soils had been extensively used in agricultural production (Table 8), here the mean height of silver birch at the age of 15 years marked as $15.3 \mathrm{~m}$.

In the plantations in SPG soil (trials No 3, 8, 10, 12, 14), the mean height of silver birch varies from 12.8 to $14.7 \mathrm{~m}$, in ASG soil (trial No 6) from 12.1 to $12.5 \mathrm{~m}$, in BUB soil (trial no 7) $14.3 \mathrm{~m}$, and in GSC soil (4Kand/Aizl), on heavy gley base material, $8.5 \mathrm{~m}$, but the mean diameter at breast height in these trials fluctuates from 9.7 to $13.2 \mathrm{~cm}$, from 10.3 to $12.5,10.9$, and $7.9 \mathrm{~cm}$, respectively (Table 8).

The productivity of silver birch plantations at the age of 15 years in different soils varies from 62 to $169 \mathrm{~m}^{3} \mathrm{ha}^{-1}$ (Table 7).

The current standing volume increment in silver birch plantation experimental trials varies from 7.54 to $29.82 \mathrm{~m}^{3} \mathrm{ha}^{-1}$ per year: the smallest increment$4.66 \mathrm{~m}^{3} \mathrm{ha}^{-1}$ per year-in 15-year-old plantations has been registered in heavy gley soil (4Kand/Aizl), but the largest, 29.72-29.82 $\mathrm{m}^{3}$ ha per year, in CAS soil (13/Gail) and in pseudogley soil (14/Med) (Table 7).

The data statistical analysis indicates that the productivity of silver birch plantations at the young stand age is also significantly smaller $(\mathrm{p} \leq 0.05)$ in heavy gley soils (4Kand/Aizl). 


\begin{tabular}{|c|c|c|c|c|c|c|c|c|c|c|c|c|c|c|}
\hline $\begin{array}{l}\text { Experimental } \\
\text { trial }\end{array}$ & $\begin{array}{c}\text { 1Grob/ } \\
\text { Bērz }\end{array}$ & $\begin{array}{l}\text { 3Kuld/ } \\
\text { Rūmn }\end{array}$ & $\begin{array}{l}\text { 4Kand/ } \\
\text { Aizl }\end{array}$ & 5Dob/Mez & 6Iec/Skuj & 7Vies/Pals & $\begin{array}{l}\text { 8Amat/ } \\
\text { Laub }\end{array}$ & 9Koc/Zar & $\begin{array}{l}\text { 10Mad/ } \\
\text { Birz }\end{array}$ & $\begin{array}{l}\text { 11Gulb/ } \\
\text { Sop }\end{array}$ & 12Rez/Bit & 13Iec/Gail & $\begin{array}{c}\text { 140zol/Med } \\
\text { (initially } 3000 \\
\text { trees ha }^{-1}\end{array}$ & $\begin{array}{c}\text { 15Ozol/Med } \\
\text { (initially } 1600 \\
\text { trees ha }^{-1}\end{array}$ \\
\hline Soil type [53] & $\mathrm{TP}$ & GSP & GSC & SP & ASG & BUB & $\mathrm{SP}$ & TSP & SPG & ASH & SPG & CAS & SPG & SPG \\
\hline $\mathrm{N}$, trees ha ${ }^{-1}$ & 1758 & 1952 & 2165 & 2650 & 2500 & 2928 & 2214 & 2354 & 1650 & 861 & 1400 & 1675 & 2765 & 1480 \\
\hline $\mathrm{D}, \mathrm{cm}$ & $10.6 \pm 2.71$ & $11.6 \pm 1.71$ & $7.9 \pm 2.21$ & $10.5 \pm 2.60$ & $10.3 \pm 2.80$ & $10.9 \pm 1.96$ & $9.7 \pm 2.60$ & $10.4 \pm 2.35$ & $10.8 \pm 3.3$ & $12.5 \pm 2.49$ & $8.8 \pm 3.6$ & $13.9 \pm 2.46$ & $12.6 \pm 2.06$ & $13.2 \pm 2.29$ \\
\hline $\mathrm{H}, \mathrm{m}$ & $12.3 \pm 1.14$ & $12.8 \pm 0.80$ & $8.5 \pm 1.00$ & $14.2 \pm 1.82$ & $12.5 \pm 2.3$ & $14.3 \pm 1.06$ & $13.3 \pm 1.83$ & $12.8 \pm 1.55$ & $13.0 \pm 2.18$ & $12.1 \pm 0.55$ & $10.0 \pm 3.0$ & $16.2 \pm 1.06$ & $14.0 \pm 1.53$ & $14.7 \pm 1.04$ \\
\hline $\mathrm{V}, \mathrm{dm}^{3}$ & 0.0534 & 0.0659 & 0.0219 & 0.0595 & 0.0512 & 0.0645 & 0.0505 & 0.0533 & 0.0582 & 0.0725 & 0.0439 & 0.0909 & 0.0489 & 985 \\
\hline $\mathrm{M}, \mathrm{m}^{3} \mathrm{ha}^{-1}$ & 82 & 101 & 47 & 128 & 138 & 145 & 112 & 131 & 135 & 62 & 61 & 169 & 143 & 122 \\
\hline $\begin{array}{l}Z_{M}, m^{3} h^{-1} \text { per } \\
\text { year }\end{array}$ & 14.33 & 12.17 & 4.66 & 13.49 & 21.69 & 25.1 & 15.72 & 20.97 & 12.07 & 8.30 & 3.72 & 29.82 & 29.72 & 24.97 \\
\hline $\begin{array}{l}\text { Significant } \\
\text { difference at } 0.05 \\
\text { level }(p<0.05)\end{array}$ & $\begin{array}{l}\text { Except } \\
\text { trials 6,7 }\end{array}$ & $\begin{array}{c}\text { Except } \\
\text { trials 2, 6, } \\
14,15\end{array}$ & $\begin{array}{l}\text { Between } \\
\text { all }\end{array}$ & $\begin{array}{c}\text { Except } \\
\text { trials } 3,12, \\
14,15\end{array}$ & $\begin{array}{c}\text { Except } \\
\text { trials } 3,4,7\end{array}$ & $\begin{array}{c}\text { Except } \\
\text { trials } 4,6\end{array}$ & $\begin{array}{c}\text { Except } \\
\text { trials } 4, \\
10,14,15\end{array}$ & $\begin{array}{c}\text { Except } \\
\text { trials 2, 6, } \\
7\end{array}$ & $\begin{array}{c}\text { Except } \\
\text { trials 2, 6, } \\
14,15\end{array}$ & $\begin{array}{l}\text { Between } \\
\text { all }\end{array}$ & $\begin{array}{c}\text { Except } \\
\text { trials 2, 6, } \\
14,15\end{array}$ & $\begin{array}{l}\text { Between } \\
\text { all }\end{array}$ & $\begin{array}{c}\text { Except } 13 \mathrm{Iec} / \\
\text { Gail }\end{array}$ & $\begin{array}{c}\text { Except } 13 \text { Iec/ } \\
\text { Gail }\end{array}$ \\
\hline
\end{tabular}

Table 7.

Growth and productivity of birch (Betula pendula Roth) plantations on agricultural lands. 
Plantation Forests: A Guarantee of Sustainable Management of Abandoned and Marginal... DOI: http://dx.doi.org/10.5772/intechopen.88373

\begin{tabular}{lcccccc}
\hline Experimental trial & Soil type & \multicolumn{5}{c}{ Mean tree volume, $\mathbf{~}^{\mathbf{3}}$} \\
\cline { 3 - 6 } & & \multicolumn{4}{c}{ Variants, planting schema } \\
\cline { 3 - 6 } & & $\mathbf{1} \times \mathbf{1} \mathbf{~ m}$ & $\mathbf{1} \times \mathbf{2 ~ \mathbf { ~ }}$ & $\mathbf{2} \times \mathbf{2} \mathbf{~ m}$ & $\mathbf{2 \times 3 \mathbf { ~ m }}$ & $\mathbf{3} \times \mathbf{3 ~ \mathbf { ~ }}$ \\
\hline 3Kuld/Rumn & SP & 0.0272 & 0.0356 & 0.0516 & 0.0603 & 0.0802 \\
\hline 10Mad/Birz & SPG & 0.0353 & 0.0530 & 0.0605 & 0.0592 & 0.1025 \\
\hline 12Rez/Bit & SPG & 0.0194 & 0.0298 & 0.0327 & 0.0360 & 0.0550 \\
\hline Average & & 0.0273 & 0.0395 & 0.0483 & 0.0518 & 0.0792 \\
\hline
\end{tabular}

Table 8

Variations in the mean tree volume of a 15-year birch depending on planting density at trial sites.

The largest cumulative volumes of mean tree for silver birch are in SPG extendedly cultivated soil (14Ozol/6Med) $0.0960 \mathrm{~m}^{3}$, in CAS soil (13lec/Gail) $0.0909 \mathrm{~m}^{3}$, and in ASG soil (6Iec/Skuj) $0.0798 \mathrm{~m}^{3}$, but the smallest cumulative volumes of mean tree have been recorded in GSC heavy gley soil in the trial 4Kand/Aizl, $0.0219 \mathrm{~m}^{3}$ (Table 7).

The growth of birch plantation, especially in the young age, depends on such factors as soil fertility, relief, microclimate, hydrological regime, and the method of establishing and tending the plantation. In terms of growth and yield, the best performance by the age of 15 years is shown by birch plantations (stock volume 112-169 $\mathrm{m}^{3} \mathrm{ha}^{-1}$ ) in fertile agricultural soils with stable moisture regime (cultivated, sod-podzolic, unsaturated brown, sod-gley alluvial soils).

It should be noted that the significant differences for the tree volume growth of birch plantation in 15 years depend on planting density (Table 8) [1, 26, 27].

Investigations show the same results than Estonian and Scandinavian researchers $[24,29,30]$; that higher density birch plantations $(10,000$ and 5000 trees $\mathrm{ha}^{-1}$ ) are profitable as short-rotation plantations of energy wood, but plantations with lower density $\left(1600,1100\right.$ trees $\mathrm{ha}^{-1}$ ) could be used for cultivating birch timber.

Research on the volume of the silver birch plantation above-ground biomass indicates that the biomass of a 10-year-old silver birch constitutes $65 \pm 12.81 \mathrm{~kg}$ $(100 \%)$ on average, of which the stem takes up $48 \pm 9.5 \mathrm{~kg}$ or $74 \%$ of the total tree biomass, but the crown biomass (branches plus leaves) $17 \pm 4.3 \mathrm{~kg}$ or $26 \%$ of the total tree biomass. A 15-year-old birch biomass constitutes $158.41 \pm 31.72 \mathrm{~kg}$ (100\%) on average, including the stem biomass $121 \pm 22.8 \mathrm{~kg}$ or $76 \%$ of the total tree biomass, but the crown biomass (branches and leaves) $37.3 \pm 14.3 \mathrm{~kg}$ or $24 \%$ of the total tree biomass (Table 9).

\section{Growth and development of alder (Alnus glutinosa (L.) Gaertn.) plantations}

Recent research indicates that alder occupies an important place in plantation forestry as well, since it grows vigorously in periodically wet areas or in areas with high groundwater levels and develops deep and broad root systems even under anaerobic conditions thanks to the absorption of oxygen through the lenticels of its trunk above the surface of the water; furthermore, alder is also capable of excreting toxic gases through the cells of its parenchyma [65]. Plantation cultivation of alder offers a high yield of wood in a relatively short period of time. It should be grown in fertile, sufficiently moist soils, where the groundwater level stays fairly high; these 


\begin{tabular}{cccc}
\hline Sample tree age (years) & Total biomass kg/\% & Stem mass kg/\% & Branch mass, $\mathbf{~ k g / \%}$ \\
\hline \multirow{2}{*}{10 years old } & $65 \pm 12.8 /$ & $48 \pm 9.5$ & $17 \pm 4.3 /$ \\
& 100 & 74 & 26 \\
\hline \multirow{2}{*}{12 years old } & $98 \pm 7.2 /$ & $71 \pm 3.9 /$ & $27 \pm 3.4 /$ \\
& 100 & 72 & 28 \\
\hline \multirow{2}{*}{15 years old } & $158 \pm 31.7 /$ & $121 \pm 22.9 /$ & $37 \pm 14.3 /$ \\
& 100 & 76 & 24 \\
\hline
\end{tabular}

Table 9.

The average indices of sample tree above-ground biomass (freshly cut) in 10-15-year-old silver birch plantations.

\begin{tabular}{|c|c|c|c|c|}
\hline \multirow[t]{2}{*}{ Experimental trials } & \multicolumn{2}{|l|}{$5 \mathrm{Dob} / \mathrm{Mez}$} & \multirow[t]{2}{*}{ 9Koc/Zar } & \multirow[t]{2}{*}{ 13Iec/Gail } \\
\hline & 1st floor & 2nd floor & & \\
\hline Soil type [53] & SP & SP & LSP & CAS \\
\hline $\mathrm{N}$, trees $\mathrm{ha}^{-1}$ & Total 3345/1st floor 2532 & 813 & 1146 & 700 \\
\hline $\mathrm{D}, \mathrm{cm}$ & $12.2 \pm 2.64$ & $6.2 \pm 1.44$ & $11.3 \pm 2.85$ & $14.5 \pm 3.42$ \\
\hline $\mathrm{H}, \mathrm{m}$ & $15.4 \pm 1.43$ & $10.9 \pm 1.56$ & $15.3 \pm 0.85$ & $10.9 \pm 1.12$ \\
\hline $\mathrm{V}, \mathrm{dm}^{3}$ & 0.0898 & 0.0184 & 0.0769 & 0.0923 \\
\hline $\mathrm{M}, \mathrm{m}^{3} \mathrm{ha}^{-1}$ & Total 249/1st floor 234 & 15 & 88 & 66 \\
\hline $\mathrm{Z}_{\mathrm{M}, \mathrm{m}^{3} \mathrm{ha}^{-1} \text { per year }}$ & 26.16 & - & 10.77 & 13.07 \\
\hline $\begin{array}{l}\text { Significant difference at } 0.05 \\
\text { level }(p<0.05)\end{array}$ & Between all & & $\begin{array}{c}\text { Except } \\
\text { 5Dob/Mez }\end{array}$ & $\begin{array}{c}\text { Except } \\
\text { 5Dob/Mez }\end{array}$ \\
\hline
\end{tabular}

Table 10.

Growth and productivity of alder (Alnus glutinosa (L.) Gaertn.) plantation in agricultural land.

are cultivated, soddy-podzolised, alluvial, podzolised gley, semi-hydromorphic, and peaty soils of high and transitional bogs with no stagnant groundwater [65].

The objective of the research project carried out by LSFRI Silava is to find out the productivity of alder in plantation-type stands in former agricultural lands. The research of alder stands is conducted at three objects: on SP soil (Dob/Mež), on LSC soil (Koc/Zar), and humus rich CAS soil (13Iec/Gail). Typically, the alder reaches DBH level during the second or third year after planting (Table 10).

Trials show that alder plantations in Sp, LSp, and CAS soils reach an average height of $10.9 \pm 1.12-15.4 \pm 1.43 \mathrm{~m}$ and diameter at the level of the chest of $11.3 \pm 2.85-14.5 \pm 3.42 \mathrm{~cm}$ at the age of 15 . The wood volume of the plantation, with the density of plantation being $1146-3345$ trees ha ${ }^{-1}$, amounts to $81-234 \mathrm{~m}^{3} \mathrm{ha}^{-1}$ (Table 10).

It should be noted that the removal of several root suckers has not been performed at the object $5 \mathrm{Dob} / \mathrm{Mez}$ and in $50 \%$ of the cases two to three root suckers were left at each trunk, while at the object 9Koc/Zar, all suckers have been removed (Table 10).

Plantation cultivation of common alder offers a high yield of wood in a relatively short period of time. It should be grown in sufficiently fertile moist soils, where the groundwater level stays fairly high; these are cultivated, sod-podzolic, alluvial, podzolic-gley, semi-hydromorphic, and peaty soils (CAS, SP, LSP, AHG, SPG, ASG, $\mathrm{BUB}$, etc.) of high and transitional bogs with no stagnant groundwater. 


\section{Growth and development of grey alder (Alnus incana (L.) Moench) plantations on agricultural lands}

Research indicates that grey alder is a promising species of trees in the climate zone of Latvia, as the volume of appropriately managed grey alder stands can reach $250-400 \mathrm{~m}^{3} \mathrm{ha}^{-1}$ within as few as $25-30$ years, with $50-70 \%$ of the trunk timber conforming to roundwood requirements $[1,17,68]$.

Research has confirmed that grey alder is particularly suitable for the development of plantations and short-rotation plantations.

It has been found that the growth rate of grey alder varies considerably in different growth conditions. In soils rich in mineral nutrients, as well as in humidity-controlled areas, the growth of grey alder in young stands and within the framework of first age class is only slightly behind the growth rate of hybrid aspen (see the section Growth Rate of Aspen and Hybrid Aspen Plantations) (Table 12 $[1,17,22,69])$.

The volume of grey alder in high-quality stands $(\mathrm{H} 20=12-20 \mathrm{~m})$ is also considerable, and as soon as within 15 years, the volume of harvested trunk timber amounts to $77-178 \mathrm{~m}^{3} \mathrm{ha}^{-1}$ (Table 12). Meanwhile, the yield of timber obtained from well-cultivated high-quality stands $(\mathrm{H} 20=20 \mathrm{~m})$ of grey alder at the age of 25 years amounts to $359 \mathrm{~m}^{3} \mathrm{ha}^{-1}$ (Table 11).

Investigations show that grey alder as a fast-growing species is suitable for plantation cultivation in sites with fertile soils and stable moisture regime. In high site index plantations $\left(\mathrm{H}_{20}=16-20 \mathrm{~m}\right)$, the stock volume of $10-15$-year grey alder may reach even $180 \mathrm{~m}^{3} \mathrm{ha}^{-1}$ (Table 12). Depending on the intensity of thinning at the early age, we may recover a definite volume of such assortments as roundwood, case timber, and firewood or wood chips. A 5-15-year grey alder coppice should be managed as short-rotation plantation, yielding 75-455 loose $\mathrm{m}^{3} \mathrm{ha}^{-1}$ of wood chips.

Development of broadleaved species: pedunculate oak (Quercus robur L.), wild cherry (Cerasus avium Moench. syn. Prunus avium), and small-leaved lime (Tilia cordata L.) plantations on agricultural lands.

Broadleaved species pedunculate oak, wild cherry, and small-leaved lime plantations on agricultural lands with naturally dry mineral soils (TSC, SP, GSC, BUB, ASG, CAS) show different growth rate than common tree species: for oak, tree height fluctuated from $2.6 \pm 0.83$ to $6.0 \pm 2.4 \mathrm{~m}$ and breast height (DBH) from $2.8 \pm 1.64$ to $6.6 \pm 3.9 \mathrm{~cm}$; for wild cherry, tree height fluctuated from $5.5 \pm 0.81$ to $7.8 \pm 0.53 \mathrm{~m}$ and DBH $5.2 \pm 1.72-11.4 \pm 2.62 \mathrm{~cm}$; and for small-leaved lime, tree height fluctuated from $7.1 \pm 0.84$ to $8.8 \pm 2.14 \mathrm{~m}$ and DBH from $8.8 \pm 2.14 \mathrm{~cm}$ to $13.6 \pm 2.80 \mathrm{~cm}$. At this stage it is not yet possible to evaluate the performance of these plantations (Table 12).

Research shows that, under the climatic conditions of Latvia, the growth rate of tree species like pedunculate oak (Quercus robur L.), small-leaved lime (Tilia cordata L.), and wild cherry (Cerasus avium (L.) Moench syn. Prunus avium L.) is slower than the local tree species (Scots pine, Norway spruce, silver birch, etc.) and 15-year-old plantations present with comparatively minor tree dimensions and thus the productive volume. This means that considerably different plantation management must be scheduled compared to the plantation management of native tree species.

Plantation cultivation of common oak proves right only in the case there is a suitable site for it: relief elevation; calcareous rock in lower soil horizons; sufficiently moist and fertile soils like soddy calcareous, soddy-podzolised, and alluvial soils with a stable moisture regime, cultivated soils with sandy loam, and loam as the parent rock; soil acidity $\mathrm{pH}-6-7-8$; and liming in case of need. In 


\begin{tabular}{|c|c|c|c|c|c|}
\hline Parameters & 5 years old & 10 years old & 15 years old & 20 years old & 25 years old \\
\hline \multicolumn{6}{|l|}{ Site index $\mathrm{H}_{20}=8 \mathrm{~m}$} \\
\hline $\mathrm{N}$, trees ha ${ }^{-1}$ & 10,000 & 5192 & 3539 & 2696 & \\
\hline $\mathrm{D}, \mathrm{cm}$ & 2.7 & 4.8 & 6.5 & 8.0 & \\
\hline $\mathrm{H}, \mathrm{m}$ & 2.3 & 4.1 & 5.7 & 7.3 & \\
\hline $\mathrm{V}, \mathrm{m}^{3}$ & 0.0008 & 0.0038 & 0.0096 & 0.0178 & \\
\hline $\mathrm{M}, \mathrm{m}^{3} \mathrm{ha}^{-1}$ & 8 & 20 & 34 & 48 & \\
\hline $\mathrm{Z}_{\mathrm{M}}, \mathrm{m}^{3} \mathrm{ha}^{-1}$ per year & 1.7 & 2.0 & 2.2 & 2.4 & \\
\hline \multicolumn{6}{|l|}{ Site index $\mathrm{H}_{20}=12 \mathrm{~m}$} \\
\hline $\mathrm{N}$, trees ha ${ }^{-1}$ & 8000 & 4251 & 2937 & 2259 & 1843 \\
\hline $\mathrm{D}, \mathrm{cm}$ & 4.1 & 7.2 & 9.8 & 12.0 & 13.9 \\
\hline $\mathrm{H}, \mathrm{m}$ & 3.4 & 5.9 & 8.2 & 10.4 & 12.5 \\
\hline $\mathrm{V}, \mathrm{m}^{3}$ & 0.0024 & 0.0108 & 0.0268 & 0.0491 & 0.0803 \\
\hline $\mathrm{M}, \mathrm{m}^{3} \mathrm{ha}^{-1}$ & 19 & 46 & 77 & 111 & 148 \\
\hline $\mathrm{Z}_{\mathrm{M}}, \mathrm{m}^{3} \mathrm{ha}^{-1}$ per year & 3.7 & 4.6 & 5.1 & 5.5 & 5.9 \\
\hline \multicolumn{6}{|l|}{ Site index $\mathrm{H}_{20}=16 \mathrm{~m}$} \\
\hline $\mathrm{N}$, trees ha ${ }^{-1}$ & 6000 & 3302 & 2328 & 1817 & 1499 \\
\hline $\mathrm{D}, \mathrm{cm}$ & 5.4 & 9.7 & 13.1 & 16.0 & 18.5 \\
\hline $\mathrm{H}, \mathrm{m}$ & 4.5 & 7.8 & 10.8 & 13.7 & 16.4 \\
\hline $\mathrm{V}, \mathrm{m}^{3}$ & 0.0050 & 0.0230 & 0.0554 & 0.1040 & 0.1688 \\
\hline $\mathrm{M}, \mathrm{m}^{3} \mathrm{ha}^{-1}$ & 30 & 76 & 129 & 189 & 253 \\
\hline $\mathrm{Z}_{\mathrm{M}}, \mathrm{m}^{3} \mathrm{ha}^{-1}$ per year & 6.1 & 7.6 & 8.6 & 9.4 & 10.1 \\
\hline \multicolumn{6}{|l|}{ Site index $\mathrm{H}_{20}=20 \mathrm{~m}$} \\
\hline $\mathrm{N}$, trees $\mathrm{ha}^{-1}$ & 4000 & 2339 & 1709 & 1368 & 1151 \\
\hline $\mathrm{D}, \mathrm{cm}$ & 6.8 & 12.1 & 16.4 & 20.0 & 23.2 \\
\hline $\mathrm{H}, \mathrm{m}$ & 5.8 & 10.0 & 13.8 & 17.3 & 20.6 \\
\hline $\mathrm{V}, \mathrm{m}^{3}$ & 0.0097 & 0.0436 & 0.1041 & 0.1930 & 0.3119 \\
\hline $\mathrm{M}, \mathrm{m}^{3} \mathrm{ha}^{-1}$ & 39 & 102 & 178 & 264 & 359 \\
\hline $\mathrm{Z}_{\mathrm{M}}, \mathrm{m}^{3} \mathrm{ha}^{-1}$ per year & 7.9 & 10.2 & 11.9 & 13.2 & 14.3 \\
\hline
\end{tabular}

Table 11.

Grey alder plantation characterising parameters in various agricultural land soils at the age of 5-15 years (site index $\mathrm{H}_{2} \mathrm{O}=8 \mathrm{~m}$ to $\mathrm{H}_{2} \mathrm{O}=2 \mathrm{O} \mathrm{m}$ ) [69].

adequately tended plantations, common oak in favourable growing conditions may by the age of 15 years reach the mean height of $6.0 \mathrm{~m}$ and the mean diameter of $6.6 \mathrm{~cm}$. To ensure $80-85 \%$ survival of the oaks planted out, the plantation should be properly and timely tended, as well as protected against the pest, disease, and wildlife damage (use of repellents, protection tubes for tree stems, etc.). Wild cherry should be cultivated on fully lighted relief elevations, suitable for the given species. Preferably, the site should be protected from the north and east winds and have well-aerated sandy loam and loamy soils with calcareous rock underneath (soil reaction $\mathrm{pH}$ 6.5-8). Wild cherry cannot be planted in terrain depressions, where it may suffer from night frosts. Site preparation is by 
Plantation Forests: A Guarantee of Sustainable Management of Abandoned and Marginal... DOI: http://dx.doi.org/10.5772/intechopen.88373

\begin{tabular}{|c|c|c|c|c|c|c|}
\hline \multicolumn{7}{|c|}{ Pedunculate oak } \\
\hline $\begin{array}{l}\text { Experimental } \\
\text { trials }\end{array}$ & $\begin{array}{l}\text { 1Priek/ } \\
\text { Ozol }\end{array}$ & $\begin{array}{l}\text { 3Kuld/ } \\
\text { Rumn }\end{array}$ & 4Kand/Aizl & $\begin{array}{l}\text { 7Vies/ } \\
\text { Pals }\end{array}$ & 11Gulb/Sop & $\begin{array}{c}\text { 13Iec/ } \\
\text { Gail }\end{array}$ \\
\hline Soil type & TSC & SP & GSC & BUB & ASG & CAS \\
\hline $\mathrm{N}$, trees ha ${ }^{-1}$ & 1580 & 1950 & 1190 & 1887 & 818 & 1650 \\
\hline $\mathrm{D}, \mathrm{cm}$ & $4.9 \pm 2.49$ & $5.1 \pm 3.49$ & $2.9 \pm 2.35$ & $6.6 \pm 3.90$ & $2.8 \pm 1.64$ & $5.9 \pm 2.67$ \\
\hline $\mathrm{H}, \mathrm{m}$ & $4.0 \pm 2.16$ & $4.3 \pm 1.47$ & $2.8 \pm 1.32$ & $6.0 \pm 2.40$ & $2.6 \pm 0.83$ & $4.9 \pm 1.73$ \\
\hline $\mathrm{V}, \mathrm{dm}^{3}$ & 0.0048 & 0.0118 & 0.0005 & 0.0095 & 0.0019 & 0.0078 \\
\hline $\mathrm{M}, \mathrm{m}^{3} \mathrm{ha}^{-1}$ & 7.6 & 23.0 & 0.6 & 18.0 & 1.6 & 12.9 \\
\hline \multicolumn{7}{|l|}{$\begin{array}{l}Z_{M}, m^{3} h a^{-1} \text { per } \\
\text { year }\end{array}$} \\
\hline $\begin{array}{l}\text { Significant } \\
\text { difference at } 0.05 \\
\text { level }(p<0.05)\end{array}$ & $\begin{array}{l}\text { Except } \\
\text { 3Kuld/ } \\
\text { Rumn }\end{array}$ & $\begin{array}{l}\text { Except } \\
\text { 7Vies/ } \\
\text { Pals, } \\
\text { 13Iec/Gail }\end{array}$ & $\begin{array}{c}\text { Except } \\
\text { 1Priek/Ozol, } \\
\text { 3Kuld/Rumn, } \\
\text { TVies/Pals, } \\
\text { 13Iec/Gail }\end{array}$ & $\begin{array}{c}\text { Except } \\
\text { 13Iec/Gail }\end{array}$ & $\begin{array}{c}\text { Except } \\
\text { 1Priek/Ozol, } \\
\text { 3Kuld/Rumn, } \\
\text { 7Vies/Pals, } \\
\text { 13Iec/Gail }\end{array}$ & $\begin{array}{l}\text { Except } \\
\text { 7Vies/ } \\
\text { Pals }\end{array}$ \\
\hline \multicolumn{7}{|l|}{ Small-leaved lime } \\
\hline Experimental trials & $\begin{array}{c}\text { 1Priek/ } \\
\text { Ozol }\end{array}$ & 7Vies/Pals & 18Krust/Paki & & & \\
\hline Soil type & TSC & BUB & SPG & & & \\
\hline $\mathrm{N}$, tree ha ${ }^{-1}$ & 1000 & 900 & 1000 & & & \\
\hline $\mathrm{D}, \mathrm{cm}$ & $13.6 \pm 2.80$ & $11.8 \pm 2.73$ & $8.8 \pm 2.14$ & & & \\
\hline $\mathrm{H}, \mathrm{m}$ & $8.6 \pm 0.95$ & $8.8 \pm 0.73$ & $7.1 \pm 0.84$ & & & \\
\hline $\mathrm{V}, \mathrm{dm}^{3}$ & 0.0145 & 0.0141 & 0.0149 & & & \\
\hline $\mathrm{M}, \mathrm{m}^{3} \mathrm{ha}^{-1}$ & 64 & 49 & 42 & & & \\
\hline \multicolumn{7}{|l|}{$\begin{array}{l}Z_{M}, m^{3} h^{-1} \text { per } \\
\text { year }\end{array}$} \\
\hline \multicolumn{7}{|l|}{$\begin{array}{l}\text { Significant } \\
\text { difference at } 0.05 \\
\text { level }(p<0.05)\end{array}$} \\
\hline \multicolumn{7}{|l|}{ Wild cherry } \\
\hline Experimental trials & $\begin{array}{c}\text { 1Priek/ } \\
\text { Ozol }\end{array}$ & $\begin{array}{l}\text { 3Kuld/ } \\
\text { Rumn }\end{array}$ & 16Tals/Zelt & & & \\
\hline Soil type & TSC & SPG & SP & & & \\
\hline $\mathrm{N}$, tree ha ${ }^{-1}$ & 1580 & 1920 & 5600 & & & \\
\hline $\mathrm{D}, \mathrm{cm}$ & $11.4 \pm 2.62$ & $8.5 \pm 1.72$ & $11.5 \pm 3.80$ & & & \\
\hline $\mathrm{H}, \mathrm{m}$ & $8.5 \pm 0.53$ & $8.2 \pm 0.81$ & $7.0 \pm 1.48$ & & & \\
\hline $\mathrm{V}, \mathrm{dm}^{3}$ & 0.0437 & 0.0251 & 0.0205 & & & \\
\hline $\mathrm{M}, \mathrm{m}^{3} \mathrm{ha}^{-1}$ & 69 & 48 & 115 & & & \\
\hline $\begin{array}{l}Z_{M}, m^{3} h^{-1} \text { per } \\
\text { year }\end{array}$ & 4.6 & 3.2 & 13.49 & & & \\
\hline $\begin{array}{l}\text { Significant } \\
\text { difference at } 0.05 \\
\text { level }(p<0.05)\end{array}$ & $\begin{array}{l}\text { Except } \\
\text { 3Kuld/ } \\
\text { Rumn }\end{array}$ & $\begin{array}{l}\text { Between } \\
\text { all }\end{array}$ & $\begin{array}{l}\text { Except 3Kuld/ } \\
\text { Rumn }\end{array}$ & & & \\
\hline
\end{tabular}

Table 12.

Development of lime (Tilia cordata L.), oak (Quercus robur L.), and European cherry (Prunus avium L.) plantations on agricultural lands. 
continuous or strip ploughing 30-40-cm deep; careful tending and stem protection are critical requirements; initial planting density is $900-1600$ trees ha $^{-1}$.

\section{Development of aspen (Populus tremula L.) and hybrid aspen (Populus tremula $x$ tremuloides Mich.) plantations on agricultural lands}

Correct selection of the site of planting is important for the establishment of productive conventional and hybrid aspen plantations, since aspen is a lightdemanding tree species and its vegetation period is long. Well-drained, fertile loam, and sandy loam soils that are rich in minerals, sod-podzolic, soddy-gley alluvial, and gley soils and agricultural land soils, where the groundwater is running and its level is comparatively high, are the most suitable soils for the cultivation of aspen [1, 70-72].

Research has demonstrated that, in order to obtain optimum volume, the plantation must contain no less than 1000-1400 trees per 1 ha until the felling of the plantation at the age of 25 while retaining the initial density of the plantation $[69,70]$.

The conducted trials indicate that at the age of 15-16, the plantations of aspen, at 2500 trees ha ${ }^{-1}$, produce $150 \mathrm{~m}^{3} \mathrm{ha}^{-1}$ stock volume and current volume growth of about $7 \mathrm{~m}^{3} \mathrm{ha}^{-1}$ per year ${ }^{-1}$, meanwhile plantations of hybrid aspen of the same age at the density of 950 trees ha ${ }^{-1}$ reach $309 \mathrm{~m}^{3} \mathrm{ha}^{-1}$ in volume with the current volume growth of $25 \mathrm{~m}^{3} \mathrm{ha}^{-1}$ year $^{-1}$ (Table 13).

The average height of trees at the age of 15 years in a common aspen plantation is $\mathrm{H}=12.4 \mathrm{~m}$ and the average diameter at chest height $\mathrm{D}=11.8 \mathrm{~cm}$, while the annual current volume growth is $6.97 \mathrm{~m}^{3} \mathrm{ha}^{-1}$ year $^{-1}$ (Table 14). In contrast, the average height of trees at the age of 16 years in the hybrid aspen plantation is $\mathrm{H} 20=20 \mathrm{~m}$, and the average diameter at breast height is $\mathrm{D}=18.9 \mathrm{~cm}$, while the annual current growth of the stock volume is $24.67 \mathrm{~m}^{3} \mathrm{ha}^{-1}$ year $^{-1}$ (Table 14). Similar current growth data for hybrid aspen plantations have also been recorded by Swedish researchers, provided that the first thinning is performed at the age of 10-11, leaving 800-900 trees $\mathrm{ha}^{-1}$; the second at the age of 15-16, leaving 500-600 trees $\mathrm{ha}^{-1}$; and the third at the age of 20 , leaving about $350-400$ trees ha ${ }^{-1}[26,72]$.

Highly productive plantations of common and hybrid aspen are possible in fertile sites of loamy and sandy loam soils with a stable moisture regime (soddy-podzolised,

\begin{tabular}{lcc}
\hline Experimental trials & Common aspen 11Gulb/Sop & Hybrid aspen 13Iec/Gail \\
\hline Soil type & ASG & CAS \\
\hline $\mathrm{N}$, trees ha $^{-1}$ & 2504 & 950 \\
\hline $\mathrm{D}, \mathrm{cm}$ & $11.8 \pm 2.93$ & $18.9 \pm 3.12$ \\
\hline $\mathrm{H}, \mathrm{m}$ & $12.4 \pm 1.42$ & $20.0 \pm 2.05$ \\
\hline $\mathrm{V}, \mathrm{dm}^{3}$ & 0.0599 & 0.325 \\
\hline $\mathrm{M}, \mathrm{m}^{3} \mathrm{ha}^{-1}$ & 150 & 309 \\
\hline $\mathrm{Z}_{\mathrm{M}}, \mathrm{m}^{3} \mathrm{ha}^{-1}$ per year & 6.97 & 24.67 \\
\hline $\begin{array}{l}\text { Significant difference at } 0.05 \text { level } \\
(p<0.05)\end{array}$ & Significant difference with & Significant difference with \\
\end{tabular}

Table 13.

Dendrometric parameters for a 15-year aspen (Populus tremula L.) and hybrid aspen (Populus tremula $x$ tremuloides mill.) at the plantations of agricultural land. 
Plantation Forests: A Guarantee of Sustainable Management of Abandoned and Marginal... DOI: $h$ ttp://dx.doi.org/10.5772/intechopen.88373

\begin{tabular}{lccc}
\hline Plantations & $\begin{array}{c}\text { Scots pine } \\
\text { plantation, age } \\
\text { 15 years }\end{array}$ & $\begin{array}{c}\text { Norway spruce } \\
\text { plantations, age } \\
\text { 15 years }\end{array}$ & $\begin{array}{c}\text { Silver birch } \\
\text { plantations, age } \\
\text { 15 years }\end{array}$ \\
\hline Number of trees ha ${ }^{-1}$ (average) & $1510-3774$ & $1400-3128$ & $1400-2650$ \\
\hline $\begin{array}{l}\text { Timber volume obtainable during thinning, } \\
\mathrm{m}^{3} \mathrm{ha}^{-1}\end{array}$ & $12-99$ & $33-67$ & $25-81$ \\
\hline $\begin{array}{l}\text { Obtainable pulpwood/firewood volume, } \\
\mathrm{m}^{3} \text { ha }^{-1}\end{array}$ & $6 / 6-50 / 49$ & $16 / 17-33 / 34$ & $7.5 / 17.5-24 / 57$ \\
\hline $\begin{array}{l}\text { Total obtainable biomass (stem wood }+ \\
\text { branches) (freshly cut)/abs.dry, } \mathrm{t} \mathrm{ha}^{-1}\end{array}$ & $5.2 / 3.1-43 / 25.5$ & $40 / 23-82 / 48$ & $22 / 18-88 / 67$ \\
(Tables 4, 6, 10)
\end{tabular}

Table 14.

The amount of timber and pulpwood plus wood waste biomass $\left(m^{3} h a^{-1} ; t h a^{-1}\right)$ (EUR) obtainable from 15-year-old scots pine, Norway spruce, and silver birch plantations.

soddy-gley, gley, podzolised gley, cultivated soils). To obtain an appreciable stock volume, the planting density should be no less than 1100 trees ha $^{-1}$ at the $85-100 \%$ survival of the stock initially planted. The stock volume of a 15 -year common aspen plantation may reach $150 \mathrm{~m}^{3} \mathrm{ha}^{-1}$, while hybrid aspen $300 \mathrm{~m}^{3} \mathrm{ha}^{-1}$. The first thinning should be done no later than at the age of 9-10 years, reducing the number of trees to 900 trees ha ${ }^{-1}$. The rotation period for hybrid aspen is $20-25$ years, while for common aspen 30-35 years. In managing aspen plantations, sufficient attention should be given to tree protection against the damage of artiodactyls and rodents, let alone the pest and disease control (Plantskids, Cervacol Extra, Wobra; Tubex and Vertex plastic protection tubes; plastic entanglements; fences).

\section{Predictable productivity of plantation forests in Latvia}

If it is planned to manage this kind of plantation as a roundwood production plantation, it is necessary to perform the first thinning of the standing volume. The projected volume of timber and biomass to be felled has been calculated by considering the number of trees to be felled and the standing volume of the tree species mean tree stem wood and branch biomass. According to the Latvian forest legislation, the optimal number of tree in pine young stands with average $\mathrm{H}=7 \mathrm{~m}$ is 1300 trees ha $\mathrm{a}^{-1}$, in Norway spruce young stands with $\mathrm{H}=8 \mathrm{~m}$ are 1100 trees ha ${ }^{-1}$, and in silver birch young stands with $\mathrm{H}=11 \mathrm{~m}$ are 900-1100 trees ha ${ }^{-1}$ [73].

Calculations show that the highest pulpwood volume and wood biomass in the first thinning are obtainable from plantations that have retained the initial planting density (Table 14) [73].

In the silver birch experimental trials, the first round tending or thinning is needed to ensure further growth, by reducing the number of trees and thus obtaining the pulpwood to be sold. Its volume calculation has been performed by the methodology of modelling roundwood assortment yield in thinning birch plantations $[74,75]$. These investigations show that the number of trees after the first thinning must be no more than 1100 trees per ha $[74,75]$.

Our research indicates that for the acquisition of energy wood higher stocking density (10,000 and 5000 trees per ha) silver birch plantations can be established, the rotation period of which could be 15 years [1]. It must be noted that despite decreasing the number of trees by 26-34\%, the total biomass (number of trees $\mathrm{x}$ medium tree mass, $\mathrm{kg}$ ) reaches about 530-942 $\mathrm{t} \mathrm{ha}^{-1}$ (Table 15). 


\begin{tabular}{lcccc}
\hline $\begin{array}{l}\text { Experimental } \\
\text { trial site }\end{array}$ & $\begin{array}{c}\text { Age } \\
\text { (years) }\end{array}$ & $\begin{array}{c}\text { Number of trees per ha/ } \\
\text { obtaining cutting out } \\
\text { number of trees ha }\end{array}$ & $\begin{array}{c}\text { Obtainable } \\
\text { volume during } \\
\text { thinning, } \\
\mathbf{m}^{\mathbf{3}} \mathbf{h a}^{-\mathbf{1}}\end{array}$ & $\begin{array}{c}\text { Obtainable pulpwood/ } \\
\text { firewood (50\% pulpwood, } \\
\text { 50\% firewood) } \mathbf{~ m}^{\mathbf{3}} \mathbf{~ h a}^{-\mathbf{1}}\end{array}$ \\
\hline 5Dob/Mez & 15 & $3345 / 2230$ & 145 & $72.5 / 72.5$ \\
\hline 9Koc/Zar & 15 & $1146 /-$ & 0 & 0 \\
\hline 13Iec/Gaili & 15 & $700 /-$ & 0 & 0 \\
\hline
\end{tabular}

Table 15.

Available volume of wood in common alder plantations at experimental trial sites.

Similar conclusions have also been published in Finland and Sweden, where it has been noted that dense birch plantations must be managed for obtaining energy wood, but sparse plantations must be designated for acquisition of the assortment $[14,24,29]$.

By the age of 15, the annual volume growth of the alder plantation is $10.77-$ $26.16 \mathrm{~m}^{3} \mathrm{ha}^{-1}$ year with the stock volume up to $249 \mathrm{~m}^{3} \mathrm{ha}^{-1}$, provided one, two, or even three root suckers are left at each stem. The first thinning, with the roundwood yield of $70-100 \mathrm{~m}^{3}$, could be performed by the age of 10-12 years, retaining only good quality stems. By careful and proper management of alder plantations, it is possible to get assortments such as veneer logs and sawlogs by the age of 30-40 years (Table 15).

According to the recommendation of Swedish researchers, if the plantations of hybrid aspen are developed for the production of chipped wood, thinning should not be performed at all and the rotation cycle is 25 years. Meanwhile, if the plantation is intended for the production of roundwood, the recommended cultivation technology is as follows: the number of original plants is $1100-1200$ trees $^{-1} \mathrm{a}^{-1}$; the first thinning is performed at the age of 10-11, leaving 700 trees ha ${ }^{-1}$; and the last thinning is done at the age of $16-17$, leaving about 400 trees ha ${ }^{-1}[26,69]$.

Calculations indicate that the volume of felled timber at the plantation of aspen is expected to average at $102 \mathrm{~m}^{2}$, while the output of pulpwood is estimated to amount to approximately $50 \%$ of the total timber yield, while $50 \%$ of the timber will be valued as firewood (Table 16).

The investigations show that to obtain an appreciable stock volume, the planting density should be no less than 1100 trees ha $^{-1}$ at the $85-100 \%$ survival of the stock initially planted. The rotation period for hybrid aspen is $20-25$ years, while for aspen 30-35 years. In managing aspen plantations, sufficient attention should be given to tree protection against the damage of artiodactyls and rodents, let alone the pest and disease control (Plantskids, Cervacol Extra, Wobra; Tubex and Vertex plastic protection tubes; plastic entanglements; fences) [1].

\begin{tabular}{lcccc}
\hline Trial site & $\begin{array}{c}\text { Age } \\
\text { (years) }\end{array}$ & $\begin{array}{c}\text { Number of trees per ha/ } \\
\text { obtainable number of } \\
\text { trees cutting out during } \\
\text { thinning, trees ha }\end{array}$ & $\begin{array}{c}\text { Obtainable } \\
\text { volume during } \\
\text { thinning, } \mathbf{~ m}^{\mathbf{3}} \mathbf{h a}\end{array}$ & $\begin{array}{c}\text { Obtainable volume: } \\
\text { roundwood } \\
(\mathbf{5 0 - 8 0 \% ) / f i r e w o o d ~} \\
\left(\mathbf{5 0 - 2 0 \% )}, \mathbf{~ m}^{\mathbf{3}} \mathbf{h a}^{-\mathbf{1}}\right.\end{array}$ \\
\hline $\begin{array}{l}\text { 11Gulb/Sop } \\
\text { (aspen) }\end{array}$ & 15 & $2504 / 1704$ & 102 & $51 / 51$ \\
\hline $\begin{array}{l}\text { 13Iec/Gail } \\
\text { (hybrid aspen) }\end{array}$ & 15 & $950 / 550$ & 179 & $143 / 36$ \\
\hline
\end{tabular}

Table 16.

Available volume of wood in aspen and hybrid aspen plantations at the age 15 years. 
Plantation Forests: A Guarantee of Sustainable Management of Abandoned and Marginal... DOI: http://dx.doi.org/10.5772/intechopen.88373

\section{Conclusion}

In studied plantations on former agricultural lands, Scots pine (Pinus sylvestris L.), Norway spruce (Picea abies (L.) Karst.), silver birch (Betula pendula Roth.), alder (Alnus glutinosa (L.) Gaertn.), grey alder (Alnus incana (L.) Moench.), aspen (Populus tremula L.), and hybrid aspen (Populus tremula $x$ tremuloides Mill.) reach a standing volume of maximum $100-300 \mathrm{~m}^{3} \mathrm{ha}^{-1}$ in 15 years, the lowest for conifers and the highest for broadleaves. To ensure potentially high-volume growth in similar plantations in the future, the number of trees per unit area should be reduced.

Spruce, in terms of growth rates and productivity, performs best in naturally dry nutrient-rich soddy-podzolised, soddy-gley alluvial, and cultivated soils with sandy loam and loam as a parent rock. In the sites like that, spruce with its shallow root system is sufficiently supplied with nutrients and protected from sharp groundwater-level fluctuations in the spring and autumn seasons with heavy precipitation.

Properly timed thinning of spruce plantations, done no later than at the age of 12-15 years, is of special importance for achieving a significant growth of stock volume and having top-quality stems. Pruning of crop trees is desired; it could be done in the localities with no threat of bark stripping by the artiodactyls.

When cultivating spruce in farmlands, protection measures should be taken against potential infection by parasitic fungi. In the case thinning is done during the growing season, the stumps of the trees removed should be treated by some fungisuppressing agent (Rotstop, etc.) to avoid the spread of root rot, caused by the fungus Heterobasidion annosum. In plantation tending care should be taken to avoid mechanical damage of tree stems. To get branch-free spruce stems, pruning up to the height of $2 \mathrm{~m}$ should be started no earlier than at the age of 12-15 years and continued in subsequent years.

According to our results, silver birch, alder, grey alder, and Norway spruce are the most suitable for short-rotation (25-40 years) plantations in naturally dry mineral soils of light and medium heavy texture in Latvian climatic conditions. The stands of increased stocking density could be useful for producing energy wood, while those of lower density-for the economically feasible production of commercial timber.

In the climatic conditions of Latvia, small-leaved lime (Tilia cordata L.), pedunculate oak (Quercus robur L.), and wild cherry (Cerasus avium (L.) Moench. syn. Prunus avium L.) have reached the standing volume of $18-39 \mathrm{~m}^{3} \mathrm{ha}^{-1}$ in 15 years after plantation establishment, except for the stand volume of wild cherry with 5600 trees per ha; accordingly we cannot evaluate their suitability for use in plantations before some $30-40$ years.

After forest establishment on farmlands, the soil tends to become more acidic. Characteristic meadow and fallow grass species are declining, while species typical to forest vegetation appear. In fertile soils, the meadow plant species are replaced by benthic eurytopic nitrophytes like Urtica dioica, Anthriscus sylvestris, and Dactylis glomerata. Forest ground-cover vegetation emerges faster in the sites on dry, lean soils.

\section{Acknowledgements}

This project has received funding from the European Union's Horizon 2020 research and innovation programme under grant agreement No 727698. The experimental plots were established as a part of the EU PHARE projects 'Support to 
private forestry of Latvia' (1996-1997) and 'Institutional support to private forestry' (1998-1999), as well as projects financed by the State Forest Service and the Ministry of Agriculture. Since 2009, research data were gathered with the support of ERDF project No. 2010/0268/2DP/2.1.1.2.0/10/APIA/VIAA/118, and research work is continuing in the scope of ERDF project No. 2013/0049/2DP/2.1.1.10/13/ APIA/VIAA/031 and HORIZON 2020 project no 727698 'Marginal lands for cultivating industrial crops: turning a burden into an opportunity (MAGIC)'.

\section{Author details}

Mudrite Daugaviete*, Dagnija Lazdina, Baiba Bambe, Andis Lazdins, Kristaps Makovskis and Uldis Daugavietis Latvian State Forest Research Institute "Silava”, Latvia

*Address all correspondence to: mudrite.daugaviete@silava.lv

\section{IntechOpen}

(C) 2020 The Author(s). Licensee IntechOpen. Distributed under the terms of the Creative Commons Attribution - NonCommercial 4.0 License (https://creativecommons.org/ licenses/by-nc/4.0/), which permits use, distribution and reproduction for non-commercial purposes, provided the original is properly cited. (cc) BY-NC 
Plantation Forests: A Guarantee of Sustainable Management of Abandoned and Marginal... DOI: http://dx.doi.org/10.5772/intechopen.88373

\section{References}

[1] Daugaviete M, Bambe B, Lazdiņš A, Lazdina D. Plantation Forests: Growth, Productivity and Impact on the Environment. Salaspils: LVMI Silava, DU AA Saule; 2017. p. 470

[2] West PW. Growing Forest Plantations. New York: Springer; 2014. p. 329

[3] Carnus JM, Parrotta J, Brockerhoff E. Planted forests and biodiversity. Journal of Forestry. 2006;104:65-77

[4] Del Lungo A, Ball J, Carll J. Global planted forests thematic study. Results and analysis. Working. Paper. FAO Paper Rome, Italy: 2006. p. 178

[5] Zanchi G, Thiel D, Green T, Lindner M. Afforestation in Europe. Final Version 26/01/07.MEACAP WP4. 2007. p. 41

[6] Paquette A, Messier C. The role of plantations in managing the world's forests in the Anthropocene. Frontiers in Ecology and the Environment2010. 2010;8(1):27-34

[7] Mathews JD. Silvicultural Systems. Oxford: Clarendon Press; 1989. p. 284

[8] Savill P, Evans J, Auclar D, Falck J. Plantation silviculture in Europe.

Department of Plant Sciences.

University of Oxford, United Kingdom: Oxford University Press; 1997. p. 283

[9] Brown C. The global outlook for future wood supply from forest plantations. FAO Working Paper No GFPOS/WP/03. 2000. p. 156

[10] Weber N, editor. NEWFOR-new forests for Europe: Afforestation at the turn of the century. In: Proceedings of the Scientific Symposium. No. 35. February 16th-17th, 2000. Freiburg, Germany. 2000. p. 244

[11] Halldorsson G, Oddsdottir ES, Sigurdsson BD, editors. AFFORNORD. Effects of Afforestation on Ecosystems,
Landscape and Rural Development. Reykholt (Iceland): TemaNord; 2008. p. 562

[12] Lazdiņš A. Predictions for efficient management of naturally afforested farmlands. Promocijas draba kopsavilkums Dr. silv. zin. grāda iegūšanai Mežzinātnes nozarē Meža ekologijas un mežkopības apakšnozarē LVMI Silava. 2011. 51.lpp. (in Latvian)

[13] Mather A, editor. Afforestation: Policies, Planning and Progress. Vol. 223. London: Belhaven Press; 1993

[14] Freedman B. Benefits of afforestation. In: Proceedings of the AFFORNORD Conference "Effects of Afforestation on Ecosystems, Landscape and Rural Development", June 18-22, Reykholt, Iceland. 2005. pp. 13-23

[15] Turnbull JW. Tree Domestication and History of Plantations (WWW document). Available from: https:// www.eolss.net/Sample-Chapters/C10/ E5-01-02-02.pdf

[16] Sedjo R, Botkin D. Using forest plantations to spare natural forests. Environment. 1986;39(10):14-20

[17] Daugaviete M, Lazdina D, Bambe B, Bardule A, Bardulis A, Daugavietis U. Productivity of different tree species in plantations and agricultural soils and related environmental impacts. Baltic Forestry. 2015;21(2):349-358

[18] Kohl M, Lasco R, Cifuentes M, Jonsson O, Korhonen K, Ph M, et al. Changes in forest production, biomass and carbon: Results from the 2015 UN FAO global Forest resource assessment. Forest Ecology and Management. 2015; 352(2015):21-34. Available from: www. elsevier.com/locate/foreco

[19] Global Forest Resources Assessment 2015. Desk Reference. Food and 
Agriculture Organization of the United Nations. Rome: 245. (WWW document) Available from: http://www.fao.org/pub lications/card/en/c/f262f48b-fe70-46c 8-9cf3-fd18119c9c3e/, skatìts 30.10.2015

[20] Johansson T. Site index curves for Norway spruce (Picea abies (L.) karst.) planted on abandoned farm land. New Forests. 1996;11:9-29

[21] Daugaviete M, Daugavietis M. The choice of tree species for afforestation of abandoned agricultural lands in Latvia. In: International Symposium "Interaction of Wood with Various Forms of Energy". September 9-10, 2008. Zvolen, Slovakia CD. 2008

[22] Lazdina D, Daugaviete M. Short rotation woody energy crops in Latvia. In: Fifth International Scientific Conference "Students on their Way to Science", Collection of Abstracts, Jelgava, 2010. 2010. pp. 30-40

[23] Kund M, Vares A, Sims A, Tullus H, Uri V. Early growth and development of silver birch (Betula pendula Roth) plantations on abandoned agricultural lands. European Journal of Forest Research. 2010;129:679-688

[24] Hynynen J, Niemistö P. Silviculture of Silver Birch in Finland. 2009.

(WWW document) http://www.wald wissen.net/lernen/weltforstwirtschaft/ fva_birke_waldbau_finnland/index_EN

[25] Lazdins A, Lazdina D, Daugaviete M, Makovskis K. Dabiski apmežojušos platību apsaimniekošana (Management of naturally afforested agricultural areas). LVMI Silava. 2011. p. 35.lpp. (in Latvian)

[26] Tullus A, Rytter L, Weih M, Tullus H. Short-rotation forestry with hybrid aspen (Populus tremula L.P. tremuloides Michx.) in northern Europe. Scandinavian Journal of Forest Research. 2012;27(1):10-29
[27] Daugaviete M, Krumina M, Kaposts V, Lazdins A. Farmland afforestation: The performance of birch Betula pendula Roth. in different soils. Baltic Forestry. 2003;9(1):9-21

[28] Daugaviete M, Liepiņš K, Liepiņš J. The growth of silver birch (Betula pendula Roth.) in plantations of different density. Mežzinātne. 2011;24: 3-16.lpp. (in Latvian)

[29] Hynynen J, Niemisto P, ViheraAarnio A, Brunner A, Hein S, Velling P. Silviculture of birch (Betula pendula Roth and Betula pubescens Ehrh.) in northern Europe. Forestry. 2010;83(1): 103-119

[30] Kund M, Vares A, Sims A, Tullus H, Uri V. Early growth and development of silver birch (Betula pendula Roth.) plantations on abandoned agricultural land. European Journal of Forest Research. 2010;129(4):679-688

[31] Liepiņš K. Growth of silver birch (Betula pendula Roth.) in plantations on farmlands in Latvia. Mežzinātne. 2011; 23(56):3-14.lpp. (in Latvian)

[32] Niemisto P. Influence of initial spacing and row-to-row distance on the crown and branch properties and taper of silver birch (Betula pendula). Scandinavian Journal of Forest Research. 1995;10(1-4):235-255

[33] Zālītis P, Dreimanis A, Daugaviete M. Management of silver birch stands. Rīga, A/S Latvijas Finieris. 2003;2003:51 (in Latvian)

[34] Rytter L, Werner M. Influence of early thinning in broadleaved stands on development of remaining stems.

Scandinavian Journal of Forest

Research. 2007;22:198-210

[35] Siren G, Perttu K, Sennerby-Forsse L, Christersson L, Ledin S, Granhall U. Energy Forestry. Uppsala, Sweden: Department of Ecology and 
Environmental Research, Department of Microbiology. Swedish University of Agricultural Sciences; 1984. p. 16

[36] Sennerby-Forsse L. Handbook for Energy Forestry. Uppsala, Sweden: Department of Ecology and Environmental Research, Swedish University of Agricultural Sciences; 1986. p. 29

[37] Ozols J. Situation in Forestry in Latvia. Mežsaimniecības rakstu krājums IV: 1926. pp. 79-90

[38] Reinholds V. Regeneration of Forests. Mežsaimniecības rakstu krājums XIII: 1935. pp. 107-117

[39] Birmbaums K. Let's Organize a Forest Days! Meža Dzīve 128 (Aprīlis): 1936. pp. 4539-4541

[40] Forest Industry in Figures and Facts. B “Zaḷās mājas”. 2019. p. 52. (In Latvian)

[41] Afforested Areas in Latvia, Forest Stands and Plantations. Available from: www.csb.gov.lv

[42] Abandoned Agricultural Lands, Dinamics. Available from: www.csb. gov.lv

[43] Sarma P. Investigations about growth of scots pine and Norway spruce stands on agricultural lands. Latvijas PSR Zinātņu Akadēmijas Vēstis. 1949. Nr. 7 (24), 31-42.lpp. (in Latvian)

[44] Maike P. Growth of silver birch silvicultures on agricultural lands. Mežsaimniecības problēmu institūta raksti. 1952;4:43-57. (in Latvian)

[45] Sacenieks R, Gaross V. The most profitable management method for Norway spruce stands growing on agricultural lands. LZA

Mežsaimniecības problēmu un koksnes k̦ìmijuas institūts. 1961. p. 54.lpp. (in Latvian)
[46] Liepa I. Increment Science. Jelgava: LLU; 1996. pp. 123-297.lpp. (in Latvian)

[47] Analyses of Soil Agrochemical Properties. Available from: www.lvgma. gov.lv

[48] Hennekens SM, Schaminte JHJ. TURBOVEG, a comprehensive data base management system for vegetation data. Journal of Vegetation Science. 2001;12: 589-591 (20) (PDF) Vegetation Ecology -An Overview. Available from: https:// www.researchgate.net/publication/ 240634299_Vegetation_ecology_-_an_ overview [Accessed: 25 March 2019]

[49] Westhoff V, van der Maarel E. The Braun-Blanquet approach. In: Whittaker RH editor.Class@cation of Plant Communities. 2nd ed. 1978. pp. 287-297. Junk, The Hague (20) (PDF) Vegetation Ecology-An Overview. Available from: https://www.researchgate.net/publica tion/240634299_Vegetation_ecology_-an_overview [Accessed: 25 March 2019]

[50] Ellenberg H, Weber HE, Diill R, Wirth V, Werner W, PauliBen D. Zeigenverte von Pflanzen in Mitteleuropa. In: Scripta Geobotanica 18. 2nd ed. 1992. pp. 1-258

[51] Arhipova I, Balina S. Statistics in Economy in and Business. Solutions with SPSS and Microsoft Excel.

Datorzinību Centres: Rīga; 2006. p. 364. (in Latvian)

[52] Holubik O, Podrazsky V, Vopravil J, Khel T, Remeš J. Effect of agricultural lands afforestation and tree species composition on the soil reaction, total organic carbon and nitrogen content in the uppermost mineral soil profile. Soil and Water Research. 2014;9:192-200

[53] Kārklinšs A. Guidelines for soil diagnosis and description. LLU: Jelgava; 2008. p. 335

[54] Kārklinš̌ A, Gemste I, Mežals H, Nikodemus O, un Skujāns R. Taxonomy 
of Latvia Soils. Jelgava:LLU 2009. $240 \mathrm{pp}$

[55] Kārkliņš A, un Līpenīte I. Apmežotas lauksaimniecībā izmantojamās zemes īpašību izpētes rezultāti. Zinātniski prakstiskā konference Lauksaimniecības zinātne veiksmīgai saimniekošanai, 21-22.02. 2013; Jelgava, LLU; pp. 84-88

[56] Kārkliņš A, Līpenīte I. Augšņu dažādība LIZ apmežošanas izpētes poligonā ZS “Medņi”. No: Līdzsvarota lauksaimniecība: LLU LF, Latvijas Agronomu biedrības, LLMZA organizētās zinātniski praktiskās konferences Raksti, 2014. gada 20-21. februāris, LLU, Jelgava: 104-110. 2014

[57] Karklins A, Lipenite I, Daugaviete M. Variability of soil properties and productivity of forests planted on agricultural land. In: Abstracts: 4th International Congress of the European Confederation of Soil Science Societies (ECSSS) Eurosoil 2012 Soil Science for the Benefit of Mankind and Environment, 2-6 July 2012, Bari, Italy. 2012. p. 2047. (Electronic edition)

[58] Karklins A, Lipenite I, Daugaviete M. Carbon stock and forest productivity planted on agricultural land. In: Abstracts: International Conference "Humus Forms and Biologically Active Compounds as Indicators of Pedodiversity”, August 27-28, 2012, Tartu, Estonia. Tartu. 2012. p. 15

[59] Nikodemus O, Kasparinskis R, Kukuls I. Influence of afforestation on soil genesis, morphology and properties in glacial till deposits. Archives of Agronomy and Soil Science. 2013;59(3): 449-465

[60] Mangalis I. Forest Regeneration and Afforestation. SIA “Et Cetera,” Rīga: 2004. p. 455. (In Latvian)

[61] Bratkovich S, Burban L, Katovich S, Locey C, Pokorny J, Wiest R. Flooding and its Effects on Trees. Miscellaneous Information Packet. St. Paul, MN: U.S. Department of Agriculture, Forest Service, State and Private Forestry, Northeastern Area; 1994. Available from: http://www.na.fs.fed.us/spfo/ pubs/n_resource/flood/cover.htm

[62] Clatterbuck WK. Shade and Flood Tolerance of Trees 2015. 2015. (WWW documents). Available from: http:// www.uaex.edu/environment-nature/ disaster/SP656.pdf

[63] Lambin EF, Ehlich D. The surface temperature-vegetation index space for land cover and land-cover change analysis. International Journal of Remote Sensing. 1996;17(3):463-487

[64] Kahle P, Baum C, Boelcke B. Effect of afforestation on soil properties and mycorrhizal formation. Pedosphere. 2005;15(6):754-760

[65] Sanborn P. Influence of broadleaf trees on soil chemical properties: A retrospective study in the sub-boreal spruce zone, British Columbia, Canada. Plant and Soil. 2001;236(1):75-82

[66] Rūsiņa S, Bambe B, Daugaviete M. Changes in herb and bryophyte layer vegetation in afforested agricultural lands. Baltic Forestry. 2011;17, 2(33): 243-255

[67] Donis J. Improvement scales of the most important tree species in Latvia. In: Jansons J. editors. Four Motives of Forest Science. Salaspils: LVMI Silava; 2014. pp. 13-39. (In Latvian)

[68] Claessens H, Oostrebaan A, Savill P, Rondeux J. A review of the characteristics of black alder (Alnus glutinosa (L.) Gaertn.) and their implications for silvicultural practices. Forestry, Vol. 83. 2010. No. 2: 163175.66]

[69] Daugavietis M, Bisenieks J, Daugaviete M. Interrelations between 
Plantation Forests: A Guarantee of Sustainable Management of Abandoned and Marginal... DOI: http://dx.doi.org/10.5772/intechopen.88373

Grey Alder stand characteristics. Baltic Forestry. 2011;17, 1(32):68-75

[70] Zālītis P. Prerequisites of Forestry. Rīga: Et cetera. 2006. p. 219. (in Latvian)

[71] Saliņš S, Smilga J. Aspen LVI. Rīga: 1960. p. 94. (In Latvian)

[72] Rytter L, Stener LG. Productivity and thinning effects in hybrid aspen (Populus tremula L. $\times$ P. Tremuloides Michx.) stands in southern Sweden. Forestry. 2005;78(3):285-295

[73] Latvian State Cabinet Regulation No. 935 "Tree Felling in the Forest lands", (effective as of 18 December 2012). WWW document: https://likumi. lv/doc.php?id=253760

[74] Prindulis U, Donis J, Šñepsts G, Strazdiņa L, Liepiņš J. un Liepiņš K. Modeling of roundwood assortment yields in felling of birch plantations. Mežzinātne. 2013;27(60): pp. 3-16. (In Latvian)

[75] Liepiņš K. Modelling of Birch Plantation Thinning Volume. 2013. Available at: http://www.silava.lv/23/sec tion.aspx/View/127 

Section 2

Sustainable Lighting at Home 



\title{
Explorative Analysis of Household Energy Consumption in Bauchi State, Nigeria
}

\author{
Abubakar Hamid Danlami and Rabi'ul Islam
}

\begin{abstract}
This study was conducted with the major aim of conducting descriptive and exploratory analyses on the socio-economic characteristics of households in Bauchi state and their pattern of energy choice and consumption. A total sample of 539 household responses were analysed, which were selected using cluster area sampling. The analysis indicates that the average monthly household income is USD 220 , and the average monthly firewood consumption per household is about 35 bundles. Moreover, about $70 \%$ of the respondents argued that they use firewood as their main source of cooking fuel. For the lighting source of energy, $65 \%$ of the households argued that they use electricity as their main source of lighting. Additionally, the correlation analysis indicates that income has a positive relationship with the quantity of energy consumption, while there is a negative relationship between the price of a particular source of energy and its consumption. The study suggests that there is a need of a good policy that will reduce the households much dependence on firewood to other cleaner sources of energy.
\end{abstract}

Keywords: firewood; cooking and lighting, energy, consumption

\section{Introduction}

Energy is one of the most important aspects of household life. It is a commodity that is vital for the existence of modern household living [1, 2]. In fact, the total welfare of a household depends on the type and the pattern of the household's energy utilisation. The household energy consumption pattern in Bauchi state can be categorised into three major dimensions: cooking, lighting and cooling purposes. For satisfying the needs of cooking, various sources are available, which includes: fuel-wood, kerosene, gas and electricity, plus elements of plant residues and animal dung which are used in some parts of the rural areas of the state. For lighting purpose, the various choices mainly include: electricity, petroleum/diesel (used for fuelling generators), kerosene, candles, traditional lamps and firewood, mostly based on socio-economic status of a household [3, 4]. Furthermore, for the purpose of drinks and space cooling, various energy sources are available which consist of mainly electricity and petroleum or diesel (gas) power generator.

Of all the above categories of fuel sources, electricity, liquefied petroleum gas (LPG) and kerosene are regarded to be either cleaned (i.e. in the case of electricity and gas) or transitional (i.e. in the case of kerosene) energy sources [5], while the 
traditional biomass fuel that include fuel-wood, animal dung and plant residues are not cleaned energy which can lead to numerous economic, social, health and environmental problems $[6,7]$.

The use of traditional lamp as the main source of lighting is a threat to the health and the life of the users; this is because such traditional lamp produces high rate of carbon monoxide that is harmful to human health; that is why in most of the rooms whereby such lamps are being used, there exist black dust in ceilings and the walls closer to the lamp. In the same vein, the use of fuel-wood for cooking and lighting purposes is totally not environmental friendly. It has negative impacts on the atmosphere and peoples' lives $[8,9]$. Apart from deforestation, desertification and soil erosion, the use of fuelwood has a very low thermal efficiency and the smoke is also hazardous to human health, especially to women and children who mostly do the cooking in homes [10]. Acute respiratory infections (ARI) in children are one of the leading causes of infant and child morbidity and mortality $[11,12]$. Studies have found associations between biomass fuel use and lung cancer. A 30-year-old woman cooking with straw or wood has an $80 \%$ increased chance of having lung cancer later in life $[13,14]$.

The underlying rational here is to encourage households to shift from the use of non-cleaned energy sources to the adoption of cleaned energy sources [15]. This is because there are so many benefits in using a cleaned energy. It has been widely argued that moving towards the use of cleaned fuels is an important option to improve the standard of living for households who rely heavily on biomass [16]. It is the key factor to improve the mode of living for rural population [17]. Moreover, encouraging households to switch to cleaned energy would lead to the consumption of less fuel per meal and less time spent for gathering fuel which could be used in other activities such as attending school and other income generating activities [5]. Cleaned energy provides easy access to education, health care and household resources. Children who do not have to collect bio fuels can attend school $[18,19]$. Switching to cleaned fuels could also free up time for women to engage in income-generating pursuits [18].

To attain these benefits, a very important and effective policy that provides access to cleaned energy is required [9]. However, such effective policy also depends on a good research which is conducted to investigate and explore households' energy consumption pattern in relevant area [20]. This study is conducted with the major aim of exploring socio-demographic features of households and their pattern of energy choice and consumption in Bauchi state, Nigeria, to assess the correlation between the energy consumption and the socio-demographic characteristics of households in Bauchi state.

The remaining part of the chapter is as follows: Section 2 consists of the review of related literature, Section 3 consists of methodology and Section 4 discussed the results and findings of the study. The last section consists of conclusions and policy implications of the study.

\section{Literature review}

This section examines and highlights the factors that influence the level of household fuel choice and consumption. Each of these factors is expected to relate with the quantity of fuel consumption of households either positively or negatively. The explanation of different categories of factors influencing the households' energy choice and consumption is explained below.

\subsection{Economic factors}

These are the factors that serve as a measure of economic status of the household which can influence the households' fuel consumption decision. For instance, 
studies have established that there is a positive relationship between the households' income and the adoption of cleaned energy [21-23]. Poorer households especially in developing countries tend to adopt firewood, plant residues, animal dung and other un-cleaned energy sources, whereas wealthier households tend to adopt energy from more cleaned sources.

A relationship also exists between the type of occupation of the household head and the nature of the energy source to be adopted by the household. Empirical studies conducted in $[2,24]$ proved that those in white-collar jobs (executives, big entrepreneurs) adopt cleaned energy, while those in blue-collar jobs (such as farming, trading) tend to adopt firewood and other biomass fuels. Home ownership, which is one of the indicators of the economic status of households, affects their decision on the type of energy sources to adopt. Those who live in their owned house tend to adopt cleaned energy source $[22,25]$. Price of energy has a negative relationship with energy consumption. When the price of a particular energy source is high, households switch to other alternative fuel available. This is in line with the law of demand and also has been established by previous studies [9, 26].

\subsection{Socio-demographic factors of households}

The type and composition of socio-demographic factors of households influence their fuel switching and consumption behaviour. For instance [27], we found that households tend to adopt cleaner energy when the head of the household is female. The age of the household head was found to have a negative relationship with the adoption of cleaned energy [27, 28]. Households adopt less cleaned energy source when the head is older. The level of education of the household head has a positive relationship with cleaned energy adoption. When the higher educated is the household head, the more he realises the negative impact of un-cleaned energy, and therefore, the less it will be adopted $[2,25]$. The location of household was also established to affect the nature of energy use. Households that live in the urban areas tend to spent more on electricity than those living in the rural areas [29]. The number of a household's members (i.e. household size) affects the household's energy consumption decision; the larger the size of a household, the lesser the adoption of cleaned energy [30,21]. Lastly in [31], it is established that there is a strong relationship between the household energy use and the level of education of the household head.

\subsection{House characteristics}

The characteristics of the building in which the households leave can also affect their energy choice behaviour. For instance, the location of the home in which the households live have serious impact on their energy consumption decision. The households that are located in urban areas adopt cleaner energy than their rural counterparts $[2,21]$. In addition, the type of the house (i.e. nature of the building) exacts some influence on household energy consumption behaviour. For instance, in $[2,21]$, it was empirically found that living in detached house has significant positive relationship with the adoption of gas, electricity and liquid fuel. The sizes of the residence in which households live also influence their energy consumption behaviour. Most of the previous studies, such as [22, 32, 33], found that the larger the size of the building, the higher the adoption of fuel wood, all things being equal. Furthermore, the number of rooms in the house is one of the building characteristics which influence households' energy consumption choice. For instance, in $[2,24]$, it was found that this variable has a positive significant relationship with the household use of liquefied petroleum gas (LPG). Share of dwellings (i.e. more than 
one household living in the same building) is one of the factors which also shapes the energy consumption behaviour of households [22].

\section{Data and methodology}

Because this chapter is a study of households at micro level, this section contains the description of the study samples and the methods used in data gathering.

\subsection{Sample size}

In this study, the total sample size was determined based on [34]. The formula for determining a good representative sample is:

$$
S=\frac{N P(1-P)}{(B / C)^{2}(N-1)+P(1-P)}
$$

where $S$, required sample size; $N$, the population size $=769,960 ; P$, the population proportion expected to answer in a particular way (the most conservative proportion is 0.50$) ; B$, the degree of accuracy expressed as a proportion (0.05); and $C$, the $\mathrm{Z}$ statistic value based on the confidence level (in this case, 1.96 is chosen for the $95 \%$ confidence level).

Therefore, the sample size can be determined as:

$$
\begin{gathered}
S=\frac{(769,960 * 0.5)(1-0.5)}{(0.05 / 1.96)^{2}(769,960-1)+(0.5)(1-0.5)}=\frac{192490}{501.067+0.25} \\
S=\frac{192490}{501.317}=384 .
\end{gathered}
$$

This formula has been widely applied in household micro level studies [35-38]. Furthermore, it commensurates with the sample size recommended by social science researchers. For instance, in [39], a rule of thumb is given for selecting a good sample size which is larger than 30 and less than 500 for most of the research; and that in case of multivariate studies, the sample size should be at least 10 times as large as the number of variables. In [40], a rule of thumb for the accurate sample size of at least 5-10 times larger than the number of variables is given. However, for the purpose of data collection for this study, a total of 750 questionnaires were distributed instead of the pre-determined sample number of 384 samples. This was to avoid a problem of non-response rate. According to [41], since it is not every selected sample that will likely response, there is a need for a researcher to increase the sample size to avoid non-response bias. Babbie (1995) (cited in [42]) argued that at least $50 \%$ rate of response is necessary for reporting and analysis. Finally, about 548 filled questionnaires were returned back, which is more than $70 \%$ of the total number of the issued questionnaires.

\subsection{Sampling technique}

For the purpose of this study, cluster area sampling method was adopted. According to [43], area sampling is a special type of cluster sampling whereby samples are grouped and clustered on the basis of geographical location areas $[44,45]$. The reason for adopting this method of sampling is that though the sampling frame for the various clusters of Bauchi state is available and was obtained 
from the office of Nigerian National Population Commission, there is no available frame containing the list of all households living in Bauchi state. Hence in this situation, area sampling is one of the most suitable techniques of data collection. As argued by various scholars, the underlying practical motivation for using area sampling is the absence of complete and accurate list of the universal elements under study since it does not depend upon the population frame [44-46]. Moreover, from [47], it was argued that in the case of cluster sampling, the full list of clusters forms the sampling frame and not the list of individual elements within the population.

The sampling technique used in this study is the multistage cluster sampling. In the first stage, the whole of the study area was divided into three groups (clusters) based on the geo-political zonal categorisation of the study area; the various categories are: Bauchi South, Bauchi Central and Bauchi North. In the second stage, two clusters (Bauchi South and Bauchi North) were selected randomly out of the three clusters.

In the third stage, these two clusters were further categorised into two subclusters: urban and rural areas. Then, a total of 10 wards were randomly selected from the urban areas, while a total of 13 wards were selected randomly from the rural areas. This gives a total of 23 selected wards used as the sampling wards. In the fourth stage, six communities were selected randomly from each of the selected wards of urban areas, which made a total of 60 communities from the urban areas. On the other hand, another six communities were randomly selected from the selected wards of the rural areas making a total of 78 communities used from the rural areas. This gives a total of 100 and 138 sampled communities used in the study. In the last stage, six households were systematically selected from each of the selected communities of the urban areas making a total of 360 (i.e. $60 \times 6=360$ ) households selected from the urban areas. On the other hand, five households were selected systematically from each of the selected communities of the rural areas making a total of 390 (i.e. $78 \times 5=390$ ) households selected from the rural areas. Finally, a total of 548 households returned the filled questionnaires out of which nine questionnaires were discarded.

\section{Results and findings}

This section contains the findings of this study. Since this study is a descriptive and exploratory analysis, the tools that were used to analyse the data are the various descriptive statistics, frequencies, percentages and correlation analyses.

\subsection{Summary of descriptive statistics}

This section provides information about the descriptive statistics. The major descriptive statistics are the mean, standard deviation, minimum and maximum. Table 1 exhibits the values of the summary statistics.

Table 1 shows that the monthly average consumption of firewood is about 35 bundles; this implies that on average, every household in Bauchi State uses more than one bundle of firewood everyday, which is a clear reflection of the high rate of firewood use in the state. Furthermore, the table indicates that the monthly average income of a household is little bit more than USD 200, with the maximum value of USD 600. This implies that most of the household in Bauchi State belong to the poor income group. In fact, Bauchi State is the third poorest state in Nigeria [48]. Furthermore, the table indicates that the average firewood price per bundle is about N75 (about \$0.40). Furthermore, it indicates that on average, the household size in 


\begin{tabular}{lccccc}
\hline Variables & $\boldsymbol{N}$ & Mean & SD & Min & Max \\
\hline Gender & 538 & 0.874 & 0.33 & 0 & 1 \\
\hline Age & 536 & 36.43 & 11.7 & 23 & 60 \\
\hline Marital status & 528 & 0.739 & 0.44 & 0 & 1 \\
\hline Household size & 536 & 7.725 & 6.04 & 2 & 30 \\
\hline Location & 537 & 0.538 & 0.50 & 0 & 1 \\
\hline Home size (ft $\left.{ }^{2}\right)$ & 536 & 52.42 & 19.3 & 20 & 110 \\
\hline Number of rooms & 536 & 6.515 & 3.81 & 2 & 23 \\
\hline Cooking fuel main source & 539 & 0.443 & 0.81 & 0 & 3 \\
\hline Hours of electricity & 519 & 27.30 & 27.8 & 0 & 97 \\
\hline Price of firewood & 483 & 76.67 & 35.3 & 30 & 220 \\
\hline Price of kerosene & 361 & 126.6 & 27.1 & 45 & 200 \\
\hline Home appliances & 535 & 15.37 & 13.1 & 0 & 57 \\
\hline Home ownership & 535 & 0.213 & 0.41 & 0 & 1 \\
\hline Years of education & 536 & 14.21 & 6.17 & 0 & 22 \\
\hline Lighting fuel main source & 532 & 0.438 & 0.67 & 0 & 2 \\
\hline Firewood quantity & 449 & 34.23 & 17.1 & 4 & 90 \\
\hline Income (USD) & 536 & 224.0 & 180 & 78 & 600 \\
\hline
\end{tabular}

Source: authors, 2019.

Table 1.

Summary of descriptive statistics of variables.

Bauchi state constitutes about eight members per household. This number approximately is tally to the estimated average household size in Bauchi state, given in [49]. The table shows that the average weekly hours of electricity supply is only 27 hours; this clearly reflects the nature of inadequate supply of electricity in the area, which is one of the factors that likely contributes to the high rate of biomass fuel use as the main source of energy by households in Bauchi state. Table 1 further shows that the average years of school experience by the heads of households in the study area is 14 years, representing a schooling experience up to the Diploma/NCE levels of education. Similarly, the reported average number of rooms in the building in which each household lives is six. This number constitutes bedrooms, rest room, sitting rooms and fallows. Additionally, the number of energy use devices possesses at home such as: bulbs, fans, ACs, televisions and radios among others shows an average value of 15 pieces of these items, which is clearly a reflection of low rate of modern energy use by households in the study area. Lastly, the table shows that the average age of household head in Bauchi state measured in terms of years is 36 years, which falls within the age group of working population.

\subsection{Socio-economic characteristics of households in Bauchi state and their pattern of energy consumption}

The objective of this study is to explore and describe the socio-economic characteristics of households in Bauchi state, Nigeria, and their pattern of energy consumption. In this section, the study explored the socio-economic characteristics of households in Bauchi state and their pattern of fuel consumption, based on the 
Explorative Analysis of Household Energy Consumption in Bauchi State, Nigeria DOI: http://dx.doi.org/10.5772/intechopen.89597

\begin{tabular}{|c|c|c|c|}
\hline Characteristics & Frequency & $(\%)$ & CUM \\
\hline \multicolumn{4}{|l|}{ Gender } \\
\hline Male & 470 & 87.36 & 87.36 \\
\hline Female & 68 & 12.64 & 100 \\
\hline \multicolumn{4}{|l|}{ Age } \\
\hline $16-30$ & 187 & 34.89 & 34.89 \\
\hline $31-45$ & 229 & 42.72 & 77.61 \\
\hline $46-60$ & 97 & 18.10 & 95.71 \\
\hline Above 60 & 23 & 4.29 & 100 \\
\hline \multicolumn{4}{|l|}{ Marital status } \\
\hline Single & 138 & 26.14 & 26.14 \\
\hline Married & 390 & 73.86 & 100 \\
\hline \multicolumn{4}{|l|}{ Level of education } \\
\hline Non-formal education & 55 & 10.26 & 10.26 \\
\hline Primary School & 27 & 5.04 & 15.30 \\
\hline Secondary & 95 & 17.72 & 33.02 \\
\hline Diploma/NCE & 191 & 35.63 & 68.66 \\
\hline B.Sc./HND & 124 & 23.13 & 91.79 \\
\hline Postgraduate & 44 & 8.21 & 100 \\
\hline \multicolumn{4}{|l|}{ Occupation } \\
\hline No standard job & 59 & 11.09 & 11.09 \\
\hline Farmer & 68 & 12.78 & 23.87 \\
\hline Teacher & 106 & 19.92 & 43.80 \\
\hline Banker & 17 & 3.20 & 46.99 \\
\hline Lecturer & 18 & 3.38 & 50.38 \\
\hline Medical practitioner & 37 & 6.95 & 57.33 \\
\hline Businessman & 99 & 18.61 & 75.94 \\
\hline Others & 128 & 24.06 & 100 \\
\hline \multicolumn{4}{|l|}{ Monthly income (USD) } \\
\hline 150 and below & 277 & 53.37 & 53.37 \\
\hline $151-\$ 300$ & 98 & 18.11 & 71.48 \\
\hline $301-\$ 450$ & 73 & 13.10 & 84.59 \\
\hline $451-\$ 600$ & 56 & 10.02 & 94.61 \\
\hline Above 600 & 32 & 5.39 & 100 \\
\hline \multicolumn{4}{|l|}{ Household size } \\
\hline $1-10$ & 424 & 79.22 & 79.22 \\
\hline $11-20$ & 94 & 17.44 & 96.66 \\
\hline 21 and above & 18 & 3.34 & 100 \\
\hline
\end{tabular}

Table 2.

Socio-economic characteristics of households in Bauchi state. 
study samples. Table 2 indicates the socio-demographic and economic characteristics of the respondents.

Table 2 shows that a majority of the respondents (87\%) are males. This is because based on the culture of people in the study area, normally males occupy the position of household head; even in a situation when the father (the head) has died, it is the younger brother of the deceased or the first born in the family, not the mother, who emerges as a new head of the family. Because the belief is that, men are stronger than women economically, socially and educationally. Therefore, a woman emerges as a household head only by chance when there is no able man in the family to look after the affairs of the family. Furthermore, Table 2 shows that most of the respondents (61\%) are within the age of middle adulthood stage (31-60 years). This is because on average, the normal marriage age for males (who are mostly the family head) begins from 25 years and above. The table further indicates that about $75 \%$ of the respondents are married, due to the fact that married people are regarded as responsible for overseeing the family affairs. The remaining $25 \%$ are regarded as single person comprising the divorced, widowed and separated. Regarding the family size, most of the respondents $(80 \%)$ argued that the size of their family members is within the range of 1-10, the range in which the number of the average family size in Bauchi state reported earlier in [49] falls (i.e. 8) and this study found the average size of a household to be 8 (see Table 1). In addition, the categories of the education level attainment shows that those who attended school up to the Diploma/NCE level have the highest rate (35\%) followed by those with the degree certificate (23\%). Those who claimed that they did not attend a formal school at all constitute about $10 \%$ of the respondents. Only $8 \%$ of the respondents claimed to have attended school at a postgraduate level. Regarding the occupation of the respondents, of all those that have chosen a stated category, teaching job (at primary or secondary levels) obtained the highest proportion (about 20\%). This is because teaching job at either primary or secondary school levels is one of the easy to find jobs for both semi-professional

\begin{tabular}{lccc}
\hline Characteristics & Frequency & (\%) & CUM \\
\hline Home ownership & & & 78.69 \\
\hline Self-owned home & 421 & 78.69 & 100 \\
Non self-owned home & 114 & 21.31 & 56.90 \\
\hline Number of rooms & & & 77.80 \\
\hline $1-5$ & 305 & 56.90 & 97.34 \\
$6-10$ & 112 & 20.90 & 100 \\
$11-15$ & 106 & 19.54 & \\
16 and above & 13 & 2.43 & 6.53 \\
\hline Home size $\left(\mathbf{f t}^{2}\right)$ & & & 32.28 \\
\hline -24 & 35 & 6.53 & 88.25 \\
$25-49$ & 138 & 25.75 & 93.29 \\
$50-74$ & 300 & 55.97 & 100 \\
$75-99$ & 27 & 5.04 & \\
100 and above & 36 & 6.72 & 46.18 \\
\hline Home location & & & \\
\hline Urban area & 289 & 53.82 & \\
Rural area & 248 & 46.18 & \\
\hline Source: Authors, 2019. & & &
\end{tabular}

Source: Authors, 2019.

Table 3.

Households' home characteristics in Bauchi state. 
(Diploma/NCE) and professional (Degree and above) workers. About $11 \%$ of the respondents argued that they do not have a standard job; they are more of casual workers. Additionally, the $24 \%$ of the respondents, which constitutes the other occupation category as specified by the respondents themselves, comprises: tailoring, butcher, mechanic, welding, building construction, civil servant, businessman, journalist, sheep and cattle rearing. Others are: carpenter, porter, sewing, blacksmith, commercial driver, prison service and wood cutter. At Last, on average, most of the respondents (53\%) argued that they usually earned a monthly income that is below $\$ 150$. This clearly indicates the high rate of poverty in the state especially in the rural areas of the state.

Furthermore, among the factors that can shape the household pattern of energy consumption and switching are the characteristics of the building in which the household live. Table 3 contains the information of the home characteristics of the households.

Table 3 shows that about 79\% of the respondents argued that they live in their self-owned home; this is especially in rural areas and some of the urban areas

\begin{tabular}{|c|c|c|c|}
\hline Characteristics & Frequency & $(\%)$ & CUM \\
\hline \multicolumn{4}{|c|}{ Main cooking fuel } \\
\hline Firewood & 378 & 70.65 & 70.65 \\
\hline Kerosene & 114 & 21.31 & 91.96 \\
\hline Electricity & 12 & 2.24 & 94.21 \\
\hline Gas & 31 & 5.79 & 100 \\
\hline \multicolumn{4}{|c|}{ Main source of lighting fuel } \\
\hline Traditional & 53 & 9.96 & 9.96 \\
\hline Semi-electrical & 127 & 23.87 & 33.83 \\
\hline Electricity & 352 & 66.17 & 100 \\
\hline \multicolumn{4}{|c|}{ Average firewood consumption monthly(bundle) } \\
\hline $1-19$ & 62 & 13.81 & 13.81 \\
\hline $20-39$ & 287 & 63.92 & 77.73 \\
\hline $40-59$ & 43 & 9.57 & 87.53 \\
\hline 60 and above & 57 & 12.69 & 100 \\
\hline \multicolumn{4}{|c|}{ Average kerosene consumption monthly (litre) } \\
\hline $1-15$ & 99 & 46.70 & 46.70 \\
\hline $16-30$ & 84 & 39.62 & 90.57 \\
\hline $31-45$ & 15 & 7.08 & 93.40 \\
\hline 46 and above & 14 & 6.60 & 100 \\
\hline \multicolumn{4}{|c|}{ Average monthly expenditure on electricity (USD) } \\
\hline 9 and below & 366 & 86.52 & 86.52 \\
\hline $10-19$ & 47 & 11.11 & 97.63 \\
\hline $20-29$ & 4 & 0.95 & 98.58 \\
\hline 30 and above & 6 & 1.42 & 100 \\
\hline \multicolumn{4}{|c|}{ Number of energy use devices at home } \\
\hline Zero & 10 & 1.87 & 1.87 \\
\hline $1-10$ & 243 & 45.42 & 47.29 \\
\hline $11-20$ & 151 & 28.22 & 75.51 \\
\hline $21-30$ & 54 & 10.09 & 85.60 \\
\hline Above 30 & 77 & 14.39 & 100 \\
\hline
\end{tabular}

Source: Authors, 2019.

Table 4.

Household energy consumption pattern in Bauchi state. 
whereby most of the houses are simple and traditional, mostly made of up mud, such kind of houses are easy to possess or built. Furthermore, a majority of the respondents (about 57\%) claimed that the number of rooms in their home is within the range of $1-5$ rooms. These include: bedrooms, sitting rooms, and any other type of rooms that are usually found at homes. On the size of plot in which the home was built, a majority of the respondents (56\%) argued that the size of the plot in which their homes was built is within the range of 50-74 sq. ft. This implies that households in Bauchi state live in a relatively large house. At Last, on the location of the respondents, $53 \%$ argued that they live in urban areas, while the remaining $47 \%$ live in rural areas of the state.

However, the information on the pattern of household fuel source, quantity of energy consumption and the amount of fuel expenditure is shown in Table 4.

Table 4 exhibits the pattern of households' energy consumption behaviour in Bauchi state. Based on the responses from the selected samples, a majority of the respondents (more than 70\%) argued that their main fuel source for cooking is firewood. This is not surprising, but it reflects the clear picture of the situation in Bauchi state whereby the majority of households in the state especially rural areas adopt firewood as the main source of cooking fuel. This is also tally with the information provided in [50]. Furthermore, 21\% of the respondents argued that they use kerosene as the major source of fuel for cooking; about $6 \%$ of the respondents use gas as the main cooking fuel source, and it is only less than $3 \%$ of the respondents claim to be using electricity as their main source of cooking fuel, mainly in the urban areas of the state. This pattern of main cooking fuel adoption is mostly due to the culture, availability and affordability. On the main source of lighting, about $10 \%$ of the respondents argued that they rely majorly on traditional source of lighting such as: traditional lamp, kerosene and charcoal. Another category of respondents (24\%) argued that they rely mostly on semi-electric source of lighting such as: battery torch light and rechargeable lanterns to source light for home use. However, the majority of the respondents argued that they rely mostly on the available electricity as their main source of lighting. This implies that most of households in Bauchi state despite the interruption in the supply of the electricity rely mostly on electricity as their main source of lighting especially urban dwellers.

\subsection{Correlation analysis of factors influencing household energy consumption in Bauchi state, Nigeria}

In this section, a correlation analysis was conducted in order to explore the nature of the correlation that exists among variables used in this study. Usually, a negative value indicates negative relationship between variables and a positive value indicates positive relationship between variables. Table 5 exhibits the correlation values for variables in this study.

Table 5 indicates the nature and magnitudes of correlations that exist between the socio-economic characteristics of households in Bauchi state and the quantity of energy consumption by households in the state. For instance, the correlation matrix exhibits that there is a negative relationship between the quantity of firewood and the price of firewood $(r=-0.13)$, firewood quantity and level of education attainment $(r=-0.07)$, price of kerosene and the quantity of kerosene $(r=-0.07)$, and hours of electricity and the kerosene quantity $(r=-0.08)$. Furthermore, negative relationships were found between monthly expenditure on electricity and variables such as: household size, price of firewood and price of kerosene (with the correlation values: $-0.08,-0.05$ and -0.05 , respectively). All these sings conform to a priori expectations. 


\begin{tabular}{|c|c|c|c|c|c|c|c|c|c|c|c|c|c|}
\hline HSZ & AGE & EDU & HHS & INC & RUM & LEC & PFW & HPS & FWQ & PKR & KRQ & XEC & HSZ \\
\hline AGE & 1.00 & & & & & & & & & & & & \\
\hline EDU & -0.05 & 1.00 & & & & & & & & & & & \\
\hline HHS & 0.29 & -0.09 & 1.00 & & & & & & & & & & \\
\hline INC & 0.28 & 0.26 & 0.19 & 1.00 & & & & & & & & & \\
\hline RUM & 0.19 & -0.09 & 0.42 & 0.12 & 1.00 & & & & & & & & \\
\hline LEC & -0.03 & 0.25 & -0.06 & 0.19 & -0.08 & 1.00 & & & & & & & \\
\hline PFW & 0.10 & -0.13 & 0.01 & 0.01 & -0.01 & -0.07 & 1.00 & & & & & & \\
\hline HPS & 0.05 & 0.03 & 0.05 & 0.16 & 0.10 & 0.14 & -0.02 & 1.00 & & & & & \\
\hline FWQ & 0.09 & -0.07 & 0.21 & 0.06 & 0.22 & 0.05 & -0.13 & -0.01 & 1.00 & & & & \\
\hline PKR & 0.06 & -0.08 & -0.06 & 0.01 & -0.01 & -0.16 & 0.15 & 0.04 & -0.22 & 1.00 & & & \\
\hline KRQ & 0.24 & -0.01 & 0.05 & 0.12 & 0.15 & -0.08 & 0.01 & 0.06 & 0.04 & -0.07 & 1.00 & & \\
\hline XEC & -0.09 & 0.19 & -0.08 & 0.08 & -0.15 & 0.11 & -0.05 & 0.13 & -0.06 & -0.05 & 0.09 & 1.00 & \\
\hline HSZ & 0.19 & 0.12 & 0.26 & 0.27 & 0.39 & 0.17 & 0.03 & 0.12 & 0.09 & -0.04 & 0.11 & 0.03 & 1.00 \\
\hline
\end{tabular}

Source: Authors, 2019.

Note: $A G E=$ age EDU = education; $H H S=$ household size; INC = income; $R U M=$ number of rooms; $L E C=$ hours of electricity supply; PFW = price of firewood $/$ bundle; HPS = home appliances; $F W Q=$ firewood quantity; $P K R=$ kerosene price per litre; $K R Q=$ kerosene quantity; $X E C=$ monthly expenditure on electricity; HSZ = home size.

\section{Table 5 .}

Variables correlation matrix. 
On the other hand, Table 5 indicates that there is a positive relationship between firewood quantity and the household size $(r=0.22)$, kerosene quantity and the variables such as: household size, income and firewood price (with the correlation values: $r=0.05,0.08$ and 0.01 , respectively). Additionally, positive relationships were found to exist between monthly expenditure on electricity and other variables such as: education, income and kerosene quantity. The values of the correlation coefficients are: $0.19,0.08$ and 0.09 , which are clear supports for a priori expectations and also support the findings of previous studies $[1,6,29,30]$.

\section{Discussion of findings}

The study found that the monthly average consumption of firewood is about 35 bundles; this implies that on average, every household in Bauchi state uses more than one bundle of firewood everyday. Furthermore, the study found that the monthly average income of a household is little bit more than USD 200, with the maximum value of USD 600. This implies that most of the household in Bauchi state belong to the poor income group. Additionally, the study found that average weekly hours of electricity supply is only 27 hours; this clearly reflects the nature of inadequate supply of electricity in the area, which is one of the factors that likely contributes to the high rate of biomass fuel use as the main source of energy by households in the state. Similarly, the reported average number of rooms in the building in which each household lives is six. This number constitutes bedrooms, rest room, sitting rooms and fallows. Additionally, the number of energy use devices possesses at home such as: bulbs, fans, ACs, televisions and radios among others shows an average value of 15 pieces of these items, which is clearly a reflection of low rate of modern energy use by households in the study area.

Furthermore, a majority of the respondents are males. This is because based on the culture of people in the study area, normally males occupy the position of household head; even in a situation when the father (the head) has died, it is the younger brother of the deceased or the first born in the family, not the mother, who emerges as new head of the family. Because the belief is that, men are stronger than women economically, socially and educationally. Therefore, a woman emerges as a household head only by chance when there is no able man in the family to look after the affairs of the family. The study further found that about $75 \%$ of the respondents are married, due to the fact that married people are regarded as responsible for overseeing the family affairs. In addition, the occupation of the respondents indicates that of all those that have chosen a stated category, teaching job (at primary or secondary levels) obtained the highest proportion. This is because teaching job at either primary or secondary school levels is one of the easy to find jobs for both semi-professions and professional workers.

Furthermore, the factors that can shape the household pattern of energy consumption and switching are the characteristics of the building in which the household live. The study found that about $79 \%$ of the respondents live in their selfowned home; this is especially in rural areas and some of the urban areas whereby most of the houses are simple and traditional, mostly made of up mud, such kind of houses are easy to possess or built. Moreover, a majority of the respondents (about $57 \%$ ) claimed that the number of rooms in their home is within the range of 1-5 rooms. These include: bedrooms, sitting rooms, and any other type of rooms that are usually found at homes. On the size of plot in which the home was built, a majority of the respondents (56\%) argued that the size of the plot in which their homes was built is within the range of $50-74$ sq. $\mathrm{ft}$. 
Based on the responses from the selected samples, a majority of the respondents argued that their main fuel source for cooking is firewood. This is not surprising, but it reflects the clear picture of the situation in Bauchi state whereby a majority of households in the state, especially rural areas, adopts firewood as the main source of cooking fuel. This is also tally with the information provided in [50]. Furthermore, $21 \%$ of the respondents argued that they use kerosene as the major source of fuel for cooking; about $6 \%$ of the respondents use gas as the main cooking fuel source, and it is only less than $3 \%$ of the respondents claim to be using electricity as their main source of cooking fuel, mainly in the urban areas of the state. This pattern of main cooking fuel adoption is mostly due to the culture, availability and affordability. On the main source of lighting, about $10 \%$ of the respondents argued that they rely majorly on traditional source of lighting such as: traditional lamp, kerosene and charcoal. Another category of respondents (24\%) argued that they rely mostly on semi-electric source of lighting such as: battery torch light and rechargeable lanterns to source light for home use. However, the majority of the respondents argued that they rely mostly on the available electricity as their main source of lighting.

\section{Conclusions}

This study conducted an exploration and descriptive analyses of the socioeconomic characteristics of households and the pattern of their energy consumption (cooking and lighting fuel consumption) in Bauchi state, Nigeria. The study explored that the average monthly income of a typical household in Bauchi state is about USD 225. The study found that a majority of households in Bauchi state use firewood as their main source of cooking fuel. On the other hand, most of the households use electricity for lighting. Furthermore, it was found that there is a positive relationship between income and the consumption of energy by households. Similarly, the same positive relationship was found to exist between household size and the consumption of firewood. On the other hand, the price of a particular energy source has a negative relationship with its consumption. Therefore, there is a need for government to discourage the high rate of firewood use as the main source of cooking fuel by embarking on the policies that will ensure the switch away of household firewood fuel to other cleaner source of cooking fuel such as electricity and gas.

\section{Conflict of interest}

No conflict of interest reported by the authors. 


\section{Author details}

Abubakar Hamid Danlami ${ }^{1 *}$ and Rabi'ul Islam²

1 Department of Economics, Faculty of Social Sciences, Bayero University, Kano, Nigeria

2 School of International Studies, College of Law, Government and International Studies (COLGIS), Universiti Utara Malaysia (UUM), Sintok, Kedah, Malaysia

*Address all correspondence to: sadiqdanlami2@gmail.com

\section{IntechOpen}

(C) 2020 The Author(s). Licensee IntechOpen. Distributed under the terms of the Creative Commons Attribution - NonCommercial 4.0 License (https://creativecommons.org/ licenses/by-nc/4.0/), which permits use, distribution and reproduction for non-commercial purposes, provided the original is properly cited. (cc) BY-NC 


\section{References}

[1] Danlami AH. An analysis of household energy choice and consumption in Bauchi state, Nigeria [thesis]. School of Economics Finance and Banking: Universiti Utara Malaysia; 2017

[2] Eakins J. An analysis of the determinants of household energy expenditures: empirical evidence from the Irish household budget survey $[\mathrm{PhD}$ thesis]. UK: University of Surrey; 2013

[3] Danlami AH, Islam R, Applanaidu SD. An analysis of the determinants of household energy choice: A search for conceptual framework. International Journal of Energy Economics and Policy. 2015; 5(1):197-205

[4] Barness F, Floor M. Rural energy in developing countries: A challenge for economic development. Annual Review of Energy and the Environment. 1996; 21:497-530

[5] Yamamoto S, Sie A, Sauerborn R. Cooking fuels and the push for cleaner alternatives: A case study from Burkina Faso. Global Health Action. 2009;2: 156-164

[6] Danlami AH. An intensity of household kerosene use in Bauchi state, Nigeria: A tobit analysi. Nigerian Journal of Management Technology \& Development. 2017;8(2):1-13

[7] Jan I, Khan H, Hayat S. Determinants of rural household energy choices: An example from Pakistan. Polish Journal of Environmental Studies. 2012;21: 635-641

[8] Danlami AH, Applanaidu SD, Islam R. Movement towards the adoption of non-traditional household lighting fuel energy in developing areas. Biofuels. 2017;10(5):623-633. DOI: 10.1080/17597269.2017.1338125
[9] Nlom JH, Karimov AA. Modeling fuel choice among households in northern Cameroon. In: WIDER Working Paper Series, 2014/038. 2014

[10] Energy Commission of Nigeria (ECN). National Energy Policy Document; 2003

[11] Emmelin A, Wall S. Indoor air pollution: A poverty-related cause of mortality among the children of the world. Chest. 2007;132:1615-1623

[12] Schirnding VY, Bruce N, Smith K, Ballard-Tremeer G, Ezzati M, Lvovsky K. Addressing the impact of household energy and indoor air pollution on the health of the poor implications for policy action and intervention measures. In: Working Group 5, a Paper Prepared for WHO on Macroeconomics and Health. 2002. Available from: http://www.who.int/ind oorair/publications/impact/en/index. html

[13] Hong CJ. Health Aspects of Domestic Use of Biomass and Coal in China: Indoor Air Pollution from Biomass Fuel. Geneva: World Health Organization; 1991. pp. 43-77

[14] WHO. Indoor air pollution from biomass fuel. In: Report of WHO Consultation; June 1991; Geneva. 1991

[15] Ritchie J, Mcdougal G, Claxto D. Complexities of household energy consumption and conservation. Journal of Consumer Research. 1981;8:233-242

[16] Lee LY. Household energy mix in Uganda. Energy Economics. 2013;39: 252-261

[17] Ganchimeg G, Havrland B. Economic analysis of household energy consumption: The case of herders in Mongolia. Agricultura Tropica et Subtropica. 2011;44:197-203 
[18] Wilkinson P, Smith KR, Joffe M, Haines A. A global perspective on energy: Health effects and injustices. Lancet. 2007;370:965-978

[19] Smith KR, Rogers J, Cowlin SC. Household Fuels and Ill Health in Developing Countries: What Improvements Can be Brought by LP Gas? Paris: World LP Gas Association and Intermediate Technology

Development Group; 2005

[20] Danlami AH, Applanaidu SD, Islam R. Axiom of the relative income hypothesis and household energy choice and consumption in developing areas: Empirical evidence using Verme model. Kasetsart Journal of Social Sciences. 2018;39:422-431

[21] Özcan KM, Gülay E, Üçdoğruk S. Economic and demographic determinants of household energy use in Turkey. Energy Policy. 2013;60:550-557

[22] Couture S, Garcia S, Reynaud A. Household energy choices and fuelwood consumption: An econometric approach using French data. Energy Economics. 2012;34:1972-1981

[23] Osiolo HH. Enhancing Household Fuel Choice and Substitution in Kenya; 2010

[24] Heltberg R. Factors determining household fuel choice in Guatemala. Environment and Development Economics. 2005;10:337-361

[25] Laureti T, Secondi L. Determinants of households' space heating type and expenditures in Italy. International Journal of Environmental Research. 2012;6(4):1025-1038

[26] Jingchao Z, Kotani K. The determinants of household energy demand in rural Beijing: Can environmentally friendly technologies be effective? Energy Economics. 2011; 34:381-388
[27] Mensah T, Adu G. An Empirical Analysis of Household Energy Choice in Ghana. Uppsala Working Paper Series No 6; 2013

[28] Suliman MK. Factors affecting the choice of households' primary cooking fuel in Sudan. In: Research Report Presented to the Economic Research Forum, Cairo, Egypt. 2010

[29] Danlami AH. Determinants of household electricity consumption in Bauchi state, Nigeria. Hyperion Economic Journal. 2017;5(1):16-28

[30] Danlami AH. Assessment of factors influencing firewood consumption in Bauchi state, Nigeria. Journal of Sustainability Science and Management. 2017;14(1):99-109

[31] Danlami AH, Applanaidu SD, Islam R. An analysis of household cooking fuel choice: A case of Bauchi state, Nigeria. International Journal of Energy Sector Management. 2018;12(2): 265-283. DOI: 10.1108/IJESM-05-20160007

[32] Danlami AH, Applanaidu SD, Islam R. From biomass cooking fuel source to modern alternative for Bauchi state households: A preliminary analysis. Biofuels. 2017;8(3):323-331. DOI: $10.1080 / 17597269.2016 .1226724$

[33] Song N, Arguilar FX, Shifley SR, Goerndt ME. Factors affecting wood energy consumption by U.S.

households. Energy Economics. 2012;34: 389-397

[34] Dillman DA. Mail and Internet Surveys: The Tailored Design Method 2007 Update with New Internet, Visual, and Mixed-Mode Guide. New Jersey, United States: John Wiley \& Sons; 2011

[35] Kofarmata YI, Danlami AH. Determinants of credit rationing among rural farmers in developing areas: Empirical evidence based on micro level 
data. Agricultural Finance Review. 2019;79(2):158-173. DOI: 10.1108/AFR03-2018-0023

[36] Danlami AH. Examination of determinants of demand for fertilizer in Tofa local government area, Kano state. Nigerian Journal of Management Technology \& Development. 2014;5(2): $1-14$

[37] Danlami AH, Islam R, Applanaidu SD, Tsauni AM. An empirical analysis of fertiliser use intensity in rural sub-Saharan Africa evidence from Tofa local government area, Kano state, Nigeria. International Journal of Social Economics. 2016; 43(12):1400-1419

[38] Danlami AH, Applanaidu SD, Islam R. A micro level analysis of the adoption and efficiency of modern farm inputs use in rural areas of Kano state, Nigeria. Agricultural Research. 2018; 8(3):392-402. DOI: $10.1007 /$ s40003-018-0373-z

[39] Roscoe JT. Fundamental Research Statistics for the Behavioural Sciences. 2nd ed. New York: Holt, Rinehart and Winston; 1975

[40] Bartlett JE, Kotrlik JW, Higgins C. Organizational research: Determining appropriate sample size in survey research. Information Technology, Learning, and Performance Journal. 2001;19(1):43-50

[41] Jeff. How to Determine a Sample Size: Tipsheet \#60. University Park, PA: Penn State Cooperative Extension. 2001. Available from: http://www.exte nsion.psu.edu/evaluation/pdf/TS60.pdf

[42] Watson SC. A primer in survey research. The Journal of Continuing Higher Education. 1998;46(1):31-40

[43] Rao RS. Area Sampling (Market Research). 2009. Available from: http:// www.citeman.com/4713-area- sampling-market-research.html

[Accessed: 07 February 2016]

[44] Valliant R, Dever JA, Kreuter F. Practical Tools for Designing and Weighting Survey Samples. London: Springer; 2013

[45] Sekaran U. Research Methods for Business: A Skill-Building Approach. 4th ed. USA: John Wiley \& Sons, Inc; 2003

[46] OECD. Glossary of Statistical

Terms. Paris: OECD; 2007

[47] Saunders M, Lewis P, Thornhill A. Research Methods for Business Students. 5th ed. England: Pearson Education; 2009

[48] NBS. Annual Abstract: Federal republic of Nigeria. 2012. Available from: http://www.nigerianstat.gov.ng [Accessed: February 2016]

[49] Uneze E, Tajudeen I, Iweala O. Cost-Effectiveness and Benefits-Cost Analysis of Some Water Interventions (The Case of Bauchi State, Nigeria); 2013

[50] Akpan M, Akpan M, Wakili A, Wakili A, Akosim C, Akosim C. Fuel wood consumption pattern in Bauchi state: A guide for energy planners in Nigeria. ASSET: An International Journal (Series A). 2010;7(1):1-11 



\title{
Roof Lighting with Recycled Plastic Bottles
}

\author{
Nancy Varela Terreros and Daniel Espinoza Díaz
}

\begin{abstract}
The carbon footprint currently produced on the planet forces universities and government entities to seek solutions to basic services and other social needs, which are positive with the environment. One of these solutions is linked to indoor lighting without electric power consumption. The Moser lamp offers a solution that takes care of environmental health and at the same time is accessible to social sectors with lower purchasing power. This lamp consists of a water bottle with chlorine exposed to sunlight. The test carried out by the authors collects data that coincide with those obtained by Moser, in the sense that they generate the lighting required for housing. The criteria of the authors are that more controlled trials should be carried out in order to determine the replicability of the exercise, as well as experiment with other elements to obtain chemiluminescence, mainly at night, since the Moser lamp can only be used together with the sunlight. Examples of these elements are luminol and synthetic luciferase and luciferin, which can chemically provide luminescence indoors.
\end{abstract}

Keywords: Moser, lamps, illuminance, bottles, chlorine, water, sunlight

\section{Introduction}

According to data from the Latin American Energy Organization (OLADE), in Latin America, there are areas that still lack electricity supply [1]. Simultaneously, there is a growing carbon footprint in the region [2], while the entire population does not have the basic economic means for subsistence.

The above is evident in Ecuador, where there is no $100 \%$ electrical coverage, mainly in rural areas [3, 4], and there is a significant percentage of the population that fails to cover the basic basket of foods. This indicator refers to the set of goods and services that are essential to meet the basic needs of the typical household composed of four members with 1.6 income earners who earn the unified basic remuneration [5]. In this context, it is imperative to propose solutions for the satisfaction of basic services that are friendly to the environment.

This document analyzes the proposal for an alternative solution to the supply of electricity, low cost and made with recycling materials. This is the Moser lamp, designed in 2002, by the Brazilian mechanic Alfredo Moser, who devised a lighting system made with plastic bottles, water, and chlorine [6].

The objective of the chapter below is to analyze the viability of this system in Ecuador. For this, its theoretical foundation and the possibilities of its use in the country are analyzed. The chapter also presents the results of an experimental test carried out by the authors, in a controlled environment. 


\section{Socioeconomic context}

\subsection{Electricity coverage in Ecuador and Latin America}

OLADE defines the electric coverage indicator as the total observation units served divided by the total observation units in the country, according to Eq. (1):

$$
\mathrm{IC}_{\mathrm{j}}=100 \mathrm{x} \frac{\mathrm{j}_{\mathrm{EE}}}{\mathrm{j}_{\mathrm{T}}}
$$

where

$\mathrm{IC}_{\mathrm{j}}$ coverage index with reference to the observation unit $j$

j observation unit: houses, homes, or people

$j_{\mathrm{EE}}$ number of observation units with electricity service

$\mathrm{j}_{\mathrm{T}}$ total number of observation units

According to OLADE, for the year 2010, in Latin America, the percentage of electrical coverage is calculated from the number of electrified homes with reference to the number of occupied homes. The highest percentage was $99.75 \%$ for Uruguay. According to this study, Ecuador had a coverage of $93.35 \%$ for the year 2010. Among the 27 member countries, 13 countries have coverage greater than 95\%, 4 have coverage between 90 and 95\%, 8 have coverage between 75 and 90\%, while 2 countries have coverage below 75\%: Nicaragua, 60\%; Haiti, 28\%. The overall percentage for the region is $92 \%$ [1].

In Ecuador, according to the official data presented by the Electricity Regulation and Control Agency (ARCONEL), the annual coverage of the electric service increased between a national total of $93.80 \%$ for the year 2008 , and $97.33 \%$ for the year 2017 [3]. These data are consistent with OLADE, and with those obtained by the National Institute of Statistics and Census (INEC), which indicate that the electricity service by public grid for the year 2014, at the national level was $98.4 \%$, breaking down this percentage into $99.7 \%$ for the urban area and $95.6 \%$ for the rural area [7].

The analyzed data indicate a reality: there is no total coverage of the electricity service in the Latin American area in general, and in Ecuador, in particular, and as indicated by census data, this lack of coverage would occur mainly in the rural area. As a comparative fact, note that by 2014 the water coverage by public network in the urban area was $92.5 \%$, while in the rural area that coverage was $46.0 \%$, that is, half that in the urban area The sewer system by public network had a coverage of $77.1 \%$ for the urban area and $22.3 \%$ for the rural area [7]. This scenario occurs in a country where the National Basic Basket of Foods is USD 735, with an estimated minimum monthly electricity consumption of USD 15, and a unified basic salary of USD 396 [5].

\subsection{Carbon footprint}

Belmaña defines the carbon footprint as "an indicator that allows accounting for all greenhouse gases emitted by direct or indirect effect by an individual, organization, event or product" [8]. In relation to the production of $\mathrm{CO}_{2}$ that is generated as a function of electricity consumption, Ignacio Cruz found in his study conducted in Mexico D.F. that, in residential consumption, the production of $\mathrm{CO}_{2}$ went from 3.7 tons for the year 1990, to 4.4 tons in the year 2010 [9]. If it is estimated that a 50-watt bulb lit for 14 hours a day for a year produces $200 \mathrm{~kg}$ of $\mathrm{CO}_{2}$, and it is expected that in his daily life a person will light more than one bulb at a time, it is of interest to find an alternative system for domestic lighting.

The World Bank, for its part, points out which main countries are in relation to the production of the carbon footprint. The highest value is presented by Qatar in 2014, 
with 43.9 metric tons per year per individual, while for that same year the lowest values are shared by Burundi, Somalia, and Sudan, which register zero production, and Chad, Democratic Republic of the Congo, Ethiopia, Madagascar, Malawi, Mali, Niger, Central African Republic, Rwanda, South Sudan, and Uganda, with 0.1 metric tons per year per individual. Ecuador has a production of 2.8, which is consistent with the average of Latin America and the Caribbean, of 3.1, for the year under study [10].

\subsection{Proposal of a lighting system}

With this background, this research is outlined on a natural lighting system, which reduces the cost of housing for low-income families, and that simultaneously supports the reduction of the carbon footprint on the planet, through the use of recycled plastic bottles and chlorine for daytime lighting. This system does not produce $\mathrm{CO}_{2}$, and its cost is minimal in relation to electricity consumption, since only $10 \mathrm{ml}$ of chlorine is required for the production of a light unit or bulb. It is estimated that in Ecuador the gallon of chlorine has an approximate cost of 2.50 USD, while electricity costs around $0.08 \mathrm{USD} / \mathrm{kWh}$ at the lowest level of consumption [3], as of the date of the present study. The practical reference used is the Moser lamp, authored by the Brazilian Alfred Moser. The test detailed below will be based on this reference.

The beneficiaries of this research are expected to be:

- The inhabitants of rural areas in Ecuador that are not connected to the public lighting network, or who want an alternative lighting system in order to reduce housing maintenance costs

- Companies that want to innovate in lighting their roofs, warehouses, or storage sites

- People without lighting service, anywhere on the planet

\section{Moser lamp}

Alfredo Moser is a mechanic from Sao Paulo, Brazil, who designed a lamp that works without electricity. The formula proposed by Moser consists of filling a recycled plastic bottle of $2 \mathrm{~L}$ with water, plus $10 \mathrm{ml}$ of chlorine, and placing it in the hole in the roof of a house [6]. According to an interview conducted by the BBC in 2013 to the inventor of this technology, a lamp so designed produces between 40 and 60 watts, depending on sunlight. According to the BBC, this invention has already been implemented in the Philippines, where 140,000 homes benefit from this new technology. It has also been implemented in other countries such as India, Bangladesh, Tanzania, Argentina, and Fiji [11].

Although the cost of implementing this technology could be subsidized by the government, the criteria of the authors of this research is that this lighting solution may well be assumed by the beneficiary families themselves, as it is based on the use of components within reach of most of them:

- Recycled bottle of $2 \mathrm{~L}$ : this element can be acquired for this object or achieved by recycling own bottles or other people's bottles. In this sense, the user can also be part of the solution for recycling other users' plastics.

- Chlorine: $10 \mathrm{ml}$ of chlorine is required to achieve the illuminance corresponding to a focus between 40 and 60 watts. In a minimum housing unit of $40 \mathrm{~m}^{2}$, 


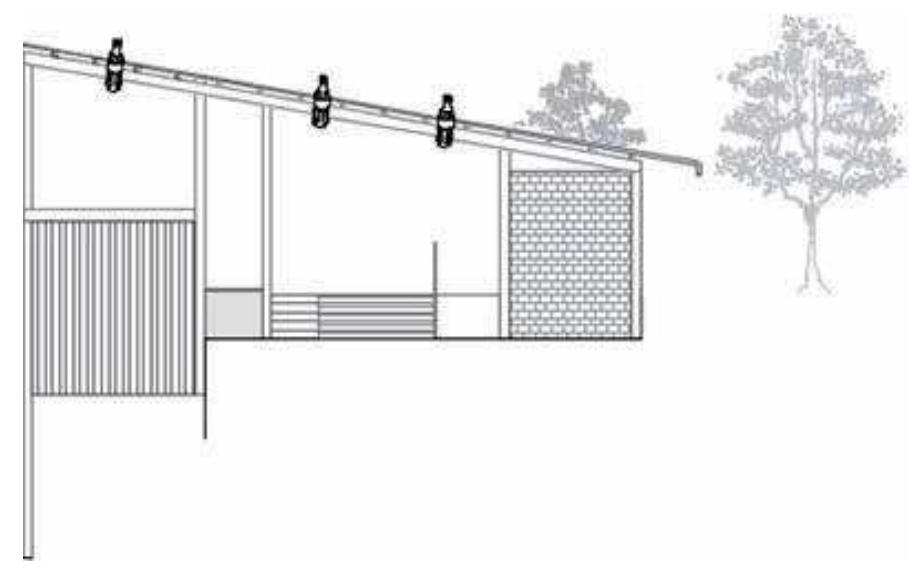

Figure 1.

Scheme of the use of the Moser lamp.

10 bulbs of 40 watts, that is, $100 \mathrm{ml}$ of chlorine, can be used to generate acceptable illuminance. Since the gallon of chlorine, or $3785 \mathrm{ml}$ of this chemical, has an average cost of USD 2.50, the cost necessary for this component of the total lighting of the house is less than USD 0.10, which is affordable for a family of limited resources.

- Water: based on the premise that homes are connected to the drinking water system, it is expected that they can achieve this component easily and economically. In addition, rural areas of Ecuador are geographically close to rivers and other bodies of raw water that can provide free supply to areas of extreme poverty that have no supply from the public drinking water network (Figure 1).

\section{Carbon footprint in Ecuador}

According to the World Wild Fund (WWF), the ecological footprint "adds all the ecological services that people demand that compete for space" [12]. In Ecuador, the Ministry of Environment notes that "the ecological footprint measures the amount of biologically productive land and water that an individual, a region, all of humanity, or a certain human activity requires to produce the resources it consumes and absorb the waste generated" [13]. One of the components of this ecological footprint is the carbon footprint. The Economic Commission for Latin America and the Caribbean (ECLAC) accepts the definition of carbon footprint as "the amount of emission of gases relevant to climate change associated with the activities of production or consumption of human beings" and also indicates that this is the "amount of tons or kilos of carbon dioxide equivalent of greenhouse gases, produced every day, generated from the burning of fossil fuels for energy production, heating, and transportation among other processes" [2].

In Ecuador, according to the Ministry of Environment, the ecological, individual footprint of an Ecuadorian, until 2013, was 1.8 times lower than the world average. However, within this component, the carbon footprint comprises $42 \%$ of the total [13]. Hence, it is important to review the production of this component, based on environmental care. 


\section{Test performed}

As part of this research process, the authors conducted a test in order to verify the effectiveness of the Moser lamp. The test consisted in the elaboration of a scale model elementary dwelling, made with basic materials, on whose roof three plastic bottles of the Moser type were placed in order to measure the luminescence inside the building.

The elements that were used were:

- Materials for scale model dwelling: the housing model was built with a wooden recycling structure. The roof was made with pressed cardboard structure and plastic cover.

- Bottles: the bottles used were $250 \mathrm{ml}$ plastic containers for recycling.

- Chlorine.

The experiment sought to measure the luminescence produced by means unrelated to electrical energy and compare it with that produced by natural light.

The first references to luminescence were made by Eilhard Wiedemann in 1988 and Henry Joseph Round in 1907. Luminescence is defined by the EcuRed online encyclopedia as "the emission of light by a substance without being motivated by heat, so it is a form of length in cold" [14]. The Wolfram scientific dictionary defines it as "any process in which energy is emitted from a material in a wavelength different from that to which it is absorbed" [15].

Since the experiment sought to produce a light emission, the measurements were made in lux (lx), which is the unit of the International System of Units (SI) that measures the level of illuminance and is equivalent to lumen $/ \mathrm{m}^{2}$. The lumen $(\mathrm{lm})$ is the SI unit that measures the luminous flux, which is a measure of the perceived light output. Contextualizing, according to the Spanish Lighting Committee (CEI), natural light outside produces "approximately 1000-2000 lux on a gray day and 100,000 on a sunny day" [16]. The Ecuadorian Construction Standard (NEC) recommends a minimum lux level of 100 for bedrooms and a maximum of 750 lux, for study or work rooms [17].

A Moser type test was performed to produce luminescence inside a home. An experimental house was built, and the illuminance was measured in the following situations:

- Outside, on a sunny day, prior to the test.

- Inside, before performing the test

- Inside, performing the test only with water

- Inside, performing the test with water and chlorine

The equipment used was a cell phone that used the Spectrum Genius Mobile Plus (SGM +) application of AsenseTEK, which is a free software used for lighting measurement. Since this is not a lux meter, $100 \%$ or accuracy should not be expected.

The test was carried out outdoors, at an altitude of $37 \mathrm{~m}$ above sea level between 1:00 pm and 2:30 pm on a sunny day. The results obtained were (Figures 2-5): 


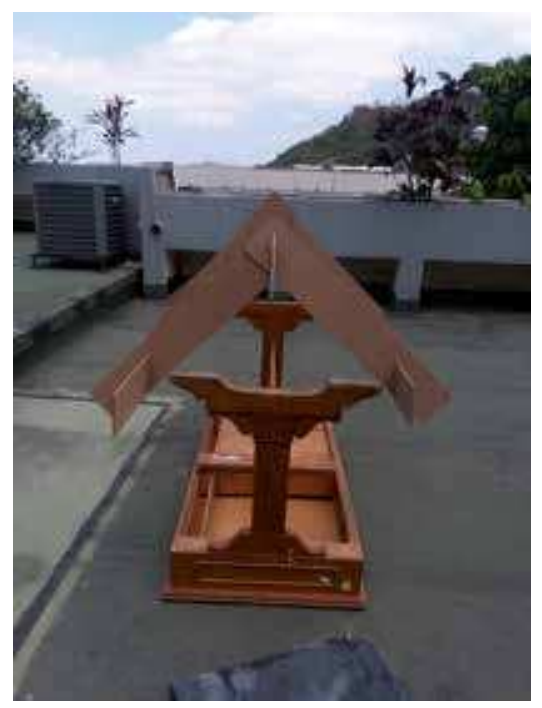

Figure 2.

Scale model of the house, without roof, used in the test.

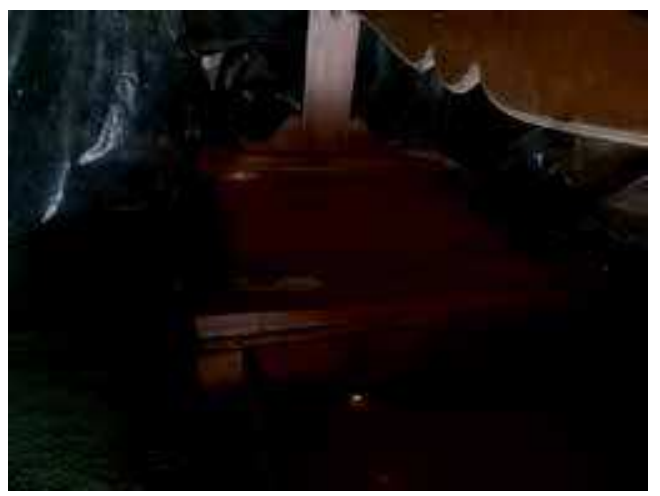

Figure 3.

Scale model of the house, with roof, before the test.

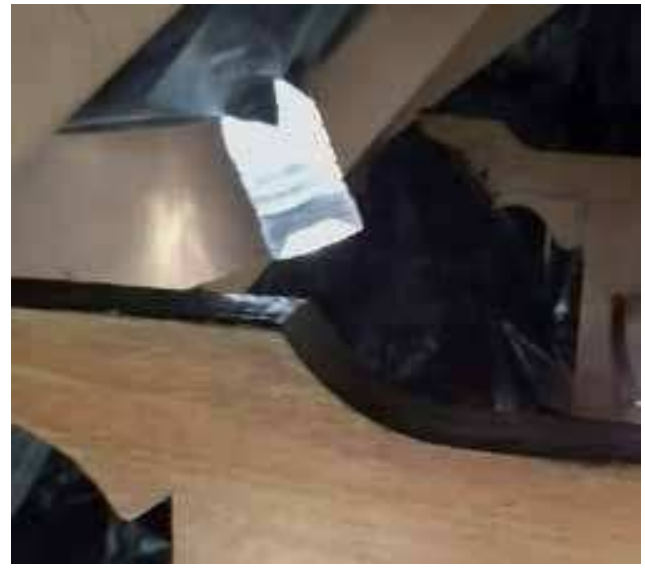

Figure 4 .

Test with one bottle of water. 


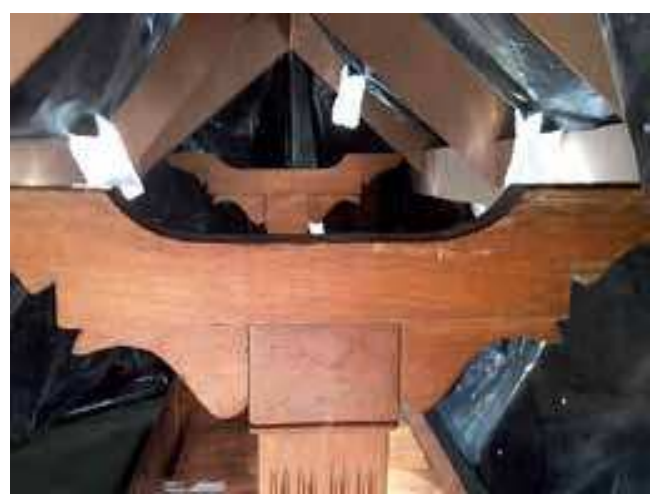

Figure 5.

Test with three bottles with water and chlorine.

- Outdoor measurement:

○ 147.743 lux (13h23)

$\circ$ Range between 46.781 and 48.852 lux (13h44)

○ $136.453 \operatorname{lux}(14 \mathrm{~h} 11)$

○ $67.455 \operatorname{lux}(14 \mathrm{~h} 21)$

- Measurement inside, before carrying out the test:

- 9 lux (13h23) unsupported measurement equipment

$\circ 28 \operatorname{lux}(13 \mathrm{~h} 37)$ measurement equipment on the floor

○ 64 lux (13h37) measurement equipment supported on the roof beam

○ 16 lux (13h44) unsupported measurement equipment

$\circ 26 \operatorname{lux}(14 \mathrm{~h} 11)$ measurement equipment on the floor

$\circ 72$ lux (14h11) measurement equipment supported on the roof beam

- Measurement outside, with bottles filled with $200 \mathrm{ml}$ of water:

○ 853 lux (13h40) with one single bottle

○ 924 lux (13h42) with two bottles

- Measurement outside, with bottles filled with $200 \mathrm{ml}$ of water plus $10 \mathrm{ml}$ of chlorine:

○ 1739 lux (14h13) with three bottles

○ 1033 lux (14h12) with two bottles 
From what has been observed, the illuminance value obtained on average with the use of chlorine, and without the use of chlorine, is within what is required for indoor lighting. However, as a continuous solution, it is appropriate to use chlorine to prevent the proliferation of bacteria inside the bottle that would dull the reflection of light.

\section{Conclusions}

There are three positive conclusions obtained from the test performed:

- The production of luminescence is the result only of the interaction between water and the sun, with the participation of chlorine to prevent the flowering of bacteria. In addition, it was experimentally proven that although there was significant illuminance only with the use of water, it was superior if chlorine was added. None of these elements result in the production of the carbon footprint. Therefore, its use is feasible and positive in relation to the care of the environment.

- The material used for the bottles was recycled, and as stated earlier, water in rural areas is freely accessible to many families or has a low cost. For research, only a minimum value was invested for the acquisition of chlorine. This means that families with lower resources have, in Ecuador, the option of using this alternative to avoid or decrease the use of electric energy for lighting inside homes. This can be used in remote rural areas, where by the year 2019 there is no $100 \%$ coverage of the electricity service. This study has not analyzed the socioeconomic reality of other Latin American countries; however, it is expected that it can be used in other sectors of the region, with the unmet need for lighting at home and with low economic resources.

- The previous conclusion implies a reduction in the basic basket of food as the cost of electricity is reduced and in extreme cases, the cost of installing the electricity service. Even if only this alternative is used for lighting, while using electric power for other daily activities, this use reduces the monthly cost for electricity consumption.

- The material used is not flammable; therefore, the risk of fire, which all electrical connections entail, is reduced. This point is of special interest in rural areas, which may be more prone to such events.

A negative conclusion that should be considered is that this solution is only viable during daylight hours, since it depends on sunlight outside. Therefore, the position of the authors is that more studies should be carried out on this subject. It is possible, for example, to find sources of luminescence through the use of luminol or with the use of synthetic luciferin and luciferase, among other chemical reagents that produce longer lighting time and which, being the result of a chemical reaction, do not require sunlight.

\section{Recommendations}

- The perforations of the ceiling plates selected for lighting should be completely covered, in order to avoid subsequent damage to the roof, the entrance of insects, or other small animals to the house and avoid rain or snow filtration. 
- The correct bottle size must be studied so that the roof does not collapse due to fatigue. A maximum size of $2-2.5 \mathrm{~L}$ is viable without reinforcement. For a larger size, it is suggested to reinforce the support structure.

- It is suggested to study the position of the sun with respect to the house to be illuminated in order to find the appropriate angle that generates efficient lighting.

- The test was carried out with colorless, transparent plastic. The point of view of the authors is that a colored plastic would produce less lighting. Its use is not suggested for this system.

\section{Author details}

Nancy Varela Terreros* and Daniel Espinoza Díaz

Catholic University of Santiago de Guayaquil, Guayaquil, Ecuador

*Address all correspondence to: nancy.varela@cu.ucsg.edu.ec

\section{IntechOpen}

(C) 2020 The Author(s). Licensee IntechOpen. Distributed under the terms of the Creative Commons Attribution - NonCommercial 4.0 License (https://creativecommons.org/ licenses/by-nc/4.0/), which permits use, distribution and reproduction for non-commercial purposes, provided the original is properly cited. (cc) BY-NC 


\section{References}

[1] Organización Latinoamericana de Energía. Cobertura Eléctrica en América Latina y El Caribe. 3rd ed. Chichester: Wiley; 2011. DOI: 10.1002/978047974704. 2012. 1132 p. Available from: http://biblioteca.olade. org/opac-tmpl/Documentos/old0236. pdf [Accessed: 15 July 2019]

[2] Schneider H, Samaniego J. La huella de carbono en la producción, distribución y consumo de bienes y servicios. 1st ed. Naciones Unidas: Santiago de Chile; 2010. 46p

[3] Agencia de Regulación y Control de Electricidad. Cobertura Anual de Servicio [Internet]. 2017. Available from: https://www.regulacionelectrica. gob.ec/produccion-anual-2/ [Accessed: 16 July 2019]

[4] Ministerio de Electricidad y Energía Renovable. Electrificación rural con energías renovables. [Internet]. 2019. Available from: http://historico.energia. gob.ec/electrificacion-rural-con-energiasrenovables/ [Accessed: 16 July 2019]

[5] Instituto Nacional de Estadísticas y Censos. Índice de Precios al Consumidor [Internet]. 2019. Available from: https:// www.ecuadorencifras.gob.ec/canasta/ [Accessed: 18 July 2019]

[6] Bartolomé M. Construcción Low Cost. Reciclado de botellas PET para su aplicación en el campo de la construcción y las instalaciones [thesis]. Valladolid: University of Valladolid; 2018

[7] Instituto Nacional de Estadísticas y Censos. Compendio de Resultados Encuesta Condiciones de Vida ECV Sexta Ronda 2015 [Internet]. Available from: https://www.ecuadorencifras. gob.ec/documentos/web-inec/ECV/ ECV_2015/documentos/ECV\%20 COMPENDIO\%20LIBRO.pdf [Accessed: 14 July 2019]
[8] Belmaña M. Plan de mejoras de la performance energética a partir de la Medición de la Huella de Carbono [thesis]. Buenos Aires: Fundación UADE Universidad Argentina de la Empresa; 2018

[9] Cruz I. Emisiones de $\mathrm{CO}_{2}$ en Hogares Urbanos. El caso del Distrito Federal. Estudios Demográficos y Urbanos. 2016;31(1):115-142

[10] Banco Mundial. Emisiones de $\mathrm{CO}_{2}$ (toneladas métricas per cápita). Available from: https://datos.bancomundial.org/ indicador/en.atm.co2e.pc?view=map. [Accessed: 19 July 2019]

[11] BBC. News Mundo. Le dio luz a quienes no la tenían y sigue pobre pero orgulloso [Internet]. 2013. Available from: https://www.bbc.com/mundo/ noticias/2013/08/130816_finde_alfredo_ moser_inventor_botella_luz [Accessed: 20 July 2019]

[12] World Wild Fund. Living Planet Report 2016 [Internet]. Available from: https://wwf.panda.org/knowledge_hub/ all_publications/ecological_footprint2/. [Accessed: 21 July 2019]

[13] Ministerio del Ambiente del Ecuador. Reporte de la Huella Ecológica Nacional y Sectorial del Ecuador-Año 2013 [Internet]. 2016. Available from: http://huella-ecologica.ambiente. gob.ec/files/Reporte_de_la_Huella_ Ecol\%C3\%B3gica_del_Ecuador_2013. pdf [Accessed: 19 July 2019]

[14] Ecured. Luminiscencia [Internet]. 2019. Available from: https://www. ecured.cu/Luminiscencia [Accessed: 24 July 2019]

[15] Diccionario Científico Wolfram. Luminiscencia [Internet]. 2019. Available from: http://scienceworld. wolfram.com/physics/Luminescence. html. [Accessed: 24 July 2019] 
[16] Comité Español de Iluminación.

Guía Técnica Aprovechamiento de la luz natural en la iluminación de edificios. Madrid: Instituto para la Diversificación y Ahorro de la Energía; 2005

[17] Ministerio de Desarrollo Urbano y Vivienda. NEC Norma Ecuatoriana de la Construcción [Internet]. 2018. Available from: https://www.habitatyvivienda. gob.ec/documentos-normativos-necnorma-ecuatoriana-de-la-construccion/ [Accessed: 26 July 2019] 



\title{
Dimensioning of an Autonomous Photovoltaic Installation: Case Study in Msaken, Sousse (Tunisia)
}

\author{
Olfa Bel Hadj Brahim Kechiche, Marwa Hamza \\ and Habib Sammouda
}

\begin{abstract}
Renewable energy production has the potential to replace traditional fossil energy and reduce the consumption invoice. In this context, a client wants to realize an autonomous photovoltaic installation for his house that is under construction, located in the city of Msaken, Sousse (Tunisia), in an isolated area of the network of the Tunisian Company of Electricity and Gas (STEG) and will be inhabited by the end of the year 2019. The installation autonomy must be 72 hours in case of bad weather. Therefore, in this chapter, we will determine the technical characteristics of each component of the installation to meet the customer's energy needs and ultimately provide the total price.
\end{abstract}

Keywords: autonomous PV installation, Msaken, Sousse (Tunisia), electrical need estimation, PV field cost

\section{Introduction}

Among the major stakes of modern times is the electricity supply, either for domestic consumption (of people) or for industrial consumption [1].

Tunisia is a country in the Middle East that lacks oil reserves. It depends entirely on oil imports from neighboring countries to meet its energy needs. The continued rise in oil prices as a result of increasing world demand and the contraction of oil supply and regional instability put extreme pressure on the Tunisian economy, resulting in difficulties and economic disturbances. The government has responded quickly and actively to overcome the negative effects and deterioration of its economy by gradually reducing its support for consumer prices for electricity and petroleum products.

For more than two decades, Tunisia has focused on the rational use of energy and the development of renewable energies [2, 3]. Ambitious energy demand management programs have reduced the rate of growth of energy consumption and substantially lowered energy intensity. In Tunisia, despite the great efforts and works carried out by the Tunisian Company of Electricity and Gas (STEG), several regions remain unconnected to the public electricity network. For example, outside regions are far from cities. This is a major problem for the inhabitants of these places. 
In this context, a client wants to realize an autonomous photovoltaic installation for his house which is under construction, located in the city of Msaken, Sousse (Tunisia), in an isolated area of the network of STEG, and will be inhabited by the end of the year 2019. The installation autonomy must be 72 hours in case of bad weather.

Therefore, an energy efficiency expert is contacted in order to determine the technical characteristics of each component of the installation to meet the customer's energy needs and ultimately provide the total price.

This chapter is divided into three sections. In the first, we will determine the energy needs of the customer. Then, through the second chapter, we will detail the steps of sizing the solar system and its components. Finally, we will give the total cost of the installation.

\section{Electrical need estimation}

Estimating the electrical needs consists of calculating the daily electrical energy consumed by the users. Thus, the electrical needs will be expressed in Wh/day (or kWh/day).

The methodology is as follows [4]:

- First, we have to identify all the electrical devices that will be powered by the autonomous photovoltaic system. For each of these devices, the rated operating power must be identified. So, we can rely on measurements directly on site or the indications on the data sheets/signs of the devices.

- Then, we will estimate the daily use time.

- The electrical power product (in $\mathrm{W}$ ) by the usage time (in $\mathrm{h}$ ) will indicate the daily energy consumed (in Wh) of the device. In the electricity field, it is customary to use the $\mathrm{W}$ and the Wh as measurement units of the power and the electrical energy, respectively.

\begin{tabular}{lccccc}
\hline Devices & $\begin{array}{c}\text { Unit power } \\
(\mathbf{W})\end{array}$ & Number & $\begin{array}{c}\text { Duration of } \\
\text { use }(\mathbf{h})\end{array}$ & $\begin{array}{c}\text { Power } \\
(\mathbf{W})\end{array}$ & $\begin{array}{c}\text { Daily energy production } \\
\left(\mathbf{E}_{\mathbf{c}}\right)\end{array}$ \\
\hline Incandescent lamp & 75 & 5 & 4 & 375 & 1.500 \\
\hline Incandescent lamp & 25 & 2 & 1 & 50 & 0.050 \\
\hline TV LED & 210 & 1 & 3 & 210 & 0.630 \\
\hline Mini fridge & 180 & 1 & 24 & 180 & 4.320 \\
\hline Laptop & 150 & 1 & 2 & 150 & 0.300 \\
\hline Laptop charger & 3 & 2 & 1 & 6 & 0.006 \\
\hline Phone & 10 & 1 & 5 & 10 & 0.050 \\
\hline Modem & 4 & 1 & 9 & 4 & 0.036 \\
\hline $\begin{array}{l}\text { Surveillance } \\
\text { camera }\end{array}$ & 12 & 1 & 24 & 12 & 0.288 \\
\hline Washing machine & 250 & 1 & 1 & 250 & 0.25 \\
\hline & Total & & & 1247 & 7.43 \\
\hline
\end{tabular}

Table 1.

Daily energy consumption. 
Dimensioning of an Autonomous Photovoltaic Installation: Case Study in Msaken, Sousse... DOI: http://dx.doi.org/10.5772/intechopen.88771

- Finally, the sum of the calculated daily energies will give an overall assessment of the building electrical needs.

The power needs and daily energy consumption are reported in Table 1.

The previous inventory allows us to draw up a balance of power and energy:

Total power: $P=1247 \mathrm{~W}$.

Daily consumption: $E=7.43 \mathrm{kWh} /$ day.

\section{Evaluation of the optimal PV module orientation and inclination}

Latitude and longitude for Msaken: $35^{\circ} 43^{\prime} 45^{\prime \prime}$ North and $10^{\circ} 34^{\prime} 50^{\prime \prime}$ East. This city is located in the northern hemisphere [5].

Optimal inclination angle formula (autonomous PV system) is given by PVGIS Software, and it is equal to $30^{\circ}$ [6].

In Tunisia, the best orientation for a photovoltaic field is that of the south. Indeed, it allows capturing a maximum of solar radiation throughout a day and a year.

Solar irradiation represents the energy and the quantity of this energy depending on the exposure of the object or the material that receives it. A horizontal surface does not receive the same amount of solar energy as a vertical one. Thus it is necessary to specify the configuration of the receiver.

The radiation varies along the year, and to project the system, it is necessary to choose which irradiance to consider. Thus, in order to calculate the average value of irradiation received by an optimally oriented and inclined surface, we use PVGIS Software (Figure 1).

Assessing the available energy in Msaken area from PVGIS software, the following values are obtained for an optimal inclination of $30^{\circ}$ with annual irradiation deficit due to shadowing (horizontal) equal to $0 \%$ (Table 2):

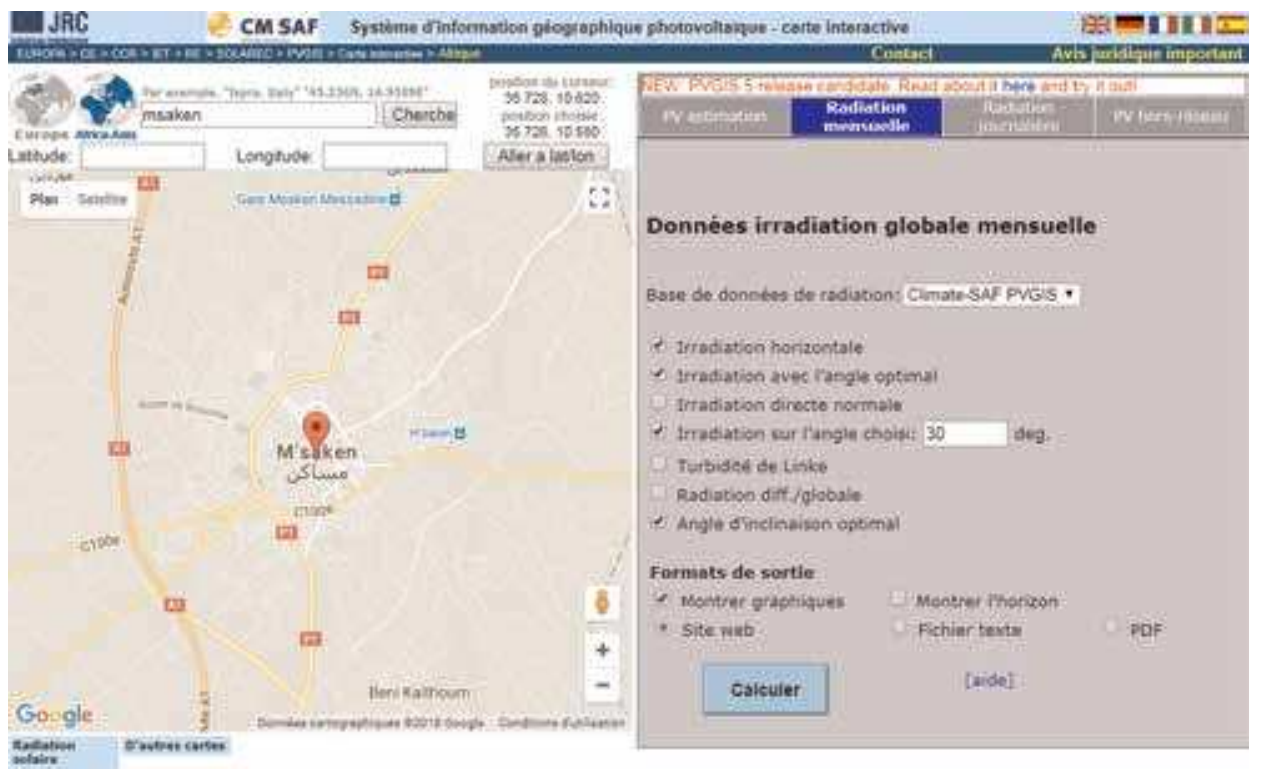

Figure 1.

Map of Msaken with coordinates [6]. 


\begin{tabular}{lllll}
\hline Month & $\mathbf{H}_{\mathbf{h}}$ & $\mathbf{H}_{\mathbf{o p t}}$ & $\mathbf{H}(\mathbf{3 0})$ & $\mathbf{I}_{\mathbf{o p t}}$ \\
\hline Jan & 2210 & 3220 & 3500 & 57 \\
\hline Feb & 3110 & 4170 & 4380 & 50 \\
\hline Mar & 4290 & 5070 & 5070 & 38 \\
\hline Apr & 5330 & 5610 & 5300 & 23 \\
\hline May & 6180 & 5950 & 5360 & 9 \\
\hline Jun & 6760 & 6240 & 5470 & 2 \\
\hline Jul & 6730 & 6340 & 5620 & 6 \\
\hline Aug & 6300 & 6400 & 5910 & 37 \\
\hline Sep & 4880 & 5560 & 5460 & 47 \\
\hline Oct & 3720 & 4810 & 4980 & 56 \\
\hline Nov & 2550 & 3680 & 3970 & 59 \\
\hline Dec & 1960 & 5910 & 3180 & 30 \\
\hline Year & 4510 & 5000 & 4850 & 57 \\
\hline
\end{tabular}

$H_{h}$ : irradiation on horizontal plane $\left(\mathrm{Wh} / \mathrm{m}^{2} /\right.$ day $) ; H_{\text {opt }}$ : irradiation on optimally inclined plane $\left(\mathrm{Wh} / \mathrm{m}^{2} /\right.$ day); $H(30)$ : irradiation on plane at angle: $30 \mathrm{deg}$. (Wh/m²/day); Iopt: optimal inclination (deg.).

Table 2.

The calculation results using PVGIS software [6].

\section{Total integration}

Total integration is a mode which the module is considered a roof element. This module plays the role as a cover. As a result, ventilation on the underside is difficult if not impossible.

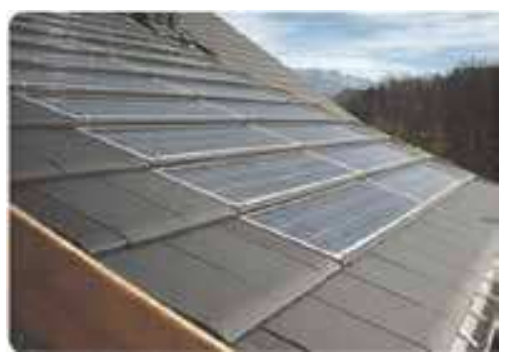

\section{Superimposed}

The superimposed assembly consists of fixing the photovoltaic modules above the cover. This type of installation allows a simple and fast installation of photovoltaic modules without roofing. Air can circulate between the cover and the modules providing better ventilation than full integration.

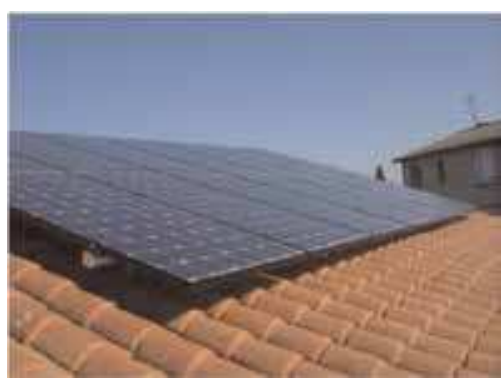

\section{On chassis}

The modules are usually mounted on a flat roof or simply on the ground, this integration mode allows maximum natural ventilation.

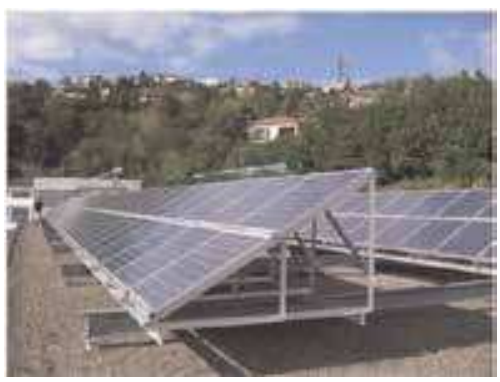

Table 3.

Types of PV panel integration in the building. 
Then in Msaken, the average value of irradiation received by an optimally oriented and inclined surface, noted $E_{i}$ and calculated using PVGIS Software is about $5 \mathrm{kWh} / \mathrm{m}^{2} /$ day.

\section{Integration of PV modules in the building}

The house is under construction, so one of three methods (described in Table 3) can be used for integrating PV modules [7]:

Consulting the client, he told us that the PV modules will be arranged using superimposed method.

\section{Installation production}

\subsection{Ratio performance (RP)}

The ratio performance (RP) makes possible the quantification of the intrinsic losses of the electrical installation. The performance ratio is, therefore, a number ranging between 0 and 1 (or 0 and 100\%) [8].

The RP is specific to each installation. Nevertheless, it is possible to estimate the RP value [9]:

- The temperature coefficient of the power KT $(\mathrm{P})$ is similar from one module to another (order of magnitude: $-0.4 \% /{ }^{\circ} \mathrm{C}$ ).

- The voltage drop in the cables is limited to $3 \%$.

- Regulator output is similar from one regulator to another (97\% of order of magnitude).

- Battery performance is about $85 \%$.

- The inverter efficiency is similar from one inverter to another (order of magnitude: 95\%).

- Other miscellaneous losses are similar from one facility to another (2\% order of magnitude).

The only really variable parameters are the integration mode and the presence or absence of a MPPT device. Thus, we can draw up a general summary table of the RP value (Table 4):

\begin{tabular}{lcccc}
\hline $\begin{array}{l}\text { Ratio } \\
\text { performance } \\
(\text { RP) }\end{array}$ & $\begin{array}{c}\text { Modules with very } \\
\text { little ventilation }\end{array}$ & $\begin{array}{c}\text { Modules with } \\
\text { little ventilation }\end{array}$ & $\begin{array}{c}\text { Modules with } \\
\text { ventilation }\end{array}$ & $\begin{array}{c}\text { Modules with } \\
\text { well ventilation }\end{array}$ \\
\hline Without MPPT & 0.55 & 0.60 & 0.65 & 0.70 \\
\hline With MPPT & 0.60 & 0.65 & 0.70 & 0.75 \\
\hline
\end{tabular}

Table 4.

Value of the ratio performance according to the breakdown of the modules. 
In our case, PV modules are superimposed. Therefore, it will be considered that this configuration allows the ventilation. In addition, we choose a regulator equipped with a MPPT device: then, the ratio performance is equal to $R P=0.7$.

\subsection{Peak power determination of the PV field}

There is a simple analytical formula to estimate the peak power of the PV field, noted as $P_{c}$ :

$$
P_{c}=\frac{E_{c}}{E_{i}} \times \frac{P_{i}}{R P}
$$

where $P_{c}$ is the peak power of the photovoltaic field; $E_{c}$ is the daily electrical energy potentially produced by the photovoltaic system, expressed in $\mathrm{kWh} / \mathrm{day}$, in our case $E_{c}=7.43 \mathrm{kWh} /$ day; $P_{i}$ is the illumination power under standard test conditions (STC), expressed in $\mathrm{kW} / \mathrm{m}^{2}$. So $P_{i}=1 \mathrm{~kW} / \mathrm{m}^{2} ; E_{i}$ is the daily solar irradiation, expressed in $\mathrm{kWh} / \mathrm{m}^{2} /$ day, received by the photovoltaic field, in our case $E_{i}=5 \mathrm{kWh} / \mathrm{m}^{2} /$ day; $R P$ is the performance ratio of the photovoltaic system, in our case $R P=0.7$.

Then, the peak power of the photovoltaic field $P_{c}$ is equal to $P_{c}=2.123 \mathrm{kWp}$.

Thus, to ensure customer comfort, we suggest installing a PV array power greater than or equal to $2.123 \mathrm{kWp}$.

\section{PV field dimensioning}

Figure 2 shows an autonomous photovoltaic installation schematic.

\subsection{Number of solar modules and characteristics}

Following the electrical requirement evaluation and the solar field, here, it is possible to size the photovoltaic field. This operation consists firstly to calculate the installation module number (Eq. (2)) [10]:

$$
N=\frac{P_{c}}{P_{r}}
$$

where $N$ is the modules number; $P_{c}$ is the peak power of the photovoltaic field; in our case $P_{c}$ should be greater than or equal to $2.123 \mathrm{kWp}$; and $P_{r}$ is the rated power of a PV module.

In the international market, there are several photovoltaic solar module technologies, as described in Figure 3:

Due to reduced manufacturing costs and maturity of the technology, crystalline modules are expected to maintain a market share of up to $80 \%$ until at least 2017 [8]. Both monocrystalline and multi-crystalline module prices have decreased considerably in the last years.

In this study, the PV module was selected due to few reasons that are worth to mention: its performance, warranty, and high efficiency. Thus, the "Polycrystalline solar panel IBC PolySol 260W (265Wc)" is chosen, so $P_{r}=260 \mathrm{~W}$. The datasheet of this module is given in [11].

Then, the installation modules number is equal to $N=10$.

To size the solar controller, inverter, cables, etc., the following PV characteristic parameters in the Standard Test Conditions (STC) will be used later. We remember that the Standard Test Conditions (STC) are [8]: 
Dimensioning of an Autonomous Photovoltaic Installation: Case Study in Msaken, Sousse... DOI: http://dx.doi.org/10.5772/intechopen.88771

- Cell temperature: $\theta=25^{\circ}=T=298.16 \mathrm{~K}$

- Incident radiation: $G=1000 \mathrm{~W} / \mathrm{m}^{2}$

- Spectral distribution of solar radiation: $A M 1.5$

The electrical characteristics of the PV module in the STC:

- Rated power: $P_{m p p}=260 \mathrm{~W}$.

- Open-circuit voltage: $V_{o c}=38.07 \mathrm{~V}$.

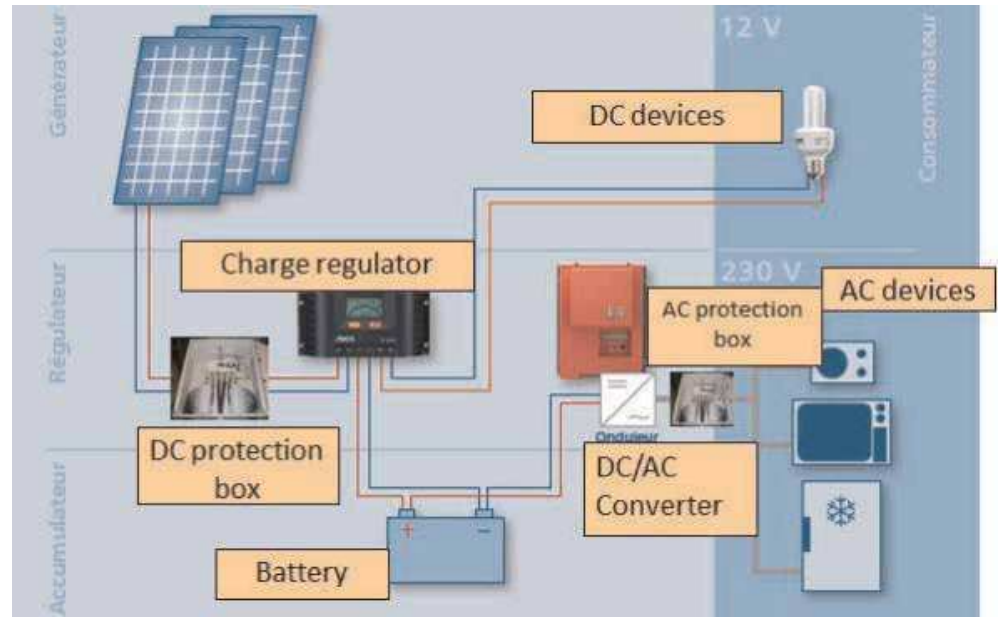

Figure 2.

Schematic of autonomous photovoltaic installation.

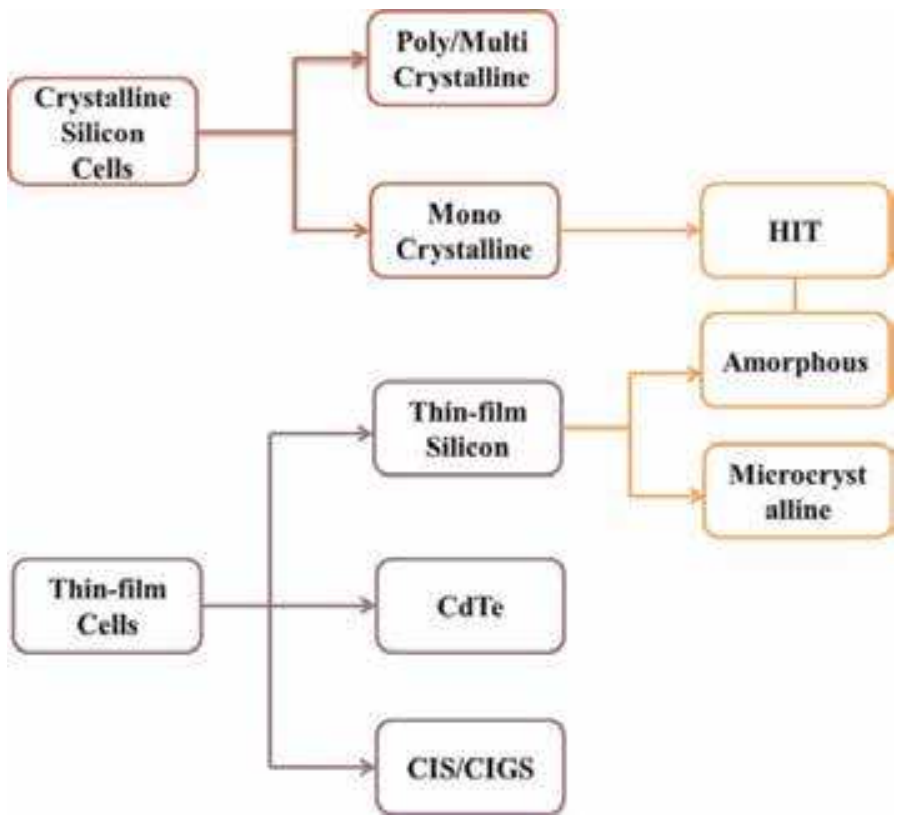

Figure 3.

PV technology classes [8]. 
- Maximum voltage: $V_{m p p}=30.57 \mathrm{~V}$.

- Short circuit current: $I_{s c}=9.19$ A.

- Maximum current: $I_{m p p}=8.56 \mathrm{~A}$

- Efficiency: $\eta=15.5 \%$

The thermal characteristics of the PV module in the STC:

- Temperature coefficient: $T_{c P_{m p p}}=-0.42 \% / \mathrm{K}$.

- Temperature coefficient: $T_{c V_{o c}}=-0.315 \% / \mathrm{K}$.

- Temperature coefficient: $T_{c I_{s c}}=0.04 \% / \mathrm{K}$.

\subsection{Dimensioning of the solar regulator}

The solar regulator is a device that is positioned between the solar modules and the batteries, also known as a charge controller. It is the guarantor of the energy level stored in the batteries [12].

Its main missions are:

- To convert the output voltage of the solar panel into voltage adapted to the charge of the batteries

- To protect the batteries by controlling their charge level. Once the batteries are full, the regulator will cut off the park recharge. At the same time, it will stop the power consumption of connected devices if the battery charge level falls below a certain safety threshold (deep discharge limit)

- To avoid reverse currents and thus protect the panel

The solar regulator is therefore an indispensable control component for the photovoltaic system. It protects the panels and batteries, thus, ensuring the system durability.

Depending on the technologies used, current charge regulators have very good yields, ranging from 85 to $98 \%$.

On the market, there are two technologies of charge controller:

- PWM (pulse width modulation): This technology makes it possible to modify the voltage of the signal coming from the panels to obtain a signal with a voltage adapted to the charge of the batteries.

- Maximum power point tracking (MPPT): This technology, which is specific to solar charge controllers, consists of scanning the voltage range across the panel and determining the voltage for which the power produced will be optimal. This allows optimizing the efficiency of the solar panels; the gain in yield is around $10 \%$. However, regulators equipped with MPPT technology are more expensive than conventional regulators. 
For most installations, a PWM regulator will be suitable. For large installations with multiple panels, MPPT regulators will be preferred. In our case, we use a MPPT regulator.

The solar regulator dimensioning is carried out according to three major parameters:

- Current compatibility

- Voltage compatibility

- Power compatibility

In this study, we choose Victron energy BlueSolar charge MPPT 150/100 as a solar regulator. Thus, we will have to check the compatibility of this regulator with this installation based on its datasheet [13] (Figure 4):

- Current compatibility: The PV module short circuit current is equal to $I_{s c}=9.19$ A under the STC conditions. The safety factor 1.25 should be applied to the $I_{s c}$, so, $1.25 \times 9.19=11.48 \mathrm{~A}$.

Thus, in order to not exceed the regulator maximum current $30 \mathrm{~A}$, the maximum number of PV strings to be paralleled is $100 / 11.48=8.7$. Therefore, with this regulator, we will be able to wire 5 strings in parallel.

- Voltage compatibility: If we use 5 strings in parallel, then each string will consist of 2 modules in series. In this case, the open circuit voltage of the string $V_{o c T}$ is $38.07 \mathrm{~V} \times 2=76.14$ Vunder STC conditions.

A coefficient of $20 \%$ is added to this value to account for the ambient temperature influence, $76.14 \times 1.2=91.368 \mathrm{~V}$. According to the regulator datasheet, the regulator input voltage must not exceed $150 \mathrm{~V}$. Therefore, the use of 2 modules in series validates this condition.

- Power compatibility: The photovoltaic module rated power (8 modules) is equal to: $P_{m p p T(\bmod u l e s)}=10 \times P_{m p p}=10 \times 260 \mathrm{~W}=2600 \mathrm{~W}$. We identify,

\begin{tabular}{|c|c|c|c|c|c|}
\hline $\begin{array}{c}\text { Controleur def chagge } \\
\text { Bluesolar }\end{array}$ & $\begin{array}{l}\text { MPPT } \\
150 / 45\end{array}$ & $\begin{array}{l}\text { MPRi } \\
\text { tsares: }\end{array}$ & $\begin{array}{l}\text { MPPT } \\
150 / 70\end{array}$ & $\begin{array}{l}\text { MPPT } \\
150 / 85\end{array}$ & $\begin{array}{l}\text { Ropt } \\
\text { Isoriog }\end{array}$ \\
\hline Tenlon de la batuerte & \multicolumn{5}{|c|}{ 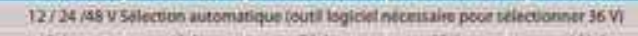 } \\
\hline Courant de churge nominal & $45 A$ & $\omega A$ & NA & as A & $100 \mathrm{~A}$ \\
\hline 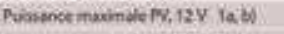 & $650 \mathrm{~W}$ & $850 \mathrm{~W}$ & $1000 \mathrm{w}$ & $1300 \mathrm{~W}$ & 1498W \\
\hline 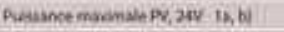 & 13006 & t200iw & $2000 \mathrm{w}$ & $24200 \%$ & $2900 \mathrm{w}$ \\
\hline 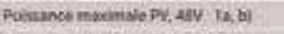 & $2600 \mathrm{~W}$ & $3440 \mathrm{~W}$ & $4000 \mathrm{~W}$ & $4900 \mathrm{~W}$ & $5800 \%$ \\
\hline Cousant mat de coutediroun PV D & 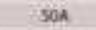 & soh & $\operatorname{son}$ & Jak & $70 \mathrm{~A}$ \\
\hline Tention WVmaximale de chicut owrent & \multicolumn{5}{|c|}{ 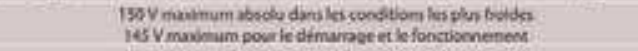 } \\
\hline 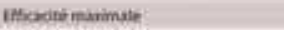 & \multicolumn{5}{|c|}{ os w } \\
\hline Ástoconesnurution & \multicolumn{5}{|c|}{$10 \mathrm{mh}$} \\
\hline Terulandecharge + Intnarption: & \multicolumn{5}{|c|}{ 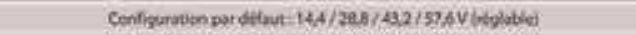 } \\
\hline Tenish de charge. Alat: & \multicolumn{5}{|c|}{ 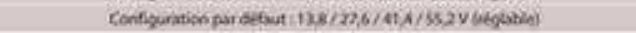 } \\
\hline Alponttrmin decherge & \multicolumn{5}{|c|}{ 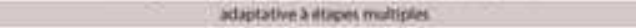 } \\
\hline Congenvation de cemptratury: & \multicolumn{5}{|c|}{$-36 \mathrm{mV} / \mathrm{Ta} \mathrm{mV} / \mathrm{-6 \textrm {a }}$ aVIC } \\
\hline Prutection & \multicolumn{5}{|c|}{ 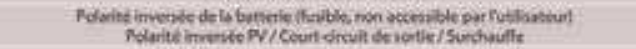 } \\
\hline Temperatiun desiniotation & \multicolumn{5}{|c|}{ 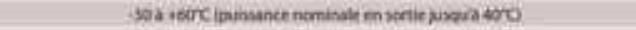 } \\
\hline Henidet & \multicolumn{5}{|c|}{ PSHisar sondeniution } \\
\hline 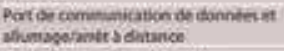 & \multicolumn{5}{|c|}{ 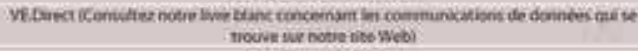 } \\
\hline Fonstiominnenten parallike & \multicolumn{5}{|c|}{ Oul gassmetuonist! } \\
\hline
\end{tabular}

Figure 4.

Victron energy 'BlueSolar charge MPPT 150/100' datasheet. 
in Figure 4, that the rated power of the MPPT regulator is $P_{m p p T(24 \mathrm{~V})}=$ $2900 \mathrm{~W} \rightarrow P_{m p p T(\text { regulator })}>P_{m p p T(\bmod u l e s)}$.

Figure 5 shows the photovoltaic module association ( 5 strings, each string is composed by 2 modules in series).

\subsection{Battery dimensioning}

The battery capacity must be able to cover all the electrical needs $\left(E_{c}\right)$.

When we size the batteries' capacity, we apply the following dimensioning rule $[12,14]$ :

- Over the duration of the reserve autonomy (NJ)

- Without any solar energy contribution

- Without ever exceeding the maximum depth of discharge (PD)

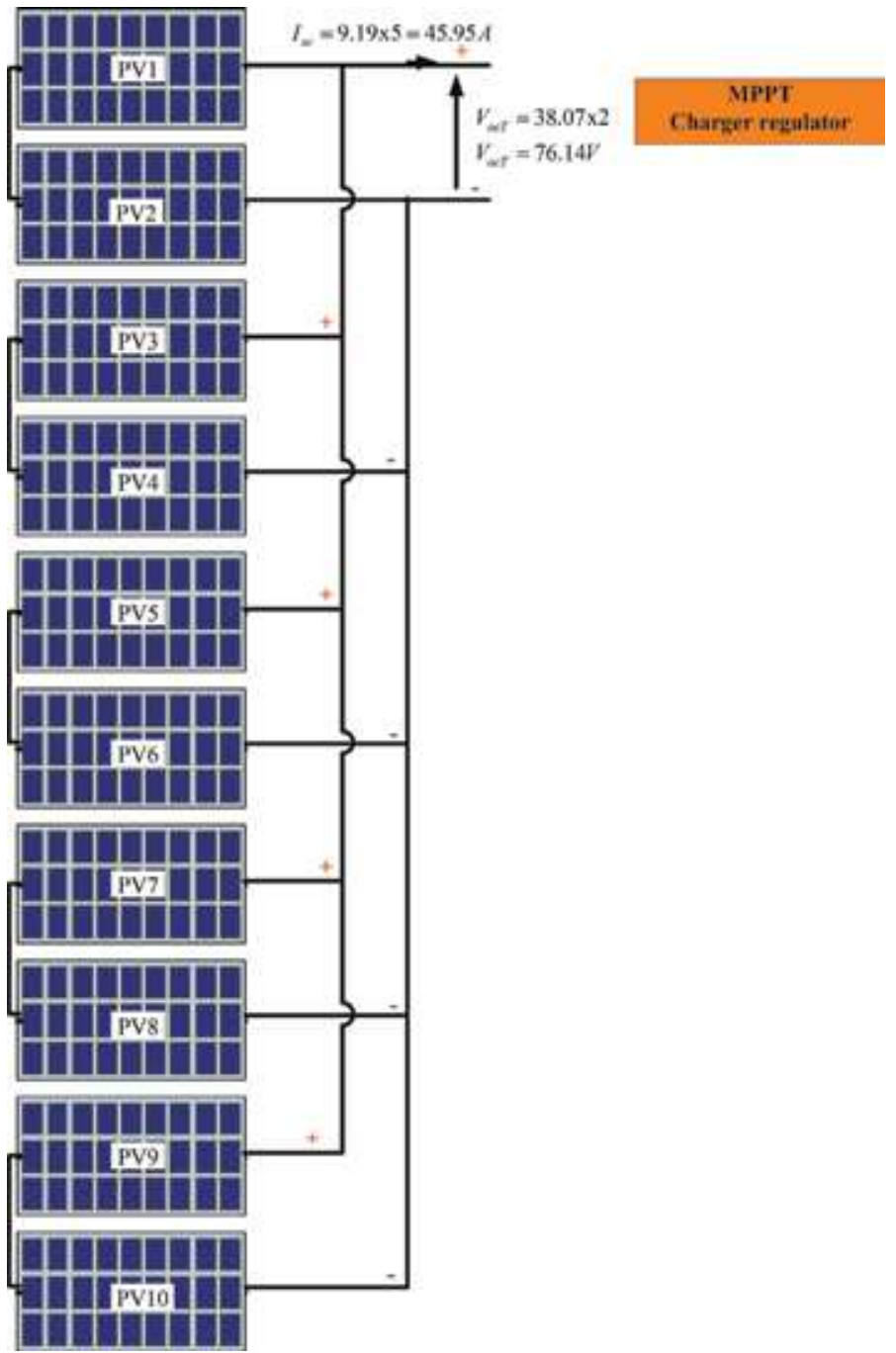

Figure 5.

Photovoltaic modules association. 
Dimensioning of an Autonomous Photovoltaic Installation: Case Study in Msaken, Sousse... DOI: http://dx.doi.org/10.5772/intechopen.88771

\subsubsection{Reserve autonomy}

We define the notion of reserve autonomy which corresponds to the desired day's number during which the batteries are able to supply, without any additional contribution from the photovoltaic field, all the electrical needs. We note $N J$ the day's number of reserve autonomy. The choice of $N J$ depends on the climatic conditions of the site and more particularly the number of consecutive days without sunshine. Usually, in Tunisia, $N J$ is fixed on 3 days.

\subsubsection{Maximum depth of discharge}

Repetition of deep discharges of the batteries should be avoided. Indeed, a too deep discharge tends to produce lead sulfate which agglomerates at the level of the electrodes. This phenomenon develops during the charging/discharging cycles and amplifies all the more as the discharge is deep. Eventually, an insulating layer of

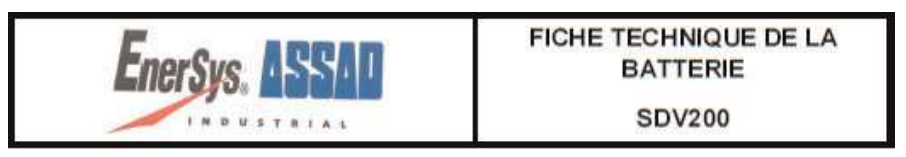

\begin{tabular}{|c|c|c|}
\hline \multicolumn{2}{|l|}{ Marque } & ENERSYS-ASSAD \\
\hline \multicolumn{2}{|l|}{ Type } & SDV200 \\
\hline \multicolumn{2}{|c|}{ Tension nominale $(\mathrm{V})$} & 12 \\
\hline \multicolumn{2}{|c|}{ Courant nominal (A) } & $0,1 \mathrm{C}$ \\
\hline \multicolumn{2}{|c|}{ Nature de la batterie } & $\begin{array}{l}06 \text { éléments de } 02 \mathrm{~V} \text { connectés en série } \\
\text { dans un coffret métallique }\end{array}$ \\
\hline \multicolumn{2}{|l|}{ Technologie } & Tubulaire \\
\hline \multirow{2}{*}{$\begin{array}{l}\text { Capacité a } \\
25^{\circ} \mathrm{C}(1,8 \mathrm{Vpc})\end{array}$} & C20 (Ah) & 200 \\
\hline & C100 (Ah) & 230 \\
\hline \multicolumn{2}{|c|}{ Longueur hors tout (mm) } & 320 \\
\hline \multicolumn{2}{|c|}{ Largeur hors tout $(\mathrm{mm})$} & 203 \\
\hline \multicolumn{2}{|c|}{ Hauteur hors tout ( $\mathrm{mm}$ ) } & 481 \\
\hline \multicolumn{2}{|c|}{ Bac } & Transparent \\
\hline \multicolumn{2}{|l|}{ Type borne } & Plate en L \\
\hline \multirow{2}{*}{$\begin{array}{l}\text { Marquage } \\
\text { borne }\end{array}$} & Positive & Signe + \\
\hline & Négative & Signe - \\
\hline \multirow{4}{*}{$\begin{array}{l}\text { Plaque } \\
\text { positive }\end{array}$} & Type & Tubulaire \\
\hline & Epaisseur ( $\mathrm{mm})$ & 9,5 \\
\hline & Nbre de tubes/plaque & 19 \\
\hline & Nbre de plaques/élément & 2 \\
\hline \multirow{3}{*}{$\begin{array}{l}\text { Plaque } \\
\text { négative }\end{array}$} & Type & Plane \\
\hline & Epaisseur $(\mathrm{mm})$ & 2,5 et 04 \\
\hline & Nbre de plaques/élément & 02 et 01 \\
\hline \multicolumn{2}{|c|}{ Pureté du plomb } & $99,99 \%$ \\
\hline \multicolumn{2}{|c|}{ Taux d'antimoine } & $\begin{array}{c}6,5 \% \text { pour les plaques positives et } 5 \% \text { pour } \\
\text { les plaques négatives }\end{array}$ \\
\hline \multicolumn{2}{|c|}{ Type séparateur } & Microporeux à faible résistance mécanique \\
\hline \multirow{2}{*}{\multicolumn{2}{|c|}{ Etiquettes }} & Etiquette face SDV200 \\
\hline & & Etiquette de niveau sur les côtés \\
\hline \multicolumn{2}{|l|}{ Electrolyte } & Acide sulfurique $\mathrm{H}_{2} \mathrm{SO}_{4}$ \\
\hline \multicolumn{2}{|c|}{ Volume d'électrolyte (L) } & 16 \\
\hline \multicolumn{2}{|c|}{ Densité de l'électrolyte à $25^{\circ} \mathrm{C}\left(\mathrm{g} . \mathrm{cm}^{-3}\right)$} & 1,240 \\
\hline \multicolumn{2}{|c|}{ Poids de la batterie avec électrolyte (Kg) } & 68 \\
\hline \multicolumn{2}{|c|}{ Température nominale de service $\left({ }^{\circ} \mathrm{C}\right)$} & 25 \\
\hline \multirow{2}{*}{ Paletisation } & Type palette & Europalette \\
\hline & Nombre/palette & 20 \\
\hline
\end{tabular}

Figure 6.

SOLAR ASSAD battery datasheet. 
lead sulfate appears and prevents chemical reactions from occurring. Then, the accumulator becomes unusable, or at least it is able to fall dramatically.

We note $P D$ the maximum discharge depth of a battery.

In this study, we chose "SOLAR ASSAD" as solar battery, $12 \mathrm{~V}$, capacity $C_{b}=230 \mathrm{Ah}$. Thus, we will have to check the necessary batteries number and serial or parallel association based on its datasheet [15] (Figure 6).

The battery capacity $C_{T}$ is calculated using the following expression:

$$
C_{T}(A h)=\left(E_{c} \times \mathrm{NJ}\right) /\left(P D \times \mathrm{U}_{\mathrm{T}}\right)
$$

where $\mathrm{NJ}$ is the number of days with insufficient sunshine (in our case $N J=3$ days); $E_{c}$ is the daily electrical energy potentially produced by the photovoltaic system expressed in $\mathrm{kWh} /$ day, in our case $E_{c}=7.43 \mathrm{kWh} /$ day; $\mathrm{U}_{\mathrm{T}}$ is the voltage in volt under which the battery is installed $(12 \mathrm{~V}, 24 \mathrm{~V}, 48 \mathrm{~V})$; in our case, 2 battery chains will be installed $\rightarrow U_{T}=24 V_{\text {; }}$ and $P D$ is the maximum discharge depth of the batteries. In practice, a maximum depth of discharge of $70 \%$ is chosen.

Then, the battery capacity $C_{T}$ is equal to $C_{T}=1327 \mathrm{Ah}$.

When we size the capacity of the batteries, we can calculate the battery number $N_{b}$ to be paralleled:

$$
N_{b}=\frac{C_{T}}{C_{b}}
$$

where $C_{T}$ is the batteries capacity, $C_{T}=1327 A h$; and $C_{b}$ is the battery capacity, according to Figure 5, $C_{b}=230$ Ah.

Then, the battery number to be paralleled is equal to $N_{b}=6$.

So the total battery number is equal to $N_{b T}=12: 2$ battery chains (to obtain $24 \mathrm{~V}$ ) on 6 parallel (to obtain capacity of $1327 \mathrm{Ah}$ ) (Figure 7).

\subsection{Autonomous or off-grid inverter dimensioning}

The off-grid inverter is the essential electronic device that converts DC low voltage from a battery or other power source to $100-120 \mathrm{~V}$ or $220-240 \mathrm{~V}$ AC voltage. Off-grid inverter produces a voltage wave, with an independent frequency from the grid. Not only does the inverter convert DC to AC power, but it may also regulate the PV system if correctly dimensioned according to the battery voltage levels $[12,14]$.

Table 5 summarizes the recommended international standards for inverters intended for photovoltaic applications. Each country adapts them to the specificities of national functioning and regulation. Manufacturers are therefore slightly modifying the final design of their products to meet the requirements of each country [16].

In our case, the solar inverter is used to convert a $24 \mathrm{~V}$ battery DC voltage into $230 \mathrm{~V}$ AC voltage identical to that of the building electricity grid.

The off-grid inverter choice is based on three criteria:

- Part DC: On the DC side, the inverter must be adapted to the system voltage imposed by the battery bank. In our case, the battery output voltage is equal to $24 \mathrm{~V}$.

- Part AC: On the AC side, the inverter will impose an output signal adapted to the devices it feeds. In our case, the frequency voltage is equal to $50 \mathrm{~Hz}$, and the effective voltage value is equal to $230 \mathrm{~V}$. 


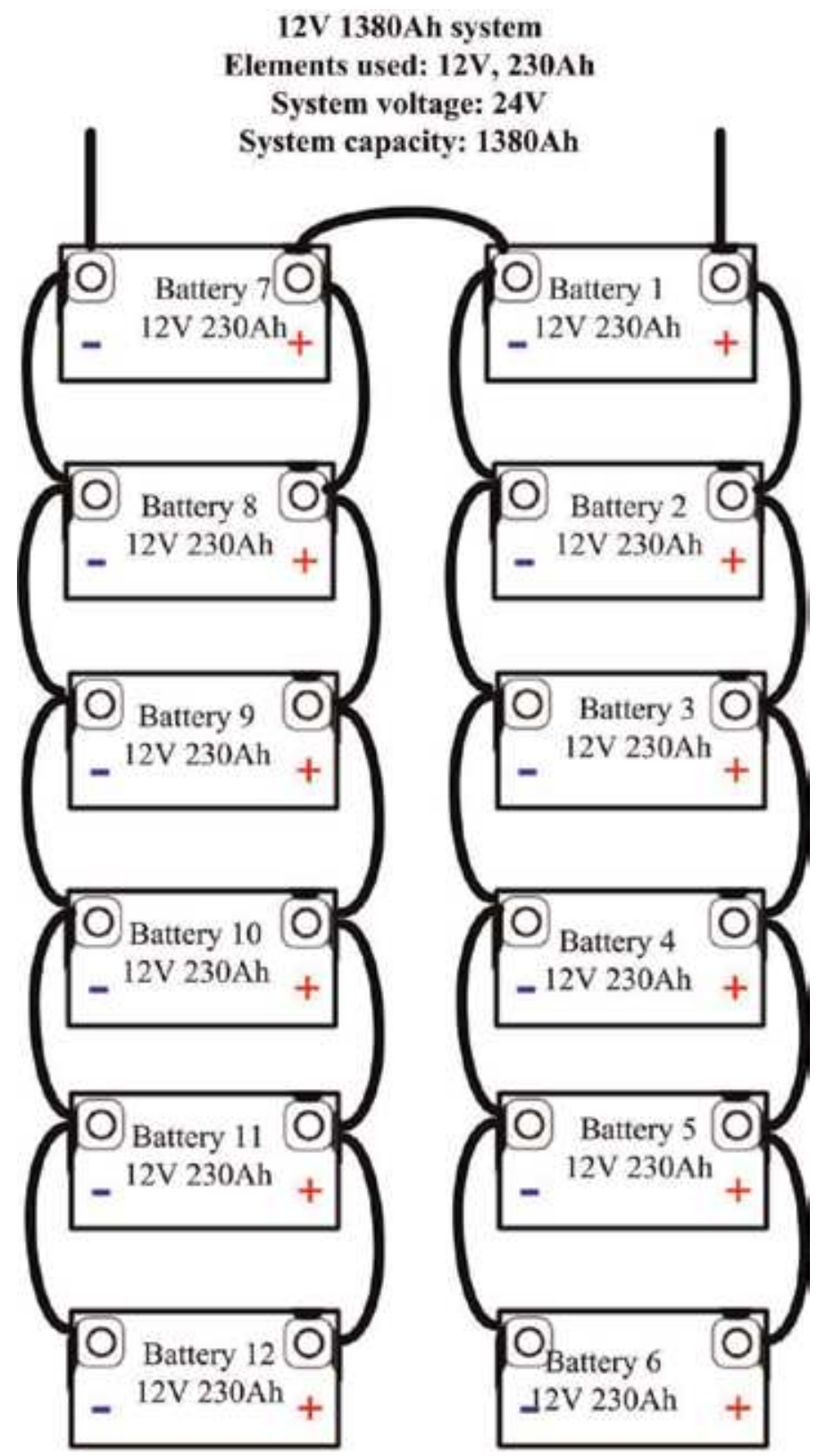

Figure 7.

Batteries association.

- Rated power: The inverter rated power should cover the sum of the all user powers. A sizing margin of $20-30 \%$ is recommended to ensure that the inverter operates at an ambient temperature of $25^{\circ} \mathrm{C}$. In this study, the user powers are equal to $2123 \mathrm{Wp}$, so the inverter rated power should be greater than $2123 \times 1.3=2760 \mathrm{~W}$.

In this study, we chose P3000-482 Off-grid DC to AC pure sine wave $24 \mathrm{~V}-$ $220 \mathrm{~V}$ solar inverter (Figure 8). Thus, we will have to check the compatibility of this inverter with this installation based on its datasheet [17] (Figure 9):

In the next study, it is necessary to: 
- Determine the cables sections that cause the least possible drop in voltage between the modules and battery-regulator-inverter and also between the inverter and loads.

- Dimension the protection components such as fuses, switch, etc.

\subsection{Dimensioning of the DC and AC cable}

\subsubsection{DC cable}

The solar cables must comply with several regulatory constraints summarized in the guide of the ETU C32-502 [18, 19].

These are specific cables subject to particular operating conditions. They must be designed to operate with ambient temperatures between -35 and $+70^{\circ} \mathrm{C}$.

Thus, it is expected that:

- The maximum permissible core temperature at steady state is $90^{\circ} \mathrm{C}$.

\begin{tabular}{|c|c|c|}
\hline & COEES ANO Sthatrotikos & SCORE AND CONTENT OF THE SBANOLVD \\
\hline Sod conseded & 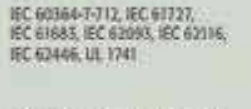 & 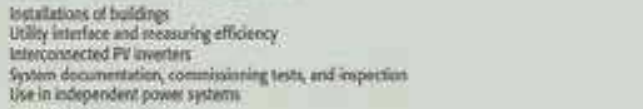 \\
\hline otf gid & 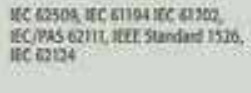 & 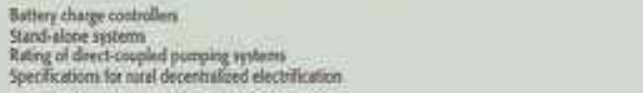 \\
\hline foval sybiens & itcis 62 ist: & 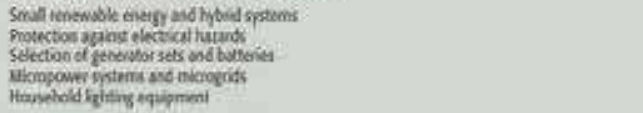 \\
\hline Motitsints & ICC 61726, IEC siaso-7, IEC s0000 & 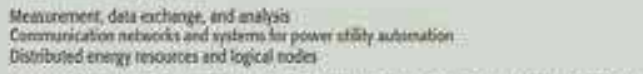 \\
\hline 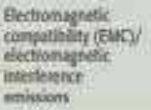 & $\begin{array}{l}\text { Exsiosa. } \\
\text { Foc pait is }\end{array}$ & 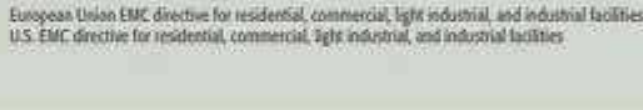 \\
\hline
\end{tabular}

Table 5 .

A summary of typical international codes and standards for PV applications.

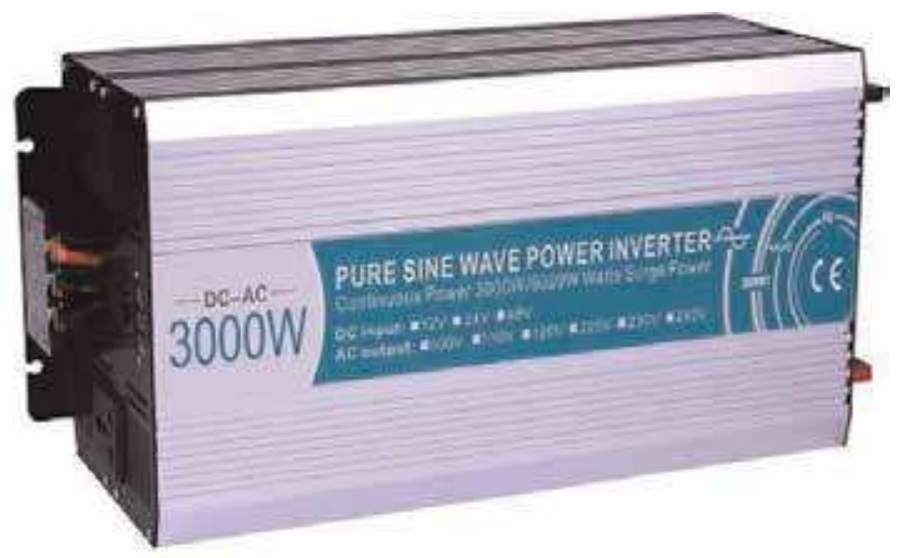

Figure 8.

$P_{3} 000-482$ Off-grid DC to AC pure sine wave 24-220 V solar inverter. 
Dimensioning of an Autonomous Photovoltaic Installation: Case Study in Msaken, Sousse... DOI: $h t t p: / / d x$.doi.org/10.5772/intechopen.88771

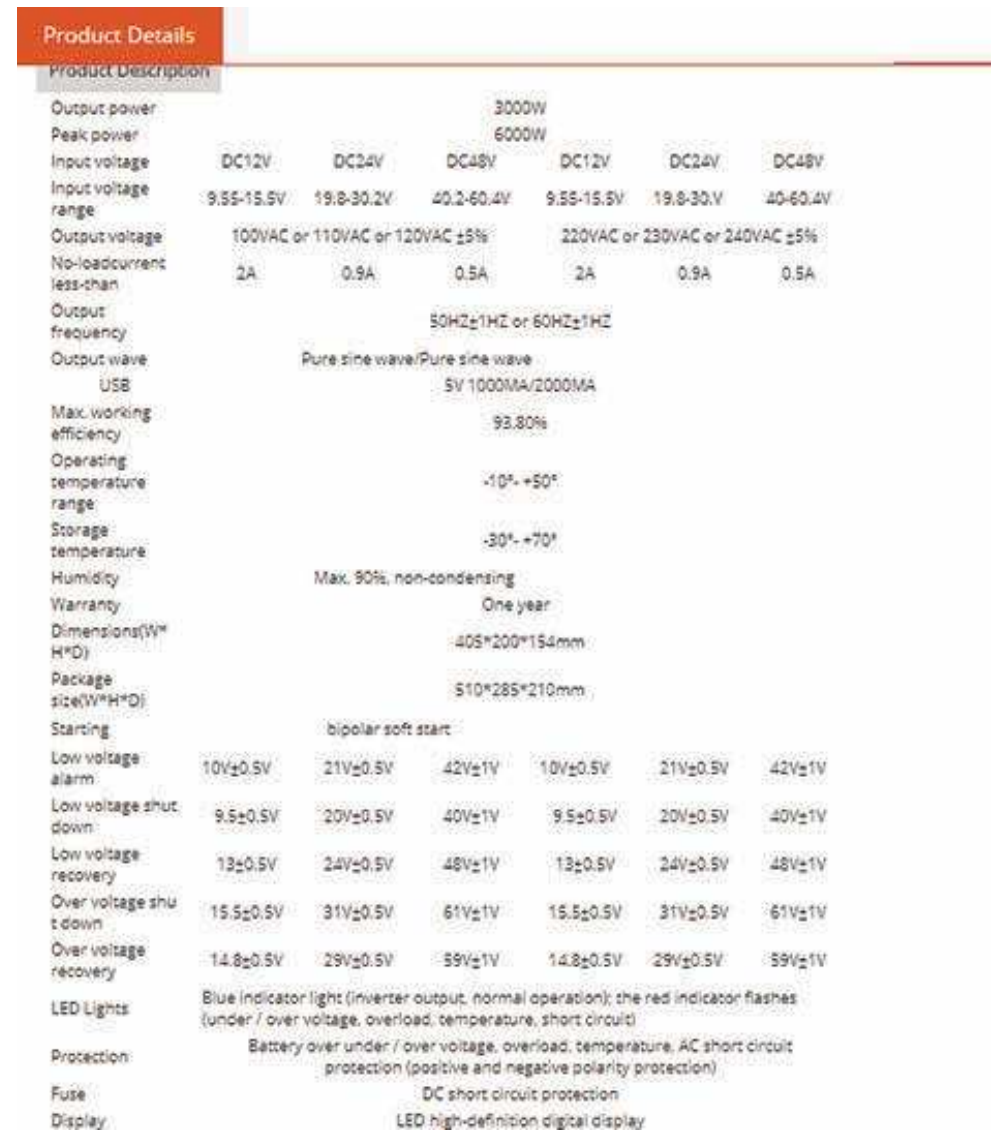

Figure 9.

Solar inverter datasheet [17].

- The maximum permissible core temperature in the overload condition is $120^{\circ} \mathrm{C}$.

The cable section choice of the installation is made according to two major criteria:

- Tolerated voltage drop

- The maximum current allowed in the cables

\subsubsection{Determination of the conductor section between the panels and the regulator}

The conductors section between the panels and the regulator can be calculated using (Eq. (5)):

$$
S=\frac{\rho \times L}{R_{\max }}
$$

where

1. $\rho$ is the substance conductivity:

Copper: $\rho_{\text {copper }}=1.7 \times 10^{-8} \Omega \mathrm{m}$

Aluminum: $\rho_{\text {Aluminum }}=2.8 \times 10^{-8} \Omega . \mathrm{m}$ 
Both values are calculated at $27^{\circ} \mathrm{C}$. At higher temperatures, the material resistance increases and the conductivity decreases.

In our case, the used conductors are copper.

2. The distance between the solar PV panels and the regulator is $L=16 \mathrm{~m}$ (outgoing and incoming cable).

3. The UTE C15-712 guide for PV installations indicates that the DC voltage drop must be less than $3 \%$ and ideally $1 \%$. In our case, it's fixed at $\sigma=1 \%$. Then, at a current of $I_{s c T}=9.19 \times 5=45.95 \mathrm{~A}$, the maximum resistance of the cable can be calculated using (Eq. (6)):

$$
R_{\max }=\frac{V_{o c T} \times \sigma}{I_{s c T}}=\frac{38.07 \times 2 \times 0.01}{45.95} \Rightarrow R_{\max }=0.0165 \Omega
$$

Then, the conductor section is equal to:

$$
S=\frac{\rho \times \mathrm{L}}{R_{\max }}=\frac{1.7 \times 10^{-8} \times 16}{0.0165}=16.48 \mathrm{~mm}^{2}
$$

A cable cross-section of $16 \mathrm{~mm}^{2}$ is sufficient to maintain the loss below $1 \%$.

\subsubsection{Determination of the conductor section between the regulator and the batteries}

Calculating the output current of a panels at its rated power:

$$
I=\frac{P_{c}}{U_{T}}=\frac{2600}{24} \Rightarrow I=108.33 \mathrm{~A}
$$

The distance between the regulator and the batteries is $L=3 \mathrm{~m}$ (outgoing and incoming cable).

Then the conductor section is equal to:

$$
S=\frac{\rho \times \mathrm{L} \times \mathrm{I}}{\sigma \times U_{T}}=\frac{1.7 \times 10^{-8} \times 3 \times 108.33}{0.01 \times 24}=23 \mathrm{~mm}^{2}
$$

A cable cross-section of $25 \mathrm{~mm}^{2}$ is sufficient to maintain the loss below $1 \%$.

\subsubsection{AC cable}

The AC cable section formula is as follows:

$$
S=\frac{\left(\rho \times b \times L \times I_{b}\right)}{\left(\varepsilon \times V_{n}\right)}
$$

where $S$ is the conductors section $\left(\mathrm{m}^{2}\right)$; $b$ is the coefficient which is 1 in threephase and 2 in single-phase; $V_{n}$ is the nominal voltage: $V_{n}=230 \mathrm{~V}$ in single-phase or $V_{n}=380 \mathrm{~V}$ in three-phase; $I_{b}$ is the maximum current; $I_{b}=\frac{P_{c}}{V_{n}}=\frac{2123}{230} \Rightarrow I=9.23 \mathrm{~A} ; \rho$ is the material resistivity $(\Omega \mathrm{m})$; in our case, the used conductors are copper; and $L$ is the conductor length $(\mathrm{m})$. The distance between the inverter and the loads is $30 \mathrm{~m} ; \varepsilon$ is the AC voltage drop; and in our case, it's fixed at $1 \%$. 
Calcul d'un cable AC
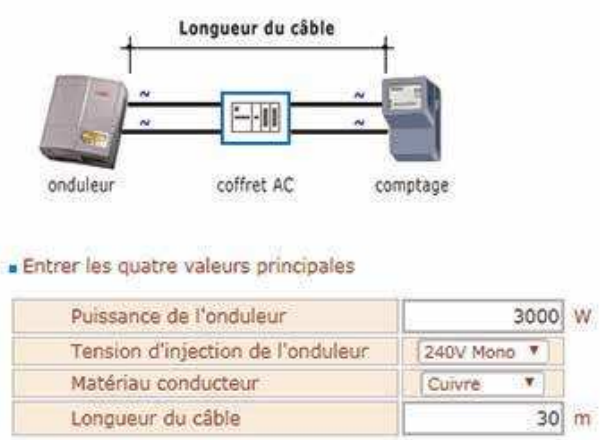

Calculer la section
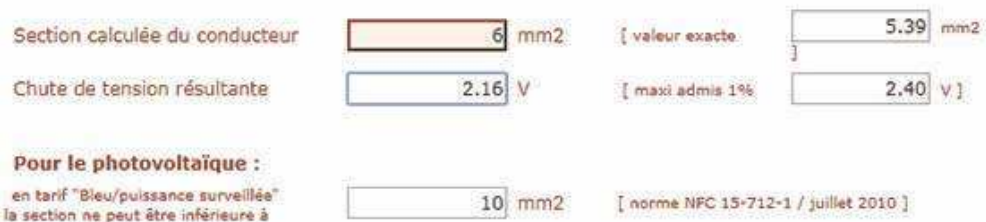

en tarif "Bleu/puiseance survellếe"

$10 \mathrm{~mm} 2$

[ norme NFC 15-712-1/ juillet 2010]

Figure 10.

The calculation results using "Sigma Tec" online calculator.

Then,

$$
S=\frac{\left(1.7 \times 10^{-8} \times 2 \times 30 \times 9.23\right)}{(0.01 \times 230)}=4.09 \mathrm{~mm}^{2}
$$

AC cable cross-section of $6 \mathrm{~mm}^{2}$ is sufficient to maintain the loss below $1 \%$.

To validate this calculation, we can use "SigmaTec" which is an online calculator of cable sections [20]. Figure 10 shows an example of calculation.

\subsection{Dimensioning of DC protection components}

Every PV installation requires an AC protection box and a DC protection box. These AC/DC electrical boxes protect the photovoltaic system on the DC part as well as on the AC part.

The protection component characteristics will be chosen based on the following standards and guides $[18,19]$ :

Standards:

1.IEC 60364-7-712: Rules for installations and locations special-photovoltaic power supplies

2.Solar (PV) NF C 15-100: Low-voltage electrical installations and regulations

Guides:

1. Guide UTE C 15-712-1: Practical guide, installation of solar photovoltaic (PV) generators.

2.UTEC guide 61,740-51 (2009): It concerns the tests of surge arresters for DC application only. These tests are based on AC surge arrester standards but differentiate for "end of life tests." 


\subsubsection{DC fuses}

According to the UTE C15-712-1, the presence of fuse is always obligatory for each of the photovoltaic chains, in order to protect the photovoltaic modules and the cables of the currents being able to flow from the park of batteries toward the panels (in particular in the dark period when the battery is able to discharge through the photovoltaic field), in the case where the regulator's nonreturn device is inoperative.

In our case, we need five fuses on each of the two extremities of PV panels (Figure 11).

\subsubsection{Calibration of fuses}

On the DC side, overcurrent occurs as back current. Above certain intensity, the return currents can damage the photovoltaic modules.

In general, photovoltaic modules can support a maximum return current that depends on the number of branches in parallel presented in Table 6:

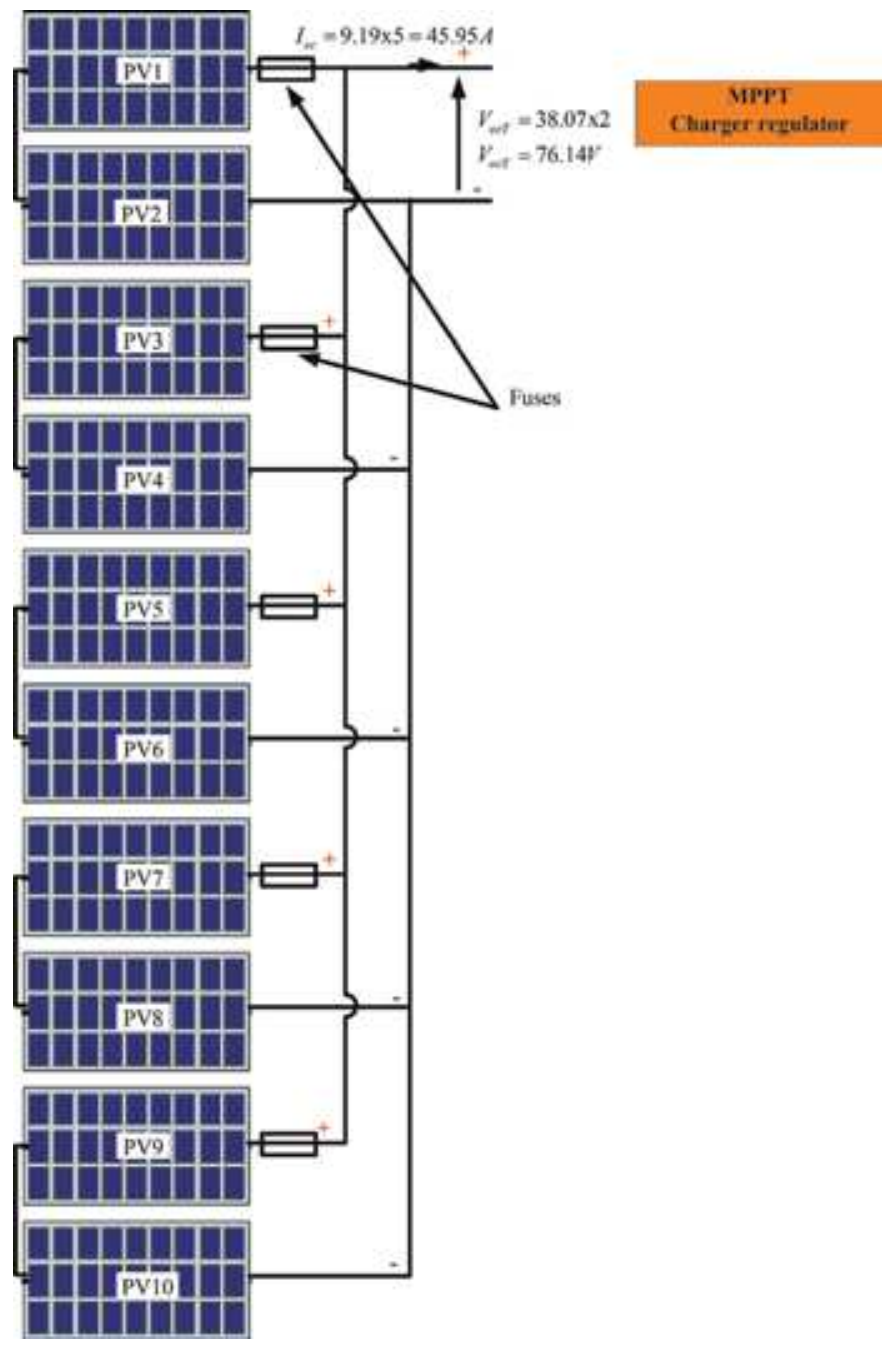

Figure 11.

Fuses location in the PV system. 
Dimensioning of an Autonomous Photovoltaic Installation: Case Study in Msaken, Sousse... DOI: http://dx.doi.org/10.5772/intechopen.88771

\begin{tabular}{lc}
\hline Number of parallel chain & Maximum value of the return current in a chain \\
\hline$N_{c}=1$ & 0 \\
\hline$N_{c}=2$ & $1.25 \times I_{s c}$ \\
\hline$N_{c}=3$ & $2 \times 1.25 \times I_{s c}$ \\
\hline$N_{c} \geq 1$ & $\left(N_{c}-1\right) \times 1.25 \times I_{s c}$ \\
\hline
\end{tabular}

Table 6.

Fuses choice.

The use of fuses also allows the shutdown of a single photovoltaic chain in the event of maintenance activities, thus avoiding the shutdown of the entire installation.

The rated current $I_{N}$ of the fuses must, in accordance with the guide of the UTE C15 712-1, comply with the following condition, (Eq. (9)):

$$
1.1 \times I_{s c, \max } 1.25 \times I_{s c} \leq I_{N} \leq I_{R M 2 \times I_{s c}}
$$

with $I_{N}$ being the rated current of the fuse or rated current of the fuse and $I_{R M}$ being the maximum return current that can support a module without being damaged

$$
\text { Then, } \begin{aligned}
& 1.1 \times 1.25 \times I_{s c} \leq I_{N} \leq 2 \times I_{s c} \\
& 12.6362 \mathrm{~A} \leq I_{N} \leq 18.38 \mathrm{~A}
\end{aligned}
$$

In addition, the fuses used must have the following characteristics:

- Being specific to a DC application

- "Fast-melting"

- Being independent of the flow direction

- Having the gPV mark

By consulting the marketed product catalogs, the choice was set for gPV fuses of $15 \mathrm{~A}$ caliber and $50 \mathrm{kA}$ breaking capacities. Table 7 shows the fuse characteristics [21]:

\subsubsection{DC lightning protection}

A lightning protection is required to protect the installations from high transient voltages. Placed between the fuse of the panels and the batteries, it will be

\begin{tabular}{lc}
\hline Number & 2 \\
\hline Rated current & $15 \mathrm{~A}$ \\
\hline Rated voltage & DC $1000 \mathrm{~V}$ \\
\hline Breaking capacity & $50 \mathrm{kA}$ \\
\hline
\end{tabular}

Table 7.

Fuse characteristics. 
connected to the ground in order to evacuate the lightning potentially attracted by the metallic structure of the modules (itself connected to the ground) [22].

Lightning protection can contain different internal components such as spark gaps or clipping diodes. These components are intended to quickly limit the voltages appearing at their terminals.

The choice between type 1 and type 2 lightning protections is determined from Table 8.

The keraunic level of a site $N K$ defines the number of thunderstorms per year in a given place. It is determined by the map given by the weather Tunisia [23].

The Sousse keraunic level equals to 47 , so in our case, $N K \geq 25$; and so, the type of surge arrester is type 2 .

- The recommended minimum discharge current $I_{n}$ is $5 \mathrm{kA}$. A higher value will give a longer life.

- The voltage $U_{c}$ of a lightning protection must be greater than or equal to $1.2 \times V_{o c}$ of PV generator; we obtain $U_{c} \geq 1.2 \times 38.07=45.68 \mathrm{~V}$.

Table 9 shows the following lightning protection characteristics.

\subsubsection{DC switch disconnector}

An electrical distribution from solar energy requires the same protections as for a conventional network. However, the DC side protections are special because direct current is difficult to interrupt if an arc occurs.

In a photovoltaic installation, it is essential to be able to cut off the power, for example, to carry out maintenance operations.

The switch disconnector choice must take into account the following criteria:

$$
\begin{gathered}
I_{n} \geq 5 \times 1.25 \times I_{s c} \Rightarrow I_{n} \geq 57.43 \mathrm{~A} \\
U_{e} \geq 2 \times \mathrm{V}_{o c} \Rightarrow U_{e} \geq 76.14 \mathrm{~V}
\end{gathered}
$$

where $I_{n}$ is the rated current of the switch disconnector $(\mathrm{A})$ and $U_{e}$ is the rated voltage of the switch disconnector $(\mathrm{V})$.

\begin{tabular}{lccccc}
\hline \multirow{2}{*}{ Installation characteristics } & \multicolumn{2}{c}{$\mathbf{N K} \leq \mathbf{2 5}$} & \multicolumn{2}{c}{ NK $\geq \mathbf{2 5}$} \\
\cline { 2 - 6 } & DC side & AC side & DC side & AC side \\
\hline Building or structure equipped with a lightning rod & Type 2 & Type 1 & Type 2 & Type 1 \\
\hline Medium voltage supply by a line wholly or partly overhead & Type 2 & Type 2 & Type 2 & Type 2 \\
\hline Medium voltage supply via a completely underground line & Type 2 & Type 2 & Type 2 & Type 2 \\
\hline
\end{tabular}

Table 8.

Lightning protection type choice [23].

\begin{tabular}{lc}
\hline Type & 2 \\
\hline Rated voltage & DC $1000 \mathrm{~V}$ \\
\hline Nominal discharge current In $(8 / 20) \mu \mathrm{s}$ & $15 \mathrm{kA}$ \\
\hline Maximum discharge current I total $(8 / 20) \mu \mathrm{s}$ & $20 \mathrm{kA}$ \\
\hline
\end{tabular}

Table 9.

Lightning protection characteristic. 


\begin{tabular}{cc}
\hline Rated voltage & $230 / 400 \mathrm{VAC}-50 \mathrm{~Hz}$ \\
\hline Rated current & $15 \mathrm{~A}$ \\
\hline
\end{tabular}

Table 10.

Switch disconnector characteristic.

\subsection{Dimensioning of AC protection components}

\subsubsection{AC switch disconnector}

The voltage at the inverter output is $230 \mathrm{~V}$. In fact, the disconnector voltage must be better than:

$$
V_{e} \geq 230 \times 1.14=262.2 \mathrm{~V}
$$

The inverter output current is equal to $10 \mathrm{~A}$. So the disconnector current is given by:

$$
I_{n} \geq 1.25 \times 10=12.5 \mathrm{~A}
$$

Table 10 shows the characteristics of the switch disconnector.

\subsubsection{Differential circuit breaker}

The electrical installation is generally considered the occurrence seat of abnormally high currents such as short circuit, overload, and indirect contacts. To guard against the pervious defects, it is preferable to install a differential circuit breaker to cut the installation if necessary. On the AC side of a photovoltaic installation, a differential magnetothermic circuit breaker upstream of each inverter must be installed.

\subsubsection{AC lightning protection}

On the AC side of a photovoltaic installation, we will install a lightning protection in order to protect the entire installation.

\section{Results and discussion}

This study throws light on the following points:

1. In Msaken, the solar irradiation varies between a minimum of $3.22 \mathrm{kWh} / \mathrm{m}^{2} /$ day and a maximum of $6.4 \mathrm{kWh} / \mathrm{m}^{2} /$ day, while mean value remained as $5 \mathrm{kWh} / \mathrm{m}^{2} /$ day.

2. The energy need of the customer was identified at $7.43 \mathrm{kWh} /$ day which corresponds to a photovoltaic field peak power $P_{c}$ equal to $P_{c}=2.123 \mathrm{kWp}$.

3. The proposed solution is to install $10 \mathrm{PV}$ modules of total power $2600 \mathrm{~W}$, while the necessary power is $2123 \mathrm{Wp}$. Thus, the customer can supply another electrical device without the need to modify the PV installation.

4. It is recommended to improve the energy efficiency of the building by studying the characteristics of each load and by proposing to the customer to replace the existing loads by others that are more economic. 


\begin{tabular}{|c|c|c|c|}
\hline Components & Quantity & $\begin{array}{l}\text { Unit price } \\
\text { (Euro) }\end{array}$ & $\begin{array}{l}\text { Total price } \\
\quad \text { (Euro) }\end{array}$ \\
\hline Solar panel polycrystalline IBC PolySol $260 \mathrm{~W}$ & 10 & 253 & 2530 \\
\hline Victron energy e BlueSolar charge MPPT 150/100 & 1 & 816 & 816 \\
\hline Solar battery ASSAD & 12 & 202,617 & 2431,404 \\
\hline $\begin{array}{l}\text { P3000-482 Off-grid DC to AC pure sine wave 24- } \\
220 \mathrm{~V}\end{array}$ & 1 & 305 & 305 \\
\hline Differential circuit breaker & 1 & 26 & 26 \\
\hline AC/DC lightning protection & 2 & 88.96 & 177.92 \\
\hline DC fuses & 5 & 12 & 72 \\
\hline AC switch disconnector & 1 & 36 & 36 \\
\hline DC switch disconnector & 1 & 170 & 170 \\
\hline DC cables $25 \mathrm{~mm}^{2}$ & $3 \mathrm{~m}$ & 9.9 & 29.7 \\
\hline DC cables $16 \mathrm{~mm}^{2}$ & $16 \mathrm{~m}$ & 2.6 & 41.6 \\
\hline AC cables $6 \mathrm{~mm}^{2}$ & $30 \mathrm{~m}$ & 1.32 & 39.6 \\
\hline Structure & 5 & 30 & 150 \\
\hline Maintenance and operational costs (Euro/year) & & & 31.5 \\
\hline Total & & & 6856.724 \\
\hline
\end{tabular}

Table 11.

$P V$ field installation cost.

\subsection{Cost analysis}

The PV field installation cost is reported in Table 11.

\section{Conclusion and prospects}

The objective of this chapter was to design and present a photovoltaic system, in the form of an autonomous power supply system for a future house located in an isolated area in Msaken, Sousse (Tunisia). An energy need analysis of the customer was carried out in order to properly size the various components of the installation.

The autonomous system presented in this chapter leads to a continuous lighting supply of the load for 72 hours. In comparison, a system connected to the network in Tunisia would lead to occasional power outages, affecting the entire installation.

To obtain a robust solar system, the photovoltaic panels must be supplemented by a charge controller, a group of batteries, and an inverter. The recommended panel assembly consists of 10 polycrystalline $260 \mathrm{~W}$ photovoltaic modules. The installation must be installed at an angle of $30^{\circ}$ south. A charge controller regulates the charge of 12 batteries "SOLAR ASSAD" of $230 \mathrm{Ah}$. An inverter is used to supply loads with alternating current. The total investment cost of the system is 6856.724Euro.

Although the results obtained in the calculations can be considered valid, some improvements can be made to the calculation method to obtain more accurate results. Thus, as short-term prospects, it will be necessary to: 
Dimensioning of an Autonomous Photovoltaic Installation: Case Study in Msaken, Sousse...

DOI: http://dx.doi.org/10.5772/intechopen.88771

- Obtain more accurate meteorological data for optimized sizing of plant components.

- Reconfigure the PV modules taking into account the optimal spacing between the rows, and optimize the shading losses.

- Validate the sizing performed using specific software such as PVsyst and Archelios $^{\mathrm{TM}}$.

- Study in more detail the future requirements of the customer such as external lighting systems with auxiliary energy saving and efficiency systems such as LEDs, voltage stabilizers, etc., and calculate whether the PV system designed meets these requirements.

- Conduct a more in-depth study on the costs associated with the PV installation analyzed. Try to obtain the cost of the components/services of a photovoltaic project located in Tunisia.

- Include an environmental analysis of the PV project.

- Try to apply the calculation method developed with other photovoltaic modules, regulators, batteries, and inverters, with a different tracking system or located on another site, and check if the results are consistent with the results previously obtained.

\section{Acknowledgements}

This project was supported by the Tunisian Ministry of Higher Education and Scientific Research under Grant LabEM-ESSTHSousse-LR11ES34.

Likewise, the authors would like to thank SOS ENERGY Company for the technical information.

\section{Conflict of interest}

The authors declare no conflict of interest. 


\section{Author details}

Olfa Bel Hadj Brahim Kechiche*, Marwa Hamza and Habib Sammouda High School of Sciences and Technology of Hammam Sousse, Laboratory of Energy and Materials (LR11ES34), Sousse University, Hammam Sousse, Tunisia

*Address all correspondence to: Olfa.Belhadjbrahimkechiche@essths.rnu.tn; belhajbrahimolfa@yahoo.fr

\section{IntechOpen}

(C) 2020 The Author(s). Licensee IntechOpen. Distributed under the terms of the Creative Commons Attribution - NonCommercial 4.0 License (https://creativecommons.org/ licenses/by-nc/4.0/), which permits use, distribution and reproduction for non-commercial purposes, provided the original is properly cited. (cc) BY-NC 


\section{References}

[1] Balghouthi M, Trabelsi SE, Ben Amara M, Ali ABH, Guizani A. Potential of concentrating solar power (CSP) technology in Tunisia and the possibility of interconnection with Europe. Renewable and Sustainable Energy Reviews. 2016;56:1227-1248

[2] El Haddad M. Development of renewable energies in Tunisia.

Renewable Energies, National Agency. 2017;October:1-2

[3] Rocher L. Energy transition and revolution in Tunisia: Politics and spatiality. Arab World Geographer. 2013;16(June) 277-xx

[4] Aide I. Support Electrique pour Installation Solaire. 2012. Available from: http://www.interaide.org/ pratiques/sites/default/files/support_ electrique_pour_installation_solaire.pdf [Accessed: 02 June 2019]

[5] Coordonnées géographiques et cartographie Msaken-Tunisia. Available from: https://www.horlogeparlante. com/coordonn\%C3\%A9es-g\%C3\%A9og raphiques-2469140.html [Accessed: 16 July 2019]

[6] PVGIS Climate-SAF database. Institute for Energy and Transport (IET), 2001-2012. Available from: https://re.jrc.ec.europa.eu/pvgis/apps4/ pvest.php? $\mathrm{map}=$ africa\&lang=fr [Accessed: 16 July 2019]

[7] Benemann J, Chehab O, SchaarGabriel E. Building-integrated PV modules. Solar Energy Materials \& Solar Cells. 2001;67(1-4):345-354

[8] International Finance Corporation (IFC) World Bank. Utility-scale solar photovoltaic power plants: A projects developer's guide. In: World Bank Group. 2015. p. 216

[9] van Sark WGJHM, Reich BMNH. Review of PV performance ratio development. World Renewable Energy

Forum, WREF. 2012;6:2012

[10] Master's degree in energy engineering design and modelling of a large-scale PV plant Escola Tècnica superior d'Enginyeria Industrial de Barcelona [M. thesis]. June 2018

[11] Polycrystalline solar panel IBC PolySol. Available from: https:// www.solaris-store.com/1307-panneausolaire-ibc-polysol-260w.html [Accessed: 12 April 2019]

[12] Carriço J. Technical and economic assessment of a $500 \mathrm{~W}$ autonomous photovoltaic system with $\mathrm{LiFePO}_{4}$ battery storage. November 2015

[13] Contrôleurs de charge BlueSolar charge avec visou connexion PV MC4. Available from: https://k8s-ecolosunproduction.s3.eu-west-3.amazonaws. com/documents/files/2757/original/ Fiche technique régulateur solaire MPPT Victron-150-45-à-150-100.pdf? 1474898697 [Accessed: 02 July 2019]

[14] Alkhalidi AAT. Design of an off-grid solar PV system for a rural shelter. School of Natural Resources Engineering and Management, Department of Energy Engineering Design of an Off-Grid Solar PV system for a rural shelter. Presented by Noor Hussain Al Dulaimi 2008203032 F. January 2018

[15] Fiche batterie Solaire Assad.

Available from: http://www.solar-powercompany.com/article/pdf/FICHE-batte rie-SOLAIRE-Assad.pdf. [Accessed: 02 July 2019]

[16] Kouro S, Leon JI, Vinnikov D, Franquelo LG. Grid-connected photovoltaic systems: An overview of recent research and emerging $\mathrm{PV}$ converter technology. IEEE Industrial Electronics Magazine. 2015;9(1):47-61 
[17] Solar inverter datasheet. Available from: https://www.aliexpress.com/item/ P3000-482-Off-grid-dc-to-ac-puresine-wave-48v-220v-solar-inverter3000w-voltage/32766770825.html [Accessed: 12 April 2019]

[18] C.-712 UTE. Installations photovoltaïques raccordées au réseau public de distribution. Ed. Diffus. par l'Union Tech. l'Electricité; 2008

[19] C.-712-1 UTE. Installations photovoltaïques raccordées au réseau public de distribution. Ed. Diffus. par l'Union Tech. l'Electricité; 2010

[20] Online Calculator of Cable Sections. Available from: http://www.sigma-tec. fr/textes/texte_cables.html

[21] Fuse-links \& fuse holders. Available from: http://solarge.tw/prod-info/prod04/PMX_en.pdf [Accessed: 02 July 2019]

[22] Installations photovoltaïques raccordées au réseau public de distribution DIMENSIONNEMENT CORRIGE Composants DC et AC. Available from: https://energypedia. info/images/a/ab/Dimensionnement_ Sujet_composant_DC_et_AC.pdf. pp. 1-34. [Accessed: 12 July 2019]

[23] La sécurité des installations photovoltaïques. 2016. Available from: https://energypedia.info/images/4/4c/ Sécurité_des_IPV-STEG-v2.pdf.

[Accessed: 08 July 2019] 


\title{
Energy Efficiency and Sustainability in Outdoor Lighting - A Bet for the Future
}

\author{
Kamrul Alam Khan, Salman Rahman Rasel, S.M. Zian Reza \\ and Farhana Yesmin
}

\begin{abstract}
Electricity from PKL tree has been developed using PKL extract previously. In this work, electricity production has been developed using living PKL tree. It has been studied that an electrochemical cell has been developed using living PKL tree. The experimental data have been demonstrated in that way, hence this method is feasible and effective. Electricity has been conducted from PKL (Pathor Kuchi leaf) using PKL extract with positive and negative electrodes. Several research papers have been published on it in the recognized journal at home and abroad. This research work has expressed the electricity generation from living PKL tree. It can be found that due to the difference of the $\mathrm{pH}$ between the soil and the living PKL tree, electricity can be produced. The performance of this electricity has been studied. This work has been developed by authors, which produced electricity from living PKL tree without damaging the PKL plants. The unused suitable land areas such as hilly areas, forest areas, and coastal areas, those could supply clean power for remote communities all over the world.
\end{abstract}

Keywords: cultivation, living PKL electricity, performance, capacity, energy efficiency

\section{Introduction}

Pathor Kuchi leaf is known as a medicinal leaf from ancient time. It has a great medicinal value, it is used for different kinds of diseases like dysentery, cholera, typhoid, kidney disease, etc. In the West Bengal, India there is no alternative about Pathor Kuchi leaf for folk medicine. People are using the leaf as a folk medicine. But, nowadays, it is using to generate electricity for low and medium power production [1-18]. Generally $\mathrm{Zn}$ and $\mathrm{Cu}$ metal is used as an electrode and the PKL extract is used as a source of the electricity [19-38]. Clean energy sources, which are pollution free and environmentally friendly, are one of the key challenges of world's future society.

The traditional sources of energy oil, gas and coal are diminishing day by day rapidly. Bangladesh is mainly dependent on gas based electricity. Conventional sources of energy will be finished within 2100 across the world. We have to depend on renewable energy sources like solar energy, wind energy, biogas energy, biomass energy, geothermal energy, wave energy, tidal energy, OTEC and hydropower, etc. PKL power from living PKL tree is the source of biomass energy. It is an innovative work around the world [39-44]. The solar PV system is providing electricity in the 
remote areas. But during night time it is needed battery which is expensive. So that living PKL tree power can play an important role to provide electricity along the remote areas across the world.

Pathor Kuchi leaf is known as a medicinal leaf from ancient time. Because it has a great medicinal value, it is used for different kinds of diseases like dysentery, cholera, typhoid, kidney disease, etc. In the West Bengal, India there is no alternative about Pathor Kuchi leaf for folk medicine. People are using the leaf as a folk medicine. But now a days, it is using to generate electricity for low and medium power production [1-18]. Generally $\mathrm{Zn}$ and $\mathrm{Cu}$ metal is used as an electrode and the PKL extract is used as a source of the electricity [19-29]. Sustainable energy sources, which are pollution free and environmentally friendly, are one of the key challenges of world's future society. Researchers discovered that living plants are literally "green" power source, which may become one of future's electricity supplies that perfectly integrates in natural environments and is accessible all over the world. The issues of the global warming are the responsible for the generation of electricity using conventional energy sources like oil, gas and coal. The climate change is distributed due to un-balanced eco-system around many part of the world. It is difficult to protect the world from global warming in an artificial way, although a numerous science and technologies are booming surrounding us. It was possible to produce $1.1 \mathrm{~V}$ using voltaic cell method. Some researchers were possible to get $1.221 \mathrm{~V}$ [45-60] using single Ag/Zn-Aloe Vera cell without using any kind of boost converter and conditioning circuit. If we can generate electricity from living plants or trees, everyone wants to be planting the trees in ones surroundings for getting electricity. Governments of many countries also suggested and motivated such a process of plantation of trees and plants to get electricity [61-75]. As a result, the number of plants and trees in the globe will also increase, which indirectly will save our planet from the serious issue of global warming by the process of plantation in near future. It may be said that living plant $\&$ tree power is improbable to replace the power sources for the most of applications after finishing the fossil fuels. Also this kind of living plants and trees electrical system could provide low cost, continuous, pollution free and sustainable power system around the globe.

\section{Methods and materials}

The research methodology of the project is described as follows:

The electrons are living around PKL plant roots those are a waste product of bacteria. PKL tree excretes organic matter into the soil, which is broken down by bacteria. The electrons are released in the breakdown process and then it is possible to harvest electricity by using electrodes without affecting the plant's and leaf's growth of the PKL in any way.

Figure 1(a) and (b) shows the PKL tree in a tub and Figure 1(c) shows the cultivation of PKL in the open field for electricity generation.

Figure 2(a) shows the cultivation of PKL electricity through PKL living tree's leaf and (b) and (c) shows the cultivation of tree's leaf electricity. Figure 2(d-m) also shows the cultivation of PKL electricity through PKL living tree's leaf.

Finally the methodology of the project can be divided by the following:

i. Design and fabrication: Easy assembly, low fabrication cost, long life and high production efficiency are the key factors of the design and the operation and maintenance would be simple, easy and low cost.

ii. Field experiments: The production efficiency of the project will be evaluated by field experiments. A set of experiments will be carried out. 


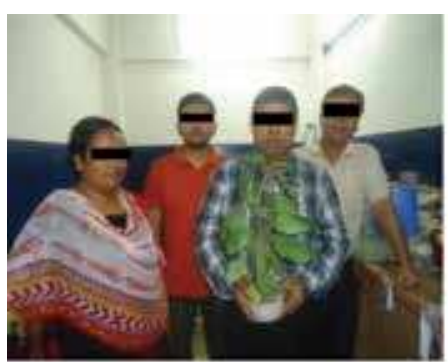

(a)

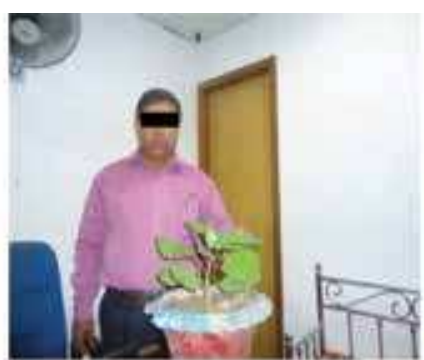

(b)

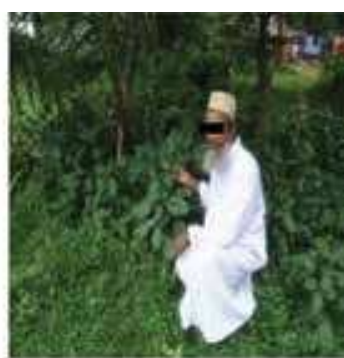

(c)

Figure 1.

Cultivation of PKL.

The effect of various factors such as open circuit voltage, short circuit current, voltage regulation, internal resistance, power \& energy density, columbic efficiency, voltaic efficiency and energy efficiency will be observed.

iii. Design parameter: It may modify the design parameters of electricity production to fix any shortcomings regarding operational, maintenance, durability, quality and quantity. A further improved PKL electricity can be implemented in an arid, remote or a coastal area to remove the difficulties in acquiring green electricity and to save many human lives

iv. Cost analysis: The fabrication cost of PKL electricity will be calculated and be compared with other conventional techniques. The produced PKL electricity selling cost will be obtained and be compared with the commercial electricity price

v. Electricity quality evaluation: The quality of the produced electricity will be examined and monitored regularly to compare with PDB standards for electricity using.

vi. A simulation model: A theoretical production model of PKL electricity based on DC and AC theory may be developed

\subsection{Definition of different parameters}

i. Open circuit voltage $\mathrm{V}_{\mathrm{oc}}$ :

The voltage without load is called open circuit voltage [51-53, 76-85]. Generally, it is denoted by $\mathbf{V}_{\mathbf{o c}}$.

\section{ii. Short circuit current $\mathrm{I}_{\mathrm{sc}}$ :}

The current without load is called short circuit current. Generally, it is denoted by $I_{\text {sc }}$.

iii. Voltage Regulation $\mathrm{V}_{\mathrm{R}}$ :

It is defined by the following equation [54-60]:

$$
V_{R}=\frac{V_{N L}-V_{F L}}{V_{F L}} \times 100 \%
$$




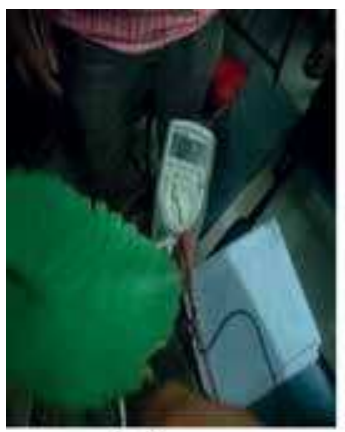

(a)

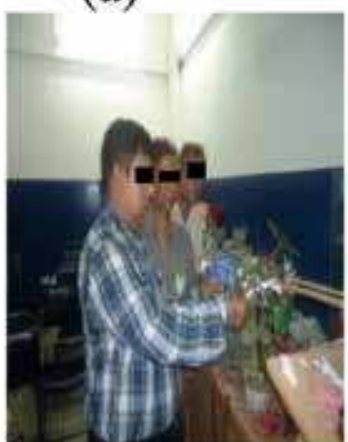

(d)

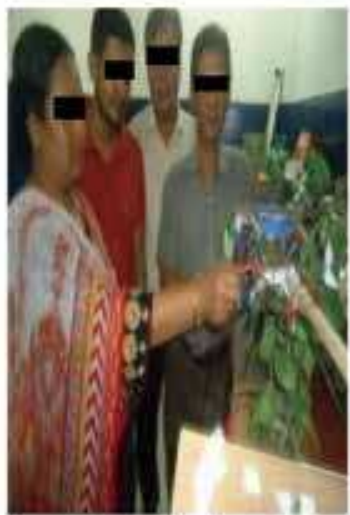

(g)

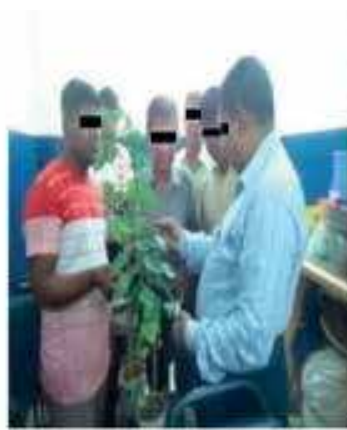

(b)

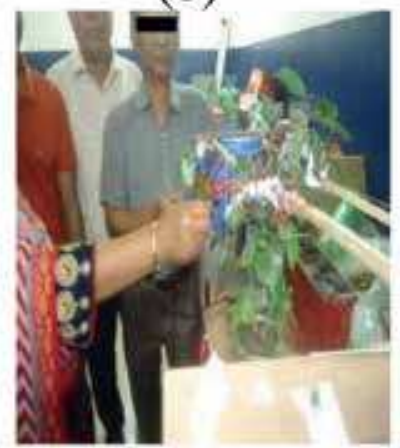

(e)

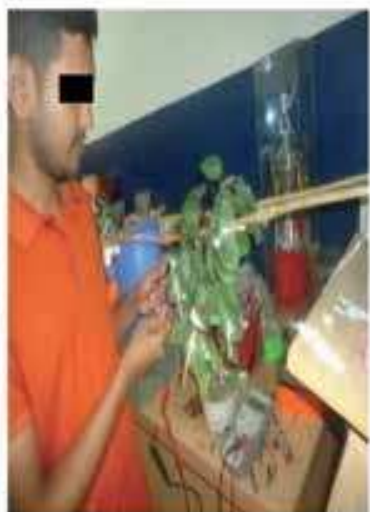

(h)

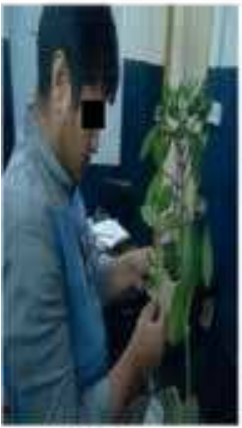

(j)

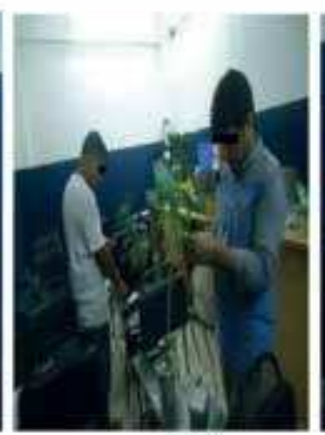

(k)

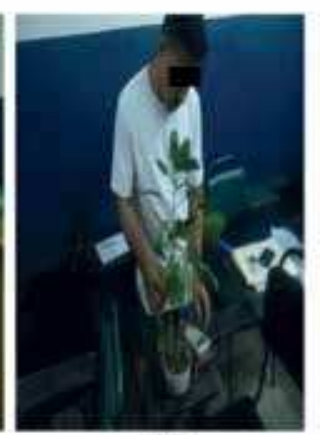

(l)

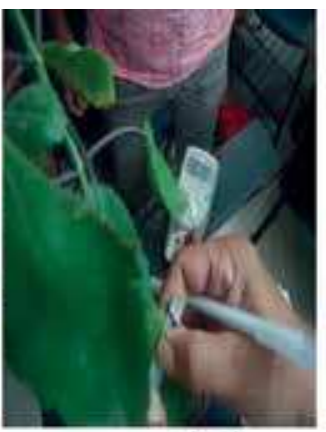

(c)

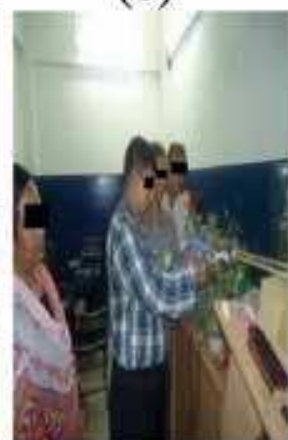

(f)

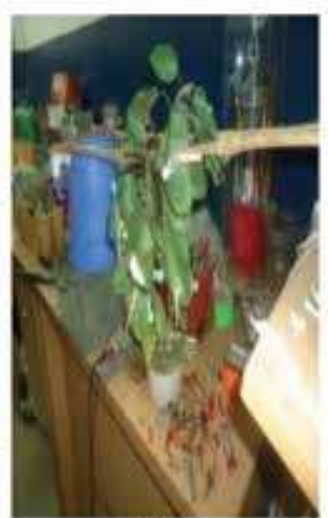

(i)

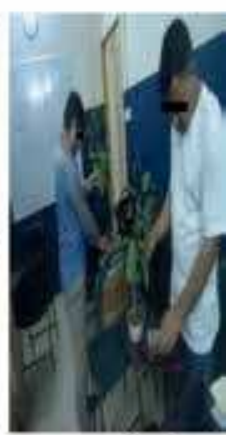

(m)

Figure 2.

Cultivation of electricity from living PKL. 
where $V_{R}=$ voltage regulation, $V_{N L}=$ no load voltage, $V_{F L}=$ full load voltage. Generally, $\mathrm{V}_{\mathrm{R}} \approx 0$ is desire, which is practically impossible [83-86].

i. PKL power density (PD) $[83,84]$ :

It is defined as the power extraction per kg PKL (Pathor Kuchi leaf).

$$
\text { The Power Density }(\mathrm{PD})=\frac{\text { Power extraction (watt) }}{\mathrm{kg}}
$$

i. Energy density (ED) of PKL [85-94]:

It is defined as the energy $(\mathrm{kWh})$ per liter:

$$
\text { The energy density }(\mathrm{ED})=\frac{\text { power extraction }(\mathrm{kWh})}{\text { litre }}
$$

Capacity of the PKL cell (AH) [95-104]:

How much current you will get for long time.

Generally, it is denoted by $C$.

$\therefore C=A H$

where $A=$ current in ampere and $H=$ Time in hour.

i. Energy efficiency of a PKL cell $\left(\eta_{c}\right)$ [105-114]:

It is defined by the following equation:

$$
\eta_{C}=\frac{P_{\text {out }}}{P_{\text {in }}}=\frac{V_{\text {out }} I t}{V_{\text {in }} I t}=\frac{V_{D} I_{D} t_{D}}{V_{C} I_{C} t_{C}}
$$

where $\eta_{C}=$ energy efficiency, $V_{D}=$ discharging voltage; $\mathrm{I}_{\mathrm{D}}=$ discharging current, $t_{D}=$ discharging time, $V_{C}=$ charging voltage, $I_{c}=$ charging current, $t_{c}=$ charging time .

i. Maximum power $\mathrm{P}_{\max }$ [115-119]:

It is defined by the following equation:

$$
P_{\max }=V_{O C} I_{S C}
$$

where $\mathrm{P}_{\max }=$ maximum power, $\mathrm{V}_{\mathrm{OC}}=$ open circuit voltage, $\mathrm{I}_{\mathrm{SC}}=$ short circuit current.

i. Load power $P_{L}$ :

It is defined by the following equation [120-123]:

$$
P_{L}=V_{L} I_{L}
$$

where $P_{L}=$ load power, $V_{L}=$ load voltage, $I_{L}=$ load current.

i. Fill factor:

It is defined as $F F=\left(V_{m} I_{m}\right) /\left(V_{o c} I_{s c}\right)$, where $V_{m}$ = useful voltage, $I_{m}=$ useful current, $\mathrm{V}_{\mathrm{oc}}=$ open circuit voltage, and $\mathrm{I}_{\mathrm{sc}}=$ short circuit current $[20,34-38,66-89,124,125]$.

ii. Standard PKL cell condition: The standard state condition of a solar cell is: The standard open circuit voltage of the solar cell is $0.5 \mathrm{~V}$. The short circuit current of a solar cell $=0.5 \mathrm{~A}$. The standard temperature of a extract of the 
PKL cell $=25^{\circ} \mathrm{C}$. The standard pressure $=1 \mathrm{~atm}$ pressure $=760 \mathrm{~mm} \mathrm{Hg}$ pressure [90-114].

\title{
2.2 Vernacular name of the PKL
}

\author{
i. Stone chips \\ ii. Air plant \\ iii. Miracle leaf \\ iv. Mother of thousands \\ v. Mother of millions \\ vi. Leaf of life \\ vii. Devil's back bone \\ viii.Pregrant leaf \\ ix. Monekey’s ear \\ x. Moneky ears \\ xi. Sotri
}

xii. Sotre, etc. [61-64]

\subsection{Land situation in Bangladesh for cultivation of PKL}

Total land $=55,000$ sq. miles $[24,65-73]$

$$
\begin{gathered}
1 \text { square mile }=640 \text { acres } \\
=3,500,000 \text { acres } / 2.5=14,080,000 \text { hectors }
\end{gathered}
$$

Total land (TL) in hector

Therefore, the nonagricultural land (NAL)

$=5,580,000$ hectors.

The $2 \%$ of NAL

$$
=111600 \text { hectors } \times 7.5=837000 \text { Bigha }[1 \text { hector }=7.5 \text { bigha }]
$$

From 1 Bigha PKL, we can get $100 \mathrm{~kW}$ electricity.

From 837,000 Bigha PKL, we can get 83,700,000 kW electricity $=83,700 \mathrm{MW}$.

The AL (agricultural land) is needed to cultivated foods and crops [81-89]. The NAL is needed for housing, roads and other multipurpose use. So that the NAL of coastal areas, hilly areas and both sides of the road can be used for cultivation of PKL to generate electricity in Bangladesh, which would be approximately $2 \%$ of NAL [90-94]. 


\subsection{Cultivation of PKL in Bangladesh}

The cultivation of PKL is so much easy $[126,127]$. This plants grow whether its leaf is kept on the ground and hence can be cultivated in a vested land, roof top of the house, courtyard and tubs what so ever [115-123]. Its leaves can be used for producing electricity within a month after cultivation of the plants [65-75, 124, 125, 128, 129].

\subsubsection{E significance/rationale}

The significance of the work is given by the following:

i. It is renewable energy sources

ii. It is biomass energy

iii. It is environment friendly

iv. It is echo friendly

v. It is cost effective

vi. It can be cultivated by anybody

vii. Even a handicapped person can cultivate this energy

viii. Unused land can be used for this purposes

ix. The two sides of the road across the country can be used to cultivate electricity

$\mathrm{x}$. The PKL tree grows everywhere even in the sand

xi. The people of the remote areas can be used this power

xii. This technology is developed locally

xiii. This technology is innovated in Bangladesh

xiv. It can compare with solar PV electricity

$\mathrm{xv}$. It will not need any extra battery during night time

xvi.It will work same during day and night time

It will also work same during rainy season whereas solar PV works less during rainy season.

\section{Results and discussion}

\subsection{Selection of electrode pair as an energy source for living PKL electricity cultivation}

It is shown in Table 1, the collected voltage has been tabulated using different electrodes of $\mathrm{Cu} / \mathrm{Zn}, \mathrm{Cu} / \mathrm{Fe}, \mathrm{Al} / \mathrm{Zn}$ and $\mathrm{Cu} / \mathrm{Al}$. 


\begin{tabular}{lccccccc}
\hline Date & $\begin{array}{c}\text { Local } \\
\text { time }\end{array}$ & $\begin{array}{c}\text { Time } \\
\text { duration }(\mathbf{h})\end{array}$ & $\begin{array}{c}\text { Voltage } \\
(\mathbf{C u} / \mathbf{Z n}) \\
\text { in volt }\end{array}$ & $\begin{array}{c}\text { Voltage } \\
(\mathbf{C u} / \mathbf{F e}) \\
\text { in volt }\end{array}$ & $\begin{array}{c}\text { Voltage } \\
(\mathbf{A l} / \mathbf{Z n}) \text { in } \\
\text { volt }\end{array}$ & $\begin{array}{c}\text { Voltage } \\
(\mathbf{C u} / \mathbf{A l}) \\
\text { in volt }\end{array}$ & Comments \\
\hline $05 / 10 / 18$ & $08 \mathrm{AM}$ & 00 & 0.95 & 0.61 & 0.42 & 0.5 & Single pair \\
\hline Do & $09 \mathrm{AM}$ & 1 & 0.95 & 0.61 & 0.41 & 0.50 & Do \\
\hline Do & $10 \mathrm{AM}$ & 2 & 0.95 & 0.60 & 0.40 & 0.51 & Do \\
\hline Do & $11 \mathrm{AM}$ & 3 & 0.95 & 0.60 & 0.39 & 0.50 & Do \\
\hline Do & $12 \mathrm{PM}$ & 4 & 0.95 & 0.61 & 0.40 & 0.49 & Do \\
\hline Do & $13 \mathrm{PM}$ & 5 & 0.95 & 0.60 & 0.39 & 0.48 & Do \\
\hline Do & $14 \mathrm{PM}$ & 6 & 0.95 & 0.61 & 0.38 & 0.48 & Do \\
\hline Do & $15 \mathrm{PM}$ & 7 & 0.95 & 0.61 & 0.38 & 0.48 & Do \\
\hline Do & $16 \mathrm{PM}$ & 8 & 0.95 & 0.60 & 0.37 & 0.48 & Do \\
\hline Do & $17 \mathrm{PM}$ & 9 & 0.95 & 0.61 & 0.36 & 0.48 & \\
\hline
\end{tabular}

Table 1.

Data for voltage harvesting for single pairs of electrodes.

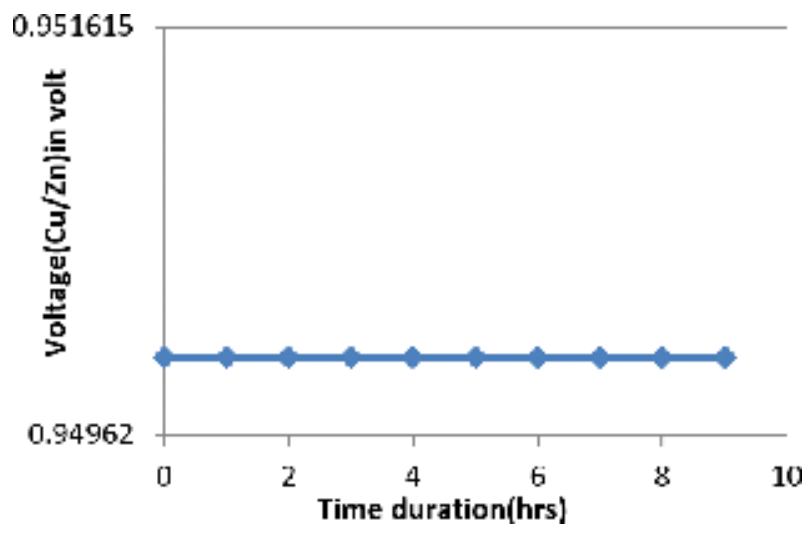

Figure 3.

Voltage-time duration profile for $\mathrm{Cu} / \mathrm{Zn}$ single electrodes.

It is shown from Figure 3, the highest open circuit voltage $\left(\mathrm{V}_{\mathrm{oc}}\right)$ for $\mathrm{Cu} / \mathrm{Zn}$ single electrodes is $0.95 \mathrm{~V}$ and the lowest open circuit voltage $\left(\mathrm{V}_{\mathrm{oc}}\right)$ is also $0.95 \mathrm{~V}$. So that the difference between the highest and lowest open circuit voltage $\left(\mathrm{V}_{\text {oc }}\right)$ is zero volt.

It is shown from Figure 4, the highest open circuit voltage $\left(\mathrm{V}_{\mathrm{oc}}\right)$ for $\mathrm{Cu} / \mathrm{Fe}$ single electrode is $0.61 \mathrm{~V}$ and the lowest open circuit voltage $\left(\mathrm{V}_{\mathrm{oc}}\right)$ is also $0.60 \mathrm{~V}$. So that the difference between the highest and lowest open circuit voltage $\left(\mathrm{V}_{\mathrm{oc}}\right)$ is $0.01 \mathrm{~V}$.

It is shown from Figure 5, the highest open circuit voltage (Voc) for $\mathrm{Al} / \mathrm{Zn}$ single electrodes is $0.42 \mathrm{~V}$ and the lowest open circuit voltage $\left(\mathrm{V}_{\mathrm{oc}}\right)$ is also $0.36 \mathrm{~V}$. So that the difference between the highest and lowest open circuit voltage $\left(V_{o c}\right)$ is $0.06 \mathrm{~V}$.

It is shown from Figure 6, the highest open circuit voltage $\left(\mathrm{V}_{\mathrm{oc}}\right)$ for $\mathrm{Cu} / \mathrm{Al}$ single electrodes is $0.51 \mathrm{~V}$ and the lowest open circuit voltage $\left(\mathrm{V}_{\mathrm{oc}}\right)$ is also $0.48 \mathrm{~V}$. So that the difference between the highest and lowest open circuit voltage $\left(\mathrm{V}_{\mathrm{oc}}\right)$ is $0.03 \mathrm{~V}$.

Finally, it is concluded that, Figures 3-6 shows the variation of Voltage with the variation of time duration profile for $\mathrm{Cu} / \mathrm{Zn}$ single electrodes. It is shown that the $\mathrm{Cu} / \mathrm{Zn}$ single pair electrode produces the highest open circuit voltage around $0.95 \mathrm{~V}$. It is also shown that it is almost constant for $9 \mathrm{~h}$. Whereas the $\mathrm{Cu} / \mathrm{Fe}, \mathrm{Al} / \mathrm{Zn}$ and 


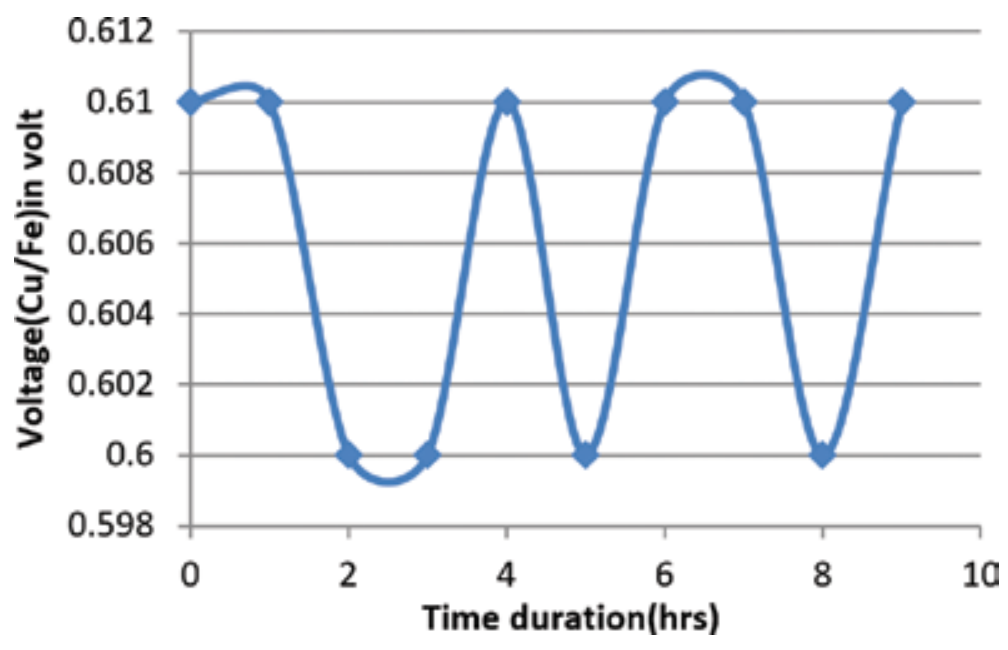

Figure 4.

Voltage-time duration profile for $\mathrm{Cu} / \mathrm{Fe}$ single pair electrodes.

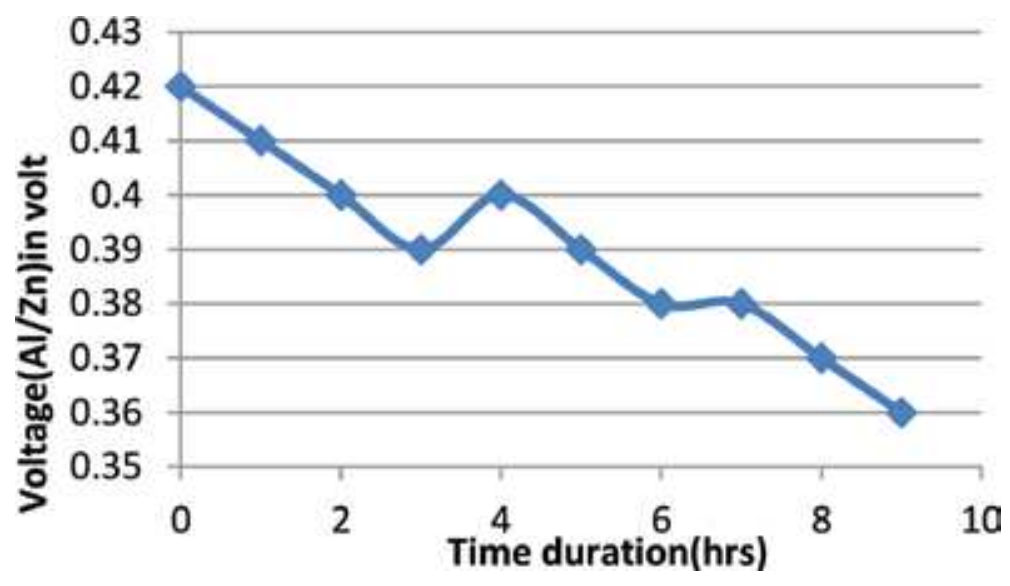

Figure 5.

Voltage-time duration profile for $\mathrm{Al} / \mathrm{Zn}$ single pair electrodes.

$\mathrm{Cu} / \mathrm{Al}$ producing highest open circuit voltages are $0.61,0.42$, and $0.5 \mathrm{~V}$, respectively, the lowest open circuit voltages are around $0.60,0.36$, and $0.48 \mathrm{~V}$, respectively.

Finally, it is found and suggested that the $\mathrm{Cu} / \mathrm{Zn}$ single pair electrode produces the highest open circuit voltage $\left(\mathrm{V}_{\text {oc }}\right)$ around $0.95 \mathrm{~V}$ and the $\mathrm{Al} / \mathrm{Zn}$ single pair electrodeproduces the lowest open circuit voltage $\left(\mathrm{V}_{\mathrm{oc}}\right)$ around $0.42 \mathrm{~V}$. It is also found that for $\mathrm{Cu} / \mathrm{Zn}, \mathrm{Cu} / \mathrm{Fe}, \mathrm{Al} / \mathrm{Zn}$ and $\mathrm{Cu} / \mathrm{Al}$ single pair electrodes, the cultivated voltage was stable up to $9 \mathrm{~h}$ during day time. The lowest open circuit voltage $\left(\mathrm{V}_{\mathrm{oc}}\right)$ difference for $\mathrm{Cu} / \mathrm{Zn}$ single pair electrodes is zero $(0) \mathrm{V}$ and the highest lowest open circuit voltage $\left(\mathrm{V}_{\text {oc }}\right)$ difference for $\mathrm{Al} / \mathrm{Zn}$ single pair electrodes is $0.06 \mathrm{~V}$.

It is shown in Table 2, the harvested voltage has been tabulated using different two pair electrodes of $\mathrm{Cu} / \mathrm{Zn}, \mathrm{Cu} / \mathrm{Fe}, \mathrm{Al} / \mathrm{Zn}$ and $\mathrm{Cu} / \mathrm{Al}$ with series combination.

It is shown from Figure 7, the highest open circuit voltage $\left(\mathrm{V}_{\mathrm{oc}}\right)$ for $\mathrm{Cu} / \mathrm{Zn}$ double electrodes is $1.85 \mathrm{~V}$ and the lowest open circuit voltage $\left(\mathrm{V}_{\mathrm{oc}}\right)$ is also $1.78 \mathrm{~V}$. So that the difference between the highest and lowest open circuit voltage $\left(\mathrm{V}_{\mathrm{oc}}\right)$ is $0.07 \mathrm{~V}$. Whereas it was zero $(0)$ for $\mathrm{Cu} / \mathrm{Zn}$ single pair electrodes. The reason behind it is that due to the connection of the electrodes by the wires, because it grows resistance for long wires due to the connections. 


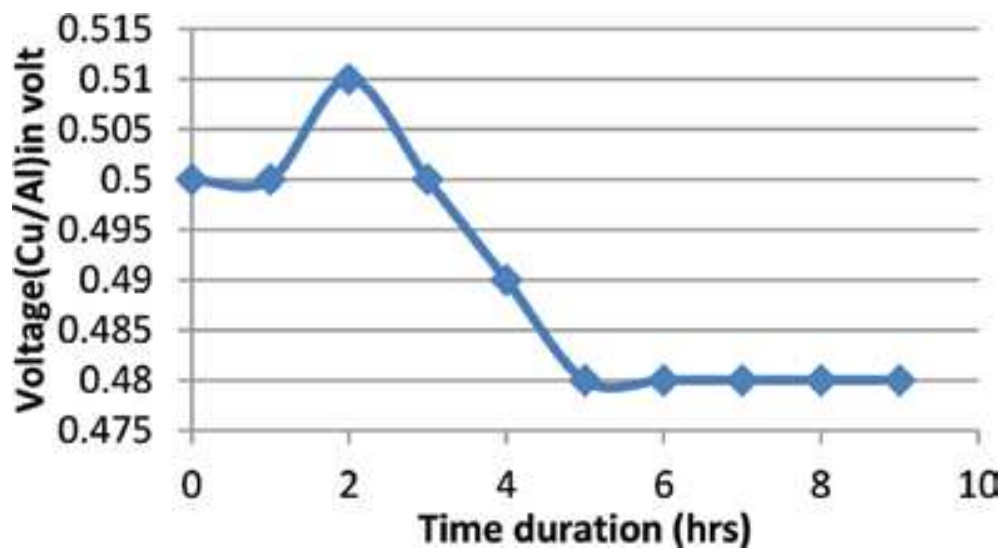

Figure 6

Voltage-time duration profile for Cu/Al single pair electrodes.

\begin{tabular}{lccccccc}
\hline Date & $\begin{array}{c}\text { Local } \\
\text { time }\end{array}$ & $\begin{array}{c}\text { Time } \\
\text { duration }(\mathbf{h})\end{array}$ & $\begin{array}{c}\text { Voltage }(\mathrm{Cu} / \\
\text { Zn) in volt }\end{array}$ & $\begin{array}{c}\text { Voltage }(\mathrm{Cu} / \\
\text { Fe) in volt }\end{array}$ & $\begin{array}{c}\text { Voltage (Al/ } \\
\text { Zn) in volt }\end{array}$ & $\begin{array}{c}\text { Voltage }(\mathrm{Cu} / \\
\text { Al) in volt }\end{array}$ & Comments \\
\hline $05 / 10 / 18$ & $08 \mathrm{AM}$ & 00 & 1.85 & 1.19 & 0.80 & 1.0 & Two pairs \\
\hline Do & $09 \mathrm{AM}$ & 1 & 1.84 & 1.20 & 0.81 & 1.0 & Do \\
\hline Do & $10 \mathrm{AM}$ & 2 & 1.82 & 1.18 & 0.80 & 1.0 & Do \\
\hline Do & $11 \mathrm{AM}$ & 3 & 1.83 & 1.18 & 0.79 & 1.0 & Do \\
\hline Do & $12 \mathrm{PM}$ & 4 & 1.82 & 1.17 & 0.80 & 0.98 & Do \\
\hline Do & $13 \mathrm{PM}$ & 5 & 1.80 & 1.17 & 0.79 & 0.95 & Do \\
\hline Do & $14 \mathrm{PM}$ & 6 & 1.80 & 1.16 & 0.78 & 0.94 & Do \\
\hline Do & $15 \mathrm{PM}$ & 7 & 1.80 & 1.17 & 0.78 & 0.94 & Do \\
\hline Do & $16 \mathrm{PM}$ & 8 & 1.80 & 1.17 & 0.77 & 0.94 & Do \\
\hline Do & $17 \mathrm{PM}$ & 9 & 1.78 & 1.16 & 0.76 & 0.93 & \\
\hline
\end{tabular}

Table 2.

Data for voltage harvesting for double pairs of electrodes (connected in series with each other).

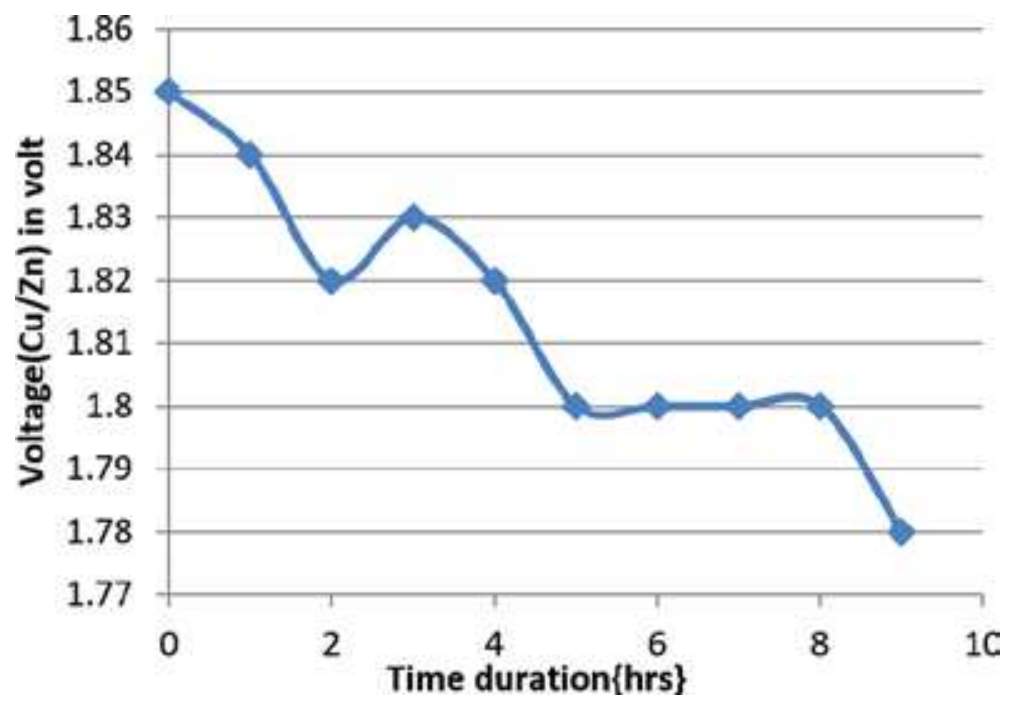

Figure 7

Voltage-time duration profile for $\mathrm{Cu} / \mathrm{Zn}$ double pair electrodes. 


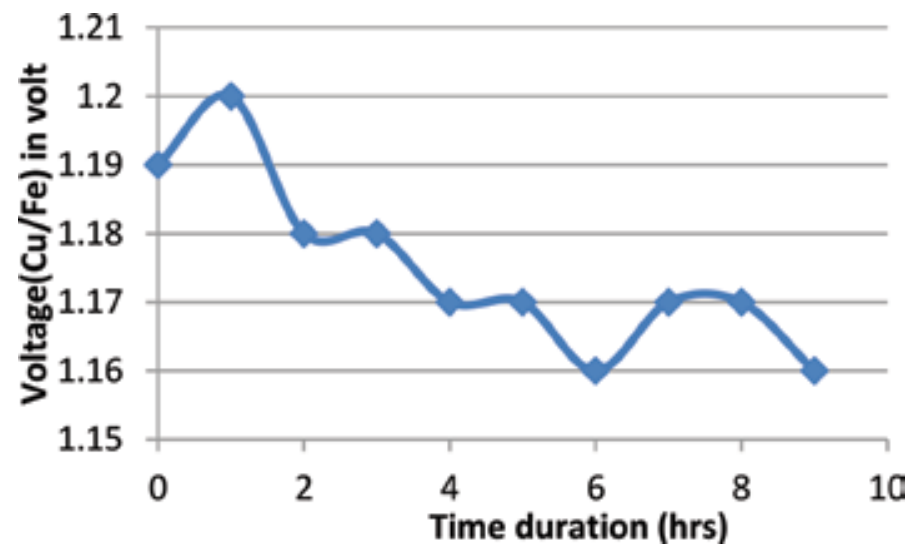

Figure 8

Voltage-time duration profile for $\mathrm{Cu} / \mathrm{Fe}$ double pair electrodes.

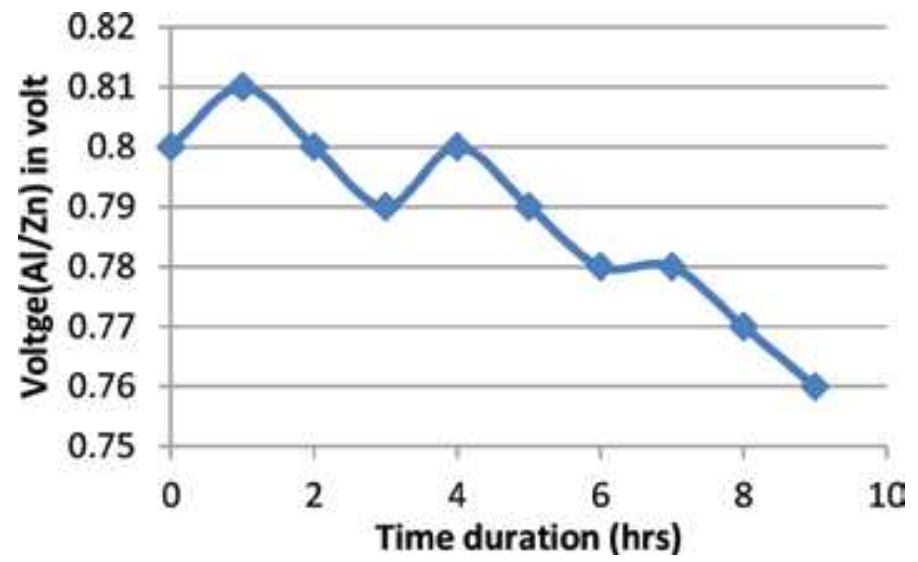

Figure 9.

Voltage-time duration profile for $\mathrm{Al} / \mathrm{Zn}$ double pair electrodes.

It is shown from Figure 8, the highest open circuit voltage $\left(\mathrm{V}_{\mathrm{oc}}\right)$ for $\mathrm{Cu} / \mathrm{Fe}$ double electrodes is $1.20 \mathrm{~V}$ and the lowest open circuit voltage $\left(\mathrm{V}_{\mathrm{oc}}\right)$ is also $1.16 \mathrm{~V}$. So that the difference between the highest and lowest open circuit voltage (Voc) is $0.04 \mathrm{~V}$. Whereas it was $0.01 \mathrm{~V}$ for $\mathrm{Cu} / \mathrm{Fe}$ single pair electrodes. The reason behind it is that due to the connection of the electrodes by the wires, because it grows resistance for long wires due to the connections.

It is shown from Figure 9, the highest open circuit voltage $\left(\mathrm{V}_{\mathrm{oc}}\right)$ for $\mathrm{Al} / \mathrm{Zn}$ double electrodes is $0.81 \mathrm{~V}$ and the lowest open circuit voltage $\left(\mathrm{V}_{\mathrm{oc}}\right)$ is also $0.76 \mathrm{~V}$. So that the difference between the highest and lowest open circuit voltage $\left(\mathrm{V}_{\mathrm{oc}}\right)$ is $0.05 \mathrm{~V}$. Whereas it was $0.04 \mathrm{~V}$ for $\mathrm{Al} / \mathrm{Zn}$ single pair electrodes. The reason behind it is that due to the connection of the electrodes by the wires, because it grows resistance for long wires due to the connections.

It is shown from Figure 10, the highest open circuit voltage $\left(\mathrm{V}_{\mathrm{oc}}\right)$ for $\mathrm{Cu} / \mathrm{Al}$ double electrodes is $1.0 \mathrm{~V}$ and the lowest open circuit voltage $\left(\mathrm{V}_{\mathrm{oc}}\right)$ is also $0.93 \mathrm{~V}$. So that the difference between the highest and lowest open circuit voltage (Voc) is $0.07 \mathrm{~V}$. Whereas it was $0.03 \mathrm{~V}$ for $\mathrm{Cu} / \mathrm{Al}$ single pair electrodes. The reason behind it is that due to the connection of the electrodes by the wires, because it grows resistance for long wires due to the connections. From the above results it is shown that the difference between the highest and lowest voltage output increases for 


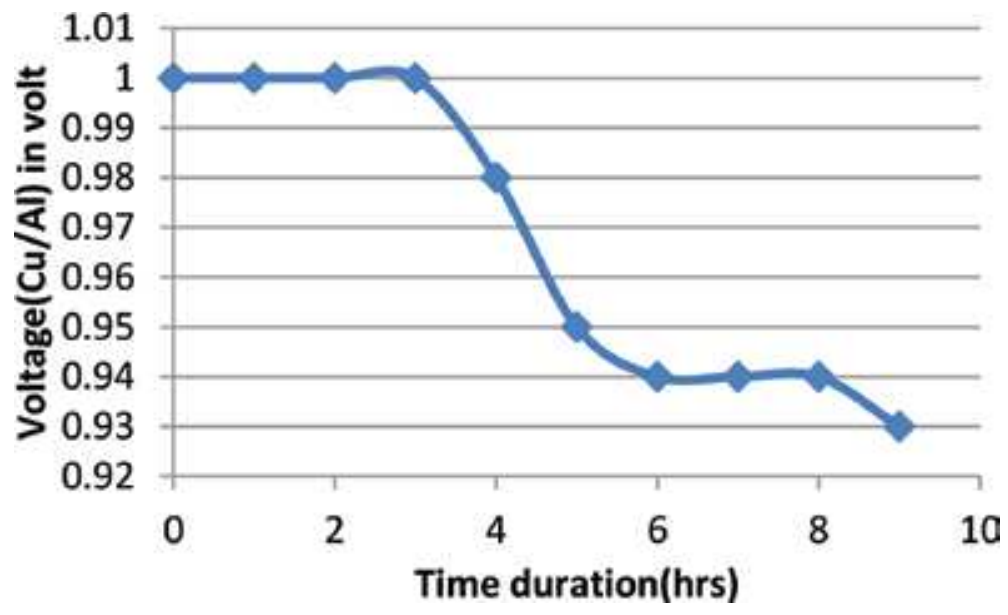

Figure 10.

Voltage-time duration profile for $\mathrm{Cu} / \mathrm{Al}$ double pair electrodes.

\begin{tabular}{llllllll}
\hline Date & $\begin{array}{l}\text { Local } \\
\text { time }\end{array}$ & $\begin{array}{l}\text { Time } \\
\text { duration } \\
(\mathbf{h})\end{array}$ & $\begin{array}{l}\text { Voltage } \\
(\mathbf{C u} / \mathbf{Z n}) \text { in } \\
\text { volt }\end{array}$ & $\begin{array}{l}\text { Voltage } \\
(\mathbf{C u} / \mathbf{F e}) \text { in } \\
\text { volt }\end{array}$ & $\begin{array}{l}\text { Voltage } \\
(\mathbf{A l} / \mathbf{Z n}) \text { in } \\
\text { volt }\end{array}$ & $\begin{array}{l}\text { Voltage } \\
(\mathbf{C u} / \mathbf{A l}) \text { in } \\
\text { volt }\end{array}$ & Comments \\
\hline $05 / 10 / 18$ & $08 \mathrm{AM}$ & 00 & 2.70 & 1.77 & 1.20 & 0.99 & Three pairs \\
\hline Do & $09 \mathrm{AM}$ & 1 & 2.71 & 1.77 & 1.20 & 0.98 & Do \\
\hline Do & $10 \mathrm{AM}$ & 2 & 2.70 & 1.76 & 1.19 & 0.98 & Do \\
\hline Do & $11 \mathrm{AM}$ & 3 & 2.69 & 1.76 & 1.19 & 0.98 & Do \\
\hline Do & $12 \mathrm{PM}$ & 4 & 2.68 & 1.76 & 1.19 & 0.98 & Do \\
\hline Do & $13 \mathrm{PM}$ & 5 & 2.68 & 1.75 & 1.19 & 0.97 & Do \\
\hline Do & $14 \mathrm{PM}$ & 6 & 2.68 & 1.75 & 1.18 & 0.97 & Do \\
\hline Do & $15 \mathrm{PM}$ & 7 & 2.68 & 1.75 & 1.18 & 0.97 & Do \\
\hline Do & $16 \mathrm{PM}$ & 8 & 2.68 & 1.75 & 1.18 & 0.97 & Do \\
\hline Do & $17 \mathrm{PM}$ & 9 & 2.68 & 1.75 & 1.18 & 0.97 & \\
\hline
\end{tabular}

Table 3 .

Data for voltage harvesting for double pairs of electrodes (connected in series with each other).

$\mathrm{Cu} / \mathrm{Zn}, \mathrm{Cu} / \mathrm{Fe}, \mathrm{Al} / \mathrm{Zn}$ and $\mathrm{Cu} / \mathrm{Al}$ double pair electrodes than the $\mathrm{Cu} / \mathrm{Zn}, \mathrm{Cu} / \mathrm{Fe}$, $\mathrm{Al} / \mathrm{Zn}$ and $\mathrm{Cu} / \mathrm{Al}$ single pair electrodes.

It is shown in Table 3, the harvested voltage has been tabulated using different three pair electrodes of $\mathrm{Cu} / \mathrm{Zn}, \mathrm{Cu} / \mathrm{Fe}, \mathrm{Al} / \mathrm{Zn}$ and $\mathrm{Cu} / \mathrm{Al}$ with series combination.

It is shown from Figure 11, the highest open circuit voltage $\left(V_{o c}\right)$ for $\mathrm{Cu} / \mathrm{Zn} 3$ electrodes is $2.70 \mathrm{~V}$ and the lowest open circuit voltage $\left(\mathrm{V}_{\text {oc }}\right)$ is also $2.68 \mathrm{~V}$. So that the difference between the highest and lowest open circuit voltage $\left(\mathrm{V}_{\mathrm{oc}}\right)$ is $0.02 \mathrm{~V}$. Whereas it was zero $(0)$ for $\mathrm{Cu} / \mathrm{Zn}$ single pair electrodes and $0.07 \mathrm{~V}$ for double electrodes respectively. The same reason behind it is that due to the connection of the electrodes by the wires, because it grows resistance for long wires due to the connections.

It is shown from Figure 12, the highest open circuit voltage $\left(\mathrm{V}_{\mathrm{oc}}\right)$ for $\mathrm{Cu} / \mathrm{Fe}$ three electrodes pair is $1.77 \mathrm{~V}$ and the lowest open circuit voltage $\left(\mathrm{V}_{\mathrm{oc}}\right)$ is also $1.75 \mathrm{~V}$. So that the difference between the highest and lowest open circuit voltage $\left(V_{o c}\right)$ is 
$0.02 \mathrm{~V}$. Whereas it was zero (0) for $\mathrm{Cu} / \mathrm{Fe}$ single pair electrodes, $0.04 \mathrm{~V}$ for double electrodes respectively. The same reason behind it is that due to the connection of the electrodes by the wires, because it grows resistance for long wires due to the connections.

It is shown from Figure 13, the highest open circuit voltage $\left(\mathrm{V}_{\mathrm{oc}}\right)$ for $\mathrm{Al} / \mathrm{Zn}$ 3electrodes pair is volt and the lowest open circuit voltage $\left(\mathrm{V}_{\mathrm{oc}}\right)$ is also $1.65 \mathrm{~V}$. So that the difference between the highest and lowest open circuit voltage (Voc) is $0.02 \mathrm{~V}$. Whereas it was zero(0) for $\mathrm{Cu} / \mathrm{Fe}$ single pair electrodes and $0.04 \mathrm{~V}$ for double electrodes respectively. The same reason behind it is that due to the connection of the electrodes by the wires, because it grows resistance for long wires due to the connections.

It is shown from Figure 14, the highest open circuit voltage $\left(\mathrm{V}_{\mathrm{oc}}\right)$ for $\mathrm{Cu} / \mathrm{Al}$ three electrodes pair is volt and the lowest open circuit voltage $\left(\mathrm{V}_{\mathrm{oc}}\right)$ is also $1.65 \mathrm{~V}$.

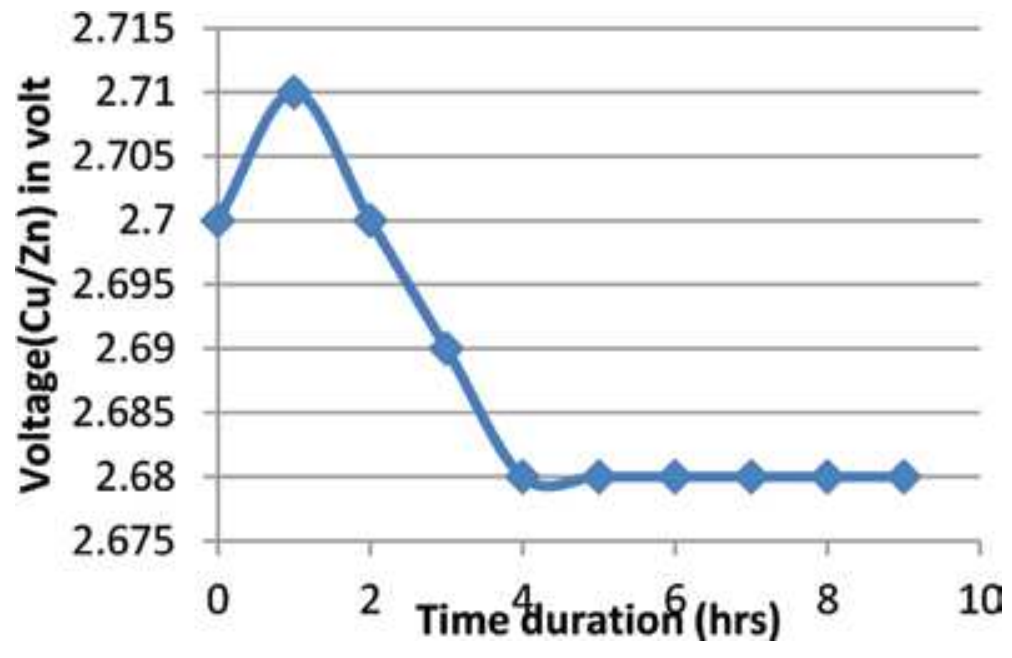

Figure 11.

Voltage-time duration profile for Cu/Zn three pair electrodes.

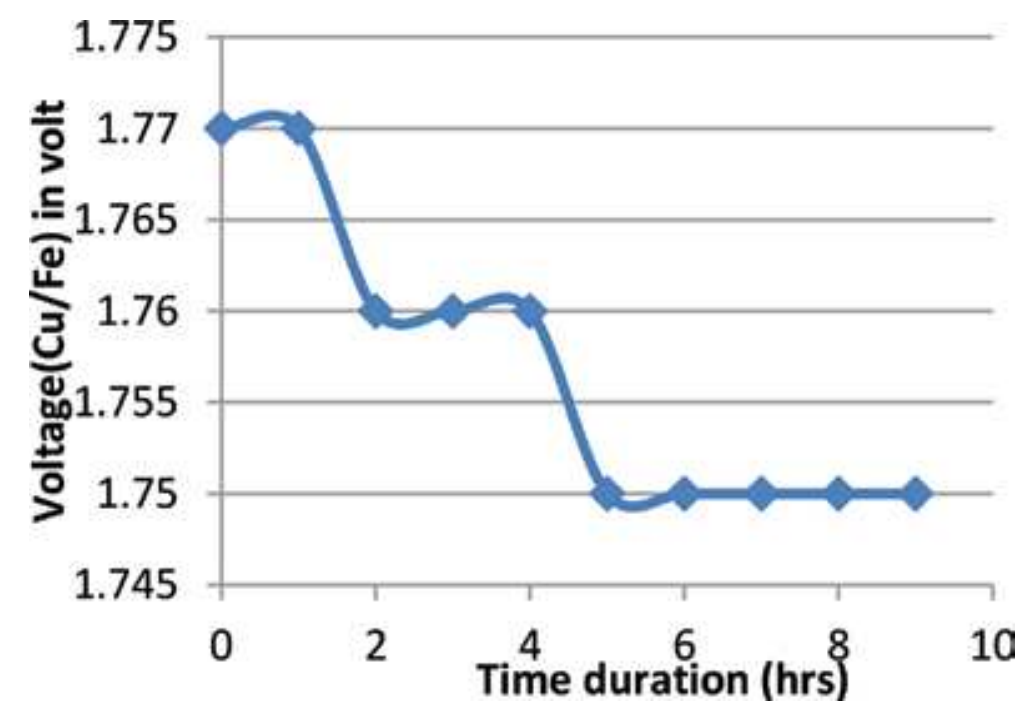

Figure 12.

Voltage-time duration profile for Cu/Fe three pair electrodes. 


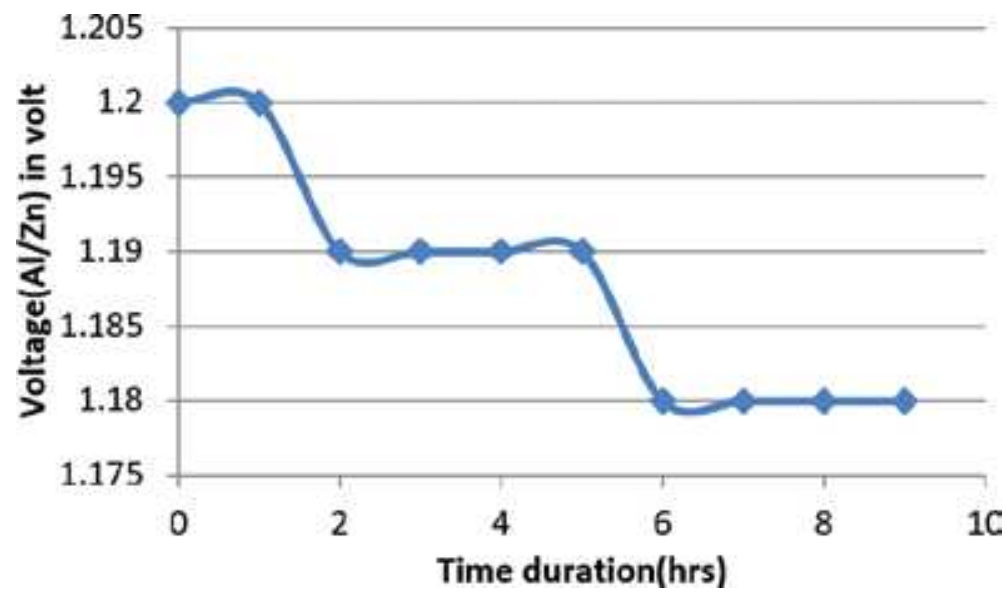

Figure 13.

Voltage-time duration profile for Al/Zn three pair electrodes.

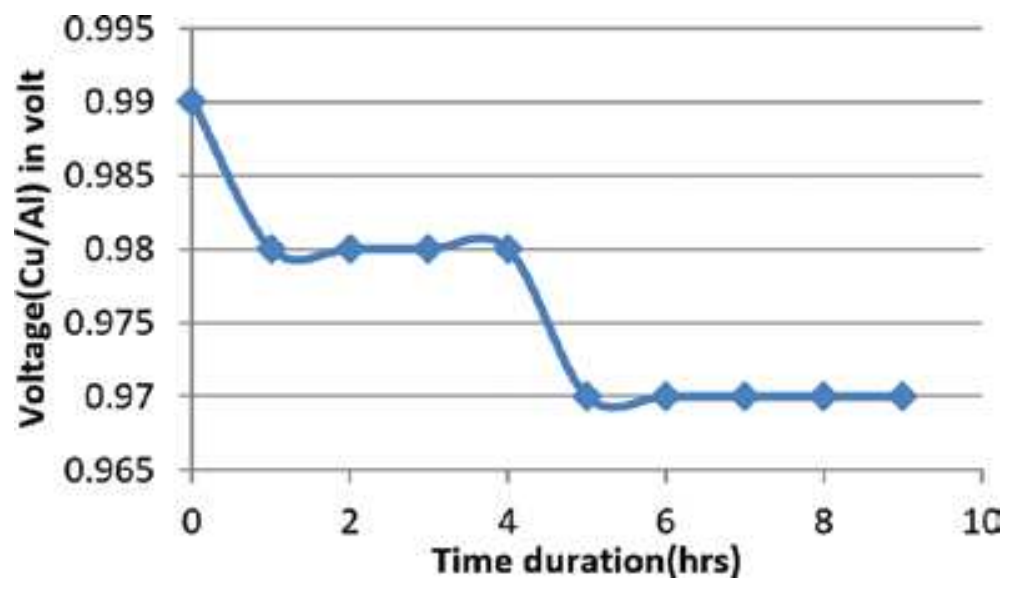

Figure 14.

Voltage-time duration profile for Cu/Al three pair electrodes.

So that the difference between the highest and lowest open circuit voltage $\left(\mathrm{V}_{\text {oc }}\right)$ is $0.02 \mathrm{~V}$. Whereas it was zero (0) for $\mathrm{Cu} / \mathrm{Al}$ single pair electrodes, $0.04 \mathrm{~V}$ for double electrodes and $0.02 \mathrm{~V}$, respectively. The same reason behind it is that due to the connection of the electrodes by the wires, because it grows resistance for long wires due to the connections.

It is shown in Table 4, the voltage difference for $\mathrm{Cu} / \mathrm{Zn}, \mathrm{Cu} / \mathrm{Fe}, \mathrm{Al} / \mathrm{Zn}$ and $\mathrm{Cu}$ / $\mathrm{Al}$ single, double and triple electrodes in volt.

\subsection{Electrochemical cell made by two living PKL trees}

\subsubsection{Description of the electrodes}

1. Description of the cathode

The length of the copper electrode is: $3 \mathrm{~cm}$

The breadth of the copper electrode is: $1 \mathrm{~cm}$ 
Energy Efficiency and Sustainability in Outdoor Lighting - A Bet for the Future

DOI: http://dx.doi.org/10.5772/intechopen.89413

\begin{tabular}{ccccc}
\hline $\begin{array}{l}\text { Number } \\
\text { of pairs }\end{array}$ & $\begin{array}{c}\text { Voltage difference } \\
\text { for Cu/Zn in volt }\end{array}$ & $\begin{array}{c}\text { Voltage difference } \\
\text { for Cu/Fe in volt }\end{array}$ & $\begin{array}{c}\text { Voltage difference } \\
\text { for Al/Zn in volt }\end{array}$ & $\begin{array}{c}\text { Voltage difference } \\
\text { for Cu/Al in volt }\end{array}$ \\
\hline 1 & 0 & 0.01 & 0.60 & 0.02 \\
\hline 2 & 0.07 & 0.03 & 0.05 & 0.07 \\
\hline 3 & 0.03 & 0.02 & 0.02 & 0.03 \\
\hline
\end{tabular}

Table 4.

Table for voltage difference for $\mathrm{Cu} / \mathrm{Zn}, \mathrm{Cu} / \mathrm{Fe}, \mathrm{Al} / \mathrm{Zn}$ and $\mathrm{Cu} / \mathrm{Al}$ in volt.

The area of the copper electrode is: $(3 \mathrm{~cm})(1 \mathrm{~cm})=3 \mathrm{~cm}^{2}$

2. Description of the anode

The length of the zinc electrode is: $3 \mathrm{~cm}$

The breadth of the zinc electrode is: $1 \mathrm{~cm}$

The area of the zinc electrode is: $(3 \mathrm{~cm})(1 \mathrm{~cm})=3 \mathrm{~cm}^{2}$

\subsubsection{Description of the electrolytes}

It was taken two living PKL plants (Tree-1 and Tree-2) for making an electrochemical cell. One leaf was selected from each tree. Each leaf was embedded by two electrodes. The voltage was collected from each leaf separately by a sophisticated multi meter. Then it was connected two living PKL plants in series connection. Then after the voltage was also collected for series connection.

\section{Results and discussion}

It is shown in Figure 15 the variation of open circuit voltage with the variation of time duration(hr) for a single leaf in tree-1. Similarly, Figure 16 the variation of open circuit voltage with the variation of time duration(hr) for a single leaf in tree-2. Finally, it is shown in Figure 17 the variation of open circuit voltage with the variation of time duration (h) for both a single leaf in tree-1and tree-2. Comparing

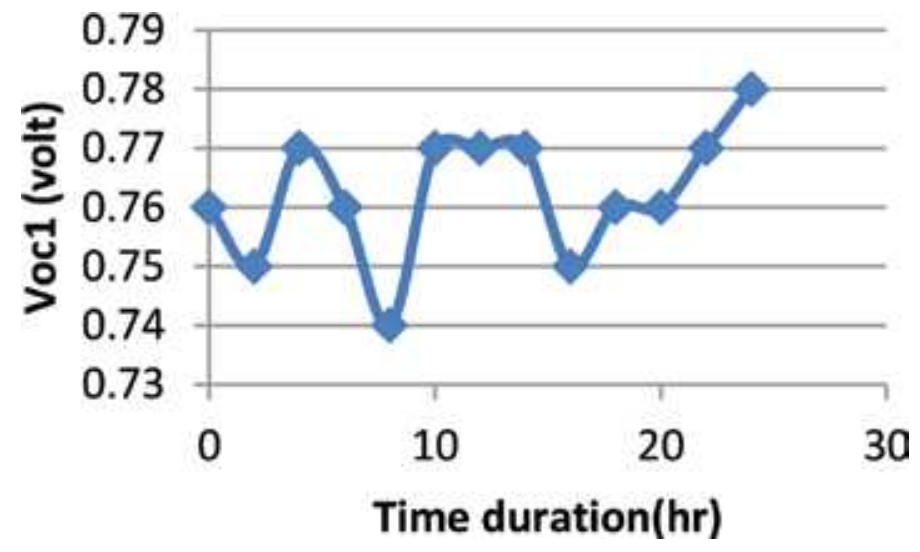

Figure 15.

Voc1-time duration curve for tree-1. 


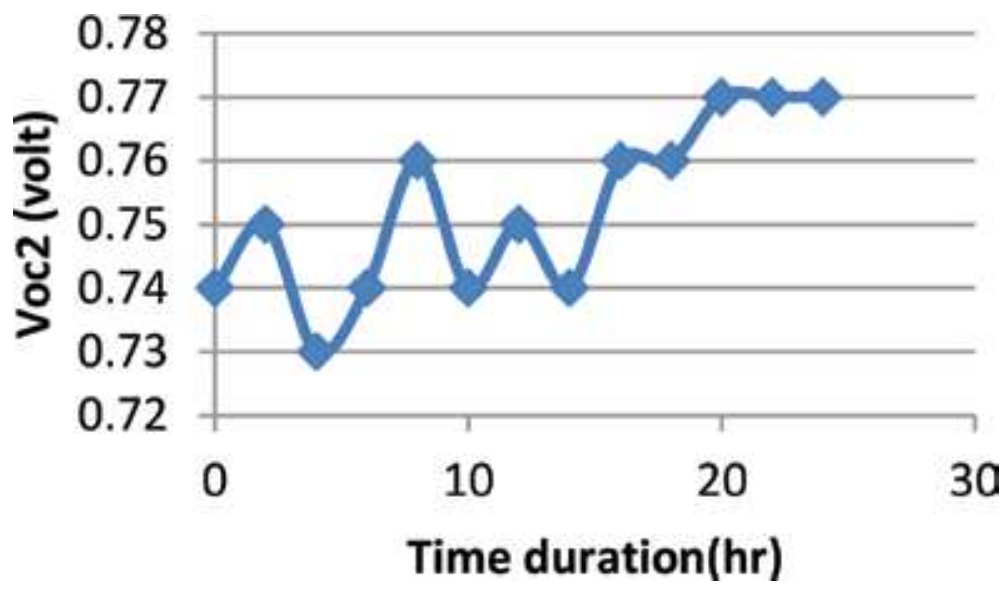

Figure 16.

Voc2-time duration curve for tree-2.

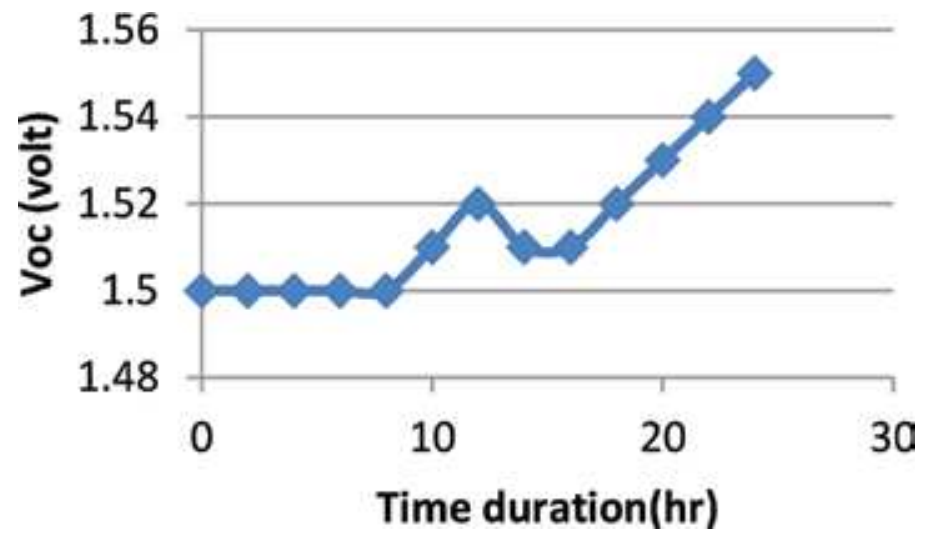

Figure 17.

Voc-time duration for both tree-1 and tree-2 in series connection.

above three figures, it can be concluded that living PKL tree can generate an electrochemical cell, since it follows the law of the series combination of voltaic cell.

\section{Conclusion}

The multi meters which were used are not calibrated properly. So that may be some errors during collection of the readings. In spite of that the authors tried to take readings very carefully. At present it is needed renewable, sustainable, pollution free and an efficient energy sources all over the world. To keep it in mind, it has been introduced some fundamental investigations are presented for producing electricity from living PKL plants. The power is produced by embedding the different electrodes like (silver and zinc, copper and zinc, etc.) and cells into the PKL living plant's leaf to allow flow of ions using redox reaction. Different experiments have been conducted using different types of the electrodes to determine the characteristics of the producing device. The research activities in this field are in infancy, in spite of that it was possible to get voltage difference around $1.10 \mathrm{~V}$ using single pair of electrodes and cell. Such hypothesis has been tested at different times 
of the different month of the year. A comparative research works have also been done and used in combination to get better results for the development of such a green power. This green power may be the guide line to get low and medium power electrical and electronic appliances in near future.

Sustainable energy sources, which are pollution free and environmentally friendly, are one of the key challenges of world's future society. The interdisciplinary team of PKL energy foundation discovered that living plants are literally "green" power source, which may become one of future's electricity supplies that perfectly integrates in natural environments and is accessible all over the world. Researchers discovered that living plants can generate, by a single leaf, required Volts, enough to simultaneously power LED light bulbs. Researchers also showed that natural leaves can act as an innovative "green" electrical generator converting into electricity. Finally, the outcome of this research work is the reactant and product ions have been identified. The generated voltage can be considered with the Nernst equation. The generated voltage can be connected in series to run the load with LED bulb and DC fan. Using an inverter can be converted AC from DC for AC appliances.

\section{Acknowledgements}

The authors are grateful to the PKL electricity research group named Farhana Yesmin, Dr. M.A. Latif, Dr. Md. Sajjad Hossain, Dr. Md. Fakrul Islam, Dr. Bapy Guha, Md. Mehdi Hassan and Dr. M. Hazrat Ali for their valuable suggestions and whole hearted cooperation during research work.

\section{Author details}

Kamrul Alam Khan ${ }^{1 *}$, Salman Rahman Rasel$^{2}$, S.M. Zian Reza ${ }^{3}$ and Farhana Yesmin ${ }^{4}$

1 Department of Physics, Jagannath University, Dhaka, Bangladesh

2 Local Government Engineering Department (LGED), Mymensingh, Bangladesh

3 Department of Physics, Uttara University, Dhaka, Bangladesh

4 Department of Civil Engineering, Dhaka Polytechnic Institute, Dhaka, Bangladesh

*Address all correspondence to: kakhan01@yahoo.com

\section{IntechOpen}

(C) 2020 The Author(s). Licensee IntechOpen. Distributed under the terms of the Creative Commons Attribution - NonCommercial 4.0 License (https://creativecommons.org/ licenses/by-nc/4.0/), which permits use, distribution and reproduction for non-commercial purposes, provided the original is properly cited. (cc) BY-NC 


\section{References}

[1] Akter T, Bhuiyan MH, Khan KA, Khan MH. Impact of photo electrode thickness and annealing temperature on natural dye sensitized solar cell. Sustainable Energy Technologies and Assessments. 2017 Ms. Ref. No.: SETAD-16-00324R2

[2] Guha B, Islam F, Khan KA. Studies on redox equilibrium and electrode potentials. IJARIIE. 2018;4(4):10921102

[3] Hamid MR. Characterization of a battery cell fueled by Bryophyllum pinnatum sap. International Journal of Scientific and Engineering Research. 2013;4(3):1-4

[4] Hamid MR, Yusuf A, Wadud AMA, Rahaman MM. Design and performance test of a prototype of a $12 \mathrm{~V}$ dc battery fueled by Bryophyllum pinnatum sap and improvement of its characteristics. International Journal of Electrical and Electronics Engineering. 2016;4(5):1-5

[5] Haque MM, Ullah AKMA, Khan MNL, Kibria AKMFF, Khan KA. Phyto-synthesis of $\mathrm{MnO}_{2}$ nanoparticles for generating electricity. In: The International Conference on Physics2018, Venue-Department of Physics, University of Dhaka, Dhaka 1000, Bangladesh, Organizer-Bangladesh Physical Society (BPS), 08-10 March. 2018

[6] Hasan M, Khan KA. Bryophyllum pinnatum leaf fueled cell: An alternate way of supplying electricity at the offgrid areas in Bangladesh. In: Proceedings of 4th International Conference on the Developments in Renewable Energy Technology [ICDRET 2016]. 2016, 2016. p. 01. DOI: 10.1109/ICDRET.2016.7421522

[7] Hasan M, Khan KA. Dynamic model of Bryophyllum pinnatum leaf fuelled
BPL cell: A possible alternate source of electricity at the off-grid region in Bangladesh. Microsystem Technologies. 2018. DOI: $10.1007 / \mathrm{s} 00542-018-4149-y$

[8] Hasan M, Khan KA. Identification of BPL cell parameters to optimize the output performance for the off-grid electricity production. In: International Conference on Physics-2018, VenueDepartment of Physics, University of Dhaka, Dhaka 1000, Bangladesh, Organizer-Bangladesh Physical Society (BPS), 08-10 March. 2018

[9] Hasan M, Haque S, Khan KA. An experimental study on the coulombic efficiency of Bryophyllum pinnatum leaf generated BPL cell. IJARIIE. 2016;2(1): 1-9

[10] Hasan MM, Khan MKA, Khan MNR, Islam MZ. Sustainable electricity generation at the coastal areas and the islands of Bangladesh using biomass resources. City University Journal. 2016;02(01):09-13

[11] Hasan M, Hassan L, Haque S, Rahman M, Khan KA. A study to analyze the self-discharge characteristics of Bryophyllum pinnatum leaf fueled BPL test cell. IJRET. 2017;6 (12):6-12

[12] Hasan M, Khan KA, Mamun MA. An estimation of the extractable electrical energy from Bryophyllum pinnatum leaf. American International Journal of Research in Sciences, Technology, Engineering and Mathematics. 2017;01 (19):100-106

[13] Hasan L, Hasan M, Khan KA, Islam SMA. SEM analysis of electrodes and measurement of ionic pressure by AAS data to identify and compare the characteristics between different biofuel based electrochemical cell. In: International Conference on 
Physics-2018, Venue-Department of Physics, University of Dhaka, Dhaka-1000, Bangladesh, OrganizerBangladesh Physical Society (BPS), 08-10 March. 2018

[14] Hassan MM, Arif M, Khan KA. Modification of germination and growth patterns of Basella alba seed by low pressure plasma. Journal of Modern Physics.: Paper ID 7503531. 2018:97-104

[15] Hossain MA, Khan MKA, Quayum ME. Performance development of bio-voltaic cell from arum leaf extract electrolytes using $\mathrm{Zn} / \mathrm{Cu}$ electrodes and investigation of their electrochemical performance. International Journal on Advanced Science, Engineering and Information Technology. 2017;5(4)

[16] Islam F, Guha B, Khan KA. Studies on $\mathrm{pH}$ of the PKL extract during electricity generation for day and night time collected Pathor Kuchi leaf. IJARIIE. 2018;4(4):1102-1113

[17] Khan MKA. Copper oxide coating for use in linear solar Fresnel reflecting concentrating collector. Journal of Renewable Energy. 1998 RE: 12.97/859

[18] Khan KA. Technical note "Copper oxide coatings for use in a linear solar Fresnel reflecting concentrating collector". Journal of Renewable Energy. 1999;17(4):603-608

[19] Khan KA. Inventors, electricity generation form Pathor Kuchi Leaf (PKL). Publication date 2008/12/31. Patent number BD 1004907; 2008

[20] Khan KA, Rasel SR, Ohiduzzaman M. Homemade PKL electricity generation for use in DC fan at remote areas. Microsystem Technologies. Springer, MITE-D-19-00131, 2019. Accepted

[21] Khan KA. Electricity generation form Pathor Kuchi leaf (Bryophyllum pinnatum). International Journal of Sustainable Agricultural Technology. 2009;5(4):146-152

[22] Khan MKA. An experimental observation of a PKL electrochemical cell from the power production view point. In: Presented as an Invited Speaker and Abstract Published in the Conference on Weather Forecasting \& Advances in Physics, 11-12 May 2018; Khulna, Bangladesh: Department of Physics, Khulna University of Engineering and Technology (KUET). 2018. pp. 75-90

[23] Khan KA, Alam MM. Performance of PKL (Pathor Kuchi Leaf) electricity and its uses in Bangladesh. International Journal of Society Development Information System. 2010;1(1):15-20

[24] Khan KA, Arafat ME. Development of portable PKL (Pathor Kuchi Leaf) lantern. International Journal of Society Development Information System. 2010;1(1):15-20

[25] Khan KA, Bosu R. Performance study on PKL electricity for using DC fan. International Journal of Society Development Information System. 2010;1(1):27-30

[26] Khan KA, Hossain MI. PKL electricity for switching on the television and radio. International Journal of Society Development Information System. 2010;1(1):31-36

[27] Khan KA, Paul S (2013) A analytical study on electrochemistry for PKL (Pathor Kuchi Leaf) electricity generation system. In: Publication Date 2013/5/21, Conference-Energytech, 2013. IEEE Publisher, IEEE. pp. 1-6

[28] Khan KA, Hossain A. Off-grid $1 \mathrm{KW}$ PKL power technology: design, fabrication, installation and operation. In: Proceedings of CCSN2018, 27-28 October, 2018 at Kolkata, India. 2018 
[29] Khan MKA, Obaydullah AKM. Construction and commercial use of PKL cell. IJARIIE. 2018;4(2): 3563-3570

[30] Khan DMKA. Prospect of solar energy for food supply in

Bangladesh. Bangladesh Journal of Scientific and Industrial Research. 2002; $37: 1-4$

[31] Khan A, Abu Salek M. A study on research, development and demonstration of renewable energy technologies, IJARIIE. 2019;5(4): 113-125

[32] Ahsan MN, Sen BK, Khan KA, Hamid Khan MA. Performance of a low cost built-in-storage solar water heater. Nuclear Science and Applications. 1999; 8:1-2

[33] Khan AJ, Khan KA, Mahmood ZH, Hossain M. Performance of an intermittently tracked linear solar Fresnel reflecting concentrator. The Dhaka University Studies, Part B (Science). 1991;39(2)

[34] Khan KA, Khan AJ, Rabbani KS. Design \& performance studies of a linear Fresnel reflecting solar concentrator-receiver system. Bangladesh Journal of Scientific Research. 1998;16(2):143-146

[35] Khan MKA. Studies on electricity generation from stone chips plant (Bryophyllum pinnatum). International Journal of Engineering \& Technology. 2008;5(4):393-397

[36] Khan MKA. Solar selective coating for use in solar concentrating collector. Bangladesh Journal of Scientific Research. 1998;16(2):249-252

[37] Khan MKA. The performance of a Fresnel reflecting concentrating collector with auxiliary heating. Bangladesh Journal of Scientific and Industrial Research. 1999;34(2)
[38] Khan MKA. Production of candles by solar system in Bangladesh. Nuclear Science \& Applications. 1998;7(1,2)

[39] Khan KA, Yesmin F, Wadud MA, Obaydullah AKM. Performance of PKL electricity for use in television. In: International Conference on Recent Trends in Electronics \& Computer Science-2019, Venue: NIT Silchar, Assam, India, Conference date: 18th and 19th of March, 2019. Organizer: Department of Electronics and Engineering, NIT Silchar, Assam, India. 2019. p. 69

[40] Mamun MA, Ibrahim M, Shahjahan M, Khan KA. Electrochemistry of the PKL electricity. In: International Conference on Recent Trends in Electronics \& Computer Science-2019, Venue: NIT Silchar, Assam, India, Conference date: 18th and 19th of March, 2019. Organizer: Department of Electronics and Engineering, NIT Silchar, Assam, India. 2019. p. 71

[41] Khan KA, Hossain MA, Kabir MA, Rahman MA, Lipe P. A study on performance of ideal and non-ideal solar cells under the climatic situation of Bangladesh. International Journal of Advance Research And Innovative Ideas in Education. 2019;5(2):975-984

[42] Hassan L, Khan KA. A study on harvesting of PKL electricity, microsystem technologies. 2019. DOI: $10.1007 / \mathrm{s} 00542-019-04625-7$

[43] Hassan SJ, Khan KA. Design, fabrication and performance study of bucket type solar candle machine. Int. J. Eng. Trach. 2007, 2007;4(3). Website: www.Gsience.Net

[44] Khan MA, Hamid Khan DMKA. Nuclear Science and Applications. June 2005;14(11)

[45] Khan KA, Rasel SR. Prospects of renewable energy with respect to energy reserve in Bangladesh. IJARII. 2018;4 (5):280-289 
[46] Khan KA, Rasel SR. Studies on wave and tidal power extraction devices. International Journal of Advance Research and Innovative Ideas in Education. 2018;4(6):61-70

[47] Khan KA, Yesmin F. PKL electricity -A step forward in clean energy. International Journal of Advance Research and Innovative Ideas in Education. 2019;5(1):316-325

[48] Khan KA, Paul S, Adibullah M, Alam MF, Sifat SM, Yousufe MR. Performance analysis of BPL/PKL electricity module. International Journal of Scientific and Engineering Research. 2013;4(3):1-4

[49] Khan KA, Paul S, Zobayer A, Hossain SS. A study on solar photovoltaic conversion. International Journal of Scientific and Engineering Research. 2013;4(3):1-6

[50] Khan KA, Bakshi MH, Mahmud AA. Bryophyllum pinnatum leaf (BPL) is an eternal source of renewable electrical energy for future world. American Journal of Physical Chemistry. 2014;3 (5):77-83. DOI: $10.11648 / \mathrm{j}$. ajpc. 20140305.15

[51] Khan KA, Alam MS, Mamun MA, Saime MA, Kamal MM. Studies on electrochemistry for Pathor Kuchi leaf power system. Journal of Agricultural and Environmental Sciences. 2016;12 (1):37-42

[52] Khan KA, Rahman A, Rahman MS, Tahsin A, Jubyer KM, Paul S. Performance analysis of electrical parameters of PKL electricity (an experimental analysis on discharge rates, capacity and discharge time, pulse performance and cycle life and deep discharge of Pathor Kuchi Leaf (PKL) electricity cell). In: IEEE Innovative Smart Grid Technologies-Asia (ISGTAsia). 2016, 2016. pp. 540-544

[53] Khan MKA, Paul S, Rahman MS, Kundu RK, Hasan MM,
Moniruzzaman M, et al. A study of performance analysis of PKL electricity generation parameters: (an experimental analysis on voltage regulation, capacity and energy efficiency of Pathor Kuchi leaf (PKL) electricity cell). In: 2016 IEEE 7th Power India International Conference (PIICON). 2016. pp. 1-6

[54] Khan MKA, Rahman MS, Das T, Ahmed MN, Saha KN, Paul S. Investigation on parameters performance of $\mathrm{Zn} / \mathrm{Cu}$ electrodes of PKL, AVL, tomato and lemon juice based electrochemical cells: A comparative study. In: 2017 3rd International Conference on Electrical Information and Communication Technology (EICT) IEEE, 2017. IEEE, Khulna, Bangladesh, Bangladesh. 2017. pp. 1-6. DOI: 10.1109/EICT.2017. 8275150

[55] Khan KA, Ali MH, Mamun MA, Haque MM, Ullah AKMA, Khan MNI, et al. Bioelectrical characteristics of $\mathrm{Zn} / \mathrm{Cu}-\mathrm{PKL}$ cell and production of nanoparticles (NPs) for practical utilization. In: 5th International Conference on 'Microelectronics, Circuits and Systems', Micro 2018, 19th and 20th May, 2018, In Association with: International Association of Science, Technology and Management. 2018. pp. 59-66. Available from: http:// www.actsoft.org

[56] Khan KA, Ali MH, Mamun MA, Ibrahim M, Obaidullah AKM, Hossain MA, et al. PKL electricity in mobile technology at the off-grid region. In: Published in the Proceedings of CCSN-2018, 27-28 October, Kolkata, India. 2018. p. 57

[57] Khan KA, Ahmed SM, Akhter MM, Alam R, Hossen M. Wave and tidal power generation. International Journal of Advance Research and Innovative Ideas in Education. 2018;4 (6):71-82 
[58] Khan KA, Bhuyan MS, Mamun MA, Ibrahim M, Hassan L, Wadud MA. Organic electricity from $\mathrm{Zn} / \mathrm{Cu}-\mathrm{PKL}$ electrochemical cell. Advances in Intelligent Systems and Computing. 2018. DOI: $10.1007 / 978981-13-1540-4$

[59] Khan KA, Bhuyan MS, Mamun MA, Ibrahim M, Hassan L, Wadud MA.

Organic electricity from $\mathrm{Zn} / \mathrm{Cu}-\mathrm{PKL}$ electrochemical cell. In: Published in the Souvenir of First International Conference of Contemporary Advances in Innovative \& Information Technology (ICCAIAIT) 2018, Organized by KEI, in collaboration with Computer Society of India (CSI), Division IV (Communication). 2018. The proceedings consented to be published in AISC Series of Springer

[60] Khan KA, Hassan L, Obaydullah AKM, Islam SA, Mamun MA, Akter T, et al. Bioelectricity: A new approach to provide the electrical power from vegetative and fruits at off-grid region. Journal of Microsystem Technology. 2018;24(3):2. DOI: $10.1007 /$ s005420183808-3

[61] Khan KA, Hasan M, Islam MA, Alim MA, Asma U, Hassan L, et al. Astudy on conventional energy sourcesfor power production. InternationalJournal of Advance Research andInnovative Ideas in Education. 2018;4(4):214-228

[62] Khan KA, Hossain MS, Kamal MM, Rahman MA, Miah I. Pathor Kuchi leaf: Importance in power production. IJARIIE. 2018;4(5)

[63] Khan KA, Hossain MA, Obaydullah AKM, Wadud MA. PKL electrochemical cell and the Peukert's law. IJARIIE. 2018;4(2):4219-4227

[64] Khan KA, Mamun MA, Ibrahim M, Hasan M, Ohiduzzaman M, Obaidullah AKM, et al. PKL electrochemical cell for off-grid areas: Physics, chemistry and technology. In:
Proceedings of CCSN-2018, 27-28

October, 2018 at Kolkata, India. 2018

[65] Khan KA, Manir SMM, Islam MS, Jahan S, Hassan L, Ali MH. Studies on nonconventional energy sources for electricity generation. International Journal of Advance Research and Innovative Ideas in Education. 2018;4 (4):229-244

[66] Khan KA, Miah MS, Ali MI, Sharma SK, Quader A. Studies on wave and tidal power converters for power production. International Journal of Advance Research and Innovative Ideas in Education. 2018;4(6):94-105

[67] Khan MKA, Obaydullah AKM, Wadud MA, Hossain MA. Bi-product from bioelectricity. IJARIIE. 2018;4(2): 3136-3142

[68] Khan KA, Rahman ML, Islam MS, Latif MA, Khan MAH, Saime MA, et al. Renewable energy scenario in Bangladesh. IJARII. 2018;4(5):270-279

[69] Khan KA, Rahman MA, Islam MN, Akter M, Islam MS. Wave climate study for ocean power extraction.

International Journal of Advance Research and Innovative Ideas in Education. 2018;4(6):83-93

[70] Khan KA, Wadud MA, Hossain MA, Obaydullah AKM. Electrical performance of PKL (Pathor Kuchi leaf) power. IJARIIE. 2018;4(2):3470-3478

[71] Khan KA, Wadud MA, Obaydullah AKM, Mamun MA. PKL (Bryophyllum pinnatum) electricity for practical utilization. IJARIIE. 2018;4(1): 957-966

[72] Paul S, Khan KA, Islam KA, Islam B, Reza MA. Modeling of a biomass energy based (BPL) generating power plant and its features in comparison with other generating plants. IPCBEE. 2012. DOI: 10.7763/ IPCBEE.2012.V44.3 
[73] Ruhane TA, Islam MT,

Rahaman MS, Bhuiyan MMH, Islam JMM, Newaz MK, et al. Photo current enhancement of natural dye sensitized solar cell by optimizing dye extraction and its loading period. Optik. 2017;149:174-183

[74] Sultana J, Khan KA, Ahmed MU. Electricity generation from Pathor Kuchi Leaf (PKL) (Bryophyllum pinnatum). Journal of the Asiatic Society of Bangladesh, Science. 2011;37(4): 167-179

[75] Khan KA, Yesmin F. Cultivation of electricity from living PKL tree's leaf. International Journal of Advance Research and Innovative Ideas in Education. 2019;5(1):462-472

[76] Khan MKA. Field testing of a Fresnel reflecting solar concentrator. Nuclear Science \& Applications. 1997;6(1,2)

[77] Khan MKA, Khan AJ, Rabbani KS. Solar thermal steam production \& distillation device by Fresnel reflecting concentrator-receiver system. Bangladesh Journal of Scientific Research. 1998;16(2):221-228

[78] Islam MS, Khan MKA. Performance studies on single crystal solar PV modules for practical utilisation in Bangladesh. International Journal of Engineering \& Technology. 2008;5(3): 348-352

[79] Khan MKA. Studies on fill factor (FF) of single crystal solar PV modules for use in Bangladesh. International Journal of Engineering \& Technology. 2008;5(3):328-334

[80] Khan MKA. Performance studies of monocrystallinne PV module considering the shadow effect.

International Journal of Engineering \& Technology. 2008;5(3):342-347

[81] Islam MS, Khan MKA. Study the deterioration of a monocrystal solar silicon PV module under Bangladesh climate. International Journal of Engineering \& Technology. 2008;5(2): 263-268

[82] Hassan SJ, Khan MKA. Design, fabrication and performance study of a single phase inverter for use in solar PV system. International Journal of Engineering \& Technology. March 2008;5(1):212-216

[83] Khan DMKA. Soap production using solar power. International Journal of Engineering \& Technology. 2009;6(1): 414-419. Website: www.gscience.net

[84] Khan DMKA. Wave and tidal power generation: An overview. International Journal of Engineering \& Technology. 2009;6(1):420-423. Website:

www.gscience.net

[85] Khan DMKA. Materials used in electricity generation by solar thermal system. International Journal of Engineering \& Technology. 2009; 6(1):515-520. Website: www. gscience.net

[86] Khan DMKA. Comparative study on single crystal and polycrystalline solar PV modules for use in Bangladesh climate. International Journal of Engineering \& Technology. 2009;6(1): 527-529. Website: www.gscience.net

[87] Khan DMKA. Solar thermal studies of open sun drying (OSD) of various crops under Bangladesh climatic condition. International Journal of Sustainable Agricultural Technology. 2009;5(7):85-94

[88] Khan DMKA. An investigation on various solar cells under the climatic condition of Bangladesh. International Journal of Engineering \& Technology. 2009;6(3):547-551

[89] Khan DMKA, Islam MS. Studies on performance of solar photovoltaic system under the climate condition of 
Bangladesh. Int. J. Soc. Dev. Inf. Syst. 2010;1(1):37-43

[90] Khan A, Zerin N, Noman Chy SM, Nurul Islam M, Bhattacharjee R. A study on voltage harvesting from PKL living plant. IJARIIE. 2019;5(5):407-415

[91] Saifuddin SM, Khan DMKA. Performance study of hybrid SPV, ST and BPL/PKL electricity generation and storage for practical utilization in Bangladesh. International Journal of Engineering \& Technology. 2010;7(2). ISSN 1812-7711

[92] Saifuddin SM, Khan DMKA. Survey of hybrid solar photovoltaic (SPV) and solar thermal (ST) collectors in Bangladesh. International Journal of Engineering \& Technology. 2010;7(3). ISSN 1812-7711

[93] Khan KA, Rasel SR. A study on electronic and ionic conductor for a PKL electrochemical cell. IJARIIE. 2019;5(2): 3100-3110

[94] Sultana Jesmin KKA, Ahmed MU. Present situation of solar photovoltaic system in different countries. ASA University Review. 2010;4(2). ISSN: 1997-6925

[95] Rahman AA, Khan DMKA. The present situation of the wave energy in some different countries of the world. IJCIT. 2010 ISSN 2078 5828(print), ISSN2218-5224(online),2(1), Manuscript code: 110754

[96] Hasnat A, Ahmed P, Rahman M, Khan KA. Numerical analysis for thermal design of a paraboloidal solar concentrating collector. International Journal of Natural Sciences. 2010, 2011; 1, 68(3):74

[97] Khan DMKA, Rubel AH.

Simulated energy scenarios of the power sector in Bangladesh. ASA University Review. 2011;592:101-110. ISSN: 19976925
[98] Sultana J, Khan MKA, Ahmed MU. Electricity generation from Pathor Kuchi Leaf (Bryophyllum pinnatum). Journal of the Asiatic Society of Bangladesh, Science. 2011;37 (2):167-179

[99] Rashid MA, Mamun RA, Sultana J, Hasnat A, Rahman M, Khan KA.

Evaluating the solar radiation system under the climatic condition of Bangladesh and computing the Angstrom coefficients. International Journal of Natural Sciences. 2012;2(1): 38-42. Received: November 2011, Accepted: March 28

[100] Sultana J, Khan KA, Mesbah Uddin Ahmed MU. The present situation of solar thermal energy in the world. ASA University Review. 2012;4(2). ISSN: 1997-6925

[101] Khan KA, Shatter MA, Paul S, Zishan SR, Yousufe MR. A study on tidal power conversion for use in Bangladesh. International Journal of Scientific and Engineering Research. 2012;3(12). ISSN 2229-5518

[102] Bhuiyan MSA, Khan KA, Jabed MA. A computerized study on the metrological parameter conversions for rural agribusiness development. Journal of Innovation \& Development Strategy. 2012;6(2):94-98

[103] Khan DMKA, Paul S, Zobayer A, Hossain SS. A study on solar photovoltaic conversion. International Journal of Scientific and Engineering Research. 2013, 2013;4(3). ISSN 22295518 (Impact Factor: 1.4)

[104] Khan DMKA, Paul S, Zobayer A, Hossain SS. A study on solar thermal conversion. International Journal of Scientific and Engineering Research. 2013; 4(3). ISSN 2229-5518 (Impact Factor: 1.4)

[105] Bhuiyan MSA, Khan KA. Software development studies on the metrological conversions for local agri-business units 
of area and volume weight measures. Journal of Innovation \& Development Strategy (JIDS) Canada. 2013;7(1). ISSN 1997-2571

[106] Ahsan MN, Kumar S, Khan MKA, Khanam MN, Khatun R, Akter S, et al. Study of spatial resolution of a positron emission tomography (PET) system. Jagannath University Journal of Science. 2013;2(1). ISSN 2224-1698

[107] Paul S, Khan KA, Kundu RK. Design, fabrication and performance analysis of solar inverter. In: Published in the Proceedings of IEEE, ENERGYTECH, USA, Participated and Presented in the "EnergyTech2013" Conference sponsored by the Institute of Electrical and Electronic Engineers (IEEE) at Case Western Reserve University in Cleveland, Ohio, USA, 21 May-23 May, 2013, USA. 2013

[108] Paul S, Khan KA, Kundu RK. Performance studies of mono-crystal silicon solar photovoltaic module with booster reflector under Bangladeshi climatic condition. In: Published in the Proceedings of IEEE, ENERGYTECH, USA. Participated and Presented in the "EnergyTech2013" Conference sponsored by the Institute of Electrical and Electronic Engineers (IEEE) at Case Western Reserve University in Cleveland, Ohio, USA, 21 May-23 May, 2013, USA. 2013

[109] Rahman AA, Khan KA. Feasibility studies on WEC (Wave Energy Converter) for use in coastal belt at Cox's Bazar of Bangladesh under the climate condition of the Bay of Bengal. International Journal of Engineering and Innovative Technology. 2013. 3660 East Bay Drive, Apartment no.116 Largo, Florida US,33771 (IMPACT FACTOR:1.895) (ISO 9001:2008 Certified)

[110] Khan KA, Latif A, Alam S, Sultana J, Ali H. A study on internal resistance of the Pathor Kuchi leaf
(PKL) cell. Journal of Agriculture and Environment. 2014;10(1):24-28

[111] Ahasan MN, Quadir DA, Khan KA, Haque MS. Simulation of a thunderstorm event over Bangladesh using WRF-ARW model. Journal of Mechanical Engineering. Transaction of the Mechanical Engineering Division, The Institute of Engineers, Bangladesh. 2014;44(2)

[112] Uddin MK, Khan MKA, Sobhan MA, Ahmed F, Nabi MN. On the implications of dynamic wireless spectrum management canons issues in uncertainty use of cognitive radio. Bangladesh Electronics Society Journal (BESJ). 2015;15(1-2):17-24

[113] Uddin MK, Khan MKA, Ahmed F, Nabi MN. A concept of potential radio spectrum administration seeking easy access spectrum (EAS) paradigm figured on signal to interference noise ratio (SINR) and interference thresholds. Bangladesh Journal of Scientific and Industrial Research. 2016; 2015. (in review)

[114] Uddin MK, Khan MKA, Sobhan MA, Ahmed F, Nabi MN. Dispensation of commons radio spectrum management framework issues in implementation: Challenges and opportunities. Journal of Electronic Engineering. 2015

[115] Uddin MK, Khan MKA, Sobhan MA, Ahmed F, Nabi MN. Dispensation of commons radio spectrum management using conceptual benefit and cost analysis framework issues in Bangladesh. Chittagong University Journal of Science. 2015

[116] Shamsuzzaman M, Sikder S, Siddiqua T, Rahman MS, Bhuiyan MMH, Khan KA, et al. Standardization of gamma radiation field for characterizing radiation detecting instrument at SSDL facilities in Bangladesh. Bangladesh Journal of 
Physics (BJP). 2015;18(65-72). ISSN: 1816-1081, BPS

[117] Kabir MU, Sobhan MA, Khan MKA, Khan MAR. Broad network wide statistics of TCP indicator measurements to reassume the status of the wireless $3 \mathrm{G}$ network monitoring. University of Information Technology and Sciences (UITS) Journal. 2015;4(2) ISSN: 2226-3128

[118] Sruti RN, Islam MM, Rana MM, Bhuiyan MMH, Khan KA, Newaz MK, et al. Measurement of percentage depth of a linear accelerator for $6 \mathrm{MV}$ and 10 MV Photon Energies. Nuclear Science and Applications, AEC, Dhaka, Bangladesh. 2015;24(1 \& 2):29-32

[119] Uddin MK, Sobhan MMA, Ahmed F, Khan MKA, Nabi MN. A potential electrical and electronic debris management model and ecological impact and awareness issues in Bangladesh. National University Journal of Science. 2015;2(1). ISSN: 1994-7763

[120] Hasan MM, Khan DMKA, Rahman MN, Islam MZ. Sustainable electricity generation at the coastal areas and the Islands of Bangladesh Using Biomass Resource. City University Journal. 2015;2(1):09-13

[121] Kabir MU, Ahmed PDF, Sobhan DMA, Khan MKA. Dispensation of commons radio spectrum management framework issues in implementation: Challenges and opportunities. Bangladesh Electronic Society (BES). 2016;16(1-2). ISSN: 1816-1510

[122] Khan KA, Alam MS, Mamun MA, Saime MA, Kamal MM. Studies on electrochemistry for Pathor Kuchi leaf power system. Journal of Bangladesh Journal of Agriculture and Environment. 2016;12(1):37-42

[123] Akter T, Bhuiyan MH, Khan KA, Khan MH. Impact of photo electrode thickness and annealing temperature on natural dye sensitized solar cell. Elsevier. 2016. Ms. Ref. No.: SETA-D16-00324R2

[124] Khan KA, Rasel SR, Ohiduzzaman M. Homemade PKL electricity generation for use in DC fan at remote areas. In: 1st International Conference on 'Energy Systems, Drives and Automations', ESDA2018. 2018. pp. 90-99

[125] Khan KA, Yesmin F. Solar water pump for vegetable field under the climatic condition in Bangladesh. International Journal of Advance Research and Innovative Ideas in Education. 2019;5(1):631-641

[126] Khan MKA. Performance of electricity generation from Bryophyllum leaf for practical utilization. Bulletin of the American Physical Society. 2017;62(1).

Abstract published and Presented in the APS April Meeting, January 28-31, Session T1 (Page No.: 201), Washington, DC, USA

[127] Ruhane TA, Islam MT, Rahaman MS, Bhuiyan MMH, Islam JMM, Newaz MK, et al. Photo current enhancement of natural dye sensitized solar cell by optimizing dye extraction and its loading period. Optik: International Journal for Light and Electron Optics. 2017. Available online 6 September 2017. In Press, Accepted Manuscript-Note to users

[128] Khan KA, Rasel SR. Solar photovoltaic electricity for irrigation under Bangladeshi climate. International Journal of Advance Research and Innovative Ideas in Education. 2019;5(2):28-36

[129] Khan KA, Rasel SR. The present scenario of nanoparticles in the world. International Journal of Advance Research and Innovative Ideas in Education. 2019;5(2):462-471 
Section 3

\section{Energy Efficiency and Sustainability in Outdoor Lighting}





\title{
Analysis of Outdoor Lighting Control Systems Applied to the New Smart City Models
}

\author{
Eduardo Ruiz Vela, Blas Ogáyar Fernandez, \\ Andrés López Valdivia and Hermoso-Orzáez Manuel Jesús
}

\begin{abstract}
Lighting accounts for more than $19 \%$ of the world's electricity consumption. Simply replacing existing lighting systems with other LED technology would reduce energy consumption by up to $40 \%$, and if we also use lighting controls, the figure can reach $80 \%$. The transition to efficient lighting technologies (LEDs) is economically one of the most realistic and simple energy efficiency initiatives. Control systems play an important role in the world of lighting. Wherever you have exterior lighting, there will be a need for control. The systems that have been used so far have precedents that date back more than 35 years and allow control and monitoring functions of groups of light points, i.e. not individually. One of the major drawbacks of these systems is that they do not have flexibility, since they do not allow the individualization of the point of light, and in addition the orders that can emit are of generic character and affect the group, obtaining a rather inaccurate information of the installation. Complete telemanagement systems are currently being developed to meet the needs of different application segments. Experience shows that it is necessary to work with open systems so that the lighting management system works and communicates with other systems such as air treatment, safety systems, etc. Intelligent lighting, in addition to its control and energy management functions, also contributes to reducing the excess of artificial light to which our cities are subject, making them more livable.
\end{abstract}

Keywords: lighting control, outdoor lighting, smart city, energy efficiency

\section{Introduction}

Lighting accounts for more than $19 \%$ of the world's electricity consumption. Simply replacing existing lighting systems with other LED technology would reduce energy consumption by up to $40 \%$, and if we also use lighting controls, the figure can reach $80 \%$. The transition to efficient lighting technologies (LED) is economically one of the most realistic and simple energy efficiency initiatives. Control systems play an important role in the world of lighting. Wherever you have exterior lighting, there will be a need for control [1].

The management of a lighting installation has two functions: control and surveillance. Control refers to operations related to switching on, switching off and reducing the light level of light sources and always refers to external factors, 
such as natural light, traffic density or traffic speed. As far as the monitoring of the installation is concerned, it will basically be related to the knowledge of the state of the light source, i.e. whether it is on or off, whether it is at the maximum or reduced level and whether it has any malfunction. By extending this surveillance to the rest of the installation, consideration is also given to the status of the network, whether a control centre has been accidentally or voluntarily opened, knowledge of the number of operating hours of each and every one of the installation components, electrical parameters, etc. When this management is carried out with a centralization in a certain point and from this point these functions are carried out, by transmission of data and remote orders, the system is called telemanagement [2].

The systems that have been used so far have precedents that date back more than 35 years and allow control and monitoring functions of groups of source of light, i.e. not individually. One of the major drawbacks of these systems is that they do not have flexibility, since they do not allow the individualization of the point of light, and in addition the orders that can emit are of generic character and affect the group, obtaining a rather inaccurate information of the installation.

Complete telemanagement systems are currently being developed to meet the needs of different application segments. Experience shows that it is necessary to work with open systems so that the lighting management system works and communicates with other systems such as air treatment, safety systems, etc. [3].

Integral light management systems (connected) that use communication nodes and optical sensors to detect the movement and regulate the intensity of light can be considered on demand systems that are integrated into a global lighting management platform.

Intelligent lighting, in addition to its control and energy management functions, also contributes to reducing the excess of artificial light to which our cities are subject, making them more livable [4].

\section{Methodology}

In the last decade, numerous lighting control systems have proliferated in the market. In a first approximation, we can divide these systems into three types: outdoor, indoor and architectural. With the adoption of a lighting control system, we optimize reliability and reduce maintenance costs, allowing us to efficiently manage the lighting system.

The objective of this work is to carry out an analysis and classification of the existing control systems in the market and then to carry out a small comparative study. For this purpose, we will analyze the existing documentation from the point of view of its general functional characteristics, without going into depth into connectivity architectures, which may be the object of other work.

We have excluded outdoor lighting control systems for discharge lamps, since the appearance of LED technology has relegated them to the background, since efficiency and flexibility are condemned to their disappearance.

For the analysis we have considered the different variables that generally define a control system, functionality, connection and driver options, in order to make a classification that helps us to apply them correctly according to the most appropriate needs and environments. For this, in each of the classified systems, we have listed their main characteristics. The energy savings that can be obtained have also been analyzed in general; for this we have based on the case studies provided by the manufacturers. 
Finally, we have discussed the different systems classified to conclude on a future projection.

\section{Types of outdoor lighting control systems}

In the city it is possible to combine different models of lighting control and connectivity that adapt to the idiosyncrasy of each area, all of them controlled from a platform. It is necessary that this is simple, starting with a progressive control of electrical panel parameters and group regulation that can be scalable to the future needs of the city (Figure 1) [5, 6].

\subsection{Luminaires}

The luminaire is a device that serves as support and connection to the electrical network of the light source. It is necessary to comply with a series of optical, electrical and mechanical characteristics, among others. In terms of optics, the luminaire is responsible for the control and distribution of the light emitted by the light source. The electrical connection between the LED module and the power supply is established via a mechanism called a driver. Stability in the power supply current is necessary to guarantee correct operation of the system, avoiding fluctuations in luminous flux.

Drivers can have each of the following functions or several at a time:

\subsubsection{Fixing output current}

If the level of light required in a specific solution falls midway between the light packages offered by the standard LED types, it is possible to customize the power level of the LED by setting the output current.

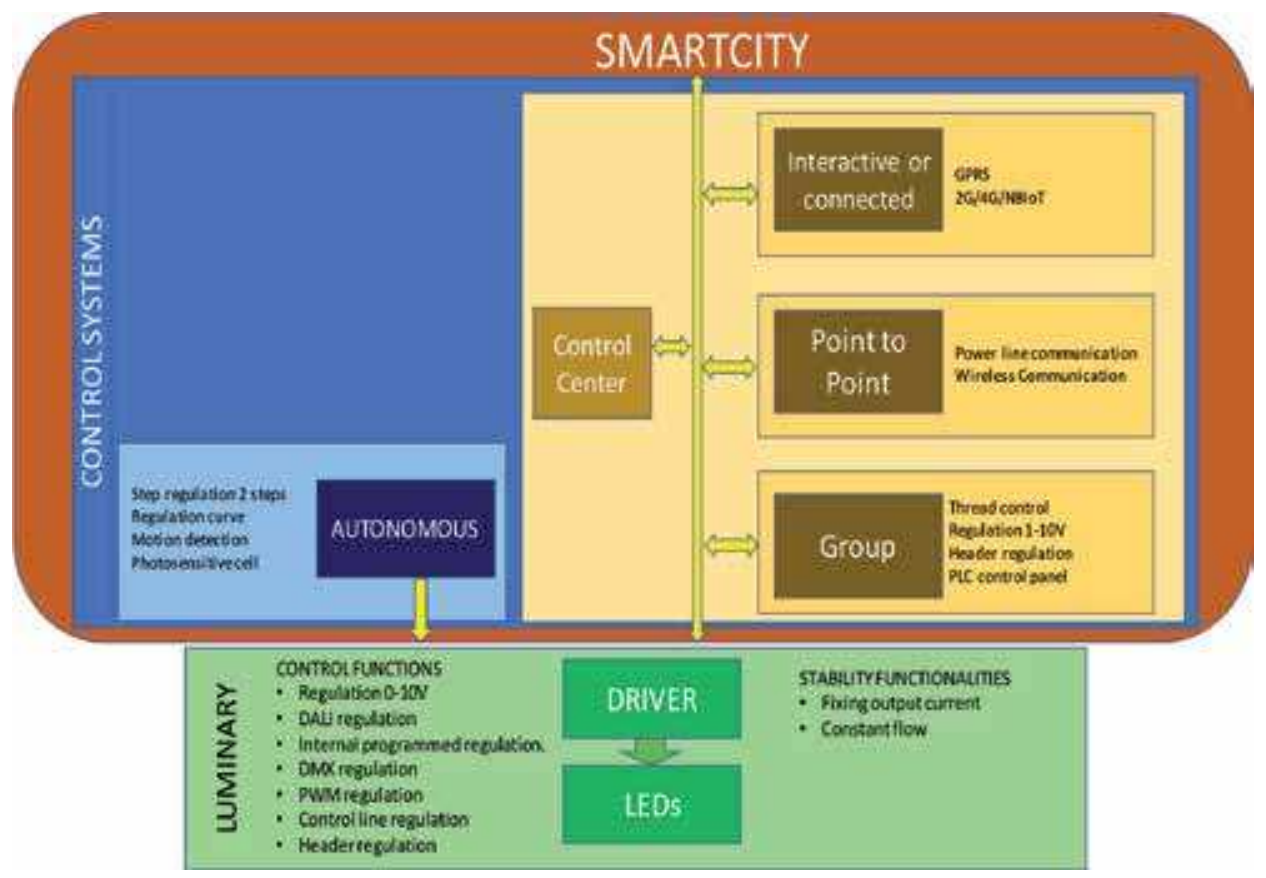

Figure 1.

Types of outdoor lighting control systems. 


\subsubsection{Regulation 1-10 V}

The 1-10 V functionality allows the regulation of the luminous flux around $1 \%$ (1 V signal) and 100\% (10 V control signal), from an analogue signal that reaches the equipment through a control line, taking into account its polarity. By means of the control line, only regulation can be carried out; switching on and off must be carried out with a relay or switch placed on the supply line of the circuit.

If the level of light required in a specific solution falls midway between the light packages offered by the standard LED types, it is possible to customize the power level of the LED by setting the output current.

\subsubsection{Regulation 1-10 V}

The 1-10 V functionality allows the regulation of the luminous flux around $1 \%$ (1 V signal) and 100\% (10 V control signal), from an analogue signal that reaches the equipment through a control line, taking into account its polarity. By means of the control line only regulation can be carried out; switching on and off must be carried out with a relay or switch placed on the supply line of the circuit.

\subsubsection{DALI regulation}

The Digital Addressable Lighting Interface, or DALI, is a very popular protocol in the lighting industry [7]. Voltages on DALI cables are usually $16 \mathrm{~V}$ without polarity. DALI cables can run close to power cables, and the maximum current is limited to $250 \mathrm{~mA}$. Using this protocol we can send regulation orders for 256 power levels. The advantage of this technology is the bidirectionality of the system (Figure 2).

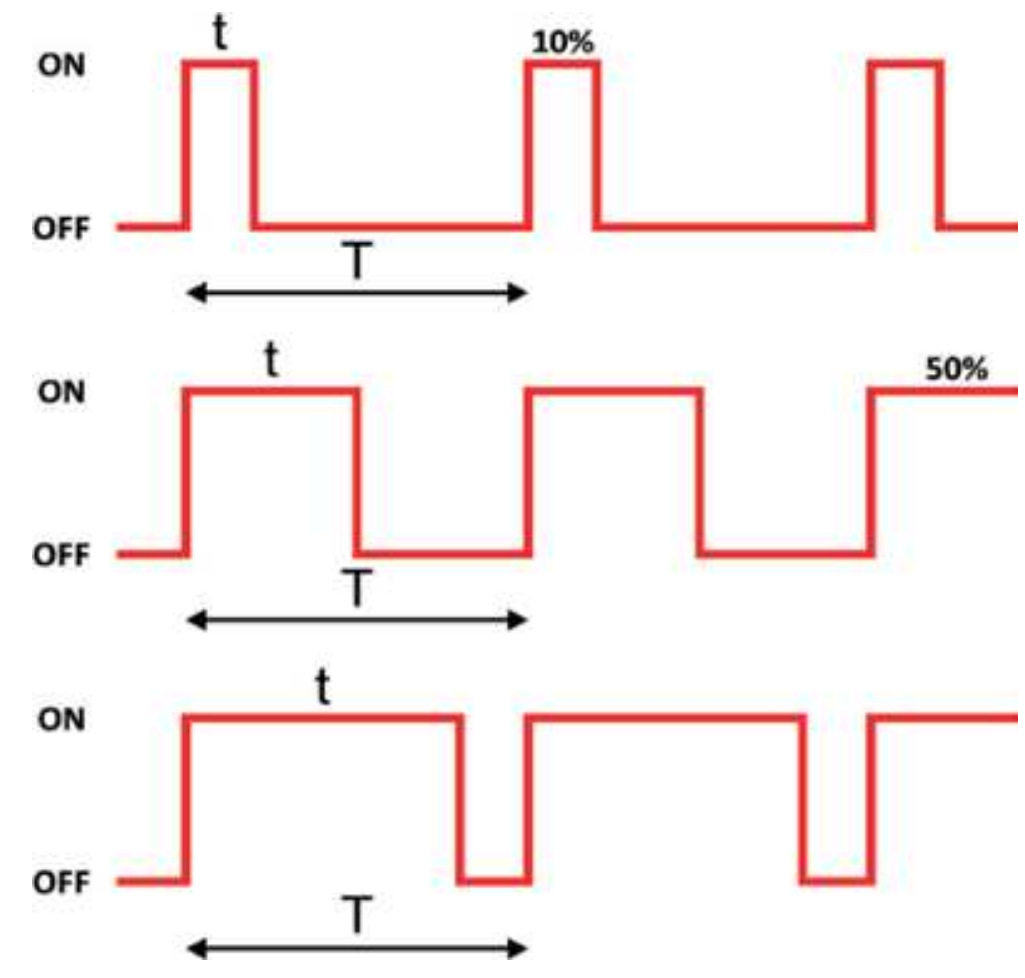

Figure 2.

PWM regulation. 


\subsubsection{Pulse width modulation}

The concept of pulse width modulation of analogue or digital signals known as PWM is a technique used for various applications, and among these is lighting. Basically what it does is to vary the working cycle of the LED by turning it on and off very quickly. If the brightness of the LED is analyzed, it depends on the power, whose value in turn is dependent on the voltage and the current applied to it $(\mathrm{P}=\mathrm{V}$.I $)$. If we want to reduce the brightness, we will have to reduce the average power delivered to the LED; for it we have to control some of the variables involved (voltage or current).

\subsubsection{Control line regulation}

This functionality supports signals from a control wire.

\subsubsection{Header regulation}

This function detects the decrease of the mains voltage.

\subsubsection{Constant luminous flux}

Light sources experience light depreciation, i.e. a decrease in luminous flux over time. In order to ensure the minimum levels required when the end of the light source cycle is approaching, most designs are calculated based on the level produced at the end of life normally LB70: 70\% of the initial lumens. This means that the system consumes more than necessary and loses $15 \%$ of energy during its service life. The constant luminous flux functionality compensates for this light loss and ensures that the required level is always delivered. Taking into account light depreciation, the driver can be programmed to start at an attenuated level in a new luminaire and gradually increase the power over the life of the light source. With this function we save energy and extend the life of the system (Figure 3).

\subsubsection{Internal programmed regulation}

This functionality allows simple, preprogrammed attenuation. Programmable drivers offer an integrated version of this feature. This integrated programmer

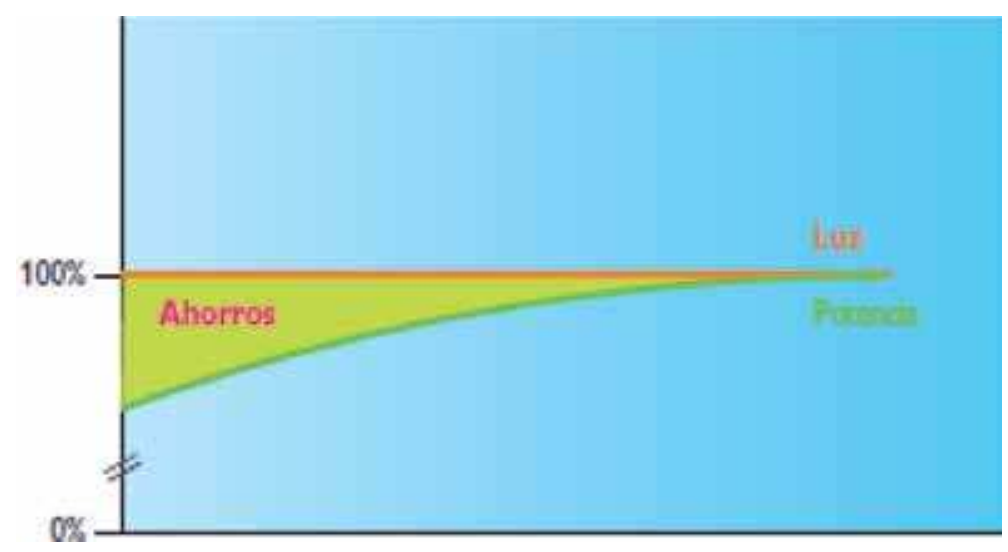

Figure 3.

Energy saving with constant luminous flux. 
allows you to regulate predefined light levels based on nighttime operating time and lighting levels.

\subsubsection{DMX regulation}

The high-speed DMX control protocol makes this the ideal solution for dynamic installations of spectacular lighting, including video playback [6, 8-10].

\subsection{Autonomous control systems}

Autonomous systems are closely related to the functionalities of the drivers described above. These devices operate independently from the luminaire itself and are normally integrated at or near the same light point. Both operation and configuration are usually simple and generally require no maintenance except for batterypowered devices. Some use presence detection or sensors, so the user can interact. They are very easy to install and have no recurring costs, and energy savings are guaranteed.

\subsubsection{Double-level control}

It is an autonomous dimming solution that automatically reduces the power of the light source from $100 \%$ to $50-60 \%$, according to the predefined model, providing energy savings without extra investment in the control infrastructure.

After synchronizing the hours of off and on of the installation, the functionality of the driver determines automatically the central point of the night. The first option will provide full light up to the central point of the night and then be adjusted 6 or 8 hours before setting the 100\% level (Figure 4).

\subsubsection{Internal programmed regulation by regulation curve}

It is a functionality that the equipment has integrated to control the lighting in an autonomous way. They use regulation curves that represent the level of light output depending on the time of day.

The control levels are programmed with a PC via a computer tool. If the lighting requirements change over time or if the established regulation is to be improved, they can be updated (Figure 5).

The controller does not have a real clock; instead, it runs a virtual clock, determined by the duration of the night operating hours.

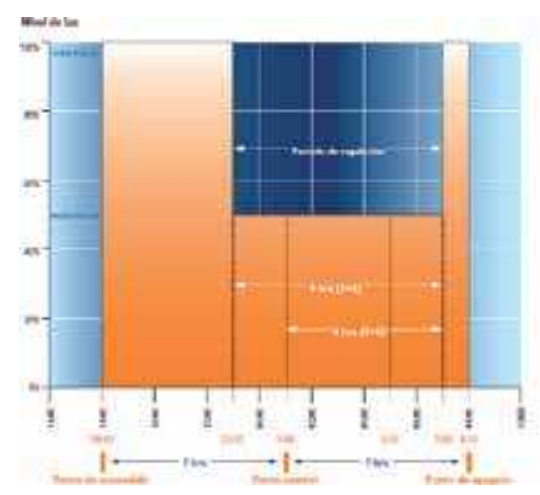

Figure 4.

Double-level control. 
Analysis of Outdoor Lighting Control Systems Applied to the New Smart City Models DOI: http://dx.doi.org/10.5772/intechopen.88834

\subsubsection{Autonomous control system with motion detection}

This system is based on the level of activity in the street and not on timetables. It detects and communicates with neighboring luminaires, anticipating pedestrian movements. Generally, the detector can control several drivers with 1-10 V or DALI functionality. It is a unique solution providing light on demand that can be adapted to the needs of each application (Figure 6).

Since it detects pedestrians, cyclists or cars at a speed of less than $30 \mathrm{~km}$ per hour, it is.

\subsection{Networked control systems}

Grid control systems interconnect several pieces of equipment within the same public lighting control panel.

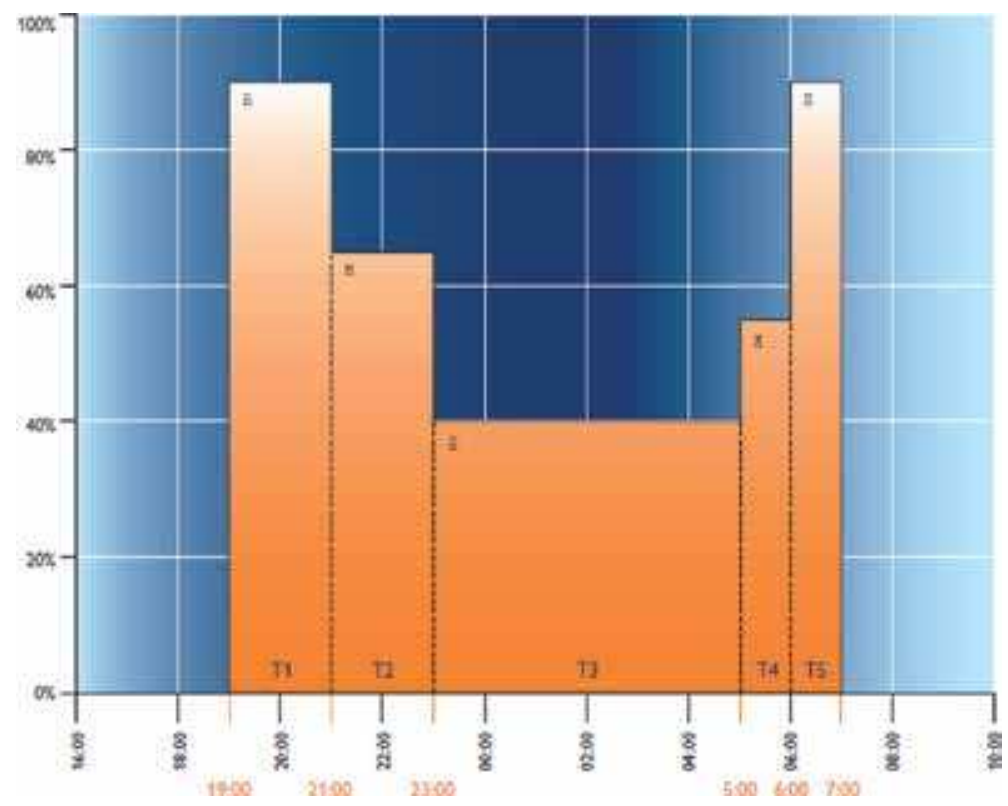

Figure 5.

Dimming curve.
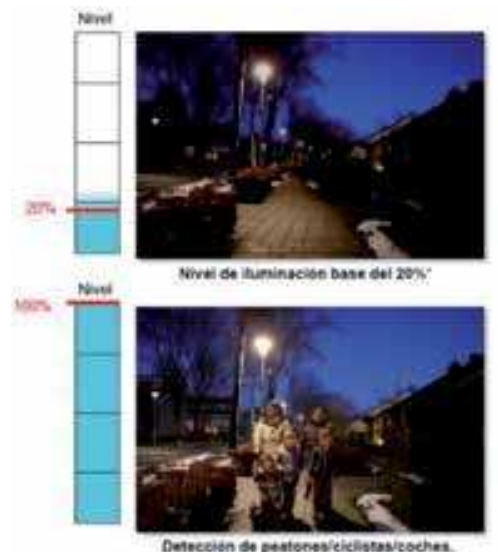

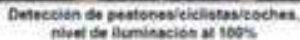

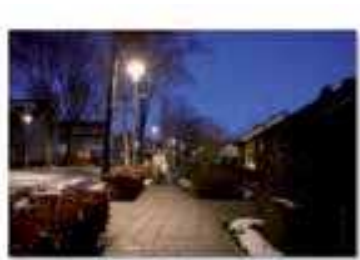

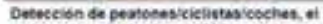

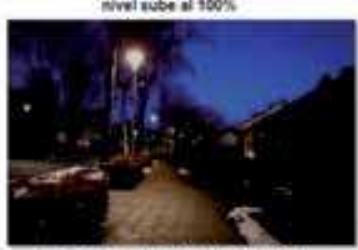

Pasabs on mincose ain dofectisa is
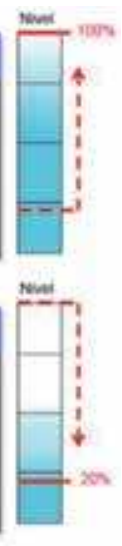

Figure 6.

Dimming by motion detection. 


\subsubsection{Group control system}

Group management systems allow centralized control of a group of light points. This type of system requires additional wiring for the transmission of the control signal, and it is also possible to transmit data over the power line [11, 12].

\subsubsection{Command thread}

The control wire system is a step control solution that allows groups of light points to be controlled up to a predetermined level via an additional control circuit. A cabinet controller feeds the driver through the control line and changes the light level of all luminaires connected to that cabinet [13].

\subsubsection{Regulation by means of $1-10 \mathrm{~V}$}

LED drivers can incorporate 1-10 V regulation. They provide continuous dimming, can reduce luminous flux $100-10 \%$ and save a substantial amount of energy during off-peak hours. This system is unidirectional since the information flows in a single direction: from the controller to the lighting equipment. On the other hand, it does not allow the equipment to be routed, and the creation of wired groups has to be carried out.

\subsubsection{Header regulation}

Mains regulation with electromagnetic ballasts has been used for more than 15 years. By lowering the mains voltage, the luminous flux is reduced proportionally. The same advantage is available on LED drivers thanks to their integrated functionality. A cabinet controller sends a signal to the driver to attenuate the luminous flux by reducing the amplitude of the mains voltage. The driver interprets the lower amplitude as a signal to reduce light levels (Figure 7).

\subsubsection{Table regulation by the feeding line (PLC)}

The main system controller (CPU), placed on the control panel, monitors and controls all other modules. With this system, the luminaires can be adjusted from the control panel. The communication between the control panel hardware and the luminaire groups is carried out through a specific communication protocol that
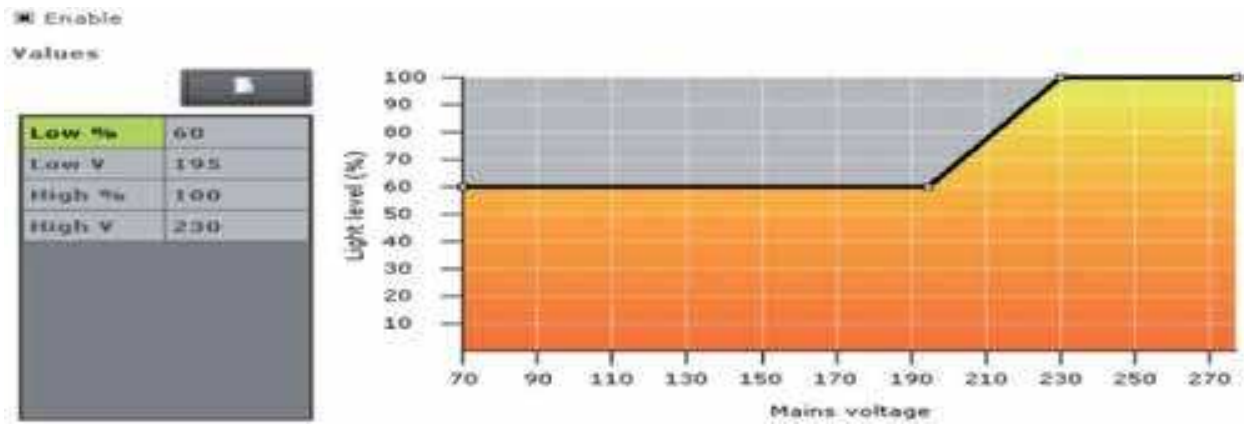

Figure 7 .

Headland adjustment. 
makes use of the electrical network as a means of transmission. The luminaires have a special driver that includes a receiver to perform the corresponding encoding of the orders received. We use the existing infrastructure. If there were problems in the regulation, we would obtain a system alarm. The CPU also serves as a communication node and as a data hub module. Bidirectional communication with the central server is done through GPRS connectivity.

The main system controller (CPU) monitors and controls all other hardware modules. With this system, the luminaires can be dimmed from the control panel. The communication between the control centre hardware and the luminaire groups is carried out through a specific communications protocol that uses the electrical network as a means of transmission. The luminaires have a special driver that includes a receiver to carry out the corresponding regulation. If there were problems with the regulation, we'd get a system alarm (Figure 8).

The data collected by the system is sent to the central server, where they are stored and remain accessible to prepare reports, correct anomalies, perform load balancing and generate emergency responses in case of accident, flood and the like.

The data collected by the system is sent to the central server. Where they are stored and remain accessible to prepare reports, correct anomalies, balance loads and generate emergency responses in the event of an accident, flood or similar.

From the central server, we can make a remote management of the lighting levels of the control panel luminaires and a control of the real state of the light points, with automatic notifications of failures and real energy measurements with complete history that provides instruments of measurement and verification.

This system is associated to a platform that will allow a remote management of the lighting levels of the luminaires of the panel, a control of the real state of the points of light, with automatic notifications of failures and measures of real energy with complete historical that proportions instruments of measurement and verification.

\subsubsection{Point-to-pint control system}

The point-to-point control systems individually control and supervise the light points associated with a lighting control panel, allowing remote diagnosis of each of the light points.

Energy savings are obtained by switching and regulating individual points according to a time model or in response to information received from an atmospheric sensor or a traffic meter. In turn, light points can be grouped according to their specific location so that they respond at the same time.

Associated to the system is a platform of services; it extracts useful information for the control and monitoring of the lighting that the user will be able to use for the maintenance and the energetic consumption, as well as to improve the lighting service (Figure 9) [14].
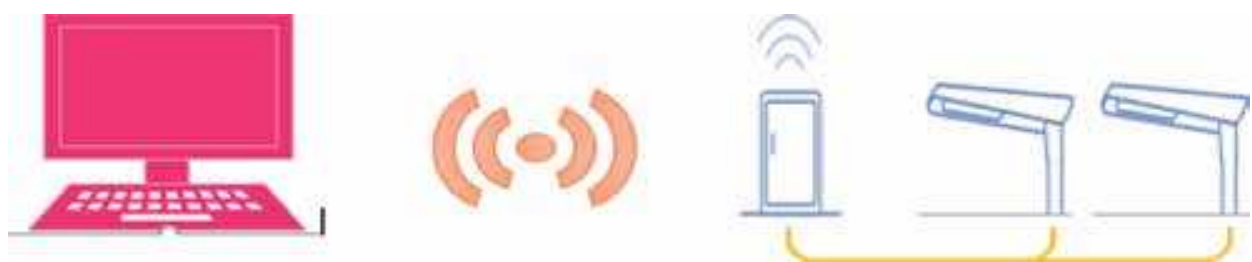

Figure 8.

Table adjustment per supply line. 


\subsubsection{Point-to-point communication}

It is based on a powerline protocol. The system applies advanced repetition technology allowing any point of light to replicate orders whenever required. Thus, it guarantees the arrival of all instructions at their destination even under adverse communication conditions (Figure 10).

\subsubsection{Wireless point-to-point control system}

The outdoor luminaire controller (OLC) is located on top of the luminaire housing. The OLC unit communicates with the controller wirelessly and securely over a distance of up to 300 meters (Figure 11) [15].

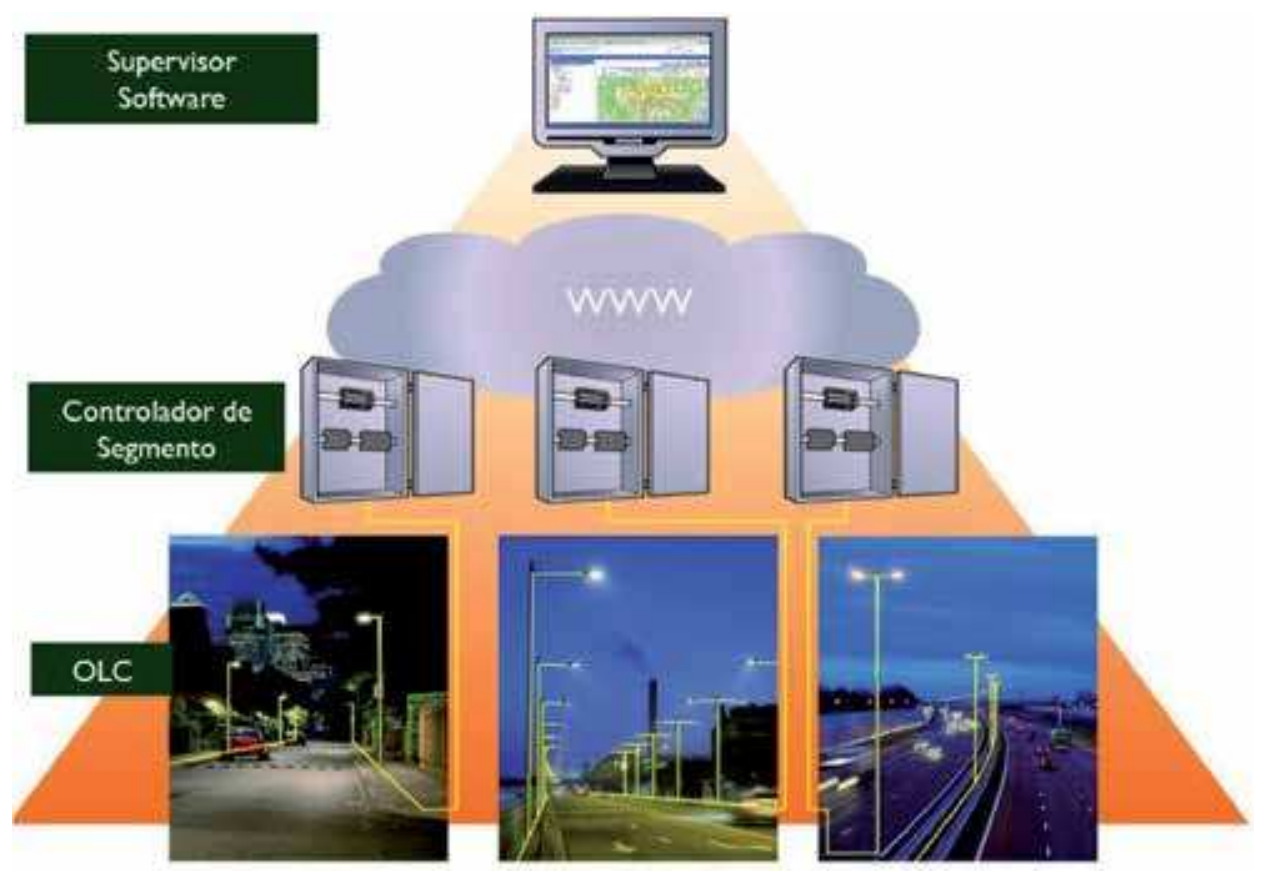

Figure 9.

Point-to-point control system.

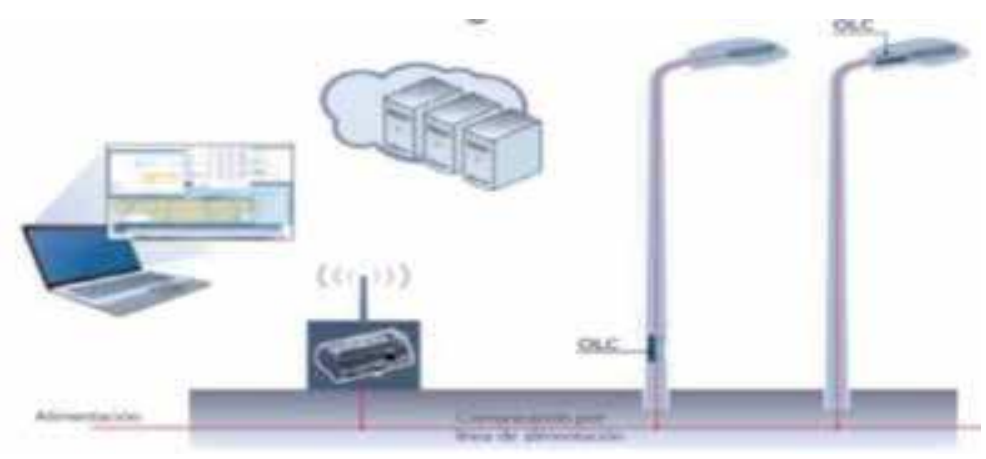

Figure 10.

Point-to-point control system and power line communication. 
The segment controller (SC) controls up to 400 OLCs and collects them for storage on the central server over the Internet, usually via GPRS. Installed on a DIN rail in a control centre, the SC can be used as an interface with other devices: traffic counters, atmospheric sensors, etc.

\subsection{Lighting switched on}

LED luminaires are digital devices that together with the Internet of Things (IoT) create a new concept of public lighting focused on greater efficiency, less environmental and economic impact [16].

The GPRS network is used for communication and control of the luminaires, without the need to install any element in the control centres nor a separate wiring from the power supply of the light points. All luminaires are managed from the GPRS network of a mobile operator (Figure 12).

The only control device of the system is the OLC installed in each of the luminaires to allow communication with the platform's servers. The luminaires also incorporate an adjustable driver. These will be connected to the electrical network in the same way as in a conventional installation. To access the system, you need a PC with an Internet connection.

The platform associated to this system has the following characteristics:

- It is a cloud with easy access from a standard browser.

- No software installation required.

- It includes storage, processing and backup of application data.
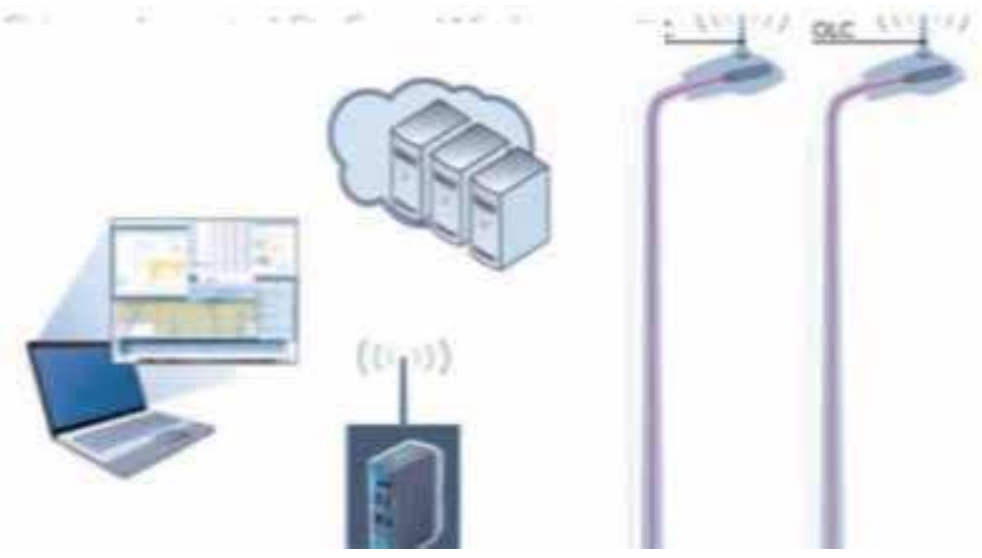

Figure 11.

Wireless point-to-point control system.
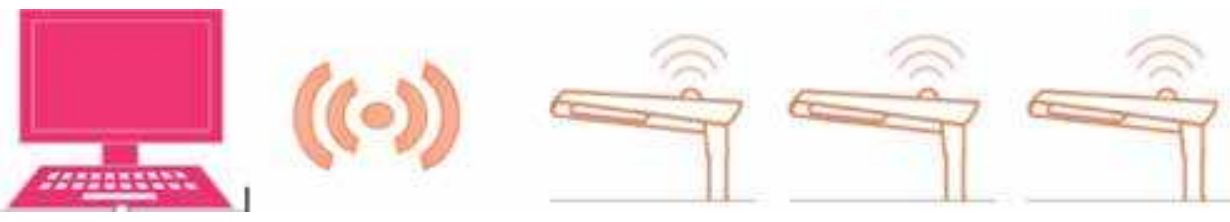

Figure 12.

Connected. 
- It is secure and scalable to be able to implement modules according to the needs of each territory or intelligent city.

It is safe and scalable to be able to implement modules according to each territory or smart city needs.

\section{Comparison of control system}

The autonomous systems reduce the consumption of electrical energy, with respect to the traditional lighting, 15-20\%, those of network in box 15-35\%, those of network point to point $45-50 \%$ and those connected $50-60 \%$. The autonomous motion detection can reach up to $70 \%$, since when there is no occupation that tends to reduce the flow of the light source to $10 \%$ normally (Table 1).

These systems control the flow of LED modules in different ways. Within the selfemployed, the double-level regulation has two states: normal and reduced operation. The internally controlled programming is governed by a curve that can be modified with a specific software and usually has several steps. The ones with control wires, regulation in headboard and 1-10 V do it presenting some determined values in the driver. The control panel regulated through the power supply line of the luminaires modifies the curve in the corresponding drivers of the luminaires of the control centre; previously this curve is configured from the associated platform and is transmitted through the power line. Point-to-point systems work like the above only that they can vary the dimming curve of a luminaire, without having to do it simultaneously in all the luminaires in the table. The connected system can change the regulation parameters of

\begin{tabular}{|c|c|c|c|c|}
\hline & Control system & Functicatality & Driver Options & Characteristics: \\
\hline $\begin{array}{l}1 \\
0 \\
T\end{array}$ & Connectied & $\begin{array}{l}\text { For complete control and } \\
\text { monitering of each } \\
\text { individual light point }\end{array}$ & DAU & 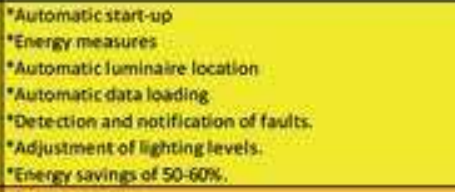 \\
\hline \multirow{5}{*}{$\begin{array}{l}\mathbf{R} \\
\mathbf{E} \\
\mathbf{D}\end{array}$} & Point to point & $\begin{array}{l}\text { For complete control and } \\
\text { monitoring of each } \\
\text { Individual light paint }\end{array}$ & $1.10 \mathrm{~V}$ & $\begin{array}{l}\text { - Needs start up } \\
\text {-Continuous regulation } \\
\text { "Prowides detailed information about the equipment } \\
\text { - Location of luminaires } \\
\text { "Averape energy savings of } 45 \text {-50\%. }\end{array}$ \\
\hline & \multirow{4}{*}{ Chart } & \multirow{4}{*}{$\begin{array}{l}\text { For monitoring and } \\
\text { controlling kroups of light } \\
\text { points }\end{array}$} & MLCicodificadon) & 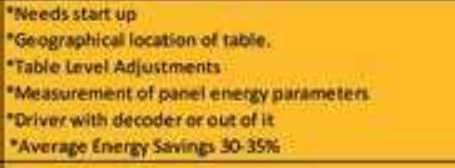 \\
\hline & & & $1-10 \mathrm{~V}$ & $\begin{array}{l}\text { "Continuous reguiation. } \\
\text { "Energer stwings of } 15,20 \% \text {. }\end{array}$ \\
\hline & & & Regulation in Header & $\begin{array}{l}\text {-9omple regulation by reducing the mains volitage. } \\
\text {-Average energy savings of } 15.20 \% \text {. }\end{array}$ \\
\hline & & & Control wice & $\begin{array}{l}\text {-Adjustment by mesns of an additional controf line } \\
\text {-Average enercy savings of } 15.20 \% \text {. }\end{array}$ \\
\hline$\hat{\mathrm{j}}$ & \multirow{3}{*}{ Autonomous } & \multirow{3}{*}{ Regulation } & Motion detection & $\begin{array}{l}\text {-Adjustment by means of a motion detector } \\
\text { "Average energy savings of up to } \pi 0 x \text {. }\end{array}$ \\
\hline N & & & $\begin{array}{l}\text { Internal programmed } \\
\text { regulation }\end{array}$ & $\begin{array}{l}\text {-Automatic regulation programmable several steps } \\
\text {-Average enengy savings of } 20.25 \%\end{array}$ \\
\hline $\begin{array}{l}0 \\
\text { i } \\
\text { s }\end{array}$ & & & Double fevel reguilation & $\begin{array}{l}\text {-Automatic regulation } 1 \text { steo } \\
\text {-Average energy savings of } 15.20 \%\end{array}$ \\
\hline
\end{tabular}

Table 1.

Summary outdoor lighting control system. 


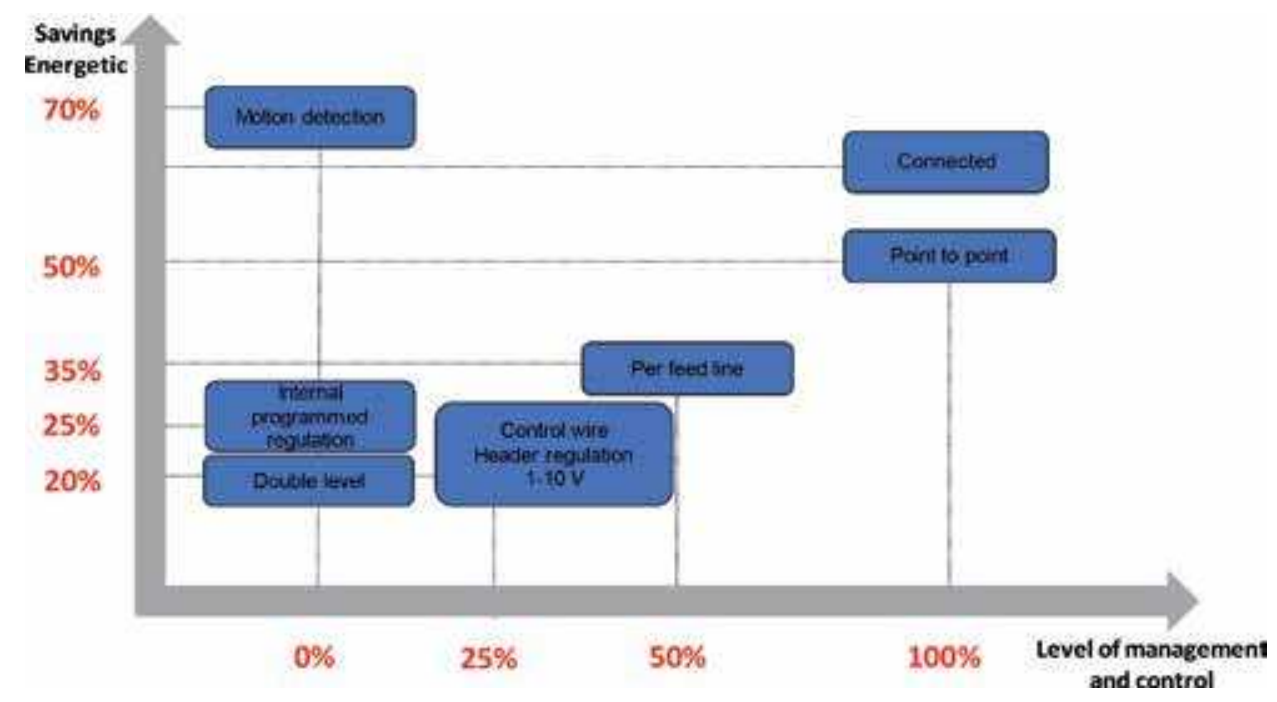

Figure 13.

Energy saving depending on the level of management.

an individual light source, directly from the platform, without having to pass the signal through any element placed in the panel or from any sensor connected to the communication node of the luminaire (OLC): presence detector, traffic density, etc. [17, 18].

Implementation is the process of programming and field verification of system elements. In the autonomous it is not necessary, as in the network of control wire, 1-10 V and regulation in head; however, it must be carried out in the network: PLC and point to point. The plug-in is a plug and play and does not require commissioning.

In all the analyzed systems, it is necessary to place, in the control panel of the public lighting, the necessary controllers in order to control the sources of light; in the autonomous and connected, it is not necessary.

The PLC box system, the point-to-point network system and the connected system are associated to a platform that acts as an interface with the user. This may be related to others at a higher level.

The monitoring of light source status, network status, operating hours, energy consumption, faults, etc. is carried out by the PLC network system, the point-topoint network system and the connected system.

The connectors used in the connected system allow power and control to be independent without special operations, integrating communication nodes, sensors, photocells, etc.

As we can see in Figure 13, as we increase the supervision, we increase the potential energy saving, and the exception is the autonomous with motion detection for the reasons above $[19,20]$.

\section{Discussion}

The implementation of the appropriate control system depends on several factors: investment, management and energy saving.

Autonomous control systems are the best option for complying with existing legislation and starting to reduce energy consumption immediately, without the need for major changes or investments in infrastructure. They operate independently the rest of the installation and control or regulate the light according to specific sensors or programs. 
The networked group management systems allow a centralized control of a group of light points, so they are aimed at finding a more advanced solution. This type of system requires additional wiring for the transmission of the control signal or the luminaires' own power supply. However, if you already have the necessary infrastructure, these solutions are very easy to install offering immediate monitoring and control over groups of light points.

Point-to-point network control systems not only control and monitor the lighting but also remotely diagnose each of the light points. These solutions achieve greater volume savings while providing maximum flexibility.

Connected or integrated light management systems are the easiest to install and can be integrated with different networked control systems. In this way, it is not only possible to control and supervise the lighting but also to remotely diagnose each of the points of light. This is possible thanks to sensors, control nodes, gateways, communications, etc. These solutions achieve the greatest volume of energy savings while providing maximum flexibility.

It is possible to combine different control systems that adapt to each area of the city, all controlled from a single platform. From there, it was possible to carry out the transformation of the city. This platform, which operates vertically and autonomously, can be integrated with the horizontal platform of the city and integrated with other services, forming part of the connected city. This concept has a high potential, with the exploitation and correlation of collected data that open the possibility of using advanced analytical methods and big data treatments, which help to make strategic decisions.

\section{Conclusion}

The adoption of LED technology enhances the renewal of lighting infrastructure, enabling the growth of innovations in cities and technology based on a safe lighting system, reliable and connected with a wide range of products and associated services.

New intelligent digital technology plays a key role in responding to the demands of cities and citizens. Improved lighting infrastructure supports connectivity and reduces maintenance operating costs in an environmentally sustainable manner. Intelligence is the logical step to make tomorrow's city more efficient, save more energy, adapt to new situations and be always prepared for the future, equipped with systems that can be controlled and monitored remotely in real time.

Connected lighting is an integral solution that allows municipal authorities to offer a better lighting service. Other systems or platforms can be connected through APIs to the lighting platform (vertical). It is essential to integrate all the information generated by the services, in this case lighting, in an open, standard and interoperable horizontal platform, which is, as a technological element, responsible for a unified management. 


\section{Author details}

Eduardo Ruiz Vela ${ }^{1}$, Blas Ogáyar Fernandez ${ }^{2 *}$, Andrés López Valdivia ${ }^{2}$ and Hermoso-Orzáez Manuel Jesús ${ }^{3}$

1 Departamento de Ingeniería Eléctrica, Escuela Politécnica Superior de la Universidad de Córdoba, Spain

2 Departamento de Ingeniería Eléctrica, Escuela Politécnica Superior de la Universidad de Jaén, Spain

3 Departamento de Ingenieria Gráfica Diseño y Proyectos, Escuela Politécnica Superior de la Universidad de Jaén, Spain

*Address all correspondence to: bogayar@ujaen.es

\section{IntechOpen}

(C) 2020 The Author(s). Licensee IntechOpen. Distributed under the terms of the Creative Commons Attribution - NonCommercial 4.0 License (https://creativecommons.org/ licenses/by-nc/4.0/), which permits use, distribution and reproduction for non-commercial purposes, provided the original is properly cited. (cc) BY-NC 


\section{References}

[1] Brock K, Den Oden E, Van Der Klaus K, Podoynitsyna K, Langerak F. Tecnological forecasting \& social change light the way for smart cities: Lessons from Philips lighting. Technological Forecasting and Social Change. 2019;142(2028):194-209

[2] Ordendaal N. Information and communication technology and local governance: Understanding the difference between cities in developed and emerging economies. Computers, Environment and Urban Systems. 2003:585-607

[3] Sittoni D, Brunelli D, Macii D, Tosato P, Petri D. Street lighting in smart cities: A simulation tool for the design of systems based on narrowband PLC. In: 2015 IEEE First International Smart Cities Conference (ISC2), Guadalajara. 2015. pp. 1-6

[4] Karlicek R, Sun CC, Zissis G, Ma R. Handbook of Advanced Lighting Technology. 2017. pp. 1-1185

[5] Lighting P, Dynalite E. Sistemas de Control de Alumbrado (CTE) Philips Lighting Controls. 2015

[6] Alumbrado PL. Sistemas de control Dynatile. Manual técnico. 2016

[7] Domingo-Pérez F, Gil-De-Castro A, Flores-Arias JM, Bellido-Outeiriño FJ, Moreno-Muñoz A. Lighting control system based on DALI and wireless sensor networks. In: 2012 IEEE PES Innovative Smart Grid Technologies (ISGT). 2012. pp. 1-6

[8] Hung NM, Lee C-H. Design of Bi-directional RDM-DMX512 converter for LED lighting control. International Journal of Fuzzy Logic and Intelligent Systems. 2013;13(2):106-115

[9] Yoowattana S, Nantajiwakornchai C, Sangworasil M. A design of embedded
DMX512 controller using FPGA and XILKernel. In: 2009 IEEE Symposium on Industrial Electronics and Applications, ISIEA 2009. Vol. 1. 2009. pp. $73-77$

[10] Yang H, Ahmad AW, Shahzad G, Lee C. Real time bidirectional wireless digital multiplexer (WiDMX512). In: International Conference on Advanced Communication Technology (ICACT). Vol. 2015. 2015. pp. 109-114

[11] Varghese SG, Kurian CP, George VI. A study of communication protocols and wireless networking systems for lighting control application. In: International Conference on Renewable Energy Research and Applications (ICRERA) 2015. Vol. 5. 2015. pp. 1301-1306

[12] Piromalis D, Arvanitis KG, Papageorgas PG, Tseles DI, Psomopoulos CS. Sensors \& transducers LEDWIRE: A versatile networking platform for smart LED lighting applications using LIN-bus and WSNs. Sensors \& Transducers. 2016;200(5):50-59

[13] F.R. Trejo-macotela and A. Garciabarrientos. Controlador Digital Mediante el Protocolo DMX-512. 2013

[14] Color and K. Led. Remotely Monitor and Manage Dynamic Cloud-Hosted Connected Lighting Software. 2013

[15] Newton S. Art-net and wireless routers. In: 2005 Asia-Pacific Conference on Communications. Vol. 2005. 2005. pp. 857-861

[16] Carrino F, Mugellini E, Khaled OA, Ouerhani N, Ehrensberger J. iNUIT: Internet of things for urban innovation. Future Internet. 2016;8(2):1-21

[17] Hu W. Effects of Resolution of Lighting Control Systems. 2018 
Analysis of Outdoor Lighting Control Systems Applied to the New Smart City Models DOI: http://dx.doi.org/10.5772/intechopen.88834

[18] Zotos $\mathrm{N}$ et al. Case study of a dimmable outdoor lighting system with intelligent management and remote control. In: 2012 International Conference on Telecommunications and Multimedia (TEMU). Vol. 1. 2012. pp. $43-48$

[19] Hermoso-Orzáez MJ, GagoCalderón A, Rojas-Sola JI. Power quality and energy efficiency in the pre-evaluation of an outdoor lighting renewal with light-emitting diode technology: Experimental study and amortization analysis. Energies. 2017;10(7)

[20] Radulovic D, Skok S, Kirincic V. Energy efficiency public lighting management in the cities. Energy. 2011;36(4):1908-1915 



\title{
Improvement the Efficiency of Distribution Network Using an Efficient Lighting System of Streets
}

\author{
Nassim Iqteit and Khalid Yahya
}

\begin{abstract}
Nowadays, improve the efficiency and reduce active loss are very important target for any electric company. One of the methods to reach this target is using appropriate street lighting and tunnel lighting systems. Control of lighting, appropriate products of lighting system, and management of the luminaire dimming will used to improve the efficiency of lighting network. Studying the lamp efficiency of low pressure sodium, LED, high pressure sodium, compact fluorescent lamps, etc. Case study and calculations of active losses in lighting system of 30 luminaire are presented in this chapter. The results discuss the impact of type and number of luminaires, distance between poles, and dimming ratio on the outdoor lighting efficiency and values of active loss in lighting network which is part of distribution networks.
\end{abstract}

Keywords: lighting network, streets, efficiency, active losses, LED, dimming, products for lighting

\section{Introduction}

The active power loss in a street lighting system depends on the complexity of the grid, types of luminaires, the number of luminaires, the unit of dimming used, the reactive power level in the network, etc. Using regulated devices, lighting dimming systems $[1,2]$ and reducing the reactive power [3] are usually used for reduction active power losses in lighting networks. Another aspect for improving the energy efficiency of a lighting road system is that it is designed to maximize the efficiency of the light flux emitted in the surrounding area whereas minimizing its losses [4]. The increase in power losses leads to increase in active power then the consuming of electricity will increase. Until now, calculating the power losses in lighting system in distribution grid, assumes that the network receive constant power from the rated light sources or luminaires throughout the lighting period. Throughout lighting operation, the rated power of luminaires may change within their lifetime. Additionally, at night time, the voltage of source may be higher than the rated grid voltage, which means greater active power consumption, higher power currents and higher power losses [5]. 
Decreasing operating hours, where it is depending on the hours of darkness and amount of daylight. Photoelectric switching is usually used to attain the minimum hours of street lighting operation. Diminution the number of lamps operating in streets; the amount of light requisite on the road depends on legal requirements, tarmac, traffic volume, type of road, speed limit and surroundings. Any change in these parameters assist to minimize the active loss in the lighting system. Installation of more efficient light sources assists to reduce the number of lamps operating and provide the same levels of illumination. Modern control system of street or tunnel lighting system contains; control unit in lighting fixture/luminaire, CPU and GSM module in switchboard of the installation, and remote data processor for management and controlling the individual installations [6]. Moreover, opening up the tunnel roof reduces the number of luminaire use in tunnels, but shadows, insufficient of lighting and difficulty in guiding the sunlight are critical points for limiting the lighting of tunnels by daylighting. In addition, all lighting installations require to be preserved to perform at maximum efficiency. Dirt on lens on panels and reflectors leads to reduced output from the luminaire [6].

Lamp types usable in street and tunnel lighting; high pressure sodium lamps, low pressure sodium lamps, metal halide lamps with quartz arc tube, metal halide lamps with ceramic arc tube, high pressure mercury lamps, linear fluorescent lamps, compact fluorescent lamps with integrated ballast, compact fluorescent lamps with non-integrated ballast, and LEDs [7].

LED technology is quickly becoming competitive with high-intensity discharge light sources for outdoor space lighting. Most LED manufacturers describe useful life based on the estimated time at which LED light output will depreciate to $70 \%$ of its initial rating; often the target is 100,000-150,000 hours for outdoor luminaires. As with all LED products, careful data gathering and research is required to assess quality, performance, and overall value. The following steps are provided as a quick summary of the outdoor lighting system [8]:

- Need to photometric test reports based on the IESNA LM-79-08 test procedure.

- Required warranty; 3-5 years is reasonable for outdoor luminaires.

- Check ingress protection (IP) ratings, and choose an appropriate rating for the intended application.

- Ask for operating temperature information and how this data relates to luminaire efficacy and lumen depreciation.

- Check color temperature for suitability in the intended application.

- Assess glare, preferably with the luminaire at intended mounting height and under typical nighttime viewing conditions, compared to incumbent technology.

- Evaluate economic payback, based on applicable energy, equipment, maintenance, and control costs for the site.

The quality, type, maintenance requirements and average annual daily traffic volume are critical in the selection of the street and tunnel lighting system. LEDs and electrode-less lamps are newer technologies on their way to be potential future tunnel lighting systems [9]. 


\section{Street lighting technologies}

\subsection{Street light sources}

There are distinct luminaires families that are used for lighting streets of cites, where these technologies are shown in Figure 1 [10]. Additionally, the power of these technologies and their applications are given in Table 1. Table 2 illustrates other technologies of lamps and their powers, luminosities. LED technologies are also used for lighting streets of cities. The life of LED technologies are defined by estimated time at which LED light output will depreciate to $70 \%$ of its initial rating; often the life time is 100,000-150,000 $\mathrm{h}$ for outdoor luminaires [8]. As clarified in Figure 2, LEDs resort to dim over time rather than tragically failing, like other technologies [11].

\subsection{Street light lamp characteristics}

Table 3 illustrates the characteristics of road light lamps usually used [11].

The main technologies of street lighting system are high pressure sodium lamps (HPS) and electronic ballast, HPS and electromagnetic ballast, and LED lamp. The comparison between these main technologies is shown in Table 4.

\subsection{Distributions, spacing and height of luminaires in the streets}

Table 5 shows the relation between the category of roads and the type of street lighting system and spacing to height ratio (SHR) [7].

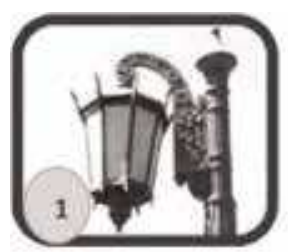

Claremont

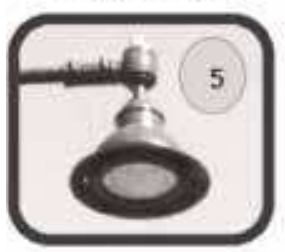

Domus

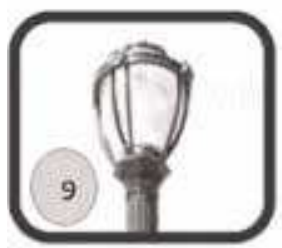

Merriweather

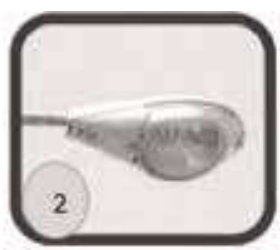

Cobra (L)

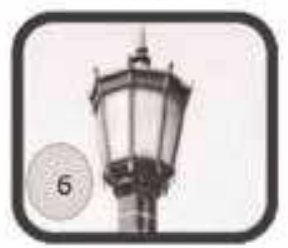

Forrest Park

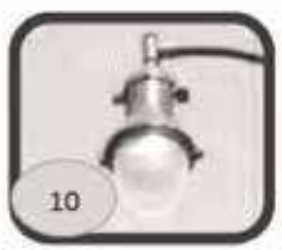

Tear Drop

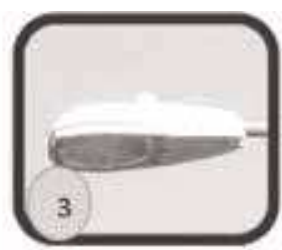

Cobra (S)

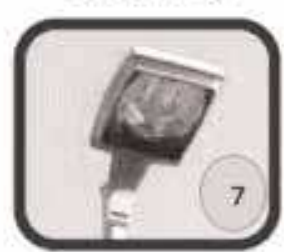

Gull Wing

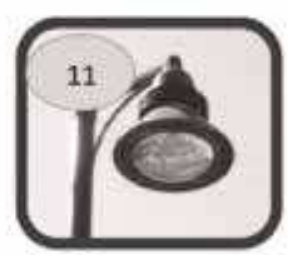

Universe

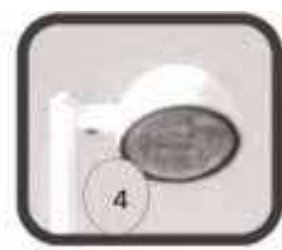

Contemporary

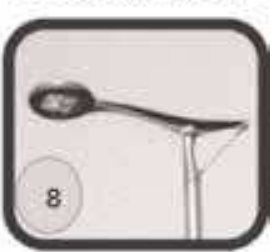

Icon Slide

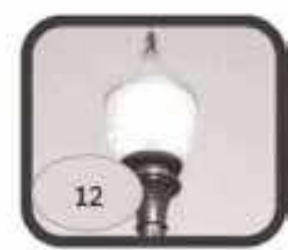

Washington

Figure 1.

12 of different luminaires technologies in the streets of cites. 


\begin{tabular}{lll}
$\begin{array}{l}\text { Luminaire } \\
\text { type }\end{array}$ & Power/type & Application \\
\hline 1 & $70 \mathrm{~W}, 100 \mathrm{~W}$ HPS & Residential street lighting \\
\hline 2 & $200 \mathrm{~W}, 250 \mathrm{~W}, 310 \mathrm{~W}$, & Arterial and/or collector street lighting \\
& $400 \mathrm{~W}$ HPS & \\
\hline 3 & $70 \mathrm{~W}, 100 \mathrm{~W}, 150 \mathrm{~W}$, & Collector and/or residential street lighting \\
\hline 4 & $200 \mathrm{~W}$ HPS & \\
\hline 5 & $400 \mathrm{~W}$ HPS (street side) & $\begin{array}{l}\text { 22” Luminaire-Arterial and/or collector street lighting } \\
\text { 17” Luminaire-Sidewalk side pedestrian lighting }\end{array}$ \\
\hline 6 & $150 \mathrm{~W}$ HPS (house side) & $\begin{array}{l}\text { Domus DMS50-Arterial and/or collector street lighting. } \\
\text { Domus DOS-Residential street lighting and/or Sidewalk } \\
\text { side pedestrian lighting. }\end{array}$ \\
\hline 7 & $250 \mathrm{~W}$ HPS, $150 \mathrm{~W}$, & Residential street lighting and/or pedestrian lighting \\
\hline 8 & $35 \mathrm{~W}, 70 \mathrm{~W}$ HPS & Arterial and/or collector street lighting \\
\hline 9 & $150 \mathrm{~W}, 250 \mathrm{~W}$ HPS & Collector and/or residential street lighting \\
\hline 10 & $35 \mathrm{~W}, 50 \mathrm{~W}, 70 \mathrm{~W}$ HPS & Residential street lighting and/or pedestrian lighting \\
\hline 11 & $35 \mathrm{~W}, 50 \mathrm{~W}, 70 \mathrm{~W}$ HPS & Arterial, collector, or residential street lighting \\
\hline 12 & $70 \mathrm{~W}$ HPS $200 \mathrm{~W}, 250 \mathrm{~W}$ HPS & Residential street lighting and/or pedestrian lighting \\
\hline
\end{tabular}

Ballast voltage: multi-tap 120/240 V, HPS: high pressure sodium.

Table 1.

The power and the applications of technologies in Figure 1.

\begin{tabular}{lcc}
\hline Type of lamp & Power range $(\mathbf{W})$ & Luminosity $\left(\mathbf{l m} / \mathbf{m}^{\mathbf{2}}\right)$ \\
\hline Incandescent & $15-150$ & $9-15$ \\
\hline Fluorescent tube & $18-58$ & $43-76$ \\
\hline Mercury vapor & $50-400$ & $30-49$ \\
\hline High pressure sodium & $50-400$ & $67-128$ \\
\hline Low pressure sodium & $18-180$ & $69-152$ \\
\hline
\end{tabular}

Table 2.

Lamp types and their powers and luminosities [6].

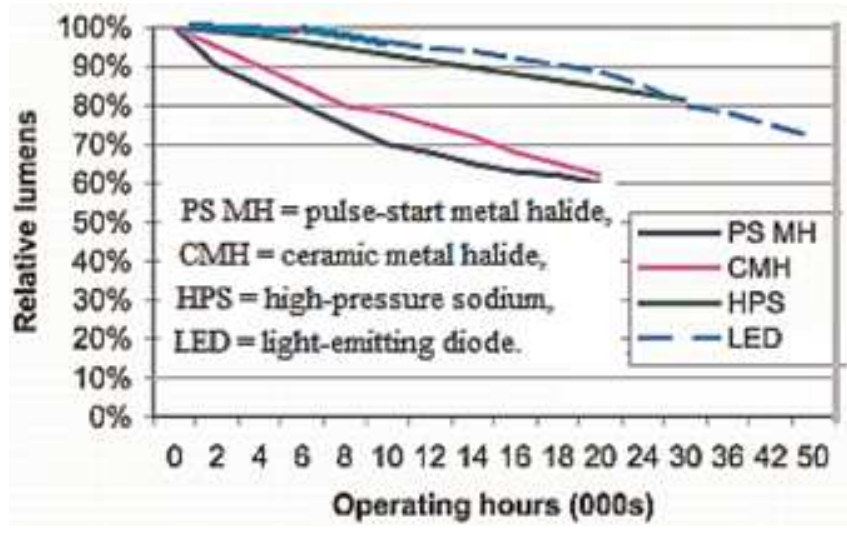

Figure 2.

Lumen depreciation rate for different lighting technologies. 
Improvement the Efficiency of Distribution Network Using an Efficient Lighting System of Streets DOI: $h$ ttp://dx.doi.org/10.5772/intechopen.88959

\begin{tabular}{|c|c|c|c|c|}
\hline Type of lamp & $\begin{array}{l}\text { Luminous } \\
\text { efficacy } \\
(\operatorname{lm} / \mathrm{W})\end{array}$ & $\begin{array}{l}\text { Color } \\
\text { rendering } \\
\text { properties }\end{array}$ & $\begin{array}{l}\text { Lamp } \\
\text { life (h) }\end{array}$ & Remarks \\
\hline $\begin{array}{l}\text { High-pressure mercury } \\
\text { vapor (MV) }\end{array}$ & $35-65$ & Fair & $\begin{array}{c}10,000- \\
15,000\end{array}$ & High energy use, poor lamp life \\
\hline Metal halide (MH) & $70-130$ & Excellent & $\begin{array}{l}8000- \\
12,000\end{array}$ & High luminous efficacy, poor lamp life \\
\hline $\begin{array}{l}\text { Low-pressure sodium } \\
\text { vapor }\end{array}$ & $100-190$ & Very poor & $\begin{array}{l}18,000- \\
24,000\end{array}$ & $\begin{array}{l}\text { Energy-efficient, very poor color } \\
\text { rendering }\end{array}$ \\
\hline $\begin{array}{l}\text { Low-pressure mercury } \\
\text { fluorescent tubular } \\
\text { lamp (T12 and T8) }\end{array}$ & $30-90$ & Good & $\begin{array}{c}5000- \\
10,000\end{array}$ & $\begin{array}{l}\text { Poor lamp life, medium energy use; } \\
\text { only available in low wattages }\end{array}$ \\
\hline $\begin{array}{l}\text { Energy-efficient } \\
\text { fluorescent tubular } \\
\text { lamp (T5) }\end{array}$ & $100-120$ & Very good & $\begin{array}{l}15,000- \\
20,000\end{array}$ & $\begin{array}{l}\text { Energy-efficient, long lamp life; only } \\
\text { available in low wattages }\end{array}$ \\
\hline $\begin{array}{l}\text { Light-emitting diode } \\
\text { (LED) }\end{array}$ & $70-160$ & Good & $\begin{array}{l}40,000- \\
90,000\end{array}$ & $\begin{array}{c}\text { High energy savings, low maintenance, } \\
\text { long life, no mercury; high investment } \\
\text { cost, nascent technology }\end{array}$ \\
\hline
\end{tabular}

Table 3.

Typical streetlight lamp characteristics.

\begin{tabular}{|c|c|c|}
\hline LED lamp & $\begin{array}{l}\text { HPS lamp and } \\
\text { electronic ballast }\end{array}$ & HPS and electromagnetic ballast \\
\hline $\begin{array}{l}\text { - Long operating life } \\
\text { (50,000 h life with } 70- \\
80 \% \text { lumen maintenance) } \\
\text { - Very low power } \\
\text { consumption } \\
\text { - Low installation and } \\
\text { maintenance costs } \\
\text { - Harmonized illumination } \\
\text { - High efficiency } \\
\text { - Dimming possibilities } \\
\text { - Contain no hazardous } \\
\text { materials } \\
\text { - Low temperature and } \\
\text { function well in cold } \\
\text { temperatures } \\
\text { - Good vibration resistant } \\
\text { characteristics } \\
\text { - Quick start and re-start (do } \\
\text { not need to firstly cool the } \\
\text { - Lystem as with HID) } \\
\text { - Fow glare and strobe-free } \\
\text { - Possible use with } \\
\text { renewable energies }\end{array}$ & $\begin{array}{l}\text { - Long lifetime (from } \\
40,000 \text { to } 60,000 \mathrm{~h} \text { ) } \\
\text { - Increased lamp life } \\
\text { (on average up to } \\
30 \% \text { longer lamp } \\
\text { life) } \\
\text { - No flickering effect } \\
\text { - Dimmable } \\
\text { - High efficiency (up } \\
\text { to } 15 \% \text { savings) } \\
\text { - Non audible noise } \\
\text { - Low weight } \\
\text { - Energy saving (up to } \\
\text { 13\%) } \\
\text { - Relatively expensive } \\
\text { - Not } \\
\text { environmentally } \\
\text { friendly }\end{array}$ & $\begin{array}{l}\text { - Long lifetime (>30 years at } \\
105^{\circ} \mathrm{C} \text { ) } \\
\text { - Low cost } \\
\text { - Suitable for extreme weather } \\
\text { conditions (humidity, } \\
\text { temperature variation, } \\
\text { lightning) } \\
\text { - Recyclable materials (magnetic } \\
\text { chokes are recyclable) } \\
\text { - Self-recovery feature (when } \\
\text { the ac mains voltage recovers } \\
\text { - Verter a disturbance) } \\
\text { - Not dimmable } \\
\text { - Not energy saving } \\
\text { - Flickering effect } \\
\text { - No constant light output }\end{array}$ \\
\hline
\end{tabular}

Table 4 .

Characteristics of lamp technologies [12].

Replacing lighting fixture/luminaire; new fixtures are generally luminous more efficient, which allows light sources with lower power to be used. Figure 3 shows IESNA outdoor fixture types classifying the distributions for spacing luminaires [8]. 


\begin{tabular}{llll}
\hline $\begin{array}{l}\text { Road } \\
\text { category } \\
\text { specification }\end{array}$ & Fast traffic & Mixed traffic & Slow traffic \\
\hline Lamps used & $\begin{array}{l}\text { almost uniquely } \\
\text { sodium lamps }\end{array}$ & $\begin{array}{l}\text { Mainly sodium and } \\
\text { high pressure } \\
\text { mercury lamps }\end{array}$ & $\begin{array}{l}\text { Mainly sodium and mercury lamps are } \\
\text { used and to lesser degree compact } \\
\text { fluorescent and metal halide lamps }\end{array}$ \\
\hline $\begin{array}{llll}\text { Power of } \\
\text { lamps used }\end{array}$ & $\begin{array}{l}\text { 150 W, 250 W HPS } \\
\text { and 131 W, 135 W and }\end{array}$ & $\begin{array}{l}\text { 250 W, 400 W } \\
\text { HPM and 100 W, }\end{array}$ & $\begin{array}{l}\text { 125 W HPM, 50 W, 70 W HPS, 70 W } \\
\text { 150 W, 250 W HPS }\end{array}$ \\
\hline $\begin{array}{l}\text { Spacing/ } \\
\text { height of } \\
\text { pole ratio } \\
\text { (SHR) }\end{array}$ & $\begin{array}{l}\text { Approximately equal } \\
\text { to 4 (e.g., 90/20, 60/ }\end{array}$ & $\begin{array}{l}\text { Varies between 4.5 } \\
\text { and 3 (e.g., 45/10, }\end{array}$ & $\begin{array}{l}\text { Between 5 and 4 (e.g., 40/8, 36/8, 25/5, } \\
\text { 30/7, 20/4) }\end{array}$ \\
\hline
\end{tabular}

Table 5 .

Type of street lighting system and spacing of poles to their height.

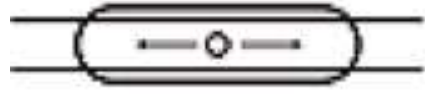

TYPE I

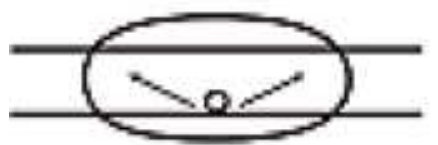

TYPE III

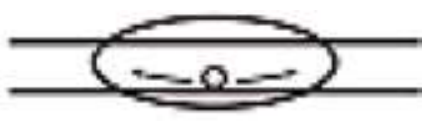

TYPE II

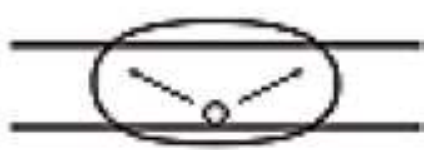

TYPE IV

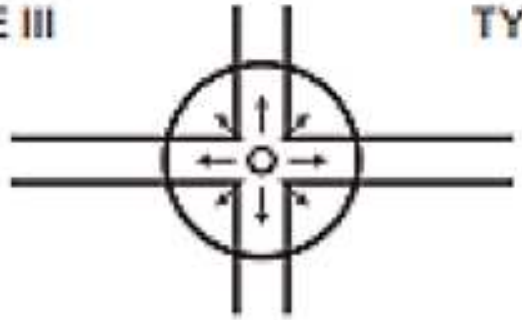

TYPE V

Figure 3 .

IESNA outdoor lighting distribution types $I-V$.

\section{Streets and tunnel lighting control}

The block diagram of street light system as given in Figure 4 composes of microcontroller, LDR, and photoelectric sensor. By using the LDR we can control and drive the lights of streets. The system of a smart street lighting system is illustrated in Figure 5 by a simplified block diagram. The system includes a microcontroller module for regulating, sensing and controlling the lighting system. This system also has different sensors, a voltage regulation circuit, a LCD and GSM/ GPRS module.

With a view to meet the demands of tunnel lighting and energy-saving preferable, stepless control method is arranged in the tunnel lighting control system. The control system is formed of vehicle detectors, data converters, luminance detectors, lighting control computer, dimming controllers and LED lamps. Figure 6 shows the block of the tunnel control system [15]. 
Improvement the Efficiency of Distribution Network Using an Efficient Lighting System of Streets DOI: http://dx.doi.org/10.5772/intechopen.88959

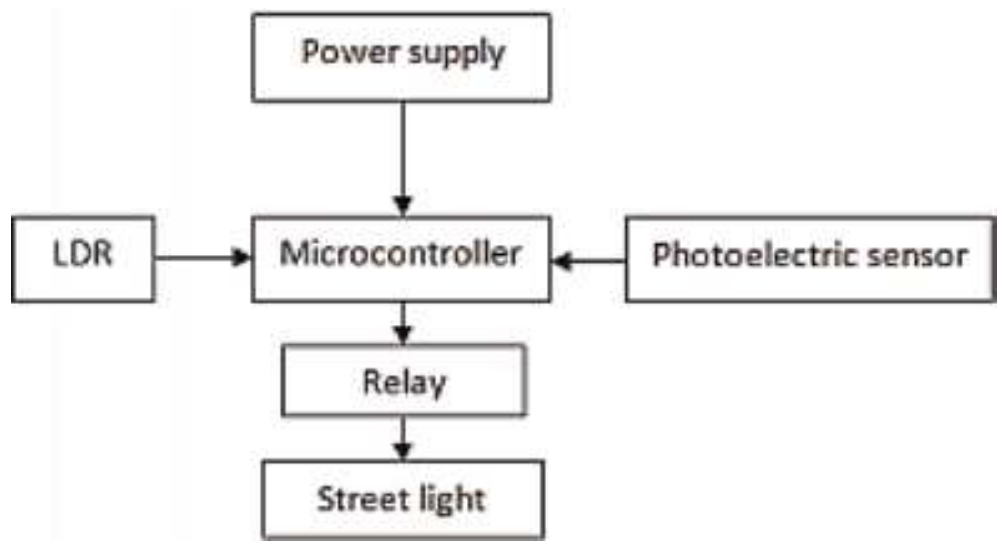

Figure 4.

Block diagram of the control of street light system [13].

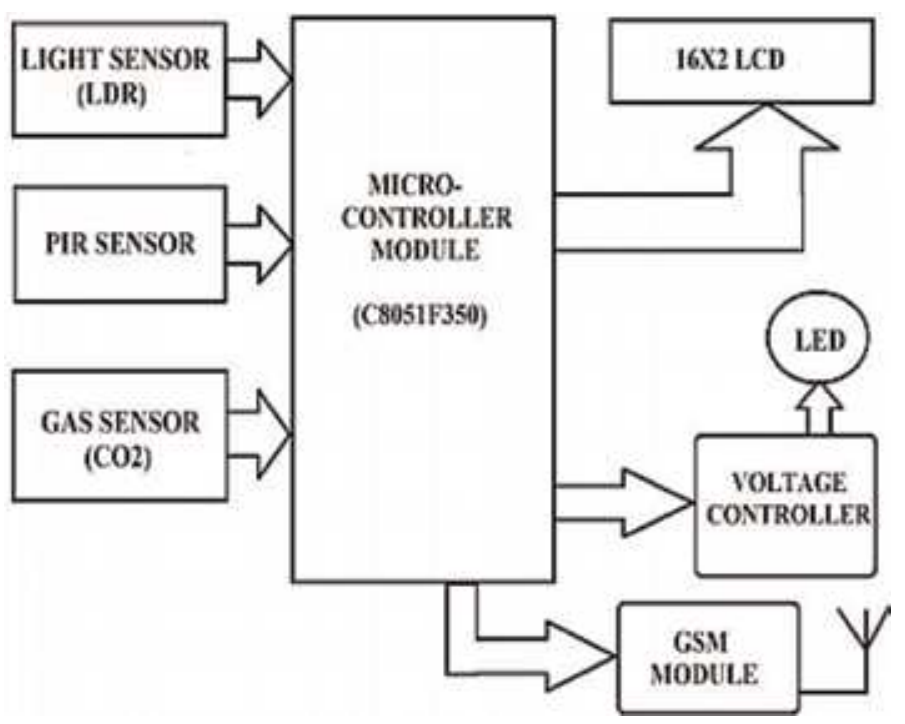

Figure 5.

Block diagram for control smart street lighting system [14].

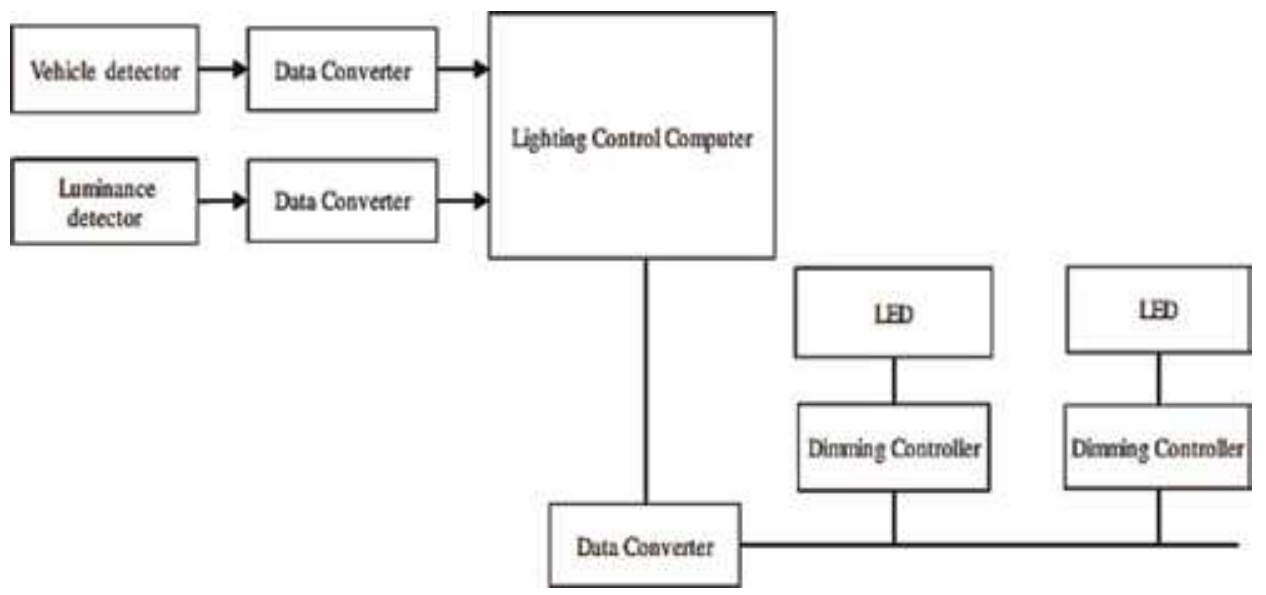

Figure 6.

Block diagram of tunnel lighting control system. 


\section{Active power losses in road lighting installation}

The lighting circuit consists of the following components: the power cable protection in the lighting panel board, relay dimming by astronomical clock (or other dimming device), three-phase feeder wiring, the pole protection, the wire connecting the pole plate with luminaire, and the luminaire. Figure 7 shows, schematically, an example of a road lighting installation with the main components [5].

The total power loss of the lighting installation $\triangle P_{\text {TOTAL }}$ can be determined from the following relationship:

$$
\Delta P_{T O T A L}=\Delta P_{C A B L E}+\Delta P_{N E U T R A L}+\Delta P_{\text {WIRE }}+\Delta P_{P P B}+\Delta P_{P P O L E}+\Delta P_{R E L A Y}
$$

where, $\Delta P_{T O T A L}$ total losses of active power, $(\mathrm{W}) ; \triangle P_{C A B L E}$ losses of active power in three (one) phase feeder wiring, $(\mathrm{W}) ; \triangle P_{\text {NEUTRAL }}$ losses of active power in neutral conductor, $(\mathrm{W}) ; \Delta P_{\text {WIRE }}$ losses of active power in wire in the pole, $(\mathrm{W})$; $\triangle P_{P P B}$ losses of active power in protection in the lighting panel board, $(\mathrm{W}) ; \triangle P_{P P O L E}$ losses of active power in protection in the pole, (W); $\Delta P_{R E L A Y}$ losses of active power in relay, $(\mathrm{W})$.

The following factors have a decisive influence on the network losses: level of luminaries dimming, network configuration (single or three phases) and number of light points. Thus, the total losses in the lighting system for the three-phase network, as defined by the Eq. (1), can be estimated as:

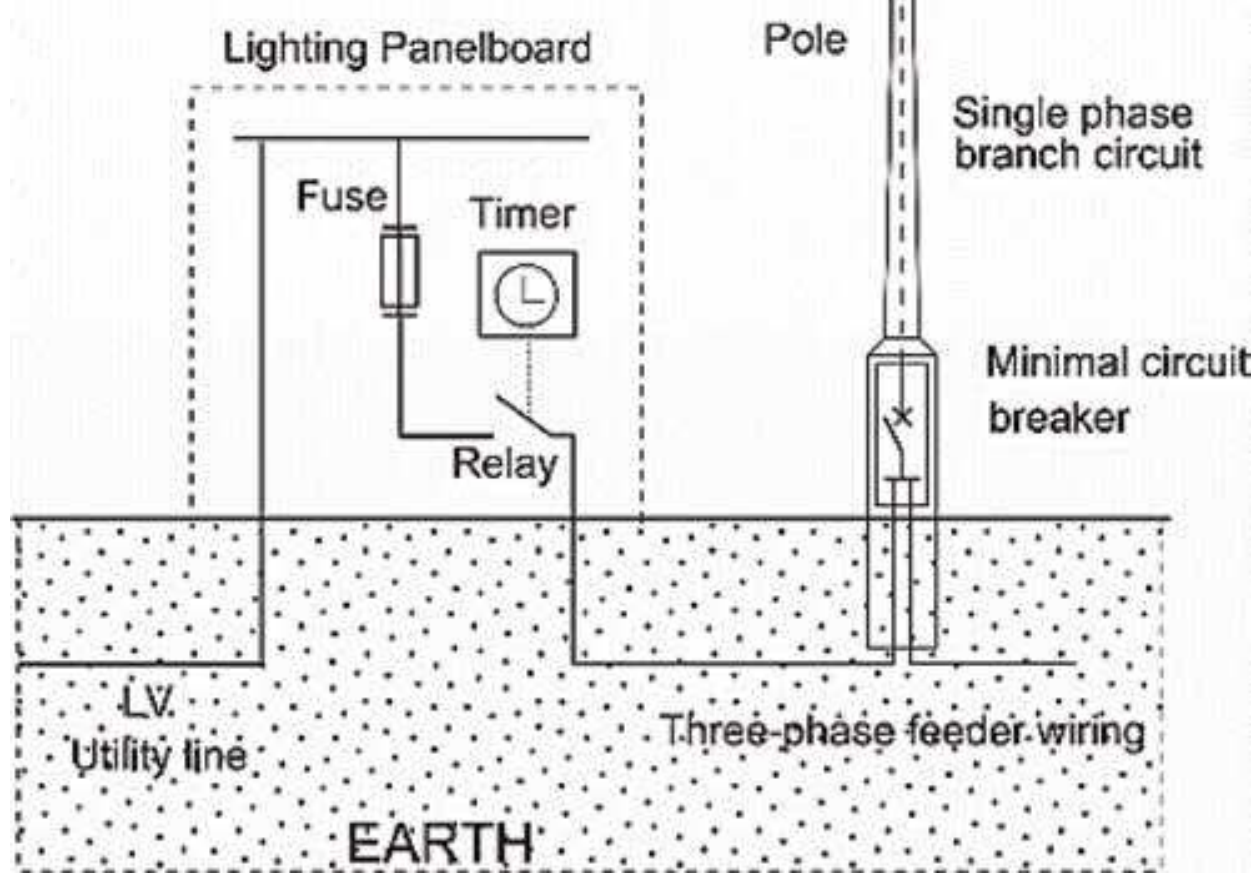

Figure 7.

Example of a road lighting installation. 


$$
\begin{gathered}
\Delta P_{\text {TOTAL }} \cong k_{\text {red }} \cdot\left[\frac{3 l}{\gamma_{C} S_{C}}\left[n^{2}\left(\frac{l_{01}+l}{l}\right)+\frac{n(n-1)(2 n-1)}{2}\right] I_{\text {Lum }}^{2}+\frac{2 l_{P W}}{\gamma_{P W} S_{P W}} I_{\text {Lum }}^{2}\right] \text { for } n_{p} \leq 3 \\
\Delta P_{\text {TOTAL }} \cong k_{\text {red }} \cdot \frac{3 l}{\gamma_{C} S_{C}}\left[n^{2}\left(\frac{l_{01}+l}{l}\right)+\frac{n(n-1)(2 n-1)}{2}\right] I_{\text {Lum }}^{2} \text { for } n_{p}>3
\end{gathered}
$$

In the case of single-phase networks,

$$
\begin{gathered}
\Delta P_{\text {TOTAL }} \cong k_{\text {red }} \cdot\left[\frac{2 l}{\gamma_{C} S_{C}}\left[n^{2}\left(\frac{l_{01}}{l}\right)+\frac{n(n-1)(2 n-1)}{6}\right] I_{\text {Lum }}^{2}+\frac{2 l_{P W}}{\gamma_{P W} S_{P W}} I_{\text {Lum }}^{2}\right] \text { for } n_{p} \leq 3 \\
\Delta P_{\text {TOTAL }} \cong k_{\text {red }} \cdot \frac{2 l}{\gamma_{C} S_{C}}\left[n^{2}\left(\frac{l_{01}}{l}\right)+\frac{n(n-1)(2 n-1)}{6}\right] I_{\text {Lum }}^{2} \text { for } n_{p}>3
\end{gathered}
$$

where the reduction factor $k_{\text {red }}$ is the coefficient of slope of the dimming characteristic. The dimming characteristic of the luminaire are the relation of the active power of the luminaire to the degree of dimming. $l_{01}$ is the distance of the first luminaire from the lighting switchboard, $(\mathrm{m}) ; l$ is the distance between poles, $(\mathrm{m})$; $\gamma_{C}$ is the electrical conductivity of feeder wiring, $\left(\mathrm{m} / \Omega \mathrm{mm}^{2}\right) ; S_{C}$ is the cross-section of feeder wiring, $\left(\mathrm{mm}^{2}\right) ; n$ is the number of luminaires per phase; $n_{p}$ is the number of lighting points (luminaires); $I_{L u m}$ is the RMS value of luminaire current, (A); $l_{P W}$ is the length of the wire that connects the pole switchboard to the luminaire, $(\mathrm{m})$; $\gamma_{P W}$ is the electrical conductivity of the wire connects the pole switchboard to the luminaire $\left(\mathrm{m} / \Omega \mathrm{mm}^{2}\right)$; and $S_{P W}$ is the cross-section of the wire connecting the pole switchboard to the luminaire, $\left(\mathrm{mm}^{2}\right)$.

Figure 8 shows an example of daily dimming characteristic. The times of switching on $\left(t_{\text {on }}\right)$ and off $\left(t_{\text {off }}\right)$ the luminaires were determined using astronomical tables of sunrises and sunsets in an installations area for luminaires.

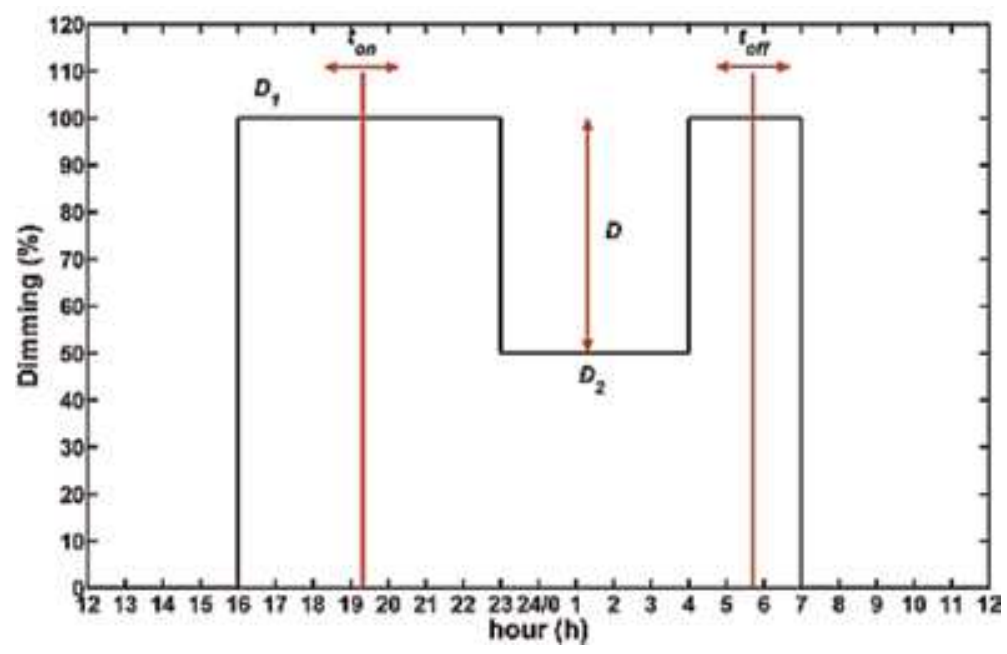

Figure 8.

Daily dimming characteristic of luminaire. 


\section{Case study and results}

\subsection{Case study}

A luminaire LUM has rated power of $140 \mathrm{~W}$ was equipped with a wireless power and luminous flux dimming system. The dimming was carried out using a program implemented on the server. The program enabled the dimming of the luminaire in the range from 10 to $100 \%$. The electrical and photometric curves of tested luminaire is given in Figure 9. The calculations presented in Sections 5.2 and 5.3 are made for a given distance between the poles reaching to $30 \mathrm{~m}$.

\subsection{Active power losses calculation results of three-phase lighting system}

The dependence of the percentage of total active power losses on the number of luminaires and dimming is shown in Figure 10. Losses at the point of light are greater in the entire dimming range than the total losses in other parts of the installation. The total percentage of $\triangle P_{T O T A L}$ in a system of 30 luminaires ranges from $0.55 \%$ for dimming $10 \%$ to $1.17 \%$ for dimming $100 \%$.

\subsection{Active power losses calculation results of a single-phase lighting system}

The dependence of $\triangle P_{\text {TOTAL }}$ as a function of the number of luminaires and dimming is shown in Figure 11. The total percentage of $\Delta P_{T O T A L}$ in a system of 30 luminaires range from $2.850 \%$ for dimming $=10 \%$ to $6.689 \%$ for dimming $=100 \%$.

\subsection{Estimation of active power losses for different distances between poles}

The results of power losses for street lighting systems with 3 and 30 luminaires as function of distance between the poles are given in Figures 12 and 13,

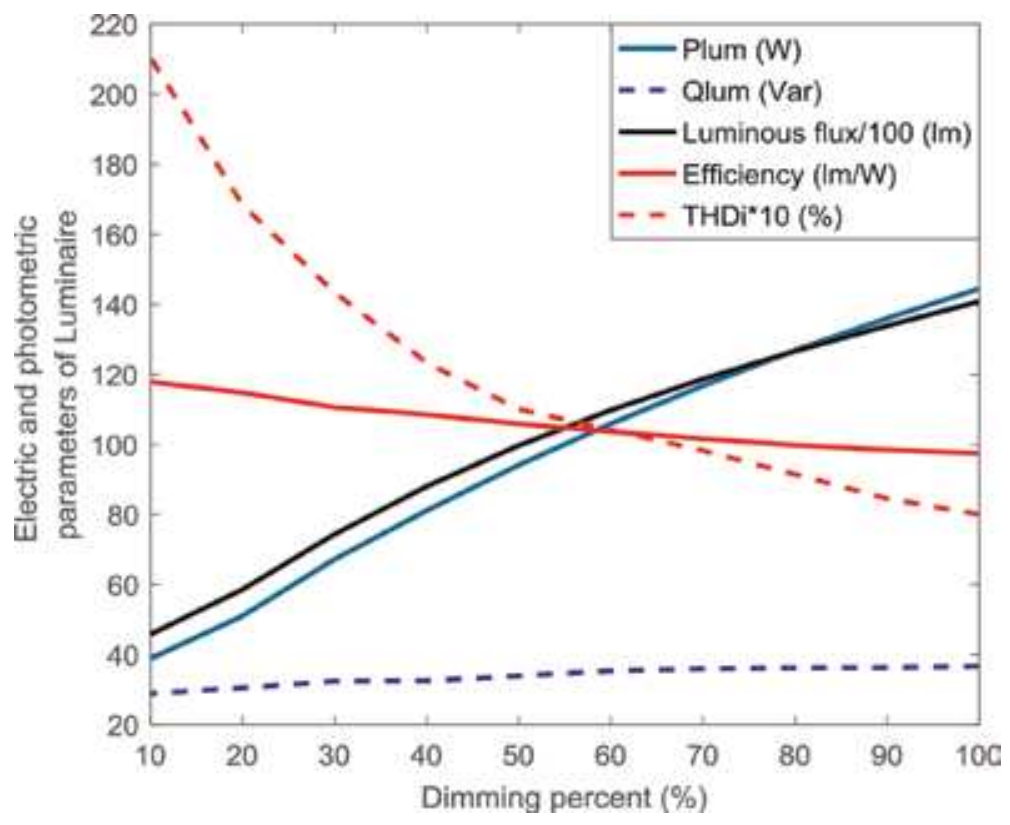

Figure 9.

Electrical and photometric curves of tested luminaire (LUM). 
Improvement the Efficiency of Distribution Network Using an Efficient Lighting System of Streets DOI: http://dx.doi.org/10.5772/intechopen.88959

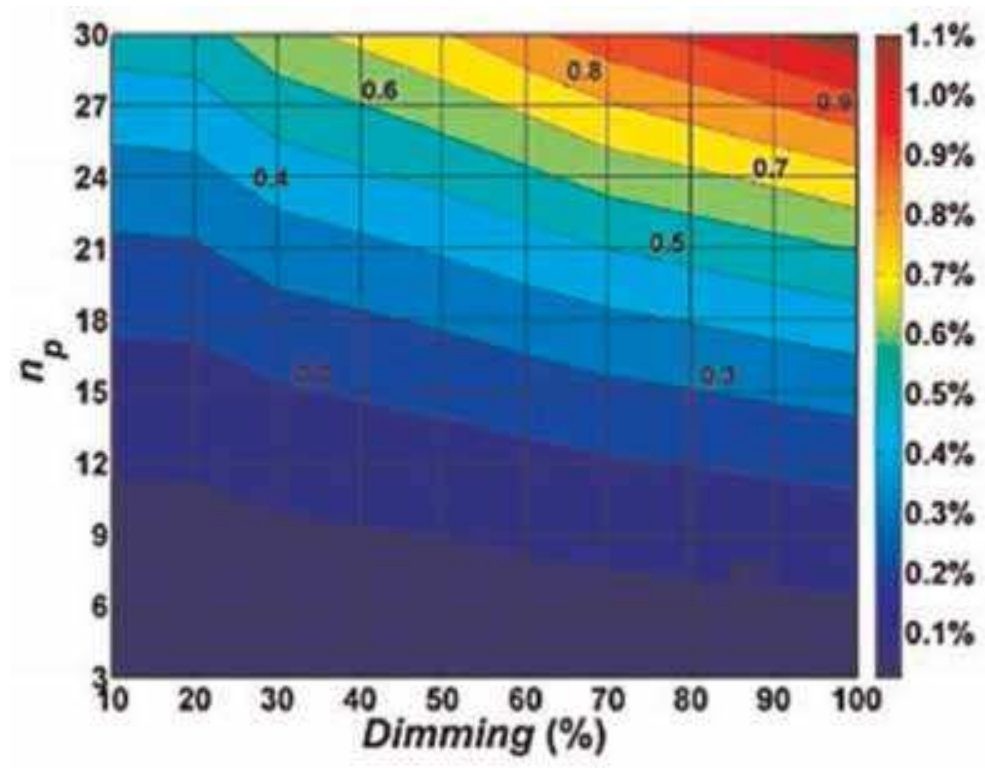

Figure 10.

Dependence of total active power losses $\triangle P_{\text {TOTAL }}$ in relation to the dimming and the number of poles $n_{p}$ for LUM [5].

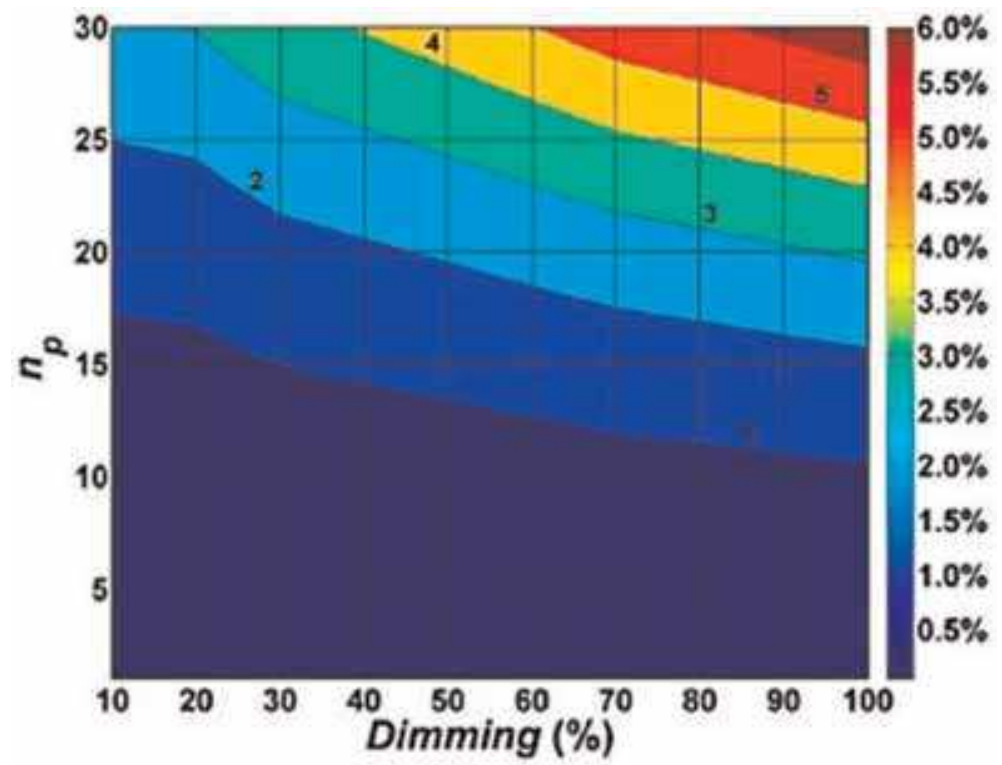

Figure 11.

Dependence of total active power losses $\triangle P_{\text {TOTAL }}$ in relation to the dimming and the number of poles $n_{p}$ for LUM [5].

respectively. The total losses percentage increase by increasing the distance between the poles as well as increasing in the dimming value lead to increase the active loss. In addition three phase lighting system has losses less than single phase system. Table 6 shows the relation between rated power of luminaires and total power losses in single and three phase system, where the number of lighting in streets is 30 luminaire at dimming $100 \%$ and $l=10=30 \mathrm{~m}$. SC $=4 \times 25 \mathrm{~mm}^{2}$, $\gamma \mathrm{C}=34 \mathrm{~m} / \Omega \cdot \mathrm{mm}^{2}$. 


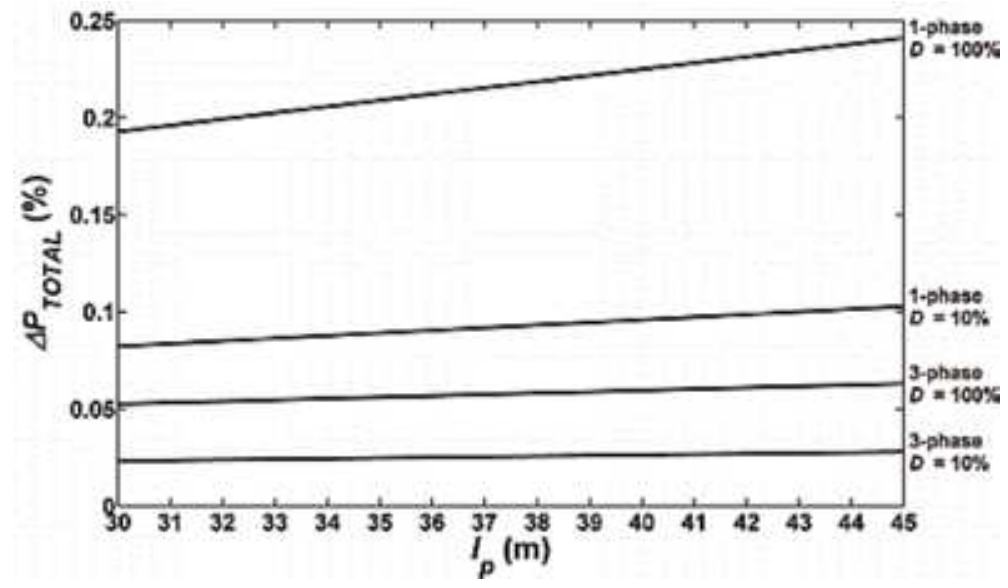

Figure 12.

Relative total power losses in relation to the distance between poles for circuit consisting of three luminaires [5].

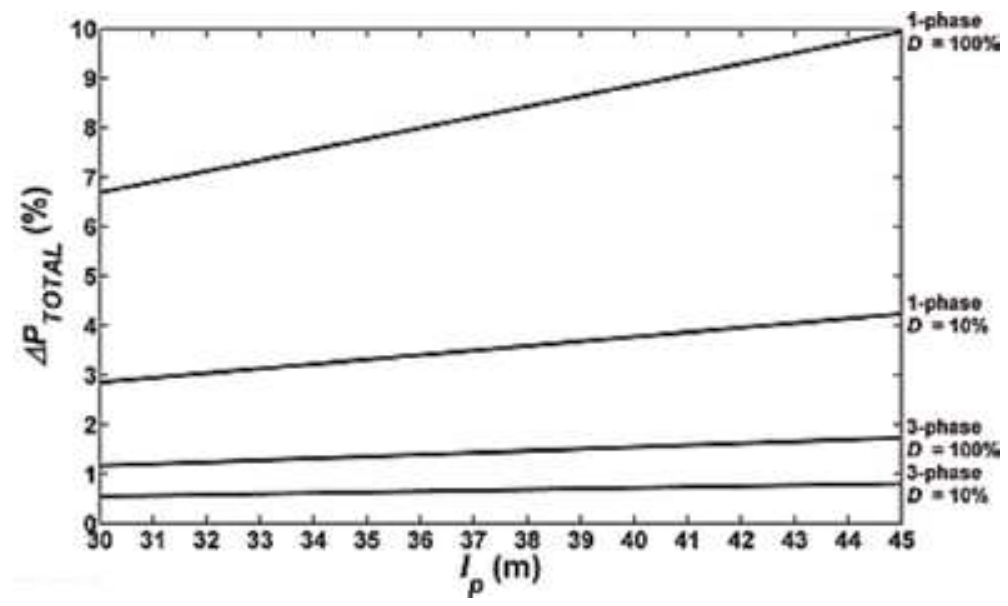

Figure 13.

Relative total power losses in relation to the distance between poles for circuit consisting of 30 luminaires [5].

\begin{tabular}{lcc}
\hline $\begin{array}{l}\text { Rated power of luminaire } \\
(\mathrm{W})\end{array}$ & $\begin{array}{c}\Delta \boldsymbol{P}_{\text {TOTAL }} \\
\text { three phase system } \\
(\mathrm{W})\end{array}$ & $\begin{array}{c}\Delta \boldsymbol{P}_{\text {TOTAL }} \text { single phase system } \\
\text { (W) }\end{array}$ \\
\hline 32 & 2.851 & 16.023 \\
\hline 85 & 16.308 & 92.687 \\
\hline 140 & 50.608 & 289.914 \\
\hline
\end{tabular}

Table 6.

Active power losses for lighting street by 30 luminaire at dimming $100 \%$ and $l=10=30 \mathrm{~m}, S C=4 \times 25 \mathrm{~mm}^{2}$, $\gamma C=34 \mathrm{~m} / \Omega \cdot \mathrm{mm}^{2}$.

\section{Conclusion}

Increasing the efficiency and reduction the active loss are very significant aim in each distribution network. Lighting grid is a one of main parts in distribution grid and reduction active loss in it is the main aim of this chapter. Different technologies 
Improvement the Efficiency of Distribution Network Using an Efficient Lighting System of Streets DOI: http://dx.doi.org/10.5772/intechopen.88959

for lighting streets and tunnels were discussed in this chapter, while the results indicate the sodium lamp and LED are the efficient technologies. Control unit for management the dimming of luminaire and using three phase lighting system instead of single phase get better the efficiency of street lighting system. The numbers of luminaire, the distance between poles, wires conductivity, environmental conditions, and category of streets are other factors can effect on the value of active loss reduction.

\section{Author details}

Nassim Iqteit $^{1 *}$ and Khalid Yahya ${ }^{2}$

1 Palestine Polytechnic University, Hebron, Palestine

2 Istanbul Gelisim University, Istanbul, Turkey

*Address all correspondence to: nassim_eng83@ppu.edu; nassimiqteit@gmail.com

\section{IntechOpen}

(C) 2020 The Author(s). Licensee IntechOpen. Distributed under the terms of the Creative Commons Attribution - NonCommercial 4.0 License (https://creativecommons.org/ licenses/by-nc/4.0/), which permits use, distribution and reproduction for non-commercial purposes, provided the original is properly cited. (cc) BY-NC 


\section{References}

[1] Pinto MF, Soares GM, Mendonça TRF, Almeida PS, Braga HAC. Smart modules for lighting. In: Proceedings of the 2014 11th IEEE/IAS International Conference on Industry Applications; 7-10 December 2014; Juiz de Fora, Brazil; 2014

[2] Todorović BM, Samardžija D. Road lighting energy-saving system based on wireless sensor network. Energy Efficiency. 2017;10:239-247

[3] Ozadowicz A, Grela J. Energy saving in the street lighting dimming systemA new approach based on the EN-15232 standard. Energy Efficiency. 2017;10: 563-576

[4] Kostic M, Djokic L. Recommendations for energy efficient and visually acceptable street lighting. Energy. 2009;34:1565-1572

[5] Sikora R, Markiewicz P, Pabjańczyk W. The active power losses in the road lighting installation with dimmable LED luminaires. Sustainability. 2018;10(12): 4742. DOI: $10.3390 /$ su10124742

[6] Energy Efficiency in Transport Infrastructure and Street lighting, Markus Radocha and Birgit Baumgartner form the Grazer Energieagentur Ges.m.b.H. GEA, Graz Austria. Available from: https://www. eltis.org/resources/training/energyconservation-through-urban-design [Published: 31 December 2005; Accessed: 30 July 2019]

[7] Contract TREN/D1/40-2005/LOT9/ S07.56457 Preparatory Studies for Ecodesign Requirements of EuPs Final Report Lot 9: Public Street Lighting. Available from: http://www.eup4light.net/assets/ pdffiles/Final/VITOEuPStreetLighting Final.pdf [Accessed: 30 July 2019]

[8] LED Application Series: Outdoor Area Lighting. Available from: https://www. energy.gov [Accessed: 30 July 2019]
[9] Buraczynski JJ, Li TK, Kwong C, Lutkevich PJ. Tunnel lighting systems. In: Fourth International Symposium on Tunnel Safety and Security; 17-19 March 2010; Frankfurt am Main, Germany; 2010

[10] Godinez R, Saunders B, Clanton D, $\mathrm{Hu}$ J. Oakland Street Light Design Manual. City of Oakland. [Online] Available from: https://www.oaklandca. gov/documents/street-lighting-designmanual [Accessed: 29 August 2019]

[11] Bank AD. LED Street Lighting Best Practices: Lessons Learned from the Pilot LED Municipal Streetlight and PLN Substation Retrofit Project (Pilot LED Project) in Indonesia. Manila, Philippines: Asian Development Bank; 2017

[12] Gil-De-Castro A, Moreno-Munoz A, Larsson A, Rosa JDL, Bollen M. LED street lighting: A power quality comparison among street light technologies. Lighting Research \& Technology. 2012;45(6):710-728. DOI: $10.1177 / 1477153512450866$

[13] Saad M, Farij A, Salah A, Abdaljalil A. Automatic street light control system using microcontroller. In: 1st International Conference on Machine Design and Automation; Turkey; 2013. pp. $92-96$

[14] Malhotra S, Kumar V. Smart street lighting system: An energy efficient approach. International Journal of Science and Research (IJSR). 2016;5(2): 1082-1085. DOI: $10.21275 / v 5 i 2$. nov161312

[15] Fan S, Yang C, Wang Z. Automatic control system for highway tunnel lighting. In: Li D, Liu Y, Chen Y, editors. CCTA. Heidelberg: Springer; 2010. pp. 116-123. DOI: $10.1007 / 978-3-$ 642-18369-0_14. IAICT. 2011; 347 


\title{
Energy Efficiency of the Road Lighting: The Impact of Active Power Losses on Energy Performance Indicators and Electricity Costs
}

\author{
Roman Sikora and Przemystaw Markiewicz
}

\begin{abstract}
Improving the energy efficiency of road lighting is currently one of the most important issues. One of the methods of improving energy efficiency is the use of dimmable luminaires. In order to be able to compare the energy efficiency of different technical solutions, EN 13201-5 introduces energy performance indicators for road lighting installations. The chapter describes energy performance indicators for road installation and the impact of active power losses on these indicators and electricity costs. In order to accurately calculate the above indicators, the active power losses in the elements of the lighting installation should be taken into account. The chapter presents the dependencies which can be used to calculate the active power losses in single- and three-phase systems. In addition, an example of calculation of energy performance indicators, active power and energy losses and electricity costs is provided. The calculation was made for an exemplary installation of road lighting with dimmable luminaires. The analysis was done for single-phase and three-phase installations.
\end{abstract}

Keywords: road lighting, energy performance indicators, cost of electricity consumption, LED luminaire, active power losses, EN 13201

\section{Introduction}

Road lighting is one of the basic elements of a road infrastructure. Proper lighting of the road (also in conflict zones with an intersection of pedestrian and motor traffic as well as in zones intended for pedestrian traffic, cycling and slowmoving vehicles) is an important element of road safety. Quantitative and qualitative lighting requirements for areas and road zones are characterised by a lighting class. The requirements for road lighting apply only to night hours. They may be subject to change at different times of the night and in different seasons. The EN 13201 [1-5] standards allow the use of different lighting classes for particular time periods of the lighting operation, e.g., depending on the traffic volume. Lowering the lighting class means reducing the requirements for lighting parameters such as 
luminance (or illuminance), longitudinal and overall uniformity and threshold increment. It is therefore possible to reduce the luminous flux of the luminaire by reducing the luminaire's power.

The luminous flux of the luminaires can be changed step by step or smoothly over a wide range. However, the depth of the reduction of the luminous flux should be limited to the level at which the requirements of EN 13201 [1-5] are fulfilled. The highest possible energy savings must not deteriorate road safety. The literature describes a number of solutions for power regulation in lighting installations [6-11]. Lighting control systems can be divided into two groups. The first group concerns the use of individual controllers equipped with astronomical clocks in the luminaires, which automatically adjust the lighting time to sunrise and sunset, implementing the most frequently set work schedules. The use of additional sensors responding to natural light, traffic, etc. increases the functionality of the lighting installation by reacting dynamically to changing surrounding conditions. The second group concerns a central controller that supports a group of luminaires or individual circuits, which is installed, e.g., in a lighting switchboard. It can also be an IT system that is part of the Smart City system, centrally managing lighting installations [11-14]. The main aim of power reduction is to improve the energy efficiency of road lighting [15-20]. This is equivalent to decreasing the electric energy consumption and $\mathrm{CO}_{2}$ emissions [15]. It should be remembered that the overall aim of road lighting is to ensure road safety, not to obtain maximum energy savings.

The flow of current through the elements of the mains causes power and energy losses. Losses of power and energy may indicate financial and technical losses. Financial losses are understood as an increase of operational costs and technical losses as an increase of electricity consumption [12, 20-24]. Power losses in road lighting installations depend, among other things, on the network system (singlephase, three-phase network), the complexity of the network (number of circuits and lighting luminaires) and the used power supply devices. In the case of road lighting installations, power losses occur primarily in such elements as supply cables (wires) and protection and control devices $[25,26]$. When calculating the electricity consumption during the design phase of a lighting installation, power losses are often omitted. This results in an undervaluation of electricity costs compared to real consumption. Analyses of energy efficiency and operating costs of lighting installations usually neglect the aspects of reactive power [27]. The first one is related to the occurrence of active power losses due to the reactive power flow. The second aspect concerns the dependence of the reactive power of the luminaire on the power and/or control conditions. The level of losses also depends on the occurrence of higher harmonics of the supply current [28-33]. The increasingly common use of dimmable luminaires, especially LED luminaires, in road lighting means that energy consumption and energy losses depend on the lighting time and the level of luminaire power reduction. Previously, energy consumption and power losses were calculated on the assumption that the luminaire consumes constant power. During the measurements of dimmable LED luminaires, a strong dependence of the power factor (reactive power) was observed, along with an increase of the higher harmonic values at the change of the level of control. Calculations of active power losses and energy consumption should be carried out for the assumed lighting schedule.

The chapter presents the method of calculating active power losses, energy performance indicators and electricity costs in road lighting installations. The described method may be used for analysis of installations with dimmable luminaires. The usefulness of the method is presented on the example of the analysis of road lighting installation with dimmable luminaires. 


\section{Energy performance indicators according to EN 13201-5 standard}

The EN 13201-5 [5] standard defines two energy efficiency indicators for road lighting: the power density indicator (PDI) $D_{P}$ and the annual energy consumption indicator (AECI) $D_{E}$. These indicators can be used to estimate the potential savings achieved by improving energy performance and reducing the environmental impact of road lighting. The defined PDI and AECI indicators are used to compare the energy performance of different variants of road lighting design. The comparison of the energy performance indicators for the different design variants of the road lighting installation is possible with the assumption of identical installation geometry. This is a limitation of the use of PDI and AECI indicators. These indicators can be applied to all traffic areas (lighting classes M, C and $\mathrm{P}$ ). The power density indicator (PDI) $D_{P}$ determines the amount of energy needed to provide adequate road lighting in accordance with the applicable EN 13201-1 [1] and EN 13201-2 [2] standards. It is calculated as the quotient of the $P$ power of the lighting installation and the sum of the products of the average lighting intensity on the horizontal plane of the area to be lit Eq. (1):

$$
D_{P}=\frac{P}{\sum_{i=1}^{n}\left(E_{i}^{a h} \cdot A_{i}\right)}
$$

According to EN 13201-2 [2], it is possible to reduce the lighting requirements of a road during a period of reduced traffic, i.e., to change the lighting class of a road, e.g., from M3 to M4. In this case, the power density indicator shall be calculated individually for road classes M3 and M4.

The annual energy consumption indicator (AECI) $D_{E}$ determines the annual electricity consumption during the year. Its value is calculated as follows Eq. (2):

$$
D_{E}=\frac{\sum_{j=1}^{m}\left(P_{j} \cdot t_{j}\right)}{A}
$$

EN 13201-5 [5] standard recommends the use of PDI and AECI together. The best variant of road lighting is when both of these indicators have minimum values.

The system power $P$ should be calculated as the sum of all the equipment necessary to light the road or road section. System power $P$ is defined as

$$
P=\sum_{k=1}^{n_{l p}} P_{k}+P_{a d}
$$

In the case of dimmable luminaires according to EN 13201-5 [5], the power reduction factor $k_{\text {redP }}$ can be introduced. The power reduction factor $k_{\text {redP }}$ determines the degree of luminaire dimming. It accepts values from 0 to 1 . For a reduction factor of $k_{\text {redP }}=1$, the luminaire is set to the maximum level $(100 \%)$ and operates at maximum power and maximum luminous flux. The standard recommends the adoption of a reduction factor for the system power of the whole lighting installation. This is not entirely correct, because the power of the $P_{a d}$ additional devices may not change as the dimming level of luminaire changes or may change in any other way. A second reduction factor may therefore be introduced to take into account changes of additional equipment power with function of dimming change $k_{\text {red }}$ ad. It can take values from 0 to 1 . Therefore, the power of the lighting installation for the $j^{\text {th }}$ period of operation can be calculated as 


$$
P=\sum_{k=1}^{n_{l p}} k_{r e d P} P_{k}+k_{r e d}^{a d} P_{a d}
$$

Estimating the $P_{a d}$ power during the design process of road lighting can be difficult. Therefore, usually at the design stage, this power is omitted in the calculations. This may cause the calculated energy performance indicators to be underestimated. In order to illustrate this, consider the following example.

\subsection{Example}

The road lighting installation consists of 10 luminaires with a power of $P=50 \mathrm{~W}$. Due to the possibility of lowering the lighting class of the road, the luminaire power (luminous flux) can be reduced by $50 \%\left(k_{\text {redP }}=0.5\right)$. It is assumed that the $P_{a d}$ power is $5 \%$ of the installed luminaire power at $100 \%$ of dimming. It does not change with the dimming change.

Total luminaire power at $100 \%$ of dimming is equal to

$$
P_{\text {inst }}=\sum_{j=1}^{10} k_{r e d^{P}} P_{\text {lum }}=10 \cdot 1 \cdot 50=500 \mathrm{~W}
$$

Calculated value of the $P_{a d}$ power is equal to

$$
P_{a d}=0.05 \cdot P=0.05 \cdot 500=25 \mathrm{~W}
$$

Total system power value at $100 \%$ of dimming

$$
P=P_{\text {inst }}+P_{a d}=500+25=525 \mathrm{~W}
$$

Total luminaire power at $50 \%$ of dimming is equal to

$$
P_{\text {inst }}^{\text {red }}=\sum_{j=1}^{10} k_{\text {redP }} P_{\text {lum }}=10 \cdot 0.5 \cdot 50=250 \mathrm{~W}
$$

Total system power value at $50 \%$ of dimming

$$
P^{r e d}=P_{i n s t}^{r e d}+P_{a d}=250+25=275 \mathrm{~W}
$$

So

$$
\frac{P_{a d}}{P_{i n s t}^{r e d}}=\frac{25}{275}=9.09 \%
$$

Power $P_{a d}$ is in this case $9.09 \%$ of the total system power and should not be omitted.

\section{Calculation of active power losses in road lighting installation}

Typical installation of road lighting consists of the following elements:

- Cable protection located in the lighting switchboard

- Relay placed in the lighting switchboard 
Energy Efficiency of the Road Lighting: The Impact of Active Power Losses on Energy Performance... DOI: http://dx.doi.org/10.5772/intechopen.88833

- Cable (wire)

- Protection in the pole (placed in the pole switchboard)

- Wire connecting the pole switchboard with luminaire

In each of the listed elements of the installation, an active power loss occurs. The total active power losses $\Delta P_{\Sigma}$ in the road lighting system are the sum of power losses in its individual elements. Road lighting installations can be single-phase or threephase. The method of calculating losses in these types of installations is similar but not identical.

For three-phase installation, the total active power losses should be calculated by dependence Eq. (5):

$$
\Delta P_{\Sigma}^{3 P}=\Delta P_{C}^{3 P}+\Delta P_{N}+\Delta P_{W}+\Delta P_{P P B}+\Delta P_{P P}+\Delta P_{R}
$$

The active power losses in the neutral conductor of the power cable should be taken into account. They are caused by the flow of higher harmonics of the zero sequence and being a multiple of the number 3 .

The total power losses of the single-phase lighting installation $\Delta P^{1 P}$ can be calculated as

$$
\Delta P_{\Sigma}^{1 P}=\Delta P_{C}^{1 P}+\Delta P_{W}+\Delta P_{P P B}+\Delta P_{P P}+\Delta P_{R}
$$

For single-phase installations, losses in the neutral conductor are included in $\Delta P^{1 P}{ }_{C}$.

For three-phase lighting installation, power losses in the cable can be determined from the relationship [34]:

$$
\Delta P^{3 p}{ }_{C}=\frac{3 l}{\gamma_{C} S_{C}}\left[n^{2}\left(\frac{l_{01}+l}{l}\right)+\frac{n(n-1)(2 n-1)}{2}\right] I_{\text {Lum }}{ }^{2}
$$

The active power losses in a cable in a single-phase installation are calculated from Formula (8) [34]:

$$
\Delta P^{1 p}{ }_{C}=\frac{2 l}{\gamma_{C} S_{C}}\left[n^{2}\left(\frac{l_{01}}{l}\right)+\frac{n(n-1)(2 n-1)}{6}\right] I_{L u m}{ }^{2}
$$

The active power losses in the neutral conductor are calculated as [34]

$$
\Delta P_{N}=\frac{l}{\gamma_{C} S_{C}}\left[9 n^{2}+\frac{l_{01}}{l}+\frac{n(3 n-1)(6 n-1)}{2}\right] \sum_{h=3}^{\infty} I_{h L u m}{ }^{2}
$$

or

$$
\Delta P_{N}=\frac{l}{\gamma_{C} S_{C}}\left[9 n^{2}+\frac{l_{01}}{l}+\frac{n(3 n-1)(6 n-1)}{2}\right] I_{N L u m^{2}}
$$

Power losses in the wire connecting the pole switchboard and luminaire are calculated by using Eq. (11):

$$
\Delta P_{W}=2 I_{L u m}{ }^{2} R_{P W}=\frac{2 l_{P W}}{\gamma_{P W} S_{P W}} I_{L u m}{ }^{2}
$$


Power losses in protection in the lighting switchboard are determined by the following dependence:

$$
\Delta P_{P P B}=3 I_{L I}^{2} R_{P P B}
$$

In the case when the protection is realised by miniature circuit breaker (MCB)

$$
R_{P P B}=R_{M C B}
$$

Knowing the rated active power losses of the minimal circuit breaker $\Delta P_{M C B}$ is given for its rated current. $R_{M C B}$ can be determined by

$$
R_{M C B}=\frac{\Delta P_{M C B}}{3 I_{M C B}^{2}}
$$

The resistance of the whole protection device, if used for protection is a fuse to protect the cable, is the sum of the resistance of the fuse and the fuse carrier Eq. (15):

$$
R_{P P B}=R_{P B F B}+R_{P B F}
$$

Resistance of fuse carrier can be determined from Eq. (16), and resistance of fuse is calculated as Eq. (17)

$$
\begin{aligned}
R_{P B F B} & =\frac{\Delta P_{P B F B}}{I_{P B F B}{ }^{2}} \\
R_{P B F} & =\frac{\Delta P_{P B F}}{I_{P B F}{ }^{2}}
\end{aligned}
$$

The active power losses in the protection device in the pole switchboard are calculated from Eq. (18)

$$
\Delta P_{P P}=3 I_{\text {Lum }}^{2} R_{P P}
$$

If a miniature circuit breaker (MCB) is used, the $R_{p p}$ resistance is equal to $R_{M C B}$ :

$$
R_{P P}=R_{M C B}
$$

If a fuse is used to protect the wire in the pole, the resistance of the whole protection device is calculated as the sum of the resistance of the fuse and the fuse carrier (Formula (15) can be used).

A relay is usually used to switch on and off the lighting circuit. The active power losses of relay are calculated as

$$
\Delta P_{R}=I_{L I}^{2} R_{R}
$$

The relay resistance $R_{R}$ can be calculated as the quotient of the rated active power losses of the $\Delta P_{R R}$ relay (given for rated current) and the square of the rated current Eq. (21):

$$
R_{R}=\frac{\Delta P_{R R}}{I_{R}^{2}}
$$

The number of light points is equivalent to the number of poles, since it is assumed that the luminaires are mounted on poles individually. 


\section{Calculation of active energy losses in road lighting installation}

In the case of road lighting installations (circuit) with luminaires without dimming (without power reduction), the active energy consumed by the circuit (installation) $E_{T}$ is equal to the product of active power of lighting circuit (installation) $P$ and lighting time $t_{\text {use }}$, according to the relation (22):

$$
E_{T}=P \cdot t_{\text {use }}
$$

For the road lighting installations with dimmable luminaires operating according to a fixed work schedule, the active energy consumed by the lighting circuit (installation) is the sum of the energy consumed at each power reduction level. It was assumed that the luminaires used in the circuit are of the same rated power and they operate according to the same daily work schedule. The active energy of the circuit is calculated as the sum of the energy absorbed at each reduction level and the number of luminaires in the $n_{l u}$ circuit (installation), according to the relation (23):

$$
E_{T}=P_{k} \cdot n_{l u} \cdot \sum_{i=1}^{n_{\text {dim }}} k_{r e d P_{i}} \cdot t_{u s e_{i}}
$$

The active energy flow in the system causes active energy losses, calculated on the basis of dependence (24):

$$
E_{\Delta P}=\Delta P_{\Sigma} \cdot t_{u s e}
$$

The total active energy losses for the $n_{\text {dim }}$ levels of luminaire control in the daily cycle can be calculated from the dependence (25):

$$
E_{\Delta P}=\sum_{i=1}^{n_{\text {dim }}} \Delta P_{\Sigma_{i}} \cdot t_{u s e_{i}}
$$

Taking into account the power reduction factor $k_{\text {redP }}$ for each level of dimming, obtain the dependence (26) for the total losses of active energy in the lighting circuit:

$$
E_{\Delta P}=\Delta P_{\Sigma} \sum_{i=1}^{n_{\mathrm{dim}}} k_{r e d P_{i}} \cdot t_{\text {use }_{i}}
$$

These dependencies assume a constant number of luminaires in the circuits and a certain length of the power line. The total active energy collected by the lighting installation is the sum of the energy taken from the luminaires, the active energy losses and energy of auxiliary devices $E_{a d}$ in the lighting components (29). The definition given in the standard [5] regarding $P_{a d}$ power is too long; the authors decided to introduce the concept of auxiliary devices of lighting installation. The $P_{a d}$ power can be defined as the sum of the auxiliary devices' power. Therefore, the power of the $P_{a d}$ can be calculated from the following equation:

$$
P_{a d}=\sum_{p=1}^{w} \sum_{d=1}^{n_{d}} P_{a d_{d, p}} \cdot k_{r e d_{d, p}}^{a d}
$$

Each auxiliary device has a different rated output marked as $P_{a d d, p}$. The $n_{d}$ variable means the number of periods of power reduction of individual auxiliary 
devices. There are $w$ auxiliary devices in the installation that must be taken into account in the calculation.

The energy $E_{a d}$ is calculated as the sum of the energy of all auxiliary devices necessary for the operation of the installation (28):

$$
E_{a d}=\sum_{p=1}^{w} \sum_{d=1}^{n_{d}} P_{a d_{d, p}} \cdot k_{r e d_{d, p}}^{a d} \cdot t_{u s e_{d, p}}^{a d}
$$

The $t^{\text {ad }}$ use variable in Formula (28) means the operating times of the individual auxiliary devices. When calculating the energy $E_{a d}$, it is not correct to take the same working time of all auxiliary devices. Each of these devices can work differently compared to the light schedule:

$$
E_{\Sigma L I}=E_{T}+E_{\Delta P}+E_{a d}
$$

After the transformation, a dependency Eq. (30) is obtained:

$$
E_{\Sigma L I}=P \cdot \sum_{i=1}^{n_{\operatorname{dim}}} k_{r e d P_{i}} \cdot t_{u s e_{i}}+\Delta P_{\Sigma} \cdot \sum_{i=1}^{n_{\operatorname{dim}}} k_{r e d P_{i}} \cdot t_{u s e_{i}}+\sum_{p=1}^{w} \sum_{d=1}^{n_{d}} P_{a d_{d, p}} \cdot k_{r e d_{d, p}}^{a d} \cdot t_{u s e_{d, p}}^{a d}
$$

\section{Calculation example}

\subsection{Electrical and photometric parameters of a dimmable LED road luminaire}

To estimate the energy efficiency of a lighting installation, it is necessary to know the electrical and photometric parameters of the luminaires. The parameters of all devices included in the installation should also be known i.e.: the types, crosssections and lengths of wires or cables, types of applied protection and control devices. These data are usually available in catalogues. In the case of dimmable luminaires, the dimming characteristics are not always presented in the catalogue. Dimming characteristics are understood as the dependence of electrical and photometric parameters of the luminaire on dimming. This also applies to files with photometric data in the eulumdat format. Manufacturers should provide photometric data for different dimming or give reduction coefficients better in the form of mathematical dependence. This will ensure adequate accuracy of calculations and will facilitate the work of the designer. If this data is unavailable, then having a sample of the luminaire, the best solution is to take measurements of electrical and photometric parameters. In this way, the characteristics of the dimming for the given regulation range can be achieved.

In order to illustrate the presented method, the calculation results for an example of a road lighting installation with dimmable luminaires are presented. Energy performance indicators according to [5], electricity consumption and costs have been calculated for the following variants:

- Without taking into account active power losses

- Taking into account the active power losses for a three-phase installation

- Taking into account the active power losses for a single-phase installation 
When power losses are omitted, the results of calculations are identical for both types of installations (single- and three-phase). In calculations, active power losses in all previously mentioned (Section 3) elements of the installation were taken into account. The LED dimmable luminaire with a rated power of $140 \mathrm{~W}$ was selected for the analysis. Implemented luminaire control enabled regulation from 10 to $100 \%$ of rated power. The manufacturer did not specify the exact power values and luminous flux of the luminaire for particular levels of dimming. Measurements were taken in the full control range with a step of $10 \%$, and the results are summarised in Table 1. The dimming levels have been adopted in accordance with the manufacturer's assumption, which apparently does not correspond to the percentage of the luminaire's power or its luminous flux.

To measure the electrical parameters of the luminaire, the FLUKE 1760 power quality analyser was used. The luminous flux was measured in an Ulbricht sphere with a diameter of $2 \mathrm{~m}$ and with the use of the SONOPAN L-100 lux metre. The Agilent 6834B power supply was used to supply the luminaire. The luminaire was powered by an undeformed (purely sinusoidal) rated voltage of RMS 230VAC.

Analysing the results of Table 1, it can be seen that $10 \%$ of the dimming actually corresponds to about $26 \%$ of the luminaire's power and about $33 \%$ of the luminous flux. It can be assumed that both the active power of the luminaire and its luminous flux change approximately linearly. Analysing changes in reactive power, it is stated that its changes compared to active power are much smaller. At $10 \%$ of the dimming, reactive power reaches $79 \%$ of the initial value. This causes the power factor to decrease to 0.78 for $10 \%$ of the dimming level. It corresponds to the value of $\operatorname{tg} \varphi=0.81$. In many countries, the permissible reactive power level will be exceeded. It should be emphasised that the luminaire has the capacitive character of the power factor.

Disturbances generated to the power supply network by LED luminaires are the results of a pulse switching technique used in the power supplies. Modern impulse power supplies are equipped with circuits limiting the emission of higher harmonics of current and PFC systems. Most often, these systems are designed for the case of the power supply under $100 \%$ of load. This usually results in an increase in the level of higher current harmonics for lower dimming levels, which causes an increase of $T H D_{I}$. For the tested power supply, the $T H D_{I}$ value increased from $8 \%$ for $100 \%$ of

\begin{tabular}{|c|c|c|c|c|c|c|c|c|c|c|}
\hline $\begin{array}{l}\text { Dimming } \\
(\%)\end{array}$ & $\begin{array}{l}P_{\text {lum }} \\
(\mathrm{W})\end{array}$ & $\begin{array}{c}P_{\text {lum }}^{\%} \\
(\%)\end{array}$ & $\begin{array}{c}Q_{l u m} \\
\text { (var) }\end{array}$ & $\begin{array}{c}Q_{\text {lum }}^{\%} \\
(\%)\end{array}$ & $\begin{array}{c}P F_{D} \\
(-)\end{array}$ & $\begin{array}{c}P F_{D D} \\
(-)\end{array}$ & $\begin{array}{l}\operatorname{tg} \varphi \\
(-)\end{array}$ & $\begin{array}{c}T H D_{I} \\
(\%)\end{array}$ & $\begin{array}{l}\Phi_{l u m} \\
(\operatorname{lm})\end{array}$ & $\begin{array}{c}\Phi_{\text {lum }}^{\%} \\
(\%)\end{array}$ \\
\hline 10 & 37.71 & 26.47 & 30.64 & 71.91 & 0.78 & 0.76 & 0.81 & 21.05 & 4579 & 32.52 \\
\hline 20 & 49.62 & 34.82 & 32.73 & 76.81 & 0.84 & 0.82 & 0.66 & 16.84 & 5859 & 41.61 \\
\hline 30 & 65.33 & 45.85 & 35.25 & 82.73 & 0.88 & 0.87 & 0.54 & 14.34 & 7437 & 52.82 \\
\hline 40 & 79.27 & 55.63 & 35.95 & 84.37 & 0.91 & 0.90 & 0.45 & 12.34 & 8804 & 62.52 \\
\hline 50 & 91.87 & 64.47 & 37.91 & 88.97 & 0.92 & 0.92 & 0.41 & 11.01 & 9971 & 70.81 \\
\hline 60 & 103.50 & 72.64 & 39.72 & 93.22 & 0.93 & 0.93 & 0.38 & 10.42 & 10,980 & 77.98 \\
\hline 70 & 114.22 & 80.16 & 40.81 & 95.78 & 0.94 & 0.94 & 0.36 & 9.82 & 11,870 & 84.30 \\
\hline 80 & 124.22 & 87.18 & 41.37 & 97.09 & 0.95 & 0.95 & 0.33 & 9.15 & 12,664 & 89.94 \\
\hline 90 & 133.56 & 93.73 & 41.86 & 98.24 & 0.95 & 0.95 & 0.31 & 8.45 & 13,390 & 95.09 \\
\hline 100 & 142.49 & 100.00 & 42.61 & 100.00 & 0.96 & 0.96 & 0.30 & 8.00 & 14,081 & 100.00 \\
\hline
\end{tabular}

Table 1.

The values of electrical and photometric parameters of LED 140 W luminaires for different levels of dimming. 
the dimming to $21 \%$ for $10 \%$ of dimming. This is a change of $163 \%$. This is also the reason for the change in the power factor of the luminaire.

In order to calculate lighting parameters on the road, it is necessary to know the light distribution curves for a given dimming. The eulumdat files with photometric data for a given dimming were not available for the analysed luminaire. Therefore, photometric measurements were taken for the whole dimming range (in 10\% increments). Based on the measurement results, the photometric files, eulumdat, were developed. Figure 1 presents the light distribution curves for the selected luminaire in a C- $\gamma$ coordinate system for $100 \%$ of dimming.

\subsection{Parameters of lighting installation}

The following assumptions were made for the calculations:

- The installation is made of copper cable with a cross-section of $4 \times 16 \mathrm{~mm}^{2}$.

- For copper, the specific conductivity value of $56 \mathrm{~m} / \Omega \mathrm{mm}^{2}$ has been assumed.

- The pole wire from the pole switchboard to the luminaire is a copper wire with a cross-section of $1.5 \mathrm{~mm}^{2}$ and length $=10 \mathrm{~m}$.

- The protection of the lighting circuit is a gG (gL)-type fuse with a rated current of $25 \mathrm{~A}$ together with a three-phase fuse carrier with a rated current of $160 \mathrm{~A}$. The catalogued active power losses for the rated current are 12 and $2.4 \mathrm{~W}$, respectively.

- For single-phase installation, the following were assumed: gG (gL)-type fuse with a rated current of $25 \mathrm{~A}$ and active power losses equal to $2.4 \mathrm{~W}$ and catalogued active power losses of single-phase fuse carrier $2.6 \mathrm{~W}$ with a rated current of $160 \mathrm{~A}$.

- The lighting circuit is switched on by a three-phase relay with a rated current of $25 \mathrm{~A}$, whose catalogue power losses for the rated current are $7.9 \mathrm{~W}$ and for single-phase catalogue power losses equal to $4.4 \mathrm{~W}$ and the rated current is $25 \mathrm{~A}$.

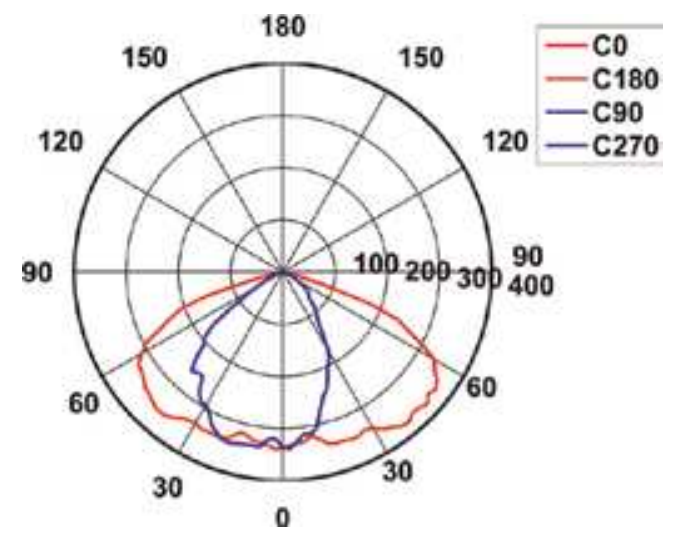

Figure 1.

Light distribution curves for the selected luminaire in a $C-\gamma$ coordinate system. 
- As a protection in the pole, a gG (gL)-type fuse with a rated current of 6 A was used together with a one-phase fuse carrier with a rated current of $16 \mathrm{~A}$. Power losses for the rated current read from the manufacturer's catalogue are, respectively, $1.7 \mathrm{~W}$ for the fuse and $3 \mathrm{~W}$ for the fuse carrier.

- The calculation was made for an installation of road lighting consisting of 30 points of light (single- and three-phase).

- The luminaires are mounted individually on the poles, i.e., the number of light points (poles) is equal to the number of luminaires.

In order to calculate the energy efficiency performance indicators, the lighting system project must be done. The list of assumed parameters of the lighting installation of the analysed road is presented in Table 2 .

\subsection{Results of the calculations of power and energy losses}

The results of calculations of lighting parameters for the analysed road are shown in Table 3. They have been made for the full range of luminous flux adjustment. On the road, the lighting class M3 was established. The calculations were performed in the DIALux ${ }^{\circledR}$ programme. The symbol $\mathrm{O} 1$ or $\mathrm{O} 2$ indicates the results for the observer 1 and 2, respectively.

The power of the $P_{a d}$ has been omitted from the calculations $\left(P_{a d}=0\right)$. For dimming levels from 90 to $60 \%$, the lighting requirements for one class lower than for full dimming are met (M4). Two lighting classes below the assumed value are met for dimming range 30-50\% (M5).

The values of the power density indicator are determined from Formula (1).

Table 4 presents the calculated values of the active power losses and in Table 5 the calculated values of power density indicator $D_{P}$. The impact of power losses on PDI is noticeable. The value of PDI in the calculation increases when active power losses are taken into account. The increase in PDI is equal to the percentage of the active power losses in relation to the total power of the lighting system. Decreasing the dimming level reduces the value of the indicator $D_{P}$. Due to linear changes in active power and light intensity in dimming, PDI value changes do not correspond to a dimming change. From the point of view of improving the energy efficiency of

\begin{tabular}{lc}
\hline Parameter & Value \\
\hline Arrangements & Single row, bottom \\
\hline Pole distance $(\mathrm{m})$ & 35 \\
\hline Height $(\mathrm{m})$ & 9.5 \\
\hline Inclination $\left(^{\circ}\right)$ & 5 \\
\hline Pole distance from roadway $(\mathrm{m})$ & 0.65 \\
\hline Boom length $(\mathrm{m})$ & 0.5 \\
\hline Number of poles & 30 \\
\hline Street width $(\mathrm{m})$ & 7 \\
\hline Maintenance factor & 2 \\
\hline
\end{tabular}

Table 2.

Parameters of road lighting installations. 


\begin{tabular}{|c|c|c|c|c|c|c|c|c|c|}
\hline \multirow[t]{3}{*}{ Dimming (\%) } & \multirow{2}{*}{\multicolumn{2}{|c|}{$\frac{L_{\text {avg }}}{\left(\operatorname{cd~m}^{-2}\right)}$}} & \multirow{2}{*}{\multicolumn{2}{|c|}{$\begin{array}{c}U_{0} \\
(\%)\end{array}$}} & \multirow{2}{*}{\multicolumn{2}{|c|}{$\begin{array}{c}U_{I} \\
(\%)\end{array}$}} & \multirow{2}{*}{\multicolumn{2}{|c|}{$\begin{array}{l}f_{T I} \\
(\%)\end{array}$}} & \multirow[t]{3}{*}{ Lighting class } \\
\hline & & & & & & & & & \\
\hline & 01 & $\mathrm{O} 2$ & 01 & $\mathrm{O} 2$ & 01 & $\mathbf{O} 2$ & 01 & 02 & \\
\hline 100 & 1.02 & 1.09 & \multirow[t]{10}{*}{0.51} & \multirow[t]{10}{*}{0.50} & \multirow[t]{10}{*}{0.74} & \multirow[t]{10}{*}{0.84} & 8 & 6 & M3 \\
\hline 90 & 0.97 & 1.04 & & & & & 8 & 6 & M4 \\
\hline 80 & 0.91 & 0.98 & & & & & 8 & 6 & M4 \\
\hline 70 & 0.85 & 0.92 & & & & & 8 & 6 & M4 \\
\hline 60 & 0.79 & 0.85 & & & & & 7 & 6 & M4 \\
\hline 50 & 0.72 & 0.78 & & & & & 7 & 6 & M5 \\
\hline 40 & 0.64 & 0.69 & & & & & 7 & 5 & M5 \\
\hline 30 & 0.54 & 0.58 & & & & & 7 & 5 & M5 \\
\hline 20 & 0.43 & 0.46 & & & & & 7 & 5 & M6 \\
\hline 10 & 0.34 & 0.36 & & & & & 6 & 5 & M6 \\
\hline
\end{tabular}

Table 3.

Calculated lighting parameters.

\begin{tabular}{lccccc}
\hline Dimming (\%) & $\boldsymbol{P}$ & $\boldsymbol{\Delta} \boldsymbol{P}_{\boldsymbol{3 P}}$ & $\boldsymbol{\Delta \boldsymbol { P } _ { \mathbf { P } }}$ & $\boldsymbol{P}+\boldsymbol{\Delta \boldsymbol { P } _ { 3 \boldsymbol { P } }}$ & $\boldsymbol{P}+\boldsymbol{\Delta} \boldsymbol{P}_{\boldsymbol{1 P}}$ \\
\cline { 2 - 5 } & $(\mathrm{W})$ & $(\mathrm{W})$ & $(\mathrm{W})$ & $(\mathrm{W})$ & $(\mathrm{W})$ \\
\hline 100 & 4334.10 & 55.76 & 320.02 & 4389.86 & 4654.12 \\
\hline 90 & 4081.20 & 49.12 & 281.85 & 4130.32 & 4363.05 \\
\hline 80 & 3806.70 & 42.95 & 246.09 & 3849.65 & 4052.79 \\
\hline 70 & 3503.70 & 37.22 & 212.77 & 3540.92 & 3716.47 \\
\hline 60 & 3178.20 & 30.62 & 174.52 & 3208.82 & 3352.72 \\
\hline 50 & 2824.50 & 24.66 & 140.05 & 2849.16 & 2964.55 \\
\hline 40 & 2433.90 & 19.50 & 109.38 & 2454.40 & 2543.28 \\
\hline 30 & 2016.90 & 14.88 & 82.49 & 2031.78 & 2099.39 \\
\hline 10 & 1531.50 & 9.44 & 51.20 & 1540.94 & 1582.70 \\
\hline
\end{tabular}

Table 4.

The calculated values of active power losses for three-and single-phase installation.

the installation is beneficial. A significant limitation in the level of the assumed reduction in the power of the installation is to meet the lighting requirements. The highest total active power losses in three-phase installation occur for luminaires with a full level of control (100\%), and they amount to $55.76 \mathrm{~W}$. By reducing the power of the luminaire, these losses decrease and are equal to only $7.01 \mathrm{~W}$. For a single-phase installation, the level of losses and their contribution to the overall power balance is significantly higher. Analysing the percentages of active power losses in particular elements of the lighting installation, it is stated that the largest share of losses (regardless of the level of dimming) occurs in the power cable.

The AECI indicator value can be calculated if the light schedule is known. The luminaires can operate at $100 \%$ light output, or at set hours, it can be reduced. It was assumed that the moment of switching on and off the installation is determined on the basis of astronomical tables. For simplicity it was assumed that the same time 
of switching on and off the installation is the same for each day of the month. From 16.00 to 19.00 and from 5.00 to 7.00 , the luminaires work with $100 \%$ of dimming. Between 23.00 and 4.00, the luminaires work with $60 \%$ of dimming. During reduced traffic hours, it is possible to lower the lighting class from M3 to M4. Based on Table 3, for $60 \%$ of dimming the lighting requirements for class M4 are met. The adopted lighting schedule is the result of this. A graphical presentation of the lighting schedule is shown in Figure 2. The time moments marked as $t_{\text {on }}$ and $t_{\text {off }}$ on Figure 2 indicate the time of switching on and off the lighting system. These times are different for each month of the year.

Table 6 presents the calculation results of AECI indicator $\left(D_{E}\right)$ for all cases considered. The calculation is based on the assumption that the installation operates with two dimming levels (marked as D1 and D2). Similarly to the $D_{p}$ indicator, lowering the dimming causes lowering its value.

\begin{tabular}{|c|c|c|c|c|}
\hline \multirow[t]{2}{*}{ Dimming (\%) } & $E^{a h}$ & $D_{P}$ & $D^{3 P}{ }_{P}$ & $D_{P}^{1 P}$ \\
\hline & $(\mathbf{l} \mathbf{x})$ & 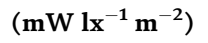 & 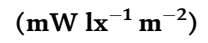 & $\left(\mathrm{mWlx^{-1 }} \mathbf{m}^{-2}\right)$ \\
\hline 100 & 19.00 & 32.11 & 32.52 & 34.48 \\
\hline 90 & 18.00 & 31.92 & 32.30 & 34.12 \\
\hline 80 & 17.00 & 31.52 & 31.87 & 33.55 \\
\hline 70 & 16.00 & 30.82 & 31.15 & 32.69 \\
\hline 60 & 15.00 & 29.82 & 30.11 & 31.46 \\
\hline 50 & 14.00 & 28.40 & 28.64 & 29.80 \\
\hline 40 & 12.00 & 28.55 & 28.79 & 29.83 \\
\hline 30 & 10.00 & 28.39 & 28.60 & 29.55 \\
\hline 20 & 8.01 & 26.91 & 27.08 & 27.81 \\
\hline 10 & 6.29 & 26.07 & 26.23 & 26.89 \\
\hline
\end{tabular}

Table 5 .

The calculated values of the energy performance indicators for three-and single-phase installation and horizontal average illumination.

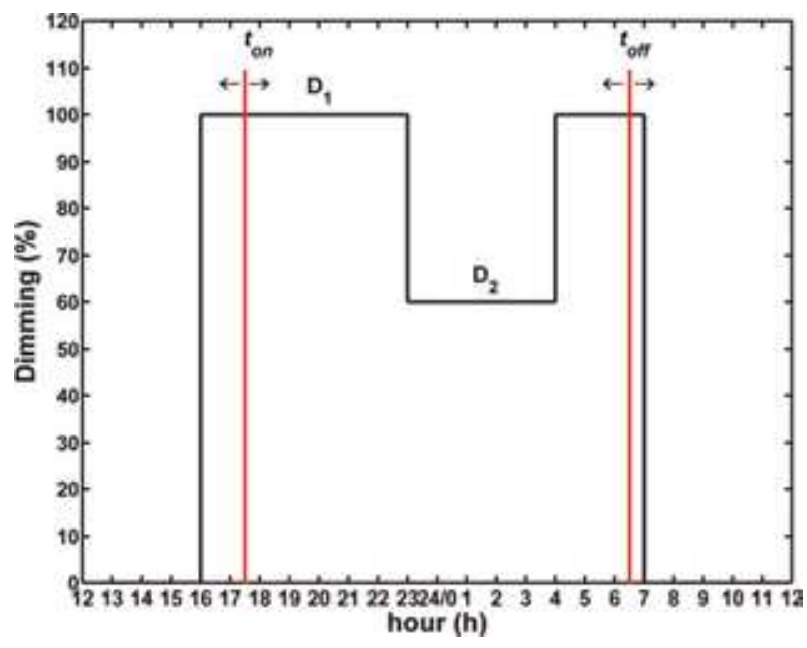

Figure 2.

Installation lighting schedule accepted for calculation. 
The value of the AECI without dimming is $2.41\left(\mathrm{kWh} \mathrm{m}^{-2}\right)$ for installations without losses. For a lighting installation operating with the assumed lighting schedule, lowering the D2 dimming level to $10 \%$ causes a decrease in the AECI value to $1.60\left(\mathrm{kWh} \mathrm{m}^{-2}\right)$ when energy losses are not taken into account. The greatest influence on the AECI value is the dimming value and lighting time with reduced luminous flux.

Table 6 shows the results of the calculation of the active energy consumed by lighting installations without dimming. The calculations are for single- and

\begin{tabular}{|c|c|c|c|}
\hline & $D_{E}$ & $D_{E}^{3 P}$ & $D_{E}^{1 P}$ \\
\hline & $\left(\mathrm{kWh} \mathrm{m}^{-2}\right)$ & $\left(\mathrm{kWh} \mathrm{m}^{-2}\right)$ & $\left(\mathrm{kWh} \mathrm{m}^{-2}\right)$ \\
\hline Without dimming & 2.41 & 2.44 & 2.59 \\
\hline $\mathrm{D} 1=100 \%, \mathrm{D} 2=90 \%$ & 2.34 & 2.37 & 2.51 \\
\hline $\mathrm{D} 1=100 \%, \mathrm{D} 2=80 \%$ & 2.27 & 2.30 & 2.43 \\
\hline $\mathrm{D} 1=100 \%, \mathrm{D} 2=70 \%$ & 2.20 & 2.22 & 2.35 \\
\hline $\mathrm{D} 1=100 \%, \mathrm{D} 2=60 \%$ & 2.11 & 2.14 & 2.25 \\
\hline $\mathrm{D} 1=100 \%, \mathrm{D} 2=50 \%$ & 2.02 & 2.04 & 2.15 \\
\hline $\mathrm{D} 1=100 \%, \mathrm{D} 2=40 \%$ & 1.78 & 1.79 & 1.88 \\
\hline $\mathrm{D} 1=100 \%, \mathrm{D} 2=30 \%$ & 1.81 & 1.83 & 1.93 \\
\hline $\mathrm{D} 1=100 \%, \mathrm{D} 2=20 \%$ & 1.69 & 1.71 & 1.80 \\
\hline $\mathrm{D} 1=100 \%, \mathrm{D} 2=10 \%$ & 1.60 & 1.61 & 1.70 \\
\hline
\end{tabular}

Table 6.

Summary of the calculated values of the annual energy consumption $D_{E}$ indicators without and including losses for single- and three-phase installation.

\begin{tabular}{|c|c|c|c|c|c|}
\hline \multirow[t]{3}{*}{ Month } & \multicolumn{5}{|c|}{ LED without dimming } \\
\hline & $E_{T}$ & $E_{T}^{3 P}$ & $E_{T}^{1 P}$ & $E^{3 P}{ }_{\Delta P}$ & $E^{1 P}{ }_{\Delta P}$ \\
\hline & $(\mathbf{k W h})$ & $(\mathrm{kWh})$ & $(\mathbf{k W h})$ & $(\mathbf{k W h})$ & $(\mathrm{kWh})$ \\
\hline January & 2015 & 2041 & 2164 & 26 & 149 \\
\hline February & 1578 & 1598 & 1694 & 20 & 116 \\
\hline March & 1478 & 1497 & 1587 & 19 & 109 \\
\hline April & 1170 & 1185 & 1257 & 15 & 86 \\
\hline May & 941 & 953 & 1010 & 12 & 69 \\
\hline June & 910 & 922 & 977 & 11 & 67 \\
\hline July & 941 & 953 & 1010 & 12 & 69 \\
\hline August & 1209 & 1225 & 1299 & 15 & 89 \\
\hline September & 1430 & 1449 & 1536 & 18 & 106 \\
\hline October & 1612 & 1633 & 1731 & 21 & 119 \\
\hline November & 1820 & 1844 & 1955 & 23 & 134 \\
\hline December & 2015 & 2041 & 2164 & 26 & 149 \\
\hline Annual & 17,120 & 17,340 & 18,384 & 220 & 1264 \\
\hline
\end{tabular}

Table 7.

Summary of the calculated values of energy consumption by lighting installation without and including losses without dimming. 
three-phase installations with and without active power losses. Table 7 presents the calculation results of the consumed active energy for the installation working with the assumed lighting schedule. Figures 3-5 show the calculated amounts of electricity consumed in the analysed variants by lighting installation on a month-permonth scale.

The annual active energy consumption for the considered lighting installation without control is $17,120 \mathrm{kWh}$. In the case of operation of road lighting installation with the assumed schedule, the annual energy consumption is reduced to $15,010 \mathrm{kWh}$. This is a decrease of $12 \%$. The highest energy consumption as well as energy losses occurs in the winter months, in December and January. The highest electricity consumption equals $2015 \mathrm{kWh}$. The lowest consumption is noted in June and equals only $910 \mathrm{kWh}$ for the analysed lighting system. For an installation without dimming, the inclusion of active power losses has resulted in a $1.28 \%$ increase of the calculated annual energy consumption for a three-phase installation compared to the calculation without taking into account power losses. For a singlephase installation, the increase in energy consumption is $7.38 \%$. The application of

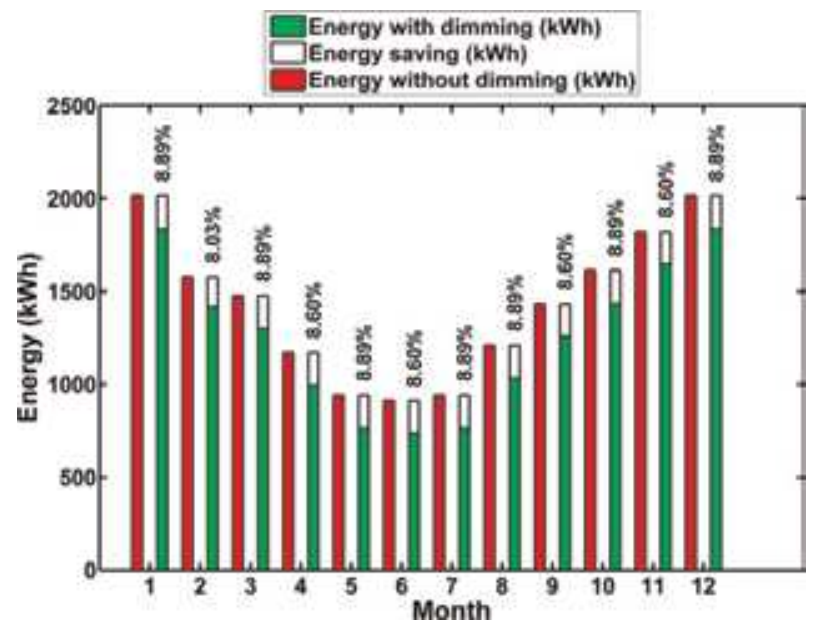

Figure 3 .

The volume of electricity consumed in the analysed variants on a monthly scale without energy losses.

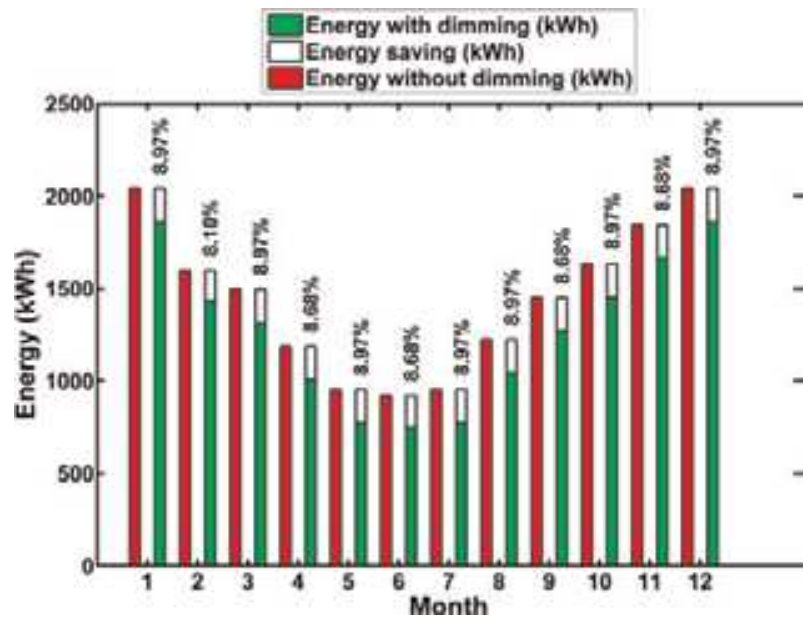

Figure 4 .

The volume of electricity consumed in the analysed variants on a monthly scale with three-phase energy losses. 


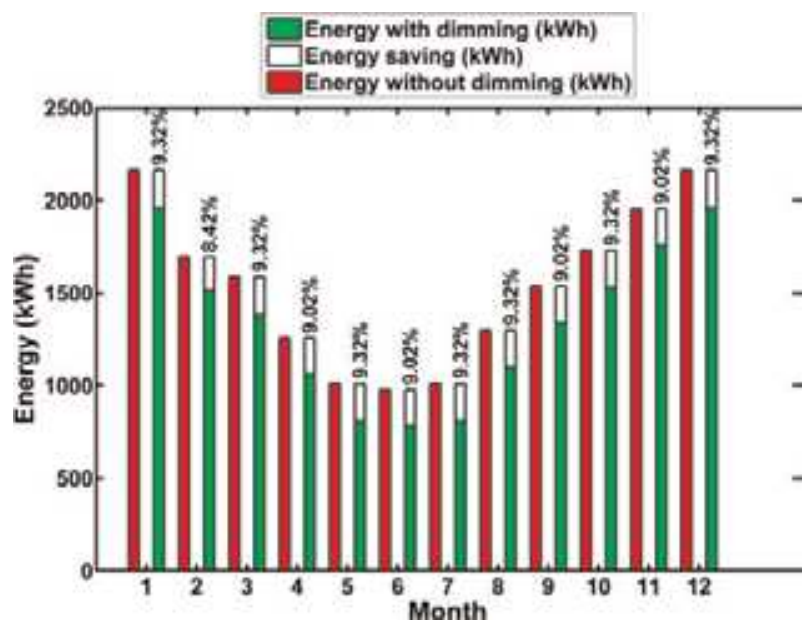

Figure 5 .

The volume of electricity consumed in the analysed variants on a monthly scale with single-phase energy losses.

the control luminous flux results in reduced energy consumption. For the threephase system, the energy consumption increased by $1.16 \%$ compared to the calculations without taking losses into account. The increase in energy consumption is $6.66 \%$ for a single-phase installation.

Analysing the monthly consumption of active energy, the smallest values occur in the spring and summer months (May, June, July), which is closely related to the working time. Also, in those months, there were the smallest active energy losses. For installations with luminaires operating at a constant power, they are

\begin{tabular}{|c|c|c|c|c|c|}
\hline \multirow[t]{3}{*}{ Month } & \multicolumn{5}{|c|}{ LED with dimming } \\
\hline & $E_{T}$ & $E_{T}^{3 P}$ & $E_{T}^{1 P}$ & $E^{3 P}{ }_{\Delta P}$ & $E^{1 P}{ }_{\Delta P}$ \\
\hline & $(\mathrm{kWh})$ & $(\mathrm{kWh})$ & $(\mathrm{kWh})$ & $(\mathbf{k W h})$ & $(\mathrm{kWh})$ \\
\hline January & 1836 & 1858 & 1962 & 22 & 126 \\
\hline February & 1416 & 1433 & 1512 & 17 & 96 \\
\hline March & 1299 & 1314 & 1385 & 15 & 87 \\
\hline April & 997 & 1008 & 1061 & 11 & 65 \\
\hline May & 761 & 770 & 808 & 8 & 47 \\
\hline June & 737 & 745 & 782 & 8 & 45 \\
\hline July & 761 & 770 & 808 & 8 & 47 \\
\hline August & 1030 & 1042 & 1097 & 12 & 67 \\
\hline September & 1257 & 1272 & 1341 & 15 & 84 \\
\hline October & 1433 & 1450 & 1530 & 17 & 96 \\
\hline November & 1647 & 1667 & 1760 & 20 & 113 \\
\hline December & 1836 & 1858 & 1962 & 22 & 126 \\
\hline Annual & 15,010 & 15,184 & 16,009 & 174 & 999 \\
\hline
\end{tabular}

Table 8.

Summary of the calculated values of energy consumption by lighting installation without and including losses with dimming. 
Energy Efficiency of the Road Lighting: The Impact of Active Power Losses on Energy Performance... DOI: http://dx.doi.org/10.5772/intechopen.88833

$26 \mathrm{kWh}$, and for installations working according to the schedule, they are equal to $22 \mathrm{kWh}$-for three-phase. Energy losses through the use of dimming have been reduced about $15 \%$ in three-phase installation. For a single-phase installation, the

\begin{tabular}{|c|c|c|c|c|c|}
\hline \multirow[t]{3}{*}{ Month } & \multicolumn{5}{|c|}{ LED without dimming } \\
\hline & $C_{T}$ & $C_{T}^{3 P}$ & $C_{T}^{1 P}$ & $C^{3 P}{ }_{\Delta P}$ & $C_{\Delta P}^{1 P}$ \\
\hline & (EUR) & (EUR) & (EUR) & (EUR) & (EUR) \\
\hline January & 231.56 & 234.54 & 248.66 & 2.98 & 17.10 \\
\hline February & 181.27 & 183.60 & 194.65 & 2.33 & 13.38 \\
\hline March & 169.81 & 172.00 & 182.35 & 2.18 & 12.54 \\
\hline April & 134.46 & 136.19 & 144.38 & 1.73 & 9.93 \\
\hline May & 108.06 & 109.45 & 116.04 & 1.39 & 7.98 \\
\hline June & 104.58 & 105.92 & 112.30 & 1.35 & 7.72 \\
\hline July & 108.06 & 109.45 & 116.04 & 1.39 & 7.98 \\
\hline August & 138.94 & 140.73 & 149.20 & 1.79 & 10.26 \\
\hline September & 164.34 & 166.45 & 176.47 & 2.11 & 12.13 \\
\hline October & 185.25 & 187.63 & 198.93 & 2.38 & 13.68 \\
\hline November & 209.15 & 211.85 & 224.60 & 2.69 & 15.44 \\
\hline December & 231.56 & 234.54 & 248.66 & 2.98 & 17.10 \\
\hline Annual & 1967.05 & 1992.36 & 2112.30 & 25.31 & 145.24 \\
\hline
\end{tabular}

Table 9.

Summary of the calculated energy cost caused by lighting installation without and including losses without dimming.

\begin{tabular}{|c|c|c|c|c|c|}
\hline \multirow[t]{3}{*}{ Month } & \multicolumn{5}{|c|}{ LED with dimming } \\
\hline & $C_{T}$ & $C_{T}^{3 P}$ & $C_{T}^{1 P}$ & $C^{3 P}{ }_{\Delta P}$ & $C^{1 P}{ }_{\Delta P}$ \\
\hline & (EUR) & (EUR) & (EUR) & (EUR) & (EUR) \\
\hline January & 210.98 & 213.51 & 225.49 & 2.53 & 14.51 \\
\hline February & 162.67 & 164.60 & 173.72 & 1.93 & 11.04 \\
\hline March & 149.23 & 150.96 & 159.18 & 1.74 & 9.95 \\
\hline April & 114.53 & 115.83 & 121.96 & 1.30 & 7.42 \\
\hline May & 87.48 & 88.42 & 92.87 & 0.94 & 5.39 \\
\hline June & 84.66 & 85.57 & 89.87 & 0.91 & 5.21 \\
\hline July & 87.48 & 88.42 & 92.87 & 0.94 & 5.39 \\
\hline August & 118.35 & 119.69 & 126.02 & 1.34 & 7.67 \\
\hline September & 144.41 & 146.10 & 154.04 & 1.68 & 9.63 \\
\hline October & 164.67 & 166.60 & 175.75 & 1.94 & 11.09 \\
\hline November & 189.23 & 191.49 & 202.17 & 2.26 & 12.94 \\
\hline December & 210.98 & 213.51 & 225.49 & 2.53 & 14.51 \\
\hline Annual & 1724.67 & 1744.70 & 1839.40 & 20.04 & 114.73 \\
\hline
\end{tabular}

Table 10.

Summary of the calculated energy cost caused by lighting installation without and including losses with dimming. 


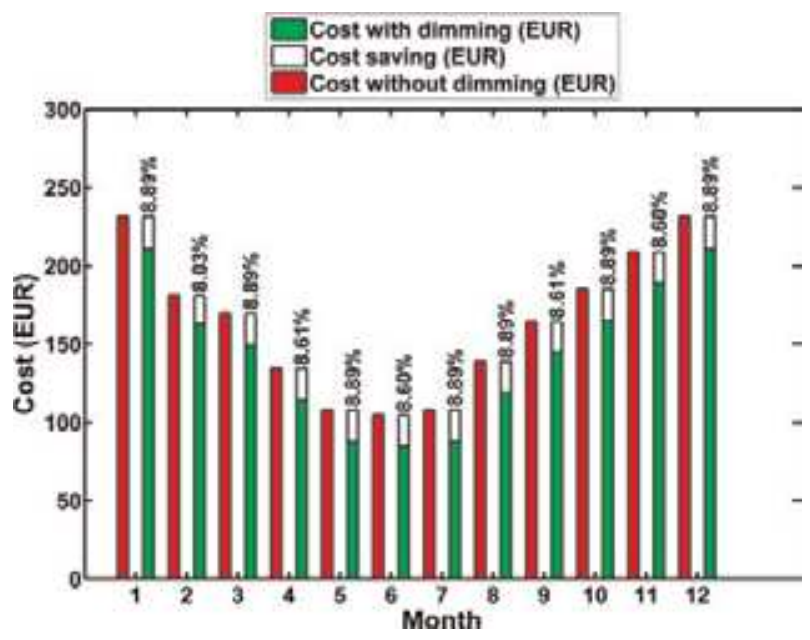

Figure 6.

Cost of electricity consumed in the analysed variants on a monthly basis without energy losses.

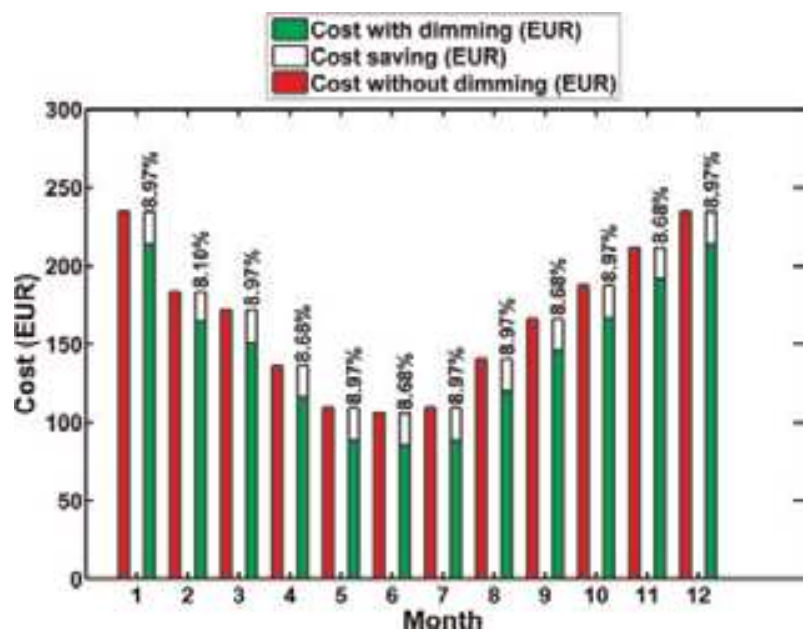

Figure 7.

Cost of electricity consumed in the analysed variants on a monthly basis with three-phase energy losses.

losses are several times greater. The use of dimming caused a reduction of energy losses equal to $18.25 \%$.

In the next part of the analysis, the estimated costs of electricity consumption of the analysed lighting installation were calculated. Similarly as before, electricity costs were calculated taking into account the losses of active power in the singleand three-phase network. The active energy price of $0.1194 €$ for $1 \mathrm{kWh}$ was adopted for the calculation. This is the average price for customers non-habitable in the EU based on [35]. The calculation results are summarised in Table 8 for installation without dimming and in Table 9 for installation with dimming. Figures 6-8 and Table 10 show the calculated electricity cost of analysed lighting installation variants on a month-per-month scale.

The use of dimming resulted in savings of $8 \%$ per month compared to installations without dimming. The annual cost of active energy losses for three-phase installation without dimming is $25.31 €$. For the same installation, the costs of the active energy losses with dimming are $20.04 €$. For a single-phase installation, these costs are $145.24 €$ (with dimming) and $114.73 €$ (without dimming), respectively. 


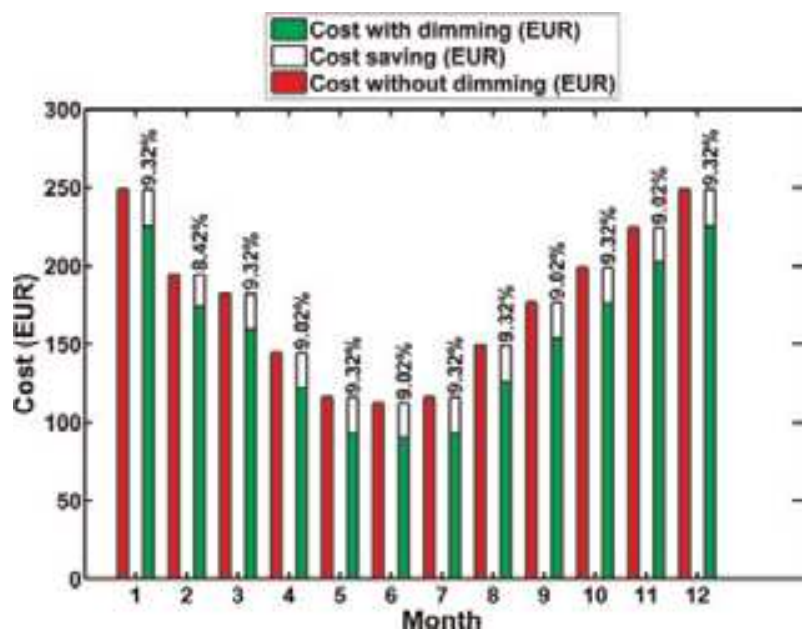

Figure 8.

Cost of electricity consumed in the analysed variants on a monthly basis with single-phase energy losses.

The costs of energy losses in a single-phase installation are more than four times higher than in a three-phase installation. The conclusion is that single-phase installations should be avoided as far as possible. If this is not possible, the energy efficiency calculations, energy balance and operating cost analysis should take into account the losses of power (energy). The financial savings achieved through dimming are proportional to the energy savings. On an annual perspective, dimming allowed to achieve financial savings:

- For the installation without taking into account active power losses is $242.38 €$

- For the installation taking into account the active power losses for a threephase installation is $247.66 €$

- For the installation taking into account the active power losses for a singlephase installation is $272.90 €$

The use of dimming has brought the greatest savings for a single-phase installation. This is due to the reduction of power losses in the lighting installation as a result of dimming.

\section{Conclusions}

The chapter presents a method of estimating electricity consumption and operating costs of road lighting installations. This method allows for the taking into account of active power losses in the calculations. These are analytical dependencies that can be used at the design stage. An analytical dependence allowing to calculate the power of auxiliary devices has been proposed. In addition, dependencies allowed for the calculation of energy consumption and electricity costs were presented. The usefulness of the proposed method is illustrated by a calculation example.

The calculation was performed for an example lighting installation consisting of 30 road luminaires. The impact of active power losses on the energy performance indicator, energy consumption and electricity costs was estimated. 
On the basis of the made analysis, the following conclusions may be concluded:

- In order to use dimming, it is necessary to calculate the lighting parameters on the road first.

- On the basis of calculations of lighting parameters on the road, it is possible to determine dimming for the assumed lighting class of the road.

- The omission of active power losses for a three-phase installation does not significantly affect the accuracy of calculations.

- For a single-phase installation, the active power losses should not be omitted because the calculation can then be made with an error of more than $5 \%$.

The energy performance indicators PDI and AECI may be used to estimate the energy efficiency of a road lighting installation. Road lighting design is typically developed as a multivariant design. The designer decides which of them should be selected for further analysis on the basis of the values of these indicators. In summary, when making a decision, the designer must give priority to the following considerations when making a decision for road safety. Electricity savings must not be given higher priority than road safety.

\section{Conflict of interest}

The authors declare no conflict of interest.

\section{Nomenclature}

$D_{P} \quad$ the power density indicator $\left(\mathrm{W} \mathrm{lx}^{-1} \mathrm{~m}^{-2}\right)$

$D_{P}^{1 P} \quad$ the power density indicator with single-phase losses $\left(\mathrm{W} \mathrm{lx}^{-1} \mathrm{~m}^{-2}\right)$

$D_{P}^{3 P} \quad$ the power density indicator with three-phase losses $\left(\mathrm{W} \mathrm{lx}{ }^{-1} \mathrm{~m}^{-2}\right)$

$E^{a h}{ }_{i} \quad$ the maintained average horizontal illuminance of the $i$-th subarea (lx)

$A_{i} \quad$ the size of the subarea " $\mathrm{i}$ " lit by the lighting installation $\left(\mathrm{m}^{2}\right)$

$D_{E} \quad$ the annual energy consumption indicator $\left(\mathrm{Whm}^{-2}\right)$

$D_{E}^{1 P} \quad$ the annual energy consumption indicator with single-phase losses $\left(\mathrm{Whm}^{-2}\right)$

$D_{E}^{3 P} \quad$ the annual energy consumption indicator with three-phase losses $\left(\mathrm{Whm}^{-2}\right)$

$P \quad$ total active power of the lighting circuit (installation) (W)

$P_{k} \quad$ active power of the $k$-th luminous point (light source; lamp device; any other devices such as a spotlight control unit, switch or photocell; and the component associated with the luminous point and necessary for its operation) (W)

$P_{a d} \quad$ total active power of all devices not included in $P_{k}$ but necessary to operate a road installation such as a remote switch or photocell, centralised light control or centralised management system, etc. (W)

$k_{\text {red }}^{P} \quad$ power reduction factor

$k_{\text {red }}^{A D} \quad$ power reduction factor of additional equipment

$P_{\text {Lum }} \quad$ active power of the luminaire (W)

$P^{\%}$ Lum active power of the luminaire (percent of rated power) 
$Q_{\text {Lum }} \quad$ reactive power of the luminaire (var)

$Q_{\text {Lum }}^{\%} \quad$ reactive power of the luminaire (percent of rated power)

$P F_{D} \quad$ displacement power factor

$P F_{D D} \quad$ distortion power factor

$\operatorname{tg} \varphi \quad$ tangent $\varphi$

THD $D_{I} \quad$ total harmonic distortion of the current

$\Phi_{\text {lum }} \quad$ luminaire flux (lumen)

$\Phi_{\text {lum }}^{\%}$ luminaire flux (percent of rated flux)

$L_{\text {avg }} \quad$ average road surface luminance $\left(\mathrm{cd} / \mathrm{m}^{2}\right)$

$U_{0} \quad$ total uniformity

$U_{I} \quad$ longitudinal uniformity

$f_{T I} \quad$ threshold increment

$P_{\text {inst }} \quad$ total active power of the luminaire (W)

$P_{\text {inst }}^{\text {red }}$ total active power of the luminaire with reduced their power (W)

$P^{\text {red }}$

total active power of the lighting circuit (installation) with reduced

luminaire power $(\mathrm{W})$

$n_{l p} \quad$ the number of lighting points associated with the lighting installation or the representative section whichever is used in the calculation

$\Delta P_{\Sigma} \quad$ total active power losses (W)

$\Delta P^{3 p}{ }_{\Sigma} \quad$ total active power losses in three-phase installation (W)

$\Delta P^{1 p}{ }_{\Sigma}$ total active power losses in single-phase installation (W)

$\Delta P^{1 p}$

$\Delta P^{3 p}{ }_{C}$

$\Delta P_{N}$

$\Delta P_{W}$

$\Delta P_{P P B}$

$\Delta P_{P P}$

$\Delta P_{R}$

$n$

$l_{01}$

$l$

$l_{P W}$

$\gamma_{C}$

active power losses in the power cable in single-phase installation (W)

active power losses in the power cable in three-phase installation (W)

active power losses in the neutral conductor of the power cable (W)

active power losses in the pole wire (W)

active power losses in the protection in the lighting switchboard (W)

$\gamma_{P W}$

$S_{C}$

$S_{P W}$

$I_{\text {Lum }}$

$I_{\text {hLum }}$

$I_{L I}$

$R_{P W}$ active power losses in the protection in the pole switchboard (W) active power losses in the contactor/relay controlling the lighting installation in the switchboard (W) number of luminaires per phase distance of the first luminaire from the lighting switchboard (m) distance between the poles $(\mathrm{m})$ length of wire in the pole $(\mathrm{m})$ conductivity of the conductor the power cable $\left(\mathrm{m} / \Omega \mathrm{mm}^{2}\right)$ conductivity of the wire the pole $\left(\mathrm{m} / \Omega \mathrm{mm}^{2}\right)$ cross-section of the conductor of the power cable $\left(\mathrm{mm}^{2}\right)$ cross-section of the of the wire the pole $\left(\mathrm{mm}^{2}\right)$

luminaire current $(\mathrm{A})$ harmonic currents of the zero sequence for $h=3,9,15$ and so on (A) lighting installation current $(\mathrm{A})$ resistance of the wire connecting the pole switchboard to the luminaire $(\Omega)$

$R_{P P B} \quad$ resistance of the protection in the lighting panelboard $(\Omega)$

$R_{M C B}$

$I_{M C B}$

$R_{P B F B}$

$R_{P B F}$

$R_{P P}$ resistance of the miniature circuit breaker $(\Omega)$ current of the miniature circuit breaker (A)

$R_{R} \quad$ resistance of the relay $(\Omega)$ resistance of the fuse carrier $(\Omega)$ resistance of the fuse $(\Omega)$

$E_{T} \quad$ active energy consumed by the lighting installation without losses (kWh)

$t_{\text {use }} \quad$ lighting time (h)

$E_{a d} \quad$ total active energy of all auxiliary devices not included in $P_{k}(\mathrm{kWh})$ 
$w \quad$ number of auxiliary devices

$n_{d} \quad$ number of working period of auxiliary devices

$n_{\text {dim }} \quad$ number of dimming period of luminaires

$t^{a d}$ use working time of auxiliary devices (h)

$E_{\Sigma L I} \quad$ total active energy consumed by the lighting installation with losses

$E_{T}^{3 P} \quad$ active energy consumed by the lighting installation with three-phase

$E^{1 P}{ }_{T} \quad$ active energy consumed by the lighting installation with single-phase

$E_{\Delta P}^{3 P} \quad$ losses (kWh)

$E_{\Delta P}^{1 P} \quad$ single-phase active energy losses $(\mathrm{kWh})$

$C_{T} \quad$ cost of electricity consumed in the installation without energy losses (EUR)

$C_{T}^{3 P} \quad$ cost of electricity consumed in the installation with three-phase losses (EUR)

$C_{T}^{1 P} \quad$ cost of electricity consumed in the installation with single-phase losses

$C^{3 P}{ }^{3 P} \quad$ cost of three-phase losses (EUR)

$C^{1 P}{ }_{\Delta P}^{\Delta P} \quad$ cost of single-phase losses (EUR)

\section{Author details}

Roman Sikora* and Przemysław Markiewicz

Institute of Electrical Power Engineering, Lodz University of Technology, Lodz, Poland

*Address all correspondence to: roman.sikora@p.lodz.pl

\section{IntechOpen}

(C) 2020 The Author(s). Licensee IntechOpen. Distributed under the terms of the Creative Commons Attribution - NonCommercial 4.0 License (https://creativecommons.org/ licenses/by-nc/4.0/), which permits use, distribution and reproduction for non-commercial purposes, provided the original is properly cited. (cc) BY-NC 
Energy Efficiency of the Road Lighting: The Impact of Active Power Losses on Energy Performance... DOI: http://dx.doi.org/10.5772/intechopen.88833

\section{References}

[1] EN 13201-1:2014. Light and lighting. Road lighting-Part 1: Guidelines on selection of lighting class

[2] EN 13201-2:2015. Light and lighting. Road lighting-Part 2: Performance requirements

[3] EN 13201-3:2015. Light and lighting. Road lighting-Part 3: Calculation of performance

[4] EN 13201-4:2015. Light and lighting. Road lighting-Part 4: Methods of measuring lighting performance

[5] EN 13201-5:2015. Light and lighting. Road lighting-Part 5: Energy performance indicators

[6] Campisi D, Gitto S, Morea D. Economic feasibility of energy efficiency improvements in street lighting systems in Rome. Journal of Cleaner Production. 2018;175:190-198. DOI: 10.1016/j.jclepro.2017.12.063

[7] Kovacs A, Batai R, Csanad Csaji B, Dudas P, Hay B, Pedone G, et al. Intelligent control for energy-positive street lighting. Energy. 2016;114:40-51. DOI: 10.1016/j.energy.2016.07.156

[8] Ożadowicz A, Grela J. Energy saving in the street lighting control system: A new approach based on the EN-15232 standard. Energy Efficiency. 2016;10: 563-576. DOI: 10.1007/s12053-016-9476-1

[9] Pinto MF, Soares GM, Mendonça TRF, Almeida PS, Braga HAC. Smart modules for lighting system applications and power quality measurements; 2014. DOI: 978-14799-5551-0/14

[10] Sun DIH, Abe S, Shoults RR, Chen MS, Eichenberger P, Farris D. Calculation of energy losses in a distribution system. IEEE Transactions on Power Apparatus and Systems. 1980;
99:1347-1356. DOI: 10.1109/

TPAS.1980.319557

[11] Todorović BM, Samardžija D. Road lighting energy-saving system based on wireless sensor network. Energy Efficiency. 2017;10:239-247. DOI: $10.1007 / \mathrm{s} 12053$

[12] Pizzuti S, Annunziato M, Moretti F. Smart street lighting management. Energy Efficiency. 2013;6:607-616. DOI: 10.1007/s12053-013-9195-9

[13] Shahzad G, Yang H, Waheed Ahmad A, Lee C. Energy-efficient intelligent street lighting system using traffic-adaptive control. IEEE Sensors Journal. 2016;16: 5397-5405. DOI: 10.1109/JSEN.2016. 2557345

[14] Radulovic D, Skok S, Kirincic V. Energy efficiency public lighting management in the cities. Energy. 2011; 36:1908-1915. DOI: $10.1016 / \mathrm{j}$.

energy.2010.10.016

[15] Tähkämö L, Halonen L. Life cycle assessment of road lighting luminairescomparison of light-emitting diode and high-pressure sodium technologies. Journal of Cleaner Production. 2015;93: 234-242. DOI: 10.1016/j.

jclepro.2015.01.025

[16] Tähkämö L, Ylinen A, Puolakka M, Halonen L. Life cycle cost analysis of three renewed street lighting installations in Finland. The International Journal of Life Cycle Assessment. 2012;17:154-164. DOI: 10.1007/s11367-011-0345-z

[17] Tetri E, Bozorg Chenani S, Räsänen RS, Baumgartner H, Vaaja M, Sierla S, et al. Tutorial: Road lighting for efficient and safe traffic environments. Leukos. 2017;13:1-19. DOI: 10.1080/ 15502724.2017.1283233 
[18] Kostic M, Djokic L.

Recommendations for energy efficient and visually acceptable street lighting. Energy. 2009;34:1565-1572. DOI: 10.1016/j.energy.2009.06.056

[19] Orzáez MJH, de Andrés Díaz JR. Comparative study of energy-efficiency and conservation systems for ceramic metal-halide discharge lamps. Energy. 2013;52:258-264

[20] Orzáez MJH, Róchaz Sola J, GagoCalderon A. Electrical consequences of large-scale replacement of metal-halide by LED luminaires. Lighting Research and Technology. 2016;50(2):282-293

[21] Queiroz LMO, Roselli MA, Cavellucci C. Energy losses estimation in power distribution systems. IEEE Transactions on Power Systems. 2012; 27:1879-1887. DOI: 10.1109/ TPWRS.2012.2188107

[22] Beccali M, Bonomolo M, Ciulla G, Galatioto A, Lo Brano V. Improvement of energy efficiency and quality of street lighting in South Italy as an action of sustainable energy action plans. The case study of Comiso (RG). Energy. 2015;92:394-408. DOI: 10.1016/j. energy.2015.05.003

[23] Leccese F, Salvadori G, Rocca M. Critical analysis of the energy performance indicators for road lighting systems in historical towns of Central Italy. Energy. 2017;138:616-628. DOI: 10.1016/j.energy.2017.07.093

[24] Lobao JA, Devezas T, Catalao JPS. Energy efficiency of lighting installations: Software application and experimental validation. Energy Reports. 2015;1:110-115. DOI: 10.1016/j. egyr.2015.04.001

[25] Lobão JA, Devezas T, Catalão JPS. Influence of cable losses on the economic analysis of efficient and sustainable electrical equipment.
Energy. 2014;65:145-151. DOI: $10.1016 /$ j.energy.2013.12.022

[26] Vysotsky VS, Nosov AA, Fetisov SS, Shutov KA. AC loss and other researches with $5 \mathrm{~m}$ HTS model cables. IEEE Transactions on Applied Superconductivity. 2011;21:1001-1004. DOI: 10.1109/TASC.2010.2084063

[27] Yan W, Hui SYR, Shu-Hung Chung H. Energy saving of large-scale high-intensity-discharge lamp lighting networks using a central reactive power control system. IEEE Transactions on Industrial Electronics. 2009;56:

3069-3078. DOI: 10.1109/

TIE.2009.2022089

[28] Emanuel AE. Summary of IEEE Standard 1459. Definitions for the measurement of electric power quantities under sinusoidal, nonsinusoidal, balanced, or unbalanced conditions. IEEE Transactions on Industry Applications. 2004;40: 869-876. DOI: 10.1109/TIA.2004.827452

[29] EN 50160: Voltage characteristics of electricity supplied by public distribution systems; 2007

[30] IEEE Std. 1459-2010: Definitions for the measurement of electric power quantities under sinusoidal, nonsinusoidal, balanced, or unbalanced conditions

[31] Jettanasen C, Pothisarn C. Analytical study of harmonics issued from LED lamp driver. In: Proceedings of the International MultiConference of Engineers and Computer Scientists 2014 Vol II; IMECS 2014; Hong Kong; 12-14 March 2014

[32] Pabjanczyk W, Sikora R, Markiewicz P, Gabryjelski Z. Influence of LED luminaires on supply network. Przeglad Elektrotechniczny. 2010; 86(10):229-232 
Energy Efficiency of the Road Lighting: The Impact of Active Power Losses on Energy Performance... DOI: http://dx.doi.org/10.5772/intechopen.88833

[33] Pabjanczyk W, Sikora R,

Markiewicz P, Gabryjelski Z. The

influence of a road LED luminaires on

the electrical power quality in a power networks. Przeglad Elektrotechniczny. 2011;87(4):120-123

[34] Gabryjelski Z, Kowalski Z. Sieci i urządzenia oświetleniowe. Zagadnienie wybrane. Łódź: Wydawnictwo

Politechniki Łódzkiej; 1997, ISBN

83-86453-95-8

[35] Available from: https://ec.europa. eu/eurostat/statistics-explained/pdf scache/45239.pdf 



\title{
The Thermal Dissipation of LED Outdoor Lighting Luminaires: Comparative Analysis for a Real Case of Study
}

\author{
Hermoso-Orzáez Manuel Jesús, Hervás-Pulido Manuel Jesús, \\ Unión-Sánchez Juan de Dios, Ogáyar-Fernández Blas \\ and Gago-Calderon Alfonso
}

\begin{abstract}
Today LED technology is being imposed, day by day, in our cities and homes as an efficient way of lighting. The performance of its lighting, durability, energy efficiency, and light, coupled with the economy of its use, is shifting to other classic forms of lighting. However, some problems associated with the durability of equipment associated with thermal dissipation and high-temperature problems, which end up affecting the light intensity and service life, are beginning to be detected. The objective of this paper is to compare the results obtained previously, at different contour temperatures, with the current practical results obtained with a FLUKETI25 thermal imaging camera. The theoretical results will be compared with the current results applied to the different luminaires. Where real thermal dissipation is studied, it is obtained for each of them in the laboratory of illumination with the thermographic camera FLUKE TI. The theoretical and experimental results are evaluated, and the results are discussed. This study shows that instead of LED technology, it is less risky for quality depreciation and durability of lighting if a project has already been achieved that favors optimal thermal dissipation, supported by the importance of choosing an appropriate design and appropriate materials.
\end{abstract}

Keywords: LED, thermal dissipation, luminaire, outdoor lighting

\section{Introduction}

\subsection{Technological evolution of public lighting}

Street lighting has undergone a great technological evolution since 1931, when the first mercury vapor lamps appeared in Europe. The principle of operation of this lamp consists of the closing of a switch producing an arc between the two electrodes of the lamp, ionizing the gas contained inside the tube initiating the main discharge. 
The discharge occurs first through the gas since the mercury is at room temperature and at a low pressure. Progressively the mercury increases its temperature and vaporizes, increasing the pressure inside the tube and consequently the voltage between the terminals of the lamp. After a few minutes, the mercury is completely volatilized and the discharge occurs through it. At this time, the luminous flux increases and the color of the source varies. When the balance is reached, the intensity is regulated by the ballast (Figure 1 and 2) [1].

These lamps need a reactance that limit the intensity passage through the tube and stabilize the discharge. They do not need starting equipment and have a capacitor connected in series with the lamp whose function will be the correction of the power factor (Figure 2).

As of 2015, new public lighting works began to be banned in Spain and their replacement in existing facilities was recommended.

In the year 1955, a more advanced and technological evolution lamp appeared with respect to mercury vapor, called high pressure sodium vapor lamp (VSAP). The characteristics of the street lighting fixtures were improved with these lamps, but the luminous efficiency and the chromatic reproduction were the weak point of these.

The principle of operation is simpler than that of mercury vapor technology and consists in that light is obtained by the emission generated in the collision of free electrons with the gas atoms of the discharge tube. Shocks excite the electrons that pass to a higher energy level. When these electrons return to their natural orbit, the emission of the photons, that is to say, the radiation of light takes place [1].

The radiations emitted by these lamps represent an emission spectrum with wider bands, where the discharge tube of the luminaire can reach up to $1000^{\circ} \mathrm{C}$ (Figure 3).

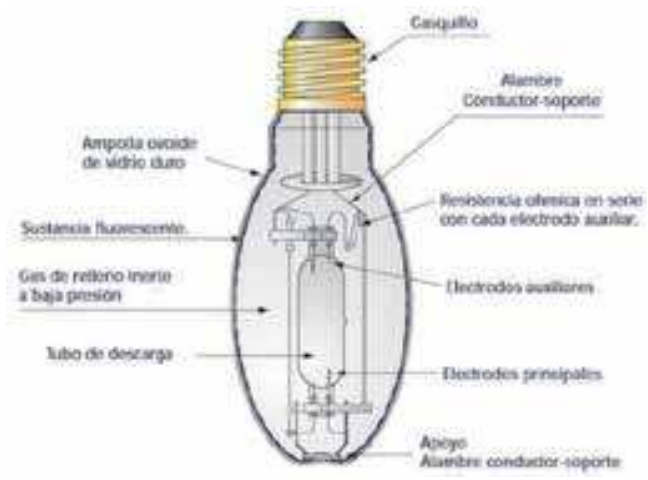

Figure 1.

Components of the mercury vapor lamp. Source: Manual INDAL lighting.

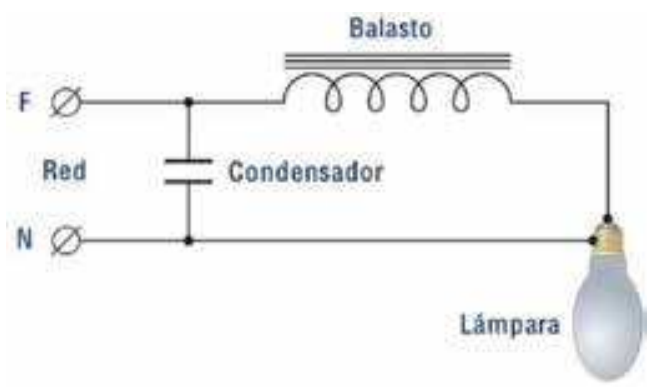

Figure 2.

Mercury vapor lamp operation scheme. Source: Own elaboration. 


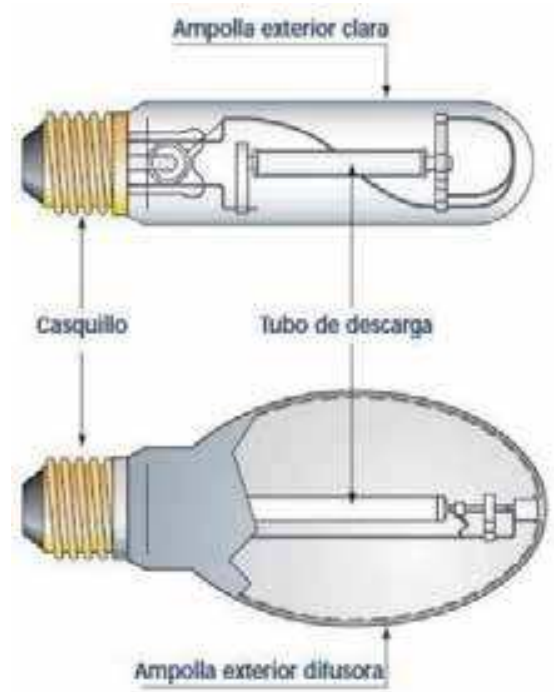

Figure 3.

Parts of the high pressure sodium vapor lamp. Source: Manual INDAL lighting.

High pressure sodium vapor luminaires need high voltage during their start-up process, then they need auxiliary equipment to turn on. The auxiliary equipment consists of a ballast and a starter that can be connected in series or semi-parallel. To correct the power factor a capacitor is connected in parallel (Figure 4).

These luminaries have a yellowish golden color, and are used for outdoor lighting, provided that the color rendering does not have to be high.

Parallel to the VSAP lamp and about the year 1960, the first metal halide (HM) lamps appeared. Inside the discharge tube, metal additives are added to enhance certain areas of the visible spectrum so that it increases its performance, both bright and colored. The spectral composition of these lamps is very complete and can be adapted to the needs of the user because it depends on the composition of the metals added.

The principle of operation is very similar to that of the mercury vapor lamp $(\mathrm{Hg})$. The light is obtained by the electric discharge that is generated by the potential difference between the electrodes. This difference causes a flow of electrons to cross the gas, and thus excite the atoms contained in the discharge tube. Depending on the iodide with which the tube is filled the excitation of the atoms will produce different colors (Figure 5) [2].

When starting the HM lamps, a very high starting voltage is required due to the halides. To achieve this, it is necessary to connect a starter, which has as a fundamental element a thyristor, responsible for supplying a peak voltage. In addition to the starter, auxiliary starting equipment contains a ballast in series with the
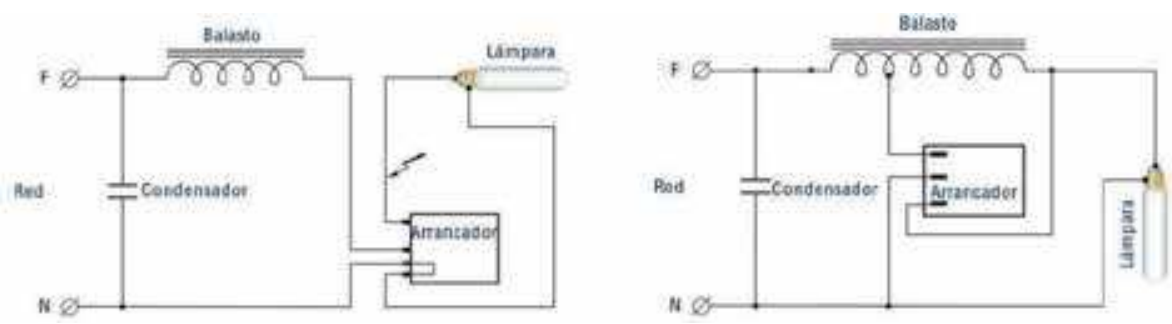

Figure 4 .

Scheme with independent starter and scheme with half-parallel starter. Source: Own elaboration. 

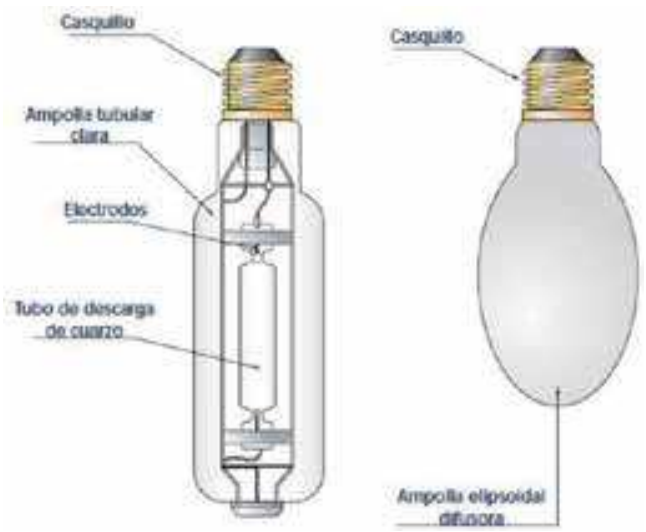

Figure 5.

Parts of the metal halide lamp. Source: Manual INDAL lighting.

discharge pipe to stabilize the discharge and a capacitor to compensate for the power factor. The time necessary to reach the regime conditions is between 3 and 5 min (Figure 6).

This type of lamps are used in places where high chromatic performance is necessary, such as sports spaces, shopping centers, facades, monuments, television broadcasts, etc.

It was from the year 2000, when the greatest technological revolution occurred regarding consumption and energy efficiency in public lighting with the development of LED technology luminaires.

These luminaires were based on the development of power LEDs. An LED is defined as a unidirectional semiconductor electronic device. When the LED is directly polarized (the anode voltage is positive, and the cathode voltage is negative) and current flows through them, the free electrons of the $\mathrm{N}$ layer move
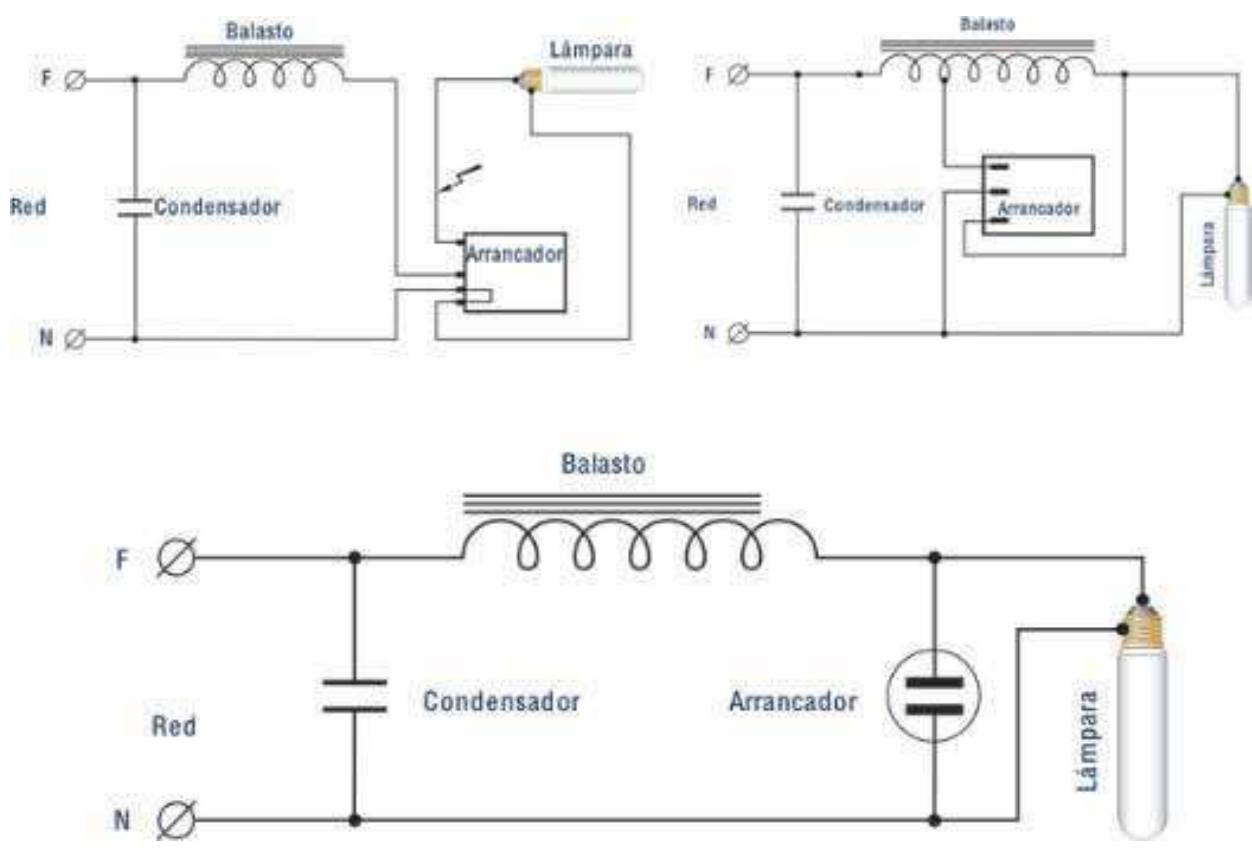

Figure 6.

Wiring diagrams with: independent starter, semi-parallel and parallel. Source: Own elaboration. 
through the diode and combine with the hollows of the layer $\mathrm{P}$, implying a fall of the band of conduction to a smaller orbital, so that the electrons release energy in the form of photons (light). The size of the band jump defines the color of the light (Figures 7 and 8).

The LEDs are designed to work with specific currents, unlike the previously exposed technologies that are built to work with a certain voltage.

These semiconductor devices are fed with a direct current source through a series resistor to limit and control the current and achieve a correct operation and lengthen the life of the component (Figure 9).

The LED luminaires are powered by power supplies (driver), which depend on the configuration of the lamp, of the direct current to provide and control the current that passes through them. The fundamental reason is that voltage variations can cause LED destruction when there is a high voltage increase. On the other hand, a decrease in voltage is used as a method of regulation.

Currently in the field of public lighting, LED diodes of high luminosity are used, they are more complex because they incorporate elements to dissipate the heat that allow to withstand greater currents to provide more luminous flux.

LEDs, thanks to the high resistance they have to environmental conditions and their advantages over incandescent lamps, can be used in any field of outdoor lighting [3].

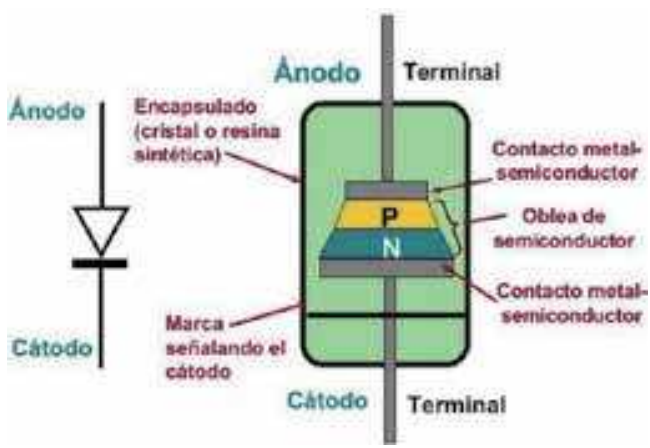

Figure 7.

Structure diode LED. Source: Manual INDAL lighting.

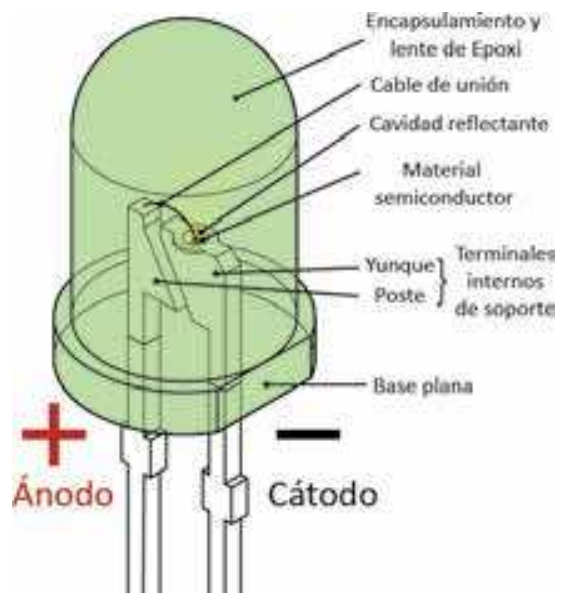

Figure 8.

Components and pinout of the LED. Source: Manual INDAL lighting. 


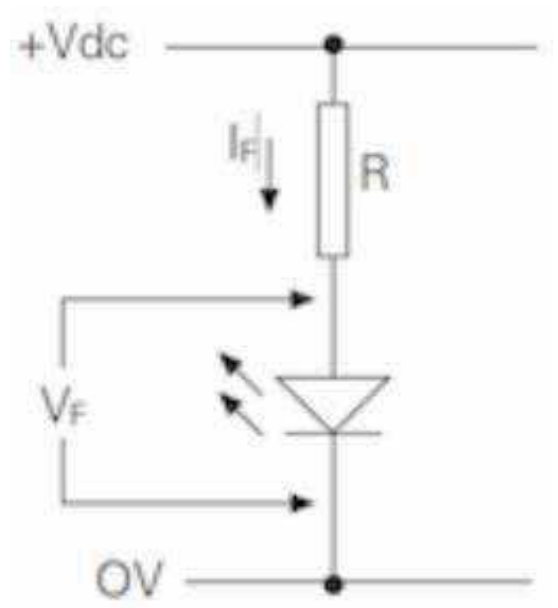

Figure 9.

Connection of an LED lamp. Source: Own elaboration.

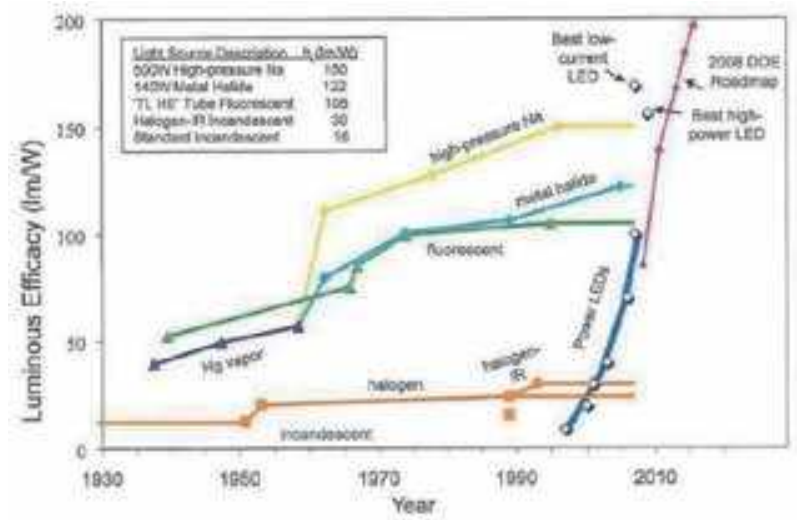

Figure 10.

Graph of evolution of public lighting. Source: INDAL lighting manual.

By way of summary and to give a more general view of the technological evolution and energy efficiency that has suffered public lighting, which has been exposed at this point, you can see the following graph which represents the energy efficiency of each luminaire and its year of appearance (Figure 10).

\subsection{SWOT analysis LED technology versus download}

The SWOT analysis is a map through which the weaknesses, threats, strengths and opportunities of an organization, project, technology, etc. are established. In our case we will perform the SWOT analysis on a technology, in this case the LED against the download technology (Table 1).

Through an analysis of the external environment and the internal characteristics of the technology to be analyzed, this tool allows obtaining a graphic representation of:

- Weaknesses: Constitute the limiting aspects of the capacity of technology development, due to its internal characteristics. 
The Thermal Dissipation of LED Outdoor Lighting Luminaires: Comparative Analysis for a Real... DOI: http://dx.doi.org/10.5772/intechopen.91400

\begin{tabular}{lll}
\hline Internal analysis & External analysis \\
\hline $\begin{array}{l}\text { Negative } \\
\text { to download }\end{array}$ & $\begin{array}{l}\text { Poor performance in high temperature } \\
\text { due to electronic components that } \\
\text { contain }\end{array}$ & $\begin{array}{l}\text { Alteration of behavior and reproduction of } \\
\text { organisms that at night coexist with white light } \\
\text { and alter their rhythm of life }\end{array}$ \\
\hline $\begin{array}{l}\text { They require a high thermal dissipation } \\
\text { to extend their useful life }\end{array}$ & $\begin{array}{l}\text { They produce less } \mathrm{CO}_{2} \text { emissions to achieve the } \\
\text { same lighting }\end{array}$ \\
\hline Positive & Low energy consumption & Greater aid and funding for its implementation \\
\hline Long durability & $\begin{array}{l}\text { Reduction of raw materials for its manufacture by } \\
\text { having a long useful life }\end{array}$ \\
\hline Less light pollution &
\end{tabular}

Table 1.

SWOT analysis LED technology versus discharge: own elaboration.

- Threats: These are all external factors that may prevent the development of this technology.

- Strengths: They gather the set of internal resources, positions of power or any type of competitive advantage over other technologies.

- Opportunities: External factors that favor the development of technology or provide the opportunity to implement improvements.

\subsection{Problems of LED technology}

The use of LED technology in lighting of public lighting seemed to pose a promising revolution with an obvious advantage: the energy savings that would be achieved by using it.

This revolution has been compromised by a series of thermal, electrical and lighting problems that have been studied as this technology began to be implemented in our cities.

Beginning with the part of thermal dissipation, one of the biggest problems that LED technology presents is the large amount of heat that has to be evacuated to the outside with respect to the discharge technology. The large number of electronic components that form a LED luminaire, makes the generation of heat inside it very large [2]. Most of the heat is produced in the driver (80\%), and in the light-emitting diodes (approx. 20\%) [4]. The heat generated in the driver is very large due to its own operation, since it is responsible for the protection of the LEDs by means of a suitable voltage and intensity.

The operation of a LED driver, is basically a full wave diode rectifier bridge, which transforms the alternating current (AC) into direct current (DC) and adapts the voltage and output currents for the correct operation of the LED. The supply voltage of a LED luminaire is the network ( $230 \mathrm{~V}$ effective), this voltage passes through a transformer of reducing voltage that adapts the voltage to the input of the bridge. The input, consists of a bridge of four diodes that lead two to two, depending on the cycle of the voltage wave (positive or negative) and that completely rectifies the voltage wave, then passes through a capacitor that is 
responsible for generate the direct current through its own charge and discharge. Once this has been generated, a Zener diode is responsible for stabilizing and cleaning the direct current so that it can be consumed by the load (LED)

(Figures 11 and 12).

As can be seen, the use of electronic components is large, and the generation of heat is very high, then a poor thermal dissipation causes a very important decrease in the useful life of the luminaire [5].

The second group of problems presented by LED technology is in the electrical part [3]. The large-scale introduction of LED lamps impacts two major disturbances in the quality of energy: distortion or harmonic contamination [6] and peak current at start-up [7].

The harmonic distortion of the LED lamps is higher than the discharge luminaires (due to the electronic components they contain). The concern of network operators is that large quantities of these luminaries will negatively impact the network with high levels of harmonics [6] and supramonics [8]. The concern is that although the absolute value of the emission of a lamp may be low, it is likely that the luminaires will be installed in large quantities and that the combined emission resulting from the lamps may be very important. This will result in heating in the conductors and consequently risk of fire in the installation if the line is not well protected.

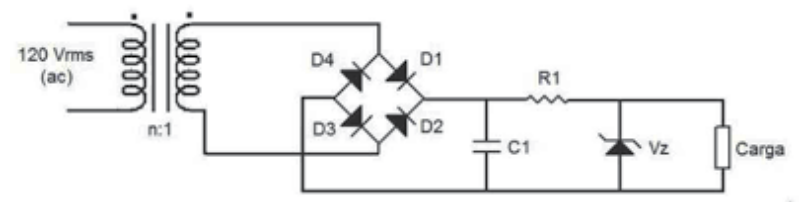

Figure 11.

LED driver components. Source: Own elaboration.
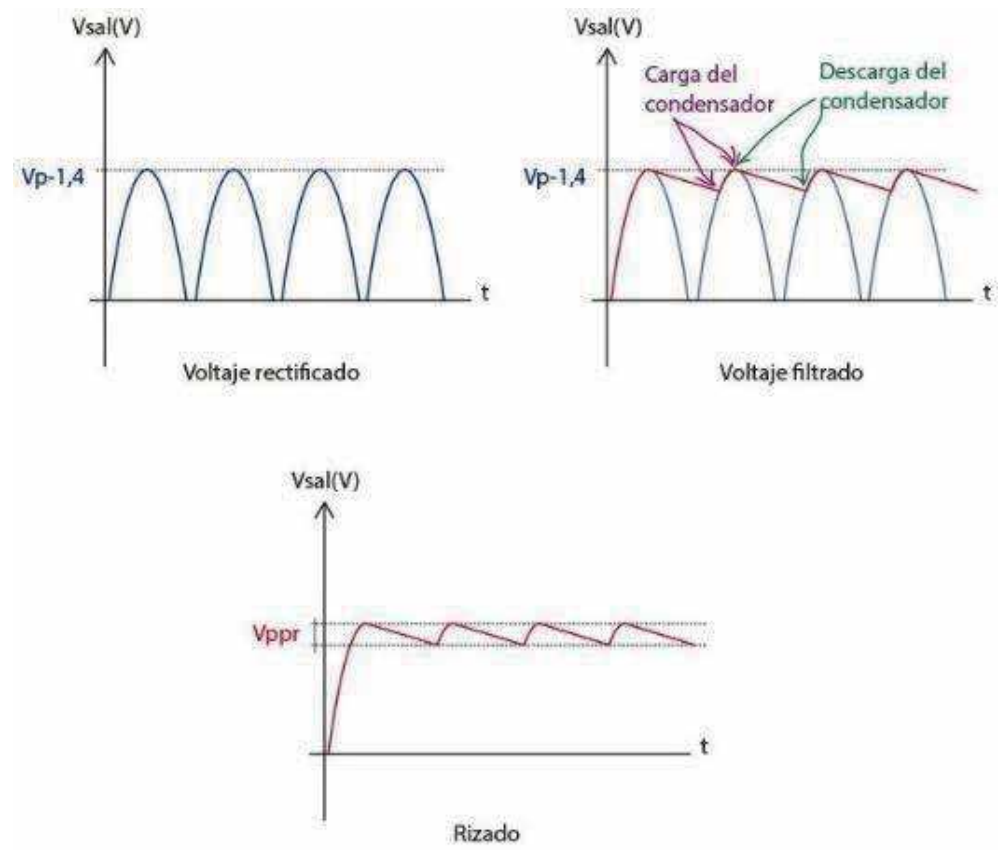

Figure 12.

Wire patterns in the LED driver. Source: Own elaboration. 
With regard to peak current at start-up, it can be said that electronic equipment in luminaires significantly improves their luminous efficiency, which increases the energy efficiency of lighting installations. However, the use of electronics [for example the use of electronic ballasts for discharge lamps or drivers for LED luminaires] can also cause some negative effects in the lighting installation. One of these effects is the large input current [7], which can greatly exceed the permissible line load and activate the overcurrent protection devices. To solve this problem, a progressive ignition is carried out by means of circuits, that is to say, turning on luminaire blocks progressively instead of provoking the massive ignition of the lamps, in order to try to mitigate this problem (Figure 13) [7].

To finish with the problems that this technology presents, we study the light part. Recent studies have shown that the use of outdoor LED lighting has a significant environmental cost, since light pollution, due to the colder color temperature in LED luminaires, degrades ecosystems throughout our planet [9].

It was expected that with the adoption of LED solutions, developed countries would appear "obscured" in the images taken by a satellite thanks to the lower impact of this technology, but its massive use has meant that this lighting simply remains or even increases (Figures 14 and 15).

The results of the study warned of the danger of making light pollution compromise "the well-being of practically any organism of our planet including humans."

This type of light has long been considered an important environmental pollutant that can affect the routines of animals, plants and microorganisms,

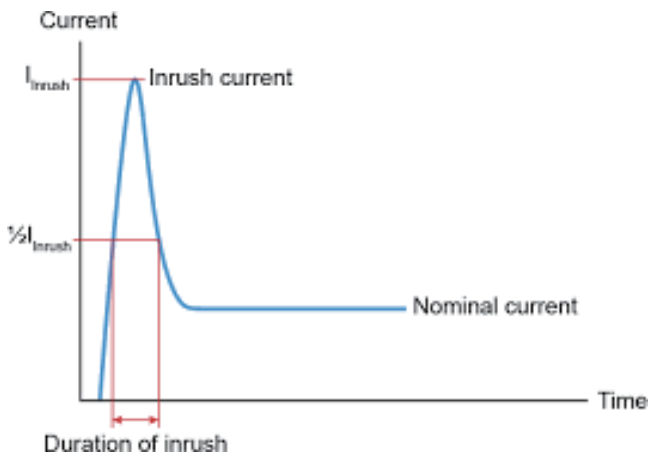

Figure 13.

Peak current in the LED light fixture. Source: eldoLED.

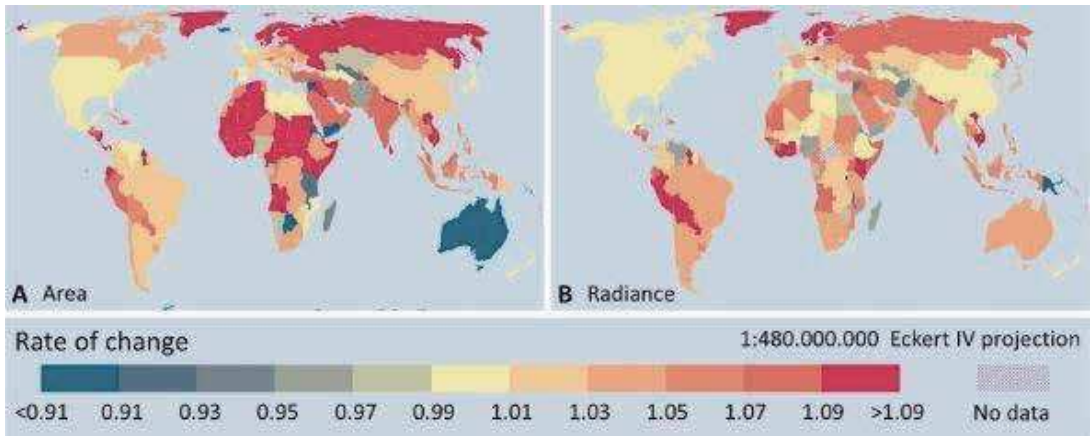

Figure 14.

Geographic patterns of changes in public lighting [6]. 


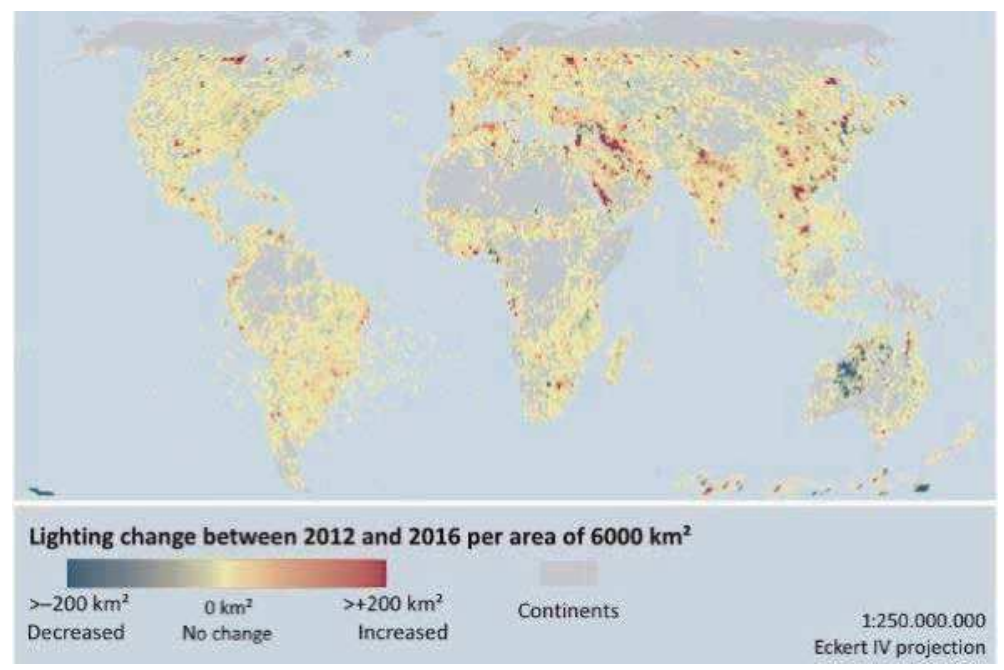

Figure 15.

Absolute change in the illuminated area from 2012 to 2016-Fuente: Ref. [6].

but also that of humans, as it disturbs the circadian rhythm, which can lead to metabolic disorders.

The problem could be minimized by using shorter wavelengths in the luminaires, that is, LED luminaires with warmer lighting. This is achieved by doping the LED, but on the contrary we would be reducing its useful life.

\section{Methodology}

\subsection{Materials and methods}

Because LED lighting has the advantage of a longer lifespan and light efficiency has also been improved, as a result, the market for LED lighting devices has grown rapidly recently. However, due to this fact, there is a serious problem of heat dissipation, since almost $70 \%$ of the total energy consumed by the LED lighting device is emitted as heat and must be eliminated to obtain greater efficiency and a longer life. The performance and lifetime of LED luminaires will become deficient and short if heat does not dissipate properly [2].

Nowadays, it is required that more power be applied to the LED device to produce more light output, therefore, the total heat generated by the LED luminaire will also be significantly increased. If it is not cooled sufficiently, both the service life and the luminous efficiency of the LED device will be reduced. Therefore, to commercialize high power LED devices, the problem of heat dissipation must be overcome first [10].

The development of an effective cooling technology is considered as an important requirement for a permissible operating regime that does not reduce the useful life of the lighting devices.

In this last study carried out in the present work, we propose a methodology for the study of the effectiveness in the dissipation of heat of the different luminaires under analysis by means of the temperature evolution curve of each one of them. The realization of said curve was carried out with the help of a thermographic camera, which will be described in detail in the following sections (Figure 16).

The realization of said thermal study was carried out simulating "real operating conditions" of the luminaires, that is, a nocturnal operating regime was simulated in 

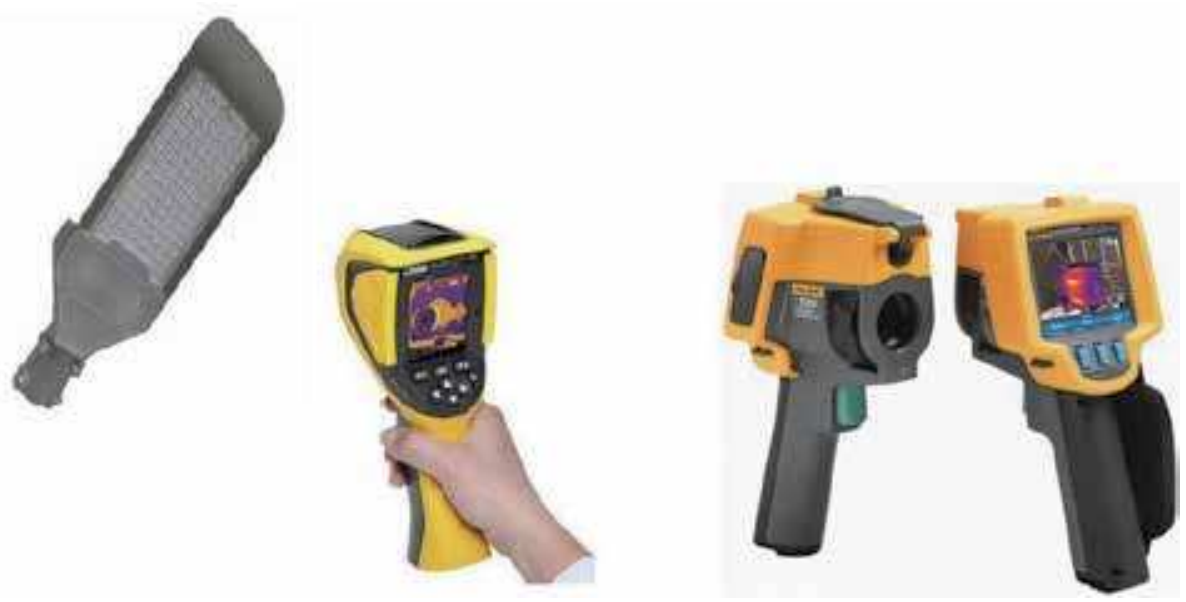

Figure 16.

Experimental set-up for temperature measurement in luminaires. Source: Self made. FLUKE Ti 25 thermal camera. Source: User manual. ThermoFiguraTi2 5 FLUKE camera.

a totally dark room at a normal ambient temperature of $25^{\circ} \mathrm{C}$ and with an interval of $8 \mathrm{~h}$. continuous work of the luminaries, which is normally the time they remain lit during the night in a normal day of operation.

This study was carried out studying the five LED luminaires.

\section{Experimental analysis and results of actual thermal dissipation in the lighting laboratory using a FLUKE TI 25 thermal imaging camera}

For the acquisition of real data of the luminaries a thermographic camera will be used in the lighting laboratory of the University of Jaén. Thermal imaging cameras are devices that convert thermal energy (heat) into visible light to analyze a particular object or scene. The produced image is known as a thermogram and is analyzed through a process called thermography. Thermographic cameras are sophisticated devices that process the captured image and display it on a screen. These images can be used for an immediate diagnosis or processed through specialized software for greater evaluation, accuracy and performance of the report. Thermographic cameras take the measurement temperature to the next level; Instead of getting a number for the temperature, you get an image that shows the

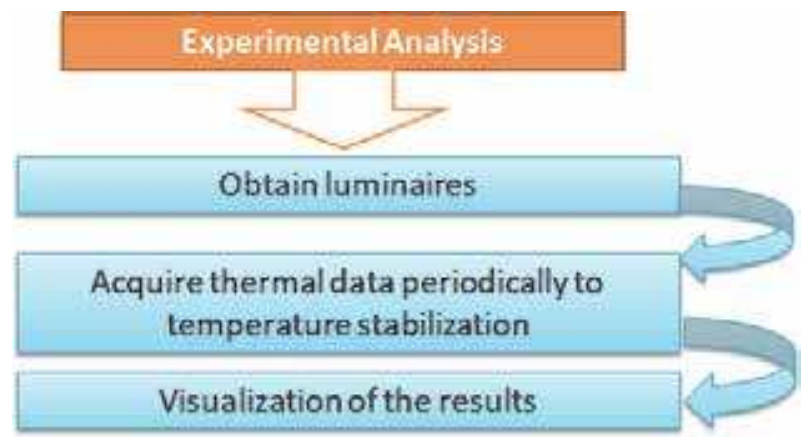

Figure 17.

Flow diagram of the methodology to follow to obtain the theoretical results in the thermal analysis of the five LED luminaires under study. Source: Self made. 


\begin{tabular}{lc}
\hline Atributo & Valor \\
\hline Sensibilidad Termal & $\leq 90 \mathrm{mK}$ \\
\hline Rango de Medición de Temperatura & $-20 \rightarrow+350^{\circ} \mathrm{C}$ \\
\hline Precisión Máxima de Medición de Temperatura & $\pm 2^{\circ} \mathrm{C}$ \\
\hline Campo de visión H x V & $23 \times 17^{\circ}$ \\
\hline Frecuencia de Actualización & $9 \mathrm{~Hz}$ \\
\hline Distancia Mínima de Enfoque & 15 (Thermal Lens) cm, 46 (Visual Lens) cm \\
\hline Tipo de Enfoque & $160 \times 120$ píxel \\
\hline Resolución del Detector & $3.7 \mathrm{plg}$ \\
\hline Tamaño del Display & $640 \times 480$ píxel \\
\hline Resolución de Display & $1.2 \mathrm{~kg}$ \\
\hline Peso & $267 \mathrm{~mm}$ \\
\hline Altura & $127 \mathrm{~mm}$ \\
\hline Anchura & Ti25 \\
\hline Número de modelo & $152 \mathrm{~mm}$ \\
\hline Longitud & \\
\hline Source: User's manual. Ti 25 FLUKE thermal imager. & \\
\hline
\end{tabular}

Table 2.

Table of specifications of the thermal imager.

temperature differences of a surface [11]. Figure 17 shows the flow diagram for the acquisition of experimental data from five LED luminaires for further study [12] and comparisons with the theoretical thermal data [13].

\subsection{Features of the thermal imager used}

The thermal imager used is a FLUKE Ti 25; this camera is manufactured to be used in very adverse work environments. It captures a digital image with an infrared and merges it. The temperature range is from -20 to $350^{\circ} \mathrm{C}$ with a pressure of $2^{\circ} \mathrm{C}$. The thermal sensitivity is $0.1^{\circ} \mathrm{C}$ at an ambient temperature of $30^{\circ} \mathrm{C}$; this describes the smallest difference between two pixels in the temperature that the camera can measure [11]. Table 1 shows the specifications of the thermal imager used for the study (Table 2).

For the study of the images taken with the thermal imager, the SmartView software that is supplied with the camera is used. This software contains functions to be able to analyze the images and organize the stored data [11].

\subsection{Emissivity}

All objects radiate infrared energy. The amount of energy radiated is based on two main factors: the surface temperature of the object and the emissivity of said surface [11]. Most of the measured objects such as painted metal, wood, water, skin and fabric are very efficient to radiate energy and it is very easy to obtain accurate measurements. For surfaces that are efficient to radiate energy (high emissivity), the emissivity factor is estimated at 95\% (or 0.95) [14]. The emissivity varies from 0 to 1 , for a black body that radiates the maximum infrared energy its value is 1 . 
However, this simplification does not work for shiny or metallic surfaces without painting, a correction of the emissivity is necessary [15].

Emissivity is a very important issue for the measurement of surface temperature without being in contact [14]. Depending on the material to be measured, the emissivity will vary [15]. The emissivity determined to obtain the temperatures of the materials has been obtained from a table of emissivities [16].

\subsection{Luminaires under experimental study}

The luminaires chosen for the acquisition of data with the thermal imager in the lighting laboratory are due to the availability of the manufacturers to provide the luminaires and luminaires that are in the lighting laboratory of the University of Jaén. In particular there are two luminaires that are currently installed throughout the city of Jáen (Figure 19).

The first luminaire under study is the ATP Air Series 7 luminaire, see Figure 18. This luminaire corresponds to a novel design for the improvement of thermal dissipation and corresponds to Model A, which has performed thermal simulation for the prediction of heat dissipation and air flow [17].

Another available luminaire is the NaviaP model by Sólydi Led Innovation, Figure 19, which corresponds to a design in which the heat sink is in contact with the environment, with a total nominal power of $60 \mathrm{~W}, 32 \mathrm{LEDs}$ with a power of 1.67 W/LED, the heat sink material is aluminum.

The next luminaire corresponds to the LH-GL1A manufactured by Luminhome Lighting (Figure 20), with a nominal power of $60 \mathrm{~W}$, which has 18 LEDs with $2 \mathrm{~W} / \mathrm{LED}$, the body and housing materials are made of an aluminum alloy [18].

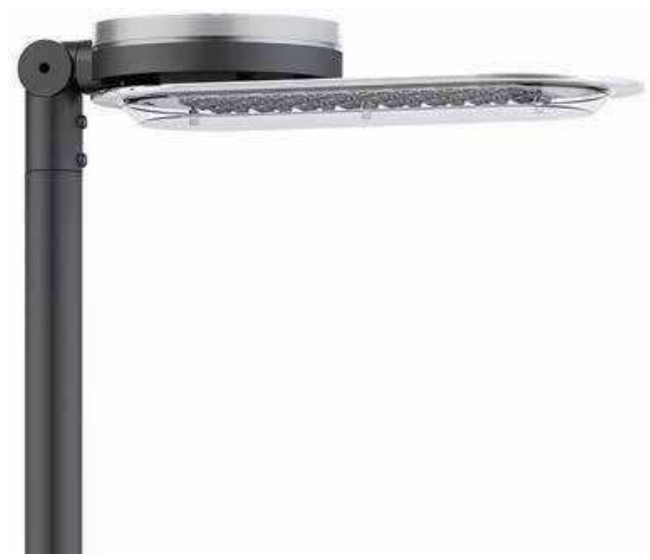

Figure 18.

Series 7 air LED luminaire from ATP lighting. Source: ATP LED catalog lighting February 2018.

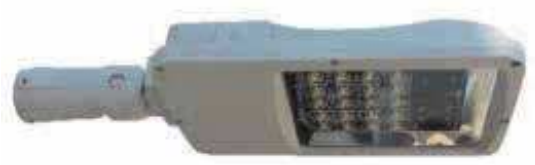

Figure 19.

LED NaviaP luminaire by Sólydi LED innovation. Source: Sólydi catalog. 
Another luminaire to which the experimental data for the study will be taken is the luminaire T1A-2-80 of Luminhome Lighting (Figure 21). The nominal power of the luminaire is $80 \mathrm{~W}$, with 2 modules of 14 LEDs, with $2.3 \mathrm{~W} / \mathrm{LED}$. The body and the housing are formed by an aluminum alloy [19].

And the last luminary present in this study corresponds to a Philips luminaire with a nominal power of $20 \mathrm{~W}$, Figure 22. It consists of 16 LEDs of a power of $1 \mathrm{~W} / \mathrm{LED}$, the body and the housing are integrated by an aluminum alloy.

In Table 3 the main characteristics belonging to the five luminaires of the present study are collected.

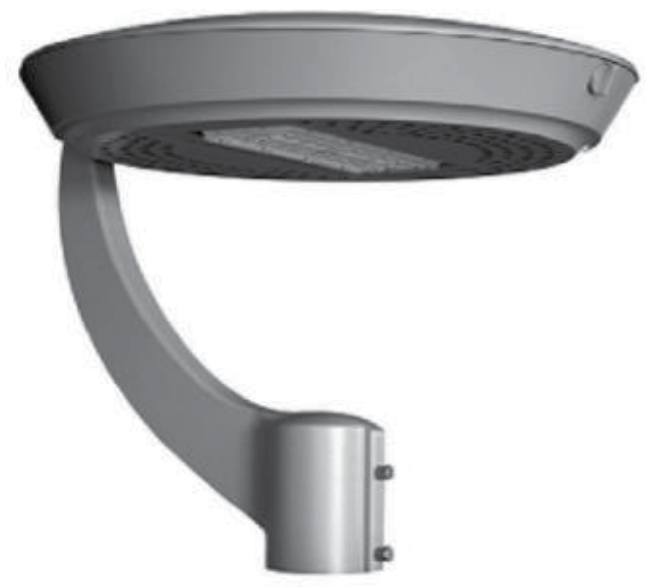

Figure 20.

Luminaire LH-GL1A by Luminhome lighting. Source: Data sheet luminaire LH-GL1A by Luminhome lighting.

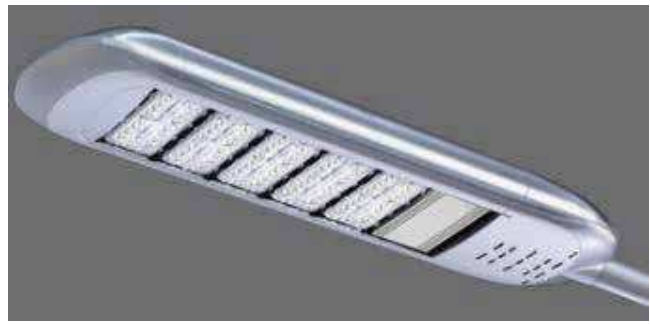

Figure 21.

Luminaire T1A-2-8o by Luminhome lighting. Source: Data sheet luminaire T1A-2-8o by Luminhome lighting.

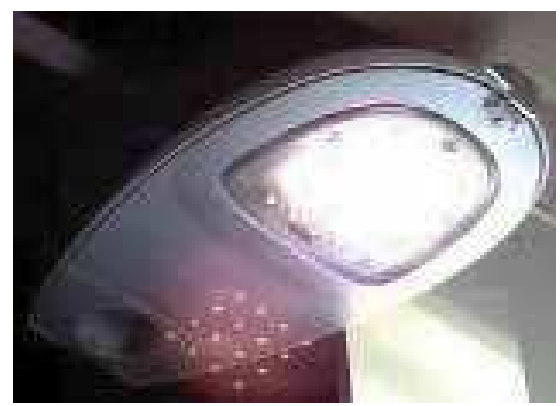

Figure 22.

Philips 20 W luminaire. Source: Self made. 
The Thermal Dissipation of LED Outdoor Lighting Luminaires: Comparative Analysis for a Real... DOI: http://dx.doi.org/10.5772/intechopen.91400

\begin{tabular}{lcccc}
\hline Model & $\begin{array}{c}\text { Nominal } \\
\text { power (W) }\end{array}$ & $\begin{array}{c}\text { Number } \\
\text { of LED }\end{array}$ & $\begin{array}{c}\text { Power by LED } \\
\text { (W/LED) }\end{array}$ & $\begin{array}{c}\text { DRIVER } \\
\text { power (W) }\end{array}$ \\
\hline ATP Aire Serie 7 & 204 & 96 & 2 & 12 \\
\hline Sólidy NaviaP & 60 & 32 & 1.67 & 7 \\
\hline LH-GL1A & 60 & 18 & 2.7 & 10 \\
\hline T1A-2-80 & 80 & 28 & 2.3 & 15 \\
\hline Philips 20 W & 20 & 16 & 1 & 4 \\
\hline Source: Self made. & & & & \\
\hline
\end{tabular}

Table 3.

Summary table of the main characteristics of each luminaire.

\subsection{Data acquired with the thermal imager}

A progressive data collection has been made from the ignition to the thermal stabilization of the equipment. Taking data periodically until the temperature has remained stable. The images of the thermal imager represent temperature in steady state, once.

\subsubsection{Thermographic data Air Series 7}

When making measurements of the heatsink with the thermal imager and being a specific material with a certain alloy or formulation in the material compound, several types of emissivities have been used to obtain the exact temperature (Figures 23-30).

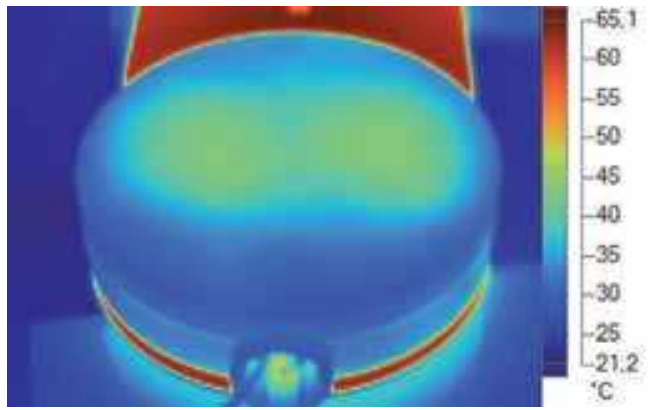

Figure 23.

Thermal data of the cover. Blue and green area. Plastic emissivity 0.92. Source: Own elaboration from software SmartView 4.1 Fluke.

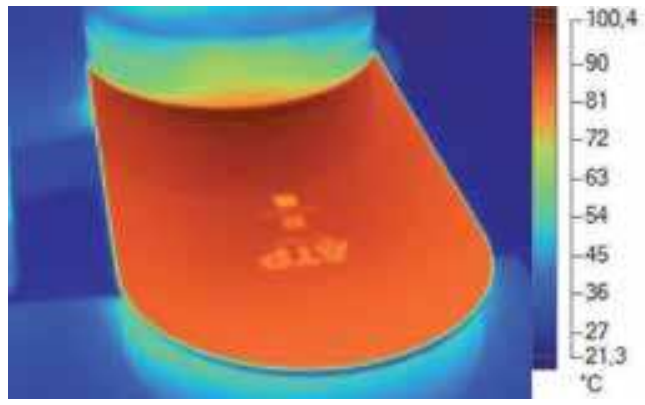

Figure 24.

Thermal data of the heatsink. Reddish area emissivity aluminum alloy 0.5. Source: Own elaboration from software SmartView 4.1 Fluke. 


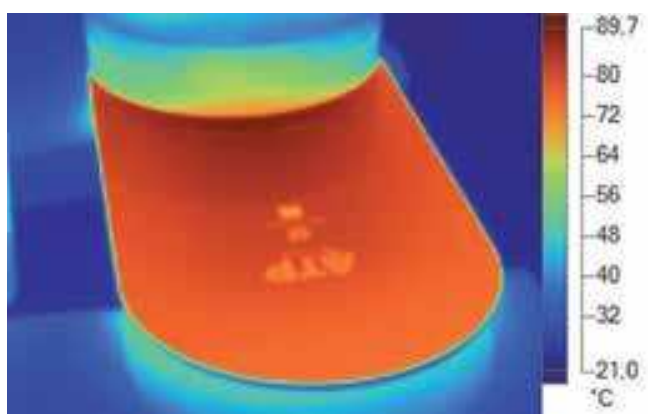

Figure 25.

Thermal data of the heatsink. Reddish area emissivity aluminum alloy 0.6. Source: Own elaboration from software SmartView 4.1 Fluke.

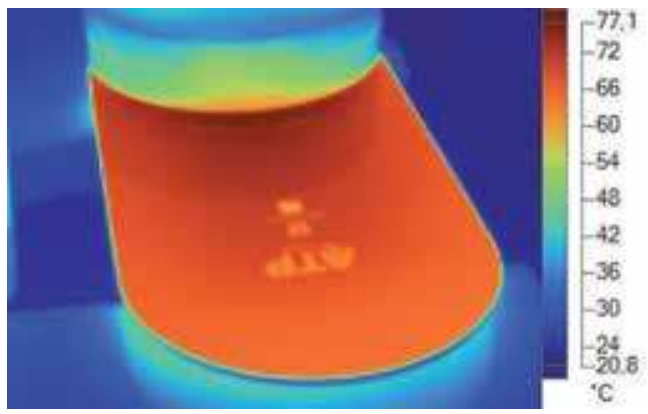

Figure 26.

Thermal data of the dissipator reddish zone. Emissivity anodized aluminum 0.77. Source: Own elaboration from software SmartView 4.1 Fluke.

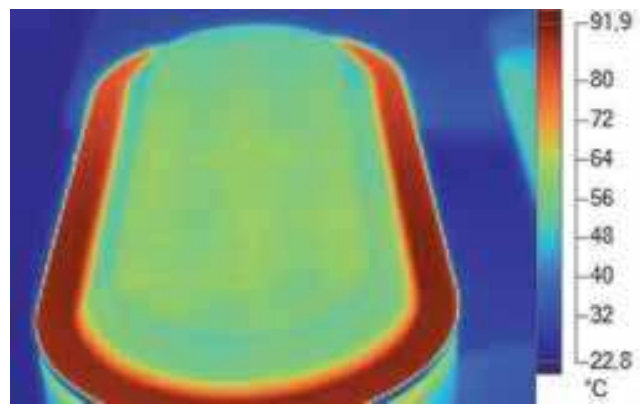

Figure 27.

Thermal data of the heatsink. Reddish area emissivity aluminum alloy 0.5. Source: Own elaboration from software SmartView 4.1 Fluke.

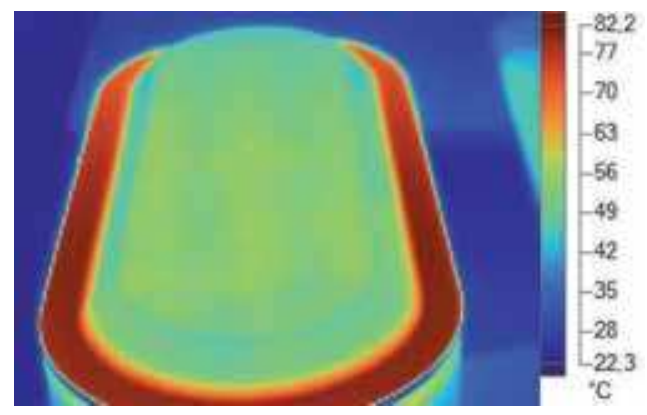

Figure 28.

Thermal data of the heatsink. Reddish area emissivity aluminum alloy 0.6. Source: Own elaboration from software SmartView 4.1 Fluke. 
The Thermal Dissipation of LED Outdoor Lighting Luminaires: Comparative Analysis for a Real... DOI: http://dx.doi.org/10.5772/intechopen.91400

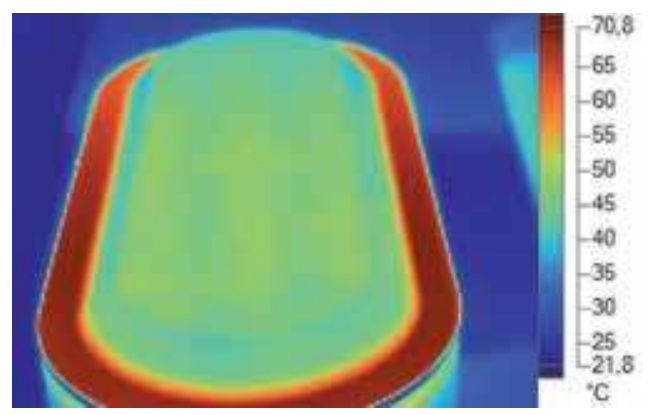

Figure 29.

Thermal data of the heatsink. Reddish area emissivity anodized aluminum 0.77. Source: Own elaboration from software SmartView 4.1 Fluke.

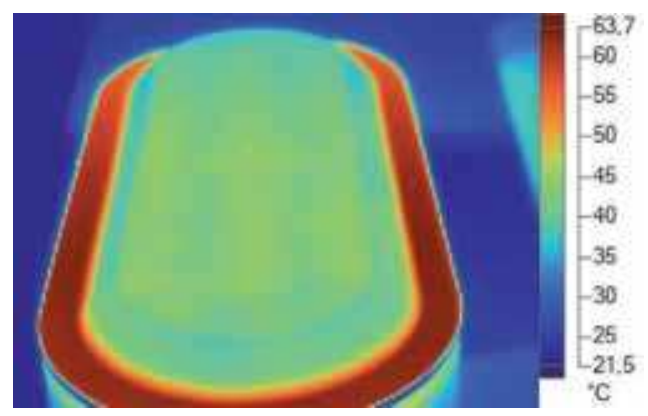

Figure 30.

Thermal data of the diffuser. Green zone plastic emissivity 0.92. Source: Own elaboration from software SmartView 4.1 Fluke.

\subsubsection{Thermographic data NaviaP}

See Figures 31 and 32.

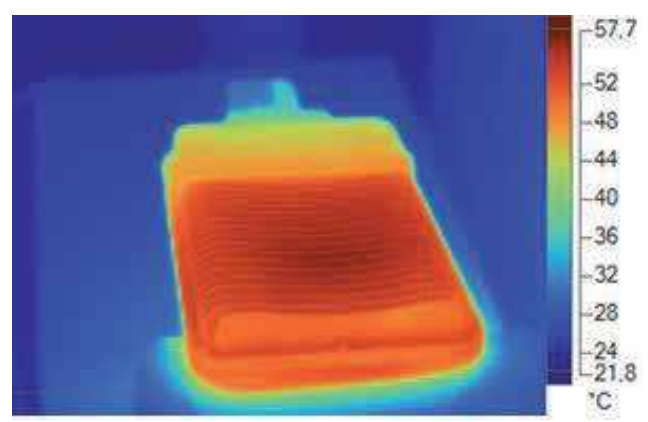

Figure 31.

Thermal data of the heatsink. Reddish area emissivity anodized aluminum 0.77. Source: Own elaboration from software SmartView 4.1 Fluke.

\subsubsection{Thermographic data LH-GL1A}

See Figures 33 and 34.

3.4.4 T1A-2-80 thermographic data

See Figures 35 and 36. 


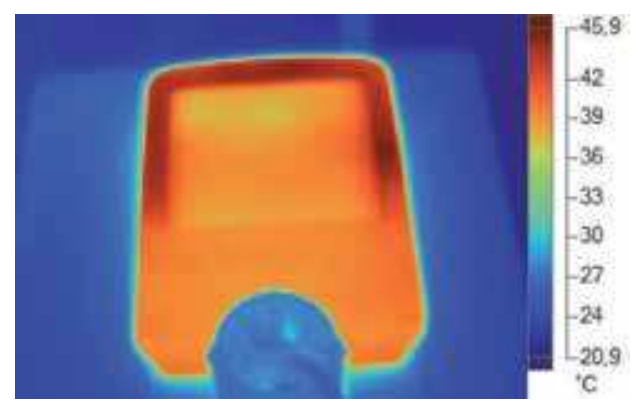

Figure 32.

Thermal data of the diffuser. Square central area orange color. Emissivity glass 0.94. Source: Own elaboration from software SmartView 4.1 Fluke.

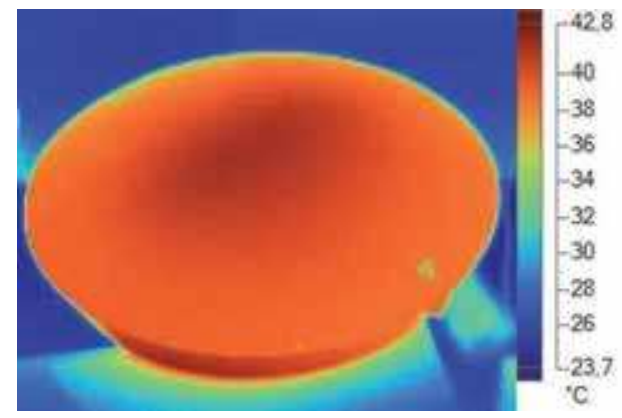

Figure 33.

Thermal data of the housing. Reddish area emissivity anodized aluminum 0.77. Source: Own elaboration from software SmartView 4.1 Fluke.

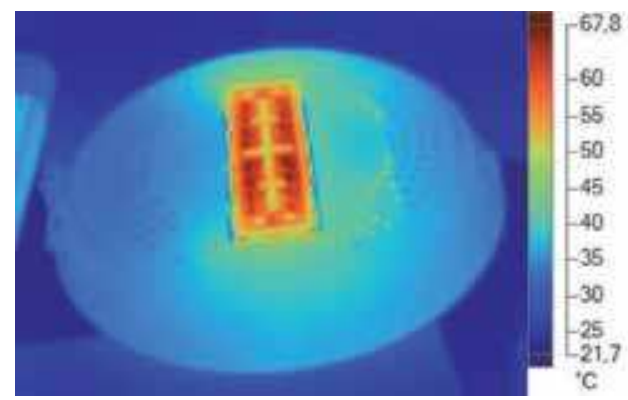

Figure 34 .

Thermal data of the diffuser. Reddish area plastic emissivity 0.92. Source: Own elaboration from software SmartView 4.1 Fluke.

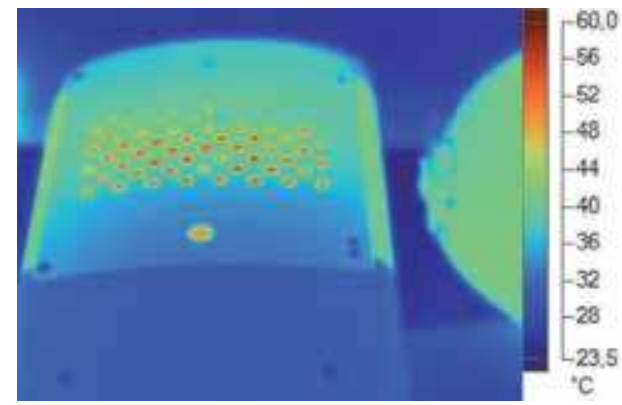

Figure 35 .

Thermal data of the housing/heatsink. Reddish area emissivity anodized aluminum 0.77. Source: Own elaboration from software SmartView 4.1 Fluke. 
The Thermal Dissipation of LED Outdoor Lighting Luminaires: Comparative Analysis for a Real... DOI: http://dx.doi.org/10.5772/intechopen.91400

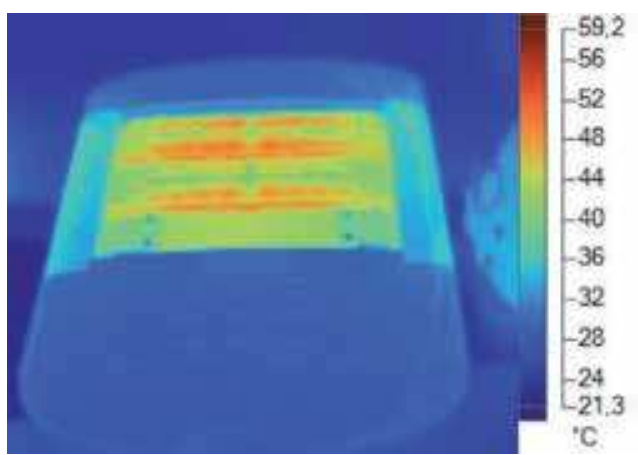

Figure 36.

Thermal data of the diffuser. Reddish area plastic emissivity 0.92. Source: Own elaboration from software SmartView 4.1 Fluke.

\subsubsection{Datos termográficos Philips $20 \mathrm{~W}$}

See Figures 37 and 38.

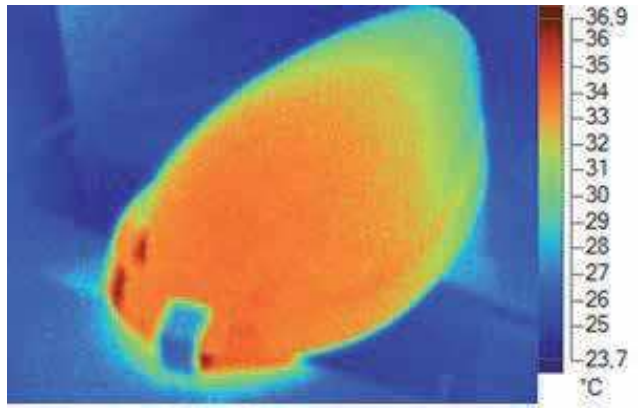

Figure 37.

Thermal data of the housing. Orange zone. Emissivity anodized aluminum 0.77. Source: Own elaboration from software SmartView 4.1 Fluke.

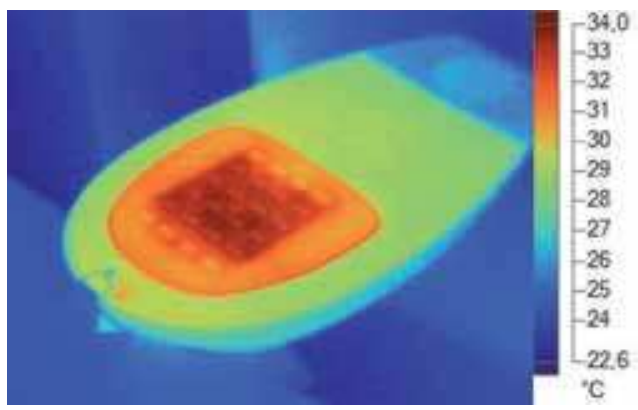

Figure 38.

Thermal data of the diffuser. Reddish area plastic emissivity 0.92. Source: Own elaboration from software SmartView 4.1 Fluke.

\subsection{Evolution of the temperature of the luminaires and maximum temperatures of the same}

In Figure 39, the evolution of the temperature is represented as the operating time increases. 
Approximately after $5 \mathrm{~h}$ of operation, as shown in Figure 39. It is appreciated that the ATP luminaire reaches a higher temperature due to the nominal power of operation that is $200 \mathrm{~W}$, significantly higher than the rest of the luminaires. As we could imagine.

Table 4 shows the maximum temperatures obtained in the last measurement of each luminaire in the heatsink or housing depending on the luminaire and the diffuser. It is appreciated that depending on the design, power, distribution of LEDs and materials, the temperatures vary from one luminaire to another.

Figure 40 shows the nominal power of each luminaire compared to the maximum temperature reached in the heatsink/housing of each luminaire when the temperature has stabilized. It is observed that there is no linearity of the nominal power with respect to the maximum temperature reached due to the different designs of the luminaires themselves and the characteristic materials that form them. With an appropriate design of the luminaire, having a sufficient sink contact

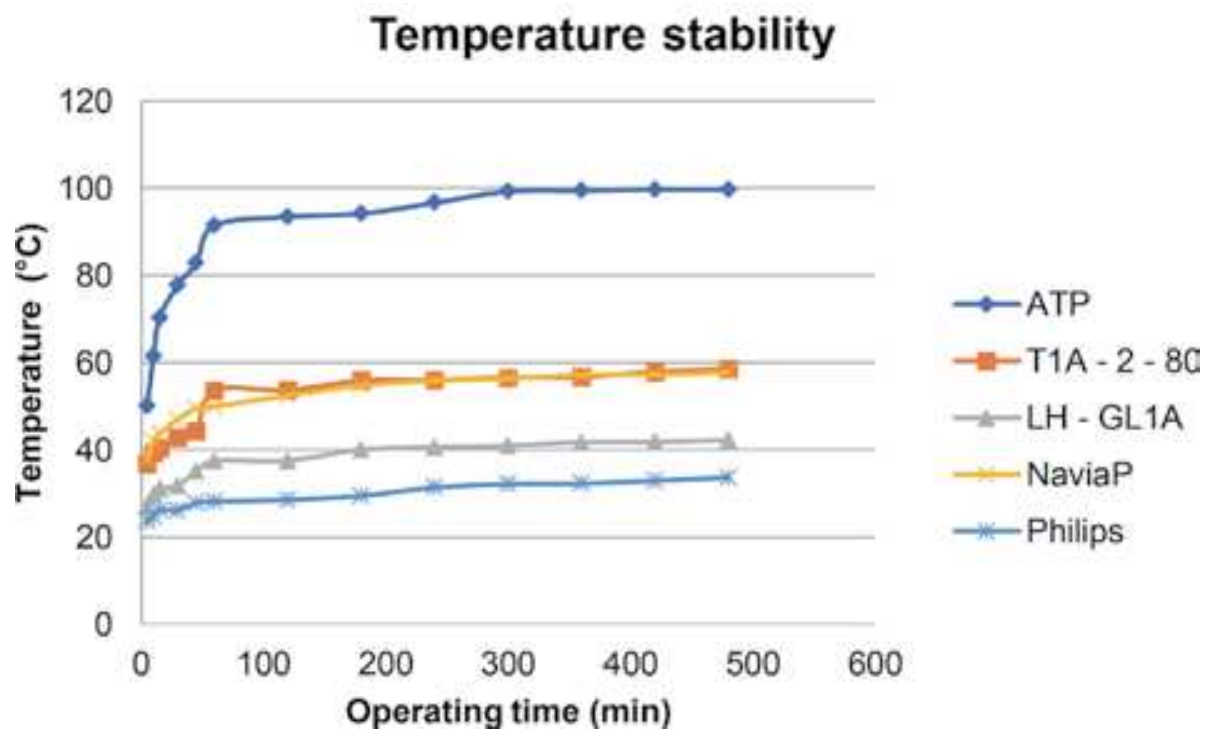

Figure 39.

Operating time (min) vs. temperature $\left({ }^{\circ} \mathrm{C}\right)$. Source: Self made.

\begin{tabular}{lcc}
\hline Model & $\begin{array}{c}\text { Maximum temperature } \\
\text { heatsink } / \text { casing }\left({ }^{\circ} \mathrm{C}\right)\end{array}$ & $\begin{array}{c}\text { Maximum diffuser } \\
\text { temperature }\left({ }^{\circ} \mathrm{C}\right)\end{array}$ \\
\hline ATP Aire Serie 7 & 99.7 & 40.2 \\
\hline Sólidy NaviaP & 57.7 & 39.3 \\
\hline LH-GL1A & 42.3 & 67.8 \\
\hline T1A-2-80 & 58.5 & 52.1 \\
\hline Philips 20 W & 33.7 & 34.0 \\
\hline Source: Self made. & & \\
\hline
\end{tabular}

Table 4 .

Summary table of the maximum temperatures of each luminaire. 
The Thermal Dissipation of LED Outdoor Lighting Luminaires: Comparative Analysis for a Real... DOI: http://dx.doi.org/10.5772/intechopen.91400

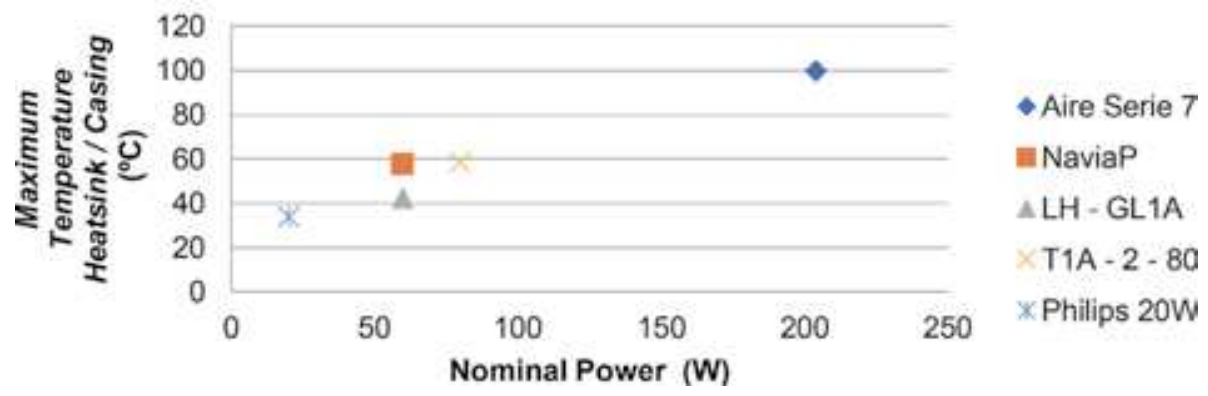

Figure 40.

Nominal power $(W)$ of each luminaire vs. maximum temperature dissipater/housing $\left({ }^{\circ} \mathrm{C}\right)$. Source: Self made.

surface and a selection of materials where the thermal conductivity is high, the results of thermal dissipation will be improved. As shown in Figure 40.

\section{Conclusions}

The purpose of this study is to compare the results of thermal simulations with experimental data acquired in the laboratory. The main objectives are compiled and concluded in this section.

This study focuses on thermal analysis to verify the materials of the luminaires and verify that the temperature of the LEDs is not too high for the proper functioning of these light-emitting diodes, causing a decrease in the useful life and a variation of the light properties of the LEDs. All electronic devices and circuits generate excess heat and require greater attention to avoid premature failures. The LEDs convert $15 \%$ of the applied energy into light and the remaining $85 \%$ into heat, this heat must be dissipated so that the durability and properties of the LEDs are not affected by the increase in temperature [10, 20-24].

The thermal measurements give the engineer information about the temperature and the air flow inside the equipment. They allow engineers to design cooling systems to optimize the design and reduce energy consumption, weight and cost, and verify that there are no problems when the equipment is built. Most thermal simulation software uses computational fluid dynamics (CFD) techniques to predict the temperature and air flow of an electronic system.

In this study, experimental data of five LED luminaires of different powers and models have been acquired and in the same conditions of contour in the lighting laboratory with the FLUKE Ti 25 thermal camera, it is indicated that the design is indeed important due to the dissipation heat of the luminaires for the effective operation of electronic devices.

At the time of favoring heat dissipation, the dissipator is the most important component to reduce the binding temperature. Most heatsinks are designed with fins to increase their contact surface with air and dissipate more heat [25]. It will be necessary to improve the design of the components of the luminaire to facilitate the dissipation of heat and favor the passage of air through the heatsink of the luminaires to lower the temperature of electronic devices. To improve the cooling, ventilations can be incorporated to improve the flow of the air inside and that can go to the outside.

A major problem with high power LED luminaires is the heat generated inside. The distribution of the LEDs and the effect of the number of LEDs lit affect the 
junction temperature and strongly participate in the degradation of the LED [26]. Most luminaires contain aluminum heatsinks as a solution. Currently, materials with new alloys and formulations for an effective thermal dissipation are being investigated, for example, aluminum nitrate has been developed to be applied as a thin layer in the dissipaters that has certain advantages over conventional dielectrics based on polymers or ceramic substrates such as excellent thermal dissipation and low thermal resistance [27]. The topic of thermal dissipation is the order of the day, materials are being investigated to be used as heat sinks that promote greater durability of LEDs due to an improvement in thermal dissipation [28].

Due to which, it is necessary to bear in mind that the lighting fixtures of public lighting of discharge and where they are replaced by LED technology, leaving the housing of the luminaires previously installed, ends up affecting the electronic devices if there is not good thermal dissipation. As previously mentioned in this section, the use of natural or forced vents would favor the dissipation of heat from the electronic components.

Electronic devices are affected by high temperatures. A high LED junction temperature reduces the useful life, varies the chromaticity and decreases the luminous flux, reducing the luminous properties.

To summarize, it has been shown that the input power is the heat generated by the luminaire and, depending on the design and the choice of materials, the joining temperature of the LEDs is higher due to the low heat dissipation that occurs in them, being detrimental to the proper functioning of LEDs. The choice of an LED, which has a lower junction temperature than can be reached in the luminaire, could decrease its properties up to $100 \%$, making this LED unusable for what corresponds to its operation.

A good design of the luminaire where the circulation of air is favored for the benefit of the dissipation of the junction temperature of the LEDs will favor the useful life and improve the efficiency and reliability of the LEDs having better lighting properties. Apart from the design, a good selection of materials for the components of the luminaire where the thermal conductivity is high favors the thermal dissipation of the luminaire. 
The Thermal Dissipation of LED Outdoor Lighting Luminaires: Comparative Analysis for a Real... DOI: http://dx.doi.org/10.5772/intechopen.91400

\section{Author details}

Hermoso-Orzáez Manuel Jesús ${ }^{1 *}$, Hervás-Pulido Manuel Jesús ${ }^{1}$, Unión-Sánchez Juan de Dios ${ }^{1}$, Ogáyar-Fernández Blas ${ }^{2}$ and Gago-Calderon Alfonso ${ }^{3}$

1 Department of Graphic Engineering Design and Projects, Universidad de Jaen, Jaen, Spain

2 Department of Electrical Engineering, Universidad de Jaen, Jaen, Spain

3 Department of Graphic Expression, Design and Projects, Universidad of Málaga, Malaga, Spain

*Address all correspondence to: mhorzaez@ujaen.es

\section{IntechOpen}

(C) 2020 The Author(s). Licensee IntechOpen. Distributed under the terms of the Creative Commons Attribution - NonCommercial 4.0 License (https://creativecommons.org/ licenses/by-nc/4.0/), which permits use, distribution and reproduction for non-commercial purposes, provided the original is properly cited. (cc) BY-NC 


\section{References}

[1] Martin F. In: Vicente AM, editor. Practical Lighting Manual. 1st ed. 03 February 2010. ISBN-10: 848744010X. ISBN-13: 978-8487440106 (in Spanish)

[2] Huang C-H, Wang G-J. A design problem to estimate the optimal fin shape of LED lighting heat sinks. International Journal of Heat and Mass Transfer. 2017;106:1205-1217. DOI: 10.1016/j.ijheatmasstransfer.2016. 10.101

[3] Hermoso-Orzáez MJ, Rojas-Sola JI, Gago Calderón A. Electrical consequences of large-scale replacement of metal halide by LED luminaires. Lighting Research and Technology. 2018;2:282-293. DOI: 10.1177/ 1477153516645647

[4] Cheng HH, Huang DS, Lin MT. Heat dissipation design and analysis of high power LED array using the finite element method. Microelectronics Reliability. 2012;5:905-911. DOI: 10.1016/j.microrel.2011.05.009

[5] Jang D, Yook S-J, Lee K-S. Optimum design of a radial heat sink with a fin-height profile for high-power LED lighting applications. Applied Energy. 2014:260-268. DOI: 10.1016/j. apenergy.2013.11.063

[6] de Castro AG, Ronnberg SK, Bollen MHJ. Light intensity variation (flicker) and harmonic emission related to LED lamps. Electric Power Systems Research. 2017:107-114. DOI: 10.1016/j. epsr.2017.01.026

[7] Markiewicz P, Sikora R, Pabjanczyk W. Statistical analysis of peak inrush current: A case study. Compel: The International Journal for Computation and Mathematics in Electrical and Electronic Engineering. 2018;3:1069-1084. DOI: 10.1108/ Compel-07-2017-0312
[8] Garrido J, Muñoz AM, de Castro AG, López VP, Leal TM. Supraharmonics emission from LED lamps: A reduction proposal based on random pulse-width modulation. Electric Power Systems Research. 2018:11-19. DOI: 10.1016/j. epsr.2018.07.032

[9] Ong T. The unfortunate side effect of LED lighting. The Verge. 2017.

Available from: https://www.theverge. com/2017/11/23/16693914/energy-ledsboost-light-pollution-worldwide

[10] Jang H, Lee JH, Byon C, Lee BJ. Innovative analytic and experimental methods for thermal management of SMD-type LED chips. International Journal of Heat and Mass Transfer. 2018;124:36-45. DOI: 10.1016/j. ijheatmasstransfer.2018.03.055

[11] Manual de uso. Cámara Termográfica Ti25 FLUKE

[12] Lee DK, Lee JM, Cho MU, Park HJ, Cha YJ, Kim HJ, et al. Influence of the thermal conductivity of thermally conductive plastics on the thermal distribution of a light-emitting diode headlight for vehicles. Journal of Nanoscience and Nanotechnology. 2018; 18(9):5904-5907. DOI: 10.1166/ jnn.2018.15587

[13] Anithambigai P, Chakravarthii MKD, Mutharasu D, Huong LH, Zahner T, Lacey D, et al. Potential thermally conductive alumina filled epoxy composite for thermal management of high power LED. Journal of Materials Science-Materials in Electronics. 2017; 28(1):856-867. DOI: 10.1007/s10854-0165600-4

[14] Chen HY, Chen CC. Determining the emissivity and temperature of building materials by infrared thermometer. Construction and Building Materials. 2016;126:130-137. DOI: 10.1016/j. conbuildmat.2016.09.027 
[15] When CD, Chai TY. Experimental investigation of emissivity of aluminum alloys and application of multispectral radiation thermometry. Applied Thermal Engineering. 2011;31(14-15): 2414-2421. DOI: 10.1016/j. applthermaleng.2011.04.005

[16] Emissivity Coefficients Materials. The Engineering ToolBox

[17] Sólydi Catálogo

[18] Hoja de características Luminaria LH - GL1A de Luminhome Lighting

[19] Hoja de características Luminaria T1A - 2 - 80 de Luminhome Lighting

[20] Verma P, Patel N, Nair N-KC. Light-emitting diode electronics, harmonic issues, and augmenting standards. IEEE Consumer Electronics Magazine. 2017;6(4):150-156. DOI: 10.1109/MCE.2017.2714280

[21] Hermoso Orzáez MJ, Gago Calderón A, Rojas-Sola JI. Power quality and energy efficiency in the preevaluation of an outdoor lightning renewal with light-emitting diode technology: Experimental study and amortization analysis. Energies. 2017;10 (7). https://doi.org/10.3390/en10070836

[22] Wu CN, Chen YL, Chen YM. Primary-side peak current measurement strategy for high-precision constant output current control. IEE Transactions on Power Electronics. 2015;2:967-975. DOI: 10.1109/TPEL.2014.2312955

[23] Gil-de-Castro A, Moreno-Muñoz A, Larsson A, de la Rosa JJG, Bollen MHJ. LED street lighting: A power quality comparison among street light technologies. Lighting Research and Technology. 2013;6:710-728. DOI: 10.1177/1477153512450866

[24] Yoomak S, Jettanasen C, Ngaopitakkul A, Bunjongjit S, Leelajindakrairerk M. Comparative study of lighting quality and power quality for LED and HPS luminaires in a roadwey lighting system. Energy and Buildings. 2018;159:542-557. DOI: 10.1016/j.enbuild.2017.11.060

[25] Karatekin C, Kokkaya O. Comparative analysis of different cooling fin types for countering LED luminaires' heat problems. Turkish Journal of Electrical Engineering and Computer Sciences. 2018;26(1): 454-466. DOI: 10.3906/elk-1602-121

[26] Ben Abdelmlek K, Araoud Z, Ghnay R, Abderrazak K, Charrada K, Zissis G. Effect of thermal conduction path deficiency on thermal properties of LED package. Applied Thermal Engineering. 2016;102:251-260t. DOI: 10.1016/j.applthermaleng.2016.03.100

[27] Hahn BD, Kim Y, Choi JJ, Ryu JH, Kim JW, Yoon WH, et al. Fabrication and characterization of aluminum nitride thick film coated on aluminum substrate for heat dissipation. Ceramics International. 2016;42(16):18141-18147. DOI: 10.1016/j.ceramint.2016.08.128

[28] Cho EC, Huang JH, Li CP, ChangJian CW, Lee KC, Hsiao YS, et al. Graphene-based thermoplastic composites and their application for LED thermal management. Carbon. 2016;102:66-73. DOI: 10.1016/j. carbon.2016.01.097 



\title{
Control Systems and Ornamental Lighting. A Case Study: Illumination of the Facade of Santiago Hospital in Úbeda (Jaén)
}

\author{
Juan Cantizani Oliva, Eduardo Ruiz Vela \\ and José Zamora Salido
}

\begin{abstract}
We propose the analysis of the control systems associated with ornamental lighting applied to the architectural and monumental heritage from our teaching experience developed since 2017 at the University of Córdoba-Illumination Faculty of Philosophy of Córdoba, year 2017, and Center of Experimental Culture in the Plaza de la Corredera, year 2018 — and the lighting project of the facade of the Hospital de Santiago de Úbeda, Jaén. The DMX system is the one which mostly fulfill the requirements of this kind of lighting. Its implementation is increasingly simple and is associated in many cases with the type of luminaire to be used and the particularity of differential wiring. This solution allows a personalized, creative, and dynamic control and the adaptation of the daily lighting to different events of singular character. It can be used as an instrument of economic revitalization of the tourist and commercial sectors, and of diffusion of the architectural and historical heritage values. The application of the Internet of Things (IoT) and Big Data could allow the creation of a predictive model that helps the spectral design of light sources and an objective tool that contributes to the confluence of art and science.
\end{abstract}

Keywords: ornamental, architectural lighting, control systems, personalized, creative and dynamic control, DMX, differential wiring

\section{Introduction}

In recent years, architectural lighting has acquired special relevance as an instrument to vindicate the architectural and historical values of heritage, and as a revitalizing economical element linked to tourist and commercial sectors [1]. Its concept has recently changed from a purely functional and security one, to a more qualitative conception that contributes to the embellishment and singularization of the city's heritage $[2,3]$.

The benefits of including control systems in lighting are unquestionable-light intensity regulation allows to reduce energy consumption enabling its adaptation to different rates and changes [4]. Traditionally, control systems related to architectural lighting have been associated with exterior lighting. The origin of this technology lies in cinematography and entertainment. Until few years ago, the 
most widespread system was the linear analogical control, which was limited by the number of channels, contacts, and connectors. With the arrival of microprocessors, the use of transmission systems using private protocols, incompatible with each other, began. Thus, in 1986, the DMX512 aroused at the request of the USITT (American Institute of theatrical technologies) to turn the communication system into an efficient standard [5].

Recently, the DXM protocol is acquiring a great development in the field of outdoor lighting and especially applied to the architectural and entertainment types, which together with the potential offered by LED technology, intelligent lighting associated with Big Data and the Internet of Things (IoT) [6]; they make illumination that can be understood as a language "light as a language," with the ability to express and transmit different situations and events.

\section{Methodology}

The analysis and the classification of the different types of control are very complex since most of the available information comes from trading houses, which use different denominations and lead to their products' diffusion and consumption.

In our case, the analysis of the different types of control arises not only from the study of the existing available documentation but also from the teaching experience developed in this field since 2017 in the Department of Electrical Engineering of the Higher Polytechnic School in the University of Cordoba.

Methodologically, a first step is proposed by an objective analysis of the variables that configure the different types of lighting control [7]. These variables have been divided into four groups-systems, methods, and functionalities of the autonomous and networked systems-whose conjugation generates the different types of control. This offers a global vision that allows us to frame and know which ones are acquiring special prominence in architectural lighting.

Next, we will focus on the DMX method, as the most developed in this particular field, analyzing its characteristics and the elements that make up its installation, based on graphics associated with our teaching experience: Lighting Faculty of Philosophy of University of Córdoba, year 2017, and Center of Experimental Culture (CEUX Building) in Plaza de la Corredera, year 2018.

Finally, we will analyze a practical case, specifically the lighting project of the facade of the Hospital de Santiago in Úbeda, which is a tool that allows us to customize the image of the building through the regulation, adjustment, timing, and programming of different scenes of light and color.

\section{Types of control systems: ornamental lighting applied to the architectural and monumental heritage}

\subsection{Generalities}

The attached table (Figure 1) includes the variables that may participate in the configuration of the different types of control in the case of interior, exterior, and ornamental outdoor lighting applied to the architectural and monumental heritage.

Control systems are classified as autonomous and network, depending on whether there is interconnection between devices. Network systems are the most used in architectural lighting, since they involve greater savings and flexibility to combine different strategies. They can be classified into a network by groups, pointto-point and interactive in case of interaction with the user (Figure 2). 
Control Systems and Ornamental Lighting. A Case Study: Illumination of the Facade of Santiago... DOI: http://dx.doi.org/10.5772/intechopen.88815

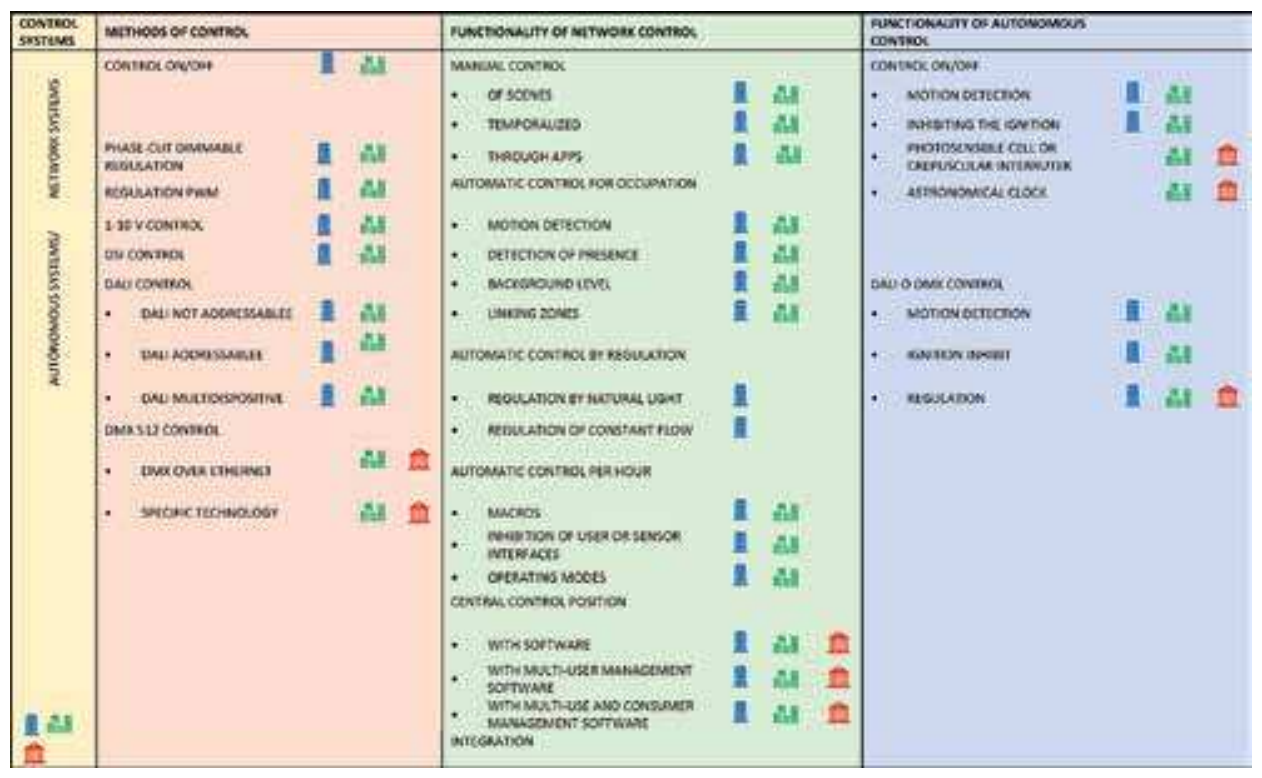

Figure 1.

Summary table of control systems and methods and the functionality of control systems. Source: own elaboration. Preferential use: $\mathbf{I}$ interior lighting, $\mathrm{H}$ exterior lighting, and if ornamental exterior lighting applied to the architectural and monumental heritage.

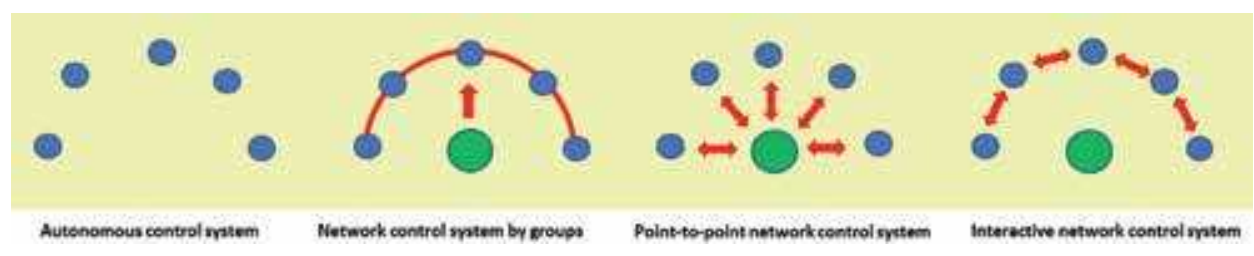

Figure 2.

Types of network control systems. Source: own elaboration.

In the first case, one can control a group of light points, while in the second, one can control and supervise individually every points of light. The latter is the most used in architectural lighting.

The methods of control must be compatible with the luminaire's driver. There are methods, such as phase-cut dimmable regulation or PWM, in which the regulation is carried out in the voltage line itself, with distance being the most limiting factor when working with direct electric current.

Other methods rely on a unidirectional signal, such as 1-10 V or DSI, since the information flows in a single direction, from the controller to the lighting equipment. In the first case, the signal is analogical on two wires sensitive to polarity, while in the second, the system is digital, lacking the polarity cable and its topology is free except for the ring or closed loop.

The Digital Addressable Lighting Interface (DALI) control is not exactly a control method, but rather a bidirectional communication standard (IEC 62386). It is independent of the manufacturer and only the logo guarantees compatibility between the equipment. It provides 256 lighting levels that translate into power levels between 0 and 100\% [8]. The advantage of this technology is the bidirectionality of the system that allows receiving feedback on the status of the luminaire. Being a digital system, the data cable lacks polarity and its topology is free except for the ring or closed loop. This greatly helps the installation, making the system 
flexible and scalable. It can be point-to-point addressable, or be associated with other devices; such as sensors or push buttons. It is a method widely used in both indoor and outdoor lighting.

In front of DALI comes the DMX Control (Digital Multiple X) as a high-speed control protocol $(250 \mathrm{~kb} / \mathrm{s})$, which is highly developed in the field of stage lighting. In case of high channel density, DMX over Ethernet can be used, which allows speeds of 10-100 Mb/s. Some trading houses have developed specific technology in order to optimize and facilitate the installation and promotion of this method of control.

The functionality of the autonomous control is related to incorporation of sensors or other devices in the ON/OFF and DALI or DMX control. The functionalities of network control can be carried out by means of manual control and automatic control by occupation or regulation, by time, and by control post, the latter being the most used in architectural lighting.

The central control station allows, through a processor and a specific software package, to control, monitor, manage, and maintain the lighting system optimally. There may be different levels of development, from a simple software to a multiuser management and consumption tool, which provides total system information (control, visualization, maintenance, individual consumption, reports, and alarms, among others). These functionalities open a wide range of possibilities in the field of architectural lighting [4].

Thus, there are multiple types of control, each one made by the addition of a system and a control method, affected by different functionalities according to the chosen option. In this scenario, with multiple options of control types for indoor and outdoor lighting, we can frame the control systems associated with architectural lighting. The most used control system is point to point network with DMX method-over Ethernet or not-, and central control functionality [9]. This type of control is based on a high-speed control protocol, which is adapted to the requirements of architectural lighting, since it allows dynamic lighting installations and also the traditional static lighting to which we are used today [10].

\subsection{Control systems for LED lighting associated with ornamental lighting applied to architectural and monumental heritage}

\subsubsection{DMX protocol (digital multiplex)}

Control by DMX (Digital Multiple X) technology is a protocol, according to the DMX512 standard, high speed $(250 \mathrm{~kb} / \mathrm{s})$ or digital signal control system developed by the USITT for the lighting of scenarios and shows. It is currently used increasingly in the field of architectural lighting.

The DMX512 [11] is based on the international EIA RS485 standard. The RS485 transfers the information by a differential line made up of two conductors. It has a high immunity to electrical and electromagnetic disturbances, due to the intrinsic characteristics of the differential amplifiers, which, in both analogical and digital applications, remove all unwanted same polarity signals, amplifying the opposite differential ones [12].

DMX requires a routing process for each luminaire. A DMX universe has 512 channels, each with a regulation capacity between 0 and 255. A monochromatic light source controlled by DMX generally uses a channel to regulate the light intensity, while an RGB projector will use three independent channels [13]. So, a DMX universe can control up to 170 independent RGB luminaires. 
Control Systems and Ornamental Lighting. A Case Study: Illumination of the Facade of Santiago... DOI: http://dx.doi.org/10.5772/intechopen.88815

In projects with high channel density, DMX is used through Ethernet, which transfers information at the speed of 10 or $100 \mathrm{Mb} / \mathrm{s}$. The Ethernet network uses a single connection cable for all the devices of the system, which allows great flexibility and a notable reduction of control cables [14].

\subsubsection{Elements that make up the installation with DMX control method}

\subsubsection{Principles of operation}

The DMX512 transmits sequentially the data to the channels in asynchronous mode, at $250 \mathrm{~Kb} / \mathrm{s}$. When the transmitter has sent the information to all 512 channels, it informs that the transmission will be made to channel 1 soon and the next cycle begins. The time spent in a cycle is about $22 \mathrm{~ms}$, so short that you cannot perceive its delay [15].

\subsubsection{Luminaires}

In order to control luminaires through DMX, they must have a driver [9]. As a general rule, the number of luminaires in each control module is limited and a DMX signal amplifier must be added to the network in case of exceeding it.

\subsubsection{Bypass and amplification boxes}

The DMX bus only supports the online topology, and the Y-type branches are forbidden, since they significantly degrade the quality of the signal and make transmission unsteady [5]. In case of derivations, or when certain lengths are exceeded (usually $300 \mathrm{~m}$ ) or more than 30 nodes, it will be necessary to use bypass and/or amplification boxes, which recondition the signal allowing to extend the distance of use (Figure 3). These boxes can be isolated to solve eventual malfunctions caused by rings to ground. In projects with a high density of DMX channels, DMX over Ethernet can be used, which allows the use of optical fiber and TCP/IP topology.

Some trading houses use specific technology to optimize the installation. In the case of Philips ${ }^{\circledR}$, it uses equipment called DataEnablers that, as a bypass box, allow the connection of data and power in order to simplify and guarantee the operation of the installation [16].

\subsubsection{Cabling}

DMX512 uses a cable with two conductors according to the characteristics indicated by the EIA RS485 standard. It consists of a twisted pair (Data (+), Data $(-)$, and GND) and shielded with a characteristic resistance of $120 \mathrm{ohm}$ (Figure 4).
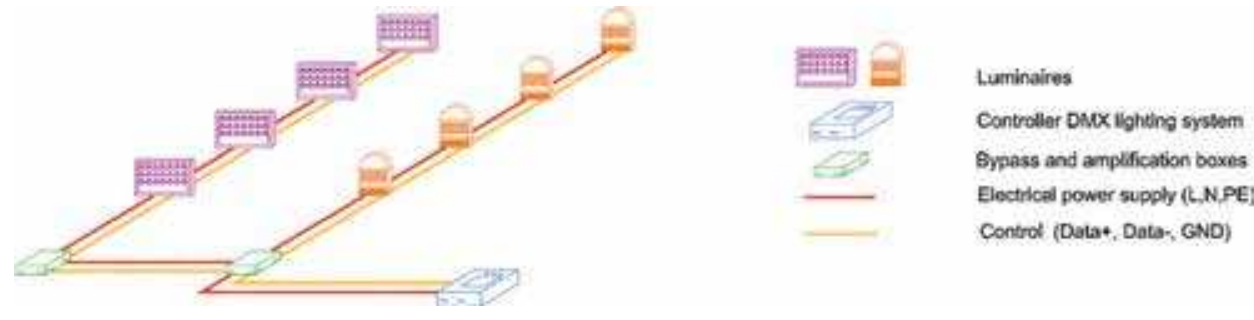

Figure 3.

Diagram of the DMX control scheme principles. Source: own elaboration. 


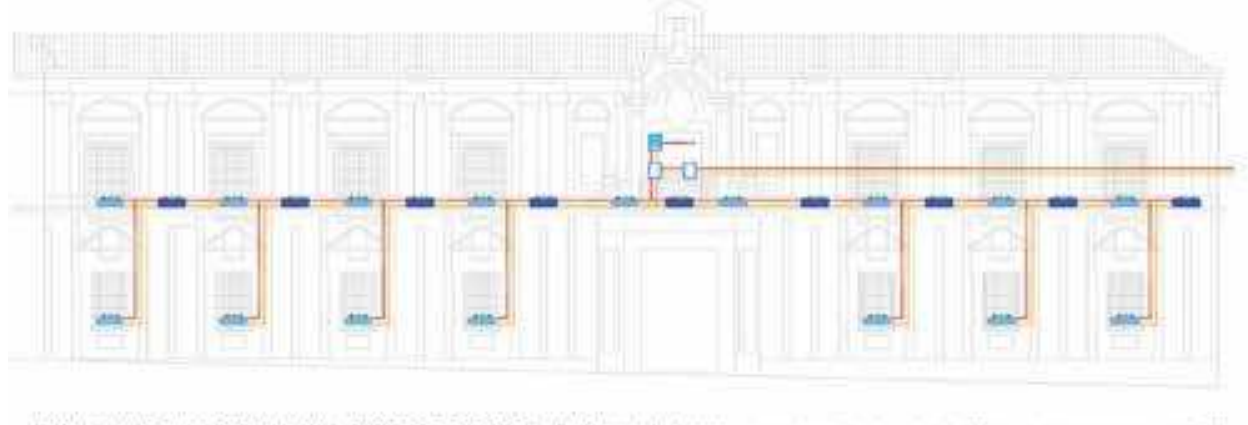

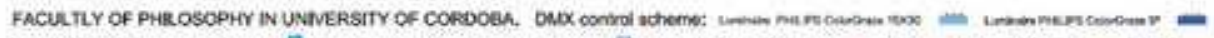

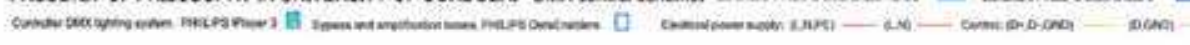
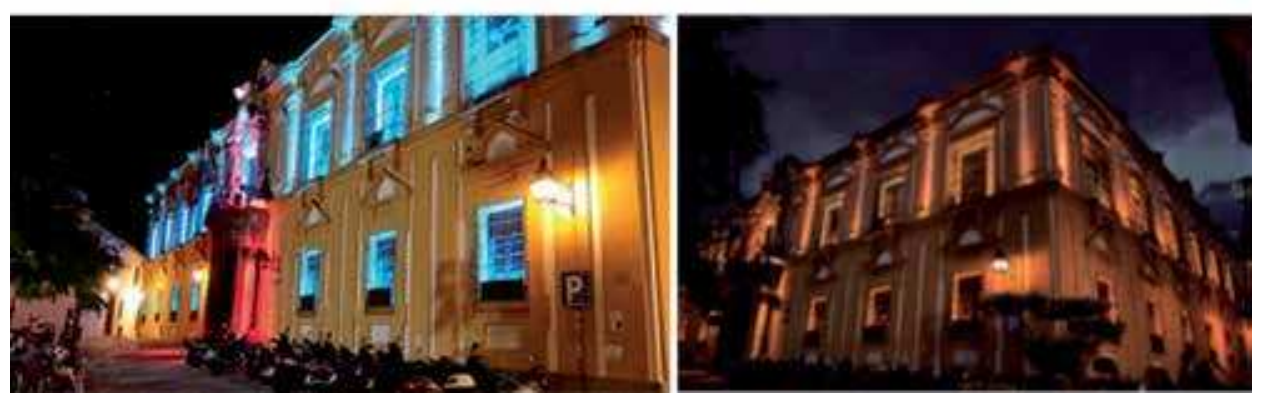

Figure 4.

Lighting and sound show Faculty of Philosophy in University of Córdoba, year 2017. Linear installation scheme formed by Color Grace luminaires of $9^{\circ}$ and $15 \times 30^{\circ}$, three DataEnablers, iPlayer controller, and wiring between supply $(L, N)$ and data $(D, G N D)$ luminaires. As a temporary installation, a bypass box was not placed. Source: own elaboration.

The maximum permissible length of the cable is about $300 \mathrm{~m}$, because losses are a limiting factor when using direct current [17].

A DMX terminator line with a $120 \mathrm{ohm}$ resistor is used to remove a lot of noise and flickering on the DMX line with fixtures since the transmission may be unstable and can cause problems [18].

DMX via Ethernet uses a single connection cable for all the devices of the system; this allows a great flexibility and a remarkable reduction of control cables [14].

\subsubsection{Controller DMX lighting system}

This device consists of a DMX controller, usually from 512 to 1024 channels, which stores a series of sequences or prerecorded scenes. It allows the adjustment of color, brightness, and intensity depending on different types of transitions [19]. It can be controlled manually or remotely, and it includes an astronomical clock for programming according to the day and time of the week (Figure 5).

There are higher performance controllers on the market, controlling up to 20 universes or 10,240 channels to 200 universes or 102,400 channels that use DMX over Ethernet [14]. They may contain, in addition to an astronomical clock, a Web user interface for remote management and the ability to be integrated in the same network with other controllers.

\subsubsection{SaaS software}

There are controllers that use software as a service (SaaS) hosted in the cloud that allows the monitoring, administration, and remote maintenance of the lighting 


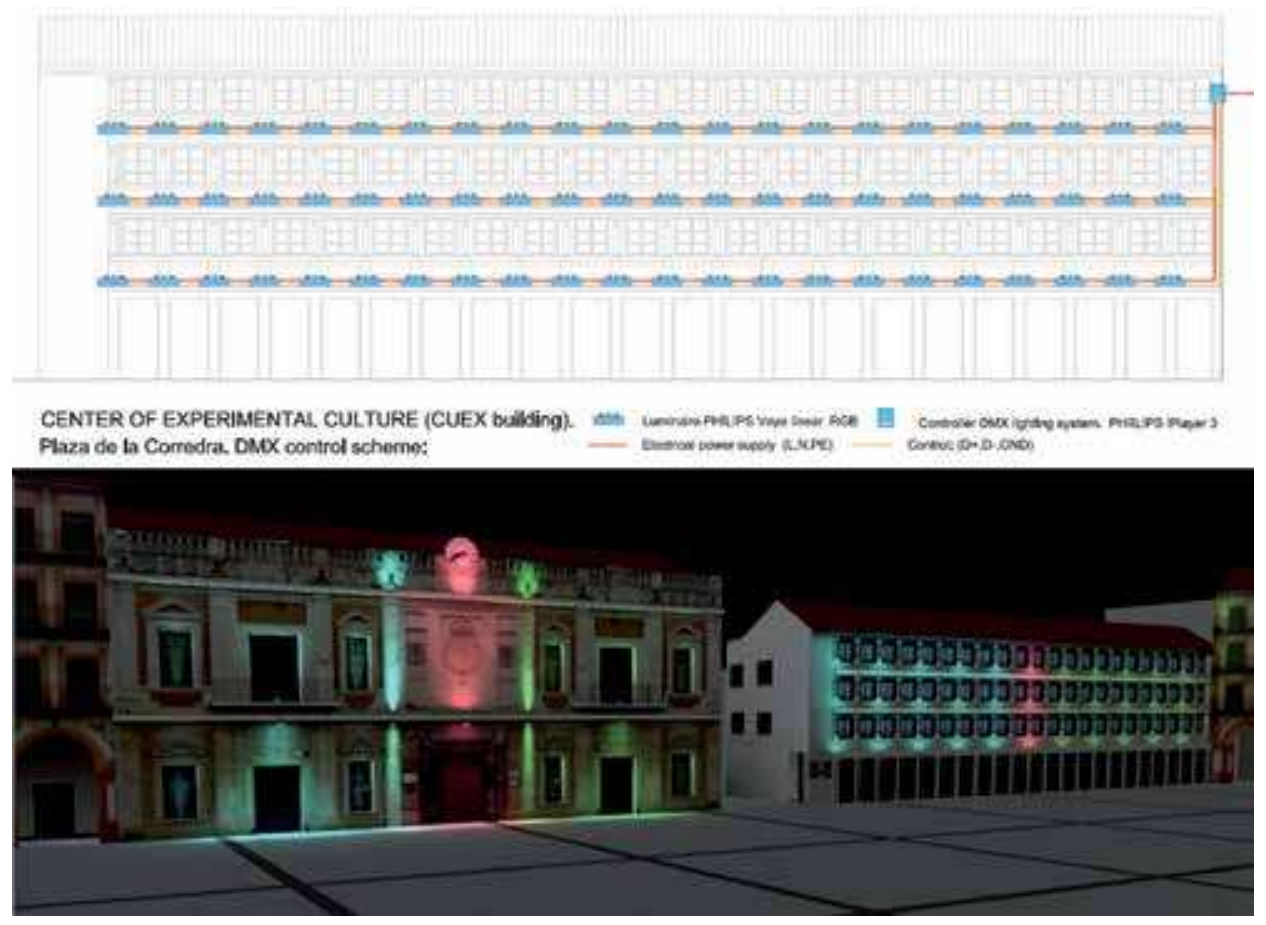

Figure 5.

CEUX building in Plaza de la Corredera, Student Lighting Competition, year 2018. Linear installation scheme was formed by Vaya Linear luminaires, which does not need DataEnablers, iPlayer controller, and wiring between power supply $(L, N, P E)$ and data ( $\left.D_{+}, D_{-}, G N D\right)$. Source: own elaboration.

installations. This solution is likely to acquire a great development in the near future, since it allows administrators and designers to perform their functions in the installation quickly and easily, monitor the performance of the system, and instantly update the software and installation. It also allows the storage of data for analysis (Big Data), diagnosis and remote solving problems, and long-term maintenance and installation costs decrease [20].

\section{Discussion}

Traditionally, the control systems associated with architectural lighting were considered as exterior lighting, being oriented in most cases to a simple time control, and limiting its study to the analysis of uniformity coefficients and levels of illuminance of facades.

Thanks to the evolution of the control systems used in the field of cinematography, together with the possibilities offered by LED technology, the implementation and development of the DMX protocol as a control system applied to the field of architectural lighting is a credible fact. This control system offers the opportunity for a new understanding of lighting based on the promotion of qualitative, dynamic, and versatile aspects $[21,22]$.

This new conception of architectural lighting has not yet permeated deeply in our society. This type of control makes possible that any installation can be configured as a daily lighting, as a singular, or be part of any show; hence it is dynamic, with changing nature and with personalization capacity [23].

Its implementation is increasingly simple and is associated with the type of luminaire used. It only has the peculiarity that it responds to a differential wiring, 
which, although it reduces the formation of noise, makes its connections very difficult. This aspect is solved when the DMX system is developed over Ethernet, achieving greater speed and wiring without the above requirements. Obviously, the development of these DMX systems also generates, as in the case of other control systems, significant energy savings and reduction of $\mathrm{CO}_{2}$ emissions [4].

The installation of the DMX control system requires the addressing of each luminaire and the need for a specialized maintenance staff which may be a problem. The new trend, based on the use of software (SaaS) with cloud service, can be a long-term solution, since the updating and maintenance of the system is continuous and instantaneous [24].

\section{Conclusions}

Color and light influence our emotions, mood, perception and performance; hence, architectural lighting is a vital tool to enhance and revitalize our cities through of the exterior lighting of its unique buildings [25].

The DMX control system is probably the type of control that best meets the demands of current architectural lighting although scarcely widespread in our society. This solution allows a personalized, creative, and dynamic control, which allows heritage beautification, and daily lighting adaptation through its programming to different events or singular shows [26].

Sector's professionalization through dynamic and intelligent lighting systems requires a highly trained staff. The replacement of an integrated luminaire in a DMX control system, in case of failure, requires its addressing in addition to its replacement, aspects for which the sector is not prepared. In this regard, there are solutions based on DMX control over Ethernet or in the use of SaaS that would facilitate remote monitoring, maintenance, and updating of the installation.

As alternatives, we must emphasize that the development of new technologies applied to LED semiconductors can enable the design and spectral control of lighting. The use of the Internet of Things (IoT) and Big Data could allow the establishment of a predictive model that helps to spectrally design light sources from the consideration of daytime lighting which may result in a way to art and science confluence [27].

\section{Practical case of the illumination of the facade of the Hospital de Santiago in Úbeda (Jaén)}

\subsection{Actual state}

\subsubsection{General description}

The Hospital de Santiago de Úbeda was declared a national monument in 1917. After the closure of the Hospital in 1975, it was used as a cultural center for exhibitions and congresses and a library. The building was designed by Pedro de Vandelvira in 1562, although completed by his son Andrés. It was built between 1562 and 1575, and must be allocated, as stated in the founding statutes in 1562 established by Don Diego de los Cobos y Molina, to a hospital for patients with "buboes" (afterward, the assistance to other diseases was extended), chapel for divine worship, and place of burial [28].

This hospital, in relation to many others built in the sixteenth century in Spain, stands out for its enormous monumentality. Built by Andrés de Vandelvira, it is one 


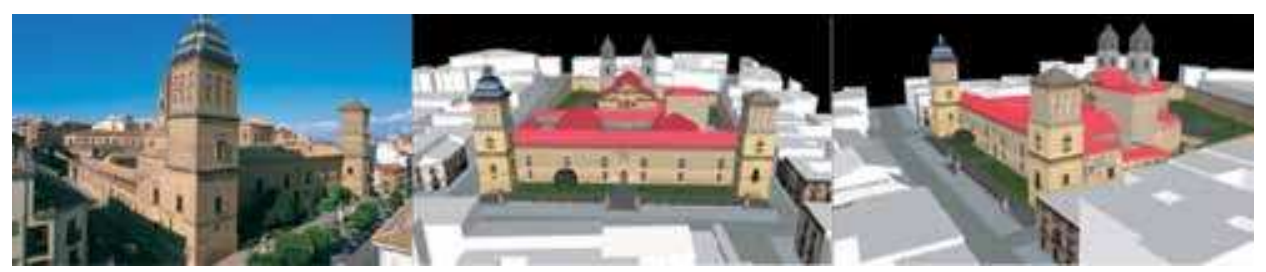

Figure 6.

External view and modeling Hospital de Santiago de Úbeda through DiaLux. Source: own elaboration.

of his most outstanding works and one of the best examples of Spanish hospital architecture of the sixteenth century.

The floor plan is symmetrical and consists of a quadrangular central courtyard chaired by the chapel, on whose corner is a monumental staircase. The main facade was destined to sick rooms. The facade is preceded by a podium that rises above the road (Figure 6). It has an important stone arch in the entrance door and two large towers at the ends. The front windows, which were smaller in size, were enlarged in the nineteenth century for hygienic reasons. The towers that delimit the facade have more a symbolic than a functional value. They were covered by glazed tiles and spires that were replaced from 1915 to 1965 by gable roofs, attaching a spire of concrete tiles and pinnacles to the North. Due to its shape, it has sometimes been called as the Andalusian Escorial.

\subsubsection{Current description of the lighting installation}

\subsubsection{General characteristics of the installation}

The measurement equipment is located in the outer box that is located at the foot of the tower. It includes the luminaires that illuminate the main facade of the hospital and those of the surrounding area. It has a $160 \mathrm{~A}$ circuit breaker, five threephase circuits, and one single phase for control and plug.

In the outer frame, there is an astronomical clock in the four circuits for the control. The total installed power is $24,890 \mathrm{~W}$, of which $8080 \mathrm{~W}$ correspond to the illumination of the facade of the Hospital de Santiago.

\subsubsection{Types of existing luminaires and current lighting criteria of the facade of the Hospital de Santiago in Úbeda}

The characteristics of the existing luminaires are the following:

- Metal-halide floor projectors and power $250 \mathrm{~W}$.

- Metal-halide projectors in columns and power $250 \mathrm{~W}$.

- Metal-halide projectors at the roofs and terraces and power $400 \mathrm{~W}$.

The analysis of the illuminance and spectrum levels was carried out using a UPRtek MK350S spectrometer. In the images, the difference in illuminance in \% of the different areas of the facade can be seen. There are very bright areas that contrast with imperceptible ones; as in the fronts and pilasters giving access to the podium or the towers that contrast with the front of the main facade (Figure 7).

The spectral distribution shows a metal-halide lamp with a clearly reproducible 61.6 chromatic reproduction index (Figure 8). 


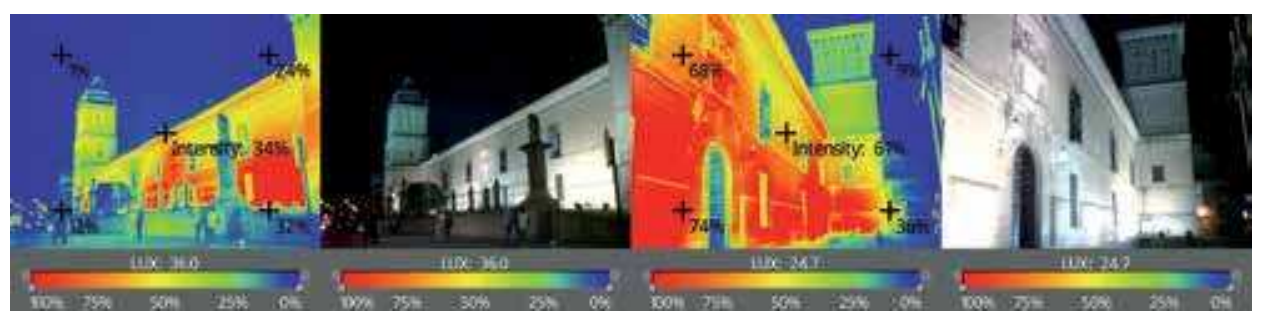

Figure 7.

Analysis of the level of illuminance in \%. Source: own elaboration.

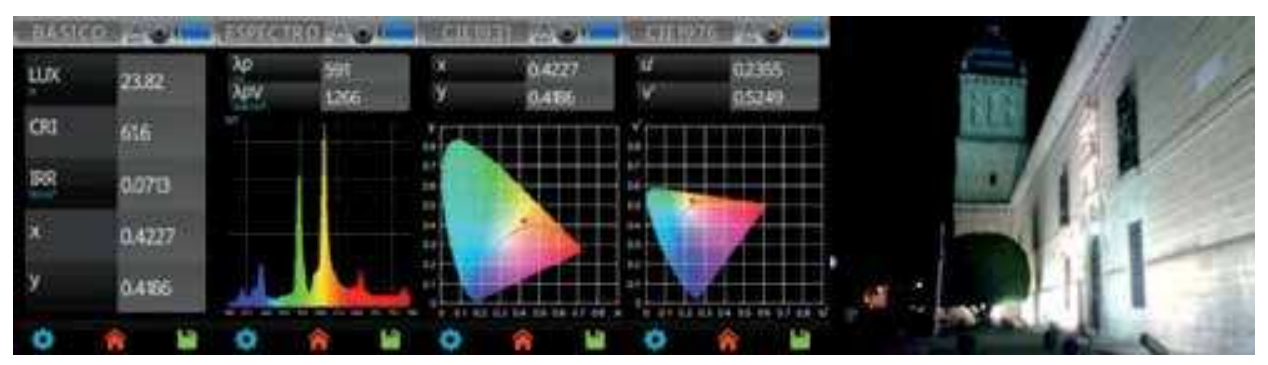

Figure 8.

Analysis of the facade illumination of the Hospital de Santiago. Source: own elaboration.

There are luminaires whose position and location are especially aggressive with the building, like projectors located in the lions of the access pilasters.

\subsection{Installation characteristics and lighting proposal}

\subsubsection{General criteria}

The general criteria followed in the lighting proposal for the facade of the Hospital de Santiago are:

a. Incorporation of a new value-illumination - to the existing reality that will enhance the presence, manifestation, and reading of this building, being one of the most relevant and representative of the Renaissance in Úbeda.

b. Energetic optimization through the implementation of control equipment that allows:

- Energetic monitoring of its operation.

- Management and robust monitoring of energy consumption through the use of information and communication technologies (ICT) including control and remote management facilities, connectivity functions, and regulation of intensity.

c. Energy improvement with an annual reduction of energy consumption and greenhouse gas emissions.

d.Control system implementation for compliance with the proposal and to combine daily lighting with creative manifestations associated with singular events. 
Control Systems and Ornamental Lighting. A Case Study: Illumination of the Facade of Santiago... DOI: $h$ ttp://dx.doi.org/10.5772/intechopen.88815

\subsubsection{Proposed luminaires}

At the main facade, we propose the replacement of the existing $250 \mathrm{~W}$ halogen lamps by other LED technologies with asymmetric optics and $53 \mathrm{~W}$ power. In addition, we will substitute the existing projectors in the access pillars to the podiumat a visible position - for four 32 W LED projectors [29] (Figure 9).

East and West towers will be illuminated by the nearest luminaires location and the minimum number of projectors with long-distance lighting capacity-just two in the East Tower and four in the West - to minimize the consumption and cost of the installation. In this way, in the East tower, we pretend to arrange an asymmetric projector on the roof, another on the facade, and two on a column; and in the West one, an asymmetrical projector on the roof and two on each column.

\subsubsection{Lighting analysis}

The lighting calculations of the planned installation have been made by Dialux, considering the determinations of mandatory compliance according to the application of current legislation.

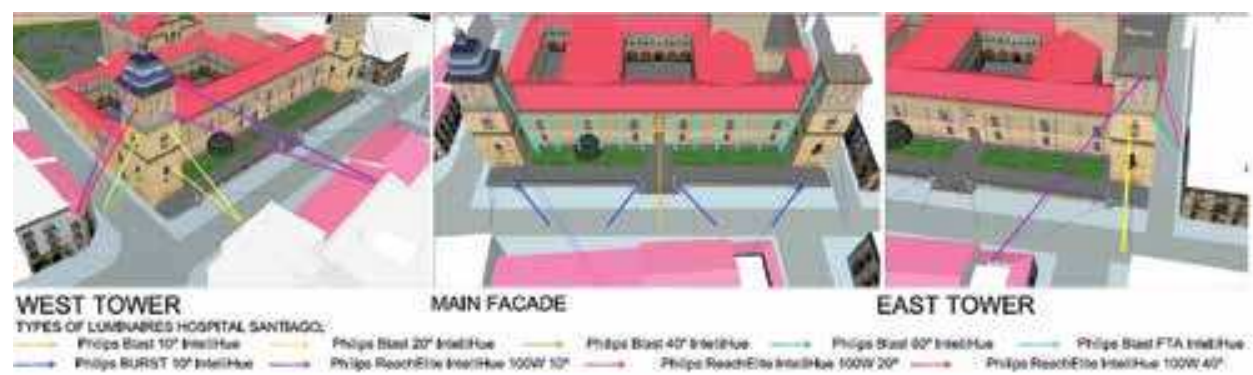

Figure 9.

Types of luminaires and lighting scheme for Hospital de Santiago. Source: own elaboration.

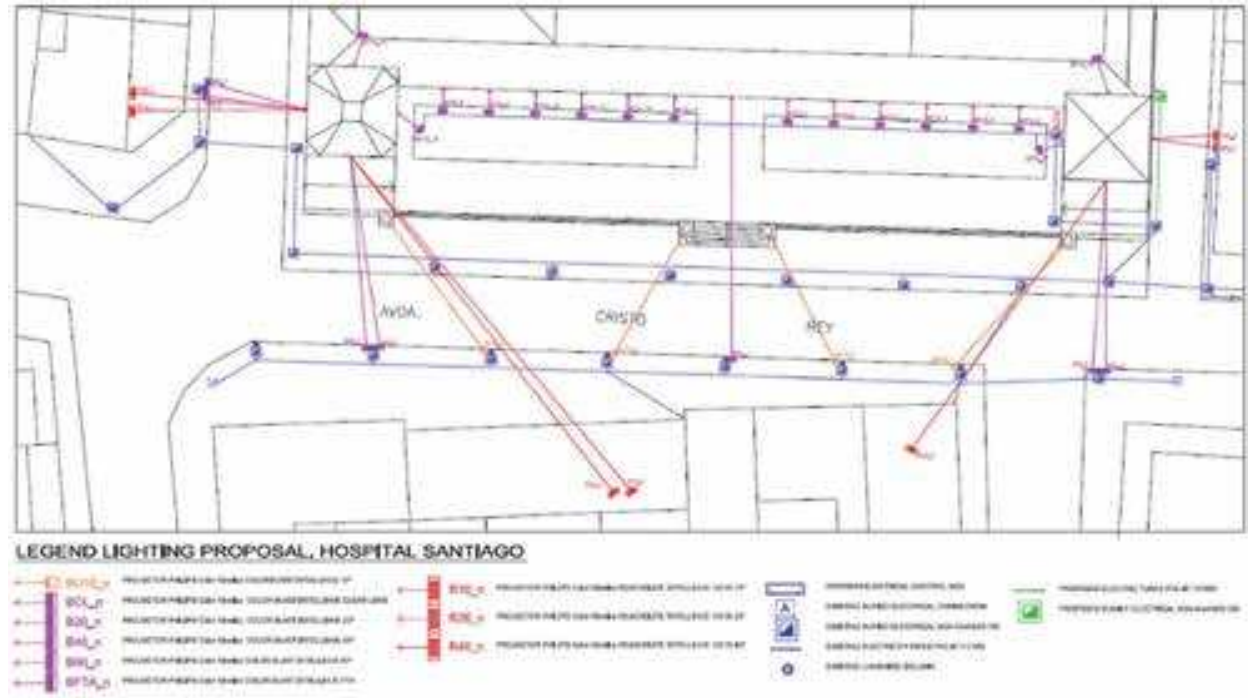

Figure 10.

Lighting proposal_-Hospital of Santiago. Source: own elaboration. 
In our case, the average illuminance levels exceed 20 lux established in case of ornamental flood lighting [30], as it is the main facade. There are no reference values by accent lighting, as in the lighting of the lateral towers and access pilasters to the podium lighting (Figure 10).

The proposal gives a greater uniformity to the lighting of the towers and access podium lighting (Figure 11), as well as improves the chromatic reproduction index to values higher than 90 .

\subsubsection{Control system installation}

The projected control team is a point-to-point network system, which will allow the remote management and monitoring of energy consumption through the use of

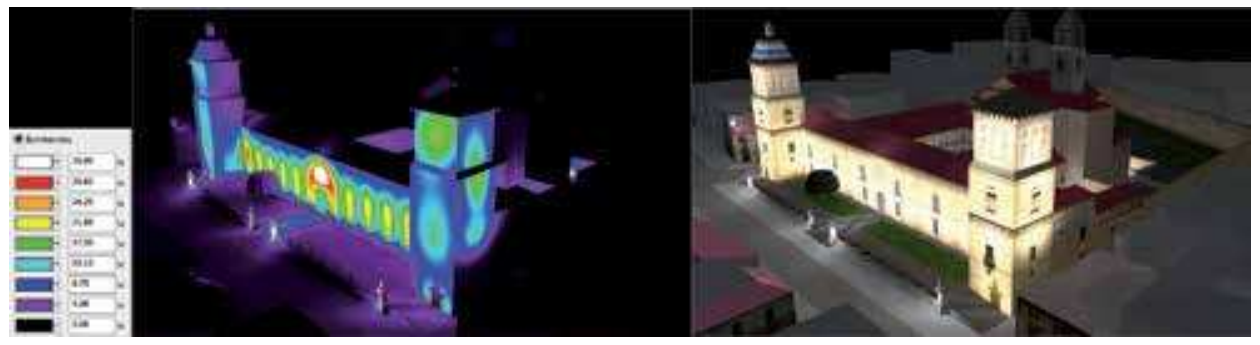

Figure 11.

Illuminance levels according to DiaLux for Hospital de Santiago. Source: own elaboration.
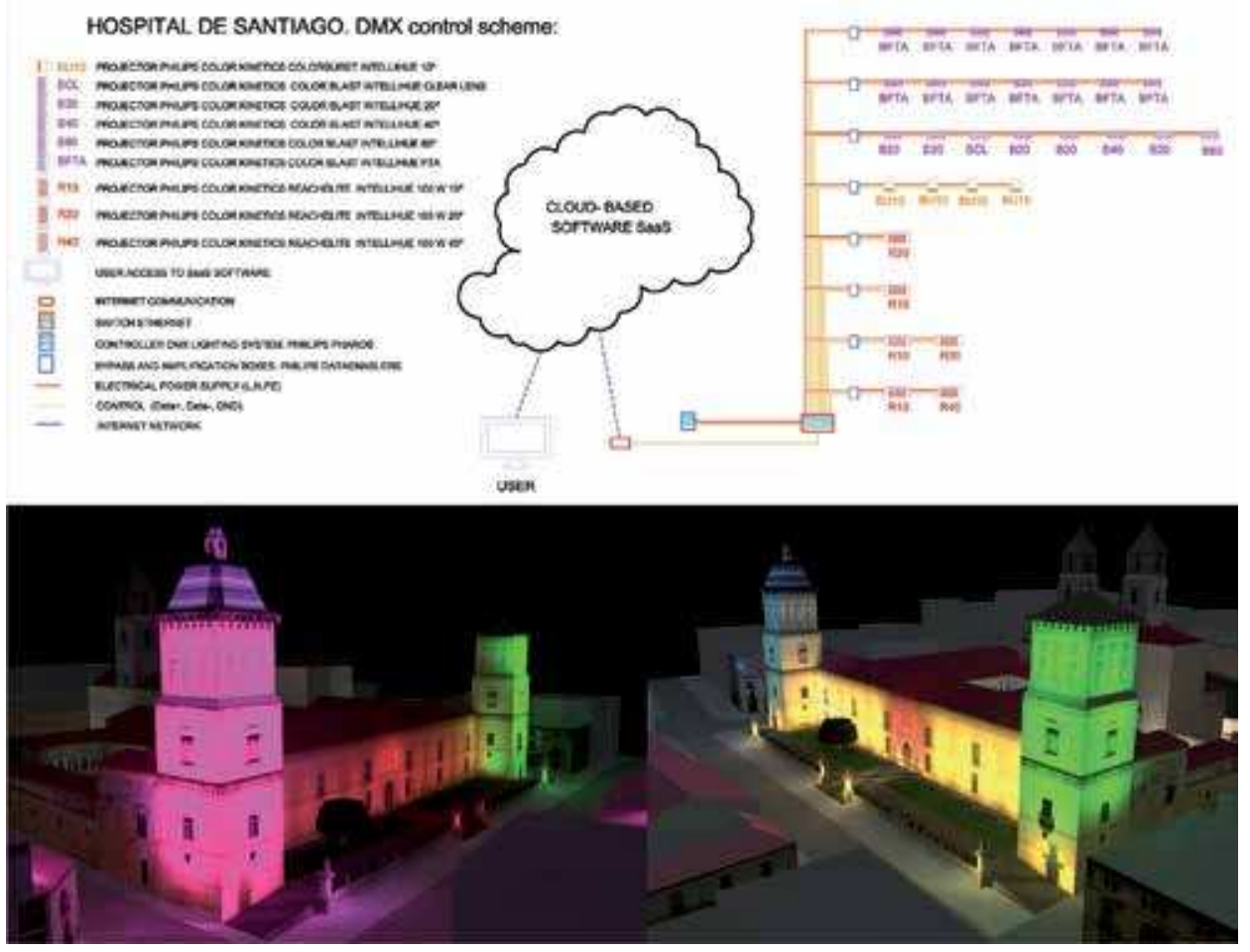

Figure 12.

Control scheme. Project of facade illumination Hospital of Santiago Úbeda. Linear installation scheme consisting of Philips Color Kinetics luminaires, 8 DataEnablers, Pharos controller, SaaS, and wiring between power supply (FNP) and data (+, -, G) luminaires. Source: own elaboration. 
Control Systems and Ornamental Lighting. A Case Study: Illumination of the Facade of Santiago... DOI: $h$ ttp://dx.doi.org/10.5772/intechopen.88815

\begin{tabular}{|c|c|c|c|c|}
\hline \multirow[b]{3}{*}{ 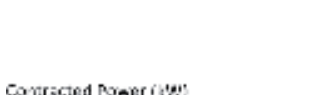 } & ACTUAL STATE & REFORMED STATE & \multirow[t]{6}{*}{ DIFFERENCE } & \\
\hline & 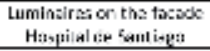 & 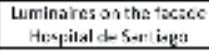 & & \\
\hline & 2,0R5 & $2, \mathrm{nna}$ & & \\
\hline \multirow{4}{*}{ 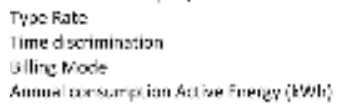 } & $3.5 \mathrm{n}$ & 3,54 & & \\
\hline & no & no & & \\
\hline & Morthte & Vion:hly & & \\
\hline & 33.178 & $8>n a$ & 3.4 .928 & 0.75 \\
\hline \multirow{2}{*}{$\begin{array}{l}\text { Oxerating latirs } \\
\text { Annus Cest (C) }\end{array}$} & 4.100 & $4.1 \mathrm{na}$ & & \\
\hline & 6.957 & 2.722 & & \\
\hline mersce phte $\mathrm{k} / \mathrm{k}$ kwhl & v. 21 & 0,21 & & \\
\hline \multirow{2}{*}{ 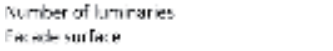 } & 32,09 & 34.00 & & \\
\hline & 2085,00 & $30,65,00$ & & \\
\hline \multirow{2}{*}{ 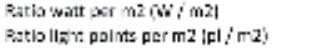 } & $3, \mathrm{BS}$ & 0,96 & & \\
\hline & 0.32 & 0,02 & & \\
\hline
\end{tabular}

Figure 13.

Table relating to the balance of installed power, $\mathrm{CO}_{2}$ emission, and annual balance. Source: own elaboration.

information and communication technologies (ICT), including control and connectivity functions, and intensity regulation.

We propose a network control system with service (SaaS) hosted in the cloud. It is made of a DMX installation connected by a device to the Internet. This solution creates a daylight that can be transformed through its programming into a singular illumination capable of creative manifestations that turn the building into a symbol of singular events (Figure 12).

\subsubsection{Installed power, $\mathrm{CO}_{2}$ emission, and annual balance}

The proposed intervention will reduce $\mathrm{CO}_{2}$ emissions and current electricity expenditure, will carry a better illumination of the facade of the Hospital de Santiago in Úbeda, and will provide, through the proposed control system, a dynamic nature to the color and intensity of the installation, enabling the change in the expressiveness of the building.

As shown in Figure 13, the proposed installation supposes the decrease of the installed power from 8080 to $2000 \mathrm{~W}$, reducing the annual consumption proportionally by $24,928 \mathrm{kWh} /$ year. The consumption of energy and greenhouse gas emissions are reduced annually by $75.25 \%$ compared to the existing one; and the annual balance in energy and economic terms supposes an annual saving of 5.235 €/year [31].

\section{Author details}

Juan Cantizani Oliva*, Eduardo Ruiz Vela and José Zamora Salido

Department of Electrical Engineering, Higher Polytechnic of the University of

Córdoba, University of Córdoba, Spain

*Address all correspondence to: p02caolj@uco.es

\section{IntechOpen}

(C) 2020 The Author(s). Licensee IntechOpen. Distributed under the terms of the Creative Commons Attribution - NonCommercial 4.0 License (https://creativecommons.org/ licenses/by-nc/4.0/), which permits use, distribution and reproduction for non-commercial purposes, provided the original is properly cited. (cc) BY-NC 


\section{References}

[1] $\mathrm{Su} \mathrm{K,} \mathrm{Li} \mathrm{J,} \mathrm{Fu} \mathrm{H.} \mathrm{Smart} \mathrm{city} \mathrm{and}$ the applications. In: Proceedings of the 2011 International Conference on Electronics, Communications and Control Engineering (ICECC 2011); 2011. pp. 1028-1031

[2] England H. External lighting for historic buildings. 2017 [Online] Available from: https://historicengland. org.uk/images-books/publications/ external-lighting-for-historic-buildings/ external-lighting2/ [Accessed: 01 June 2019]

[3] Giordano E. Outdoor lighting design as a tool for tourist development: The case of Valladolid. European Planning Studies. 2018;26(1):55-74

[4] Hu W. Effects of Resolution of Lighting Control Systems. Sydney School of Architecture, Design and Planning. The University of Sydney; 2018

[5] Hung NM, Lee C-H. Design of bi-directional RDM-DMX512 converter for LED lighting control. The International Journal of Fuzzy Logic and Intelligent Systems. 2013;13(2):106-115

[6] Carrino F, Mugellini E, Khaled OA, Ouerhani N, Ehrensberger J. iNUIT: Internet of things for urban innovation. Future Internet. 2016;8(2):1-21

[7] Lighting P. Dynalite controls. Technology overview controls. 2014 [Online]. Available from: https://cdn. dynalite.org/public-download/2947/ bd40c4247432c0917b35dda8c1e3bf05 [Accessed: 01 June 2019]

[8] Domingo-Pérez F, Gil-De-Castro A, Flores-Arias JM, Bellido-Outeiriño FJ, Moreno-Muñoz A. Lighting control system based on DALI and wireless sensor networks. In: 2012 IEEE PES Innovative Smart Grid Technologies (ISGT 2012); 2012. pp. 1-6
[9] Patel M, Mukherjee S. Lighting Control Protocols and Standards. In: RK et al. editor. Handbook of Advanced Lighting Technology. Switzerland: Springer International Publishing; 2017. pp. 1-24

[10] Yoowattana S, Nantajiwakornchai C, Sangworasil M. A design of embedded DMX512 controller using FPGA and XILKernel. In: 2009 IEEE Symposium on Industrial Electronics \& Applications (ISIEA 2009); Vol. 1; 2009. pp. 73-77

[11] Trejo-Macotela FR, Garciabarrientos A. Controlador Digital Mediante el Protocolo DMX-512. In 2013 Simposio Iberoamericano Multidisciplinar Ciencias e Ingenierias. Sept 2013. pp. 281-286

[12] Varghese SG, Kurian CP, George VI. A study of communication protocols and wireless networking systems for lighting control application. In: 2015 International Conference on Renewable Energy Research and Applications (ICRERA 2015); Vol. 5; 2015. pp. 1301-1306

[13] Piromalis DD, Arvanitis KG, Papageorgas PG, Tseles DI, Psomopoulos CS. Sensors \& transducers LEDWIRE: A versatile networking platform for smart LED lighting applications using LIN-Bus and WSNs. Sensors \& Transducers Journal. 2016;200(5):50-59

[14] Newton S. Art-Net and wireless routers. In: 2005 Asia-Pacific Conference on Communications; 2005;2005:857-861

[15] Yang H, Ahmad AW, Shahzad G, Lee C. Real time bidirectional wireless digital multiplexer (WiDMX512). In: International Conference on Advanced Communication Technology (ICACT); Vol. 2015; 2015. pp. 109-114

[16] Lighting P. Catalogo sistemas de Control. 2013 [Online]. Available from: 
http://images.philips.com/is/content/ PhilipsConsumer/PDFDownloads/Spain/ ODLI20160203_001-UPD-es_ES-Philips_ Lighting_catalogo_de_sistemas_de_ control.pdf [Accessed: 01 June 2019]

[17] Cassera M. DMX Desmystified [Online]. 2018. Available from: https:// www.theatreartlife.com/staying-still/ dmx-demystified/ [Accessed: 22 July 2019]

[18] Cadena R. Automated Lighting The Art and Science of Moving and ColorChanging Lights. New York: Routledge; 2017

[19] López C, Doval J, Pereira M, Pérez S, Dios J, López O. DMX512 controller for high brightness RGB LED matrix. In: IEEE International Symposium on Industrial Electronics; Vol. 01; 2007. pp. 3025-3029

[20] Philips ActiveSite Specification Sheet. Philips ActiveSite Controller. Remotely monitor and manage dynamic cloud-hosted connected lighting software. 2019 [Online]. Available from: https://www.docs.colorkinetics. com/ActiveSite/Philips-ActiveSiteSpecSheet.pdf [Accessed: 01 June 2019]

[21] Talebian K. Day for Night: The Role of Artificial Lighting in Returning People to Urban Public Spaces. Gazimağusa, North Cyprus: Eastern Mediterranean University; 2012

[22] Besenecker UC, Krueger T. Luminous color in architecture: Exploring methodologies for designrelevant research. ENQUIRY: The ARCC Journal. 2015;12(1):35-46

[23] Seitinger S, Perry DS, Mitchell WJ. Urban pixels: Painting the city with light. In: Proceedings of the CHI'09; 2009. pp. 839-848

[24] Zotos N et al. Case study of a dimmable outdoor lighting system with intelligent management and remote control. In: 2012 International Conference on Telecommunications and Multimedia (TEMU 2012); Vol. i; 2012. pp. 43-48

[25] Valdez MT, Ferreira CM, Barbosa FPM. Electrical Engineering course using PBL - the lighting of historical buildings. In: IEEE Global Engineering Education Conference (EDUCON). 2018. pp. 351-355

[26] Boring S, Gehring S, Wiethoff A, Blöckner AM, Schöning J, Butz A. Multi-user interaction on media facades through live video on mobile devices. In CHI 2011 Session Interaction on Mobile Devices. Vancouver, BC, Canada. 2011. pp. 2721-2724

[27] Tokuç A, Köktürk G. The science and art of architectural lighting using smart materials. In: 46th International HVAC\&R Congress and Exhibition; 2018. pp. 109-114

[28] Lorite Cruz PJ. Una aproximación a la distribución de la Capilla del Hospital de Santiago de Úbeda antes de su desacralización, así como un estudio de sus ternos conservados en las cajoneras del Santuario del Gavellar. ARGENTARIA, Rev. Hist. Cult y Costumbrista las Cuatro Villas. Jaén y sus pueblos. 2019;21:55-72

[29] Kyba CCM, Mohar A, Pintar G, Stare J. Reducing the environmental footprint of church lighting: Matching façade shape and lowering luminance with the EcoSky LED. International Journal of Sustainable Lighting. 2017;19(2):132-141

[30] España Ministerio de Industria turismo y comercio, Real decreto 1890/2008, de 14 de noviembre, por el que se aprueba el Reglamento de eficiencia energética en instalaciones de alumbrado exterior y sus Instrucciones técnicas complementarias EA-01 a EA-07. Boletín Oficial del Estado; 2008. pp. 45988-46057 
[31] Hermoso-Orzáez MJ,

Gago-Calderón A, Rojas-Sola JI.

Power quality and energy efficiency in the pre-evaluation of an outdoor lighting renewal with light-emitting diode technology: Experimental study and amortization analysis. Energies.

2017;10(7):1-13 



\section{Edited by Manuel Jesús Hermoso-Orzáez and Alfonso Gago-Calderón}

The lighting of both exteriors and interiors is a field within electrical and lighting engineering, where important technological changes have been taking place oriented towards environmental sustainability and energy efficiency. LED technology has been gradually gaining ground in the world of lighting over other technologies due to its high lighting and energy efficiency and savings. However, some problems related to overheating or associated regulation are emerging. This has prompted the search for new, more efficient, and sustainable forms of lighting. This book presents successful cases related to energy efficiency and lighting that may be of great interest to those trying to enter the world of scientific research. 